Michel Satya Naslavsky

A contribuição de estudos populacionais em idosos saudáveis: base de dados genômicos, compreensão do envelhecimento e lateralidade cerebral

The contribution of population studies in healthy elders: genomic database, understanding aging and brain laterality 
Michel Satya Naslavsky

A contribuição de estudos populacionais em idosos saudáveis: base de dados genômicos, compreensão do envelhecimento e lateralidade cerebral

The contribution of population studies in healthy elders: genomic database, understanding aging and brain laterality

Tese apresentada ao Instituto de Biociências da Universidade de São Paulo como requisito parcial para a obtenção do título de Doutor em Ciências, na Área de Biologia (Genética).

Orientadora: Profa. Dra. Mayana Zatz

São Paulo 
Naslavsky, Michel Satya

A contribuição de estudos populacionais em idosos saudáveis: base de dados genômicos, compreensão do envelhecimento e lateralidade cerebral

$214 \mathrm{pp}$.

Tese (Doutorado) - Instituto de Biociências da Universidade de São Paulo. Departamento de Genética e Biologia Evolutiva. São Paulo, 2015.

1. Genômica populacional 2. Envelhecimento cerebral 3. Lateralidade cerebral I. Universidade de São Paulo. Instituto de Biociências. Departamento de Genética e Biologia Evolutiva.

Esta é uma versão revisada e corrigida. A original encontra-se disponível no Instituto de Biociências da USP.

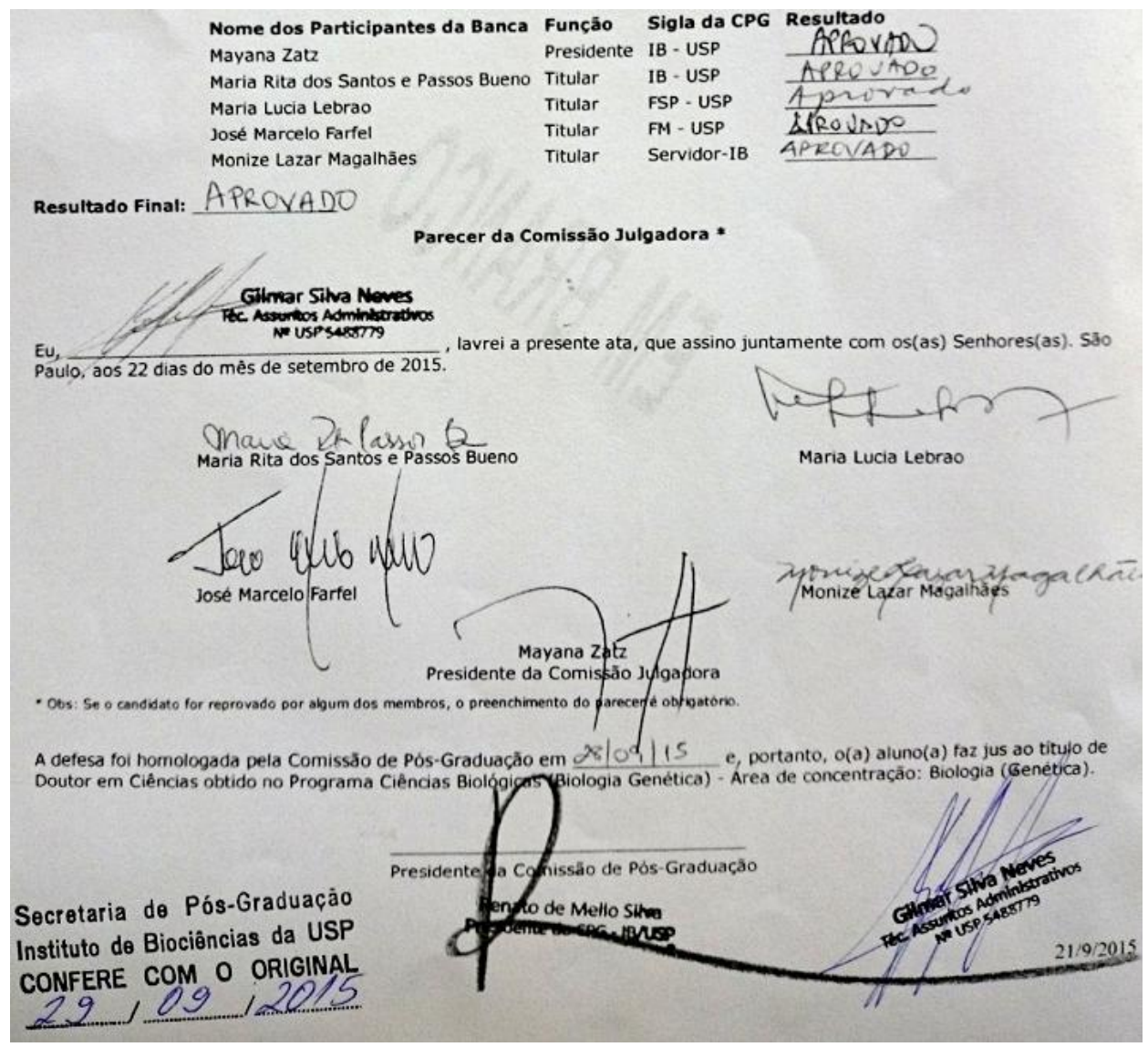




\section{Dedicatória}

Quem falou "mãe só tem uma" deve ser um desafortunado!

Eu, por exemplo, tenho a satisfação de dizer que tenho várias mães:

Algumas estão por aqui; outras não mais.

Algumas são muito mais velhas do que eu; outras são mais novas.

Algumas são homens; outras são mulheres; e outras são.

Algumas compartilham genética comigo; outras não.

Algumas estão perto; outras estão bem longe.

Algumas mães são personagens de livros, de filmes, de séries; outras não, mas poderiam ser.

Fui adotado inúmeras vezes pelas pessoas que adotei.

Sendo algumas ou outras, sou um pouco de todas as mães que conheci e conhecerei.

E às mães dedico esta tese. 


\section{Agradecimentos}

Agradeço à Mayana Zatz, orientadora, mentora e amiga, por me receber em seu grupo tão repleto de pessoas fantásticas, ideias inovadoras, ímpeto socio-político e motivação científica. Atributos que são sem dúvida um mero reflexo de sua liderança.

Aos voluntários de todas os projetos com os quais tive contato. A ciência só progride com a disposição e paciência daqueles que participam, independentemente de qual papel estejam desempenhando.

Às agências de fomento e instituições que aprovaram e suportaram os projetos: Fundação de Amparo à Pesquisa do Estado de São Paulo (Fapesp, processos 17428-8/2011; 57899-7/2008; 08028-1/2013), Conselho Nacional de Desenvolvimento Científico e Tecnológico (CNPq, processo INCT 15/2008), Financiadora de Estudos e Projetos (Finep), Instituto Israelita de Ensino e Pesquisa do Hospital Israelita Albert Einstein (IIEPAE).

Ao Centro de Pesquisa sobre o Genoma Humano e Células-tronco (CEGH-CEL) pelo apoio inestimável em todas as etapas, sempre facilitando a execução e fornecendo o timbre de reputação, referência e excelência em suas atividades.

Às minhas famílias. Sou sortudo e tenho várias: tio Zepa, Mari, Milah e Marina. Mainha (Deborah) e Voinha (Ruth) ל ז ז Tia Giselle e Harald. Mário, Inês, Juliana e Rodrigo. Fábio, França, Guiminha, Campinas, Emi, Emmanuel e Pedro.

Aos colaboradores diretos dos estudos descritos nesta tese, os quais contribuiram, confiaram e elegeram a base de dados como parte de seus estudos: Dra. Maria Lúcia Lebrão, Dra. Yeda Duarte, Dr. Edson Amaro, Dr. José Marcelo Farfel, Dra. Lea Grinberg, Dra. Telma Busch, Dr. João Kitajima, Dr. Fernando Kok, Dr. David Schlesinger, Dr. Rodrigo Toledo, Dra. Suzana Ezquina, Dra. Carla Rosenberg, e Dra. Maria Rita Passos-Bueno.

Aos professores do IB, Dra. Regina Mingroni, Dra. Mariz Vainzof, Dra. Célia Koiffmann, Dr. Diogo Meyer, Dra. Luciana Haddad, Dr. Paulo Otto, Dra. Débora Bertola. Aos amigos e professores da UFPE João Ricardo Mendes de Oliveira, Eduarda Larrazábal e Paulo Andrade.

Aos professores que me receberam no exterior: Dr. Marco Catani e Dr. Michel Thiebaut de Schotten no Institute of Psychiatry do King's College London (onde também fui recebido pela Dra. Agnes Nishimura), Drs. Maya e Oren Schuldiner e Dr. Shai Fuchs no Weizmann Institute of Science e Dr. Nissim Benvenisty na Hebrew University of Jerusalem, Dr. Alysson Muotri e Dra. Helen Miranda na UCSD.

Aos amigos do laboratório 211: Natale Cavaçana, brilhante e criativa, um orgulho de ser seu amigo; Monize Lazar, tão sábia e disposta, sempre presente; Melinda Beccari, que acompanha pacientemente meu humor de qualidade duvidosa com tanta sagacidade e doçura; Thiago Rosa, que compartilha da noção que gastronomia é uma ciência; Naila Lourenço, que transmite o cuidado para todos; Inês Macedo e sua carioca felicidade que contagia; Uirá Melo e Thalita Figueiredo, que trouxeram mais Nordeste inteligente para São Paulo; Luiz Caires e Ernesto Goulart, que trouxeram um acolhimento mineiro.

Aos amigos do Genoma: Amanda Assoni, que acredita que sou otimista (isso sim é otimismo!); Ju Gomes, Giu Coatti e Mayra Pelatti, pelas conversas filosóficas; Marcos Valadares, Mari Secco, Eder Zucconi, Natassia Vieira (que estuda o Ringo e o Gringo) e Peter Serafini, pela inspiração empreendedora 
que tanto cativo; Guilherme Yamamoto, que comigo forma a minoria mafiosa judaico-nipônica; às meninas da prestação de serviço Katia, Meire, Vanessa e Monica por me aturarem.

Aos amigos, colegas e colaboradores que fiz na USP e alguns já foram para longe: Luciana Licínio, Miguel Mitne, Gilda Montalbano, Henrique Andrade, Bárbara de Bellis, Luciano Brito, Lucas Alvizi, Roberto Fanganiello, Karina Griesi, Joanna Meira, Tatiana Jazedje, Carolina Malcher, Bruno Pimenta, David Marco Antonio, Stephanie Alcântara, Áurea Bach, Gabi Polster, Dani Moreira, Andressa Morales, Estela Cruvinel, Simone Ferreira, Heloisa Bueno, Rodrigo Atique, Felipe Ishiy, Clarice Savastano, Fernando Molina, Gabriel Bandeira, Lilian Kimura, Dani Rosado, Tania Matsumoto, Ana Mões, Martha San Juan França. Sem o apoio deles seria tudo mais difícil.

Ao apoio essencial de Constância Gotto, Antonia Cerqueira, Roberto, Lilian, Vanessa Sato, Wagner Falciano, Deisy Morais, Helenice, Sr. Cícero, Erika, Helder e Shirlene.

Aos amigos que fiz no Hospital Israelita Albert Einstein: Liana Guerra, Joana Balardin, Karina e Alda, Anelise Rodrigues, Adriano de Santis, Bira Machado, Elisa Kozasa.

Aos amigos e professores do Colégio Israelita que acompanharam o começo da minha carreira acadêmica: Arthur Azoubel, Beno Koatz, Bernardo Sitcovsky, Daniel Horowitz, Eduardo Kreimer, Gabriel Costa, Guilherme Weinberg, Rafael Foinquinos, Samuel Bortnik Samy Charifker, Shuly Lederman, Ticiana Reis, Vivian Guendler e Yuri Sobel. Também aos amigos e professores do Colégio Santa Maria: Eduarda Paiva, Rafael Tavares e Saulo Cadete.

Aos amigos: Vodo, Thais Lancman, Kiko Azoubel, Reush, Raizel, Ari, Vitão, Fabão, Danilo Dunas, Monica Buava, Luiza Demoro, Groo, Mari Arroxelas, Breno José, Ju Russar, Julio e Marcela da Fonte. Recebi muito apoio de Ana Bouqvar e Frank Wiggers e a eles também sou muito agradecido. Um agradecimento especial à Andrea Naccache por tantas horas acumuladas de reflexões.

À Marina Gratão, que me deu todo o suporte da forma mais carinhosa possível durante a escrita desse trabalho. Sítio arqueológico que sou, só alguém como ela para ter paciência na escavação.

E como disse Albert Einstein a Arthur Cohen, em 1928: "It would be better if you began to teach others only after you yourself have learned something."

Nada seria possível sem o aprendizado que recebi de todos vocês! 


\section{Epígrafe}

From this distant vantage point, the Earth might not seem of any particular interest.

But for us, it's different. Consider again that dot. That's here. That's home. That's us.

On it everyone you love, everyone you know, everyone you ever heard of, every human being who ever was, lived out their lives.

The aggregate of our joy and suffering, thousands of confident religions, ideologies, and economic doctrines,

every hunter and forager, every hero and coward,

every creator and destroyer of civilization,

every king and peasant,

every young couple in love,

every mother and father, hopeful child, inventor and explorer,

every teacher of morals,

every corrupt politician,

every "superstar",

every "supreme leader", every saint and sinner in the history of our species lived there

- on a mote of dust suspended in a sunbeam.

From Pale Blue Dot, by Carl Sagan (1934-1996) 


\section{Prefácio do autor}

Este texto é a compilação de temas conectados pelo projeto conduzido durante o curso de meu doutorado.

A idealização do eixo principal, genética do envelhecimento, partiu da abertura de uma nova linha de pesquisa da minha orientadora, Profa. Dra. Mayana Zatz. Competente investigadora da genética de doenças neuromusculares e neurodegenerativas e uma das introdutoras da pesquisa em células-tronco no Brasil, a Profa. Mayana idealizou em 2007 no programa de fomento Institutos Nacionais de Ciência e Tecnologia (INCT) do Conselho Nacional de Pesquisa (CNPq) a necessidade de gerar e aprofundar conhecimentos sobre a variação genômica de idosos, especificamente octagenários, saudáveis, de modo a criar uma base útil como padrão de referência para estudos de doenças genéticas.

A ideia permaneceu cristalizada até o início de 2010, momento da minha entrada no grupo de pesquisa do Centro de Estudos do Genoma Humano (CEGH), quando o projeto me foi apresentado. O meu interesse foi imediato. Porém, diante de um estudo de âmbito generalista, seria necessário determinar um foco objetivo para a elaboração de um projeto de doutorado. Foi-me sugerido o tema da genética da lateralidade cerebral, levantado em discussões iniciais e rapidamente capturado por mim após rápida consulta a bibliografia corrente. Um tema de amplo interesse da comunidade científica que, apesar de muito investigado, permanece com perguntas em aberto e diversas inconsistências.

Assim, abriu-se caminho no CEGH, que há mais de três décadas se dedica a pesquisa de doenças genéticas, para a pesquisa da variação genômica em indivíduos saudáveis e, no sub-projeto que tornou-se o meu doutorado, variação de um fenótipo normal, não diretamente associado com doenças.

O texto está organizado em quatro capítulos, com três partes temáticas. A primeira parte destina-se a situar a genômica num contexto populacional (capítulo I), bem como justificar a realização de uma coleta de grande porte de material biológico e dados de uma população brasileira (Capítulo II). Uma introdução ao assunto deve ajudar o leitor a compreender os desafios e a urgência de tal realização. Em seguida, ficam expostos os objetivos referentes ao capítulo, a descrição das amostras, dos métodos e das colaborações. Uma breve explanação sobre o êxito da coleta, dados resumidos e comentários sobre os trabalhos resultantes das colaborações compõem a sequência textual, com referências diretas aos trabalhos anexados no capítulo. Por fim, as conclusões e perspectivas são expostos.

A segunda parte refere-se ao tema envelhecimento cerebral, um dos focos de pesquisa importantes da amostra em questão. O Capítulo III se inicia com uma introdução sobre envelhecimento, do processo específico no cérebro e das patologias associadas, guia o leitor até os objetivos do capítulo, seguido da descrição metodológica e de comentários sobre os trabalhos resultantes além da exposição de dados adicionais, anexados no final do capítulo. Por fim, conclusões e perspectivas sobre os temas comentados neste capítulo.

A última parte, composta pelo Capítulo IV, relata a abordagem proposta para a investigação da genética da lateralidade cerebral através do estudo de associação entre fenótipos cerebrais e variação genômica para a amostra aqui apresentada. O tema de lateralidade cerebral é introduzido, seguido de consequências de um cérebro lateralizado, estudos de genética deste fenótipo. Exposto o objetivo, comenta-se sobre as estratégias para procurar responder as questões sobre o tema e os resultados obtidos até o momento. Finaliza-se com os próximos passos e perspectivas deste estudo. 
Resumo

Naslavsky, MS. A contribuição de estudos populacionais em idosos saudáveis: base de dados genômicos, compreensão do envelhecimento e lateralidade cerebral. 2015. $214 \mathrm{f}$. Tese (Doutorado) - Instituto de Biociências, Universidade de São Paulo, São Paulo, 2015.

Com a redução progressiva dos custos de sequenciamento completo do genoma humano, os estudos populacionais tornam-se viáveis. A interpretação dos dados e integração com informações clínicas, entretanto, apresentam-se como desafios crescentes. O conhecimento sobre a variabilidade genética e sua interação com fenótipos complexos podem ser ampliados com estudos de grande porte em populações miscigenadas, em particular de sociedades com heterogeneidades sociais, culturais e históricas, ainda pouco representadas globalmente na área da genômica. Este trabalho apresenta um conjunto de estudos colaborativos que se basearam em uma amostra de natureza representativa de idosos da cidade de São Paulo (amostra SABE, aproximadamente 1400 indivíduos) e em de octogenários cognitivamente saudáveis (amostra $80+$, aproximadamente 130 indivíduos). Além de questionários e testes, DNA dos participantes foi obtido e exomas sequenciados para cerca de 600 indivíduos. Esta base permitiu a construção de grupos controles para diversos estudos de associação de variantes causais ou de suscetibilidade a doenças raras como distrofia muscular de cinturas, tumores do sistema endócrino e síndrome de Noonan, entre outras, além de integrar, como referência populacional local, o sistema de análise de variantes do serviço de diagnóstico molecular do Centro de Pesquisas sobre o Genoma Humano e Células-tronco da Universidade de São Paulo. Por ser uma amostra de idosos, além de permitir a construção de uma base eficiente para controles comparativos de doenças raras ou de início precoce, tornou-se possível a execução de projetos sobre envelhecimento cerebral através do recrutamento cerca de 580 indivíduos para ressonância magnética. Estudos com marcadores de demências, como polimorfismos do gene $A P O E$ (associado à doença de Alzheimer) indicaram que a população brasileira apresenta riscos diferenciais em relação a populações de outros países, provavelmente devido à estrutura populacional única do ponto de vista de ancestralidade genética e composição socio-econômica. Por fim, os estudos com ressonância magnética e genômica permitiram a investigação do fenótipo de lateralidade cerebral, que engloba dominâncias manual e de linguagem, que está presente de forma variável em seres humanos e está envolvida com distúrbios neuropsiquiátricos como dislexia e esquizofrenia. Foi possível detectar associação entre variantes do gene FOXP2, implicado no neurodesenvolvimento da linguagem, e endofenótipos assimétricos de tratos de substância branca envolvidos na produção da fala. $\mathrm{O}$ presente trabalho abre caminho para diversos novos projetos dada a escala de dados sociodemográficas, clínicos, funcionais e genômicos.

Palavras-chave: genômica populacional, envelhecimento cerebral, lateralidade cerebral 


\begin{abstract}
Naslavsky, MS. The contribution of population studies in healthy elders: genomic database, understanding aging and brain laterality. 2015. 214 p. Thesis (PhD) - Biosciences Institute, University of São Paulo, São Paulo, 2015.

Due to the progressive reduction of genome sequencing costs, population studies become feasible. Interpretation of subsequent data and integration with clinical information, however, impose a growing challenge. The knowledge about genetic variability and its interaction with complex phenotypes could be expanded with large scale admixed population studies, particularly in those samples that live in socially, culturally and historically heterogeneous communities, so far globally underrepresented in the genomics field. This thesis presents a collection of collaborative studies that were based on a population-representative sample of elderly from the city of São Paulo (SABE sample, approximately 1400 subjects) and a cognitively healthy octogenarians sample $(80+$ group, approximately 130 subjects). Comprehensive questionnaires and functional tests were obtained, along with DNA from all subjects and exome sequences from about 600 of them. This database allowed the assembly of control groups to several association studies with causal and susceptibility variants to rare disorders such as limb-girdle muscular dystrophy, endocrine system tumors and Noonan syndrome, among others, and, in addition, composed as a local population reference the analyses' protocols in the molecular diagnosis service of the Human Genome and Stem-cell Research Center at the University of São Paulo. As this is an elderly sample, it was possible not only to build an efficient control group to compare with patients affected by rare or early onset disorders, but to promote projects on brain aging through recruitment of about 580 subjects to magnetic resonance imaging (MRI). Studies with markers of dementia, such as APOE gene polymorphisms (involved in Alzheimer's disease), suggested that the Brazilian population might present different risks compared to other countries, probably due to its unique population structure from the genetic ancestry standpoint and socioeconomic composition. As a final project, MRI and genomics studies were performed to investigate the phenotype of brain laterality, which comprises handedness and language dominance and it is variable among humans, with involvement with neuropsychiatric disorders such as dyslexia and schizophrenia. It was possible to detect an association between variants of FOXP2 gene, which is involved in neurodevelopmental processes of language, and asymmetry endophenotypes of white matter tracts that form the speech production circuitry. This effort opens several pathways to develop new projects due to the scale of sociodemographic, clinical, functional and genomic data.
\end{abstract}

Keywords: population genomics, brain aging, brain laterality 


\section{Lista de Figuras}

Figuras

Descrição

Figura 1 Representação de haplótipos

Figura 2 Análise de associação por miscigenação (admixture mapping)

Figura 3 Ancestralidade da população brasileira

Figura 4 Estudo com três amostras de populações brasileiras.

Figura 5 Desenho experimental das coletas do Estudo SABE

Figura 6 Evidências da contribuição genética para a longevidade

Figura 7

Modelo hipotético de dinâmica de biomarcadores e progressão para doença de Alzheimer (DA)

Figura 8 Genes associados à doença de Alzheimer (DA)

Figura 9 Correlação entre resultados dos testes cognitivos 3MS e MMSE

Figura 10 Resultados da avaliação do estado cognitivo por 3MS em função da idade

Figura 11

Figura 12

Redução da espessura cortical com a idade

Figura 13

Figura 14

Figura 15

Figura 16

Figura 17

Figura 18

Figura 19

Modelo teórico para genética da lateralidade Right Shift de Marian Annett (1972)

Dissecção de tratos subcorticais

Representação das divisões de grupos por fenótipos de assimetria dos tratos de substância branca

Redução da assimetria de espessura cortical com o envelhecimento

Histograma de índices de dominância manual

Distribuição de força e habilidade nas mãos esquerda e direita

Tratografia para os sete tratos selecionados por hemisfério de um indivíduo

Histogramas de anisotropia fracionada (FA) média do segmento longo do fascículo arqueado (LS)

Histogramas de anisotropia fracionada (FA) média do segmento anterior do

Figura 20 fascículo arqueado (AS)

Figura 21

Histogramas de anisotropia fracionada (FA) média do segmento posterior do fascículo arqueado (PS)

Figura 22 Histogramas de anisotropia fracionada (FA) média do trato aslant frontal (FAT)

Figura 23 Histogramas de anisotropia fracionada (FA) média do fascículo fronto-occipital inferior (IFOF)

Figura 24

Histogramas de an inferior (ILF)

Figura 25 Histogramas de anisotropia fracionada (FA) média do fascículo uncinado (Unc)

Figura 26 Correlações obtidas a partir de comparação dos tratos extraídos de dez indivíduos

utilizando o método automatizado e individual para seis parâmetros quantitativos

Capítulo Página

I $\quad 21$

II $\quad 36$

39

44

III $\quad 123$

129

132

139

140

140

185

189

194

197

199

200

201

202

202

202

203 


\section{Lista de Tabelas}

Tabelas

Descrição

Medidas coletadas pelo Estudo SABE em cada etapa e número máximo de participantes por medida

Tabela 1

Tabela 2 Distribuição dos indivíduos do projeto SABE por idade

Tabela 3 Distribuição dos indivíduos do projeto SABE por sexo

Tabela 4

Tabela 5

Tabela 6

Tabela 7

Tabela 8

Distribuição dos indivíduos da amostra $80+$ por idade

Distribuição dos indivíduos da amostra $80+$ por sexo

Distribuição dos indivíduos da amostra SABE por idade e RM

Distribuição dos indivíduos da amostra SABE por sexo e RM

Proporção dos indivíduos da amostra SABE com declínio cognitivo por idade

Tabela 9

Proporção dos indivíduos da amostra 80+ com declínio cognitivo por idade

Números de indivíduos $(\mathrm{N})$ por índices de lateralidade (LI) do questionário EHI e frequências

Tabela 10

Tabela 11 Coeficientes de correlação (Pearson) por indivíduo para 14 tratos por cérebro

Tabela 12 para 14 tratos por cérebro

Tabela 13

\section{Capítulo Página}

II 45

47

48

III $\quad 137$

137

137

137

138

138

IV $\quad 198$

206

206

207 


\section{Lista de Anexos}

Anexos

Descrição

Anexo 1

Does germ-line deletion of the PIP gene constitute a widespread risk for cancer? Association between the p27 rs2066827 variant and tumor multiplicity in patients

Anexo 2

Anexo 3

Anexo 4

Anexo 5

Anexo 6

Anexo 7

Anexo 8

Anexo 9

Anexo 10

Anexo 11

Anexo 12

Anexo 13

Anexo 14

Anexo 15

Anexo 16

Anexo 17

$$
\text { harboring MEN1 germline mutations }
$$

p27 variant and corticotropinoma susceptibility: a genetic and in vitro study

Comprehensive assessment of the disputed RET Y791F variant shows no association with medullary thyroid carcinoma susceptibility

A defect in the RNA-processing protein HNRPDL causes limb-girdle muscular

$$
\text { dystrophy } 1 G(L G M D 1 G)
$$

Rare variants in SOS2 and LZTR1 are associated with Noonan syndrome

Schinzel-Giedion Syndrome in two Brazilian patients: report of a novel mutation in SETBPI and literature review of the clinical features

Rare variants in the epithelial cadherin gene underlying the genetic etiology of nonsyndromic cleft lip with or without cleft palate

$$
\text { African ancestry protects against Alzheimer's disease-related neuropathology }
$$$$
\text { Is APOE } \varepsilon 2 \text { always a protective allele? }
$$

Factors associated with lower gait speed among the elderly living in a developing country: a cross-sectional population-based study

Termo de Consentimento Livre e Esclarecido - HIAE Versão em português do Visual Analog Mood State (VAMS)

Questionário geral sobre saúde auto-reportada

Questionário de dominância motora: Edinburgh Handedness Inventory

Questionário de depressão - modelo Beck

Testes de estado cognitivo - 3MS e MMSE
Capítulo Página

II

56

59

67

77

89

97

107

115

III 146

153

158

167

168

169

170

171

174 


\section{Lista de Abreviaturas}

Abreviaturas

\section{Significado}

3MS MMSE expandido

ACTH Hormônio adrenocorticotrófico

AIM Ancestry Informative Marker - Marcador informativo de ancestralidade

APOE Gene codificante da Apolipoproteína E (ApoE)

AS Segmento anterior do fascículo arqueado

AVC Acidente vascular cerebral

A $\beta \quad$ Peptídeo $\beta$-amilóide

BC

Banco de Cérebros (Banco de Encéfalos Humanos do Grupo de Estudos em Envelhecimento

Cerebral da FMUSP)

BWA Burrows-Wheeler Aligner - Alinhador de sequências Burrows-Wheeler

CEGH-CEL Centro de Pesquisas sobre o Genoma Humano e Células-tronco

CEPID Centros de Pesquisa, Inovação e Difusão

DA Doença de Alzheimer

DLB Dementia with Lewy bodies - Demência com corpos de Lewy

DMC Distrofia Muscular de Cinturas

DNA Ácido desoxirribonucléico

DTI Diffusion tensor imaging - Imagem por difusão

DWI Omagem ponderada de difusão

EHI Edinburgh Handedness Inventory - Questionário de dominância manual Edinburgh

ELA Esclerose lateral amiotrófica

EPIGEN Genomic Epidemiology of Complex Diseases in Population-based Brazilian Cohorts

FA Anisotropia fracionada

FAPESP Fundação de Amparo à Pesquisa do Estado de São Paulo

FAT Trato frontal Aslant

FDA US Food and Drug Administration

FMUSP Faculdade de Medicina da USP

FTLD Frontotemporal lobal dementia - Demência dos lobos frontotemporais

GATK Genome Analysis Toolkit - Ferramentas para análise genômica

GWAS Genome-wide association study - Estudo de associação por varredura genômica

HapMap International HapMap Project - Projeto internacional de mapeamento de haplótipos

HAROLD Hemispheric Asymmetry Reduction in OLDer adults - Redução da assimetria hemisférica em idosos

HDL High density lipoproteins - Lipoproteínas de densidade alta

HGMD Human Gene Mutation Database

HGSC International Human Genome Sequencing Consortium

HIAE Hospital Israelita Albert Einstein

HLA Human Lymphocyte Antigen - Antígeno de linfócitos humanos

HWE Hardy-Weinberg equilibrium - Equilíbrio de Hardy-Weinberg

IBD Identity by descent - Identidade por descendência

IFOF Fascículo fronto-occipital inferior

IIEPAE Instituto Israelita de Ensino e Pesquisa Albert Einstein

IL28B Gene interferon lambda3

ILF Fascículo longitudinal inferior

IRB Institutional Review Board

LI Índice de lateralidade 


\begin{tabular}{|c|c|}
\hline LLA & Leucemia linfóide aguda \\
\hline LS & Segmento longo do fascículo arqueado \\
\hline MAF & Minor allele frequency - Frequência do alelo mais raro \\
\hline MCI & Mild cognitive impairment - Declínio cognitivo leve \\
\hline MD & Difusibilidade média \\
\hline MEN1 & Neoplasia Endócrina Múltipla tipo 1 \\
\hline МHC & Major Histocompatibity Complex - Complexo principal de histocompatibilidade \\
\hline MMSE & Mini-mental State Examination - Mini-exame do estado mental \\
\hline atBrainLab & Neuroanatomy and Tractography Laboratory, King's College London \\
\hline NHGRI & National Human Genome Research Institute \\
\hline NMDA & N-metil D-aspartato \\
\hline NS & Síndrome de Noonan \\
\hline OMIM & Online Mendelian Inheritance in Man \\
\hline OR & Odds Ratio - Razão de chances \\
\hline PCA & Principal Component Analysis - Análise de componentes principais \\
\hline PCR & Polymerase Chain Reaction - Reação em cadeia da polimerase \\
\hline PRDM9 & Gene \\
\hline PS & Segmento posterior do fascículo arqueado \\
\hline REAP & Relatedness Estimation in Admixed \\
\hline $\mathbf{R M}$ & Ressonância Magnética \\
\hline RNA & Ácido ribonucléico \\
\hline ROI & Region of interest - Região de interesse \\
\hline RS & Right Shift theory - Teoria de desvio à direita (Marian Annett) \\
\hline rsfMRI & Ressonância magnética funcional em estado de repouso \\
\hline SABE & Estudo Saúde, Bem Estar e Envelhecimento \\
\hline SCAALA & Social Changes, Asthma and Allergy in Latin America Programme \\
\hline SGS & Síndrome de Schinzel-Giedion \\
\hline SKAT & $\begin{array}{l}\text { SNP-set (Sequence) Kernel Association Test - Teste de associação de conjuntos de SNPs/sequências } \\
\text { por padrões }\end{array}$ \\
\hline SNP & Single Nucleotide Polymorphism - Polimorfismo de base única \\
\hline SSJ & Síndrome de Stevens-Johnson \\
\hline SVOC & Serviço de Verificação de Óbitos da Capital \\
\hline $\operatorname{tagSNP}$ & SNP representante de bloco haplotípico \\
\hline TUG & Time Up and Go - Teste de velocidade de marcha \\
\hline Unc & Fascículo uncinado \\
\hline USP & Universidade de São Paulo \\
\hline VAMS & Visual Analog Mood Scale - Escala de humor por avaliação visual \\
\hline VEGF & Vascular endothelial growth factor - Fator de crescimento vascular endotelial \\
\hline VLDL & Very low density lipoproteins - Lipoproteínas de densidade muito baixa \\
\hline WMA & World Medical Association \\
\hline
\end{tabular}




\section{Sumário}

\section{Capítulo I}

Genômica no contexto populacional

1. Sequenciamento do genoma humano

2. Variabilidade genômica

3. Ancestralidade e miscigenação

4. Implicações da miscigenação

5. Considerações finais

6. Referências bibliográficas

População brasileira: oportunidades para estudos genômicos

1. Introdução

1.1. Composição da população brasileira

1.2. Estudos de genômica populacional no Brasil

1.2. Bancos de dados locais para referência em variabilidade genômica 39

2. Objetivo

3. Amostras, métodos e colaborações

3.1. Amostra do Estudo SABE

3.2. Amostra 80+

3.3. Processamento de DNA

3.4. Aplicação dos dados e colaborações

4. Resultados e discussão

5. Considerações finais e perspectivas

6. Referências bibliográficas

Anexos do Capitulo II

Envelhecimento e neurogenética

1. Introdução

1.1. A urgência de pesquisas Envelhecimento

1.2. Conceitos biológicos

1.3. Envelhecimento cerebral

1.4. Demências

2. Objetivo

3. Amostras e métodos

3.1. Amostra 80+

3.2. Amostra Banco de Cérebros

3.3. Processamento do DNA

3.4. Ressonância magnética do cérebro 
3.5. Questionários

3.6. Testes cognitivos e funcionais

4. Resultados e discussão

5. Considerações finais e perspectivas

6. Referências bibliográficas

\section{Capítulo IV}

Lateralidade cerebral

1. Introdução

1.1. Dominância motora e de linguagem

1.2. Bases neurológicas da lateralidade cerebral

1.3. Consequências da lateralização e do desvio em humanos 180

$\begin{array}{lr}\text { 1.4. Genética da lateralidade cerebral } & 182\end{array}$

1.5. Fascículo arqueado: dissecção virtual $\quad 188$

2. Objetivo

3. Amostra e métodos

3.1. Amostra SABE e 80+

3.2. Diffusion Tensor Imaging (DTI): dissecção de tratos e fascículos

3.3. SNP-set Kernel Association Test (SKAT)

3.4. Outras medidas de lateralização

4. Resultados e discussão

4.1. Redução da assimetria cortical

4.2. Distribuição de medidas de lateralização funcional

4.3. Dissecção automatizada

4.4. Dissecção manual: validação

4.5. Associação entre genes candidatos e índices de lateralidade

5. Considerações finais e perspectivas

6. Referências bibliográficas 
Capítulo I

\section{Genômica no contexto populacional}

1. Sequenciamento do genoma humano

As ciências biológicas vivem um momento de revolução. Áreas de estudos cujas denominações se encerram em "-ômica" correspondem a um dos maiores desafios científicos já propostos na biologia: genômica, transcriptômica, epigenômica, proteômica e metabolômica se propõem a cavar profundamente a complexidade de cada nível dos sistemas biológicos, acima representados pelo dogma da biologia molecular, mas não restritos a ele. $\mathrm{O}$ obstáculo inicial da geração dos dados, incluindo os custos envolvidos, a padronização de técnicas moleculares e até a análise primária, vem sendo transposto num passo rápido.

Para exemplificar este cenário, exponha-se a genômica. O Projeto Genoma Humano, como ficou apelidado o esforço empenhado pelo International Human Genome Sequencing Consortium (HGSC), componente multi-institucional e de base fundamentalmente pública, e Celera Genomics, time corporativo e financiado pela iniciativa privada, foi anunciado em 2001 após 11 anos do início e US\$ 3 bilhões (Lander et al., 2001; Venter et al., 2001). A versão publicada então correspondia a uma análise parcial, a qual foi complementada em 2003.

A metodologia utilizada pelo time da Celera Genomics foi aplicada à, como ficou conhecida na época, "corrida genômica" com o objetivo duplo de redução dos custos e do tempo de projeto. A proposta de US\$ 300 milhões em três anos, apesar de ambiciosa, ofereceu a sistematização no processo de sequenciamento e, de fato, acelerou a completude do projeto. A abordagem utilizada pela corporação, o whole-genome shotgun, baseada na fragmentação aleatória de todo o genoma e sequenciamento dos fragmentos para posterior reposicionamento ordenado, porém era insuficiente para reconstituir os grande blocos cromossômicos. Este esforço foi complementado pela abordagem utilizada no consórcio público, o qual mapeava as posições genômicas através do sequeciamento ordenado de grandes fragmentos orientados, 
conhecido como map-based ou hierarchical shotgun sequencing. O rascunho do genoma humano publicado em 2001 foi o marco para a ciência, tanto na geração do conhecimento primordial em genômica humana, como na geração de novas tecnologias, no questionamento ético e na discussão legislativa acerca do tema. (Lander et al., 2001; Venter et al., 2001)

Algumas constatações, no entanto, funcionaram como quebra de paradigmas bastante estabelecidos na genética e bioquímica. Imediatamente verificou-se que a espécie humana teria cerca de 25 mil genes ou menos, apenas $20 \%$ do estimado previamente. Esta constatação permite a inferência que a complexidade dos processos de diversificação funcional é maior do que o previsto até então, uma vez que a variabilidade transcriptômica e proteômica situa-se a, ao menos, uma ordem de grandeza acima. Ou seja, os mecanismos que permitem a transferência de informação entre o que está codificado no genoma e os produtos finais são mais frequentes e complexos do que a simples correlação direta "um gene-uma proteína". (Venter et al., 2001)

A metodologia utilizada por ambas as iniciativas do Projeto Genoma Humano iniciava-se com a seleção dos doadores de DNA, cuja inclusão baseava-se em aprovação por comitês de ética conduzida por recomendações da World Medical Association (WMA) através da Declaração de Helsinki corrente e análise por comitês revisores institucionais (Institutional Review Boards ou IRBs). (Dove, 1999; Lander et al., 2001; Venter et al., 2001). A seleção também objetivava balancear o número de doadores do sexo masculino e feminino, e de origens étnicas (auto-declaradas) distintas. Por fim, o DNA de 21 voluntários foi utilizado no esforço privado e de um número não declarado foi utilizado no esforço público o que já permitiria a inferência de algum grau de variabilidade genômica. (Lander et al., 2001; Venter et al., 2001) Este número, limitado particularmente pelos custos do sequenciamento e capacidade de análise, seria, no entanto, aquém do suficiente para constituir um genoma de referência em sua plena aplicação, uma vez que não refletia a variabilidade populacional das principais ramificações étnicas. A função inquestionável do sequenciamento do genoma humano se revelaria, portanto, na formação de um rascunho básico sobre o qual muitos níveis de informação seriam adicionados nas décadas seguintes.

\section{Variabilidade genômica}

A variação genética humana pode ser definida pela frequência de polimorfismos, que pode variar bastante entre populações; e pelo tamanho das variantes, que pode informar com algum 
grau de confiabilidade um efeito deletério. As técnicas utilizadas para detectar e investigar a natureza das variantes são dependentes de algumas características: o sequenciamento completo do genoma humano, apesar de cobrir grande parte das variantes, não é um método eficiente para detectar grandes deleções em heterozigose, por exemplo. Repetições longas (com múltiplas cópias), a exemplo das repetições de hexanucleotídeos da C9ORF72 associadas a formas esporádicas de Esclerose Lateral Amiotrófica (Dejesus-Hernandez et al., 2011) ainda são um desafio técnico.

Curiosamente, a diferença média estimada entre dois indivíduos humanos é de menos de $0,5 \%$ e o tipo de variante mais comumente responsável por esta diferença é o polimorfismo de base única (SNP), onde um único nucleotídeo varia entre dois indivíduos para uma mesma posição. A frequência do alelo mais raro (minor allele frequency - MAF) é, por definição estrita, maior que $1 \%$ (polimorfismos menos frequentes são comumente denominados "variantes raras", e podem chegar a frequencia de apenas um indivíduo). Estima-se que em torno de 10 milhões de SNPs tenham MAF maior que 1\%, dos quais 5 milhões sejam mais frequentes que $10 \%$. Calcula-se que $85 \%$ dos 1,5 milhões de SNPs com MAF maior que 20\%, sejam comuns a todas as populações humanas. O restante dos SNPs frequentes, no entanto, parecem variar especificamente em cada tronco populacional (Khoury et al.).

Para investigar o papel da genética nas doenças humanas, o primeiro passo após o sequenciamento do genoma humano foi o desenvolvimento de um panorama de variação genética comum. Um dos marcos mais relevantes foi a caracterização dos haplótipos comuns, inicialmente a três grandes populações continentais, no International HapMap Project (International Hapmap), uma base de dados pública para guiar estudos de genética em características humanas, inclusive doenças. Esta iniciativa vem contribuindo para o mapeamento das variações comuns nas populações, sendo o tipo mais comum os polimorfismos de base única (SNPs), e seus padrões de distribuição ao longo do genoma através da determinação dos haplótipos em desequilíbrio de ligação (fenômeno em que dois locos são encontrados juntos numa frequência maior do que o esperado pela distribuição independente de cada um). Tal mapeamento foi a base para estudos de associação por varredura genômica, ou genome-wide association studies (GWAS), os quais já identificaram centenas de locos novos associados a doenças e tratos humanos (Khoury et al., 2004; Manolio et al., 2008).

Dentre os 10 milhões de SNPs com frequência maior que 1\% ao longo do genoma, ou seja, em média um a cada 300 bases, metade tem frequência maior que $10 \%$ e mais de 100 mil SNPs parecem ser específicos de alguma grande população. Apesar de os custos de 
genotipagem e sequenciamento estarem em plena queda, é inviável determinar todo o conjunto de variantes para indivíduos em projetos de GWAS uma vez que estes estudos requerem um número amostral da ordem de dezenas de milhares de indivíduos. Tradicionalmente, os estudos de genética que identificaram os primeiros fatores que contribuem com doenças focalizavam nas variantes que segregavam em famílias afetadas. Variantes estas que exerciam um grande efeito, muitas vezes interferindo em importantes vias proteicas e causando as doenças genéticas graves. Este padrão de herança, conhecido como padrão monogênico ou Mendeliano, explica as doenças mais raras - muitas vezes poucas famílias no mundo são afetadas - e serviu para identificar a função (normal e patológica) de diversos genes. No entanto, hipotetiza-se que as características de doenças complexas, mais comuns nas populações, sejam majoritariamente influenciadas por múltiplos genes e fatores ambientais, em que cada variante contribui com um efeito de baixo a moderado e, dessa forma, exigem estudos com mais participantes.

Um dos objetivos do HapMap é mapear não apenas os SNPs de diferentes populações, mas também estimar suas frequências e sua agregação em blocos haplotípicos através da medida de desequilíbrio de ligação. SNPs físicamente próximos no genoma tendem a ser herdados juntos numa frequência superior à esperada pela mera distribuição randômica, exceto quando são separados por uma região de recombinação preferencial (hot spots de recombinação) ou indetectáveis por conversão gênica, fenômeno decorrente do mecanismo de recombinação e cuja ocorrência vem sendo verificada com mais precisão recentemente (Strachan et al.).

Dessa maneira, é possível identificar blocos do genoma (haplótipos) que contem determinadas combinações de SNPs e realizar a genotipagem de apenas alguns SNPs por bloco (tagSNP). Este bloco é população dependente, aumenta de tamanho conforme o nível do grupo se aproxima do indivíduo (populações tem blocos menores que comunidades e famílias) e diminui de tamanho com a idade da população de origem (populações mais antigas, ou seja, com mais gerações, foram sujeitas a mais eventos de recombinação e mutação) (Ardlie et al., 2002). A figura 1-A ilustra uma mutação ancestral em um bloco com recombinações adjacentes. 


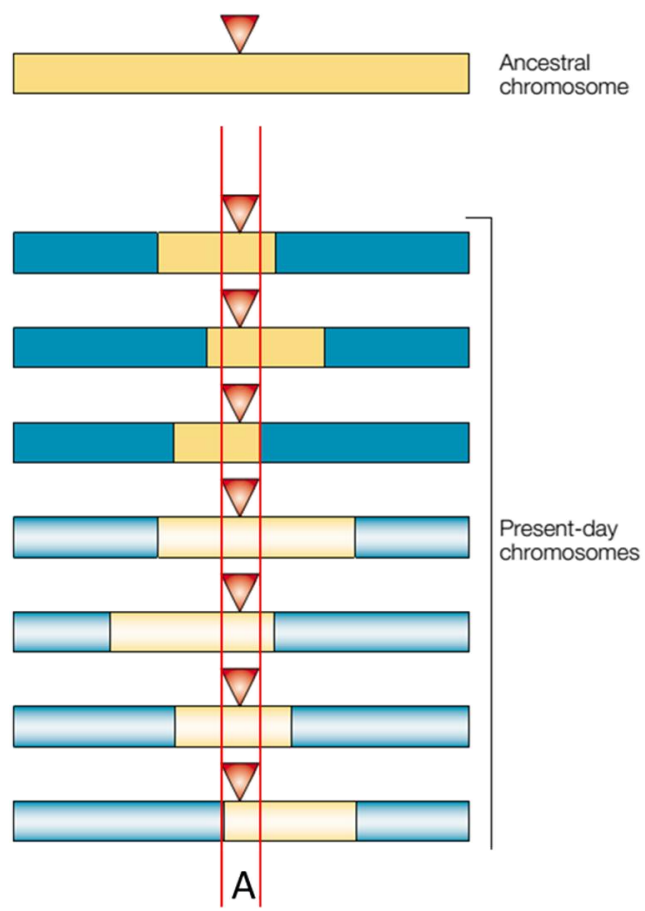

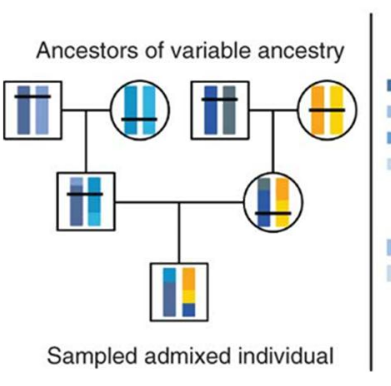

B

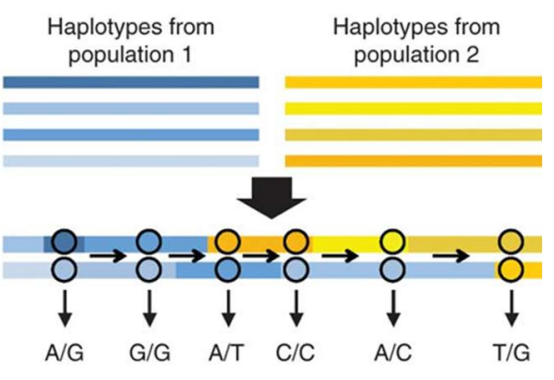

C

Figura 1. Representação de haplótipos. Uma mutação indicada por um triângulo vermelho em (A) pode ser detectada em GWAS onde um tagSNP do trecho entre faixas vermelhas é genotipado (sobreposição). Os blocos haplotípicos em amarelo refletem a combinação ancestral, que foi parcialmente perdida ao longo das gerações através de recombinação. (Adaptado de Ardlie, 2002). (B) e (C) representam o cenário de miscigenação, nos quais segmentos cromossômicos de diferentes origens resultam em haplótipos reduzidos. (Adaptado de Wegmann, 2011).

\section{Ancestralidade e miscigenação}

As implicações dos blocos haplotípicos, SNPs em desequilíbrio de ligação, os quais variam de tamanho de acordo com a região genômica e com a população, são identificadas, em particular, nos estudos de associação realizados em populações miscigenadas. A história de formação de cada população como, por exemplo a ocorrência de efeito fundador ou expansões, ou ainda o arranjo de miscigenação que é variável e dependente dos padrões culturais específicos de cada população irão determinar a arquitetura genômica e devem ser levados em consideração em estudos epidemiológicos. A prioridade de pesquisa em mapear haplótipos específicos de cada população é reconhecida desde as primeiras tentativas de estabelecer os padrões de desequilíbrio de ligação. Modelos demográficos das expansões e contrações populacionais, interações sociais em conjunto com o conhecimento dos mecanismos moleculares que regem a conversão gênica e os pontos de recombinação preferencial, forças de seleção positiva, negativa e balanceadora são essenciais para entender a 
dinâmica de formação dos blocos em desequilíbrio de ligação e a função dos padrões de variabilidade ali encontrados (Ardlie et al., 2002).

A primeira fase do HapMap Project trouxe os dados genotípicos de aproximadamente três milhões de SNPs de uma amostra baseada em quatro populações e 270 indivíduos. Uma questão relevante levantada a partir disto e parcialmente atendida nas fases seguintes da iniciativa, e em outros projetos recentes de grande porte diz respeito à capacidade de realizar estudos de associação entre genótipos e fenótipos. Como o poder estatístico é afetado quando os tagSNPs (polimorfismos representativos de um bloco haplotípico) são selecionados de um painel de referência mas genotipados em uma amostra de outra população? Ou seja, a imputação das variantes não genotipadas a partir dos tagSNPs funcionaria para outras populações?

Em um primeiro estudo do gênero realizado por Debakker e cols. (2006), apenas com SNPs comuns (MAF > 5\%), observou-se que os tagSNPs de referência foram capazes de manter poder estatístico inferencial em níveis esperados $(>85 \%)$, porém reduzido quando amostras de populações de origem africana eram incluídas (mesmo quando testadas em conjunto com a população de origem africana do HapMap). Esta redução de poder estatístico foi compensada com a adição de mais tagSNPs, porém observou-se neste estudo que a seleção de tagSNPs poderia ser mais eficiente se for incorporado conhecimento sobre a ancestralidade das amostras. Demonstrou-se, portanto, que, ao menos para SNPs comuns, a estratégia de tagSNPs amplamente favorecida pelo HapMap é robusta para transferência entre populações, com pouca perda de poder estatístico (De Bakker et al., 2006). Permanecem, no entanto, as limitações para populações com distanciamento ou miscigenação em relação aos parentais incluídos na fase inicial do HapMap, em conjunto com as observações sobre ancestralidade demonstradas no trabalho de De Bakker e cols. (2006), que incluiu populações de etnia autodeclarada.

Indivíduos de populações recentemente miscigenadas tem, por definição, seus ancestrais de duas ou mais populações divergentes e, portanto, seus cromossomos são mosaicos de segmentos de diferentes origens (figura 1-B). Métodos para mapear as taxas de recombinação foram desenvolvidos inicialmente para populações não-miscigenadas, baseados em núcleos familiares a partir dos quais é possível inferir o número de meioses e os pontos de recombinação. Os esforços para obtenção de um mapa de recombinação de populações miscigenadas se iniciaram em 2011 a partir de uma amostra composta por norte-americanos de origem africana e caribenhos de origem africana, com a criação de um método baseado na identificação de "interruptores de ancestralidade" (ancestry-switches), os quais marcam os 
eventos de recombinação que ocorreram entre cromossomos parentais de diferentes origens. Era previsto que eventos identificáveis por estes "interruptores" seriam um sub-conjunto aleatório de todos os eventos de recombinação e não haveria padrões específicos de locais de recombinação preferencial diferentes para populações miscigenadas. De fato, observou-se correspondência entre os mapas para localização de eventos de recombinação para estas populações e outras não-miscigenadas, além de uma baixa sensibilidade de detecção de distorções locais causadas por desequilíbrio de ligação (Wegmann et al., 2011). A taxa média de recombinação geral entre estas populações e as populações de origem europeia ou africana variam sutilmente, uma medida que provavelmente é decorrente de ruído metodológico. Curiosamente, na escala individual, as médias de recombinação nos americanos de origem africana parecem estar em um nível intermediário entre africanos e europeus, numa proporção que se aproxima do coeficiente médio de ancestralidade (por exemplo, $80 \%$ africano e $20 \%$ europeu). Observou-se também que grandes eventos cromossômicos, em particular inversões, são críticos para mudanças locais de taxa de recombinação. Este estudo também notou que há consistência nos padrões de recombinações mediados por PRDM9, um modificador epigenético que participa do mecanismo de recombinação meiótica e que foi diferenciado na divergência de populações europeias e africanas (Wegmann et al., 2011). No caso dos indivíduos miscigenados, onde a frequência de heterozigotos para este gene é maior do que nas populações parentais, os indivíduos podem apresentar padrões intermediários de recombinação e a variabilidade deste processo é provavelmente causada por outros modificadores (Berg et al., 2010).

A verificação das frequências de variantes não sinônimas putativamente deletérias é relevante em populações miscigenadas, uma vez que maiores proporções genômicas com ancestralidade africana contribuem para uma menor distribuição de variantes deletérias em homozigose. Sugere-se que esse efeito seja decorrente do movimento de migrações dos primeiros humanos para fora do continente africano (modelo Out of Africa), o qual reduziu a diversidade genética pelo fenômeno de bottleneck, quando uma subpopulação migra e carrega apenas parte da diversidade para outra região geográfica isolada. A dinâmica decorrente de um episódio de bottleneck seguida de uma rápida expansão no tamanho populacional (o que estima-se que ocorreu com os humanos nas diversas migrações da África para a Europa, em particular nos últimos milhares de anos) pode elevar as frequências de mutações deletérias, em especial as fracamente deletérias. Como resultado, a deriva genética passa a ser uma força evolutiva mais relevante do que a eventual seleção natural negativa, em variantes de maior frequência. O padrão de distribuição dos alelos deletérios entre homozigotos e heterozigotos 
pode influenciar a carga genética e agir como fatores de risco em diferentes ambientes (diminuidores de fitness) em populações com histórias naturais distintas (Lohmueller, 2014).

Desde o final dos anos 1980, desenvolveram-se métodos para agregar a estudos de associação entre variantes genômicas e doenças ou tratos complexos o conhecimento sobre a miscigenação genômica (Chakraborty e Smouse, 1988), seguido de contribuições importantes mais recentes após a revolução genômica (Patterson et al., 2004). Em genética de plantas e de animais, particularmente em espécies de organismos-modelo, as linhagens encontradas com fenótipos pouco usuais e de herança complexa são estudadas com cruzamentos com outras linhagens que não os carregam. Evidentemente que na espécie humana tais experimentos não são eticamente praticáveis, no entanto utilizar-se do conhecimento acerca de movimentos populacionais, migrações recentes e miscigenação entre populações (até então isoladas por muitas gerações) poderia de forma análoga contribuir para avaliar a associação entre variantes genômicas e tratos complexos, de prevalências variáveis de acordo com a população de origem. A figura 2 exemplifica de forma simplificada como tal análise é realizada. Exemplos de fenótipos frequentemente encontrados em populações específicas vão desde artrite reumatoide em indígenas americanos, esclerose múltipla e câncer de pele em caucasianos, diabetes em polinésios e hipertensão e câncer de próstata em negros africanos. Com tais informações de prevalências população-específicas, um desenho experimental para esclerose múltipla, por exemplo, dependeria da análise dos pacientes afro-americanos com proporções variáveis de genomas caucasianos (Patterson et al., 2004). 


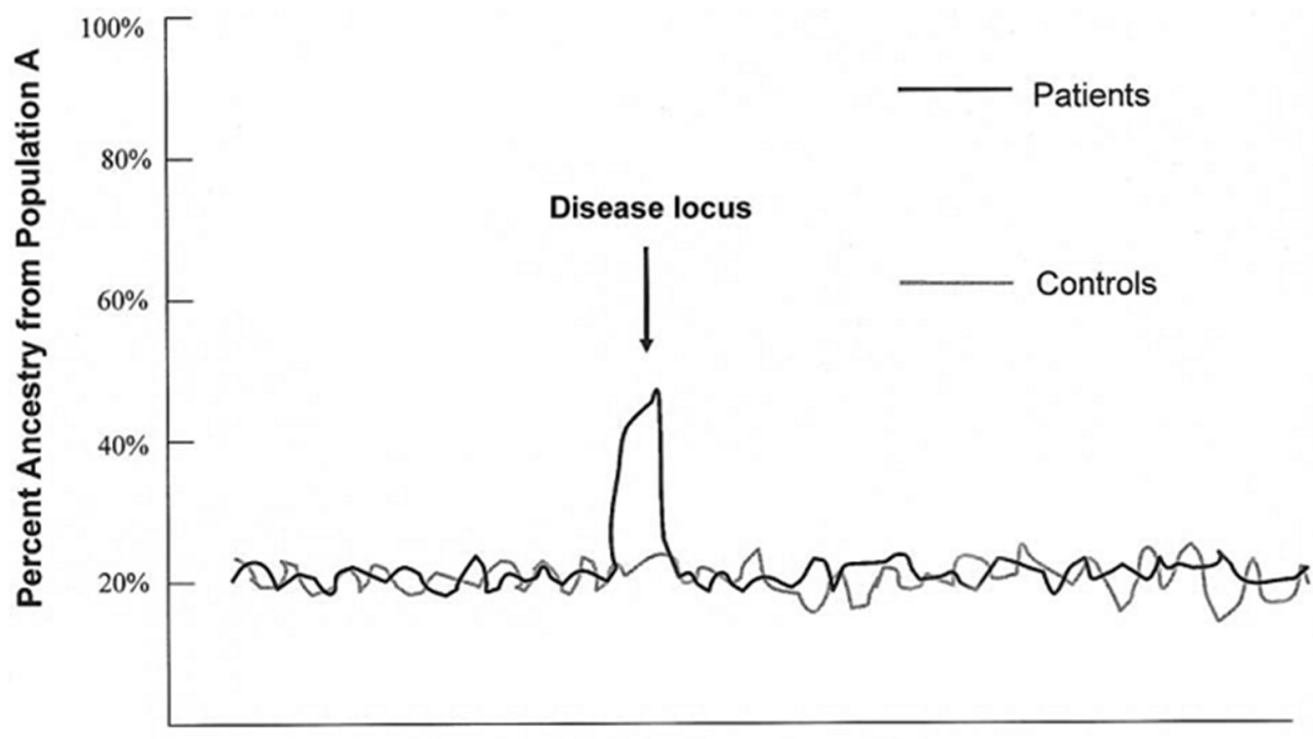

A

\section{Chromosome position (Centimorgans)}
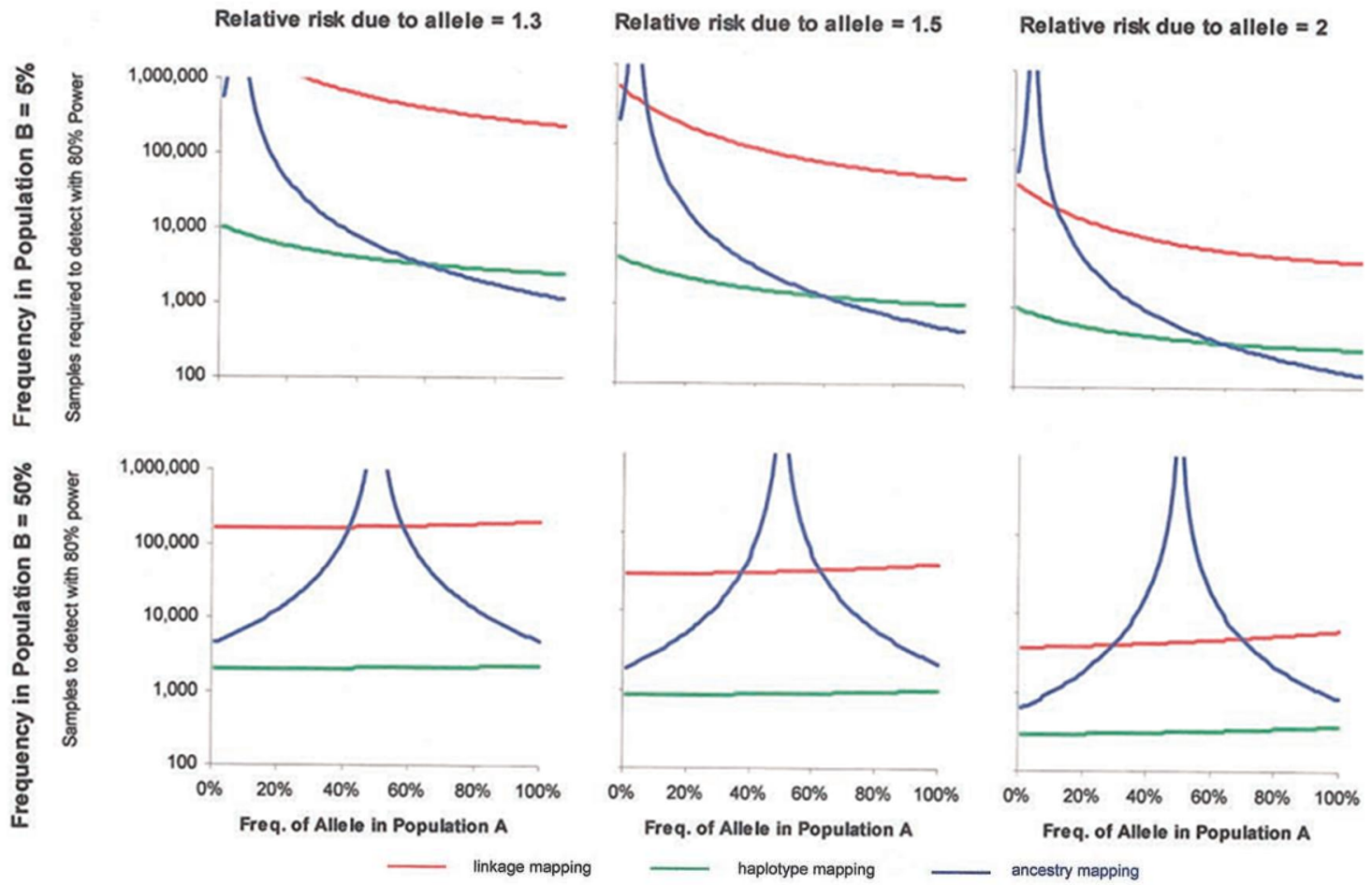

B

Figura 2. Análise de associação por miscigenação (admixture mapping). Em (A), coloca-se um exemplo putativo de como um loco associado a doença aparecerá numa análise de mapeamento por miscigenação. Em torno do loco, uma proporção mais alta que o esperado de ancestralidade originada de uma das populações parentais, partindo da hipótese de herança da região pelos pacientes. A largura do pico é determinada pelo número de gerações desde a miscigenação. Em (B), a estimativa de poder de detecção de um loco associado à doença, variando com a frequência do alelo numa população A em seis cenários: três riscos relativos $(1.3,1.5$ e 2) e duas frequências do alelo na população B. Estas simulações mostram que menos indivíduos são necessários para detectar através de mapeamento por ancestralidade do que por linkage, e em algumas situações, a vantagem é observável também em relação a estudos de associação tradicional com haplótipos (por análise de desequilíbrio de ligação, requerendo mais marcadores). Retirado de Patterson e cols., 2004. 


\section{Implicações da miscigenação}

Como mencionado anteriormente, a maior parte dos estudos de associação por varredura genômica incluíram amostras de populações europeias. Este viés não foi casual, uma vez que o objetivo era minimizar a variabilidade relacionada à ancestralidade a fim de evitar a superestimativa de sinais falso-positivos de associação decorrentes de estratificação populacional. Este fenômeno, típico de estudos caso-controle, consiste na presença de subgrupos com diferentes frequências dentro dos grupos assinalados como casos e controles. Os subgrupos comumente são compostos por diferentes etnias, mas nem sempre a ancestralidade é o parâmetro que explica a estratificação populacional. O risco de não levar em consideração estas subdivisões é o de associar espuriamente variantes cuja segregação se dá por outras características que não o fenótipo ou trato estudado (Foulkes, 2009). Por outro lado, métodos estatísticos que levem em consideração tais diferenças de frequências e mapas de blocos de desequilíbrio de ligação população-específica auxiliam a identificação de regiões associadas a fenótipos e como o background genético (associado a ancestralidade ou a eventos populacionais daquele grupo estudado) pode modificar o grau ou mesmo a natureza da associação.

A disparidade entre o número de estudos realizados com populações de origem europeia foi comentada por Need e Goldstein (2009), em um estudo descritivo que expõe o risco da não representatividade de populações parentais, ou mesmo miscigenadas, em particular num período de integração e movimento global, cuja dinâmica de populações caminha claramente para um maior grau de miscigenação. Este desvio pode acarretar graves consequências para a interpretação de dados clínicos e políticas públicas. Um exemplo é o tratamento de hepatite C crônica que tem menor eficiência em norte-americanos afrodescendentes do que em norteamericanos de origem europeia devido a diferentes frequências alélicas no interferon lambda3 (IL28B). O alelo de maior responsividade ao tratamento é encontrado em menor frequência em afrodescendentes. Curiosamente, neste mesmo grupo, aqueles que são portadores homozigotos desta variante apresentam maior responsividade ao tratamento que os portadores dos genótipos menos responsivos mas de outra origem, inclusive europeia, ilustrando a complexidade da relação entre frequência de variantes (influenciando um efeito populacional aos tratamentos) e a interação entre locos (afrodescendentes carregam outras variantes que em combinação podem mudar a direção da eficiência deste tratamento) (Ge et al., 2009). 
Um segundo exemplo é uma variante HLA-B*1502 da classe I B dos antígenos de linfócitos humanos (HLA), o qual está associado à síndrome de Stevens-Johnson (SSJ), uma resposta cutânea a certas drogas como a carbamazepina, utilizada em tratamento de epilepsia. A variante foi descrita inicialmente em chineses, onde a frequência se aproxima a $100 \%$ em alguns grupos de pacientes com SSJ causada por carbamazepina, em relação a $8 \%$ da população geral ou 3\% dos tolerantes à droga (Chung et al., 2004). Outras variantes podem ser responsáveis por causar tal reação em pacientes de origem europeia. Esta distribuição levou o US Food and Drug Administration (FDA) a elaborar um protocolo de triagem de HLA para todos os pacientes asiáticos antes de se prescrever carbamazepina, mas não para pacientes não-asiáticos. A recomendação é um avanço importante para políticas públicas de direcionamento da eficiência no uso de drogas e manejo de possíveis respostas adversas, porém traz considerações práticas sobre o que qualifica alguém a fazer parte de um grupo ou não (Ferrell e Mcleod, 2008).

A farmacogenética e, mais recentemente, a farmacogenômica são áreas de investigação do efeito da variação genética em parâmetros de farmacocinética, farmacodinâmica, efeitos colaterais de fármacos e, em escala populacional, da distribuição desta variação em grupos populacionais que irão consumir fármacos. O impacto da miscigenação populacional na farmacogenômica é um assunto de grande interesse, uma vez que a maioria das populações do mundo vem aumentando o grau de mistura entre origens e boa parte das populações miscigenadas estão em localidades de alta densidade populacional e número de indivíduos.

Suarez-Kurtz (2005) publicou uma breve revisão comentando, para populações miscigenadas, das diferenças em frequências alélicas em genes associados a processos de absorção e disponibilização orgânica de fármacos. Por exemplo, a enzima tiopurina Smetiltransferase (codificada pelo gene TPMT), cuja função é degradar antimetabólitos de purina (como 6-mercaptopurina e azatioprina) utilizados em tratamento de leucemia linfóide aguda (LLA) em crianças. As variantes desta enzima influenciam sua atividade e, portanto, capacidade de processar tais fármacos, com consequências na eficiência do tratamento. A genotipagem de TPMT pré-tratamento de LLA já é comum em diversos centros pediátricos. A distribuição das frequências destes alelos de TPMT com função conhecida sobre a atividade varia dentro de e entre populações distintas, a exemplo de TPMT*3C que varia entre 0,2 e 0,8\% em europeus e 5,4 e 7,6\% em quenianos (Suarez-Kurtz, 2005).

O autor discute que é essencial mapear a estrutura populacional para dissociar as influências ambientais e de composição genômica variável sobre o efeito de um (ou um conjunto de) polimorfismos na farmacodinâmica e farmacocinética. No entanto, populações 
recentemente miscigenadas com diferentes fenótipos associados à farmacologia podem contribuir com o conhecimento acerca da fisiopatologia das doenças (Suarez-Kurtz, 2005). Os polimorfismos em $C Y P 2 A 6$, por exemplo, interferem no catabolismo da nicotina, uma das principais causas de dependência em tabagistas e foram estudados em brasileiros (Vasconcelos et al., 2005). A probabilidade de dependência para portadores do alelo $C Y P 2 D 6^{*} 1 B$, em uma ou duas cópias é de 3 a 14 vezes menor comparado com homozigotos para o alelo selvagem, e este padrão é observável apenas em indivíduos auto-declarados como brancos. Apesar de não ser um estudo controlado para ancestralidade genética, é uma observação que pode apontar para a influência da miscigenação populacional sobre um "fenótipo farmacológico".

A oportunidade de estudar populações miscigenadas se reflete na tendência de que as estruturas sociais se modifiquem dentro de um curto intervalo de tempo, mesmo em localidades tradicionalmente pouco miscigenadas (como países desenvolvidos); e em sociedades já miscigenadas, cuja mudança se apresenta em escala de tamanho populacional e inclusão social. Compreender as diferentes estruturas populacionais e como tais composições interferem no risco a doenças e dinâmica farmacogenômica é, simultaneamente, um desafio dada a complexidade e especificidade de variáveis e uma necessidade urgente (Suarez-Kurtz et al., 2012).

Os dados expostos acima são exemplos do quão importante é agregar a discussão sobre ancestralidade e miscigenação em estudos de genômica e, posteriormente, sua tradução para informações clínicas, procedimentos e até recomendações de políticas públicas.

\section{Considerações finais}

O esforço para sequenciamento do genoma humano permitiu a construção da primeira referência completamente mapeada das posições e constituição dos genes. No entanto, o desafio de investigar a variabilidade genética humana e sua influência nos fenótipos normais e patológicos persiste. Num aspecto global, compreender as diferenças entre as populações humanas pode auxiliar em diversos aspectos os estudos de associação para descobertas de genes, através do mapeamento de blocos haplotípicos e, consequentemente, inferência de genótipos e também na análise de associação por miscigenação (admixture mapping). $\mathrm{O}$ interesse não se limita à compreensão das dinâmicas populacionais ou mesmo evolução da espécie humana, mas também à aplicação clínica para a conduta de diferentes opções de 
tratamentos ou diagnósticos baseados na interação entre os genótipos de risco e a ancestralidade.

Nesse sentido, estudar populações miscigenadas pode oferecer uma oportunidade para a comunidade científica avançar com o conhecimento sobre o genoma humano. O caso da população brasileira será tratado no próximo capítulo. 


\section{Referências bibliográficas}

ARDLIE, K. G.; KRUGLYAK, L.; SEIELSTAD, M. Patterns of linkage disequilibrium in the human genome. Nat Rev Genet, v. 3, n. 4, p. 299-309, 2002.

BERG, I. L. et al. PRDM9 variation strongly influences recombination hot-spot activity and meiotic instability in humans. Nat Genet, v. 42, n. 10, p. 859-63, 2010.

CHAKRABORTY, R.; SMOUSE, P. E. Recombination of haplotypes leads to biased estimates of admixture proportions in human populations. Proc Natl Acad Sci U S A, v. 85, n. 9, p. 3071-4, 1988.

CHUNG, W. H. et al. Medical genetics: a marker for Stevens-Johnson syndrome. Nature, v. 428, n. 6982, p. 486, 2004.

DE BAKKER, P. I. et al. Transferability of tag SNPs in genetic association studies in multiple populations. Nat Genet, v. 38, n. 11, p. 1298-303, 2006.

DEJESUS-HERNANDEZ, M. et al. Expanded GGGGCC hexanucleotide repeat in noncoding region of C9ORF72 causes chromosome 9p-linked FTD and ALS. Neuron, v. 72, n. 2, p. 245-56, 2011.

DOVE, A. WMA to revise medical research guidelines. World Medical Association. Nat Med, v. 5, n. 6, p. 598, 1999.

FERRELL, P. B., JR.; MCLEOD, H. L. Carbamazepine, HLA-B*1502 and risk of Stevens-Johnson syndrome and toxic epidermal necrolysis: US FDA recommendations. Pharmacogenomics, v. 9, n. 10, p. 1543-6, 2008.

FOULKES, A. S. Applied statistical genetics with R : for population-based association studies. New York: Springer Verlag, 2009. xxiii, 252 p. ISBN 97803878955360387895531.

Disponível em: http:/www.loc.gov/catdir/enhancements/fy0913/2009284624-d.html

GE, D. et al. Genetic variation in IL28B predicts hepatitis C treatment-induced viral clearance. Nature, v. 461, n. 7262 , p. 399-401, 2009.

INTERNATIONAL HAPMAP, C. The International HapMap Project. Nature, v. 426, n. 6968, p. 789-96, 2003.

KHOURY, M. J.; LITTLE, J.; BURKE, W. Human genome epidemiology : a scientific foundation for using genetic information to improve health and prevent disease. Oxford ; New York: Oxford University Press, 2004. xix, 549 p. ISBN 0195146743 (cloth alk. paper).

Disponível em: http://www.loc.gov/catdir/enhancements/fy0614/2003048623-d.html

LANDER, E. S. et al. Initial sequencing and analysis of the human genome. Nature, v. 409, n. 6822, p. 860$921,2001$.

LOHMUELLER, K. E. The distribution of deleterious genetic variation in human populations. Curr Opin Genet Dev, v. 29, p. 139-46, 2014.

MANOLIO, T. A.; BROOKS, L. D.; COLlinS, F. S. A HapMap harvest of insights into the genetics of common disease. J Clin Invest, v. 118, n. 5, p. 1590-605, 2008.

PATTERSON, N. et al. Methods for high-density admixture mapping of disease genes. Am J Hum Genet, v. 74, n. 5, p. 979-1000, 2004.

STRACHAN, T.; READ, A. P.; STRACHAN, T. Human molecular genetics. 4th. New York: Garland Science, 2011. xxv, 781 p. ISBN 9780815341499 (pbk.)

SUAREZ-KURTZ, G. Pharmacogenomics in admixed populations. Trends Pharmacol Sci, v. 26, n. 4, p. 196201, 2005. 
SUAREZ-KURTZ, G. et al. Pharmacogenomic Diversity among Brazilians: Influence of Ancestry, SelfReported Color, and Geographical Origin. Front Pharmacol, v. 3, p. 191, 2012.

VASCONCELOS, G. M.; STRUCHINER, C. J.; SUAREZ-KURTZ, G. CYP2A6 genetic polymorphisms and correlation with smoking status in Brazilians. Pharmacogenomics J, v. 5, n. 1, p. 42-8, 2005.

VENTER, J. C. et al. The sequence of the human genome. Science, v. 291, n. 5507, p. 1304-51, 2001.

WEGMANN, D. et al. Recombination rates in admixed individuals identified by ancestry-based inference. Nat Genet, v. 43, n. 9, p. 847-53, 2011. 
Capítulo II

\section{População brasileira: oportunidades para estudos genômicos}

1. Introdução

\subsection{Composição da população brasileira}

A população brasileira atual é composta pelos três grandes grupos continentais doadores de patrimônio genético: africanos, ameríndios e europeus. As hipóteses correntes apontam que os primeiros ameríndios no Brasil se estabeleceram há pelo menos 14.000 anos baseado em dados obtidos de remanescentes na região de Lagoa Santa, Minas Gerais, e compatíveis com as evidências de ocupação das Américas (Hubbe et al., 2014). Os primeiros americanos são descendentes de influxo populacional reconhecido a partir da Ásia através do estreito de Bering, há cerca de 16.000 anos e com rápida ocupação de toda a extensão do continente até a Terra do Fogo em poucas centenas de anos (Cavalli-Sforza, 1997; Haynes, 2002) teriam permanecido isolados até o período das grandes navegações europeias. Novas evidências, no entanto, não descartam a interpolação com outras incursões mais recentes, a exemplo de polinésios, cujas variantes genéticas mitocondriais foram encontradas em esqueletos de índios Botocudos de comunidades isoladas (Malaspinas et al., 2014).

Em 1500, os europeus ibéricos (portugueses) se estabeleceram em território sul-americano e, pouco tempo depois, passaram a importar para a nova colônia escravos africanos, de vários territórios. Estima-se que dos 10 milhões de africanos trazidos para as colônias europeias em continente americano, cerca de 4 milhões tenham vindo para o Brasil, um número dez vezes maior que o levado aos Estados Unidos (Miller e Smith, 1997). A imigração de africanos durou todo o período de vigência da escravatura, do século XVI ao século XIX, e diferentes origens compuseram os diferentes fluxos de imigração forçada. Tanto as populações nativas ameríndias quanto os grupos africanos trazidos foram fontes de miscigenação com os colonizadores europeus, majoritariamente entre homens europeus e mulheres das populações subjugadas. Este padrão comportamental foi observado não apenas em estudos históricos 
como também em linhagens de DNA mitocondrial (Alves-Silva et al., 2000) e haplótipos dos cromossomos Y, realizados em grupos de todas as regiões do Brasil (Palha et al., 2012).

A partir de meados do século XIX até o século XX, outros grupos passaram a migrar para o Brasil, dentre eles italianos, espanhois, alemães, sírios, libaneses, japoneses e coreanos (Franco et al., 1999) e recentemente outras populações sul-americanas como bolivianos e peruanos, além de haitianos, senegaleses, ganeses, chineses, indianos e paquistaneses. As dinâmicas socioeconômicas que estão subjacentes a estes fluxos migratórios, em cada época e escala, proporcionaram diferentes distribuições geográficas dentro do Brasil, sendo a cidade de São Paulo o destino de boa parte das migrações recentes (Fernandes et al., 2014). Em relação aos fluxos anteriores a região norte contou com maior proporção de descendentes de ameríndios, nordeste com maior concentração de africanos, sul e sudeste com maior concentração de europeus (Palha et al., 2012).

\subsection{Estudos de genômica populacional no Brasil}

Uma busca ao portal de GWAS está descrita na tabela 1 do trabalho de Need e Goldstein (2009), com quase 90\% dos estudos realizados com populações europeias e o restante distribuídos em asiáticos, hispânicos, ameríndios e menos de 5\% em populações miscigenadas. Para exemplificar de forma sucinta o cenário, uma busca semelhante foi realizada. O acesso no dia 12/07/2015 ao mesmo portal da National Human Genome Research Institute (NHGRI), o GWAS Catalog (Welter et al., 2014), a busca por número de GWAS revelou 2111 estudos, dos quais filtrados pelos termos "Europe *" (1449 estudos), "African*" (180 estudos), “Asian*" (84 estudos), "Chinese*" (163 estudos) e "Native*” (1 estudo) e "Brazil*" (3 estudos). Os termos foram seguidos de asterisco para não excluírem sufixos diferentes. Os três resultados obtidos com o termo "Brazil*" são estudos que incluiram amostras de brasileiros e, curiosamente, utilizaram a expressão "Brazilian ancestry".

O primeiro estudo foi realizado pelo consórcio que investiga suscetibilidade a leishmaniose visceral em parceria com o Wellcome Trust Case Control Consortium e diversos grupos de regiões onde a doença é prevalente e que puderam contribuir com amostras (Leish et al., 2013). Neste caso, os dois principais grupos foram da Índia e do Brasil, o primeiro de uma amostra populacional e o segundo de um estudo de famílias de Belém, Pará e Natal, Rio Grande do Norte. Devido à endemicidade dos patógenos e variabilidade genética dos hospedeiros, o estudo investigou a ocorrência de associação separadamente e buscou identificar regiões apontadas por ambas as populações através de uma meta-análise. Foi 
identificado um único sinal combinado (conjunto de variantes associadas ao trato) na região HLA-DRB1-HLA-DQA1 do complexo principal de histocompatibilidade (MHC), ainda que não tenha sido o maior sinal encontrado na população brasileira. $\mathrm{O}$ sinal foi replicado em outra amostra de indivíduos indianos, porém não foi realizada validação na população brasileira, o que provocou cautela entre os autores do estudo ao não estabelecer se o sinal associado poderia resultar em vínculo causativo na amostra brasileira, agir como modificador, ser um fator de suscetibilidade população-específica ou espécie-específica (do parasita) ou mesmo um falso-positivo. Um comentário pertinente realizado pelos autores é sobre o quão comum é a ocorrência de desequilíbrio de ligação em genes do sistema MHC, de uma maneira população-específica, dificultando a análise de associação (Leish et al., 2013). Este dado é particularmente importante no caso de estudos baseados em famílias, uma vez que há uma sobre-representitativade de determinados haplótipos que segregam em famílias e, neste caso específico, famílias de uma subpopulação (brasileiros das regiões Norte e Nordeste) ainda pouco mapeada.

O segundo estudo encontrado de GWAS com uma amostra populacional brasileira buscou variantes que afetam o padrão de progressão de doença de Chagas para estágios clínicos mais avançados e graves (Deng et al., 2013). A manifestação mais relevante é um tipo de cardiomiopatia crônica e a fisiopatologia subjacente à progressão para esta condição que envolve vias inflamatórias e auto-imunidade. Estudos prévios indicavam a influência da genética neste fenótipo com padrão familial, ao menos para parte dos pacientes envolvidos. $\mathrm{O}$ estudo baseou-se em genotipagem de SNPs e aferiu-se a ancestralidade genética dos indivíduos, cruzando os dados com cor/etnia auto-reportada. Esta análise serviu apenas como parâmetro para ajuste de estratificação populacional, uma vez que os autores não incluíram os dados de ancestralidade na análise de associação (por exemplo, divisão de subcategorias baseadas em agrupamentos por ancestralidade). Os resultados deste estudo não atingiram significância estatística após correção para múltiplos testes, porém apontaram que variantes no gene SLCO1B1 (transportador de íons, expresso em coração) estão associados a cardiomiopatia crônica de Chagas. Além disso, um dos endofenótipos medidos, o intervalo PR do eletrocardiograma, demonstrou associação com variantes em COL14A2 (família de colágenos), HSPB8 (proteína de choque térmico) e ACCN1 (canal de íons), todos com descrições associadas a fenótipos cardíacos, mas sem replicação para os fenótipos aqui estudados. Os autores comentam que o alto grau de variabilidade genética da coorte pode ter reduzido o poder estatístico da associação (Deng et al., 2013). 
O terceiro estudo buscou a identificação de variantes associadas à sensibilidade palativa ao amargo, um fenótipo não ligado a doenças (Ledda et al., 2014). Em uma amostra apenas de brasileiros, associaram-se variantes numa região do cromossomo 12 que concentra genes de receptores de sabor amargo de diferentes origens, como cafeína e quinina, tanto na amostra base quanto numa segunda amostra de validação. Dentro do contexto de miscigenação populacional, o estudo apontou que a população (selecionada e não-representativa do ponto de vista epidemiológico) foi ajustada para estratificação populacional e apresentou, na região adjacente às variantes associadas, dois blocos haplotípicos de diferentes padrões em desequilíbrio de ligação correspondentes à ancestralidade europeia, africana e asiática. Curiosamente, duas das variantes associadas estão numa mesma região mas são haplótipoespecíficas (de acordo com a origem populacional). O comentário dos autores sugere que a miscigenação populacional e a análise da estrutura foram fundamentais para separar tais sinais estatísticos de associação sob a perspectiva de provável função (especificidade dos sabores amargos testados) (Ledda et al., 2014).

Tradicionalmente, a raça e etnia auto-reportadas foram interpretadas como variáveis para categorizar grupos na tentativa de homogeneizar as prováveis diferenças decorrentes de estruturas genômicas de ancestralidades distintas. Diversos estudos podem ser encontrados utilizando esta estratégia, a exemplo da associação de uma variante do fator de crescimento vascular endotelial (VEGF) e retinopatia em diabéticos, cujo efeito parece ser dependente da proporção de ancestralidade europeia em brasileiros (Errera et al., 2007). Diante de tamanha complexidade de miscigenação populacional, alguns estudos foram realizados para compreender a contribuição de cada população parental presente no genoma dos brasileiros atualmente. Um dos primeiros estudos realizados acerca do assunto, genotipou 10 alelos população-específicos, termo posteriormente renomeado como "marcadores informativos de ancestralidade" (AIMs ou ancestry informative markers) em cerca de 350 brasileiros de todas as regiões, objetivando verificar a correlação entre raça/cor da pele auto-declarada e outros fenótipos morfológicos e ancestralidade (Parra et al., 2003). O resultado confirmou que raça/cor da pele auto-declarada não é um bom preditor de ancestralidade, dada a grande dispersão entre proporções de ancestralidade africana (figura 3-A). Este padrão foi confirmado utilizando-se outro painel de 90 AIMs (Kosoy et al., 2009) em estudo realizado pelo nosso grupo (trabalho completo exibido como anexo 9 no capítulo III, página 145) com uma amostra maior de indivíduos provenientes especificamente da cidade de São Paulo (Schlesinger et al., 2011), conforme exposto na figura 3-B. Também na cidade de São Paulo, um estudo com 138 indivíduos portadores de doença cardíaca construiu um painel de 250 
AIMs a partir da genotipagem de pouco mais que 350 mil SNPs e comparou com 11 populações da fase 3 do HapMap. Estimou-se 15\% a ancestralidade ameríndia, em 24\% a ancestralidade africana e em $61 \%$ a ancestralidade europeia. A análise por componentes principais mostrou uma distribuição bastante difusa entre os indivíduos (figura 3-C) (Giolo et al., 2012).
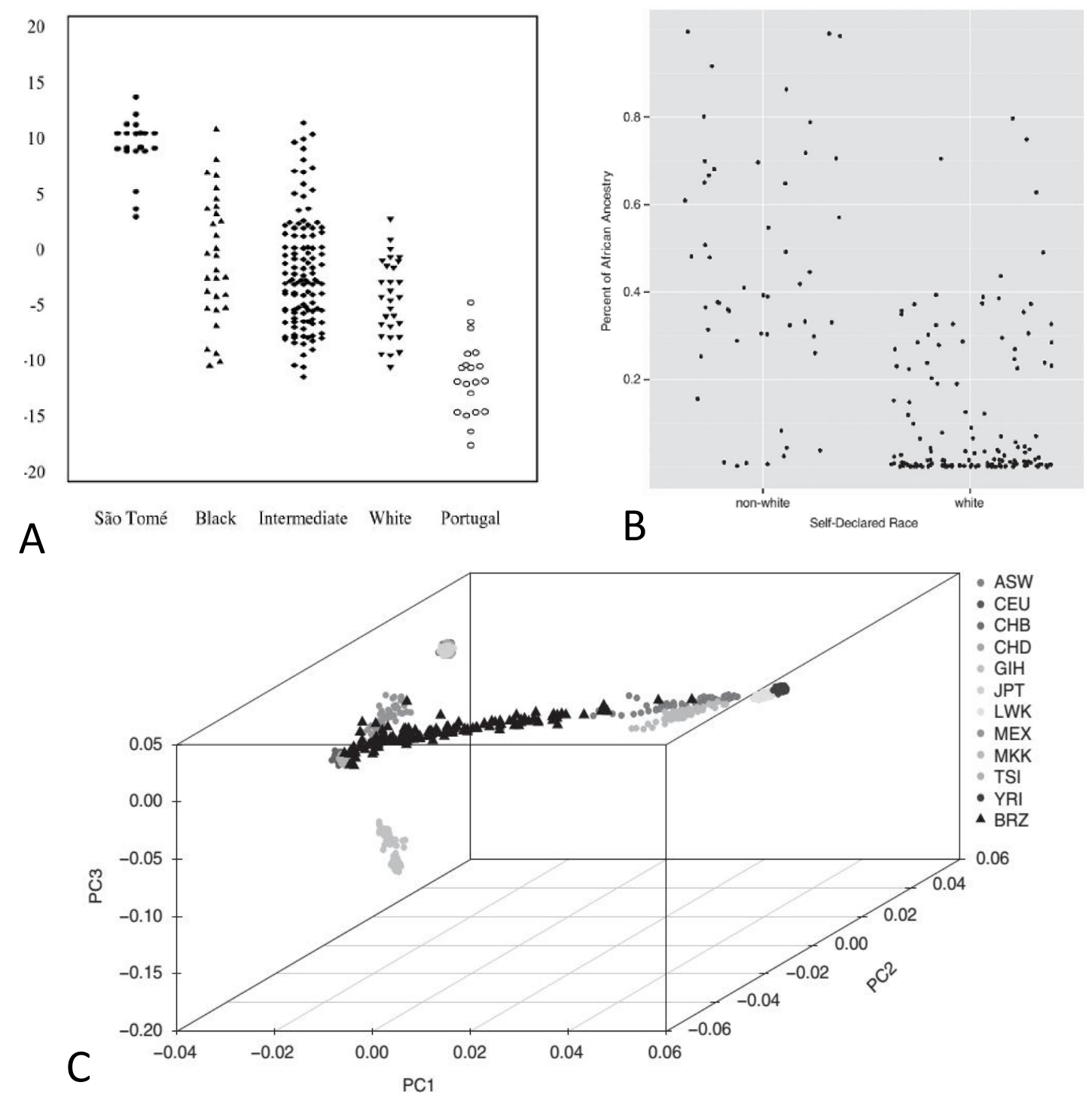

Figura 3. Ancestralidade da população brasileira. Parra e colaboradores (2003), utilizando 10 AIMs em indivíduos de várias regiões do Brasil, sugeriram que a cor de pele auto-declarada não é suficiente para predizer o grau de ancestralidade. A escala de 20 a -20 representa o sentido de maior para menor proporção de ancestralidade africana (A) (retirada parcialmente de Parra e cols, 2003). Este dado foi replicado por Schlesinger e colaboradores (2011) em um gráfico contendo dados de indivíduos de São Paulo genotipados para 90 AIMs (B) (retirada de Schlesinger e cols, 2011). Giolo e colaboradores (2012) utilizaram paineis de 250 AIMs e estimaram a ancestralidade por análise de componentes principais (PC) utilizando as populações do sul da Italia (TSI), africanos do sudoeste do continente (ASW) e mexicanos de Los Angeles (MEX, os quais tem um grande componente de ameríndios). Os três principais PCs estão dispostos em (C) (retirada de Giolo e cols, 2012). 
O trabalho mais recente utilizou três amostras populacionais que conjuntamente formam o maior estudo de ancestralidade genômica realizado com brasileiros (Kehdy et al., 2015). As amostras correspondem ao consórcio EPIGEN, uma iniciativa que reúne coortes de três cidades brasileiras: Pelotas, Rio Grande do Sul; Bambuí, Minas Gerais; e Salvador, Bahia (Lima-Costa et al., 2015).

A amostra de Pelotas é baseada numa coorte de nascidos em 1982, e contou originalmente com 99,2\% dos nascidos neste ano, aproximadamente 5900 indivíduos (Victora e Barros, 2006), numa cidade de aproximadamente 200 mil habitantes. Os indivíduos foram acompanhados por diversas ondas de coletas, com diferentes dados coletados em cada onda. Nos anos de 2004-2005, DNA foi coletado durante as visitas e genotipados para SNPs em 2012, objetivando realizar diversos estudos de associação (Horta et al., 2015). A amostra de Bambuí elegeu cerca de 1600 idosos acima de 60 anos da cidade homônima, cuja população é de cerca de 15 mil habitantes, no ano de 1997. Coletaram-se diversas variáveis sociais, demográficas, econômicas e de saúde, além de material biológico para realização de análises laboratoriais. A extração do DNA deu-se a partir de 2008 (Lima-Costa et al., 2011). A coorte de Salvador faz parte de um grupo de pesquisa para doenças respiratórias e alérgicas denominada SCAALA (Social Changes, Asthma and Allergy in Latin America Programme). A amostra é composta por três coortes de crianças de até três anos de idade oriundas de diversas regiões da cidade a partir de 1997, as quais vem sendo seguidas para estudos de prevalência e incidência das doenças respiratórias e associação com diversas variáveis sociodemográficas e de saúde, além da coleta de material biológico (Barreto et al., 2006).

Indivíduos dos três grupos acima descritos foram incluídos no consórcio EPIGEN com os objetivos, dentre outros, de identificar e quantificar os componentes de ancestralidade evidenciando a subestrutura de populações brasileiras de diferentes domínios sociogeográficos, compreender a dinâmica de miscigenação que pode ter originado tais padrões de ancestralidade e correlacionar os aspectos históricos com a estrutura genética, bem como estudar como a miscigenação e graus de parentesco entre os indivíduos podem contribuir para modelar a carga de mutações potencialmente deletérias (Kehdy et al., 2015). Os autores utilizaram o DNA de quase 6500 indivíduos do EPIGEN, 1300 da coorte de crianças de Salvador (SCAALA), 1400 da coorte de idosos de Bambuí e 3800 da coorte de nascidos em 1982 (agora adultos) de Pelotas. O padrão de genotipagem foi de aproximadamente 2 milhões de SNPs em plataforma da Illumina. Como esperado do ponto de vista histórico, a análise de ancestralidade global média utilizando os métodos vastamente empregados ADMIXTURE (Alexander et al., 2009) e por análise de componentes principais 
(PCA) (Patterson et al., 2006) revelou-se que a população de Salvador tem em média uma maior proporção de ancestralidade africana (50,8\% em relação a cerca de $15 \%$ das outras populações, mas curiosamente menor que dos afroamericanos miscigenados) e as populações de Bambuí e Pelotas com maiores proporção de ancestralidade europeia (77\% comparado com $43 \%$ de Salvador. A proporção de fragmentos genômicos ameríndios foi de $6,4 \%, 6,7 \%$ e $8 \%$, respectivamente. Estes resultados estão ilustrados nas figuras 4-B e 4-C abaixo. Curiosamente, alguns anos antes as diferenças regionais de diferentes populações de brasileiros foi classificada como mais uniformes que o esperado (Pena et al., 2011), provavelmente devido à aplicação de outras metodologias de amostragem e tratamentos estatísticos para análise de tais diferenças.

A análise de parentesco foi realizada usando o método Relatedness Estimation in Admixed Populations (REAP) (Thornton et al., 2012) e os gráficos da figura 4-A apontam que a população de Bambuí apresenta mais indivíduos relacionados entre si que as outras populações (maiores probabilidades de Identidade por Descendência $>0$ ), algo esperado pelo tamanho menor da comunidade, maior isolamento e maior homogeneidade socioeconômica. $\mathrm{O}$ estudo também mostrou que as populações menos miscigenadas do EPIGEN (Bambuí e Pelotas) apresentam mais cruzamentos preferenciais entre indivíduos de mesma ancestralidade, por caracterísitcas socioeconômicas e históricas. Pelotas apresenta pouco grau de parentesco entre indivíduos, porém um padrão semelhante de subdivisão baseada em ancestralidade. Em termos de dinâmica populacional, também foram confirmados os padrões de homens de origem europeia com mulheres de origens africanas e ameríndias através de marcadores no cromossomo Y e no DNA mitocondrial. A dissecção das ancestralidades europeia e africana mostrou que os brasileiros destas três populações tem uma maior proporção de europeus da região sul (península ibérica, mediterrâneo e oriente médio), e que especificamente a população de Pelotas tem uma composição marcada por mais europeus do norte. Em relação à origem dos africanos, a composição dos genomas também se correlaciona com as evidências históricas de fluxos de escravos do oeste do continente africano (população Yoruba) povoando o norte e nordeste do Brasil e africanos do leste do continente (populações Bantu) compondo o fluxo para sudeste e sul do país (Kehdy et al., 2015).

O mesmo estudo de Kehdy e colaboradores (2015) também verificou, através do sequenciamento do genoma completo de 10 indivíduos de cada subpopulação brasileira, a quantidade de variantes não sinônimas potencialmente deletérias, algo que se tornou um assunto de relevância recente, como comentado no capítulo I. Os autores estimaram algo esperado pelos padrões comentados por Lohmueller (2014), em que o número de variantes 
deletérias em homozigose é maior de acordo com maior proporção de ancestralidade europeia, porém tal correlação é perdida na população com menor proporção (neste caso, de Salvador). A diversidade, medida por heterozigose, segue o caminho inverso e diminui com a maior ancestralidade europeia (Kehdy et al., 2015).
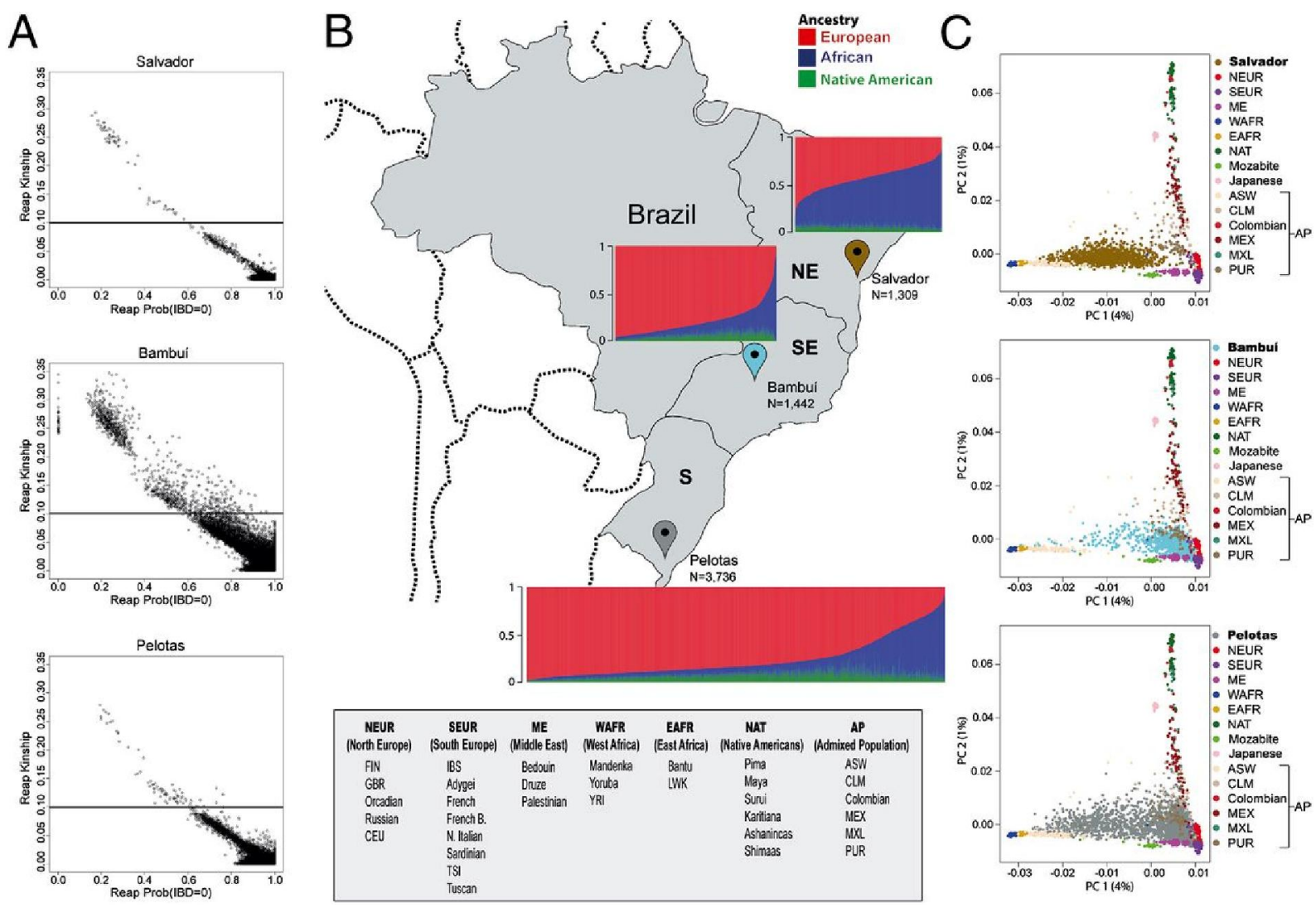

Figura 4. Estudo com três amostras de populações brasileiras. Retirada de Kehdy e cols. (2015). (A) representa o grau de parentesco em cada população participante do EPIGEN, calculado a partir da medida de probabilidade de zerar a identidade por descendência (IBD), com a linha representando o limiar de parentesco (acima dele, estão os indivíduos com maior probabilidade de parentesco com outros membros). (B) representa os locais de cada grupo populacional incluído no EPIGEN e suas respectivas distribuições de ancestralidade global para três populações obtidas pelo ADMIXTURE. (C) expõe para os três grupos o posicionamento em relação a populações de diversas origens, inclusive miscigenadas, que estão listadas no quadro cinza.

\subsection{Bancos de dados locais para referência em variabilidade genética}

Foram descritas, até o momento, considerações sobre as importâncias dos estudos de populações miscigenadas para compreensão das dinâmicas subjacentes à história natural humana; da correção para estratificação populacional para controle em estudos de associação para identificação de genes candidatos; da otimização que fenótipos complexos de diferentes frequências de acordo com a população (admixture mapping); do detalhamento de como 
blocos haplotípicos se comportam em diferentes composições populacionais; e da análise que diferentes perfis populacionais apresentam frequências específicas de alelos funcionais, deletérios ou não.

Soma-se a isso o limitado número de estudos genômicos de grande porte realizados com brasileiros e as evidências cumulativas acerca do perfil único e grande escala de miscigenação recente da população brasileira. Torna-se, portanto, de grande interesse científico e clínico a investigação de como a nossa população se apresenta em relação a fatores de risco previamente descritos, frequências de variantes raras de função potencialmente deletéria e base referencial para estudos de genômica locais, controles para busca de alterações genômicas causadoras de doenças raras e/ou de início precoce.

A estimativa da prevalência de mutações causadoras de doenças ou fatores de risco genéticos (previamente conhecidos ou identificados após triagem para alterações previamente conhecidas) na população brasileira é a linha de pesquisa há décadas de diversos grupos de genética do país. Pontualmente, verificou-se a prevalência de mutações de diversas doenças de herança mendeliana como distrofias musculares de Duchenne, Becker (Passos-Bueno et al., 1990; Vainzof et al., 1991) e do tipo Cinturas (Vainzof et al., 1999), fibrose cística (Raskin et al., 2003); fatores de risco de doenças complexas e de herança multifatorial como doença arterial coronariana (Izar et al., 2003), hipertensão essencial (Freitas et al., 2007), hiperbilirrubinemia moderada (Mezzacappa et al., 2010), diabetes tipo 1 (Guimaraes et al., 2009), carcinogênese e câncer cervical (Ferreira Da Silva et al., 2010; Laprano et al., 2014), melanoma (Goncalves et al., 2011); e suscetibilidade a infecções e parasitoses como leishmaniose (Castellucci et al., 2014), doença de Chagas (Williams-Blangero et al., 2012) e dengue (Cardozo et al., 2014). A lista de fatores testados pontualmente em amostras brasileiras é, ao menos, uma ordem de grandeza maior que a citada aqui, no entanto uma busca sistemática com métodos epidemiológicos em uma amostra representativa da população ainda inexiste no país.

Com a redução progressiva de custos dos métodos de sequenciamento de DNA e progresso em métodos bioinformáticos e estatísticos para análise de dados de sequenciamento em larga escala, a pesquisa em genômica tem contribuído para a descoberta de dados interessantes sobre o número de variantes potencialmente deletérias presentes em genomas e com frequências globalmente maiores que as preditas anteriormente. Um estudo realizado por Daniel MacArthur e colaboradores (2012) propôs e desenvolveu uma busca sistemática de variantes de perda de função em genes codificadores de proteínas ao longo do genoma humano. Esperava-se que a quantidade de variantes de perda de função, potencialmente 
deletérias, seria reduzida em indivíduos saudáveis. Demonstrou-se, entretanto, que o número pode chegar a aproximadamente 100 por genoma, resultando em cerca de 20 genes completamente inativados, apontando para uma capacidade redundante do genoma humano em tolerar tais alterações (Macarthur et al., 2012).

O estudo utilizou o sequenciamento completo de 185 genomas humanos analisados com parte da fase piloto do projeto 1000 Genomes, de três grande grupos populacionais: Yoruba (africanos da Nigéria), caucasianos e asiáticos (chineses e japoneses). A definição utilizada para perda de função foi a de variantes que resultassem em códons de parada, interferissem em sítios de processamento de RNA (splicing), inserções/deleções que modificassem o quadro de leitura do transcrito, ou grandes deleções que removam o primeiro éxon ou mais que $50 \%$ da sequência codificante da proteína. Para identificar as variantes de perda de função, filtros bioinformáticos foram aplicados para levar em conta o contexto local da sequência (regiões repetitivas resultam em dados de confiança reduzida), anotação funcional (regiões que afetam sítios não-canônicos de regulação de splicing ou próximas ao final do quadro de leitura), efeitos de outras variantes próximas e, evidentemente, qualidade do sequenciamento e do mapeamento ao genoma referencial. Em seguida, a validação dos achados foi realizada por genotipagem com outros métodos que não o sequenciamento, objetivando eliminar falsos positivos gerados por erros de sequenciamento. O total de 1285 variantes com perda de função foram identificados numa média de 100 por indivíduo e 20 em homozigose, indivíduos de origem africana apresentam mais diversidade média. Os autores comentam que a baixa cobertura da fase piloto do 1000 Genomes dificulta a detecção de variantes mais raras, que as variantes estão enriquecidas em grupos gênicos ligados a receptores olfatórios e praticamente depletadas de genes implicados em interação física com outras proteínas, regulação transcricional e desenvolvimento anatômico, que há uma série de mutações previamente conhecidas por causar doenças recessivas de início precoce como amaurose congênita de Leber (degeneração retiniana), ictiose arlequim, osteogênese imperfeita e Tay-Sachs (degeneração nervosa) (Macarthur et al., 2012).

Há diversas explicações possíveis acerca da tolerância do genoma às variantes potencialmente deletérias serem encontradas em número maior do que o previamente esperado. A penetrância (proporção de indivíduos portadores da mutação e que manifestam a doença) reduzida pode ser explicada por mecanismos que variam de simples a complexos e para grande parte das mutações ainda são desconhecidos. As variantes podem danificar uma proteína que mesmo intacta não seria necessária para a saúde do portador da mutação (exemplo de um papel redundante daquela proteína na via ou nas vias a que pertence); 
indivíduos podem ser portadores que, em homozigose ou heterozigose composta, manifestarão a doença por um padrão recessivo; a mutação pode se manifestar de forma dominante, mas o fenótipo ser leve e os indivíduos serem classificados dentro do espectro de variação normal; a doença pode ser de início tardio com expressão idade ou sexodependentes; ou a doença pode requisitar outras variantes genéticas e/ou fatores ambientais para se manifestar clinicamente (Cooper et al., 2013). Nota-se também que os indivíduos participantes do 1000 Genomes são classificados como normais por não terem doenças raras ou de início precoce, mas nada impede que doenças cuja penetrância se dê tardiamente ou que fenótipos limítrofes a outras doenças não estejam presentes nos participantes.

A construção de catálogos com variantes de alta penetrância causadoras de doenças mendelianas como o Online Mendelian Inheritance in Man (OMIM) e o Human Gene Mutation Database (HGMD) e variantes de baixa penetrância que contribuam com doenças complexas como o GWAS Catalog (NHGRI) é fundamental para compreender o papel das mutações e sua prevalência nas populações; o risco real para os portadores das variantes, em particular em combinação com outras variantes apresentadas por ele, de origem ancestral ou que segreguem em sua família; e os achados incidentais, cuja condução ética ainda está em plena discussão, uma vez que a interpretação ainda é dificultada por não se saber ao certo o papel de mutações potencialmente deletérias diante de estudos que revelam indíviduos “normais" portadores dessas mutações (Macarthur et al., 2012; Xue et al., 2012).

Diante do exposto, fica evidente que bases de dados genômicos locais são requisitos para compreendermos como é a constituição genômica sob o aspecto da ancestralidade, em particular em populações miscigenadas. As bases devem ser preferencialmente representativas da população, densa e cuidadosamente fenotipadas e, para contornar os problemas de penetrância reduzida dependente da idade, composta por indivíduos mais velhos cujo histórico de saúde exclua doenças raras ou de início precoce (ou que esta exclusão seja possível pelo método de amostragem, de caráter representativo da população em questão).

\section{Objetivo}

Promover a coleta de uma base de indivíduos idosos da população de São Paulo, em caráter representativo, para construção de um banco de dados de referência genômica e controle para doenças genéticas raras e de início precoce. 
3. Amostras, métodos e colaborações

\subsection{Amostra do Estudo SABE}

A Pesquisa SABE (Saúde, Bem Estar e Envelhecimento) surgiu em 1999 inicialmente em sete cidades latinoamericanas (Bridgetown, Barbados; Buenos Aires, Argentina; Havana, Cuba; Cidade do México, México; Montevidéu, Uruguai; Santiago, Chile; e São Paulo, Brasil) em formato de estudo multicêntrico a partir de um convênio interagencial coordenado pela Organização Pan-Americana de Saúde e integrado pela Comissão Econômica para a América latina e o Caribe, o Fundo de População das Nações Unidas, o Programa de Envelhecimento das Nações Unidas, a Organização Internacional do Trabalho e o Banco Interamericano de Desenvolvimento. O objetivo inicial foi de suprir a demanda por informação e indicadores do segmento populacional dos idosos, faixa etária com crescimento notável, em particular nos países desenvolvidos e em desenvolvimento. No Brasil, a participação foi coordenada pela Profa. Maria Lúcia Lebrão e Prof. Ruy Laurenti (Faculdade de Saúde Pública da Universidade de São Paulo, USP) e pela Profa. Yeda Aparecida de Oliveira Duarte (Escola de Enfermagem, USP) e apoiado pela Fundação de Amparo à Pesquisa do Estado de São Paulo (Fapesp) e Ministério da Saúde (LebrãO et al., 2003). O prosseguimento da Pesquisa SABE no contexto brasileiro será referido a partir daqui como "Estudo SABE" ou apenas "SABE".

A metodologia inicial do SABE correspondeu a uma amostra probabilística resultante de sorteio, baseada no censo do município de São Paulo de 1568 indivíduos acima de 60 anos somados a uma amostra compensatória de 575 indivíduos seguindo procedimento de ponderação semelhante. A amostra total de 2143 indivíduos correspondeu a coorte A-00 (coorte A, ano 2000). O seguimento a cada cinco anos buscou re-contatar os coletados na onda anterior e adicionar uma nova coorte por método semelhante para balancear o número de participantes. A coleta correspondente à primeira re-chamada de 2005 foi realizada em 2006 . O estudo tem, portanto, um desenho longitudinal (a mesma coorte seguida por vários timepoints) e transversal (uma fotografia do ano coletado), conforme mostra a figura 5 abaixo, modificada de uma versão gentilmente seguida pelas autoras do projeto SABE. 


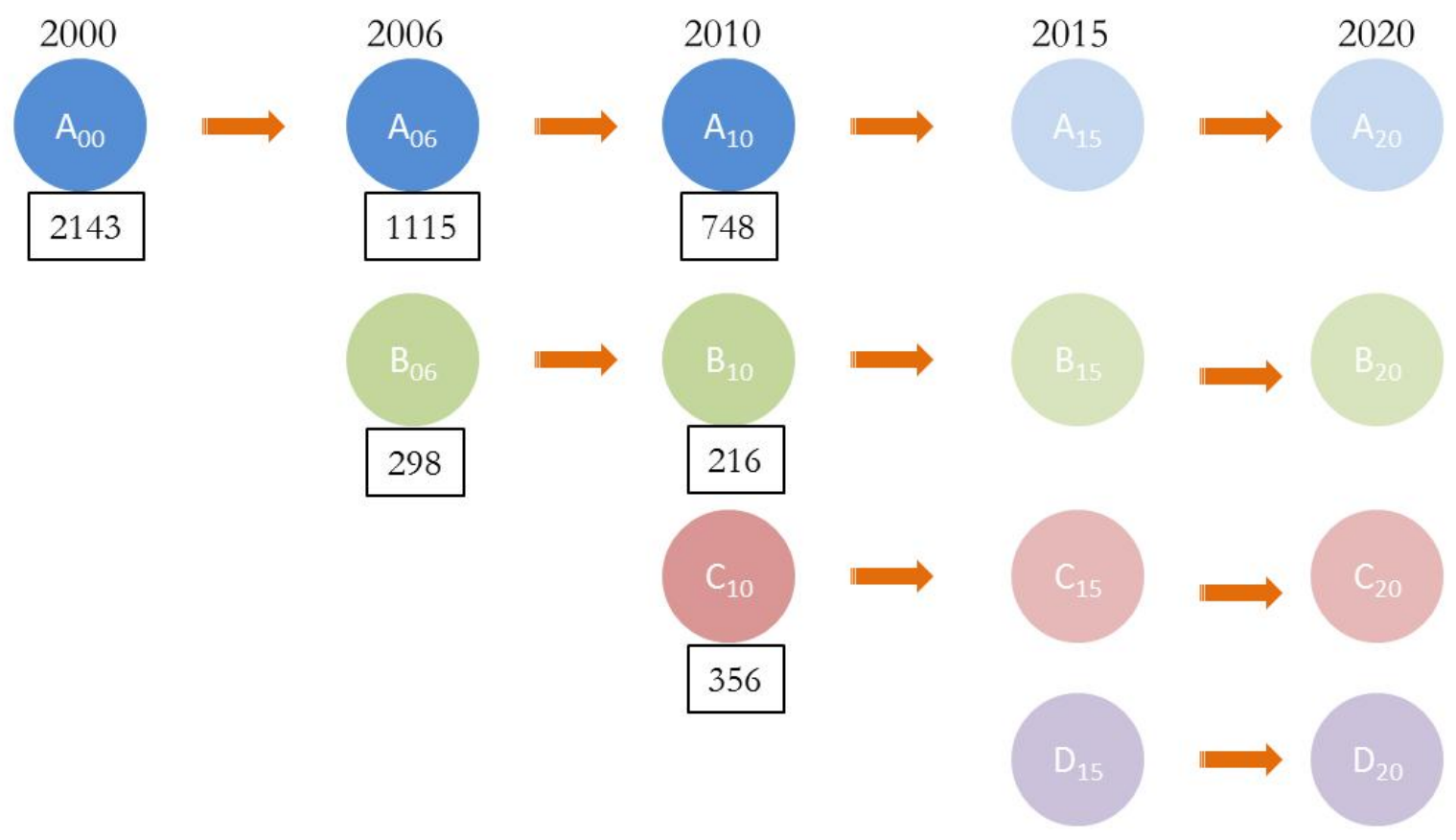

Figura 5. Desenho experimental das coletas do Estudo SABE. A primeira coorte A-00 foi coletada no ano 2000 e composta por 1568 indivíduos somados a 575 indivíduos acrescidos para compensar a mortalidade na população de maiores de 75 anos. Em seguida, a coleta de 2006 consistiu na re-chamada da coorte A-00 constituindo a coorte A-06 e adição de nova coorte (B-06) com mesma metodologia de amostragem. A sucessão do projeto está neste momento na coleta de 2010. Ilustração adaptada de figura gentilmente cedida pelas Profas. Maria Lúcia Lebrão e Yeda Duarte.

A base de informações coletadas pelo projeto $\mathrm{SABE}$ é formada por um extenso questionário, que inicialmente continha onze seções compreendendo vários aspectos da vida do idoso como dados pessoais, avaliação cognitiva (Mini-mental State Examination - MMSE e adaptações), estado de saúde, estado funcional, medicamentos, uso e acesso aos serviços, rede de apoio familiar e social, história laboral, moradia, antropometria, flexibilidade e mobilidade. Ao longo das recoletas, novos dados foram obtidos e amostras biológicas coletadas objetivando mapear biomarcadores associados a saúde. Os questionários estão publicamente disponíveis em http://www.fsp.usp.br/sabe/.

A tabela 1 apresenta de forma resumida os dados obtidos em todas as coletas da amostra SABE. Os participantes do Estudo SABE são convidados a participar do projeto e são signatários do Termo de Consentimento Livre e Esclarecido que conta aprovação pela Comissão de Ética em Pesquisa da Faculdade de Saúde Pública. 
Tabela 1. Medidas coletadas pelo Estudo SABE em cada etapa e número máximo de participantes por medida

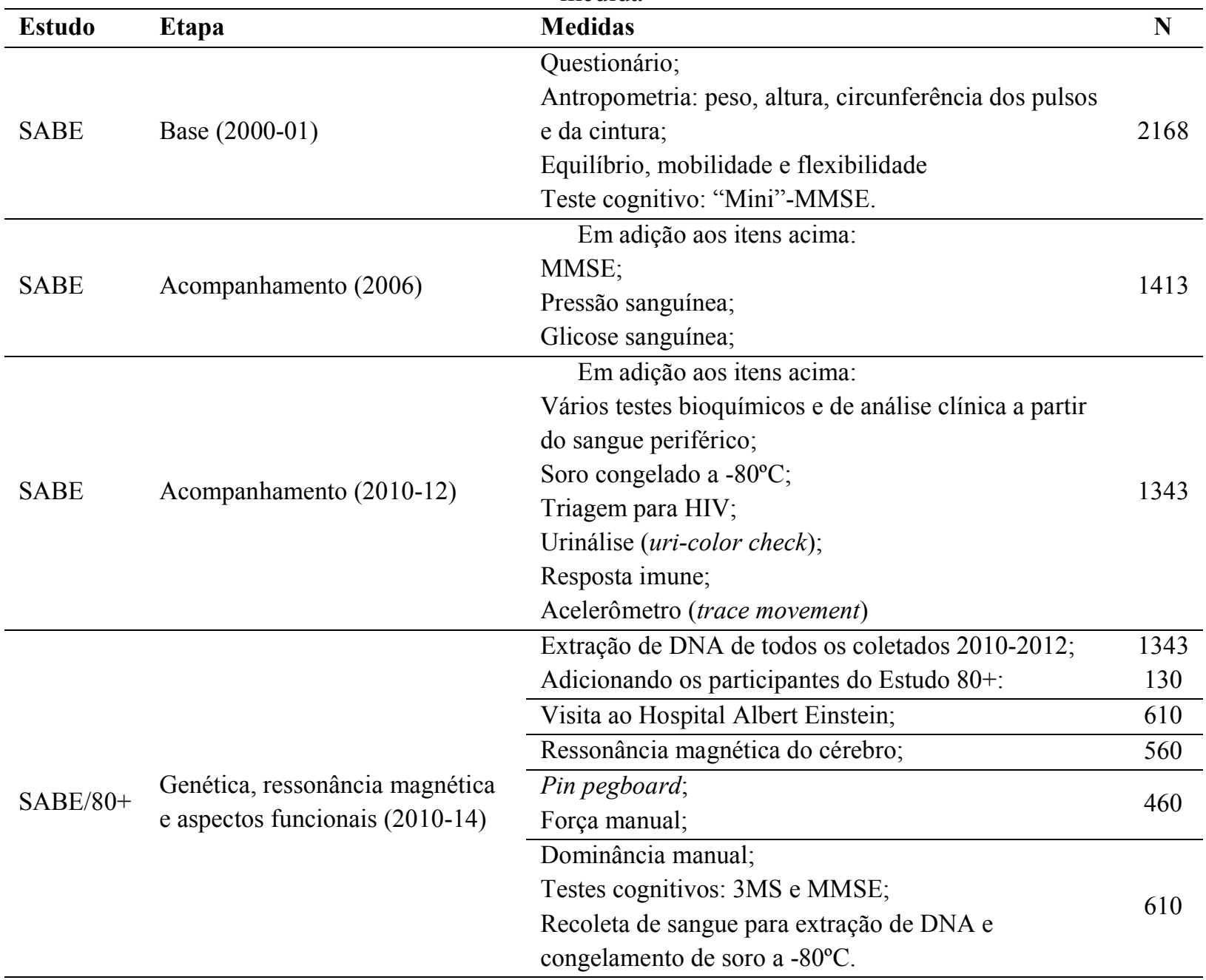

\subsection{Amostra $80+$}

Conceitualmente, a ideia por trás do Projeto $80+$ vem sendo trabalhada pela Profa. Mayana Zatz desde a aprovação, em 2008, do grande projeto de financiamento no Centro de Pesquisas sobre o Genoma Humano e Células-tronco (então Centro de Estudos do Genoma Humano CEGH, do Instituto de Biociências da USP), Institutos Nacionais de Ciência e Tecnologia (INCT), do Conselho Nacional de Pesquisas (CNPq).

O CEGH-USP é um centro de referência em pesquisas na área de genética humana, em serviço de aconselhamento genético e em diagnóstico molecular de pacientes portadores de diversas formas de doença genética. Inicialmente, o maior foco eram doenças neuromusculares e neurodegenerativas, mas o serviço se estendeu para diversos fenótipos. Há cerca de 10 anos, o CEGH-USP iniciou pesquisas com células-tronco, objetivando 
compreender como, do ponto de vista celular, os genomas de indivíduos afetados participavam na fisiopatologia das doenças estudadas. Outro objetivo, de longo prazo, é desenvolver métodos terapêuticos a partir das células-tronco. Em 2008, uma nova linha de pesquisa do CEGH-USP foi sugerida: investigar variantes genômicas que contribuam com a longevidade. Além de compreender a saúde da população que envelhece, o objetivo de criar um parâmetro de interpretação do potencial patogênico de mutações encontradas em jovens, a partir da sua busca em idosos saudáveis, motivou o início deste projeto no ano de 2010, denominado 80+. A partir de 2012, o CEGH passou a se chamar Centro de Pesquisas sobre o Genoma Humano e Células-tronco (CEGH-CEL) com a aprovação da nova fase de Centros de Pesquisa, Inovação e Difusão (CEPID) da Fapesp, no qual um dos pilares investigativos é sobre envelhecimento e aspectos biológicos a ele conectados.

A amostra $80+$ consiste de idosos octagenários cognitivamente saudáveis, recrutados no CEGH-CEL para triagem do estado cognitivo, preenchimento de questionários e coleta de sangue. Todos os indivíduos foram convidados para a realização de ressonância magnética do cérebro no Hospital Israelita Albert Einstein (HIAE), cujo Comitê de Ética em Pesquisa avaliou e aprovou o projeto. A descrição dos métodos e resultados parciais obtidos com esta amostra estão colocados no capítulo III.

\subsection{Processamento de DNA}

O sangue periférico dos participantes foi coletado em tubos padrão com EDTA e o DNA foi extraído por protocolo padrão de lise alcalina com o auxílio do sistema de automação Qiagen Autopure LS. As amostras foram eluídas em TE, armazenadas em tubos com rosca e anel de vedação, a $4^{\circ} \mathrm{C}$ e quantificadas por espectrofotometria em NanoDrop (Thermo Scientific), onde foi verificada a qualidade pela razão de absorbâncias em 280nm e 260nm. Todas as amostras foram devidamente catalogadas e nomeadas com vínculo chaveado para pareamento com as identificações dos Estudos SABE e 80+.

O sequenciamento do exoma das 604 amostras randomicamente selecionadas da amostra SABE foi realizado pelo serviço do Children's Hospital of Philadelphia. O kit de captura utilizado foi Agilent SureSelect v2. O pipeline de bioinformática aplicado foi o seguinte: o alinhamento dos fragmentos sequenciados foi realizado com a ferramenta BWA (BurrowsWheeler Aligner); a conversão, ordenamento e indexação dos arquivos alinhados foi feito através do Picard; a qualidade do sequenciamento e outros parâmetros foram recalibrados com 
o GATK (Genome Analysis Toolkit); e a anotação de variantes foi feita com o Annovar. Os dados estão custodiados nos servidores do CEGH-CEL do Instituto de Biociências da USP e o acesso é exclusivo do grupo de bioinformática liderado por Guilherme Lopes Yamamoto, também pesquisador colaborador do grupo.

\subsection{Aplicação dos dados e colaborações}

A aplicação imediata dos dados de sequenciamento de exomas de 604 indivíduos da amostra $\mathrm{SABE}$ foi a incorporação dos dados de frequência alélica ao serviço de diagnóstico molecular do CEGH-CEL.

Diversos grupos de pesquisadores já utilizaram a base de indivíduos da amostra SABE como controles, uma vez que são representativos da população (ou seja, com prevalência de doenças proporcionais a mesma distribuição etária na população, com a probabilidade de ocorrência de doenças raras e de início precoce reduzidas). Estudos realizados antes do sequenciamento dos exomas ou investigando a frequência de alterações potencialmente patogênicas ou que confiram suscetibilidade a doença que não estejam representadas no exoma (variantes intergênicas, microdeleções etc) receberam alíquotas e informações básicas sobre os indivíduos da amostra (por exemplo, sexo, idade, etnia auto-declarada, status de câncer). Após o sequenciamento, os colaboradores receberam as frequências alélicas das variantes interrogadas, além de informações básicas sobre a amostra.

\section{Resultados e discussão}

As distribuições dos indivíduos da amostra SABE por idade e sexo estão representadas nas tabelas 2 e 3, respectivamente, incluindo a subproporção dos indivíduos que tiveram exomas sequenciados até o momento.

Tabela 2. Distribuição dos indivíduos do projeto SABE por idade

\begin{tabular}{ccccc}
\hline & \multicolumn{2}{c}{ SABE Amostra Total } & \multicolumn{2}{c}{ SABE Exomas } \\
\hline Classes de idade (anos)* & N & Frequência (\%) & N & Frequência (\%) \\
\hline $60-70$ & 601 & 44,79 & 218 & 36,09 \\
$70-80$ & 376 & 27,98 & 251 & 41,56 \\
$80-90$ & 292 & 21,75 & 131 & 21,69 \\
$90+$ & 74 & 5,48 & 4 & 0,66 \\
\hline Total & 1343 & 100,00 & 604 & 100,00 \\
\hline
\end{tabular}

*Limite superior de classe não incluso 
Tabela 3. Distribuição dos indivíduos do projeto SABE por sexo

\begin{tabular}{ccccccc}
\hline & \multicolumn{2}{c}{ SABE Amostra Total } & \multicolumn{3}{c}{ SABE Exomas } \\
\hline Sexo & $\mathbf{N}$ & $\begin{array}{c}\text { Frequência } \\
\mathbf{( \% )}\end{array}$ & $\begin{array}{c}\text { Idade } \\
\text { (média } \pm \text { d.p.) }\end{array}$ & $\mathbf{N}$ & $\begin{array}{c}\text { Frequência } \\
\text { (\%) }\end{array}$ & $\begin{array}{c}\text { Idade } \\
\text { (média } \pm \text { d.p.) }\end{array}$ \\
\hline Masculino & 485 & 36,11 & $72,93 \pm 9,84$ & 390 & 64,57 & $73,96 \pm 6,91$ \\
Feminino & 858 & 63,89 & $73,29 \pm 9,56$ & 214 & 35,43 & $73,15 \pm 7,06$ \\
\hline Total & 1343 & 100,00 & $73,16 \pm 9,66$ & 604 & 100,00 & $73,67 \pm 6,97$ \\
\hline
\end{tabular}

A integração dos dados de exomas da amostra SABE ao serviço de diagnóstico molecular do CEGH-CEL e projetos de pesquisa associados ao INCT-CNPq e CEPID-Fapesp já contribuiu como ferramenta de filtro para a análise de mais de 900 paineis de genes testados para pacientes e cerca de 400 exomas completos.

Os estudos resultantes de colaboração que utilizaram os dados de variantes genômicas na amostra SABE estão apresentados neste capítulo como anexos a partir da página 55 . O primeiro estudo (Anexo 1) sugere a associação entre uma microdeleção de aproximadamente 69kb no cromossomo 7q34 e câncer (Silva et al., 2013). O estudo chama a atenção para esta deleção que foi encontrada por array-CGH inicialmente em cinco pacientes com câncer de início precoce ou com histórico positivo para câncer na família. A deleção engloba o gene PIP (prolactin-induced protein), cuja expressão foi previamente associada à progressão tumoral e cuja função inclui apoptose, proliferação celular e migração. A deleção não é rara: encontrada em 13 dos 1097 indivíduos do 1000 Genomes, 6 em um grupo de 219 indivíduos e 10 dos 847 indivíduos do SABE triados. O provável risco conferido pela deleção deve ser levado em consideração pela relativa alta frequência (Silva et al., 2013).

Os três estudos seguintes investigaram variantes associadas a tumores endócrinos. $\mathrm{O}$ Anexo 2 é um artigo que investiga a associação entre uma mutação não sinônima no inibidor de ciclo celular p27 (gene $C D K N 1 B$ ) e Neoplasia Endócrina Múltipla tipo 1 (MEN1). A hipótese trabalhada foi do papel desta mutação como modificador, uma vez que os 100 pacientes do estudo são portadores de mutações no gene $M E N 1$, cuja perda de função foi extensivamente associada com a doença. Comparado aos controles, a maioria de participantes da amostra SABE, um dos alelos de p27 foi encontrado sobre-representado no grupo dos pacientes em particular naqueles com maior quantidade de glândulas neoplásicas (Odds Ratio $=18,33 ; P=0,002)$ sugerindo um papel modulador na manifestação dos múltiplos tumores (Longuini et al., 2014). A mesma variante foi investigada nos mesmos controles e em outros pacientes portadores de tumores endócrinos esporádicos como adenomas pituitários, feocromocitomas, carcinoma medular de tireoide e adenomas na paratireoide conforme mostra o estudo disposto no Anexo 3. A associação foi encontrada para adenomas pituitários, 
especificamente os secretores de hormônio adrenocorticotrófico (ACTH), sugerindo um papel tecido-específico para o modificador p27 (Sekiya et al., 2014). Mutações no proto-oncogene RET (rearranged during transfection) foram descritas para os tipos de câncer citados acima, em particular carcinoma medular de tireoide (MTC). A associação é frequente o suficiente para ser incluída em recomendações do Consenso sobre MTC da American Thyroid Association, o qual sugere, como estratégia profilática, a tireodectomia total nos indivíduos portadores de determinadas mutações em RET. Para compreender a potencial patogenicidade das mutações e o papel de modificadores neste gene, o mesmo grupo investigou a frequência de uma variante com funções pouco conhecidas (Y791F). Os resultados foram descritos no Anexo 4, que demonstra que o polimorfismo é raro, mas mais frequente em populações de origem europeias e que a ausência de associação direta desta variante sozinha com a doença pode implicar em uma mudança da interpretação sobre quais mutações em RET seriam indicadas para ações profiláticas (Toledo et al., 2015).

O Anexo 5 contém um trabalho do nosso grupo, o qual reporta a identificação de novas mutações associadas à Distrofia Muscular de Cinturas (DMC) tipo 1G (Vieira et al., 2014). O estudo descreve a identificação de duas famílias afetadas, uma brasileira e uma uruguaia, com sobreposição de vários sintomas, além do clássico envolvimento da musculatura das cinturas pélvica e escapular. A região genômica associada, 4q21, foi mapeada por linkage na família brasileira e posteriormente na família uruguaia. O sequenciamento do genoma completo de afetados de ambas as famílias, seguido de extensas etapas de filtros, incluindo os de frequência para MAF < 0,01 de variantes do 1000 Genomes, dos 6500 exomas do Exome Sequencing Project e dos 604 exomas dos idosos da amostra SABE, permitiu a identificação de duas mutações distintas na mesma posição do gene HNRPDL. O gene, envolvido com processamento de RNA, foi estudado em modelo de interação gênica em leveduras através de mutação em códon de parada de HRP1 (homólogo de HNRPDL) seguida de cruzamento com biblioteca de linhagens de levedura com proteínas fusionadas a GFP. A perda de HRP1 afetou a localização celular de diversas organelas e proteínas de processamento de RNA, observado por microscopia de fluorescência em larga escala, sugerindo a importância deste homólogo. Em seguida, o knockdown do homólogo de HNRPDL em modelo animal Zebrafish também mostrou efeitos drásticos com fenótipos musculares nitidamente observáveis. Os pacientes afetados por DMC1G também apresentam a proteína HNRPDL difusa no músculo em relação aos parentes não afetados. O conjunto de envidências favorece a associação entre as mutações identificadas e a fisiopatologia de DMC1G (Vieira et al., 2014). 
Os estudos seguintes investigaram novas mutações em doenças monogênicas raras de herança autossômica dominante ou por mutações novas em cópia única. A síndrome de Noonan (NS) é caracterizada por baixa estatura, dismorfismos craniofaciais, anormalidades cardíacas e uma série de outros fenótipos associados. NS é considerada uma RASopatia, uma vez que a desregulação da via sinalizadora de RAS/MAPK está subjacente em indivíduos afetados e mutações em vários genes ligados à via foram descritas. $\mathrm{O}$ trabalho descrito no Anexo 6 identificou variantes potencialmente patogênicas em probandos afetados por NS que não carregavam mutações previamente descritas. Duas mutações não sinônimas foram identificadas no gene $S O S 2$, o qual, apesar de não ser previamente associado a NS, tem um homólogo SOS1 com mutações descritas em NS. Um achado interessante foi sobre o gene LZTR1, até então não associado a NS, onde cinco mutações não sinônimas segregam com o fenótipo de quatro famílias brasileiras e uma família polonesa com membros afetados (Yamamoto et al., 2015). A síndrome de Schinzel-Giedion (SGS) é uma doença neurodegenerativa congênita caracterizada por dismorfismos faciais específicas, deficiência intelectual e retardo no desenvolvimento. Mutações em heterozigose no gene SETBP1 foram descritas em afetados por SGS. A função deste gene é pouco conhecida, mas sabe-se que seu produto se liga com domínios SET de proteínas oncogênicas que participam na metilação de caudas de histonas, sugerindo papel na regulação da expressão gênica. Duas mutações novas não sinônimas presentes em dois pacientes de SGS foram identificadas e publicadas no estudo do Anexo 7 (Carvalho et al., 2015). Em ambos os estudos, os exomas da amostra SABE foram utilizados como filtros para variantes raras e controles populacionais com correspondência geográfica com as origens dos pacientes.

A base de exomas da amostra SABE foi utilizada recentemente para triagem de mutações com provável função patogênica em pacientes afetados por fissuras labiopalatinas não sindrômicas e fissuras palatinas. Brito e colaboradores (2015) investigaram variantes em $C D H 1$, que codifica uma E-caderina (envolvida em adesão epitelial), em mais de 200 probandos afetados por um dos dois tipos de fissuras em casos familiais e não-familiais. A associação de variantes neste gene com os fenótipos foi previamente identificada, tornando-o um candidato para os casos investigados e ainda sem diagnóstico molecular. Entre os achados, uma mesma variante missense no exon 6 de $C D H 1$ foi identificada em duas famílias não aparentadas em padrão de herança autossômico dominante com penetrância incomplete; outra variante missense no exon 15 do mesmo gene; e uma variante com provável perda de função (provocando códon de parada no exon 8) também segregando em casos familiais. Para alguns casos descritos na literatura, os fenótipos de fissuras foram observados em associação com 
uma forma hereditária de câncer gástrico difuso, com segregação de variantes em CDH1. Este estudo buscou esta associação nas famílias portadoras das novas variantes idenfiticadas e testaram o potencial invasivo através de ensaio in vitro e não observaram diferenças, nem cosegregação de câncer nos membros da família, sugerindo que variantes de $C D H 1$ podem ou não influenciar a associação entre fenótipos de maneira dependente da distribuição posicional das mutações no produto protéico (Brito et al., 2015). A publicação decorrente desta colaboração está no Anexo 8.

\section{Considerações finais e perspectivas}

A redução do custo de sequenciamento possibilitou o aumento significativo na escala geração de dados. No entanto, há um longo caminho a ser percorrido no que se refere às capacidades de interpretação dos dados genômicos em virtude da complexidade entre os parâmetros de variabilidade genética, clínica, estrutura populacional e dinâmicas populacionais. Vive-se um momento único de oportunidades de construção de bases de dados para melhor entender a complexidade genômica de populações miscigenadas e como a variabilidade genética se corresponde com a variabilidade clínica. Em um mundo cada vez mais miscigenado, temos uma janela curta de tempo para potencialmente amostrar populações isoladas ou recentemente miscigenadas e integrar os dados, a fim de otimizar estudos de associação com doenças e características de natureza complexa. A população brasileira oferece muitas variáveis favoráveis para tais estudos.

O presente capítulo foi uma continuação do anterior no sentido de situar os desafios e atuais propostas de solução de questões científicas atreladas a eles. Demonstramos capacidade de reunir especialistas de diferentes áreas como epidemiologia, estatística, medicina e genética, com o intuito de incluir mais uma ferramenta de auxílio para a interpretação de dados genômicos com uma grande amostra de representação populacional da cidade de São Paulo.

No entanto, muitos passos ainda precisam ser percorridos, alguns deles em pleno andamento:

- Completar o sequenciamento do restante dos indivíduos da amostra SABE. A perspectiva atual é de cumprir esta etapa através de uma grande colaboração com um centro nos Estados Unidos que tem capacidade técnica de sequenciar e auxiliar 
na interpretação dos dados. A análise da ancestralidade genômica das amostras está prevista na colaboração;

- Verificar a frequência de alelos descritos como patogênicos, ou de suscetibilidade, objetivando a construção de um mapa de prevalência que poderá ajudar a reinterpretar o papel das mutações. Este mapa também pode incluir frequências de variantes associadas a farmacogenômica, contribuindo com uma perfilagem da população brasileira;

- Investigar aspectos epigenéticos das amostras, objetivando compreender a interação com o ambiente e como isso explicaria a variabilidade fenotípica;

- Elaborar um protocolo de conduta de como lidar com achados incidentais. Uma base normativa populacional é essencial para melhor compreender a fronteira de variação normal e patogênica em uma população. 


\section{Referências bibliográficas}

ALEXANDER, D. H.; NOVEMBRE, J.; LANGE, K. Fast model-based estimation of ancestry in unrelated individuals. Genome Res, v. 19, n. 9, p. 1655-64, 2009.

ALVES-SILVA, J. et al. The ancestry of Brazilian mtDNA lineages. Am J Hum Genet, v. 67, n. 2, p. 444-61, 2000.

BARRETO, M. L. et al. Risk factors and immunological pathways for asthma and other allergic diseases in children: background and methodology of a longitudinal study in a large urban center in Northeastern Brazil (Salvador-SCAALA study). BMC Pulm Med, v. 6, p. 15, 2006.

BRITO, L. A. et al. Rare Variants in the Epithelial Cadherin Gene Underlying the Genetic Etiology of Nonsyndromic Cleft Lip with or without Cleft Palate. Hum Mutat, 2015.

CARDOZO, D. M. et al. Evidence of HLA-DQB1 Contribution to Susceptibility of Dengue Serotype 3 in Dengue Patients in Southern Brazil. J Trop Med, v. 2014, p. 968262, 2014.

CARVALHO, E. et al. Schinzel-Giedion syndrome in two Brazilian patients: Report of a novel mutation in SETBP1 and literature review of the clinical features. American Journal of Medical Genetics Part A, v. 167, n. 5 , p. $1039-1046,2015$.

CASTELLUCCI, L. C. et al. Host genetic factors in American cutaneous leishmaniasis: a critical appraisal of studies conducted in an endemic area of Brazil. Mem Inst Oswaldo Cruz, v. 109, n. 3, p. 279-88, 2014.

CAVAlli-SFORZA, L. L. Genes, peoples, and languages. Proc Natl Acad Sci U S A, v. 94, n. 15, p. 7719-24, 1997.

COOPER, D. N. et al. Where genotype is not predictive of phenotype: towards an understanding of the molecular basis of reduced penetrance in human inherited disease. Hum Genet, v. 132, n. 10, p. 1077-130, 2013.

DENG, X. et al. Genome wide association study (GWAS) of Chagas cardiomyopathy in Trypanosoma cruzi seropositive subjects. PLoS One, v. 8, n. 11, p. e79629, 2013.

ERRERA, F. I. et al. Functional vascular endothelial growth factor $-634 \mathrm{G}>\mathrm{C}$ SNP is associated with proliferative diabetic retinopathy: a case-control study in a Brazilian population of European ancestry. Diabetes Care, v. 30, n. 2, p. 275-9, 2007.

FERNANDES, D.; CASTRO, M.; MILESI, R. O fluxo de imigração recente para o Brasil e a política governamental: os sinais de ambiguidade. Notas preliminares. Caderno de Debates Refúgio, Migrações e Cidadania, v. 9, n. 9, 2014.

FERREIRA DA SILVA, I. et al. TP53 genetic polymorphisms and environmental risk factors associated with cervical carcinogenesis in a cohort of Brazilian women with cervical lesions. J Toxicol Environ Health A, v. 73, n. 13-14, p. 888-900, 2010.

FRANCO, M. H. et al. Albumin genetic variability in South America: Population distribution and molecular studies. Am J Hum Biol, v. 11, n. 3, p. 359-366, 1999.

FREITAS, S. R. et al. Combined analysis of genetic and environmental factors on essential hypertension in a brazilian rural population in the Amazon region. Arq Bras Cardiol, v. 88, n. 4, p. 447-51, 2007.

GIOLO, S. R. et al. Brazilian urban population genetic structure reveals a high degree of admixture. Eur J Hum Genet, v. 20, n. 1, p. 111-6, 2012.

GONCALVES, F. T. et al. European ancestry and polymorphisms in DNA repair genes modify the risk of melanoma: a case-control study in a high UV index region in Brazil. J Dermatol Sci, v. 64, n. 1, p. 59-66, 2011.

GUIMARAES, R. L. et al. Functional polymorphisms of DEFB1 gene in type 1 diabetes Brazilian children. Autoimmunity, v. 42, n. 5, p. 406-13, 2009. 
HAYNES, G. The early settlement of North America : the Clovis era. Cambridge ; New York: Cambridge University Press, 2002. xiv, 345 p. ISBN 0521819008 (hardback)

HORTA, B. L. et al. Cohort Profile Update: The 1982 Pelotas (Brazil) Birth Cohort Study. Int J Epidemiol, v. 44, n. 2, p. 441-441e, 2015.

HUBBE, M. et al. Cranial morphological diversity of early, middle, and late Holocene Brazilian groups: implications for human dispersion in Brazil. Am J Phys Anthropol, v. 155, n. 4, p. 546-58, 2014.

IZAR, M. C. et al. Risk Factors, biochemical markers, and genetic polymorphisms in early coronary artery disease. Arq Bras Cardiol, v. 80, n. 4, p. 379-95, 2003.

KEHDY, F. S. et al. Origin and dynamics of admixture in Brazilians and its effect on the pattern of deleterious mutations. Proc Natl Acad Sci U S A, v. 112, n. 28, p. 8696-701, 2015.

KOSOY, R. et al. Ancestry informative marker sets for determining continental origin and admixture proportions in common populations in America. Hum Mutat, v. 30, n. 1, p. 69--78, 2009.

LAPRANO, T. D. et al. Association of TP53 codon 72 and intron 3 16-bp Ins/Del polymorphisms with cervical cancer risk. Tumour Biol, v. 35, n. 8, p. 7435-40, 2014.

LEBRÃO, M. L. C.; DUARTE, Y. A. D. O.; PAN AMERICAN HEALTH ORGANIZATION. REPRESENTAÇÃO DO BRASIL. O Projeto SABE no município de São Paulo : uma abordagem inicial. 1a. Brasília, DF, Brasil: Organização Pan-Americana de Saúde, OPAS/OMS, 2003. 255 p. ISBN 8587943308.

LEDDA, M. et al. GWAS of human bitter taste perception identifies new loci and reveals additional complexity of bitter taste genetics. Hum Mol Genet, v. 23, n. 1, p. 259-67, 2014.

LEISH, G. E. N. C. et al. Common variants in the HLA-DRB1-HLA-DQA1 HLA class II region are associated with susceptibility to visceral leishmaniasis. Nat Genet, v. 45, n. 2, p. 208-13, 2013.

LIMA-COSTA, M. F.; FIRMO, J. O.; UCHOA, E. Cohort profile: the Bambui (Brazil) Cohort Study of Ageing. Int J Epidemiol, v. 40, n. 4, p. 862-7, 2011.

LIMA-COSTA, M. F. et al. Genomic ancestry and ethnoracial self-classification based on 5,871 communitydwelling Brazilians (The Epigen Initiative). Sci Rep, v. 5, p. 9812, 2015.

LONGUINI, V. C. et al. Association between the p27 rs2066827 variant and tumor multiplicity in patients harboring MEN1 germline mutations. European Journal of Endocrinology, v. 171, n. 3, p. 335-342, 2014.

MACARTHUR, D. G. et al. A systematic survey of loss-of-function variants in human protein-coding genes. Science, v. 335, n. 6070, p. 823-8, 2012.

MALASPINAS, A. S. et al. Two ancient human genomes reveal Polynesian ancestry among the indigenous Botocudos of Brazil. Curr Biol, v. 24, n. 21, p. R1035-7, 2014.

MEZZACAPPA, M. A. et al. Clinical and genetic risk factors for moderate hyperbilirubinemia in Brazilian newborn infants. J Perinatol, v. 30, n. 12, p. 819-26, 2010.

MILLER, R. M.; SMITH, J. D. Dictionary of Afro-American slavery. Westport, Conn.: Praeger, 1997. xix, 892 p. ISBN 0275957993 (alk. paper).

PALHA, T. et al. Disclosing the genetic structure of Brazil through analysis of male lineages with highly discriminating haplotypes. PLoS One, v. 7, n. 7, p. e40007, 2012.

PARRA, F. C. et al. Color and genomic ancestry in Brazilians. Proc Natl Acad Sci U S A, v. 100, n. 1, p. $177-$ 82, 2003.

PASSOS-BUENO, M. R. et al. Screening of deletions in the dystrophin gene with the cDNA probes Cf23a, Cf56a, and Cf115. J Med Genet, v. 27, n. 3, p. 145-50, 1990. 
PATTERSON, N.; PRICE, A. L.; REICH, D. Population structure and eigenanalysis. PLoS Genet, v. 2, n. 12, p. e190, 2006.

PENA, S. D. et al. The genomic ancestry of individuals from different geographical regions of Brazil is more uniform than expected. PLoS One, v. 6, n. 2, p. e17063, 2011.

RASKIN, S. et al. High allelic heterogeneity between Afro-Brazilians and Euro-Brazilians impacts cystic fibrosis genetic testing. Genet Test, v. 7, n. 3, p. 213-8, 2003.

SCHLESINGER, D. et al. African ancestry protects against Alzheimer's disease-related neuropathology. Mol Psychiatry, 2011.

SEKIYA, T. et al. p27 variant and corticotropinoma susceptibility: a genetic and in vitro study. Endocrine Related Cancer, v. 21, n. 3, p. 395-404, 2014.

SILVA, A. G. et al. Does germ-line deletion of the PIP gene constitute a widespread risk for cancer? Eur J Hum Genet, v. 22, n. 3, p. 307-309, 2013.

THORNTON, T. et al. Estimating kinship in admixed populations. Am J Hum Genet, v. 91, n. 1, p. 122-38, 2012.

TOLEDO, R. A. et al. Comprehensive assessment of the disputed RET Y791F variant shows no association with medullary thyroid carcinoma susceptibility. Endocr Relat Cancer, v. 22, n. 1, p. 65-76, 2015.

VAINZOF, M. et al. Sarcoglycanopathies are responsible for $68 \%$ of severe autosomal recessive limb-girdle muscular dystrophy in the Brazilian population. J Neurol Sci, v. 164, n. 1, p. 44-9, 1999.

VAINZOF, M. et al. Screening of male patients with autosomal recessive Duchenne dystrophy through dystrophin and DNA studies. Am J Med Genet, v. 39, n. 1, p. 38-41, 1991.

VICTORA, C. G.; BARROS, F. C. Cohort profile: the 1982 Pelotas (Brazil) birth cohort study. Int J Epidemiol, v. 35, n. 2, p. 237-42, 2006.

VIEIRA, N. M. et al. A defect in the RNA-processing protein HNRPDL causes limb-girdle muscular dystrophy $1 G$ (LGMD1G). Human Molecular Genetics, v. 23, n. 15, p. 4103-4110, 2014.

WELTER, D. et al. The NHGRI GWAS Catalog, a curated resource of SNP-trait associations. Nucleic Acids Res, v. 42, n. Database issue, p. D1001-6, 2014.

WILLIAMS-BLANGERO, S. et al. Host genetics and population structure effects on parasitic disease. Philos Trans R Soc Lond B Biol Sci, v. 367, n. 1590, p. 887-94, 2012.

XUE, Y. et al. Deleterious- and disease-allele prevalence in healthy individuals: insights from current predictions, mutation databases, and population-scale resequencing. Am J Hum Genet, v. 91, n. 6, p. 1022-32, 2012.

YAMAMOTO, G. L. et al. Rare variants in SOS2 and LZTR1 are associated with Noonan syndrome. Journal of Medical Genetics, v. 52, n. 6, p. 413-421, 2015. 


\section{Does germ-line deletion of the PIP gene constitute a widespread risk for cancer?}

European Journal of Human Genetics (2014) 22, 307-309; doi:10.1038/ejhg.2013.134; published online 19 June 2013

We wish to draw the attention of cancer geneticists to a particular genetic variant of the Prolactin-Induced Protein (PIP) gene that may be an important predisposing factor to cancer because of its high frequency and significant association with cancer, as determined in this study. In an initial copy number variation (CNV) screen for germ-line deletions in 123 Brazilian cancer patients selected as high risk either because of early age of onset (pediatric cancer) or a positive family history (TP53-negative Li-Fraumeni and APC/MUTYHnegative Familial Adenomatous Polyposis patients), a previously undescribed microdeletion was discovered in four patients. The deletion carried in these patients was apparently identical (Figure 1), with a size of $69 \mathrm{~kb}$ and similar base-pair position in chromosome region $7 \mathrm{q} 34$. All four deletions were validated by qPCR and found to harbor only the PIP and TAS2R39 (taste receptor type 2 member 39) genes. TAS2R39 is a member of $\sim 30$ TAS2R bitter taste receptors, ${ }^{1}$ several of which are known to exhibit variation in copy number. It is unlikely that TAS2R39 has a role in tumorigenesis, and will not be considered further in this submission. We here refer to the deletion encompassing the PIP gene as PIP-São Paulo, following the convention of adding the place of discovery to the gene name. This deletion was not detected in a control group of 260 non-related individuals from the São Paulo urban area that had attended our genetic service for reasons other than cancer (normal relatives of patients with intellectual disabilities). The difference in deletion frequency between patients and controls was significant at the 0.01 level (Fisher's exact test). Another example of the PIP-São Paulo deletion was serendipitously detected in a TP53-mutated patient who was not part of these cohorts, but had been investigated by aCGH for presenting with an atypically severe course of cancer that commenced at 4 years of age with the diagnosis of a rhabdomyosarcoma, followed by choroid plexus tumor (7 years of age), liposarcoma and osteochondroma (10 years of age), and finally passed away at 11 years. This patient was not included in the statistics of the patientcontrol comparison; however, a possible interaction between the TP53 mutation and PIP-São Paulo deletion may have contributed to the severity of the cancer progression.

Following our initial observations, we interrogated the 1000 Genomes Project database and found a comparable deletion to be present in 13 out of 1097 individuals: 9 of European and 4 of LatinAmerican origin (see Supplementary Table 1). Manual review of the sequence data in this region indicated that 7 out of the 13 individuals had sufficient sequence depth to determine that they shared identical breakpoints. From this information, we designed PCR primers and were able to amplify across the breakpoints in all the five Brazilian deletion cases. Subsequent sequencing of the PCR fragments (see Supplementary Figure 1) demonstrated that all identified PIP-São Paulo deletions were identical to the deletions present in the 1000 Genomes Project data set. In a replicate study, we determined by breakpoint PCR the frequency of PIP deletions in an independent Brazilian cancer group (219 individuals) that had either presented with more than one primary cancer prior to 60 years of age

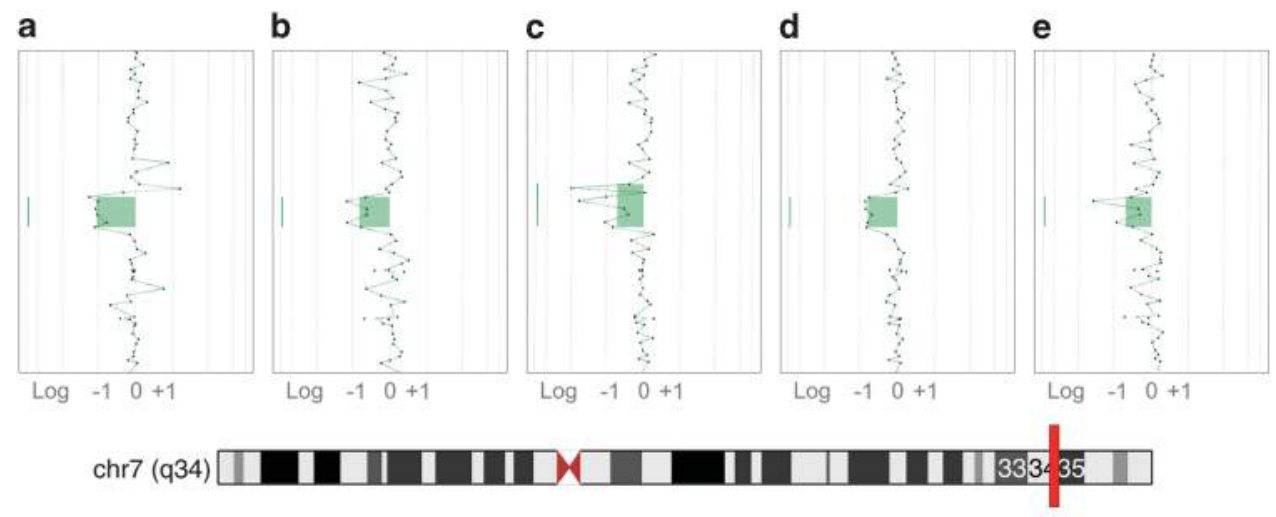

\begin{tabular}{|c|c|c|c|c|c|c|c|c|c|c|}
\hline 1 & & & & $\begin{array}{c}100 \mathrm{~K} \\
142800000\end{array}$ & 142850000 & $142900000 \mid$ & 142950000 & \multicolumn{3}{|c|}{143000000} \\
\hline $\begin{array}{l}\text { Ucsc } \\
\text { genes }\end{array}$ & I & 1 & 1 & & PIP $H$ & TAS2R39 I & I & H & $\mathrm{H} H \mathrm{H}+\mathrm{H}$ & 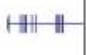 \\
\hline
\end{tabular}

Figure 1 PIP-São Paulo microdeletion at 7q34, detected by array-CGH in cancer patients. Array-CGH profile of a chromosome region at 7q34 (microarray platform Agilent 180K-Agilent Technologies, Santa Clara, CA, USA), showing heterozygous losses of a similar genomic segment (green bars) (image adapted from the Genomic Workbench software, Agilent Technologies): (a) Patient 1; (b) Patient 2; (c) Patient 3; (d) Patient 4 and (e) Y87 (TP53-mutated patient who was not part of the cohorts). In the chromosome 7 ideogram, the red bar marks the microdeletion area, which is showed in detail underneath. The deleted segment (solid green bar) is shown in the context of the genomic region. UCSC genes are also represented (figure adapted from UCSC Genome Bioinformatics, http://genome.ucsc.edu, GRCh37). 
Table 1 Characteristics of the PIP-São Paulo deletion patients: mutation status, clinical phenotype, type of tumor and age at diagnosis

\begin{tabular}{|c|c|c|c|c|}
\hline Patient ID & Cohort & Mutation status & Tumor (age) & Other characteristics \\
\hline Patient 1 & LFS/LFL & Non-mutated & Dermatofibrosarcoma (55) & LFL Eeles 1 \\
\hline Patient 2 & LFS/LFL & Non-mutated & Endometrium sarcoma (65) & LFL chompret \\
\hline Patient 3 & Pediatric & - & $\begin{array}{l}\text { Pilocytic astrocytoma of the } \\
\text { fourth ventricle (9) }\end{array}$ & $\begin{array}{l}\text { Slender build; triangular face; strabismus; bilateral } \\
\text { ptosis of eyelids; palpebral } \\
\text { fissures slant down; sparse eyebrows; hypoplastic } \\
\text { alae nasi; hypoplastic maxilla; right unilateral } \\
\text { auricular pit; left unilateral auricular tag and one } \\
\text { café-au-lait spot }\end{array}$ \\
\hline Patient 4 & FAP & Non-mutated & Colorectal cancer (56) & $\begin{array}{l}\text { Missense variant not previously reported } \\
\text { (c.5365G > C p.Val1789Leu) }\end{array}$ \\
\hline Patient 5 & Multiple tumors & - & Colorectal cancer (47) & Adenoma (50) \\
\hline Patient 6 & Multiple tumors & - & Rhabdomyosarcoma (13), breast cancer (38) & \\
\hline Patient 7 & Multiple tumors & - & Ewing (16), schwanoma (21) & Dermatofibroma (21) \\
\hline Patient 8 & Multiple tumors & - & Osteosarcoma (13) & fibroadenoma (31), fibroadenoma (35) \\
\hline Patient 9 & $\begin{array}{l}\text { Familial } \\
\text { melanoma }\end{array}$ & - & Melanoma (53) & \\
\hline Patient 10 & $\begin{array}{l}\text { Familial } \\
\text { melanoma }\end{array}$ & - & Melanoma (46) & \\
\hline Y87 & LFS/LFL ${ }^{a}$ & $\begin{array}{l}\text { TP53 mutation (S241Y } \\
\text { TCC }>\text { TAC) }\end{array}$ & $\begin{array}{l}\text { Rhabdomyosarcoma (4), choroid plexus } \\
\text { tumor ( } 7 \text { ), liposarcoma (10) }\end{array}$ & $\begin{array}{l}\text { Osteochondroma (10), passed away (11) LFL } \\
\text { chompret }\end{array}$ \\
\hline
\end{tabular}

Abbreviations: FAP, Familial adenomatous polyposis; LFS/LFL, Li-Fraumeni syndrome/Li-Fraumeni-like.

aNot included in the analysis.

(166 individuals) or were probands of hereditary melanoma families (53 individuals with no CDKN2A or CDK4 mutations). This identified a further 6 individuals, who had had cancer and carried the PIP deletion (2.6\%), as opposed to 10 out of 847 individuals $(1.2 \%)$ from a second control group. As in the initial study, the deletion frequency in the replicate study in cancer patients was higher than that in controls, although this was not significant at the $5 \%$ level $(P=0.11)$. However, when cancer and control samples from both studies were pooled, statistical significance was attained $(P=0.04$, Fisher's exact test). Importantly, heterogeneity tests demonstrated that no significant differences existed at the 0.05 level between the two control and two patient samples, respectively. We conclude that the relatively frequent germ-line deletion of the PIP gene has more than a two-fold increase in frequency in the Brazilian cancer patients compared with the Brazilian controls. The clinical phenotype, mutation status, type of tumor and age of diagnosis of all patients carrying the PIP-São Paulo deletion are summarized in Table 1, demonstrating that several types of cancer are involved in this study and that no single type or group of cancers predominates. Presence of the PIP-São Paulo deletion was investigated in paraffin blocks from several different primary tumors taken from four of the deleted patients. In all samples, except for one from patient 7, the PIP-São Paulo deletion was detected (Supplementary Figure 1); additionally, at least one exon of the PIP gene was amplified from each of the tested samples, indicating that one allele was retained, similar to blood. Unfortunately, DNA quality did not allow sequence screening for point mutations or other deletions that may have occurred in the remaining allele. We conclude that if the PIP-São Paulo deletion is directly responsible for tumor induction, this has not occurred by induction of homozygosity of the deletion itself in the cases studied.

To date, several publications have reported association between PIP expression and tumor progression, particularly for prostate and breast cancers. ${ }^{2,3}$ The gene has been implicated in multiple functions, including apoptosis, cell proliferation and migration, ${ }^{4}$ but mutations have only been studied in tumor cell lines and never investigated as germ-line mutations. According to the TCGA database (http://cancergenome.nih.gov/), PIP gains in tumors are more frequent than deletions; however, data in different type of tumors are very heterogeneous and difficult to interpret. We have no specific insights into the mechanisms through which the PIP-São Paulo deletion could be oncogenic.

It is evident from the foregoing that the PIP-São Paulo deletion is not specific to Brazil. Inspection of the HapMap3 database shows that the haplotype adjacent to the deletion (Table 2) is either absent or extremely rare in African populations. Interestingly, although about $\sim 25 \%$ of the 1094 individuals sequenced in data set 1 of the 1000 Genome Project were of African origin, none of the 13 individuals carrying the deletion were African and, except for one Colombian and two Mexican individuals from Los Angeles, CA, USA, all others were of European origin. Ethnic certainty of Brazilian cancer patients and controls is obscured by miscegenation and ethnic diversity; however, they are most likely to be mainly Caucasians, given the relatively high Caucasian composition of São Paulo, and through hospital attendance preferences and other socioeconomic differences. It is probable that PIP-São Paulo arose in an European population as a founder mutation that was subsequently exported to the New World.

The crucial question of whether the PIP-São Paulo deletion constitutes a widespread cancer risk can only be answered by similar investigations in other countries, which we hope will be stimulated by this report. However, maintenance of a deletion variant associated with cancer at such high frequency is surprising and probably implies that, if the cancer association is confirmed by independent studies, PIP-São Paulo appears to have a relatively low cancer penetrance rate so that many carriers either do not manifest cancer or do so at later age, following transmission of the deletion to their offspring, similar to the well-documented Brazilian TP53 variant R337H4. Whereas $\mathrm{R} 337 \mathrm{H}$ has an estimated population frequency of $\sim 0.3 \%$ in Southern Brazil and exhibits an $\sim 8 \%$ penetrance rate in families with adrenocortical cancer, ${ }^{5}$ PIP-São Paulo is practically an order of magnitude more frequent (estimated at $\sim 2 \%$ in European 
Table 2 SNPs, genomic positions (Hg19) and the common haplotype deduced from the proximal region of the patients with $7 q 34$ deletion

\begin{tabular}{lcc}
\hline SNP ID & Genomic position (bp) & Haplotype \\
\hline rs4252461 & 142616964 & $\mathrm{G}$ \\
rs4252400 & 142627330 & $\mathrm{G}$ \\
rs8176049 & 142637728 & $\mathrm{~T}$ \\
rs6949788 & 142638447 & $\mathrm{~T}$ \\
rs8176025 & 142642121 & $\mathrm{G}$ \\
rs8176009 & 142645680 & $\mathrm{C}$ \\
rs41515149 & 142648931 & $\mathrm{~T}$ \\
rs8176001 & 142649042 & $\mathrm{~A}$ \\
rs3757853 & 142650225 & $\mathrm{C}$ \\
rs8175963 & 142657525 & $\mathrm{C}$ \\
rs8175950 & 142661445 & $\mathrm{~T}$ \\
rs10261905 & 142679840 & $\mathrm{~A}$ \\
rs1011672 & 142697445 & $\mathrm{C}$ \\
rs6960104 & 142727310 & $\mathrm{C}$ \\
rs7782579 & 142747913 & $\mathrm{C}$ \\
rs7801166 & 142747955 & $\mathrm{~A}$ \\
rs1994497 & 142816677 & $\mathrm{~A}$ \\
rs10243198 & 142821960 & $\mathrm{G}$ \\
\hline
\end{tabular}

Abbreviation: SNP, single-nucleotide polymorphism.

populations from the 1000 Genome Project data set) and appears as a very frequent factor associated with increased cancer risk. Further, if the PIP-São Paulo deletion frequency is at least two-fold higher in European cancer patients than in controls, as in the São Paulo study, then even allowing for a low penetrance rate, there would be an increased cancer risk for Europeans. In the case of PIP-São Paulo, it is the high frequency and not the penetrance that constitutes the main risk parameter. This completely unanticipated aspect deserves a rapid, coordinated response to confirm whether indeed such an increased risk exists, and if so, to establish its magnitude and specificity. Rapid and cost-effective detection of the deletion can be performed using either PCR across the breakpoints, or copy number estimates by RT-PCR, MLPA and so on.

The exact genome location of PIP-São Paulo is chr7: 142824847142893913 (Genome build GRCh37/hg19).

\section{CONFLICT OF INTEREST}

The authors declare no conflict of interest.

\section{ACKNOWLEDGEMENTS}

We thank all patients and their families for volunteering to participate in this study. This work was supported by grants from the Brazilian National Institute of Science and Technology in Oncogenomics (FAPESP 2008/57887-9 and CNPq 573589/08-9), and FAPESP (2009/00898-1; 2009/0888-5). We thank the Biobank from the AC Camargo Cancer Hospital for providing DNA samples. We also thank Benjamin Heck, Benedito Mauro Rossi, Érika Maria Monteiro Santos and Cecilia Costa for the clinical classification and selection of cancer patients.

Amanda G Silva ${ }^{1}$, Ana CV Krepischi ${ }^{1}$, Giovana T Torrezan ${ }^{1}$, Leonardo P Capelli ${ }^{1}$, Dirce M Carraro ${ }^{1}$, Carla S D'Angelo ${ }^{2}$, Celia P Koiffmann², Mayana Zatz², Michel S Naslavsky ${ }^{2}$, Cibele Masotti ${ }^{2}$, Paulo A Otto ${ }^{2}$, Maria IW Achatz ${ }^{1}$, Ryan E Mills ${ }^{3,4}$, Charles Lee ${ }^{3}$, Peter L Pearson ${ }^{2}$ and Carla Rosenberg ${ }^{\star, 2}$

${ }^{1}$ A.C. Camargo Cancer Center, São Paulo, Brazil; ${ }^{2}$ Department of Genetics and Evolutionary Biology, Institute of Biosciences, University of São Paulo, São Paulo, Brazil; ${ }^{3}$ Department of Pathology, Brigham and Women's Hospital and Harvard Medical School, Boston, Massachusetts, USA; ${ }^{4}$ Department of Computational Medicine \& Bioinformatics, University of Michigan Medical School, Ann Arbor, MI, USA E-mail: carlarosenberg@uol.com.br

1 Behrens M, Meyerhof W: Bitter taste receptors and human bitter taste perception. Cell Mol Life Sci 2006; 63: 1501-1509.

2 Fritzsche FR, Thomas A, Winzer KJ et al: Co-expression and prognostic value of gross cystic disease fluid protein 15 and mammaglobin in primary breast cancer. Histol Histopathol 2007; 22: 1221-1230.

3 Autiero $\mathrm{M}$, Culerrier $\mathrm{R}$, Bouchier $\mathrm{C}$ et al: Abnormal restriction pattern of PIP gene associated with human primary prostate cancers. DNA Cell Biol 1999; 18: 481-487.

4 Debily MA, Marhomy SE, Boulanger $V$ et al: A functional and regulatory network associated with PIP expression in human breast cancer. PLOS One 2009; 4: e4696.

5 Achatz MI, Olivier M, Le Calvez F et al: The TP53 mutation, R337H, is associated with Li-Fraumeni and Li-Fraumeni-like syndromes in Brazilian families. Cancer Lett 2007; 245: 96-102.

Supplementary Information accompanies this paper on European Journal of Human Genetics website (http://www.nature.com/ejhg) 


\title{
Association between the p27 rs2066827 variant and tumor multiplicity in patients harboring MEN1 germline mutations
}

\author{
Viviane C Longuini ${ }^{1}$, Delmar M Lourenço Jr' ${ }^{1}$, Tomoko Sekiya ${ }^{1}$, Osorio Meirelles ${ }^{13}$, \\ Tatiana D Goncalves', Flavia L Coutinho', Guilherme Francisco ${ }^{6}$, Luciana H Osaki ${ }^{15}$, \\ Roger Chammas $^{6}$, Venancio A F Alves ${ }^{7}$, Sheila A C Siqueira7, David Schlesinger ${ }^{11,12}$, \\ Michel S Naslavsky ${ }^{11}$, Mayana Zatz ${ }^{11}$, Yeda A O Duarte ${ }^{8}$, Maria Lucia Lebrão9, \\ Patricia Gama ${ }^{15}$, Misu Lee ${ }^{14}$, Sara Molatore ${ }^{14}$, Maria Adelaide A Pereira ${ }^{5}$, \\ Raquel S Jallad², Marcello D Bronstein², Malebranche B Cunha-Neto ${ }^{3}$, \\ Bernardo Liberman ${ }^{10}$, Maria Candida B V Fragoso ${ }^{4}$, Sergio P A Toledo ${ }^{1,16}$, \\ Natalia S Pellegata ${ }^{14}$ and Rodrigo A Toledo ${ }^{1,+}$

\footnotetext{
${ }^{1}$ Endocrine Genetics Unit (Laboratorio de Investigacao Medica/LIM-25), ${ }^{2}$ Neuroendocrinology Unit, ${ }^{3}$ Neuroendocrinology-Neurosurgery Unit, ${ }^{4}$ Adrenal Unit (LIM-42), ${ }^{5}$ General Endocrinology Unit, ${ }^{6}$ Experimental Oncology Laboratory (LIM-24), ${ }^{7}$ Department of Pathology, ${ }^{8}$ Nursing School and ${ }^{9}$ School of Public Health of Hospital das Clínicas, University of Sao Paulo School of Medicine, Sao Paulo, Brazil, ${ }^{10}$ Brigadeiro Hospital, Sao Paulo, Brazil, ${ }^{11}$ Human Genome Research Center, University of Sao Paulo, Sao Paulo, Brazil, ${ }^{12}$ Instituto do Cérebro, Instituto Israelita de Ensino e Pesquisa Albert Einstein, Sao Paulo, Brazil, ${ }^{13}$ National Institute of Aging, National Institutes of Health (NIH), Bethesda, Maryland, USA, ${ }^{14}$ Institute of Pathology, Helmholtz Zentrum München, Neuherberg, Germany ${ }^{15}$ Institute of Biomedical Sciences, University of Sao Paulo, Sao Paulo, Brazil and ${ }^{16}$ Division of Endocrinology, Federal University of Sao Paulo (UNIFESP), Sao Paulo, Brazil

${ }^{\dagger}$ (R A Toledo is now at Division of Hematology and Medical Oncology, Department of Medicine, Cancer Therapy and Research Center, University of Texas Health Science Center, 7703 Floyd Curl Drive, MC 7880, San Antonio, Texas 78229-3900, USA)
}

Correspondence
should be addressed
to R A Toledo
Email
toledorodrigo@usp.br or
toledorodrigo79@gmail.com

\begin{abstract}
Objective: To date, no evidence of robust genotype-phenotype correlation or disease modifiers for multiple endocrine neoplasia type 1 (MEN1) syndrome has been described, leaving the highly variable clinical presentation of patients unaccounted for.

Design: As the CDKN1B (p27) gene causes MEN4 syndrome and it is transcriptionally regulated by the product of the MEN1 gene (menin), we sought to analyze whether p27 influences the phenotype of MEN1-mutated patients. The cohort consisted of 100 patients carrying germline MEN1 gene mutations and 855 population-matched control individuals. Methods: Genotyping of the coding p27 c.326T > G (V109G) variant was performed by sequencing and restriction site digestion, and the genotypes were associated with clinical parameters by calculating odds ratios (ORs) and their 95\% Cls using logistic regression.

Results: There were significant differences in P27 V109G allele frequencies between controls and MEN1-mutated patients $(\mathrm{OR}=2.55, P=0.019, \mathrm{Cl}=1.013-5.76)$. Among patients who are $\geq 30$ years old carrying truncating MEN1 mutations, the T allele was strongly associated with susceptibility to tumors in multiple glands (three to four glands affected vs one to two glands affected; $\mathrm{OR}=18.33 ; P=0.002, \mathrm{Cl}=2.88-16.41$ ). This finding remained significant after the Bonferroni's multiple testing correction, indicating a robust association. No correlations were observed with the development of MEN1-related tumors such as hyperparathyroidism, pituitary adenomas, and enteropancreatic and adrenocortical tumors.
\end{abstract}


Conclusions: Our study suggests that the $p 27$ tumor suppressor gene acts as a disease modifier for the MEN1 syndrome associated with MEN1 germline mutations. If confirmed in independent patient cohorts, this finding could facilitate the management of this clinically complex disease.

\section{Introduction}

Multiple endocrine neoplasia type 1 (MEN1) is a challenging syndrome due to its extraordinary clinical complexity. MEN1 was first described by Wermer (1954) (1) as the syndrome of adenomatosis of the anterior pituitary, the parathyroids and the pancreatic islets, and the stomach and the duodenum'. As Wermer (2) extended the clinical screening, neoplasias in the adrenal cortex were also included in the panel of MEN1 clinical features. Additionally, he also delineated the genetics of MEN1, describing this disorder as having a dominant inheritance associated with 'mosaic pleiotropism'.

Since the initial reports by Wermer, the chromosomal locus of this disease has been mapped to 11q13 (3), and the gene, named MEN1, has been identified by the positional cloning method $(4,5)$. To date, more than 1300 MEN1 mutations have been reported worldwide, and molecular analysis of at-risk asymptomatic relatives is offered to affected families $(6,7,8,9)$. Although the implementation of such testing helps the clinical management of this syndrome, further studies still need to be conducted to reduce the potential of post-genetic analyses uncertainties $(8,9,10,11)$. For example, while in the absence of a detectable mutation, mutation-negative asymptomatic relatives are excluded from the periodic clinical surveillance, the presence of a mutation remains baffling, as patients harboring exactly the same MEN1 mutation (including first-degree relatives) usually present very different clinical and tumoral outcomes $(4,5,6,7,8,9,10,11,12)$.

Owing to the lack of a genotype-phenotype correlation, the current MEN1 guidelines recommend that all patients carrying MEN1 mutations should be treated equally and subjected to an intense clinical surveillance to diminish the chance of a late diagnosis of MEN1-associated neoplasias and a consequently poor prognosis (10). Such recommendations have proven to be beneficial, but as the tracking of these patients is lifelong and not all mutation-positive individuals develop the full spectrum of MEN1-related tumors, new translational research approaches are required to optimize the follow-up protocols. This strategy could reduce the effort currently spent by both physicians and patients, and thus minimize the financial costs without reducing the quality of care $(6,7,8,9)$. In this context, the identification of genetic-phenotypic modifiers of the disease would facilitate the prediction of outcomes for MEN1 mutation-positive patients and would provide useful information for the refinement of clinical protocols for these patients $(11,12)$.

The CDKN1B ( $p 27)$ gene that encodes the p27 cell cycle inhibitor has recently been identified as a molecule associated with a MEN1-like phenotype in patients without a MEN1 germline mutation (MEN4 syndrome) $(13,14)$. Interestingly, the $C D K N 1 B$ gene is transcriptionally regulated by the product of the MEN1 gene (the menin protein), suggesting that MEN1 and p27 may share a common endocrine tumorigenic pathway $(15,16)$. Considering the increasingly important role of p27 in the susceptibility to endocrine neoplasias, we currently sought to investigate whether the p27 rs2066827 (c.326T > G; V109G) genetic variant of this gene, previously associated with an increased risk for several tumor entities (17), acts to modify the clinical manifestations of patients harboring germline MEN1 mutations.

\section{Patients and methods}

Written informed consent was obtained from the subjects in accordance with the Institutional Review Boardapproved protocols from each center. The University of Sao Paulo Ethical Committee protocol numbers were the following: 0425/08, 0549/09, 462/09, 1231/09, 0050/10, and 0031/10. The study was conducted between July 2007 and March 2011.

\section{MEN1 patients}

A total of 100 DNA blood samples from Brazilian patients with a clinical diagnosis of MEN1 (50 males and 50 females; average age at diagnosis 36.5, 13-71-year-old) and 
harboring a germline mutation in the MEN1 gene were investigated $(8,18,19)$. Patients were of heterogeneous ethnic backgrounds, although the majority of them were Caucasians. Patients were followed up and treated by several units of the Division of Endocrinology, Hospital das Clinicas of the University of Sao Paulo Medical School (Endocrine Genetics Unit, Neuroendocrinology Unit, Neurosurgery Unit, and Adrenal Unit). The clinical diagnosis of the MEN1-related endocrine tumors was performed using standardized clinical, biochemical, and imaging procedures, as reported previously $(20,21)$. After surgery, tumors were confirmed through pathological features and immunostaining with endocrine-specific antibodies.

The frequencies of MEN1-related tumors in the 100 patients were as follows: hyperparathyroidism (HPT; 100\%); pituitary adenomas (61.4\%); enteropancreatic neuroendocrine tumors (89.5\%); and adrenocortical tumors (59.6\%). The overall cohort was used for the comparison of allelic and genotype frequencies in MEN1 patients and healthy control individuals. Additionally, to assess the potential impact of p27 in the phenotypic modulation in MEN1 patients, a cutoff at the age of 30 years was used to avoid age-related issues regarding tumor development.

Seventy two MEN1 patients ( $\geq 30$ years) MEN1 patients with complete medical information for the four main MEN1-related glands (parathyroids, pituitary, adrenals, and endocrine pancreas/duodenum) were included according to the first criterion (age) in the phenotypic modulation studies, which considered the development of each type of tumor and the total number of affected glands in each patient. Furthermore, the type of MEN1 mutation was also considered. As described in almost all other MEN1 cohorts reported, MEN1 truncating mutations were more frequent than missense mutations and were present in 57 out of the $72 \geq 30$-year-old MEN1 patients (79.2\%) $(8,18$, $19,20,21)$. The clinical features of this very informative cohort of patients for testing the hypothesis of genetic-phenotypic modulators (all $\geq 30$ years old and carrying truncating MEN1 mutations) are listed in Supplementary Table 1, see section on supplementary data given at the end of this article and the list of MEN1 mutations in Supplementary Table 2. Briefly, all patients developed HPT $(57 / 57,100 \%), 51$ patients had enteropancreatic neuroendocrine tumors $(51 / 57,89.5 \%), 35$ patients developed pituitary adenomas (35/57, 61.4\%), and 34 patients presented adrenocortical tumors (34/57, 59.6\%). Regarding the number of affected glands, three, eight, 26 , and 20 patients developed tumors in one to four
MEN1-related main glands respectively (Supplementary Table 1). Owing to the reduced number of $\geq 30$-year-old MEN1 patients who had developed tumors in only one or two glands, groups with one to two and three to four tumors were combined for statistical purposes.

\section{Control individuals}

The control group comprised 885 tumor-free adult/elderly subjects distributed as $54 \%$ of females and $46 \%$ of males, with a mean age of 65.2 years (677 of them were 30 -yearsold or older) from the same demographics and ethnicity as patients. In accordance to the Census of the Brazilian Institute of Geography and Statistics (IBGE, Instituto Brasileiro de Geografia e Estatística, www.ibge.gov.br), the frequencies of White/White Latinos and African/ Mulatos in the Sao Paulo area are 78 and 13\% respectively. We have similar frequencies in our study, White/White Latinos (79\%) and African/Mulatos (10\%), indicating that our selection has fulfilled the population-matched criteria to case-control studies. In order to prevent the analysis of 'controls' who had no tumors at young age but who could eventually develop them later, we collected samples of people still healthy at the average age of 65 years. Thus, the cohort of tumor-free controls is 30 years older than the group of patients. To exclude from our analysis a possible effect of sex hormones, gender distribution between patients (50\% of females and $50 \%$ of males) and controls (54\% of females and $46 \%$ of males) was similar.

Blood DNA samples and medical data from healthy individuals were provided by two DNA databanks located at the Department of Oncology, University of Sao Paulo School of Medicine, and at the Human Genome Research Center, Biosciences Institute, University of Sao Paulo.

\section{Single nucleotide polymorphism genotyping}

PCRs were performed using previously described primers, and both DNA strands were sequenced from the purified PCR products using the Big Dye Terminator v3.1 Kit and an automated sequencer (ABI Prism 3130xl DNA Analyzer; Life Technologies) (21). The p27 single nucleotide polymorphism (SNP) V109G was genotyped by direct sequencing in the initial 140 samples. After verifying that the PCR-restriction fragment length polymorphisms (with BglI enzyme, New England Biolabs, Ipswich, MA, USA) showed $100 \%$ of accuracy in comparison with the sequencing results, the remaining samples were then genotyped by digestion. 


\section{Statistical analyses}

Hardy-Weinberg equilibrium was assessed by $\chi^{2}$ statistics, and the best fitting model was determined according to the $P$ values using parsimony. The assessment of tumor risk was performed through a comparison of genotype frequencies between the cases and the controls using $\chi^{2}$ statistics and odds ratios (ORs) with 95\% CIs in logistic regression models. A number of clinical variants such as the presence of the four main MEN1-related tumors (HPT; pituitary adenomas - ACTH-, GH-, and PRL-secreting and nonsecreting pituitary adenomas; and secreting and nonsecreting enteropancreatic neuroendocrine tumors and adrenocortical lesions) were assessed by logistic regression. MEN1 gene mutation types (missense or truncating) were also treated as cofactors in the statistics. Multiple testing correction was performed using the conservative Bonferroni's method.

\section{Phenotypic modulation analysis}

In the current study, we aimed to evaluate the possible phenotypic modulation of rs2066827 in the tumor multiplicity of MEN1 syndrome. Based on the ageassociated penetrance curves for MEN1, young patients are likely to develop additional tumors as they come to adulthood and get older, so in order to avoid age-related bias, we included only patients carrying germline MEN1 mutations, who were older than 30 years. Therefore, we increased the chances of assessing a clearer sign of the possible modulation effect. In total, 72 patients passed these criteria: 57 patients who are $>30$-year-old with MEN1 truncating mutations and 15 patients who are $>30$-year-old with missense mutations.

\section{Results}

\section{rs2066827 in MEN1 patients and controls}

As no robust genotype-phenotype correlation has ever been documented for MEN1 syndrome associated with germline mutations in the MEN1 gene $(4,5,6,7,8,9$, $10,11)$, we tested the hypothesis that the tumor suppressor gene $p 27$ might act as a genetic modifier for clinical manifestations in MEN1 patients. We first compared the allelic frequencies of the V109G polymorphism between MEN1 patients and controls. As these patients carry a germline mutation in the MEN1 gene (11q13) and $p 27$ is located in a different locus (12p13.1), no significant differences in these frequencies were initially
Table 1 Genotype frequencies of the 277 V109G variant in the controls and MEN1 patients.

\begin{tabular}{lccc}
\hline Genotype & Controls & & MEN1 patients \\
\cline { 1 - 1 } GG & 116 & 7 \\
GT & 406 & 37 \\
TT & 363 & 56 \\
Total & 885 & 100 \\
\hline
\end{tabular}

expected. However, a statistically significant higher frequency of the TT genotype at p27 V109G (56.0\%) was found in the MEN1 patients compared with the controls (41.0\%; $n=100, P=0.002$; Table 1 ). Such an unanticipated finding can be obtained by chance when analyzing small sample groups (i.e. due to false positives). However, we investigated a large cohort of a total of 985 populationmatched individuals, including 885 controls and 100 patients. Thus, the present data supports the occurrence of over-representation of the T allele at SNP rs2066827 in the MEN1 patients.

\section{Phenotypic modulation of rs2066827 in MEN1 overall cohort}

We then examined whether the higher frequency of the $\mathrm{T}$ allele in the MEN1 patient cohort might play a role in modulating their clinical features, which are presented in Supplementary Table 1. Although there was no association between the $\mathrm{T}$ allele and the development of specific MEN1-related tumors (HPT, pituitary adenomas, enteropancreatic tumors, and adrenocortical lesions), we found a strong association between the presence of at least one $T$ allele and a higher number of affected neoplastic glands in patients carrying truncating MEN1 mutations (three to four neoplastic glands vs one to two neoplastic glands; $\mathrm{OR}=18.33 ; P=0.002, \mathrm{CI}=2.88-16.41)$. Our data indicated that MEN1 patients older than 30 years carrying a truncating MEN1 mutation and the $p 27$ c.326 GT or TT genotypes at the SNP rs2066827 had a striking 18.3 times higher chance of developing tumors in three or all four major MEN1-related glands than patients at the same age, who carried the same type of mutation, but with the third genotype, GG, at the SNP rs2066827 genotype (assuming the co-dominant model). Similar results were obtained in all other models tested, with ORs varying from 4.3 to 20.8 (Tables 2 and 3). Among the 54 patients of our cohort with three to four tumors, only two were homozygous GG (3.7\%); five out of $18(27.8 \%)$ patients with one to two tumors showed this genotype, indicating that GG probably acts as a 'protective' genotype $(P=0.002)$. 
To test the robustness of these findings, we used the conservative Bonferroni's method to calculate an adjusted and more stringent threshold for significance according to the multiple testing performed $(0.05 / 10=P<0.005)$. Our findings remained significant after this correction, indicating that our data were really robust. Interestingly, we have recently shown that the $G$ allele is associated with the protection against pituitary adenoma development, more specifically, against sporadic corticotropinomas (Sekiya et al., submitted). In addition, another recent study has shown that the same G allele at SNP p27 326 resulting in V109G is a genetic marker of better post-surgical outcomes for medullary thyroid carcinoma in Italian patients (22).

It is well accepted that pediatric MEN1 patients usually present fewer MEN1-related tumors than adults. However, as observed in our patient cohort and in others reported previously, the full manifestation of the disease (with the development of all four of the main MEN1related tumors) does not occur in every adult patient older than 30 years $(9,10,19,20,22,23,24,25)$. In fact, we found that age was not a risk factor for developing multiple tumors in three or four glands among our patients aged 30 years or more $(P=0.70)$. This result further strengthens our finding of the role of p27 V109G in tumor risk modulation in the MEN1 syndrome.

\section{Phenotypic modulation of rs2066827 in MEN1 families}

We further evaluated whether our finding was due to some unique SNP genotyping occurring in family(ies) investigated. Our cohort is composed of one large family harboring the c.308delC mutation and several other small families, hence we analyzed the individual families separately and the same pattern observed in the overall cohort ( $\mathrm{T}$ allele being associated with more tumors) was found in both the large family and the remaining smaller families separably (Supplementary Table 3, see section on supplementary data given at the end of this article). This result indicates that the phenotypic features associated with p27 SNP rs2066827 are not due to a MEN1 family or MEN1 mutation specificity, but they are probably the result of a broader, and therefore more interesting, mechanism of regulation.

\section{Discussion}

To date, no evidence of robust genotype-phenotype correlation or disease modifiers for MEN1 syndrome has been described. The results obtained in the analysis of our cohort, clinically and genetically selected to be 
informative, revealed that $p 27$ rs2066827 polymorphism can influence the clinical outcome of MEN1 patients. This represents the identification of the first potentially strong genetic modifier of the phenotypic features of this complex syndrome.

Notably, previous reports have demonstrated the role of p27 in endocrine tumor risk and tumorigenesis, including studies on naturally occurring (MENX rats) and engineered animal models with p27 deficiency, in which endocrine tumors develop at a high frequency $(13,26,27)$. Moreover, germline $p 27$ mutations predispose patients to MEN4, also called MEN1-like syndrome $(13,14)$. Interestingly, in vitro studies have shown a functional correlation between the product of the MEN1 gene (menin protein) and the expression of the $p 27$ gene that may be associated with the role of $p 27$ SNP rs2066827 as a phenotypic modifier of MEN1-mutated patients reported herein. Additionally, menin forms a transcriptional activation complex together with the MLL2 methyltransferase and RNA polymerase II, and this complex regulates the expression of the $p 27$ gene in pancreatic $\beta$-cells $(15,16,28,29)$. Therefore, it is postulated that the truncation of menin (resulting in a loss of function) in MEN1 patients/tumors consequently leads to decreased p27 mRNA levels. Functional assessment of the $p 27 \mathrm{~V} 109 \mathrm{G}$ variant has not been reported so far, and the mechanism by which it might influence tumor susceptibility and tumorigenesis is currently unknown. Such nucleotide change affects an amino acid located in the domain mediating the binding of $\mathrm{p} 27$ to the $\mathrm{p} 38^{\mathrm{Jab} 1}$ protein, and this interaction mediates the nuclear export of p27 and its subsequent degradation (30). Thus, it has been speculated that this V109G variant might interfere with the interaction of $\mathrm{p} 27$ with $\mathrm{p} 38^{\mathrm{Jab} 1}$ and could therefore lead to an increased nuclear stability for p27 (31). The combination of MEN1 truncation and the $p 27$ SNP V109 may potentially further impair p27 function.

Interestingly and consistent with the data from humans presented herein, the effects of genetic background and modifiers on the phenotype of embryonic lethality in Men1-knockout mouse models have been demonstrated previously. By backcrossing Men $1^{+/-}$ mice, the authors generated the $\mathrm{C} 57 \mathrm{BL} / 6$ and 129 S6/SuEv strains; a significant early lethality in the $129 \mathrm{~S} 6 / \mathrm{SuEv}$ strain was found after analyzing a large number of embryos (32). These data underline the importance of the genetic background in influencing the MEN1 phenotype and implicate a role for genetic modifiers in this syndrome in mice, in a finding parallel to the data presented herein for humans. 
The reason as to why no association was found between SNP rs2066827 and tumor multiplicity in patients carrying missense MEN1 gene mutations is currently unknown, but may be due to the smaller number of cases with missense mutations in our patient cohort. Alternatively, it is possible that the change of only one amino acid in the menin protein may lead to the activation of downstream molecular mechanisms that are not fully dependent on p27. Recent studies have shown that several MEN1 missense mutations do not change the protein stability compared with WT menin (33), but may lead to unique gene expression profiles (34).

There are conflicting findings in the literature regarding the risk/protection associated with rs2066827 T/G alleles. A recent meta-analysis has evaluated the association data of eight studies encompassing 3799 controls and 3591 patients with non-endocrine tumors (oral squamous cell, prostate, breast cancer, and pancreatic cancer) and found no correlation between the rs2066827 variant and the overall cancer risk in the general population (35). As $p 27$ is a tumor susceptibility gene for multiple endocrine tumors in both humans and rats, and has recently been reported to be somatically mutated in small intestine neuroendocrine tumors (36), we decided to investigate its role specifically in modulating the risk of endocrine tumors. In conclusion, we identified $p 27$ rs2066827 as a genetic variant that influences the clinical manifestation of MEN1 adult patients carrying the most frequent type of MEN1 gene defects, i.e. truncating mutations. To our knowledge, this is the first strong genotype-phenotype correlation found in the MEN1 syndrome and, if confirmed in other cohorts, it may improve genetic counseling and the clinical management of this highly complex syndrome. Furthermore, as $p 27$ is a downstream gene in the MEN1 tumorigenesis-driven pathway, a disease-modifying mechanism for the 'mosaic pleiotropism' described by Wermer in MEN1 may be involved (Supplementary Fig. 1, see section on supplementary data given at the end of this article), a hypothesis that might be worthy of in vitro testing in the future.

\section{Supplementary data}

This is linked to the online version of the paper at http://dx.doi.org/10.1530/ EJE-14-0130.

\section{Declaration of interest}

M D Bronstein declares an association with the following companies: Ipsen, Novartis, and Pfizer (consultant, speaker, and grant/research support). The remaining authors have nothing to disclose.

\section{Funding}

This study was supported by the fund from the DAAD/CAPES PROBRAL program (Brazil/Germany collaboration) with research grants to $\operatorname{Dr} S \mathrm{P} A$ Toledo and Dr N S Pellegata. T Sekiya, D M, Lourenço, and R A Toledo received fellowships from FAPESP. S P A Toledo received research and productivity grants from CNPq.

\section{References}

1 Wermer P. Genetic aspects of adenomatosis of endocrine glands. American Journal of Medicine 195416 363-371. (doi:10.1016/ 0002-9343(54)90353-8)

2 Wermer P. Endocrine adenomatosis and peptic ulcer in a large kindred. Inherited multiple tumors and mosaic pleiotropism in man. American Journal of Medicine 196335 205-212. (doi:10.1016/ 0002-9343(63)90212-2)

3 Larsson C, Skogseid B, Oberg K, Nakamura Y \& Nordenskjöld M. Multiple endocrine neoplasia type 1 gene maps to chromosome 11 and is lost in insulinoma. Nature 1988332 85-87. (doi:10.1038/332085a0)

4 Chandrasekharappa SC, Guru SC, Manickam P, Olufemi SE, Collins FS, Emmert-Buck MR, Debelenko LV, Zhuang Z, Lubensky IA, Liotta LA et al. Positional cloning of the gene for multiple endocrine neoplasiatype 1. Science 1997276 404-407. (doi:10.1126/science.276.5311.404)

5 Lemmens I, Van de Ven WJ, Kas K, Zhang CX, Giraud S, Wautot V, Buisson N, De Witte K, Salandre J, Lenoir G et al. Identification of the multiple endocrine neoplasia type 1 (MEN1) gene, The European Consortium on MEN1. Human Molecular Genetics 19976 1177-1183. (doi:10.1093/hmg/6.7.1177)

6 Lemos MC \& Thakker RV. Multiple endocrine neoplasia type 1 (MEN1): analysis of 1336 mutations reported in the first decade following identification of the gene. Human Mutation 200829 22-32. (doi:10.1002/humu.20605)

7 Lairmore TC, Piersall LD, DeBenedetti MK, Dilley WG, Mutch MG, Whelan AJ \& Zehnbauer B. Clinical genetic testing and early surgical intervention in patients with multiple endocrine neoplasia type 1 (MEN 1). Annals of Surgery 2004239 637-645. (doi:10.1097/01. sla.0000124383.98416.8d)

8 Lourenco DM Jr, Toledo RA, Coutinho FL, Margarido LC, Siqueira SA, dos Santos MA, Montenegro FL, Machado MC \& Toledo SP. The impact of clinical and genetic screenings on the management of the multiple endocrine neoplasia type 1. Clinics 200762 465-476. (doi:10.1590/ S1807-59322007000400014)

9 Pieterman CR, Schreinemakers JM, Koppeschaar HP, Vriens MR, Rinkes IH, Zonnenberg BA, van der Luijt RB \& Valk GD. Multiple endocrine neoplasia type 1 (MEN1): its manifestations and effect of genetic screening on clinical outcome. Clinical Endocrinology 200970 575-581. (doi:10.1111/j.1365-2265.2008.03324.x)

10 Brandi ML, Gagel RF, Angeli A, Bilezikian JP, Beck-Peccoz P, Bordi C, Conte-Devolx B, Falchetti A, Gheri RG, Libroia A et al. Guidelines for diagnosis and therapy of MEN type 1 and type 2. Journal of Clinical Endocrinology and Metabolism 200186 5658-5671. (doi:10.1210/ jcem.86.12.8070)

11 Lips CJ, Höppener JW, Van Nesselrooij BP \& Van der Luijt RB. Counseling in multiple endocrine neoplasia syndromes: from individual experience to general guidelines. Journal of Internal Medicine 2005 257 69-77. (doi:10.1111/j.1365-2796.2004.01429.x)

12 Lips CJ, Dreijerink KM \& Höppener JW. Variable clinical expression in patients with a germline MEN1 disease gene mutation: clues to a genotype-phenotype correlation. Clinics 201267 49-56. (doi:10.6061/clinics/2012(Sup01)10)

13 Pellegata NS, Quintanilla-Martinez L, Siggelkow H, Samson E, Bink K, Höfler H, Fend F, Graw J \& Atkinson MJ. Germ-line mutations in p27Kip1 cause a multiple endocrine neoplasia syndrome in rats and 
humans. PNAS 2006103 15558-15563. (doi:10.1073/pnas. 0603877103)

14 Agarwal SK, Mateo CM \& Marx SJ. Rare germline mutations in cyclindependent kinase inhibitor genes in multiple endocrine neoplasia type 1 and related states. Journal of Clinical Endocrinology and Metabolism 200994 1826-1834. (doi:10.1210/jc.2008-2083)

15 Hughes CM, Rozenblatt-Rosen O, Milne TA, Copeland TD, Levine SS, Lee JC, Hayes DN, Shanmugam KS, Bhattacharjee A, Biondi CA et al. Menin associates with a trithorax family histone methyltransferase complex and with the hoxc8 locus. Molecular Cell 200413 587-597. (doi:10.1016/S1097-2765(04)00081-4)

16 Karnik SK, Hughes CM, Gu X, Rozenblatt-Rosen O, McLean GW, Xiong Y, Meyerson M \& Kim SK. Menin regulates pancreatic islet growth by promoting histone methylation and expression of genes encoding p27Kip1 and p18INK4c. PNAS 2005102 14659-14664. (doi:10.1073/pnas.0503484102)

17 Li G, Sturgis EM, Wang LE, Chamberlain RM, Spitz MR, El-Naggar AK, Hong WK \& Wei Q. Association between the V109G polymorphism of the p27 gene and the risk and progression of oral squamous cell carcinoma. Clinical Cancer Research 200410 3996-4002. (doi:10.1158/ 1078-0432.CCR-04-0089)

18 Lourenco DM Jr, Coutinho FL, Toledo RA, Montenegro FL, CorreiaDeur JE \& Toledo SP. Early-onset, progressive, frequent, extensive, and severe bone mineral and renal complications in multiple endocrine neoplasia type 1-associated primary hyperparathyroidism. Journal of Bone and Mineral Research 201025 2382-2391. (doi:10.1002/jbmr.125)

19 Coutinho FL, Lourenco DM Jr, Toledo RA, Montenegro FL, CorreiaDeur JE \& Toledo SP. Bone mineral density analysis in patients with primary hyperparathyroidism associated with multiple endocrine neoplasia type 1 after total parathyroidectomy. Clinical Endocrinology 201072 462-468. (doi:10.1111/j.1365-2265.2009.03672.x)

20 Lourenco DM Jr, Toledo RA, Mackowiak II, Coutinho FL, Cavalcanti MG, Correia-Deur JE, Montenegro F, Siqueira SA, Margarido LC, Machado MC et al. Multiple endocrine neoplasia type 1 in Brazil: MEN1 founding mutation, clinical features, and bone mineral density profile. European Journal of Endocrinology 2008159 259-274. (doi:10.1530/EJE-08-0153)

21 Toledo RA, Lourenco DM Jr, Coutinho FL, Quedas E, Mackowiack I, Machado MC, Montenegro F, Cunha-Neto MB, Liberman B, Pereira MA et al. Novel MEN1 germline mutations in Brazilian families with multiple endocrine neoplasia type 1. Clinical Endocrinology 200767 377-384. (doi:10.1111/j.1365-2265.2007.02895.x)

22 Pasquali D, Circelli L, Faggiano A, Pancione M, Renzullo A, Elisei R, Romei C, Accardo G, Coppola VR, De Palma M et al. CDKN1B V109G polymorphism a new prognostic factor in sporadic medullary thyroid carcinoma. European Journal of Endocrinology 2011164 397-404. (doi:10.1530/EJE-10-0929)

23 Giraud S, Zhang CX, Serova-Sinilnikova O, Wautot V, Salandre J, Buisson N, Waterlot C, Bauters C, Porchet N, Aubert JP et al. Germ-line mutation analysis in patients with multiple endocrine neoplasia type 1 and related disorders. American Journal of Human Genetics 199863 455-467. (doi:10.1086/301953)

24 Wautot V, Vercherat C, Lespinasse J, Chambe B, Lenoir GM, Zhang CX, Porchet N, Cordier M, Béroud C \& Calender A. Germline mutation profile of MEN1 in multiple endocrine neoplasia type 1: search for correlation between phenotype and the functional domains of the MEN1 protein. Human Mutation 200220 35-47. (doi:10.1002/ humu.10092)

25 Tham E, Grandell U, Lindgren E, Toss G, Skogseid B \& Nordenskjöld M. Clinical testing for mutations in the MEN1 gene in Sweden: a report on 200 unrelated cases. Journal of Clinical Endocrinology and Metabolism 200792 3395. (doi:10.1210/jc.2007-0476)

26 Fero ML, Rivkin M, Tasch M, Porter P, Carow CE, Firpo E, Polyak K, Tsai LH, Broudy V, Perlmutter RM et al. A syndrome of multiorgan hyperplasia with features of gigantism, tumorigenesis, and female sterility in p27(Kip1)-deficient mice. Cell 199685 733-744. (doi:10.1016/S0092-8674(00)81239-8)

27 García-Fernández RA, García-Palencia P, Sánchez MÁ, Gil-Gómez G, Sánchez B, Rollán E, Martín-Caballero J \& Flores JM. Combined loss of p21(waf1/cip1) and p27(kip1) enhances tumorigenesis in mice. Laboratory Investigation 201191 1634-1642. (doi:10.1038/labinvest. 2011.133)

28 Karnik SK, Chen H, McLean GW, Heit JJ, Gu X, Zhang AY, Fontaine M, Yen MH \& Kim SK. Menin controls growth of pancreatic $\beta$-cells in pregnant mice and promotes gestational diabetes mellitus. Science 2007 318 806-809. (doi:10.1126/science.1146812)

29 Milne TA, Hughes CM, Lloyd R, Yang Z, Rozenblatt-Rosen O, Dou Y, Schnepp RW, Krankel C, Livolsi VA, Gibbs D et al. Menin and MLL cooperatively regulate expression of cyclin-dependent kinase inhibitors. PNAS 2005102 749-754. (doi:10.1073/pnas.0408836102)

30 Tomoda K, Kubota Y \& Kato J. Degradation of the cyclin-dependentkinase inhibitor p27Kip1 is instigated by Jab1. Nature 1999398 160-165. (doi:10.1038/18230)

31 Schöndorf T, Eisele L, Göhring UJ, Valter MM, Warm M, Mallmann P, Becker M, Fechteler R, Weisshaar MP \& Hoopmann M. The V109G polymorphism of the p27 gene CDKN1B indicates a worse outcome in node-negative breast cancer patients. Tumour Biology 200425 306-312. (doi:10.1159/000081396)

32 Lemos MC, Harding B, Reed AA, Jeyabalan J, Walls GV, Bowl MR, Sharpe J, Wedden S, Moss JE, Ross A et al. Genetic background influences embryonic lethality and the occurrence of neural tube defects in Men1 null mice: relevance to genetic modifiers. Journal of Endocrinology 2009203 133-142. (doi:10.1677/JOE-09-0124)

33 Shimazu S, Nagamura Y, Yaguchi H, Ohkura N \& Tsukada T. Correlation of mutant menin stability with clinical expression of multiple endocrine neoplasia type 1 and its incomplete forms. Cancer Science 2011102 2097-2102. (doi:10.1111/j.1349-7006.2011.02055.x)

34 Farrell WE, Azevedo MF, Batista DL, Smith A, Bourdeau I, Horvath A, Boguszewski M, Quezado M \& Stratakis CA. Unique gene expression profile associated with an early-onset multiple endocrine neoplasia (MEN1)-associated pituitary adenoma. Journal of Clinical Endocrinology and Metabolism 201196 1905-1914. (doi:10.1210/jc.2011-1127)

35 Wei F, Xu J, Tang L, Shao J, Wang Y, Chen L \& Guan X. p27(Kip1) V109G polymorphism and cancer risk a systematic review and meta-analysis. Cancer Biotherapy \& Radiopharmaceuticals 201227 665-671. (doi:10.1089/cbr.2012.1229)

36 Francis JM, Kiezun A, Ramos AH, Serra S, Pedamallu CS, Qian ZR, Banck MS, Kanwar R, Kulkarni AA, Karpathakis A et al. Somatic mutation of CDKN1B in small intestine neuroendocrine tumors. Nature Genetics 201345 1483-1486. (doi:10.1038/ng.2821)

Received 13 February 2014

Revised version received 27 May 2014

Accepted 11 June 2014 


\title{
p27 variant and corticotropinoma
}

susceptibility: a genetic and

in vitro study

\author{
Tomoko Sekiya', Marcello D Bronstein ${ }^{2}$, Katiuscia Benfini ${ }^{14}$, Viviane C Longuini ${ }^{1}$, \\ Raquel S Jallad ${ }^{2}$, Marcio C Machado², Tatiana D Goncalves', Luciana H Osaki", \\ Leonardo Higashi $^{8}$, Jose Viana-Jr ${ }^{7,9}$, Claudio Kater ${ }^{9}$, Misu Lee ${ }^{14}$, Sara Molatore ${ }^{14}$, \\ Guilherme Francisco ${ }^{4}$, Roger Chammas ${ }^{4}$, Michel S Naslavsky ${ }^{10}$, David Schlesinger ${ }^{10,12}$, \\ Patricia Gama"1, Yeda A O Duarte ${ }^{5}$, Maria Lucia Lebrão ${ }^{6}$, Mayana Zatz ${ }^{10}$, \\ Osorio Meirelles ${ }^{13}$, Bernardo Liberman ${ }^{8}$, Maria Candida B V Fragoso ${ }^{3}$, \\ Sergio P A Toledo', Natalia S Pellegata ${ }^{14}$ and Rodrigo A Toledo, ${ }^{1+}$

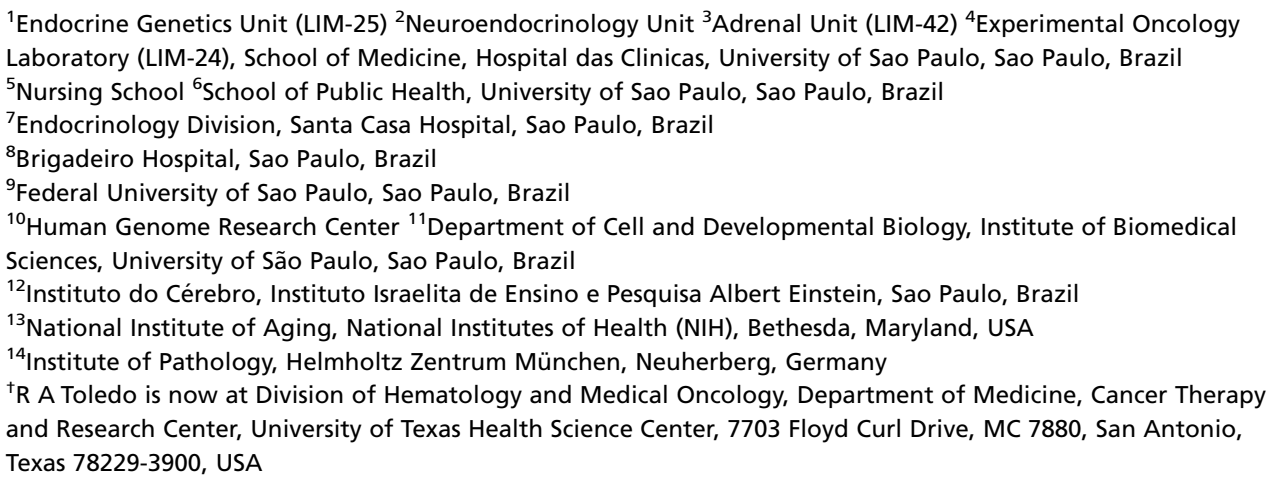

Correspondence should be addressed to R A Toledo Email toledorodrigo@usp.br; toledorodrigo79@gmail.com

\begin{abstract}
Germline mutations in $p 27^{k i p 1}$ are associated with increased susceptibility to multiple endocrine neoplasias (MEN) both in rats and humans; however, the potential role of common polymorphisms of this gene in endocrine tumor susceptibility and tumorigenesis remains mostly unrecognized. To assess the risk associated with polymorphism rs 2066827 (p27-V109G), we genotyped a large cohort of Brazilian patients with sporadic endocrine tumors (pituitary adenomas, $n=252$; pheochromocytomas, $n=125$; medullary thyroid carcinoma, $n=51$; and parathyroid adenomas, $n=19)$ and 885 population-matched healthy controls and determined the odds ratios and $95 \% \mathrm{Cls}$. Significant associations were found for the group of patients with pituitary adenomas $(P=0.01)$, particularly for those with ACTH-secreting pituitary adenomas $(P=0.005)$. In contrast, no association was found with $\mathrm{GH}$-secreting pituitary tumors alone or with the sporadic counterpart of MEN2-component neoplasias. Our in vitro analyses revealed increased colony formation and cell growth rate for an AtT20 corticotropin mouse cell line overexpressing the p27-V109G variant compared with cells transfected with the WT p27. However, the genotypic effects in genetic and in vitro approaches were divergent. In accordance with our genetic data showing specificity for ACTH-secreting pituitary tissues, the overexpression of p27-V109G in a GH3 somatotropin rat cell line resulted in no difference compared with the WT. Pituitary tumors are one of the major clinical components of syndromes associated with the p27 pathogenic mutations
\end{abstract}
Key Words
- endocrine tumor
- p27
- corticotropinoma
- pituitary tumor

(C) 2014 Society for Endocrinology Printed in Great Britain
Published by Bioscientifica Ltd 
MENX and MEN4. Our genetic and in vitro data indicate that the common polymorphism rs2066827 may play a role in corticotropinoma susceptibility and tumorigenesis through a molecular mechanism not fully understood thus far.

\section{Introduction}

In the last two decades, genetic studies of endocrine tumor syndromes have identified a number of susceptibility genes including several tumor suppressors (multiple endocrine neoplasia type 1 (MEN1), VHL, NF1, SDHA, SDHB, SDHC, SDHD, SDHAF2, PRKAR1A, AIP, TMEM127, MAX, p15 ${ }^{I N K 4 B}$ (CDKN2A), p18 ${ }^{I N K 4 C}$ (CDKN2C), p21 ${ }^{\text {CIP1 }}$ $(C D K N 1 A)$, and $\left.p 27^{\text {Kip1 }}(C D K N 1 B)\right)$ and two protooncogenes (RET and HIF2A (EPAS1)) (Pellegata et al. 2006, Agarwal et al. 2009, Zhuang et al. 2012, Toledo et al. 2013 and Supplementary refs 1-13 see section on supplementary data given at the end of this article). The genes predisposing to endocrine tumors encode transcription factors or molecules that are involved in a variety of processes such as hypoxia, cell-cycle inhibition, the citric acid cycle and the electron transfer chain, cAMP and Ras pathways, and in both mTOR and myc and glial cell linederived neurotrophic tyrosine kinase signaling. Among the recently described tumor susceptibility genes for endocrine tumors is the CDKN1B gene, which codes for the cyclin kinase inhibitor p27 $7^{\text {Kip1 }}$ (p27). p27 inhibits cyclin and cyclin-dependent kinase (Cdk) complexes which are essential for cell-cycle progression from G1 to $\mathrm{S}$ phases. $\mathrm{p} 27$ is mutated in a MEN syndrome both in rats and human patients (Pellegata et al. 2006, Marinoni \& Pellegata 2010). The germline mutations in CDKN1B so far identified in patients (12 in total) affect the stability of p27 protein, its localization, its ability to interact with partner proteins, or the efficiency of transcription of the mutated CDKN1B allele (Pellegata 2012). Usually, p27 is not somatically mutated, but its expression is reduced or lost in more than $50 \%$ of all human tumors, including endocrine tumors (Chu et al. 2008). In addition to the pathogenic mutations, $C D K N 1 B$ harbors single-nucleotide polymorphisms (SNPs) within or in the vicinity of the coding sequence, several with a low allelic frequency $(<5 \%)$ and three of which are potentially functional: $-838 \mathrm{C}>\mathrm{A}$ (rs36228499), $-79 \mathrm{C}>\mathrm{T}$ (rs34330), and 326T $>$ G (V109G, rs2066827). Indeed, patients with the variant AA genotype at position -823 of $C D K N 1 B$ present low risk of restenosis following coronary stenting, and the variant $-838 \mathrm{~A}$ allele is associated with augmented gene transcription (González et al. 2004), whereas the $-79 \mathrm{C}>\mathrm{T}$ allelic variant is related to reduced transcription in in vitro studies (Landa et al. 2010). Furthermore, the coding 326T $>$ G (V109G) allelic variant has been associated with cancer risk and progression of different tumors including prostate cancer (Kibel et al. 2003), oral squamous cell carcinoma (Li et al. 2004), invasive epithelial ovarian cancer (Gayther et al. 2007), highgrade breast tumors (Tigli et al. 2005), and pancreatic carcinoma (Chen et al. 2010). A recent study has shown that the variant $G$ allele at position 326 protects against thyroid cancer development (Pasquali et al. 2011), so that the role of the V109G polymorphism in increasing/ decreasing tumor risk remains to be determined.

In the present study, we investigated the potential influence of the p27 rs2066827 (V109G) polymorphism on the risk of developing endocrine tumors in a large cohort of 447 Brazilian patients presenting the following sporadic endocrine tumors: pituitary adenomas $(n=252)$, pheochromocytomas $(n=125)$, medullary thyroid carcinoma (MTC; $n=51$ ), and parathyroid adenomas/hyperparathyroidism (HPT; $n=19)$. The results were compared with those for 885 healthy patients, representative of Brazilian controls. In vitro analyses were performed to further assess the role of p27-V109G in pituitary adenoma cells.

\section{Subjects and methods}

\section{Study population}

All samples were collected in research centers in the Sao Paulo region of Brazil. Patients and controls were derived from matched population ancestry, composed of majority White and White-Latins, and also Asians, African-Americans, and individuals with mixed (undetermined) ancestry.

\section{Demographic information}

The patients were treated in three different hospitals (Hospital das Clinicas, Hospital Brigadeiro, and Hospital Santa Casa) all located within Sao Paulo city. The controls were collected from two different centers: one in 
the same hospital where the patients were treated (Hospital das Clinicas) and the other one located in the Basic Science Building of the University of Sao Paulo (IB-USP).

\section{Characterization of the control group}

The samples were obtained from two DNA banks of healthy individuals at the Medical School (FM-USP, Department of Oncology) and at the Biosciences Institute (IB-USP, Human Genome Research Center) at the University of Sao Paulo.

The control group comprised 885 tumor-free adult/ elderly subjects distributed as $54 \%$ females, $46 \%$ males, with a mean age of 65.2 years ( 677 of them were 30 years old or older). In order to prevent the analysis of 'controls' that had no tumors at a young age but who could eventually develop them later, we collected samples of people still healthy at the average age of 65 years. Thus, the cohort of tumorfree controls is 25 years older than the group of patients.

To exclude from our analysis a possible effect of sex hormones, the sex distribution of the patients (59\% females and $41 \%$ males) and controls (54\% females and $46 \%$ of nine males) was similar.

We further characterized our study population with regard to the ethnicity and genotype/allele frequencies comparing with public databases and previous genetic studies of rs2066827. The frequencies of White/White Latinos (79\%) and African/Mulatos (10\%) in our control group were very similar to those assessed by The Brazilian Institute of Geography and Statistics (IBGE, Instituto Brasileiro de Geografia e Estatística), which reported frequencies of 78 and $13 \%$ of White/White Latinos and African/Mulatos, respectively, in the Sao Paulo area in the 2000 Census (www.ibge.gov.br). Allele frequencies found in our population study were compared with those reported in eight papers, which genotyped rs2066827 from controls of Caucasian and Asian ethnicity and from the USA, Canada, Malaysia, and China, as well as from four populations analyzed by the 1000 Genomes Project (CAUC1, AFR1, HISP1, and PAC1). As expected, the frequencies of the Brazilian population ( $\mathrm{G}, 36 \%$ and $\mathrm{T}, 64 \%$ ) were more similar to those for Caucasians (G, 24\% and T, 76\%) and Hispanics ( $G, 30 \%$ and $T, 70 \%)$, than to those for Asians (G, 12\% and T, 88\%) and Africans (G, 36\% and T, 34\%).

\section{Patients}

The study analyzed 447 patients from matched population ethnicity that were clinically diagnosed with several types of sporadic endocrine tumors, including two different types of pituitary adenomas ( $n=252)$ : GH-secreting/ acromegaly $(n=161)$ and adrenocorticotropic hormone (ACTH)-secreting/Cushing's disease $(n=91)$; parathyroid adenomas/HPT $(n=19) ;$ MTC $(n=51) ;$ and adrenomedullary tumors/pheochromocytomas $(n=125)$. Gender distribution was of $59 \%$ females and $41 \%$ males and the mean age at diagnosis was 40.7 years. They were diagnosed and treated at the Hospital das Clinicas of University of Sao Paulo Medical School (Endocrine Genetics Unit, Neuroendocrinology Unit, and Adrenal Unit), as well as at the Endocrine Divisions of the Hospital Brigadeiro (Sao Paulo) and Hospital Santa Casa (Sao Paulo).

The diagnosis of endocrine tumors was performed by standardized clinical, biochemical, and imaging examinations (Toledo et al. 2009, 2010a, Lourenco et al. 2010). Other possible endocrine tumors were ruled out in each patient. After surgery, tumors were confirmed through pathological criteria and immunostaining for endocrinespecific antibodies. We should mention that all cases with MTC included in the study were examined for the presence of mutations in the hot-spot exons of the RET proto-oncogene (exons 10, 11, and 13-16), and none were found (Santos et al. 2006, Toledo et al. 2010b). TMEM127 and RET mutations were ruled out in the 51 cases with pheochromocytomas as previously described (Yao et al. 2010). The previously described cases from our MEN1 cohort (Toledo et al. 2010a) were not included in this study.

Written informed consents were obtained from all subjects in accordance with Institutional Review Boardapproved protocols from each center. The protocols from the University of Sao Paulo are numbered as 0425/08, 0549/09, 1231/09, 0050/10, and 0031/10.

\section{SNP genotyping}

The genomic DNA of each subject was isolated from peripheral blood using standard salting-out protocol or commercially available DNA extraction kits (DNeasy Blood \& Tissue Kit, Qiagen). For the initial 140 DNA samples, the SNP 326T $>$ G (V109G) was genotyped by direct sequencing. PCRs were performed using primers previously described (Pellegata et al. 2006) and both DNA strands were sequenced from purified PCR products using Big Dye Terminator v3.1 (Life Technologies) and an automated sequencer (ABI Prism 3130xl DNA Analyzer, Life Technologies).

The presence of the polymorphic $\mathrm{G}$ allele creates a restriction site for the enzyme BglI $\left(5^{\prime} \ldots G C C N N N N^{\wedge} N G G C . . .3^{\prime}\right)$. Thus, we genotyped the rest of the DNA samples using a PCR-restriction fragment length polymorphism approach 
as previously described (Kibel et al. 2003) after having verified that this method had 100\% accuracy compared with sequencing (Supplementary Fig. 1, see section on supplementary data given at the end of this article). Amplicons of 762 bp containing codon 109 were generated by using a PTC-200 DNA thermocycler (Peltier thermal cycler; MJ Research, Inc., Waltham, MA, USA) with $10 \mathrm{ng}$ of gDNA as template and the following primers: p27-V109G_F: GTCGGGGTCTGTGTCTTTTG and p27-V109G_R: GCCAGGTAGCACTGAACACC. The digestion step was carried out at $37^{\circ} \mathrm{C}$ for $3 \mathrm{~h}$ with the enzyme BglI (New England BioLabs, Beverly, MA, USA). After digestion, the enzyme was inactivated at $85^{\circ} \mathrm{C}$ for $20 \mathrm{~min}$ and the genotypes were identified according to the bands visualized on 3\% agarose gels (Supplementary Fig. 1).

\section{Statistical analyses}

Hardy-Weinberg equilibrium of the genetic variants at codon 109 in CDKN1B (p.V109G) was assessed using $\chi^{2}$ statistics, and the best fitting model was determined according to the $P$ values using parsimony. Assessment of tumor risk was performed through comparison of genotype frequencies between cases and controls using $\chi^{2}$ statistics and odds ratios (ORs) with 95\% CIs using logistic regression models. A modified Bonferroni'scorrected nominal threshold of $P=0.05 / n^{*}$ was used to correct for multiple hypothesis testing, of which $n^{*}$ is the number of independent comparisons (ACTHoma, GHoma, pheochromocytoma, and MTC) considering G and $\mathrm{T}$ as the risk allele. The variants, 'all sporadic endocrine tumors' and 'sporadic counterpart of MEN1/2-component neoplasias'; were not considered independent and were not included in the threshold correction. Age and sex adjustments were performed in the statistical analyses.

\section{Expression vectors, cell lines, and transfections}

The p27V109G mutations were introduced by site-directed mutagenesis (Quikchange II Site-Directed Mutagenesis Kit; Stratagene, Waldbronn, Germany) in the WT human $C D K N 1 B$ cDNA cloned in a pYFP backbone as described previously (Pellegata et al. 2006). AtT-20/D-16v (kindly provided by Dr M C Zatelli) and HeLa cells (LGC Standards, Wesel, Germany) were maintained in DMEM, respectively, supplemented with $10 \%$ FCS, $20 \mathrm{mM}$ L-glutamine, 100 units/ml penicillin G sodium, and $100 \mu \mathrm{g} / \mathrm{ml}$ streptomycin sulfate. GH3 cells (ATCC, Manassas, VA, USA) were grown in F12 medium supplemented with 15\% horse serum, $2.5 \%$ FCS, $20 \mathrm{mM}$ L-glutamine, 100 units $/ \mathrm{ml}$ penicillin G sodium, and $100 \mu \mathrm{g} / \mathrm{ml}$ streptomycin. Transient transfection was carried out as described previously (Pellegata et al. 2006).

\section{Protein extraction and western blotting}

To extract total proteins, the cells were collected, washed twice in PBS, and lysed in RIPA buffer essentially as previously reported (Pellegata et al. 2006). Protein concentration was assessed by BCA assay (Pierce Chemical Co., Rockford, IL, USA). Total extracts were subjected to PAGE using Bis-Tris 4-12\% NuPAGE gels, blotted, and probed with the following antibodies: monoclonal, against p27 (BD Biosciences, Franklin Lakes, NJ, USA); and monoclonal anti- $\alpha$-tubulin (Sigma). Immunoreactive proteins were visualized using West Pico chemiluminescent substrates (Pierce Chemical Co.). The bands that we obtained by western blotting were quantified using the Molecular Imager ChemiDoct XRS.

\section{Clonogenic assay and growth curve}

To examine their clonogenic activity, AtT-20/D-16v were plated in six-well plates (500 000/well) and transfected with p27-wt, p27-V109G, or GFP empty vector using Fugene-6 (Roche). Subsequently, the cells were trypsinized, diluted $1: 6$, and replated in $10 \mathrm{~cm}$ plates. Twenty-four hours later, the cells were selected for 6 weeks by adding $300 \mu \mathrm{g} / \mathrm{ml}$ to the culture medium and stained with $0.3 \%$ crystal violet in $30 \%$ ethanol. Colonies containing a minimum of 50 cells were scored.

Clones derived from AtT-20/D-16v cells stably expressing exogenous p27-wt, p27-V109G, or GFP were plated in duplicate (100 000/well) in 12-well plates in full medium plus $300 \mu \mathrm{g} / \mathrm{ml} \mathrm{G418}$. The number of cells was counted every 2 days over a 7 -day period using a cell counter.

\section{Immunofluorescence}

Immunofluorescence was carried out on AtT20 cells grown on coverslips and transfected with p27-wt, p27-V109G, or GFP vector. Twenty-four hours later, the transfected cells were fixed in $2 \%$ paraformaldehyde in PBS for $30 \mathrm{~min}$ at room temperature. The cell nuclei were stained with $1 \mu \mathrm{g} / \mathrm{ml}$ Hoechst for $5 \mathrm{~min}$ at room temperature and mounted on glass slides. Images were generated using a Zeiss Axiovert 200 epifluorescence microscope including an Apotome unit (Zeiss, Jena, Germany) using the YFP and the DAPI channel and processing was carried out using Zeiss Computer Software (AIM 3.2). 


\section{Results}

\section{p27-V109G in controls}

Genotype frequencies of the SNP rs2066827 were assessed in the control group of 885 representative healthy Brazilian individuals and were distributed as follows: $\mathrm{GG}=116,13.1 \%$; $\mathrm{GT}=406,45.9 \%$; and $\mathrm{TT}=363,41.0 \%$. The allele frequencies $(\mathrm{G}=0.36$ and $\mathrm{T}=0.64)$ of our cohort of controls were more similar to those reported in the SNP databases and in previous genetic studies for Hispanic $(\mathrm{G}=0.30$ and $\mathrm{T}=0.70)$ and Caucasian $(\mathrm{G}=0.24$ and $\mathrm{T}=0.76)$ populations than those for Asians $(\mathrm{G}=0.12$ and $\mathrm{T}=0.88)$ or Africans $(\mathrm{G}=0.72$ and $\mathrm{T}=0.28)$ (Table 1$)$. No significant deviation from the Hardy-Weinberg equilibrium was observed for the two alleles.

\section{Association of p27-V109G and sporadic counterpart of MEN1-component neoplasia}

Genotyping analysis of the overall group including 447 patients with endocrine tumors provided the following genotypic frequencies: $\mathrm{GG}=49,11 \%$; $\mathrm{GT}=200,44.7 \%$; and $\mathrm{TT}=198,44.3 \%$. We observed a significant overrepresentation of the $\mathrm{T}$ allele (valine) in the patients with sporadic counterpart of MEN1-component neoplasias ( $n=271$, parathyroid neoplasias and pituitary adenomas), compared with the 885 controls $(\mathrm{OR}=1.25$; 95\% CI $=1.02-1.54 ; P=0.03)$. Accordingly, the presence of the polymorphic allele G (GT or GG genotypes) was significantly associated with decreased susceptibility to sporadic counterpart of MEN1-component neoplasias (protection), fitting both recessive (OR $=0.72 ; 95 \%$ $\mathrm{CI}=0.55-0.94 ; P=0.019)$ as well as dominant $(\mathrm{OR}=0.72$; 95\% CI $=0.54-0.97 ; P=0.03$ ) models (Table 2).

\section{Absence of association of p27-V109G and sporadic counterpart of MEN2-component neoplasia}

No significant association was observed between the p27-V109G polymorphism and the group of sporadic tumors belonging to the MEN2 spectrum (MTC and pheochromocytoma; $P=0.35$ ), as well as the groups containing exclusively MTC $(P=0.27)$ or pheochromocytoma $(P=0.57)$. Also, no significant differences were found between the genotypic and allelic frequencies of the controls and the group of patients with sporadic counterpart of MEN1- and MEN2-component neoplasias $(P=0.25$; Table 2$)$. Primary HPT was initially included in both MEN1 and MEN2 groups, but its exclusion did not change the results.

\section{Absence of association of p27 rs36228499 and sporadic tumors}

In addition to SNP V109G, we analyzed in our controls and patient cohorts the allelic frequencies of another SNP located in the noncoding region of p27 (rs36228499), which has been studied previously and shown not to be associated with endocrine/thyroid tumors (Landa et al. 2010), and, according to the HapMap, is not in linkage disequilibrium with the SNP V109G (rs2066827). The genotyping was carried out by PCR and Sanger sequencing (primers -838 F: TGGCCTCGGAGAAATTAAAA and

Table 1 Allele and genotype distribution of the rs2066827 V109G variant of p27 in controls and patients diagnosed with sporadic endocrine tumors investigated

\begin{tabular}{|c|c|c|c|c|c|c|}
\hline & Total & G & $\mathbf{T}$ & GG & GT & TT \\
\hline Sporadic counterpart of MEN1-component neoplasias & 271 & 168 & 349 & 30 & 108 & 133 \\
\hline sporadic counterpart of MEN2-component neoplasias & 195 & 143 & 275 & 21 & 101 & 73 \\
\hline Sporadic pituitary adenomas & 252 & 155 & 323 & 28 & 99 & 125 \\
\hline Sporadic ACTHomas & 91 & 50 & 111 & 10 & 30 & 51 \\
\hline Sporadic GHomas & 161 & 105 & 212 & 18 & 69 & 74 \\
\hline Sporadic HPT & 19 & 13 & 26 & 2 & 9 & 8 \\
\hline Sporadic MTCs & 51 & 42 & 69 & 8 & 26 & 17 \\
\hline Sporadic pheochromocytomas & 125 & 88 & 180 & 11 & 66 & 48 \\
\hline All tumors & 447 & 298 & 598 & 49 & 200 & 198 \\
\hline Healthy controls & 885 & 638 & 1132 & 116 & 406 & 363 \\
\hline
\end{tabular}

Sporadic counterpart of multiple endocrine neoplasia type 1 (MEN1)-component neoplasias - types of sporadic endocrine tumors that are included in the clinical phenotype of the MEN1 syndrome as hyperparathyroidism and pituitary adenomas; sporadic counterpart of MEN2-component neoplasias - types of sporadic endocrine tumors that are included in the clinical phenotype of the MEN2 syndrome medullary thyroid carcinoma (MTC) and pheochromocytomas; ACTHomas, ACTH-secreting pituitary adenomas; GHomas, GH-secreting pituitary adenomas, also know as somatotropinomas; HPT, parathyroid adenomas/hyperparathyroidism; G and T represent the alleles that observed in the V109G p27 Kip1 SNP; and GG, GT, and TT are the observed genotypes.

http://erc.endocrinology-journals.org DOI: 10.1530/ERC-13-0486
(C) 2014 Society for Endocrinology Printed in Great Britain 


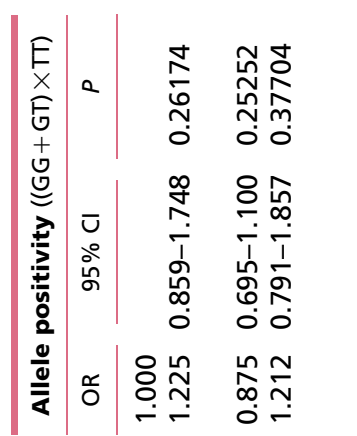

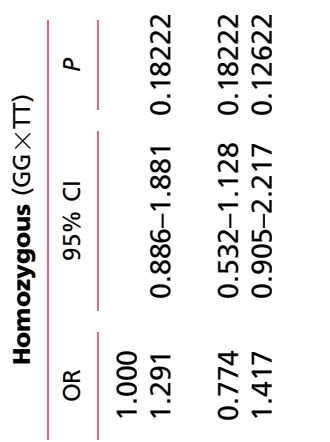

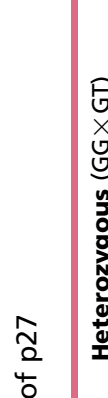

F| \&

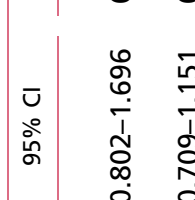

잉

.

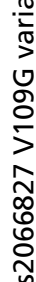

政

言

$$
\text { 气ั }
$$$$
\text { . }
$$

http://erc.endocrinology-journals.org DOI: 10.1530/ERC-13-0486

$\frac{1}{6}$

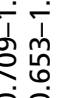

$=\log _{\infty}^{\infty} \stackrel{n}{g}$

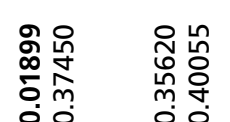

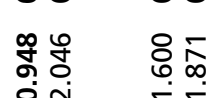

ำ

난?

०० 0 0

종ำ

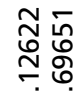

$\circ \circ$

능

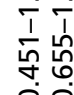

융

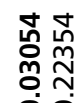

ơ

ลั่

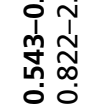

商

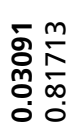

方交

ํㅜㅇ 꿈

등

ํํㅇํ.

กิ융

IT

ํํㅇ용

耪

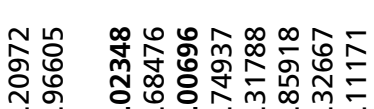

กั

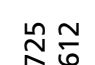

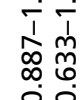

00000000

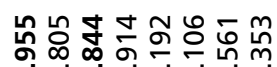

ำ

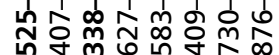

०ू० 000000

ํํㅇ응

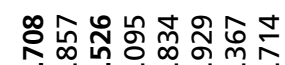

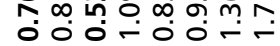

$\sum_{\substack{n \\ \infty}}^{m}$

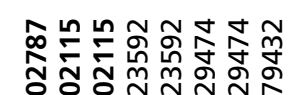

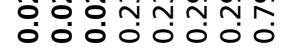

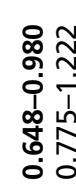

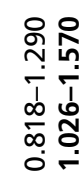

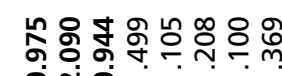

ำ

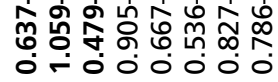

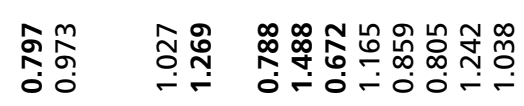

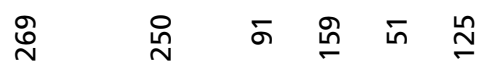
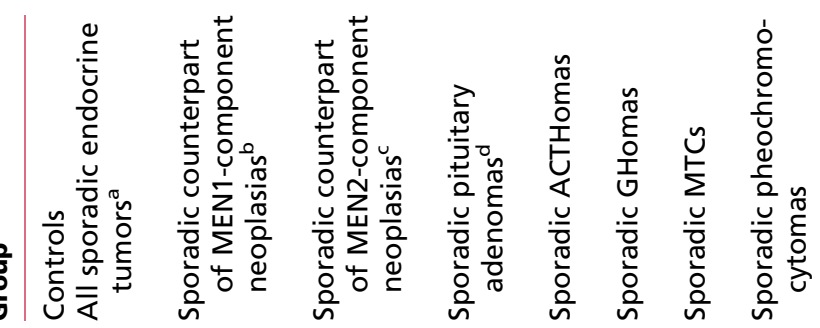

ఫั

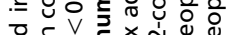

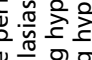

政

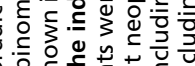

等.

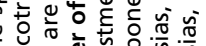

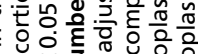

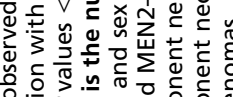

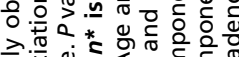

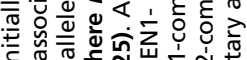

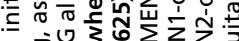

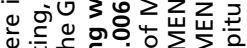

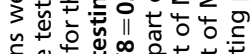

o 응

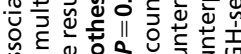

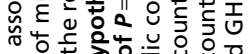

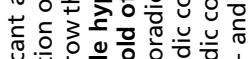

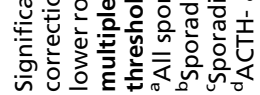


-838 R: TTAAGGCTGAGCGAACCATT) and the frequencies observed in our controls $(G=0.51$ and $T=0.49)$ and patients $(G=0.54$ and $T=0.46)$ were similar between each other, and both were more similar to the frequencies reported for the European/HapMap-CEU population $(\mathrm{G}=0.56$ and $\mathrm{T}=0.44)$ than to those found in African/ HapMap-YRI populations $(\mathrm{G}=0.75$ and $\mathrm{T}=0.25)$.

\section{The role of p27-V109G specifically in ACTH-pituitary tumors}

Protection by the G allele (GT and GG genotypes) was seen overall in the sporadic pituitary adenoma group $(\mathrm{OR}=0.70 ; 95 \% \mathrm{CI}=0.53-0.93 ; P=0.01)$ and more especially in the ACTH-secreting pituitary adenoma group $(\mathrm{OR}=0.54 ; 95 \% \mathrm{CI}=0.35-0.84 ; P=0.005)$. The observed association between rs2066827 and corticotropinomas was still significant after correction for multiple testing using the conservative Bonferroni's method, indicating that this finding is robust. In contrast, the presence of the $\mathrm{G}$ allele was not associated with protection from acromegaly $(P=0.24)$.

To determine whether the $\mathrm{T}$ or $\mathrm{G}$ allelic variants at codon 109 of p27 may be associated with specific functions in ACTH-secreting cells, we performed in vitro analyses comparing the effects of p27-wt (TT) or p27V109G (GG) overexpression in a mouse corticotropinoma cell line (AtT20). Following transfection of p27-wt and
p27-V109G in these cells, we observed that the p27-V109G variant protein localizes to the nucleus, as the WT protein does (Supplementary Fig. 1). We then assessed the effects of both variants on cell growth by performing colony formation assays. The results were compared with the rat somatotroph adenoma-derived GH3 cell line. We found that AtT20 cells transfected with p27-V109G show a 50\% increase in the number of colonies when compared with cells either transfected with p27-wt or with empty vector (Fig. 1). In contrast, both variant proteins show similar growth suppression of GH3 cells (Fig. 1 and Supplementary Figs 2 and 3, see section on supplementary data given at the end of this article). This phenotype is in agreement with the increase in cell proliferation observed in AtT20-derived clones stably expressing exogenous p27-V109G when compared with clones expressing p27-wt or transfected with empty vector (data not shown). Thus, in vitro, the two p27 variant proteins show a different behavior in AtT20 corticotrope adenoma cells when compared with GH3 somatotrope adenoma cells.

\section{Discussion}

In the last few years, mutations in the CDKN1B p27 gene have been identified as the cause of a novel syndrome (named MEN4) that is characterized by multiple endocrine tumors with a spectrum similar to the MEN1 syndrome
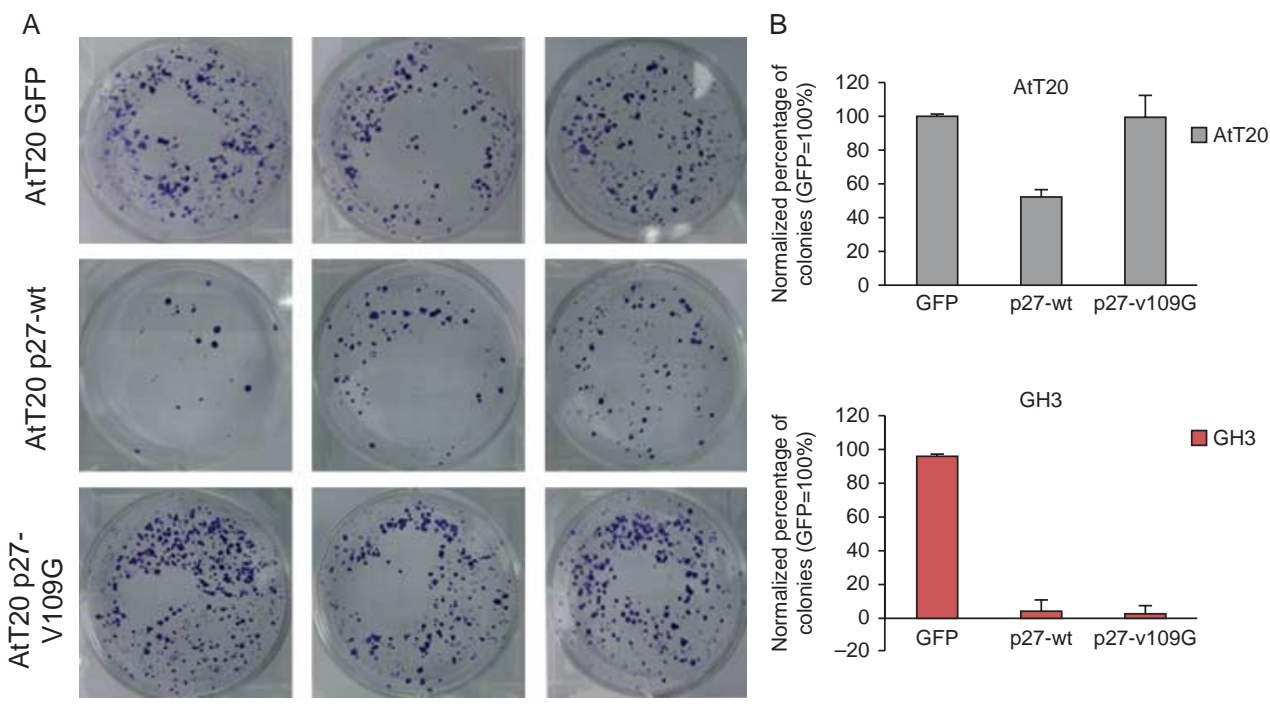

\section{Figure 1}

The effect of overexpression of both variants, p27-wt (TT) and p27-V109G (GG), on cell growth in a mouse corticotropinoma cell line (AtT20) and the rat somatotroph adenoma-derived GH3 cell line (A). AtT20 cells transfected with p27-V109G show a $50 \%$ increase in the number of colonies when compared with either cells transfected with p27-wt or with empty vector, while both variant proteins show similar growth suppression of $\mathrm{GH} 3$ cells (B). 
(Pellegata et al. 2006, Georgitsi et al. 2007, Agarwal et al. 2009, Marinoni \& Pellegata 2010, Pellegata 2012). While this article was under revision, somatic mutations and deletions of $C D K N 1 B$ were reported in a subset of neuroendocrine tumors of the small intestine (Francis et al. 2013). In addition to these rare pathogenic mutations, CDKN1B contains numerous SNPs, including a frequent polymorphism (rs2066827, V109G), which has been found to be associated with the risk of or protection from cancer, depending on the tumor type. Specifically, the V109G polymorphism has been shown to have a protective effect on overall survival of patients with sporadic pancreatic carcinoma (Chen et al. 2009), while it is associated with increased risk of progression and poor prognosis for prostate and breast cancer patients (Kibel et al. 2003, Tigli et al. 2005).

In this study, we analyzed the role of the V109G genetic variant in $C D K N 1 B$ in a case-control study, including 447 Brazilian patients with different types of sporadic endocrine tumors and 885 adult healthy representative Brazilian controls. We found an association between rs2066827 and susceptibility to tumors belonging to the MEN1 tumor spectrum (i.e. pituitary adenomas), while no role in the risk of developing tumors belonging to the MEN2 tumor spectrum (i.e. MTC and pheochromocytoma) could be demonstrated (Table 2). We are aware that the ethnic intermix of the Brazilian population can be an important issue for case-control studies like ours, so we addressed this point by further characterizing our cohorts. According to the Brazilian government database (IBGE) for the Sao Paulo area, where all the samples were collected and the study took place, our cohort is composed for the most part of whites and presented no sampling bias. In accordance, the allele frequencies we found for this genetic variant and for a second SNP in the noncoding sequence of $C D K N 1 B$ (rs36228499) were similar to those reported in public databases and in previous genetic studies for Caucasians and Hispanics.

Positive association with rs2066827 was found in the pituitary adenoma group, including both somatotropinomas and corticotropinomas $(P=0.01)$; however, more specific association was observed with the corticotropinomas $(P=0.005)$ (Table 2). The association between rs2066827 and corticotropinomas remained significant after the calculation of the adjusted $P$ value cut-off using the conservative Bonferroni's method as a correction for multiple testing $(P=0.00625)$. In contrast, rs2066827 was not associated either with sporadic counterpart of MEN2component neoplasias or with MTC or pheochromocytoma groups $(P>0.05$ in all models tested). To our knowledge, this is the first study that investigated p27 polymorphisms in pheochromocytoma, while two independent reports that were recently published analyzed the role of p27 variants in European MTC cohorts (Landa et al. 2010, Pasquali et al. 2011). In accordance to our results for Brazilian MTC patients, no association of p27-V109G with increased risk of sporadic MTC was observed in a large cohort of Spanish MTC cases, while a borderline significance was observed in the analysis of tumor risk of Italian MTC patients (Landa et al. 2010, Pasquali et al. 2011).

We could demonstrate that rs2066827 associates with a specific molecular phenotype in corticotrope cells but not in somatotrope cells. Indeed, the ectopic overexpression of p27-V109G in AtT20 cells, as opposed to p27-wt, does not inhibit cell growth and actually seems to promote cell proliferation. In contrast, no differences in the cell growth characteristics of p27-wt and p27-V109G were observed in somatotroph cells. As the expression of p27-V109G is associated with increased cell growth and proliferation in AtT20 cells, it is not easy to reconcile these findings with the results of the association studies. The fact that AtT20 cells express high endogenous levels of p27 and still show sustained proliferation may indicate that this experimental model, the only one available for corticotrope adenomas, might not be ideal for reproducing the situation of the expression of $\mathrm{p} 27$ variants in vivo in individuals.

Patients with germline pathogenic mutations in p27 (MEN4 syndrome) may develop ACTH-secreting adenoma, although rarely (Lee \& Pellegata 2013). Previous studies have shown that p27 is consistently and frequently downregulated in corticotropinomas, but not in other types of pituitary adenomas (Dahia et al. 1998). Moreover, a crucial role for $\mathrm{p} 27$ in the regulation of the proliferation of pituitary proopiomelanocortin (POMC) cells producing ACTH has also been demonstrated in animal studies, and p27-deficient mice develop POMC tumors at high frequencies (Fero et al. 1996).

The exact molecular mechanism involved in p27V109G change is still not clear. While the structure of the $\mathrm{N}$ - and C-terminal domains of p27 has been resolved and the interactions with key partners such as cyclins and CDKs have been mapped, the structure of the central domain of the protein (amino acids 97-151) is still unknown. The amino acid valine 109 is located in the central portion of the protein, within a domain that mediates the binding of $\mathrm{p} 27-\mathrm{p} 38^{\mathrm{Jab} 1}$ (Tomoda et al. 1999). The interaction of the two proteins mediates the nuclear export of p27 and its subsequent degradation. 
Interestingly, the substitution of the aspartic acid at position 108 by glycine impairs the formation of this complex (Tomoda et al. 2002) and it has been speculated that this variant might interfere in the interaction with $\mathrm{p} 38^{\mathrm{Jab} 1}$, and thereby increase the stability of p27 in the nucleus (Schöndorf et al. 2004). Experimental evidence is nevertheless required to confirm this hypothesis.

In addition to our finding of a potential role of rs2066827 in corticotropinomas, another p27 polymorphic variant, $-79 \mathrm{C}>\mathrm{T}$ (rs34330), was specifically correlated with a high risk of developing the follicular variant of papillary thyroid carcinoma (Landa et al. 2010), indicating that reduced $C D K N 1 B$ gene transcription could be involved in the molecular mechanism that mediates the pathogenic effects of this variant.

There are conflicting findings in the literature regarding the risk/protection associated with rs2066827 T/G alleles. A recent meta-analysis has evaluated the association data of eight studies encompassing 3799 controls and 3591 patients with non-endocrine tumors (oral squamous cell, prostate, breast cancer, and pancreatic cancer) and found no correlation between the rs2066827 variant and the overall cancer risk in the general population (Wei et al. 2012). Since p27 is a tumor susceptibility gene for multiple endocrine tumors in both humans and rats, we decided to investigate specifically endocrine tumors. Based on our results, it seems worthwhile to assess whether the V109G genetic variant may modify individual susceptibility to additional endocrine tumors, i.e. entero-pancreatic tumors, prolactinomas, nonfunctioning pituitary adenomas, parathyroid carcinomas, or adrenocortical carcinomas, and to investigate cohorts of patients from different populations.

\section{Supplementary data}

This is linked to the online version of the paper at http://dx.doi.org/10.1530/ ERC-13-0486.

\section{Declaration of interest}

M D Bronstein declares an association with the following companies: Ipsen, Novartis, and Pfizer (consultant, speaker, and grant/research support). The remaining authors have nothing to disclose.

\section{Funding}

The study was supported by the DAAD/CAPES PROBRAL program (Brazil/Germany collaboration) with research grants to Drs S P A Toledo and N S Pellegata. T Sekiya and R A Toledo received fellowships from FAPESP, and S P A Toledo received research and productivity grants from $\mathrm{CNPq}$

\section{Author contribution statement}

N S Pellegata, S P A Toledo, and R A Toledo designed the project; M D Bronstein, R S Jallad, M C Machado, T D Goncalves, L H Osaki, J Viana-Jr, C Kater, B Liberman, M C B V Fragoso, and S P A Toledo provided clinical data and DNA samples from patients; G Francisco, R Chammas, M S Naslavsky, D Schlesinger, Y A O Duarte, M L Lebrão, and M Zatz provided clinical data and DNA samples from healthy controls; T Sekiya, V C Longuini, L H Osaki, and $\mathrm{R}$ A Toledo performed and analyzed the genetic experiments; B Katiuscia and N S Pellegata performed and analyzed the in vitro assays; O Meirelles and R A Toledo performed the statistical analysis; T Sekiya, M D Bronstein, M C B V Fragoso, P Gama, S P A Toledo, N S Pellegata, and R A Toledo contributed to discussions; and $\mathrm{R}$ A Toledo wrote the paper with inputs from N S Pellegata, T Sekiya, and S P A Toledo.

\section{References}

Agarwal SK, Mateo CM \& Marx SJ 2009 Rare germline mutations in cyclindependent kinase inhibitor genes in multiple endocrine neoplasia type 1 and related states. Journal of Clinical Endocrinology and Metabolism 94 1826-1834. (doi:10.1210/jc.2008-2083)

Chen J, Li D, Killary AM, Sen S, Amos CI, Evans DB, Abbruzzese JL \& Frazier ML 2009 Polymorphisms of $p 16, p 27, p 73$, and MDM2 modulate response and survival of pancreatic cancer patients treated with preoperative chemoradiation. Annals of Surgical Oncology 16 431-439. (doi:10.1245/s10434-008-0220-8)

Chen J, Amos CI, Merriman KW, Wei Q, Sen S, Killary AM \& Frazier ML 2010 Genetic variants of $p 21$ and $p 27$ and pancreatic cancer risk in non-Hispanic Whites a case-control study. Pancreas 39 1-4. (doi:10.1097/MPA.0b013e3181bd51c8)

Chu IM, Hengst L \& Slingerland JM 2008 The Cdk inhibitor p27 in human cancer prognostic potential and relevance to anticancer therapy. Nature Reviews. Cancer 8 253-267. (doi:10.1038/nrc2347)

Dahia PL, Aguiar RC, Honegger J, Fahlbush R, Jordan S, Lowe DG, Lu X, Clayton RN, Besser GM \& Grossman AB 1998 Mutation and expression analysis of the p27/kip1 gene in corticotrophin-secreting tumours. Oncogene 16 69-76. (doi:10.1038/sj.onc.1201516)

Fero ML, Rivkin M, Tasch M, Porter P, Carow CE, Firpo E, Polyak K, Tsai LH, Broudy V, Perlmutter RM et al. 1996 A syndrome of multiorgan hyperplasia with features of gigantism, tumorigenesis, and female sterility in p $27^{\text {Kip1 }}$-deficient mice. Cell 85 733-744. (doi:10.1016/S00928674(00)81239-8)

Francis JM, Kiezun A, Ramos AH, Serra S, Pedamallu CS, Qian ZR, Banck MS, Kanwar R, Kulkarni AA, Karpathakis A et al. 2013 Somatic mutation of CDKN1B in small intestine neuroendocrine tumors. Nature Genetics $\mathbf{4 5}$ 1483-1486. (doi:10.1038/ng.2821)

Gayther SA, Song H, Ramus SJ, Kjaer SK, Whittemore AS, Quaye L, Tyrer J, Shadforth D, Hogdall E, Hogdall C et al. 2007 Tagging single nucleotide polymorphisms in cell cycle control genes and susceptibility to invasive epithelial ovarian cancer. Cancer Research 67 3027-3035. (doi:10.1158/ 0008-5472.CAN-06-3261)

Georgitsi M, Raitila A, Karhu A, van der Luijt RB, Aalfs CM, Sane T, Vierimaa O, Mäkinen MJ, Tuppurainen K, Paschke R et al. 2007 Germline $C D K N 1 B / \mathrm{p} 27^{\mathrm{Kip} 1}$ mutation in multiple endocrine neoplasia. Journal of Clinical Endocrinology and Metabolism 92 3321-3325. (doi:10.1210/jc.2006-2843)

González P, Díez-Juan A, Coto E, Alvarez V, Reguero JR, Batalla A \& Andrés V 2004 A single-nucleotide polymorphism in the human $\mathrm{p} 27^{\mathrm{kip} 1}$ gene $(-838 \mathrm{C}>\mathrm{A})$ affects basal promoter activity and the risk of myocardial infarction. BMC Biology 2 2-5. (doi:10.1186/ 1741-7007-2-2)

Kibel AS, Suarez BK, Belani J, Oh J, Webster R, Brophy-Ebbers M, Guo C, Catalona WJ, Picus J \& Goodfellow PJ 2003 CDKN1A and CDKN1B polymorphisms and risk of advanced prostate carcinoma. Cancer Research 63 2033-2036. 
Landa I, Montero-Conde C, Malanga D, De Gisi S, Pita G, Leandro-García LJ, Inglada-Pérez L, Letón R, De Marco C, Rodríguez-Antona C et al. 2010 Allelic variant at $-79(\mathrm{C}>\mathrm{T})$ in $C D K N 1 B\left(\mathrm{p} 27^{\mathrm{Kip} 1}\right)$ confers an increased risk of thyroid cancer and alters mRNA levels. Endocrine-Related Cancer 17 317-328. (doi:10.1677/ERC-09-0016)

Lee M \& Pellegata NS 2013 Multiple endocrine neoplasia type 4. Frontiers of Hormone Research 41 63-78. (doi:10.1159/000345670)

Li G, Sturgis EM, Wang LE, Chamberlain RM, Spitz MR, El-Naggar AK, Hong WK \& Wei Q 2004 Association between the V109G polymorphism of the $p 27$ gene and the risk and progression of oral squamous cell carcinoma. Clinical Cancer Research 10 3996-4002. (doi:10.1158/1078-0432.CCR-04-0089)

Lourenço DM Jr, Coutinho FL, Toledo RA, Montenegro FL, Correia-Deur JE \& Toledo SP 2010 Early-onset, progressive, frequent, extensive, and severe bone mineral and renal complications in multiple endocrine neoplasia type 1-associated primary hyperparathyroidism. Journal of Bone and Mineral Research 25 2382-2391. (doi:10.1002/jbmr.125)

Marinoni I \& Pellegata NS 2010 p27kip1: a new multiple endocrine neoplasia gene? Neuroendocrinology 93 19-28. (doi:10.1159/000320366)

Pasquali D, Circelli L, Faggiano A, Pancione M, Renzullo A, Elisei R, Romei C, Accardo G, Coppola VR, De Palma M et al. 2011 CDKN1B V109G polymorphism a new prognostic factor in sporadic medullary thyroid carcinoma. European Journal Endocrinology 164 397-404. (doi:10.1530/EJE-10-0929)

Pellegata NS 2012 MENX and MEN4. Clinics 67 13-18. (doi:10.6061/ clinics/2012(Sup01)04)

Pellegata NS, Quintanilla-Martinez L, Siggelkow H, Samson E, Bink K, Höfler H, Fend F, Graw J \& Atkinson MJ 2006 Germ-line mutations in $\mathrm{p} 27^{\text {Kip } 1}$ cause a multiple endocrine neoplasia syndrome in rats and humans. PNAS 103 15558-15563. (doi:10.1073/pnas.0603877103)

Santos MA, Nunes AB, Abelin N, Ezabella MC, Toledo RA, Lourenço DM Jr, Hayashida CY, Fonseca II \& Toledo SP 2006 Genetic screening of multiple endocrine neoplasia type 2 experience of the USP Endocrine Genetics Unit. Arquivos Brasileiros de Endocrinologia e Metabologia 50 7-16. (doi:10.1590/S0004-27302006000100003)

Schöndorf T, Eisele L, Göhring UJ, Valter MM, Warm M, Mallmann P, Becker M, Fechteler R, Weisshaar MP \& Hoopmann M 2004 The V109G polymorphism of the p27 gene CDKN1B indicates a worse outcome in node-negative breast cancer patients. Tumour Biology 25 306-312. (doi:10.1159/000081396)

Tigli H, Buyru N \& Dalay N 2005 Molecular analysis of the $p 27 / k i p 1$ gene in breast cancer. Molecular Diagnosis 9 17-21. (doi:10.2165/00066982200509010-00003)
Toledo SP, Lourenço DM Jr, Santos MA, Tavares MR, Toledo RA \& Correia-Deur JE 2009 Hypercalcitoninemia is not pathognomonic of medullary thyroid carcinoma. Clinics 64 699-706. (doi:10.1590/ S1807-59322009000700015)

Toledo RA, Mendonca BB, Fragoso MC, Soares IC, Almeida MQ, Moraes MB, Lourenço DM Jr, Alves VA, Bronstein MD \& Toledo SP $2010 a$ Isolated familial somatotropinoma 11q13-LOH and gene/protein expression analysis suggests a possible involvement of AIP also in non-pituitary tumorigenesis. Clinics 65 407-415. (doi:10.1590/S180759322010000400010)

Toledo RA, Wagner SM, Coutinho FL, Lourenço DM Jr, Azevedo JA, Longuini VC, Reis MT, Siqueira SA, Lucon AM, Tavares MR et al. $2010 b$ High penetrance of pheochromocytoma associated with the novel C634Y/Y791F double germline mutation in the RET protooncogene. Journal of Clinical Endocrinology and Metabolism 95 1318-1327. (doi:10.1210/jc.2009-1355)

Toledo RA, Qin Y, Srikantan S, Morales NP, Li Q, Deng Y, Kim SW, Pereira MA, Toledo SP, Su X et al. 2013 In vivo and in vitro oncogenic effects of HIF2A mutations in pheochromocytomas and paragangliomas. Endocrine-Related Cancer 20 349-359. (doi:10.1530/ ERC-13-0101)

Tomoda K, Kubota Y \& Kato J 1999 Degradation of the cyclin-dependentkinase inhibitor p27 ${ }^{\mathrm{Kip} 1}$ is instigated by Jab1. Nature 398 160-165. (doi:10.1038/18230)

Tomoda K, Kubota Y, Arata Y, Mori S, Maeda M, Tanaka T, Yoshida M, Yoneda-Kato N \& Kato JY 2002 The cytoplasmic shuttling and subsequent degradation of p2 $7^{\mathrm{Kip} 1}$ mediated by Jab1/CSN5 and the COP9 signalosome complex. Journal of Biological Chemistry 277 2302-2310. (doi:10.1074/jbc.M104431200)

Wei F, Xu J, Tang L, Shao J, Wang Y, Chen L \& Guan X 2012 p27 ${ }^{\text {Kip1 }}$ V109G polymorphism and cancer risk a systematic review and meta-analysis. Cancer Biotherapy \& Radiopharmaceuticals 27 665-671. (doi:10.1089/cbr. 2012.1229)

Yao L, Schiavi F, Cascon A, Qin Y, Inglada-Pérez L, King EE, Toledo RA, Ercolino T, Rapizzi E, Ricketts CJ et al. 2010 Spectrum and prevalence of FP/TMEM127 gene mutations in pheochromocytomas and paragangliomas. Journal of the American Medical Association 304 2611-2619. (doi:10.1001/jama.2010.1830)

Zhuang Z, Yang C, Lorenzo F, Merino M, Fojo T, Kebebew E, Popovic V, Stratakis CA, Prchal JT \& Pacak K 2012 Somatic HIF2A gain-of-function mutations in paraganglioma with polycythemia. New England Journal of Medicine 367 922-930. (doi:10.1056/NEJMoa1205119)

Received in final form 5 February 2014

Accepted 6 February 2014

Made available online as an Accepted Preprint

14 February 2014 


\title{
Comprehensive assessment of the disputed RET Y791F variant shows no association with medullary thyroid carcinoma susceptibility
}

\author{
Rodrigo A Toledo', Roxanne Hatakana', Delmar M Lourenço Jr ${ }^{1}$, Susan C Lindsey ${ }^{6}$, \\ Cleber P Camacho ${ }^{6}$, Marcio Almeida ${ }^{9}$, José V Lima Jr ${ }^{10}$, Tomoko Sekiya', \\ Elena Garralda ${ }^{8}$, Michel S Naslavsky ${ }^{4}$, Guilherme L Yamamoto ${ }^{4}$, Monize Lazar ${ }^{4}$, \\ Osorio Meirelles ${ }^{11}$, Tiago J P Sobreira7, Maria Lucia Lebrao ${ }^{3}, Y^{7}$ (a A O Duarte ${ }^{2}$, \\ John Blangero ${ }^{9}$, Mayana Zatz ${ }^{4}$, Janete M Cerutti ${ }^{5}$, Rui M B Maciel ${ }^{6}$ and \\ Sergio P A Toledo, ${ }^{1,6}$ \\ ${ }^{1}$ Endocrine Genetics Unit (Laboratório de Investigação Médica/LIM-25) of Hospital das Clínicas, \\ University of São Paulo School of Medicine, São Paulo, São Paulo 05403-010, Brazil \\ ${ }^{2}$ Nursing School, ${ }^{3}$ School of Public Health, and ${ }^{4}$ Human Genome Research Center, University of São Paulo, \\ São Paulo, São Paulo, Brazil \\ ${ }^{5}$ Division of Genetics, Genetic Bases of Thyroid Tumors Laboratory, Department of Morphology and Genetics, and \\ ${ }^{6}$ Division of Endocrinology, Laboratory of Molecular and Translational Endocrinology, Department of Medicine, \\ Federal University of São Paulo, São Paulo, São Paulo, Brazil \\ ${ }^{7}$ Brazilian National Laboratory of Biosciences, Campinas, São Paulo, Brazil \\ ${ }^{8}$ Centro Integral Oncológico Clara Campal, Hospital Universitário Sanchinarro, Madrid, Spain \\ ${ }^{9}$ Department of Genetics, Texas Biomedical Research Institute, AT\&T Genomic Computing Center, \\ San Antonio, Texas, USA \\ ${ }^{10}$ Endocrinology Division, Santa Casa Hospital, São Paulo, São Paulo, Brazil \\ ${ }^{11}$ Laboratory of Epidemiology and Population Sciences, National Institute on Aging, Bethesda, Maryland, USA
}

Correspondence should be addressed to R A Toledo Emails toledorodrigo@usp.br or toledorodrigo79@gmail.com

\begin{abstract}
Accurate interpretation of germline mutations of the rearranged during transfection (RET) proto-oncogene is vital for the proper recommendation of preventive thyroidectomy in medullary thyroid carcinoma (MTC)-prone carriers. To gain information regarding the most disputed variant of RET, ATA-A Y791F, we sequenced blood DNA samples from a cohort of 2904 cancer-free elderly individuals (1261 via Sanger sequencing and 1643 via wholeexome/genome sequencing). We also accessed the exome sequences of an additional 8069 individuals from non-cancer-related laboratories and public databanks as well as genetic results from the Catalogue of Somatic Mutations in Cancer (COSMIC) project. The mean allelic frequency observed in the controls was 0.0031 , with higher occurrences in Central European populations (0.006/0.008). The prevalence of RET Y791F in the control databases was extremely high compared with the 40 known RET pathogenic mutations $(P=0.00003)$, while no somatic occurrence has been reported in tumours. In this study, we report new, unrelated Brazilian individuals with germline RET Y791F-only: two tumour-free elderly controls; two individuals with sporadic MTC whose Y791F-carrying relatives did not show any evidence of tumours; and a 74-year-old phaeochromocytoma patient without MTC. Furthermore, we showed that the co-occurrence of Y791F with the strong RET C634Y mutation explains the aggressive MTC phenotypes observed in a large affected family that was initially reported as Y791F-only. Our literature review revealed that limited analyses
\end{abstract}

http://erc.endocrinology-journals.org DOI: 10.1530/ERC-14-0491 Printed in Great Britain

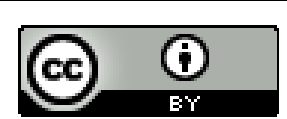

This work is licensed under a Creative Commons Attribution 3.0 Unported License. 
have led to the misclassification of RET Y791F as a probable pathogenic variant and, consequently, to the occurrence of unnecessary thyroidectomies. The current study will have a substantial clinical influence, as it reveals, in a comprehensive manner, that RET Y791F only shows no association with MTC susceptibility.

Endocrine-Related Cancer (2015) 22, 65-76

\section{Introduction}

MEN2 (MIM \#164761) is a dominantly inherited multiglandular tumour syndrome that presents with a high penetrance of medullary thyroid carcinoma (MTC; observed in virtually $100 \%$ of cases), phaeochromocytoma (50\%) and parathyroid adenoma and/or hyperplasia (20\%) (Eng et al. 1996). Germline gain-of-function mutations of the rearranged during transfection (RET) proto-oncogene, mostly occurring in exons 8, 10, 11, 13, 14, 15 and 16, activate RET via autophosphorylation of the transmembrane receptor tyrosine kinase; these mutant receptors are highly expressed in MEN2-related tissues, leading to tumour growth. The International Consortium on MTC of 1996 (Eng et al. 1996), the 2001 Consensus on MENs (Brandi et al. 2001) and the updated American Thyroid Association (ATA) Consensus on MTC (Kloos et al. 2009) recommend that individuals carrying a germline disease-causing RET mutation should be subjected to early prophylactic total thyroidectomy, which is currently the only effective approach for preventing the progression of MTC. For the purpose of molecular diagnosis and for adequate surgical management of patients and their relatives, it is crucial to know whether a $R E T$ gene variant identified via genetic testing is a benign polymorphism, a variant of unknown clinical significance or a pathological disease-causing mutation (Toledo et al. 2006).

Biased genetic analyses of highly selected patients, in addition to relatively small numbers of controls, may result in a misunderstanding and misclassification of the pathogenicity of rare variants of medically actionable genes (Weber \& Eng 2005). In this context, there is currently a great debate in the literature regarding the potential pathogenicity of the c.2372A $>$ T Y791F variant in exon 13 of RET (Berndt et al. 1998, Fitze et al. 2002, 2004, Gimm et al. 2002, Brauer et al. 2004, Plaza-Menacho et al. 2007, Tamanaha et al. 2007, Vestergaard et al. 2007, Eng 2010, Erlic et al. 2010, Cerutti \& Maciel 2013, Pęczkowska et al. 2013, Rich et al. 2014).

Recently, we described nine MEN2A families carrying both the classical RET C634Y mutation and the RET Y791F variant, which revealed a previously unrecognised role for
Y791F in the MEN2 syndrome. Although further analysis is still needed, our results indicate that Y791F may modify the effects of other concurrent RET mutations and may therefore act as a modifier variant (Toledo et al. 2010). However, the role of RET Y791F-only in MTC/MEN2related pathogenesis and susceptibility is currently a matter of dispute (Vestergaard et al. 2007, Kloos et al. 2009, Eng 2010, Erlic et al. 2010, Rich et al. 2014 and Supplementary References, see section on supplementary data given at the end of this article).

The current study represents the largest analysis focusing on the RET (ATA-A) Y791F variant performed to date, including new data from Sanger and next-generation sequencing analyses of 2904 healthy adult/elderly individuals. We also accessed genetic and genomic findings from multiple public databases, resulting in the analysis of a total of 11544 healthy individuals and 18163 cancer samples.

\section{Subjects}

Written informed consent was obtained from the subjects, in accordance with the protocols approved by the Institutional Review Board of each participating centre.

\section{Cohorts of new investigated controls}

In this study, we report data from 2904 previously uninvestigated individuals from three tumour-free adult/ elderly cohorts. The first cohort comprised 1261 healthy adult/elderly Brazilians (54\% females and 46\% males), with a mean age of 65.2 years. Blood DNA samples from these individuals were subjected to Sanger sequencing of RET exon 13 in our laboratory at the University of Sao Paulo School of Medicine. This cohort included samples from the School of Public Health of the University of Sao Paulo and control samples from the Experimental Oncology Laboratory (LIM-24) of the University of Sao Paulo School of Medicine. The ethnicity of the tumour-free adult/elderly subjects was 79\% White/White Latino and 10\% African and mixed Black/Caucasian.

Published by Bioscientifica Ltd. 
The second cohort has been designated the SABE60+ cohort and is a control group that was assembled and subjected to whole-exome sequencing by the Human Genome and Stem Cell Research Center (HUG-CELL) of the University of Sao Paulo. SABE60+ consists of 604 Brazilian individuals from Sao Paulo City (214 males and 390 females), with minimum and maximum ages of 63.3 and 92.2 respectively, and an average age of $74.2 \pm 6.9$ years. The majority of the individuals in this cohort were White (57.62\%), followed by mixed Black/Caucasian (18.38\%), Black (7.45\%), Asian (1.99\%) and Amerindian (0.33\%). Approximately 7\% (6.62\%) of the individuals answered positively to belonging to another ethnicity, and $7.62 \%$ did not answer this question.

The third cohort investigated in this study is the T2D-GENES cohort, which comes from a large collaborative study composed of 1039 completely sequenced individuals. The primary focus of this study group is the discovery of new genes associated with the development of type 2 diabetes using the information provided by large human pedigrees. Each sequenced pedigree contains between 22 and 86 individuals distributed across three to five generations. The sample population is composed of Mexican-American (48.9\% males) individuals living in San Antonio, Texas (SATX), who are part of the large San Antonio Family Study (SAFS) project, which has been ongoing for more than 25 years, with a primary focus on cardiovascular diseases.

\section{Public databases}

Genetic and genomic data from the following non-tumourenriched public databases were accessed: i) the NHLBI GO Exome Sequencing Project; ii) the database of single nucleotide polymorphisms (dbSNP) of the National Center for Biotechnology Information (NCBI), National Library of Medicine and iii) Ensembl (European Bioinformatics Institute, EBI, and European Molecular Biology Laboratory, EMBL), from the Wellcome Trust Sanger Institute (WTSI). The genotyping results for the 1000 European-American controls reported by Erlic et al. (2010) were also included.

In addition, genetic and genomic findings from the cancer-specific Catalogue of Somatic Mutations in Cancer (COSMIC) database were also accessed, while variant classifications were obtained from the databases of the ARUP MEN2/RET program of the Department of Pathology, University of Utah (Margraf et al. 2009).

All of the data from the databases were obtained between 20 July and 23 July 2014, and the websites for each database are listed at the end of the article.

\section{Literature review}

The PubMed and Google Scholar databases were used for the literature review. Space limitations prevented us from providing more thorough coverage of the topic, and we apologise to those whose work could not be cited. An extended list of the studies on RET Y791F is included as online supplementary data.

\section{Methods}

\section{DNA extraction, PCR and Sanger sequencing}

Blood DNA was extracted using the salting out method and a Qiagen kit (Qiagen). PCR amplification of RET exon 13 was carried out using $10 \mathrm{ng}$ of gDNA and the following primers: F: $5^{\prime}$-AACTTGGGCAAGGCGATGCA-3' and R: 5'-AGAACAGGGCTGTATGGAGC-3'. The PCR products were run on a $1 \%$ agarose gel, and specific $277 \mathrm{bp}$ amplicons (Supplementary Fig. 3, see section on supplementary data given at the end of this article) were then purified using the ExoSap-IT enzyme (USB Co., Cleveland, $\mathrm{OH}$, USA). BigDye Terminator v.3.1 cycle sequencing (Applied Biosystems) was employed to sequence the reaction products, and the samples were run on an $\mathrm{ABI}$ Prism 3130xl - Genetic Analyzer (Applied Biosystems).

\section{Whole-exome and whole-genome sequencing}

Whole-exome sequence data were generated using Agilent SureSelect v2 technology for targeted exon capture, and the obtained reads were aligned using the BurrowsWheeler Aligner (BWH) tool. Piccard was employed to convert, sort and index the aligned data files; the sequence quality scores were recalibrated using Genome Analysis Toolkit (GATK); and annotation of the variants was performed using Annovar.

Whole-genome sequencing (WGS) of 586 individuals was performed externally by Complete Genomics, Inc. (CGI, Mountain View, CA, USA) via a sequence-by-ligation method. The paired-end sequencing reads $(70 \mathrm{bp})$ were mapped using the human reference genome (V 37.2), with a mean coverage of $60 \times$. Variant calling was performed by CGI using version 2.0.3.1 of their proprietary pipeline. The false discovery rate estimates for SNP calls on the CGI platform ranged from 0.2 to $0.6 \%$. The variant calls within the WGS were processed using CGA Tools software (version 1.5.0, build 31), made available by CGI. The WGS information was employed together with the pedigree information and a previously generated genome-wide association chip for effective imputation of

Published by Bioscientifica Ltd. 
offspring using the MACH Bayesian imputation algorithm (Li 2010). The final sample comprised 1039 individuals genotyped using nearly 23 million SNPs.

\section{Protein structure analysis}

The structure of the RET receptor was generated based on the crystal structure of the RET tyrosine kinase domain bound to adenosine that has been recently deposited in the RCSB-PDB protein databank (ID: 4CKJ, Plaza-Menacho et al. 2014) and using the software program YASARA (Krieger et al. 2009). The RET domains were determined using the Conserved Domain Database (CDD), and a figure was generated with DOG 2.0 (Ren et al. 2009).

\section{In silico pathogenic prediction}

Four packages with different algorithms were used to investigate the pathogenicity of RET Y791F in silico: SIFT; PMUT; Align-GVGD; and POLYPHEN2 (the websites are listed at the end of the article).

\section{Statistical analysis}

Statistical analysis was performed by $\mathrm{O}$ Meirelles using IBM SPSS (www-01.ibm.com/software/analytics/spss/).

\section{Results}

\section{RET Y791F in the tumour-free cohorts}

The analyses of 22138 alleles from the control subjects revealed that $\mathrm{Y} 791 \mathrm{~F}$ is a very rare $\mathrm{SNP}$, with a frequency that varies greatly among the analysed populations (Fig. 1 and Supplementary Table 1, see section on supplementary data given at the end of this article). In accordance with an initial

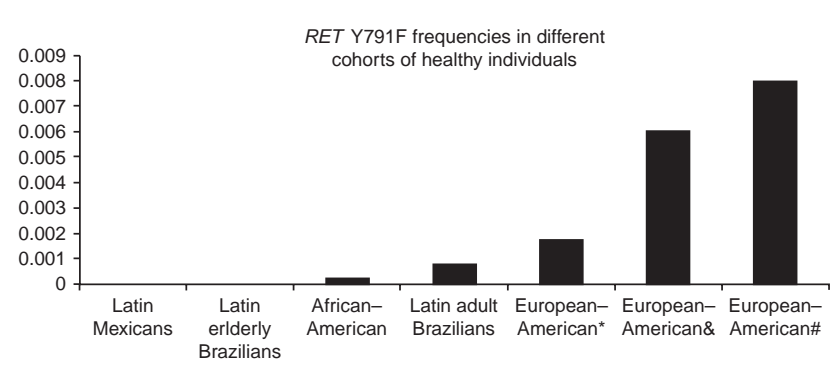

Figure 1

RET Y791F frequencies in different control populations/cohorts. The highest frequencies are observed in the populations from central Europe, especially Germany. Details of the populations are provided in

Supplementary Table 1. report from Europe (Berndt et al. 1998), the three EuropeanAmerican cohorts of control individuals presented the highest frequencies, which ranged from 0.0017 to 0.008 . The three Latin cohorts together with the African-American population presented the lowest frequencies of RET Y791F, ranging from 0 to 0.0007 (Supplementary Table 1). Notably, both the original Y791F MTC cases reported by Berndt et al. (1998) and the screen of 1000 controls conducted by Erlic et al. (2010), which identified the highest allelic frequency among the controls, are from Germany. In addition, as discussed later in this study, the largest cohort of patients carrying the Y791F variant also comes from Germany, indicating a probably higher prevalence of the Y791F variant in this country. Interestingly, one of the healthy Y791F-only Brazilian individuals reported in this study and the two unrelated Brazilian cases with sporadic MTC who also carried the variant (descriptions of these individuals are provided later in this report) were direct descendants of Germans. In addition, at least two out of the nine Brazilian MEN2A families with C634Y/Y791F that we had previously reported were of German descent (Toledo et al. 2010, Valente et al. 2013). However, no cases harbouring C634Y/Y791F have been reported outside of Brazil thus far.

Owing to possible incomplete assessment of the phenotypic features of affected individuals or late disease onset, the control databases may conceivably include patients with rare diseases such as (familial) MTC and MEN2 syndrome who carry pathogenic RET variants. To explore the chance of this situation occurring, we assessed whether the Exome Sequencing Project (ESP) exome variation database (which is not a tumour-enriched databank) included any classical disease-associated RET mutations. No alleles corresponding to strong RET mutations, classified as an MTC level-3 risk by the consensus on MENs or as levels C-D by the ATA MTC guidelines, were found in the ESP control databases (Fig. 2 and Supplementary Fig. 1, see section on supplementary data given at the end of this article). Notably, one allele of the low-risk V804M mutation, which is classified as MTC risk 1/ATA-A, was found among the 13000 RET alleles from the ESP database. Valine 804 is a gatekeeper residue that is critical for ATP binding and activation of the RET kinase receptor. Protein conformation analyses have revealed that the V804M and V804L mutations modify the ATP-binding pockets of RET, facilitating ATP binding and conferring resistance to the multikinase inhibitor vandetanib, which is approved for the treatment of advanced MTC (Carlomagno et al. 2004, Wells et al. 2010). The identification of heterozygous RET V804M in the controls may be due to the relatively mild phenotype or late onset of MTC that is frequently associated with this

Published by Bioscientifica Ltd. 


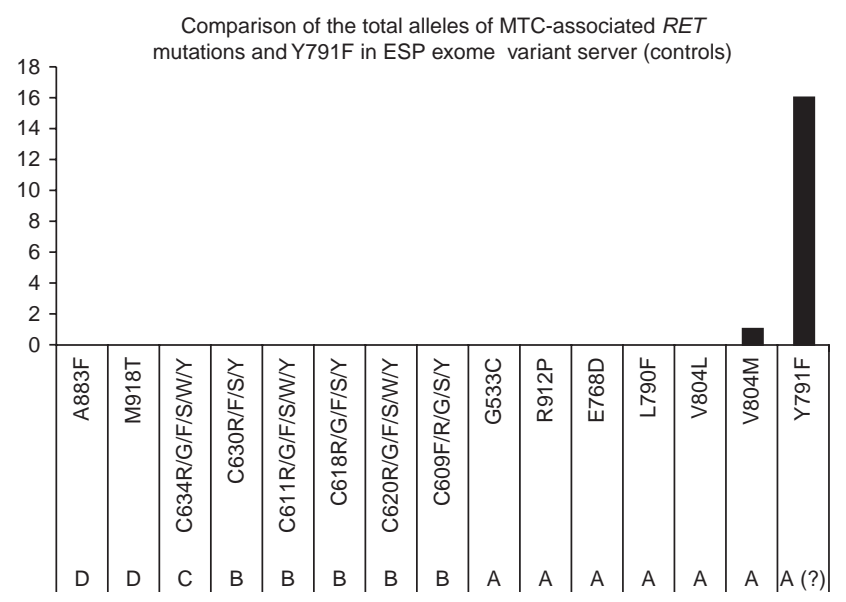

Figure 2

No RET ATA-B, C or D alleles were found in the ESP control databases. Only one instance of the V804M allele (ATA-A) was found among the 13000 sequenced alleles, indicating a very low frequency of bona fide MTCrelated $R E T$ mutations in healthy individuals. In contrast, 15 alleles of $Y 791 \mathrm{~F}$ were found within the ESP control databases, indicating that the frequencies of this specific variant behave differently, possibly as an accompanying genetic modifier or as a benign polymorphism.

variant (Feldman et al. 2000). The ESP dataset also included one allele of each of the three RET variants G321K, K666E, and R866W. These three last variants are very rare and are noted on the ATA guidelines as 'mutations based on limited families/case reports and may represent variants of unknown significance' (Kloos et al. 2009).

In contrast to the absence/very low frequency of bona fide RET-activating mutations in the ESP dataset, the Y791F variant was present in 14 individuals, one of whom was homozygous ( $\mathrm{N}$ alleles $=15)$. This allelic frequency is significantly higher than that observed among the remaining RET mutations $(P=0.00003)$.

\section{Previously unreported tumour-free elderly individuals harbouring RET Y791F}

In this study, we report two Brazilian RET Y791F carriers who were identified during the genetic screening of the healthy elderly controls by Sanger sequencing performed in our laboratory. The first subject is a 76-year-old woman who has never developed tumours and presents no health complications. She has been followed by the Hospital das Clínicas in Sao Paulo (HC-FMUSP) for routine check-ups. Her calcitonin level was undetectable $(<2 \mathrm{pg} / \mathrm{ml})$ in September 2014 , and she reports no history of tumours in her family. Her father was German and died at the age of 75 due to a heart attack. Her 45-year-old daughter (an only child) was invited to come to the hospital to provide blood for biochemical examinations and genetic testing; her calcitonin level was $<2 \mathrm{pg} / \mathrm{ml}$, and sequencing analysis revealed that she harboured the WT allele.

Less information is available regarding the second subject with RET Y791F. She was also followed by HC-FMUSP for routine check-ups, and her medical report shows no tumour development or presence of other serious clinical features. She died in 2008 at the age of 94 .

In accordance with our data on elderly individuals carrying RET Y791F without any history of tumours, a recent study that analysed the exome data of 44 centenarian Ashkenazi Jews has found two individuals $(2 / 44=0.045)$ harbouring the $R E T$ Y791F variant (Freudenberg-Hua et al. 2014).

\section{Evaluation of RET Y791F in MTC, MEN2, hyperpara- thyroidism (HPT) and phaeochromocytoma shows no association with susceptibility to endocrine neoplasia}

Berndt et al. (1998) first reported the presence of the Y791F variant in MTC patients in 1998. In addition to the mutational hotspots in exons 10 and 11, the authors reported exon 13 as a new potential hotspot following the identification of the L790F and Y791F variants in patients with familial MTC. In the original paper, the two RET Y791F families were small and included a combined total of only three clinically affected individuals (Berndt et al. 1998). The association linking Y791F to familial MTC/MEN2 is based on limited and selected cohorts. More importantly, there is no convincing data in the literature showing co-segregation of Y791F with MTC (Supplementary References).

Additionally, Gimm et al. (2002) analysed German patients with mutations in codons 790 and 791 and suggested a mild form of the disease.

Through a review of the literature, we found two large families reported to carry RET Y791F; one family is from Denmark with Central Europe descendants, and the other is from Brazil. Vestergaard et al. (2007) initially identified a Danish young case with goitre carrying RET Y791F and subsequently performed genetic screening of a total of 27 family members. It is noteworthy that 15 of the family members were Y791F carriers, and none exhibited abnormal clinical or biochemical results. The calcitonin levels of the carriers and non-carriers in this family did not differ significantly, and total thyroidectomy was postponed (Vestergaard et al. 2007). The second kindred were a large Brazilian RET Y791F family with 17 carriers, ten of whom were diagnosed with MTC, including cases with the early and aggressive phenotype (Tamanaha et al. 2007).

Published by Bioscientifica Ltd. 
Although this family was initially described as an Y791Fonly family, a subsequent analysis indicated that these patients also harboured the bona fide activating germline RET C634Y mutation (Cerutti \& Maciel 2013, Valente et al. 2013). These results are in accordance with the previous report of C634Y-Y791F cis being found in four Brazilian MEN2A families (Toledo et al. 2010).

The largest reported cohort of patients carrying RET Y791F was described by Frank-Raue and colleagues and comprised 22 German MTC/MEN2 cases and 34 screened relatives. The authors concluded that Y791F carriers develop milder clinical features and achieve higher cure rates compared with carriers of the codon 790 and 804 mutations (Frank-Raue et al. 2008). No control samples from the German population were analysed in this study. Patients with Y791F who display hyperparathyroidism and no MTC have been reported as well (Vierhapper et al. 2005). Another study identified RET Y791F in German patients with glioblastoma multiforme and gastric and pancreatic cancers who showed no clinical features of MTC or MEN2 (Rückert et al. 2011).

In accordance with the results of studies by Erlic et al. (2010) and Pęczkowska et al. (2013) showing occasional phaeochromocytoma cases with co-occurrence of the RET Y791F variant and pathogenic variants in other phaeochromocytoma-related genes, we identified a 68 -year-old male with phaeochromocytoma carrying the RET Y791F variant and the new germline variant $\mathrm{D} 236 \mathrm{~N}$ in the $S D H B$ gene. Nevertheless, the pathogenicity of the latter variant is still uncertain.

\section{Two new MTC patients harbouring RET Y791F without a family history of endocrine neoplasias}

In this study, we report a 37-year-old female followed by the MEN clinic of the Federal University of Sao Paulo (UNIFESP) who presented a thyroid nodule with cytological results indicative of Hürthle cell neoplasm and an extremely high calcitonin level $(2079 \mathrm{pg} / \mathrm{ml}$, normal $=8.5 / 5.0 \mathrm{pg} / \mathrm{ml})$. During physical examination, the patient showed no cutaneous lichen amyloidosis, marfanoid habitus or mucosal neuromas. She underwent total thyroidectomy with prophylactic central neck dissection. A pathological analysis revealed a $2.5 \mathrm{~cm}$ MTC on the left thyroid lobe and lymphocytic thyroiditis with clusters of hyperplastic Hürthle cells. The tumour was confined to the thyroid, and the 20 lymph nodes that were analysed showed no evidence of metastasis. A genetic analysis of all of the RET hotspot exons revealed the $Y 791 \mathrm{~F}$ variant. Three years after surgery, the calcitonin levels of this patient remain undetectable $(<2 \mathrm{pg} / \mathrm{ml})$; her carcinoembryonic antigen (CEA) level was $1.6 \mathrm{ng} / \mathrm{ml}$, and cervical ultrasonography showed no sign of relapse. Additionally, her clinical and biochemical screening results were negative for phaeochromocytoma and hyperparathyroidism.

Screening of this patient's family revealed no history of endocrine tumours. Her 32-year-old sister also carries the RET Y791F variant and presented a thyroid ultrasound exhibiting thyroiditis and no nodules and biochemical examinations showing no evidence of MTC (calcitonin levels $<1 \mathrm{pg} / \mathrm{ml}$ ) or primary hyperparathyroidism. She was followed by another service and inadvertently underwent thyroidectomy. Pathological analysis found no evidence of MTC or C-cell hyperplasia. Her mother (59 years old) and her two sons (18 and 11 years old) did not harbour the RET Y791F variant and presented low calcitonin levels. Her father, who was probably the obligatory carrier, died in a car accident at the age of 46 years with no signs of the disease. He was from Germany. The lack of a family history of MTC in this family with three carriers argues that the RET Y791F variant is not an endocrine-neoplasia-susceptibility variant. Unfortunately, similar to this family, other asymptomatic relatives with the Y791F variant have also undergone unnecessary thyroidectomies (Supplementary References).

Recently, we have identified another patient with MTC harbouring the RET Y791F variant from the city of Curitiba, Brazil. The patient, a 35-year-old woman, was diagnosed with a thyroid nodule. The patient underwent a thyroidectomy, and the final histological analysis revealed MTC. An extended RET analysis (exons 1-12 and 14-21) was performed, and no other mutations were identified. The patient has a 9-year-old daughter exhibiting normal thyroid ultrasound results. The patient also has a German background.

\section{A new elderly phaeochromocytoma patient harbouring RET Y791F without MTC}

A RET Y791F germline variant was observed in a patient being followed at Santa Casa Hospital in Sao Paulo, who was referred to our laboratory for genetic testing at the University of Sao Paulo. The remaining RET hotspot exons were sequenced, and no variant was identified. The patient was a 74-year-old man diagnosed with a left adrenal incidentaloma $(9 \times 8.3 \times 6.5 \mathrm{~cm})$. He had shown hypertension for the past 14 years, in addition to exhibiting chronic atrial fibrillation and subclinical autoimmune hyperthyroidism. His surgical pathology was diagnostic of phaeochromocytoma $(8.5 \mathrm{~cm}$ and $220 \mathrm{~g})$, and the results

Published by Bioscientifica Ltd 
of his thyroid ultrasound examination were compatible with thyroiditis without nodules. His calcitonin and calcium/parathyroid hormone levels were normal. No family history of tumours was reported, and the sequencing results for the TMEM127 gene showed no mutations. This case is another example of an elderly individual harbouring the RET Y791F variant without any increased risk for MTC.

\section{RET Y791F in human tumours}

The number of RET ATA mutations observed in the COSMIC genetic and genomic dataset increased substantially according to the mutation's aggressiveness: $94.1 \%$ of the ATA RET mutations occurring in cancers belong to the ATA C-D classification (strong mutations), while only 1.4\% are weak ATA-A RET mutations (Fig. 3 and Supplementary Tables 2 and 3 , see section on supplementary data given at the end of this article). Among the ATA-A risk mutations, the most common variant is $\mathrm{V} 804 \mathrm{M}$, while the remaining variants are very rare and with an uncertain functional effect according to the ATA classification.

Among the entire COSMIC dataset of 18163 tumour samples with available RET genotypes, only one (a lymphoid neoplasm, ID: COSM1159820) presented the RET Y791F variant $(0.002 \%$ - no information available

\begin{tabular}{|c|c|}
\hline ATA classification & RET mutations on COSMIC \\
\hline ATA-A & $8(1.4 \%)$ \\
\hline ATA-B & $26(4.5 \%)$ \\
\hline ATA-C & $64(11.2 \%)$ \\
\hline ATA-D & $474(82.9 \%)$ \\
\hline Total & 572 \\
\hline
\end{tabular}

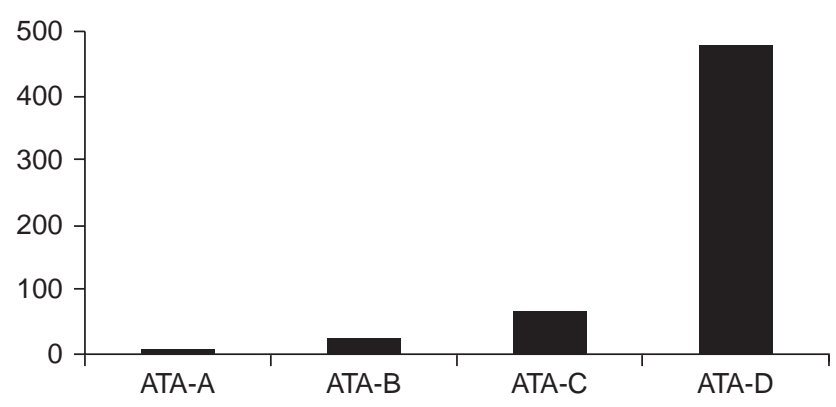

Figure 3

The number of RET mutations observed in the COSMIC cancer genetic and genomic dataset increases substantially according to the ATA mutation aggressiveness classification: $94.1 \%$ of the RET mutations found in cancers belong to the ATA C-D classification (strong mutations), while only $1.4 \%$ consist of weak ATA-A RET mutations. One of the $8(12.5 \%)$ ATA-A variants is $Y 791 \mathrm{~F}$, corresponding to $0.17 \%$ of the mutations. regarding somatic or germline status). Of the 1549 MTCs in the COSMIC dataset, 625 (40.3\%) exhibited a RET mutation, none of which were Y791F, indicating that there is not a frequent association between this variant and MTC tumourigenesis (Supplementary Table 4, see section on supplementary data given at the end of this article).

In addition to the lack of evidence regarding a 'driver' property of RET Y791F in human tumours, two reports describing results indicative of a 'passenger' role for Y791F. The first case is an Y791F MTC patient in whom the most aggressive RET mutation, M918T, was identified somatically, which is most probably the cause of MTC (Fitze et al. 2002). The second case has been recently reported by Carlino et al. (2014) who described a patient with pancreatic carcinoma presenting the typical KRAS G12D mutation and the RET Y791F variant. There is no information as to whether the Y791F mutation was germline or somatic in this patient, but as KRAS G12D is a very well-described pancreatic cancerdriver mutation, the results strongly indicate a minor/ non-pathological role for RET Y791F. Interestingly, the patient is Caucasian, was born in Australia and has a German surname (Carlino, electronic communication).

\section{RET Y791F in HSCR}

RET Y791F was first described in a case of Hirschsprung's disease (HSCR) (Seri et al. 1997). HSCR is a genetically heterogeneous disorder, and inactivation (nonsense and frameshift) mutations in RET are its primary cause (Edery et al. 1994). In families harbouring activating RET mutations occurring primarily in extracellular domains (i.e. exon 10), such as C620R, it has been classically reported that HSCR develops in up to $7 \%$ of carriers. Since the initial report, other Y791F-carrier HSCR cases with no evidence of MTC have been reported, raising the question as to whether this variant is actually involved in tumourigenesis (Virtanen et al. 2013).

\section{In silico RET Y791F analyses}

All four of the software programs used in this study predicted low or very low pathogenicity for the RET Y791F variant (data not shown). Although the software programs employ different algorithms to calculate potential pathogenicity, they all use evolutionary conservation, which indicated that an amino acid change at Tyrosine 791 is more likely to be tolerated, rather than being lethal or pathogenic. Our assessment of the RET protein structure indicate that Y791F localises to the N-lobe, in $\beta 4$, and is close to the ATP-binding site (Supplementary Fig. 3),

Published by Bioscientifica Ltd. 
which is a region that does not commonly contain strong RET mutations.

\section{In vitro RET Y791F assays}

Plaza-Menacho et al. (2007) investigated the RET Y791F variant in vitro and reported ligand-independent activation. According to the results of this previous study, Y791F is an autophosphorylated monomeric activated receptor that leads to the constitutive activation of STAT3. However, the mechanism of STAT3 activation occurs via Src, JAK1 and JAK2, which differs from the classical RET C634R activation mechanism (Plaza-Menacho et al. 2007). In a later study, Hyndman et al. (2013) analysed in vitro RET variants that had been previously reported in HSCR cases and showed that Y791F behaved similarly to the WT protein in many respects, with similar RET/pERK/pSTAT3 phosphorylation, surface localisation, and RNA and protein stability being observed. Nevertheless, unlike to the RET WT protein and similarly to other HSCR variants, Y791F was associated with reduced levels of cell migration and no ability to promote colony formation (Hyndman et al. 2013). Although this last study did not include bona fide RETactivating mutations for comparison, the results indicate WT-like functional and molecular effects of Y791F, rather than Y791F acting as a gain-of-function mutation.

A third study by Cosci et al. (2011) combined in silico and in vitro assays to analyse known pathogenic mutations of RET, such as C634R and M918T and 'rare medium/lowrisk' variants, including Y791F. Correlations between the results obtained using different approaches were observed primarily for the stronger variants, while the overall results and classification of the weaker variants remained unclear. The in silico classification of RET Y791F was deleterious, although focus and soft agar assays indicated Y791F to be a weak and probably non-pathogenic variant (Cosci et al. 2011). In contrast, the high proliferation rates associated with Y791F, C634R and M918T achieved statistical significance, but these results were inconclusive, as several probably non-pathogenic variants, such as V648I, also achieved statistical significance.

The three studies of RET cited above, together with many others in the literature, show how difficult and sometimes capricious it can be to characterise a weak variant using in vitro or in silico approaches, especially in genes related to genotypes with major medical implications, such as the recommendation for total thyroidectomy in the case of RET. To the best of our knowledge, there is no animal model of the RET Y791F variant.

\section{RET Y791F as a potential phenotypic modifying variant in cases with pathogenic $R E T$ mutations}

The data that we were able to generate and review in the current study indicate a clear lack of pathogenicity of RET Y791F-only. However, the possible role of Y791F as a phenotype-modifying variant cannot be discarded. In fact, we have recently reported four MEN2A families carrying the classical RET C634Y mutation and Y791F in cis (Toledo 2010). The patients presented aggressive MTC (codon C634-like pattern) associated with an increased susceptibility to unusually large bilateral phaeochromocytomas. This finding is indicative of a modifier effect of $\mathrm{Y791F}$ when associated with classical disease-causing RET mutations (Toledo 2010). In the same study, we described in vitro analyses performed in Dr Lois Mulligan's laboratory (ON, Canada), demonstrating that the double C634Y/ Y791F RET receptor is significantly more highly phosphorylated than either the WT receptor or the single C634Y and Y791F RET mutants (Toledo et al. 2010). Interestingly, an association between RET C634Y and Y791F has been recently observed in five additional Brazilian families (Cerutti \& Maciel 2013, Valente et al. 2013). In addition to $\mathrm{C} 634 \mathrm{Y} / \mathrm{Y} 791 \mathrm{~F}$, the presence of $\mathrm{Y791F}$ has been reported in patients harbouring other disease-associated RET mutations, such as C620F, V804L and M918T (Jindrichova et al. 2004). Although current knowledge shows no relevant clinical effect, the possible mechanism of such co-occurrence seems worth exploring in the future.

\section{Known RET missense variants identified through whole-exome/genome sequencing}

Four variants classified as ATA-A mutations (S649L, V804M, R844Q and S891A) (Kloos et al. 2009) were rarely found in the whole-exome/genome sequences of the tumour-free individuals assessed in the current study. The V804M and S891A variants are also included in the RET list as MTC level 1 mutations (Brandi et al. 2001). As mentioned earlier, V804M is a well-described gatekeeper mutation associated with a mild, late-onset phenotype, which could explain its rare occurrence in the presumably healthy cohort (1/13000 alleles in the ESP dataset, 0.00007). The frequencies of V804M and Y791F in the controls were very different and were compatible with a true, low-risk mutation and a rare non-pathogenic variant respectively (Fig. 2 and Supplementary Fig. 2, see section on supplementary data given at the end of this article). In addition, a novel change involving Valine 804 (c.2411C > T; p.V804A) was, to the best of our knowledge, identified

Published by Bioscientifica Ltd. 
Table 1 The nine new variants of the RET proto-oncogene identified via whole-exome and whole-genome sequencing in the current study

\begin{tabular}{|c|c|c|c|}
\hline Casuistic & Nucleotide & Codon & RET protein \\
\hline SABE60+ & C1352T & 451 & T451M* \\
\hline SATX & T1418A & 473 & L473Q \\
\hline SATX & A1462T & 488 & T488S \\
\hline SABE60+ & C1573T & 525 & R525W \\
\hline SABE60+ & C1678T & 560 & P560S \\
\hline SABE60+ & G1799T & 600 & R600L \\
\hline SATX & C2077T & 693 & R693C \\
\hline SABE60+ & C2225T & 742 & T742M \\
\hline SABE60+ & A2255G & 752 & Y752C \\
\hline SATX & T2411C & 804 & V804A \\
\hline
\end{tabular}

\begin{tabular}{lcc} 
dbSNP or ESP & & SIFT \\
\cline { 1 - 1 } Not reported & & D \\
Not reported & D \\
Not reported & T \\
Not reported & D \\
Not reported & D \\
Not reported & D \\
Not reported & D \\
Not reported & D \\
Not reported & T \\
Not reported & D
\end{tabular}

\begin{tabular}{c} 
PolyPhen2 \\
\hline B \\
D \\
B \\
D \\
D \\
B \\
D \\
D \\
D \\
D
\end{tabular}

\begin{tabular}{ll}
\hline $\boldsymbol{n}$ \\
\hline 1 \\
3 \\
1 \\
1 \\
1 \\
1 \\
2 \\
1 \\
1 \\
1
\end{tabular}

\begin{tabular}{c}
\hline $\begin{array}{c}\text { Genotype } \\
\text { frequency }\end{array}$ \\
\hline 0.0008 \\
0.0014 \\
0.0004 \\
0.0008 \\
0.0008 \\
0.0008 \\
0.0001 \\
0.0008 \\
0.0008 \\
0.0005
\end{tabular}

Please see the discussion and interpretation of these findings in the main text. The T451M variant is not present in the control databases (dbSNP and ESP), but it was identified in two endometrium carcinomas (COSMIC project IDs: 1584958 and 918112). The other variants have not been reported in COSMIC. D, damaging; B, benign; T, tolerated; SABE60 +, University of Sao Paulo; SATX, San Antonio, Texas.

for the first time in this study (Table 1, allelic frequency of 0.00001 in the SATX control cohorts). An in silico analysis using both SIFT and Polyphen2 indicated the V804M and V804A changes to be pathogenic.

In accordance with our results for S649L, seven individuals from the ESP dataset were also identified as harbouring this variant, which has been presumably associated with late-onset, non-aggressive MTC (ColomboBenkmann et al. 2008).

RET V292M was also found in the SABE60+ cohort ( 1 out of 1218 of the sequenced alleles, 0.0008). This variant is classified as pathogenic in the ARUP MEN2 and $\mathrm{dbSNP} / \mathrm{NCBI}$ databases, but it has not been included in the MTC guidelines (Eng et al. 1996, Kloos et al. 2009). Currently, limited evidence is available regarding the pathogenicity of this variant.

The previously reported RET Y791N variant was identified in two control individuals analysed via Sanger sequencing $(2 / 2522,0.008)$ : a 76 -year-old male and a 55 -year-old female. There is no evidence of pathogenicity of this variant in the literature; it was initially reported in a case of HSCR and later in the sister of an MTC case harbouring RET R770Q (Ruiz-Ferrer et al. 2006, Frank-Raue et al. 2010).

\section{Novel RET missense variants identified via whole-exome/genome sequencing}

Nine of the RET missense variants identified herein via massive parallel DNA sequencing have not been reported in the dbSNP/NCBI or ESP databanks and, to the best of our knowledge, are novel (Table 1). Eight of the variants were classified as damaging by Polyphen 2 or SIFT; six were classified as damaging by both software programs; and one variant was classified as benign/tolerated by both software programs (Table 1). Despite the rarity of these variants and the in silico predictions, the fact that our population was composed of healthy adult/elderly individuals with no familial history of tumours indicates that these variants are probably benign polymorphisms or lowpenetrance genetic changes. If new evidence appears in the future indicating pathogenicity in these variants, especially V804A, which occurs at a known RET hotspot, we will contact the carriers and offer genetic counselling, molecular testing and specific clinical screening.

\section{Conclusions of the current comprehensive assessment of RET Y791F}

1. There is no robust evidence from either our data or the literature indicating that RET Y791F-only may cause familial MTC or MEN2 syndrome (reports addressing very small families should not be considered to be informative). RET Y791F, like other non-pathogenic variants of RET, can be found in sporadic MTC patients, but its presence alone does not indicate an increased MTC risk.

2. The frequencies of the RET Y791F variant detected in large cohorts of healthy individuals are characteristic of the behaviour of a rare benign polymorphism, rather than a medically actionable pathogenic mutation of the RET proto-oncogene.

Lessons from findings 1 and 2:

- Asymptomatic germline RET Y791F-only carriers (with no other disease-causing mutations of RET) should not undergo preventive total thyroidectomy 
based on the genetics. Familial risk, clinical outcomes, and biochemical and imaging data are the most valuable resources for managing these cases.

- There is no indication that genetic and clinical screening of family members of typical sporadic MTC cases harbouring RET Y791F-only is beneficial.

3. The patients with familial MTC/MEN2 who were initially reported to be RET Y791F-only carriers were also found to harbour other associated disease-causing RET variants (C634Y in cis), leading to the disease.

Lessons from finding 3 :

- Genetic testing for RET is only complete when sequencing of all of the hotspot mutations in exons 8 and 10-16 is successfully performed. That is, sequencing of the remaining exons should not cease when the first suspect variant is identified.

- Sequencing or re-sequencing of the hotspot exons of the RET gene (and possibly the full gene depending on the phenotype) of familial MTC/MEN2 patients initially described as RET Y791F-only carriers can reveal medically actionable pathogenic mutations in the RET proto-oncogene.

- Limitations of PCR, such as allelic drop-out (PCR failure of one allele) and/or preferential amplification (hypo-amplification of one allele), may be responsible for false-negative RET genetic results. Therefore, the use of a second set of primers (with different sequences than those used for the initial PCR and sequencing run) is recommended for the re-sequencing of questionable cases.

4. Phaeochromocytoma patients initially reported to be RET Y791F-only carriers can harbour variants of other genes, e.g. VHL or $S D H x$, that are most probably the cause of the disease.

Lesson from finding 4 :

- Established clinical predictors and algorithms should be used to sequence phaeochromocytomasusceptibility genes in phaeochromocytoma cases that are initially reported as RET Y791F-only.

5. Biased genetic analysis of highly selected patients and a relatively small number of controls can result in misunderstanding and misclassification of the pathogenicity of rare variants in medically actionable genes. Lesson from finding 5 :

- The analysis of large and informative datasets from tumour-free individuals constitutes an accessible and useful tool for improving the interpretation of a molecular diagnosis and aiding in genetic counselling and the clinical management and treatment of carriers.

\section{Final comments about the era of NGS}

The scientific and medical community working on RETrelated diseases needs to be aware of the implications related to the dramatic increase in the number of new variants of this gene being identified in the current nextgeneration sequencing era. In fact, nine new RET variants were identified in the present study. Moreover, it is imperative to use caution when interpreting genetic variants with limited information. At the same time, access to genetic data from large cohorts presents an opportunity to re-evaluate the clinical behaviour of disputed RET variants, such as Y791F.

\section{Websites}

1. NHLBI ESP Exome Sequencing Project: http://evs.gs. washington.edu.

2. dbSNP/NCBI: http://www.ncbi.nlm.nih.gov/SNP.

3. Ensembl EBI/EMBL/WTSI: http://www.ensembl.org.

4. COSMIC: http://cancer.sanger.ac.uk/cancergenome/ projects/cosmic.

5. ARUP RET database, Univ. Utah: http://arup.utah. edu/database/MEN2/MEN2_display.php.

6. SIFT: sift.jcvi.org.

7. PMUT: http://mmb2.pcb.ub.es:8080/PMut/.

8. POLYPHEN2: http://genetics.bwh.harvard.edu/pph2/.

9. Align-GVGD: http://agvgd.iarc.fr/.

Supplementary data

This is linked to the online version of the paper at http://dx.doi.org/10.1530/ ERC-14-0491.

Declaration of interest

The authors declare that there is no conflict of interest that could be perceived as prejudicing the impartiality of the research reported.

\section{Funding}

This study was supported by funds from the Conselho Nacional de Desenvolvimento Científico e Tecnológico (CNPq), grant number 401.990/2010-9 and the Fundação de Amparo à Pesquisa do Estado de São Paulo (FAPESP) grants number 2013/01476-9 (to S P A Toledo) and 2006/60402-1 and 2010/51547-1 (to R M B Maciel). S P A Toledo, J M Cerutti and $\mathrm{R} M \mathrm{~B}$ Maciel are investigators with the CNPq. R A Toledo has received a Ciências Sem Fronteiras CNPq postdoctoral fellowship and is currently working at the Centro Nacional de Investigaciones Oncológicas (CNIO) in Madrid. R Hatakana, T Sekiya, S C Lindsey, D M Lourenço Jr, and R A Toledo received research fellowships from FAPESP. SPA Toledo is a Senior Professor in the Division of Endocrinology, Department of Medicine, Federal University of São Paulo, SP, Brazil, with a grant from the Programa 
de Visitante Nacional Senior - Edital 028/2013 - from the Coordenadoria de Aperfeiçoamento de Pessoal de Nível Superior (CAPES), Brazil.

\section{Acknowledgements}

The authors would like to acknowledge all of the subjects and volunteers who participated in this study. They would also like to thank Dr Roger Chammas (Experimental Oncology Laboratory/LIM-24, University of Sao Paulo School of Medicine) and Dr Patricia L Dahia (University of Texas Health Science Center at San Antonio) for their support.

\section{References}

Berndt I, Reuter M, Saller B, Frank-Raue K, Groth P, Grussendorf M, Raue F, Ritter MM \& Höppner W 1998 A new hot spot for mutations in the ret protooncogene causing familial medullary thyroid carcinoma and multiple endocrine neoplasia type 2A. Journal of Clinical Endocrinology and Metabolism 83 770-774. (doi:10.1210/jcem.83.3.4619)

Brandi ML, Gagel RF, Angeli A, Bilezikian JP, Beck-Peccoz P, Bordi C, Conte-Devolx B, Falchetti A, Gheri RG, Libroia A et al. 2001 Guidelines for diagnosis and therapy of MEN type 1 and type 2 . Journal of Clinical Endocrinology and Metabolism 86 5658-5671. (doi:10.1210/jcem.86.12.8070)

Brauer VF, Scholz GH, Neumann S, Lohmann T, Paschke R \& Koch CA 2004 RET germline mutation in codon 791 in a family representing 3 generations from age 5 to age 70 years: should thyroidectomy be performed? Endocrine Practice 10 5-9. (doi:10.4158/EP.10.1.5)

Carlino MS, Kwan V, Miller DK, Saunders CA, Yip D, Nagrial AM, Tomlinson J, Grimmond SM, Scolyer RA, Kefford RF et al. 2014 New $R A S$-mutant pancreatic adenocarcinoma with combined BRAF and MEK inhibition for metastatic melanoma. Journal of Clinical Oncology (In Press). (doi:10.1200/JCO.2013.51.5783)

Carlomagno F, Guida T, Anaganti S, Vecchio G, Fusco A, Ryan AJ, Billaud M \& Santoro M 2004 Disease associated mutations at valine 804 in the RET receptor tyrosine kinase confer resistance to selective kinase inhibitors. Oncogene 23 6056-6063. (doi:10.1038/sj.onc.1207810)

Cerutti JM \& Maciel RM 2013 An unusual genotype-phenotype correlation in MEN 2 patients: should screening for RET double germline mutations be performed to avoid misleading diagnosis and treatment? Clinical Endocrinology 79 591-592. (doi:10.1111/cen.12155)

Colombo-Benkmann M, Li Z, Riemann B, Hengst K, Herbst H, Keuser R, Gross U, Rondot S, Raue F, Senninger N et al. 2008 Characterization of the RET protooncogene transmembrane domain mutation S649L associated with nonaggressive medullary thyroid carcinoma. European Journal of Endocrinology 158 811-816. (doi:10.1530/EJE-07-0817)

Cosci B, Vivaldi A, Romei C, Gemignani F, Landi S, Ciampi R, Tacito A, Molinaro E, Agate L, Bottici V et al. 2011 In silico and in vitro analysis of rare germline allelic variants of RET oncogene associated with medullary thyroid cancer. Endocrine-Related Cancer 18 603-612. (doi:10.1530/ERC-11-0117)

Edery P, Lyonnet S, Mulligan LM, Pelet A, Dow E, Abel L, Holder S, NihoulFékété C, Ponder BA \& Munnich A 1994 Mutations of the RET protooncogene in Hirschsprung's disease. Nature 367 378-380. (doi:10.1038/ 367378a0)

Eng C 2010 Mendelian genetics of rare - and not so rare - cancers. Annals of the New York Academy of Sciences 1214 70-82. (doi:10.1111/j.1749-6632. 2010.05789.x)

Eng C, Clayton D, Schuffenecker I, Lenoir G, Cote G, Gagel RF, van Amstel HK, Lips CJ, Nishisho I, Takai SI et al. 1996 The relationship between specific RET proto-oncogene mutations and disease phenotype in multiple endocrine neoplasia type 2. International RET mutation consortium analysis. Journal of the American Medical Association 276 1575-1579. (doi:10.1001/jama.1996.03540190047028)
Erlic Z, Hoffmann MM, Sullivan M, Franke G, Peczkowska M, Harsch I, Schott M, Gabbert HE, Valimäki M, Preuss SF et al. 2010 Pathogenicity of DNA variants and double mutations in multiple endocrine neoplasia type 2 and von Hippel-Lindau syndrome. Journal of Clinical Endocrinology and Metabolism 95 308-313. (doi:10.1210/jc.2009-1728)

Feldman GL, Edmonds MW, Ainsworth PJ, Schuffenecker I, Lenoir GM, Saxe AW, Talpos GB, Roberson J, Petrucelli N \& Jackson CE 2000 Variable expressivity of familial medullary thyroid carcinoma (FMTC) due to a RET V804M (GTG $\rightarrow$ ATG) mutation. Surgery 128 93-98. (doi:10.1067/msy.2000.107103)

Fitze G, Schierz M, Bredow J, Saeger HD, Roesner D \& Schackert HK 2002 Various penetrance of familial medullary thyroid carcinoma in patients with RET protooncogene codon 790/791 germline mutations. Annals of Surgery 236 570-575. (doi:10.1097/00000658-200211000-00006)

Fitze G, Saeger HD, Roesner D \& Schackert HK 2004 Management of multiple endocrine neoplasia syndrome type 2 families in association with rare germline mutations of the RET proto-oncogene. Klinische Pädiatrie 216 270-276. (doi:10.1055/s-2004-44902)

Frank-Raue K, Machens A, Scheuba C, Niederle B, Dralle H, Raue F \& German MEN2 Study Group 2008 Difference in development of medullary thyroid carcinoma among carriers of RET mutations in codons 790 and 791. Clinical Endocrinology(Oxford) 69 259-263. (doi:10.1111/j.1365-2265.2008.03215.x)

Frank-Raue K, Döhring J, Scheumann G, Rondot S, Lorenz A, Schulze E, Dralle H, Raue F \& Leidig-Bruckner G 2010 New mutations in the RET protooncogene-L881V - associated with medullary thyroid carcinoma and -R770Q - in a patient with mixed medullar/follicular thyroid tumour. Experimental and Clinical Endocrinology \& Diabetes 118 550-553. (doi:10.1055/s-0029-1241851)

Freudenberg-Hua Y, Jan Freudenberg J, Vacic V, Abhyankar A, Emde AK, Ben-Avraham D, Barzilai N, Oschwald D, Christen E, Koppel J et al. 2014 Disease variants in genomes of 44 centenarians. Molecular Genetics \& Genomic Medicine 2 438-450. (doi:10.1002/mgg3.86)

Gimm O, Niederle BE, Weber T, Bockhorn M, UkkatJ, Brauckhoff M, Thanh PN, Frilling A, Klar E, Niederle B et al. 2002 RET proto-oncogene mutations affecting codon 790/791: a mild form of multiple endocrine neoplasia type 2A syndrome? Surgery 132 952-959. (doi:10.1067/msy. 2002.128559)

Hyndman BD, Gujral TS, Krieger JR, Cockburn JG \& Mulligan LM 2013 Multiple functional effects of RET kinase domain sequence variants in Hirschsprung disease. Human Mutation 34 132-142. (doi:10.1002/ humu.22170)

Jindrichova S, Vcelak J, Vlcek P, Neradilova M, Nemec J \& Bendlova B 2004 Screening of six risk exons of the RET proto-oncogene in families with medullary thyroid carcinoma in the Czech Republic. Journal of Endocrinology 83 257-265. (doi:10.1677/joe.1.05838)

Kloos RT, Eng C, Evans DB, Francis GL, Gagel RF, Gharib H, Moley JF, Pacini F, Ringel MD, Schlumberger M et al. 2009 Medullary thyroid cancer: management guidelines of the American Thyroid Association. Thyroid 19 565-612. (doi:10.1089/thy.2008.0403)

Krieger E, Joo K, Lee J, Lee J, Raman S, Thompson J, Tyka M, Baker D \& Karplus K 2009 Improving physical realism, stereochemistry, and sidechain accuracy in homology modeling: four approaches that performed well in CASP8. Proteins 77 (Suppl 9) 114-122. (doi:10.1002/prot.22570)

Li Y, Willer CJ, Ding J, Scheet P \& Abecasis GR $2010 \mathrm{MaCH}$ : using sequence and genotype data to estimate haplotypes and unobserved genotypes. Genetic Epidemiology 34 816-834. (doi:10.1002/gepi.20533)

Margraf RL, Crockett DK, Krautscheid PM, Seamons R, Calderon FR, Wittwer CT \& Mao R 2009 Multiple endocrine neoplasia type 2 RET protooncogene database: repository of MEN2-associated RET sequence variation and reference for genotype/phenotype correlations. Human Mutation 30 548-556. (doi:10.1002/humu.20928)

Pęczkowska M, Kowalska A, Sygut J, Waligórski D, Malinoc A, JanaszekSitkowska H, Prejbisz A, Januszewicz A \& Neumann HP 2013 Testing new susceptibility genes in the cohort of apparently sporadic phaeochromocytoma/paraganglioma patients with clinical 
characteristics of hereditary syndromes. Clinical Endocrinology $\mathbf{7 9}$ 817-823. (doi:10.1111/cen.12218)

Plaza-Menacho I, van der Sluis T, Hollema H, Gimm O, Buys CH, Magee AI, Isacke CM, Hofstra RM \& Eggen BJ 2007 Ras/ERK1/2-mediated STAT3 $\mathrm{Ser}^{727}$ phosphorylation by familial medullary thyroid carcinomaassociated RET mutants induces full activation of STAT3 and is required for $c$-fos promoter activation, cell mitogenicity, and transformation. Journal of Biological Chemistry 282 6415-6424. (doi:10.1074/jbc.M608952200)

Plaza-Menacho I, Barnouin K, Goodman K, Martínez-Torres RJ, Borg A, Murray-Rust J, Mouilleron S, Knowles P \& McDonald NQ 2014 Oncogenic RET kinase domain mutations perturb the autophosphorylation trajectory by enhancing substrate presentation in trans. Molecular Cell 53 738-751. (doi:10.1016/j.molcel.2014.01.015)

Ren J, Wen L, Gao X, Jin C, Xue Y \& Yao X 2009 DOG 1.0: illustrator of protein domain structures. Cell Research 19 271-273. (doi:10.1038/cr.2009.6)

Rich TA, Feng L, Busaidy N, Cote GJ, Gagel RF, Hu M, Jimenez C, LeeJE, Perrier N, Sherman SI et al. 2014 Prevalence by age and predictors of medullary thyroid cancer in patients with lower risk germline RET proto-oncogene mutations. Thyroid 24 1096-1106. (doi:10.1089/thy.2013.0620)

Rückert F, Görgens H, Richter I, Krex D, Schackert G, Kuhlisch E, Fitze G, Saeger HD, Pilarsky C, Grützmann R et al. 2011 RET-protooncogene variants in patients with sporadic neoplasms of the digestive tract and the central nervous system. International Journal of Colorectal Disease 26 835-840. (doi:10.1007/s00384-011-1150-7)

Ruiz-Ferrer M, Fernández RM, Antiñolo G, López-Alonso M, Eng C \& Borrego S 2006 A complex additive model of inheritance for Hirschsprung disease is supported by both RET mutations and predisposing RET haplotypes. Genetics in Medicine 8 704-710. (doi:10.1097/01.gim.0000245632.06064.f1)

Seri M, Yin L, Barone V, Bolino A, Celli I, Bocciardi R, Pasini B, Ceccherini I, Lerone M, Kristoffersson U et al. 1997 Frequency of RET mutations in long- and short-segment Hirschsprung disease. Human Mutation 9 243-249. (doi:10.1002/(SICI) 1098-1004(1997)9:3 < 243::AIDHUMU5 > 3.0.CO;2-8)

Tamanaha R, Camacho CP, Ikejiri ES, Maciel RM \& Cerutti JM 2007 Y791F RET mutation and early onset of medullary thyroid carcinoma in a Brazilian kindred: evaluation of phenotype-modifying effect of germline variants. Clinical Endocrinology 67 806-808. (doi:10.1111/ j.1365-2265.2007.02964.x)
Toledo SP, dos Santos MA, Toledo RA \& Lourenço DM Jr 2006 Impact of RET proto-oncogene analysis on the clinical management of multiple endocrine neoplasia type 2. Clinics (Sao Paulo) 61 59-70. (doi:10.1590/ S1807-59322006000100011)

Toledo RA, Wagner SM, Coutinho FL, Lourenço DM Jr, Azevedo JA, Longuini VC, Reis MT, Siqueira SA, Lucon AM, Tavares MR et al. 2010 High penetrance of pheochromocytoma associated with the novel C634Y/Y791F double germline mutation in the RET protooncogene. Journal of Clinical Endocrinology and Metabolism 95 1318-1327. (doi:10.1210/jc.2009-1355)

Valente FO, Dias da Silva MR, Camacho CP, Kunii IS, Bastos AU, da Fonseca CC, Simião HP, Tamanaha R, Maciel RM \& Cerutti JM 2013 Comprehensive analysis of RET gene should be performed in patients with multiple endocrine neoplasia type 2 (MEN 2) syndrome and no apparent genotype-phenotype correlation: an appraisal of p.Y791F and p.C634Y RET mutations in five unrelated Brazilian families. Journal of Endocrinological Investigation 36 975-981. (doi:10.3275/8997)

Vestergaard P, Vestergaard EM, Brockstedt H \& Christiansen P 2007 Codon Y791F mutations in a large kindred: is prophylactic thyroidectomy always indicated? World Journal of Surgery 31 996-1001. (doi:10.1007/ s00268-006-0446-1)

Vierhapper H, Rondot S, Schulze E, Wagner L, Hanslik S, Niederle B, Bieglmayer C, Kaserer K \& Baumgartner-Parzer S 2005 Primary hyperparathyroidism as the leading symptom in a patient with a Y791F RET mutation. Thyroid 15 1303-1308. (doi:10.1089/thy. 2005.15.1303)

Virtanen VB, Pukkala E, Kivisaari R, Salo PP, Koivusalo A, Arola J, Miettinen PJ, Rintala RJ, Perola M \& Pakarinen MP 2013 Thyroid cancer and co-occurring RET mutations in Hirschsprung disease. Endocrine-Related Cancer 20 595-602. (doi:10.1530/ERC-13-0082)

Weber F \& Eng C 2005 Editorial: Germline variants within RET: clinical utility or scientific playtoy? Journal of Clinical Endocrinology and Metabolism 90 6334-6336. (doi:10.1210/jc.2005-2030)

Wells SA Jr, Gosnell JE, Gagel RF, Moley J, Pfister D, Sosa JA, Skinner M, Krebs A, Vasselli J \& Schlumberger M 2010 Vandetanib for the treatment of patients with locally advanced or metastatic hereditary medullary thyroid cancer. Journal of Clinical Oncology 28 767-772. (doi:10.1200/JCO.2009.23.6604)

Received in final form 24 November 2014

Accepted 25 November 2014

Made available online as an Accepted Preprint

25 November 2014 


\title{
A defect in the RNA-processing protein HNRPDL causes limb-girdle muscular dystrophy $1 G$ (LGMD1G)
}

\author{
Natássia M. Vieira ${ }^{1,2,3,4, \dagger}$, Michel S. Naslavsky1, ${ }^{1}$, Luciana Licinio', Fernando Kok,5,6, \\ David Schlesinger 1,6,7, Mariz Vainzof ${ }^{1}$, Nury Sanchez ${ }^{8}$, João Paulo Kitajima ${ }^{1,6}$, Lihi Gal ${ }^{9}$, \\ Natale Cavaçana1, Peter R. Serafini ${ }^{2,3,4}$, Silvia Chuartzman ${ }^{9}$, Cristina Vasquez ${ }^{8}$, Adriana \\ Mimbacas $^{10}$, Vincenzo Nigro ${ }^{11}$, Rita C. Pavanello', Maya Schuldiner ${ }^{9}$, Louis M. Kunkel ${ }^{2,3,4}$ \\ and Mayana Zatz ${ }^{1, *}$
}

${ }^{1}$ Human Genome and Stem Cell Center, Biosciences Institute, University of São Paulo, São Paulo, Brazil, ${ }^{2}$ Program in Genomics, Department of Pediatrics and ${ }^{3}$ The Manton Center for Orphan Disease Research, Children's Hospital Boston, Boston, MA, USA, ${ }^{4}$ Department of Genetics, Harvard Medical School, Boston, MA, USA, ${ }^{5}$ Department of Neurology, University of São Paulo Medical School, São Paulo, Brazil, ${ }^{6}$ Mendelics Análise Genômica, São Paulo, Brazil, ${ }^{7} \mathrm{Hospital}$ Israelita Albert Einstein, São Paulo, Brazil, ${ }^{8} \mathrm{Hospital}$ de Clínicas, Montevideu, Montevideo, Uruguay, ${ }^{9}$ Department of Molecular Genetics, Weizmann Institute of Science, Rehovot, Israel, ${ }^{10}$ Department of Genetics, Clemente Estabele Institute, Montevideo, Uruguay and ${ }^{11}$ TIGEM (Telethon Institute of Genetics and Medicine), Napoli, Italy

Received December 5, 2013; Revised February 13, 2014; Accepted March 17, 2014

Limb-girdle muscular dystrophies (LGMD) are a heterogeneous group of genetically determined muscle disorders with a primary or predominant involvement of the pelvic or shoulder girdle musculature. More than 20 genes with autosomal recessive (LGMD2A to LGMD2Q) and autosomal dominant inheritance (LGMD1A to LGMD1H) have been mapped/identified to date. Mutations are known for six among the eight mapped autosomal dominant forms: LGMD1A (myotilin), LGMD1B (lamin A/C), LGMD1C (caveolin-3), LGMD1D (desmin), LGMD1E (DNAJB6), and more recently for LGMD1F (transportin-3). Our group previously mapped the LGMD1G gene at 4q21 in a Caucasian-Brazilian family. We now mapped a Uruguayan family with patients displaying a similar LGMD1G phenotype at the same locus. Whole genome sequencing identified, in both families, mutations in the HNRPDL gene. HNRPDL is a heterogeneous ribonucleoprotein family member, which participates in mRNA biogenesis and metabolism. Functional studies performed in S. cerevisiae showed that the loss of HRP1 (yeast orthologue) had pronounced effects on both protein levels and cell localizations, and yeast proteome revealed dramatic reorganization of proteins involved in RNA-processing pathways. In vivo analysis showed that hnrpdl is important for muscle development in zebrafish, causing a myopathic phenotype when knocked down. The present study presents a novel association between a muscular disorder and a RNA-related gene and reinforces the importance of RNA binding/processing proteins in muscle development and muscle disease. Understanding the role of these proteins in muscle might open new therapeutic approaches for muscular dystrophies.

\section{INTRODUCTION}

The limb-girdle muscular dystrophies (LGMDs) are a heterogeneous group of genetically determined progressive disorders of the muscle with a primary or predominant involvement of the pelvic or shoulder girdle musculature. Mutations in $>20$ genes with autosomal recessive (LGMD2A-Q) and autosomal dominant inheritance (LGMD1A-H) have been mapped/identified to

\footnotetext{
${ }^{*}$ To whom correspondence should be addressed. Tel: +55 1130917563; Fax: + 55 1130917419; Email: mayazatz@usp.br

${ }^{\dagger}$ These two authors contributed equally for this work.
} 
date $(1-6)$. The autosomal dominant forms are relatively rare and represent $<10 \%$ of all LGMD (2). Among the eight autosomal dominant forms that have been mapped, only six genes have been identified to date: LGMD1A (myotilin), LGMD1B (lamin A/C), LGMD1C (caveolin-3), LGMD1D (desmin), LGMD1E (DNAJB6) and more recently LGMD1F [transportin-3 (TNPO)] $(5,6)$. The causal genes still remained unknown for LGMD1G and LGMD1H (3).

We have previously mapped LGMD1G at $4 \mathrm{q} 21$ in a fourgeneration Brazilian family of European ancestry, with a maximum logarithm of odds (LOD)-score of 6.6. The disease was characterized by late and variable muscular weakness. The initial symptoms were proximal lower limbs involvement and weakness followed by upper limbs proximal weakness. As detailed in the first report (4), limitation of finger and toe flexion was also a characteristic of this condition. Type II diabetes was seen in 5 out of 10 patients, but also in three unaffected family members. No cataracts, clinical myotonia or electroneuromyographydetected myotonic phenomena were found when the family was first described. Biceps muscle biopsy taken from one more severely affected patient showed a predominantly myopathic histopathological pattern associated with rimmed vacuoles (4).

Subsequently, we have identified a genealogy from Uruguay with 18 affected members by an autosomal dominant form of LGMD1G which was mapped in the same region. Whole genome sequencing allowed us to identify the mutation in both families in the HNRPDL gene.

\section{RESULTS}

\section{Mapping and clinical findings}

The genealogies of the Brazilian and Uruguayan families are depicted in Figure 1A and B, respectively.

Linkage analysis in the unrelated LGMD1G Uruguayan family, using flanking microsatellite markers for the $4 \mathrm{q} 21$ region showed a maximum LOD-score of 4.8 also at $4 \mathrm{q} 21$. Just like the original Brazilian family, the Uruguayan clinically affected members presented an adult-onset disease with proximal limb-girdle weakness that included finger and toe flexion limitation. In 8 out of 11 examined patients, the onset was in proximal lower limbs involving subsequently the upper limbs. In three of them it started with proximal weakness in the upper limbs (difficulty to raise the arms). The age of onset varied from 15 to 53 years old $(36.6 \pm 13.7)$. As an additional phenotype, 6 out of 11 clinically affected individuals presented cataracts (three bilateral and three unilateral) with onset before the age of 50. Type II diabetes, with onset at the age of 53, was present in one patient. A careful clinical and neurological examination revealed that none of the patients had myotonic phenomena.

In the Brazilian family, there are 17 affected members distributed in three generations (Fig. 1A), and at least two asymptomatic cases: II-2 died in her 90s and never showed any muscular weakness; her son, III-1 who should also be a carrier of the mutation died at the age of 63 without any reported symptoms. Three additional asymptomatic individuals carried the causative variant; IV-23, IV-25 and V-1, but they are still within the range of age of onset (30-47 years old). Recently, two patients presented bilateral cataract with onset at ages 35 and 56 years. In the Uruguayan family (Fig. 1B), there are 18 affected patients.
Here, also three clinically unaffected members (III-5, IV-1 and IV-7) were found to carry the causative variant but were still within the age of manifestation when examined. Nonetheless, it is clear from both families that the disease progresses with age in most patients with no evidence of clinical anticipation, does not display full penetrance and that both sexes are equally affected.

\section{Two distinct mutations in the same codon}

The combined analysis of both families reduced the candidate region to $<3.5 \mathrm{MB}$ (positions 81985539 to 85468682 in University of California Santa Cruz (UCSC) Human Genome v19). Whole genome sequencing was undertaken for three affected patients (two Brazilian and one Uruguayan) by an Illumina HiSeq2000 platform. In each family, a different variant in chromosome 4, position 83347676 was identified (Supplementary Material, Table S1). The base is located within the HNRPDL gene (heterogeneous nuclear ribonucleoprotein D-like), also known as JKTBP (NM_031372.3, c.1667, p.D378). The mutation in exon 6 was G>A (p.D378N) in the Brazilian family, causing an amino acid change from aspartate to asparagine, while in the Uruguayan family the mutation was $G>C$ (p.D378H), causing a change to histidine (Fig. 1C). These mutations were confirmed using Sanger sequencing in 13 Brazilian (10 affected and 3 asymptomatic) and 12 Uruguayan ( 9 affected and 3 asymptomatic) members and neither present in 14 nonaffected adult members from both families nor in 604 Brazilian controls older than 60 . The conservation profile of the residue was performed in PolyPhen2 (7) and its alignment is indicated in Supplementary Material, Figure S1. Sequencing of 70 isolated undiagnosed LGMD cases from Brazil or atypical forms of myotonic-like phenotype failed to identify any further mutations in the HNRPDL gene.

\section{Loss of hrp1 in yeast affects RNA-processing proteins}

The yeast HNRPDL orthologue is called hrp1. These proteins are $42 \%$ identical over a $66 \%$ query cover of the human protein ( $P$-value of 1e-45) with overlaps in functions, as shown by a Gene Ontology enrichment analysis (Supplementary Material, Table S2). Using automated mating technologies, we assessed the loss of HRP1 on the levels and localization of all yeast proteins $(8,9)$. A mutation in $\Delta h r p l$ was introduced into almost 6000 yeast strains each carrying a fusion of one yeast protein with a c-terminal Green fluorescent protein (GFP) tag (10). The hrpl mutation had pronounced effects on both protein levels and cell localizations demonstrating that loss of this protein is detrimental to cellular physiology. Interestingly, the loss of HRP1 on the yeast proteome revealed dramatic reorganization of proteins involved in RNA-processing pathways. The RNA helicases Prp43 and Dbp2, which are both involved in rRNA maturation, were completely excluded from their natural place in the nucleolus and now reside in the cytosol rendering them, most probably, inactive. A similar phenotype was observed for Urb2, a nucleolar protein required for normal metabolism of the rRNA primary transcript (Fig. 2). In addition, a large number of proteins were up-/down-regulated indicating the extent of cellular stress (Supplementary Material, Table S3). 


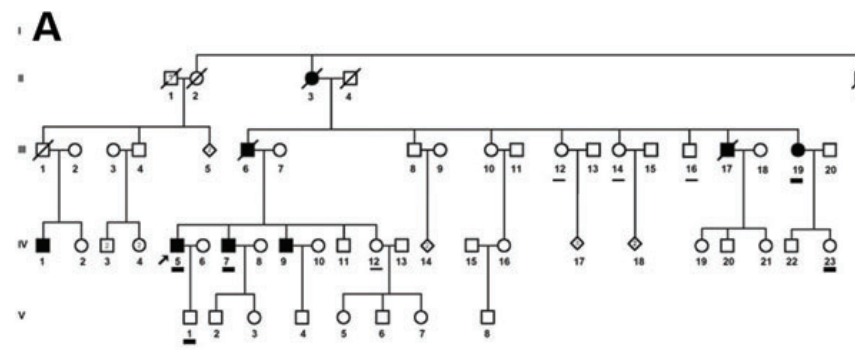

B

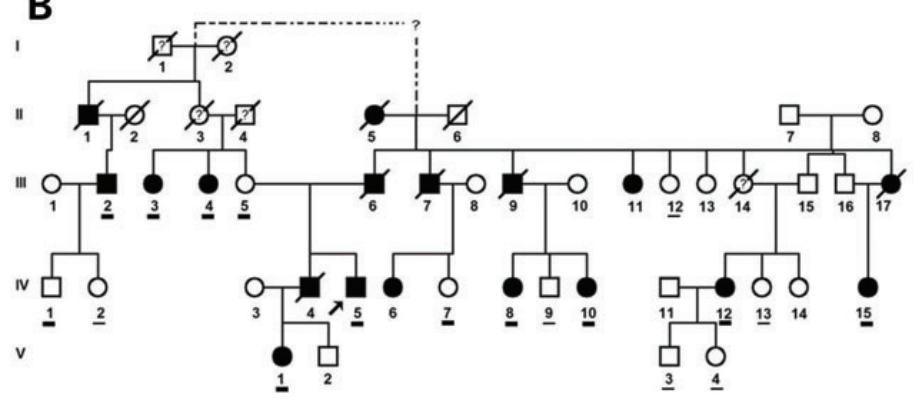

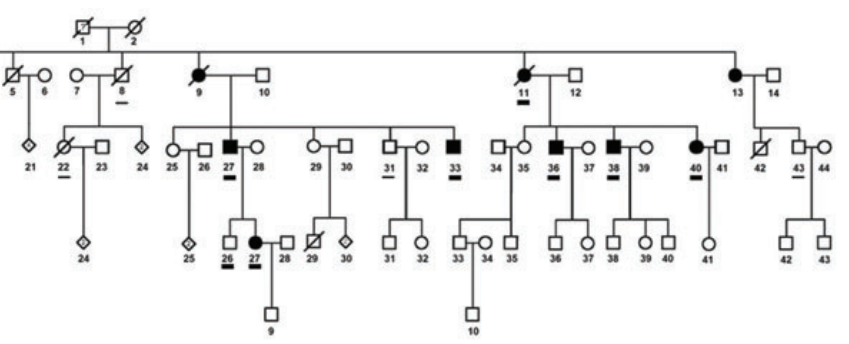

C

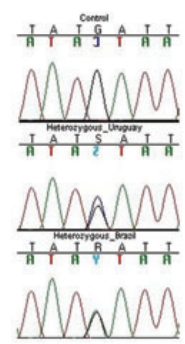

Figure 1. Thick segments under individual numbers indicate mutated and thin segments indicate non-mutated, according to Sanger sequencing. (A) Pedigree of Brazilian family. Proband (arrow): IV-5. Mutated (Sanger) (NM_031372.3 c.1132G > A) and symptomatic: II-11, III-19, III-27, III-33, III-36, III-38, III-40, IV-5, IV-7, IV-27. Mutated and asymptomatic: IV-23, IV-26, V-1. Non-mutated: II-8, III-12, III-14, III-16, III-22, III-31, III-43, IV-12. Biopsies were done in III-31, III-33 and IV-9. (B) Pedigree of Uruguayan family. Proband (arrow): IV-5. Mutated (Sanger) (NM_031372.3 c.1132G >C) and symptomatic: III-2, III-3, III-4, IV-5, IV-8, IV-10, IV-12, IV-15, V-1. Mutated and asymptomatic: III-5, IV-1, IV-7. Non-mutated: III-12, IV-2, IV-9, IV-13, V-3, V-4. (C) Eletropherogram regions containing alterations in Uruguayan and Brazilian affected family members compared with a healthy control.

\section{Hnrpdl is important for zebrafish muscle development}

To analyse the in vivo role of HNRPDL in muscle, we used a loss of function approach in zebrafish. Fish hnrpdl (GenBank Accession: NP_998557.1) was found to have 85\% identity with the human sequence. An antisense oligonucleotide morpholino (MO) was designed to specifically target the translation start site of hnrpdl. Wild-type (AB) zebrafish embryos were injected with a translation blocking MO designed to knockdown hnrpdl expression in parallel with a control MO. Microinjection hnrpdl MO at the one-cell stage leads to a dose-dependent downregulation of the expression of the hnrpdl gene (Fig. 3A). Injected fish were quantified 4 days post-fertilization ( $4 \mathrm{dpf})$ based on abnormal phenotypes (Fig. 3B). Depending on MO dosage, injected embryos showed a range of severity such as body shape defects or twisted tails (Fig. 3C). Additionally, movements of hnrpdl morphants were restricted and uncoordinated, which is consistent with a myopathy. Immunohistochemical staining of MO injected fish showed abnormalities in the V-shaped chevron pattern typically associated with a normal fish. The myofibres were also disorganized as shown by birefringence and myosin heavy chain (MCH) immunofluorescence (IF) (Fig. 3D).

\section{LGMD1G patients show diffuse HNRPDL in their muscle}

Muscle histological features revealed variable findings apparently related to the progression of the disease in two patients from the Brazilian family (Fig. 4A). While the most severely affected case (IV-9) showed a clear myopathic pattern, with degeneration, fibre size variation with discrete perimysial fibrosis, several necrotic fibres and rimmed vacuoles, the other less severely affected (III-33) showed an almost normal histological pattern. Furthermore, evidence of neurogenic involvement was observed in both patients, including the presence of small angulated fibres, predominance of type II fibres and a discrete fibre type grouping pattern on the ATPases reaction, compatible with a neurogenic involvement.

Immunohistochemical and western blot (WB) analyses revealed normal pattern for dystrophin, calpain3, dysferlin, telethonin and $\alpha-, \beta$-sarcoglycans [previously shown in our original report (4)] and $\gamma$-sarcoglycans as shown in Figure 4A.

Since HNRPDL is a candidate to physically interact with TNPO1 in RNA-processing events $(11,12)$ analysing the distribution patterns of these proteins in the muscle of patients versus controls is of great interest.

Immunohistochemical analysis identified the presence of HNRPDL protein in the nuclei of the control as well as in patients, co-localizing with TNPO1 (Fig. 4B). However, an apparently higher variability in nuclear labelling was observed in the patients: some nuclei presented a strong condensed HNRPD-L labelling while in others, HNRPDL showed a diffused pattern around the nuclei more frequently than the observed in normal muscle. Interestingly, a similar observation was previously reported in conditions where there is no transportation of HNRPDL by TNPO1 (11).

\section{DISCUSSION}

HNRPDL is a heterogeneous ribonucleoprotein (hnRNP) family member, along with HNRNPD, HNRNPL, SRSF3 and PTBP1. This family has been shown to function in mRNA biogenesis and mRNA metabolism, including alternative splicing, mRNA 


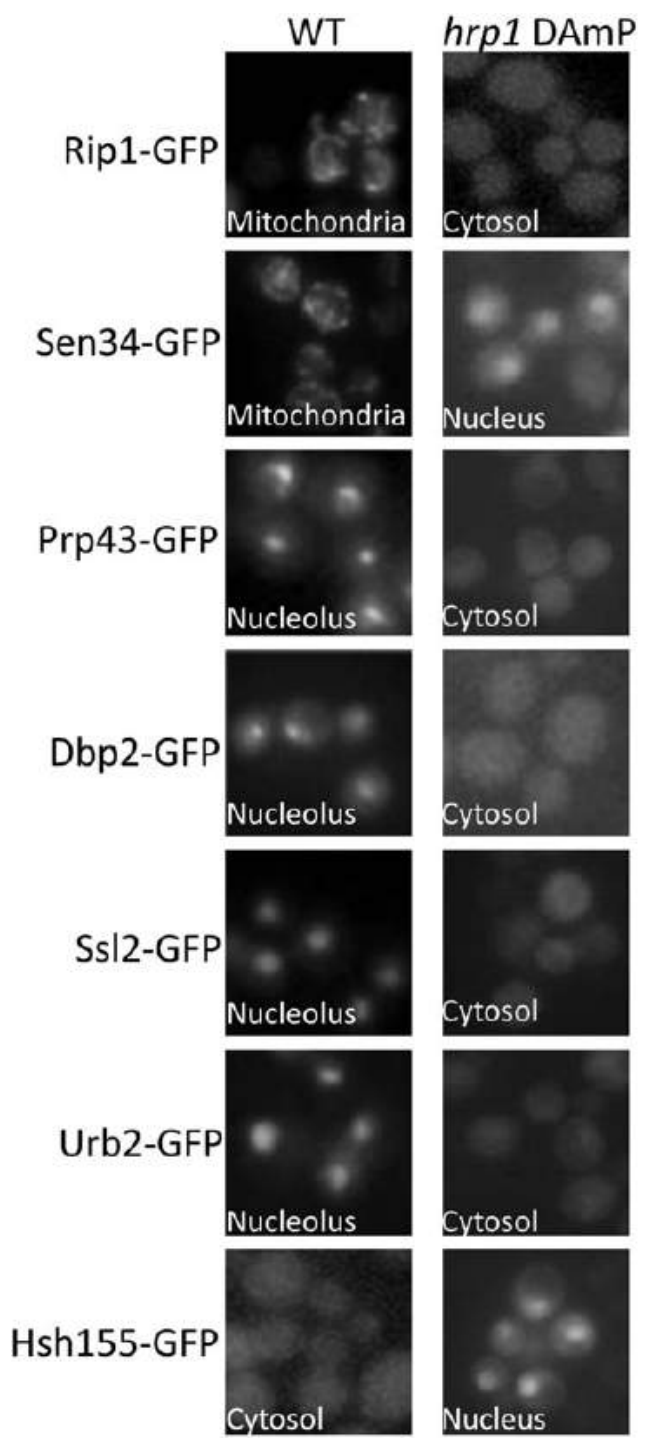

Figure 2. Images of seven proteins involved in RNA processing, whose localization was shifted in the absence of HRP1. A null mutation in HRP1 was introduced into almost 6000 yeast strains each carrying a fusion of one yeast protein with a c-terminal GFP tag. All proteins levels and localizations were followed and mutants (right column) were compared with control cells with a normal copy of HRP1 (left column). Loss of HRP1 caused a dramatic reorganization in the subcellular localization of proteins involved in RNA-processing pathways demonstrating a central role for this protein in determining RNA-processing physiology. Loss of the HRP1, the yeast homologue of HNRPDL, causes dramatic changes in the localization of proteins required for RNA processing.

nuclear export, translational regulation and turnover (11). HNRPDs participate in the splicing of specific exons in pre-mRNA of transcripts from important muscle-related genes. HnRNPF, hnRNPG and hnRNPH regulate alternative splicing of alpha- and beta-tropomyosin and hnRNPG is also involved in dystrophin splicing (13). HnRNPA1 and hnRNP $\mathrm{A} / \mathrm{B}$ interact with PABPN1, a gene that when mutated causes adult-onset oculopharyngeal muscular dystrophy (OPMD). In OPMD patients, hnRNPA1 is sequestered in intranuclear insoluble aggregates interfering with RNA export and causing muscle cell death (14). Abnormal hnRNPH also inhibits nuclear export of mRNA containing expanded CUG repeats (15) and is also associated with aberrant splicing in myotonic dystrophy type 1 (16). Cataracts, a feature of the myotonic dystrophy spectrum, were the present in six members of the Uruguayan LGMD1G family and more recently in two of the Brazilian family.

Interestingly, Drosophila smooth gene mutant, orthologue of the mammalian hnRNPL, shows decreased motor function and a progressive dystrophic muscle phenotype (17). Our in vivo study in zebrafish showed that movements of hnrpdl morphants were restricted and uncoordinated, especially in response to touch, which supports the importance of hnrpdl in muscle development and function, consistent with a myopathy (18). Thus, our findings reinforce the role of the hnRNP family in muscle pathology.

Additionally, our functional studies show the importance of hnrpdl in RNA-processing pathways in yeast. Interestingly, the diffuse hrp1 labelling found in the yeast mutant was also observed in the nucleus of LGMD1G patients' muscle fibres, which might suggest an impaired traffic of the mutant HNRPDL into the nuclei. Recently, TNPO3 was identified as the gene responsible for LGMD1F. It belongs to a family of importin $\beta$ super-family proteins that import numerous proteins into the nucleus, including serine/arginine-rich proteins (SR proteins) that control mRNA splicing $(5,6)$. On the other hand TNPO1 mediates the nuclear import of M9-bearing proteins and has been shown to bind the nuclear localization signal in the C-terminal of HNRPDL $(11,12)$. LGMD1F and $1 \mathrm{G}$ might share a common and novel pathological mechanism, still unrelated to the known LGMD molecular mechanisms.

In conclusion, we have identified mutations in HNRPDL associated with LGMD1G. We also provide evidence that the impairment of HNRPDL homologues cause a rearrangement of RNA-related proteins both in localization and level parameters in yeast and a muscular phenotype in zebrafish. Our study may provide a link between this disease and the group of myopathies caused by impaired RNA binding/processing proteins, which had been previously associated with oculopharyngeal muscular dystrophy as well as myotonic dystrophies type 1 and 2, disorders caused by dynamic mutations. This work significantly contributes to our understanding of inherited muscular dystrophies.

\section{MATERIAL AND METHODS}

The study was approved by the institutional ethics committee and all patients signed informed consent forms.

\section{Muscle IF analyses}

From the Brazilian family, a muscle biopsy was taken from biceps muscle from the index case affected brother at the age of 38 (patient IV-3, Fig. 1), and from one additional affected relative (II-33). The muscles were cryo-protected and snap frozen in liquid nitrogen. Routine histological and histochemical analyses include staining for HE, modified Gomori trichrome, SDH, NADH, acid phosphatases and ATPase at $\mathrm{pH}$ 9.4 and 4.3 .

Protein analyses were done through IF and WB methodologies, as previously described (4). The following antibodies 
A

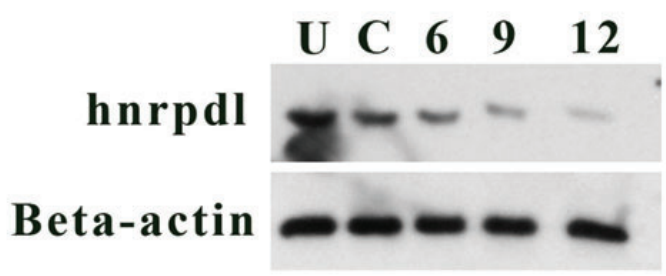

B

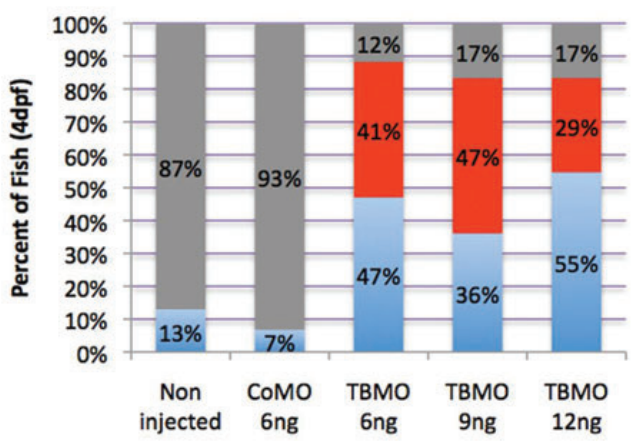

D

Non injected

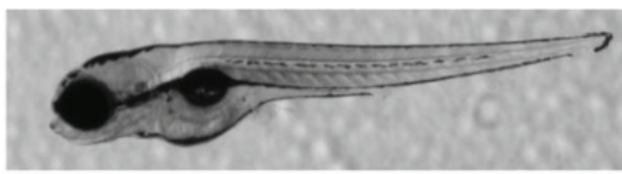

Control MO

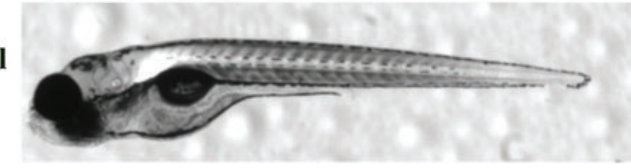

TBMO 6ng
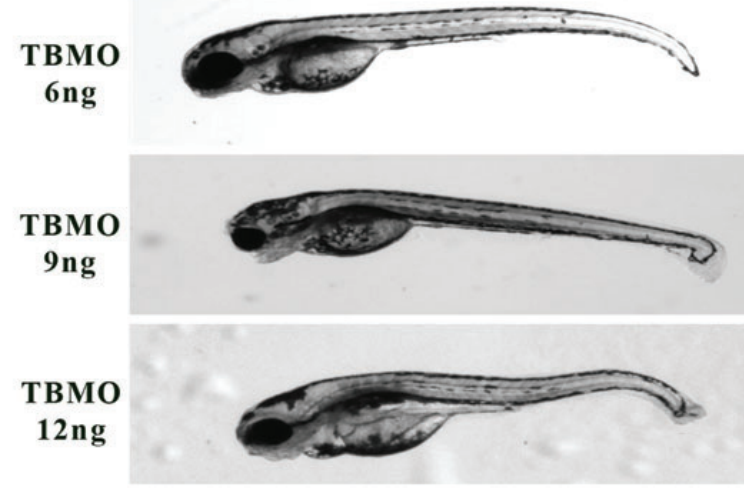

mormal

abnormal

w dead
C
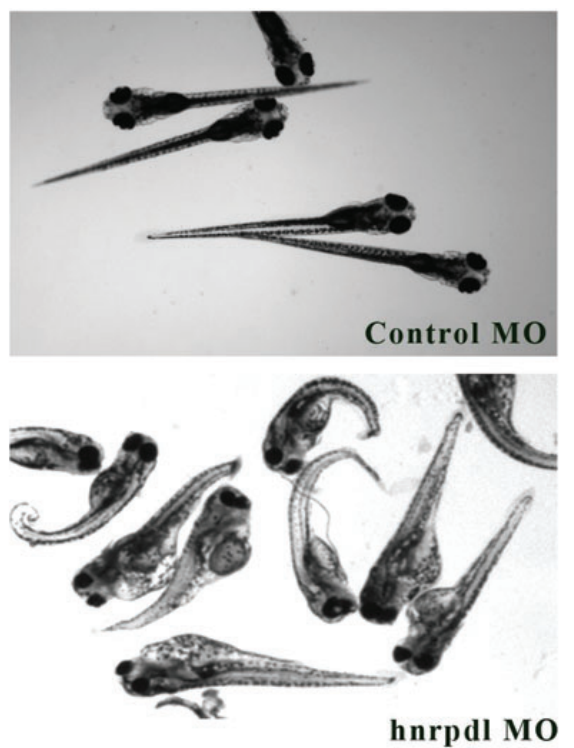

hnrpdl MO

Birefringence
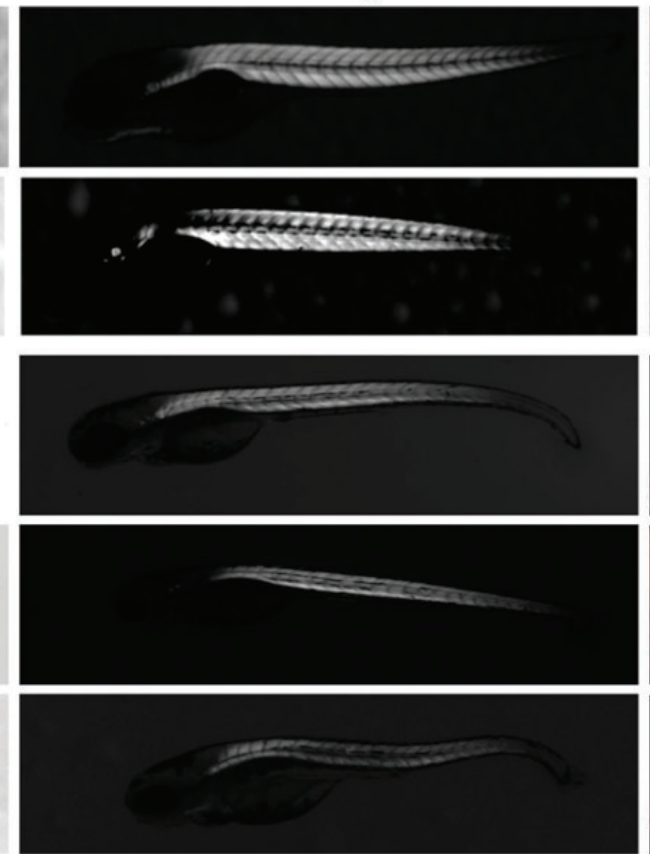
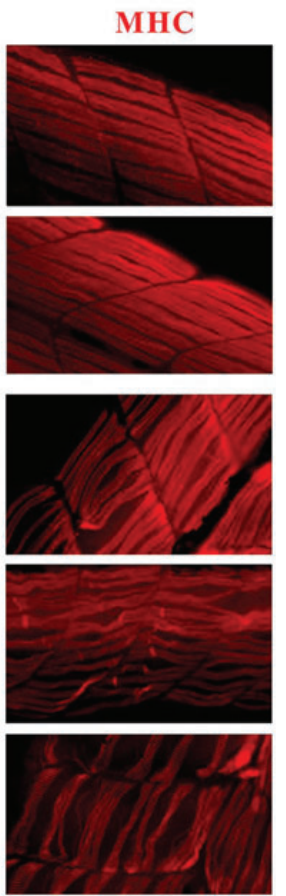

Figure 3. hnrpdl knockdown in zebrafish. (A) Western blot confirming a dose-dependent hnrpdl MO knockdown with either 6,9 or $12 \mathrm{ng}$ hnrpdl translation blocking MO. Beta-actin was used as a loading control. (B) Injected fish were quantified 4 days post-fertilization (4dpf) based on abnormal phenotypes, which were defined by body shape defects like shortened or twisted tails, and swimming impairments, such as slow motility in response to touch, or rotating in circles. Compared with fish injected with control MO, hnrpdl morphants were more abnormal in the $9 \mathrm{ng}$ concentration, while the number of dead embryos increased at the $12 \mathrm{ng}$ concentration, which is likely due to toxicity. Three separate experiments were performed; graph shows the average number of fish per group. (C) Phase images of injected fish with hnrpdl MO (9 ng) and control MO. Note abnormal body shape seen in majority of injected fish. (D) Phase image, birefringence and IF staining with MCH antibody of hnrpdl knockdown in zebrafish. Note the dose-dependent effect of low birefringence and disorganized muscle fibres in the hnrpdl morphant fish muscle when compared with the control MO and non-injected fish $(n=10)$. Non-injected, AB zebrafish; CoMo, control morpholino injected fish; TBMO, translational blocking hnrpdl MO; ng, nanograms.

were used: dystrophin, sarcoglycans $\alpha, \beta, \gamma$ and $\delta$, calpain-3, dysferlin and telethonin. Additionally, the following primary antibodies were used: polyclonal rabbit anti-HNRPDL (1/100,
Sigma), monoclonal anti- TNPO1 (1/20, Novus Biologicals). As secondary antibodies, anti-mouse-FITC and anti-rabbit-Cy3 (Sigma) in the concentration of $1 / 100$ were used. 

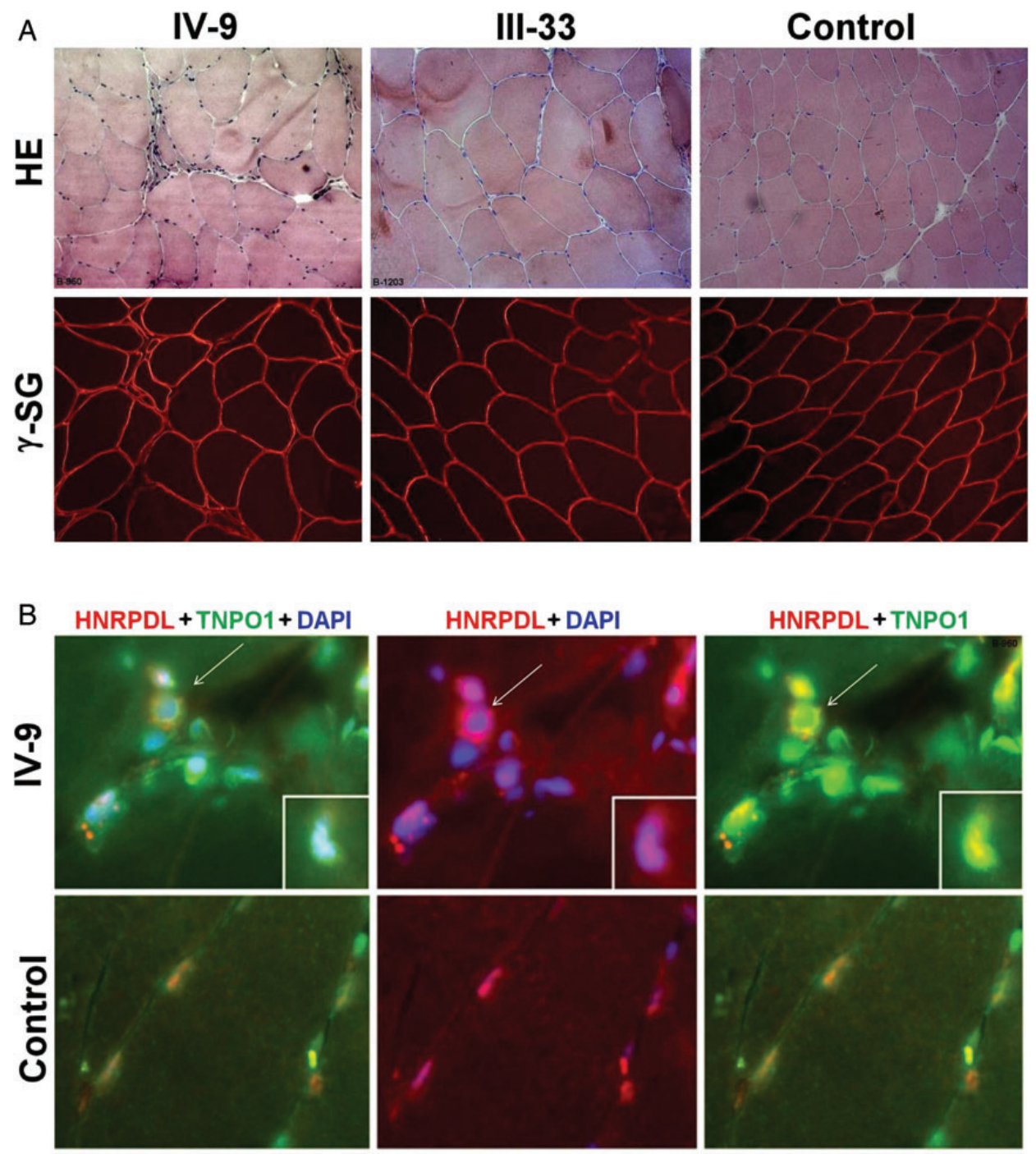

Figure 4. Muscle analyses in two Brazilian affected members. (A) HE staining showing histopathological alterations in patient IV-9 and in less affected patient III-33, as compared with a normal control, and an immunohistochemical reaction for $\gamma$-SG to illustrate the pattern of sarcolemmal labelling. Magnification: $200 \times$. (B) Double immunohistohemical analysis for HNRPDL and TNPO1. Magnification $400 \times$. Arrow showing nuclei with peripheral diffused labelling, and detail showing a nucleus with strong condensed labelling.

\section{Genome sequencing}

DNA was isolated from the blood by the standard methodology. Libraries were subsequently sequenced as 100-base paired-end runs (average insert size of 300 bases). Read alignment and variant calling was performed by the Illumina CASAVA 1.9 pipeline software. An average of $120 \mathrm{~GB}$ in aligned sequences was produced per sample, yielding a genome sampling depth of $\sim 40 \times$ and $>95 \%$ of the UCSC hg19 reference genome sampled at 10 reads or more. Moreover, samples were genotyped using the HumanOmni2.5-8v1 microarray. NGS alignment and genotyping pipeline was also redone using Broad Institute's Best Practices (BWA 0.7; GATKv2.4; HaplotypeCaller), but no further variants in the linked region were identified.

As a downstream variant analysis, the resulting variant list for each sample was filtered using the 1000 Genomes variants (phase 1 release v3), the NHLBI Exome Sequencing Project (ESP6500) variants and 604 high-coverage exomes from randomized, population-based Brazilian controls. Variants with minor allele frequency $>0.01$ were removed from analysis.

\section{Insertion of $\Delta h r p 1$ into the yeast GFP library expressing cytosolic mCherry}

The synthetic genetic array (SGA) technique was performed between a MATa haploid strain harbouring the $\Delta h r p 1:: \operatorname{kan}^{\mathrm{R}} \mathrm{de}-$ letion from the deletion library collection (19) and the GFP collection (::HIS3) (10) expressing a TEF $2_{\mathrm{pr}}$-mCherry::URA3 integrated into the URA3 locus (20). In this collection of strains, a GFP was integrated carboxy-terminally into the genomic locus of each yeast open reading frame, maintaining the chromosomal context and preserving the natural promoter of each gene. The cytosolic fluorescence allows us to segment the images into hundreds of individual yeast cells for each strain and to extract protein abundance (detected as GFP 
fluorescence) under the desired condition. Mating was performed on rich-media plates, selection for diploid cells was performed on plates lacking both HIS and URA and containing G418. Sporulation was then induced by transferring cells to nitrogen starvation plates for 5 days. Haploid cells containing all desired mutations were selected by transferring cells to plates containing all selection markers alongside the toxic amino acid derivatives Canavanine and Thialysine (Sigma-Aldrich) to select against remaining diploids and lacking leucine to select for only spores with an 'alpha' mating type $(8,9)$. The SGA procedure was validated by inspecting representative strains for the deletion and the presence of the GFP-tagged strains and for the cytosolic mCherry expression. To manipulate the collection in high-density format (384), we used a RoToR bench top colony arrayer (Singer Instruments, UK).

\section{High-throughput fluorescence microscopy}

The manipulated 5330 strains as described above were grown in 501 synthetic (SD) medium [0.67\% yeast nitrogen base without amino acids (Conda Pronadisa) and 2\% dextrose] containing the appropriate supplements for selection in 384-well plates (Cat. Number 781 162, Greiner). Microscopic screening was performed using an automated microscopy set-up as previously described $(9,20)$. Cells were moved from agar plates into liquid 384-well polystyrene growth plates using the RoTor arrayer (Singer). Liquid cultures were grown over night in SD medium in a shaking incubator (LiCONiC Instruments) at $30^{\circ} \mathrm{C}$. A JANUS liquid handler (Perkin Elmer), which is connected to the incubator, was used to back-dilute the strains to $\sim 0.25$ OD into plates containing the same medium. Plates were then transferred back to the incubator and were allowed to grow for $3.5 \mathrm{~h}$ at $30^{\circ} \mathrm{C}$ to reach the logarithmic growth phase, as was validated in preliminary calibration. The liquid handler was then used to transfer strains into glass bottom 384-well microscope plates (Matrical Bioscience) coated with Concanavalin A (Sigma-Aldrich) to allow cell adhesion. Wells were washed twice in medium to remove floating cells and reach cell monolayer. Plates were then transferred into an automated inverted fluorescent microscopic ScanR system (Olympus) using a swap robotic arm (Hamilton). Imaging of plates was performed in 384-well format using a $60 \times$ air lens $(\mathrm{NA}=0.9)$ in $\mathrm{SD}$ medium at $24^{\circ} \mathrm{C}$ with a cooled $\mathrm{CCD}$ camera (Hamamatsu ORCA-ER). Images were acquired at GFP (excitation at 490/20 nm, emission at 535/50 nm) and mCherry (excitation at $572 / 35 \mathrm{~nm}$, emission at $632 / 60 \mathrm{~nm}$ ) channels.

\section{Image analysis}

Our screening assay was designed to explore yeast cell biology by assessing two cellular key features of interest: subcellular localization and fluorescence intensity. To analyse these images, we have utilized an in-house script to browse manually and assign localization rapidly and efficiently. To extract proteomic abundance from images, we utilized the Olympus ScanR analysis software. This allows for the pre-processing of images by background subtraction, and segmentation of images to identify individual cells as separate objects. Data on expression intensity were compared with a WT library that does not have the $\Delta h r p 1$ background. In addition, manual inspection of the images allows us to assign localization for each protein relative to a control strain.

\section{Zebrafish knockdown}

A translation blocking $\mathrm{MO}$ directed at the zebrafish hnrpdl gene (TBMO) (5'-TTCAAA(ATG)CAGGCCGAAGAGCAAG-3') was designed against the initiation methionine shown in parenthesis. A standard negative control MO (5'-CCTCTTACCTCA GTTACAATTTATA-3') was used for control injections. All MOs were ordered from Gene Tools. Zebrafish were injected at the 1-2 cell stage with either 6,9 or 12 and were assessed for phenotypic changes at 4 days post-fertilization ( $4 \mathrm{dpf}$ ), each injection was performed three times. Approximately 200 embryos were injected at each dosage.

\section{Birefringence assay}

The muscle phenotype was detected by using a birefringence assay, a technique used to analyse muscle quality due to the unique ability of highly organized sarcomeres to rotate polarized light. The birefringence assay is performed by placing anaesthetized embryos on a glass polarizing filter and covering them with a second polarizing filter. The filters are placed on an underlit dissecting scope and the top polarizing filter is twisted until the light refracting through the zebrafish's striated muscle is visible. The fish do not need to be sacrificed for this technique.

\section{Zebrafish immunostaining}

Immunostaining was performed in $4 \mathrm{dpf}$ embryos. Embryos were fixed in $4 \%$ paraformaldehyde in PBS at $4{ }^{\circ} \mathrm{C}$ overnight and dehydrated in $100 \%$ methanol. After rehydration, $4 \mathrm{dpf}$ embryos were incubated in $0.1 \%$ collagenase (Sigma) in PBS for $60 \mathrm{~min}$. Blocking solution containing $0.2 \%$ saponin was used for $4 \mathrm{dpf}$ embryos. Anti-slow muscle $\mathrm{MCH}$ antibody (F59, Developmental Studies Hybridoma Bank; 1:50) was used. The embryos were placed in 3\% methyl cellulose or mounted on a glass slide and observed with fluorescent microscopes (Nikon Eclipse E1000 and Zeiss Axioplan2).

\section{AUTHORS' CONTRIBUTIONS}

Study concept and design were performed by: N.V., M.S.N., F.K., L.L., J.K., D.S., M.V., M.S., L.K., M.Z.Acquisition of data was carried out by N.V., M.S.N., F.K., L.L., N.S., L.G., D.S., N.C., P.S., S.C., C.V., A.M., M.V., R.P., M.Z. Statistical analysis and interpretation of the data were performed by N.V., M.S.N., F.K., L.L., N.S., J.K., L.G., D.S., N.C., P.S., C.V., A.M., V.N., M.V., R.P., M.S., L.K., M.Z. The manuscript was drafted by N.V., M.S.N., M.V., M.S., N.C., M.Z., Critical revision of the manuscript was performed by N.V., M.S.N., V.N., M.V., M.S., L.K., M.Z. Funding was obtained by D.S., V.N., M.V., M.S., L.K., M.Z.

\section{SUPPLEMENTARY MATERIAL}

Supplementary Material is available at $H M G$ online. 


\section{ACKNOWLEDGEMENTS}

We thank Professors Maria Lúcia Lebrão and Yeda Duarte for access to Brazilian population-based controls from the SABE Project at the Faculdade de Saúde Pública da USP, University of São Paulo. This work was funded by CEPID-FAPESP, INCT, CNPq, FINEP, and a generous grant from Roberto and Renata Ruhman.

Conflict of Interest statement. None declared.

\section{FUNDING}

This work was supported by the following funding agencies: Fundaçäo de Amparo a Pesquisa do Estado de S.Paulo (FAPESP); INCT: Instituto Nacional de Ciência e Tecnologia; CNPq: Conselho Nacional de Desenvolvimento Científico e tecnológico; FINEP: Financiadora Nacional de Estudos e Projetos; The Bernard and Alva Gimbel Foundation.

\section{REFERENCES}

1. Mitsuhashi, S. and Kang, P.B. (2012) Update on the genetics of limb girdle muscular dystrophy. Semin. Pediatr. Neurol., 19, 211-218.

2. Zatz, M., de Paula, F., Starling, A. and Vainzof, M. (2003) The 10 autosomal recessive limb-girdle muscular dystrophies. Neuromuscul. Disord., 13, $532-544$.

3. Bisceglia, L., Zoccolella, S., Torraco, A., Piemontese, M.R., Dell'Aglio, R., Amati, A., De Bonis, P., Artuso, L., Copetti, M., Santorelli, F.M. et al. (2010) A new locus on 3p23-p25 for an autosomal-dominant limb-girdle muscular dystrophy, LGMD1H. Eur. J. Hum. Genet., 18, 636-641.

4. Starling, A., Kok, F., Passos-Bueno, M.R., Vainzof, M. and Zatz, M. (2004) A new form of autosomal dominant limb-girdle muscular dystrophy (LGMD1G) with progressive fingers and toes flexion limitation maps to chromosome 4p21. Eur. J. Hum. Genet., 12, 1033-1040.

5. Torella, A., Fanin, M., Mutarelli, M., Peterle, E., Del Vecchio Blanco, F., Rispoli, R., Savarese, M., Garofalo, A., Piluso, G., Morandi, L. et al. (2013) Next-generation sequencing identifies transportin 3 as the causative gene for LGMD1F. PLoS ONE, 8, e63536.

6. Melia, M.J., Kubota, A., Ortolano, S., Vilchez, J.J., Gamez, J., Tanji, K., Bonilla, E., Palenzuela, L., Fernandez-Cadenas, I., Pristoupilova, A. et al. (2013) Limb-girdle muscular dystrophy $1 \mathrm{~F}$ is caused by a microdeletion in the transportin 3 gene. Brain, 136, 1508-1517.
7. Adzhubei, I.A., Schmidt, S., Peshkin, L., Ramensky, V.E., Gerasimova, A., Bork, P., Kondrashov, A.S. and Sunyaev, S.R. (2010) A method and server for predicting damaging missense mutations. Nat. Methods, 7, 248-249.

8. Tong, A.H., Evangelista, M., Parsons, A.B., Xu, H., Bader, G.D., Page, N., Robinson, M., Raghibizadeh, S., Hogue, C.W., Bussey, H. et al. (2001) Systematic genetic analysis with ordered arrays of yeast deletion mutants. Science, 294, 2364-2368.

9. Cohen, Y. and Schuldiner, M. (2011) Advanced methods for high-throughput microscopy screening of genetically modified yeast libraries. Methods Mol. Biol., 781, 127-159.

10. Huh, W.K., Falvo, J.V., Gerke, L.C., Carroll, A.S., Howson, R.W., Weissman, J.S. and O'Shea, E.K. (2003) Global analysis of protein localization in budding yeast. Nature, 425, 686-691.

11. Kawamura, H., Tomozoe, Y., Akagi, T., Kamei, D., Ochiai, M. and Yamada, M. (2002) Identification of the nucleocytoplasmic shuttling sequence of heterogeneous nuclear ribonucleoprotein D-like protein JKTBP and its interaction with mRNA. J. Biol. Chem., 277, 2732-2739.

12. Imasaki, T., Shimizu, T., Hashimoto, H., Hidaka, Y., Kose, S., Imamoto, N., Yamada, M. and Sato, M. (2007) Structural basis for substrate recognition and dissociation by human transportin 1. Mol. Cell., 28, 57-67.

13. Nasim, M.T., Chernova, T.K., Chowdhury, H.M., Yue, B.G. and Eperon, I.C. (2003) HnRNP G and Tra2beta: opposite effects on splicing matched by antagonism in RNA binding. Hum. Mol. Genet., 12, 1337-1348.

14. Fan, X., Messaed, C., Dion, P., Laganiere, J., Brais, B., Karpati, G. and Rouleau, G.A. (2003) HnRNP A1 and A/B interaction with PABPN1 in oculopharyngeal muscular dystrophy. Can. J. Neurol. Sci., 30, 244-251.

15. Kim, D.H., Langlois, M.A., Lee, K.B., Riggs, A.D., Puymirat, J. and Rossi, J.J. (2005) HnRNP H inhibits nuclear export of mRNA containing expanded CUG repeats and a distal branch point sequence. Nucleic Acids Res., 33, 3866-3874.

16. Paul, S., Dansithong, W., Kim, D., Rossi, J., Webster, N.J., Comai, L. and Reddy, S. (2006) Interaction of muscleblind, CUG-BP1 and hnRNP $\mathrm{H}$ proteins in DM1-associated aberrant IR splicing. EMBO J., 25, 4271-4283.

17. Draper, I., Tabaka, M.E., Jackson, F.R., Salomon, R.N. and Kopin, A.S. (2009) The evolutionarily conserved RNA binding protein SMOOTH is essential for maintaining normal muscle function. Fly (Austin), 3, 235-246.

18. Guyon, J.R., Steffen, L.S., Howell, M.H., Pusack, T.J., Lawrence, C. and Kunkel, L.M. (2007) Modeling human muscle disease in zebrafish. Biochim. Biophys. Acta, 1772, 205-215.

19. Giaever, G., Chu, A.M., Ni, L., Connelly, C., Riles, L., Veronneau, S., Dow, S., Lucau-Danila, A., Anderson, K., Andre, B. et al. (2002) Functional profiling of the Saccharomyces cerevisiae genome. Nature, 418, 387-391.

20. Breker, M., Gymrek, M. and Schuldiner, M. (2013) A novel single-cell screening platform reveals proteome plasticity during yeast stress responses. J. Cell. Biol., 200, 839-850. 


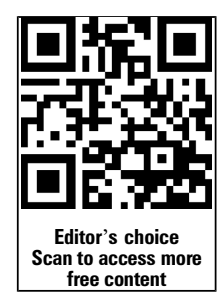

- Additional material is published online only. To view please visit the journal online (http://dx.doi.org/10.1136/ jmedgenet-2015-103018).

For numbered affiliations see end of article.

\section{Correspondence to} Dr Débora Romeo Bertola, Unidade de Genética, Instituto da Criança do Hospital das Clinicas da Faculdade de Medicina da Universidade de São Paulo, Av. Dr. Enéas Carvalho de Aguiar, 647, São Paulo, SP CEP 05403-000, Brazil; debora.bertola@usp.br

Received 13 January 2015 Revised 4 March 2015 Accepted 5 March 2015 Published Online First 20 March 2015

\title{
Rare variants in SOS2 and LZTR1 are associated with Noonan syndrome
}

\author{
Guilherme Lopes Yamamoto, ${ }^{1,2}$ Meire Aguena, ${ }^{2}$ Monika Gos, ${ }^{3}$ Christina Hung, ${ }^{4}$ \\ Jacek Pilch, ${ }^{5}$ Somayyeh Fahiminiya, ${ }^{6}$ Anna Abramowicz, ${ }^{3}$ Ingrid Cristian, ${ }^{7}$ \\ Michelle Buscarilli, ${ }^{1}$ Michel Satya Naslavsky, ${ }^{2}$ Alexsandra C Malaquias, ${ }^{8}$ \\ Mayana Zatz, ${ }^{2}$ Olaf Bodamer, ${ }^{4}$ Jacek Majewski, ${ }^{6}$ Alexander A L Jorge, ${ }^{8}$ Alexandre \\ C Pereira, ${ }^{9}$ Chong Ae Kim, ${ }^{1}$ Maria Rita Passos-Bueno, ${ }^{2}$ Débora Romeo Bertola ${ }^{1,2}$
}

\section{ABSTRACT \\ Background Noonan syndrome is an autosomal} dominant, multisystemic disorder caused by dysregulation of the RAS/mitogen activated protein kinase (MAPK) pathway. Heterozygous, pathogenic variants in 11 known genes account for approximately $80 \%$ of cases. The identification of novel genes associated with Noonan syndrome has become increasingly challenging, since they might be responsible for very small fractions of the cases.

Methods A cohort of 50 Brazilian probands negative for pathogenic variants in the known genes associated with Noonan syndrome was tested through whole-exome sequencing along with the relatives in the familial cases. Families from the USA and Poland with mutations in the newly identified genes were included subsequently.

Results We identified rare, segregating or de novo missense variants in SOS2 and LZTR1 in 4\% and 8\%, respectively, of the 50 Brazilian probands. SOS2 and LZTR1 variants were also found to segregate in one American and one Polish family. Notably, SOS2 variants were identified in patients with marked ectodermal involvement, similar to patients with SOS1 mutations. Conclusions We identified two novel genes, SOS2 and LZTR1, associated with Noonan syndrome, thereby expanding the molecular spectrum of RASopathies. Mutations in these genes are responsible for approximately $3 \%$ of all patients with Noonan syndrome. While SOS2 is a natural candidate, because of its homology with SOS1, the functional role of LZTR1 in the RAS/MAPK pathway is not known, and it could not have been identified without the large pedigrees. Additional functional studies are needed to elucidate the role of LZTR1 in RAS/MAPK signalling and in the pathogenesis of Noonan syndrome.

\section{INTRODUCTION}

Noonan syndrome (NS (MIM 163950)) is an autosomal dominant disorder characterised by short stature, craniofacial dysmorphism, short and/or webbed neck, cardiac abnormalities, cryptorchidism in men and coagulation defects. ${ }^{1}$ NS is caused by dysregulation of the RAS/MAPK pathway, which plays a role in diverse biological functions, including proliferation, migration, survival, cell fate determination, differentiation and senescence. Heterozygous pathogenic variants in several genes, PTPN11, KRAS, SOS1, RAF1, SHOC2, NRAS, CBL, BRAF and MAP2K1, account for approximately $75 \%-80 \%$ of all NS cases. ${ }^{2}$ The clinical phenotype of NS overlaps with other disorders caused by mutations in the RAS/MAPK pathway. These disorders including NS are collectively named RASopathies. ${ }^{3}$

During the last 2 years, whole-exome sequencing (WES) and whole genome sequencing have been applied to identify disease-causing variants in the remaining $20 \%$ of the NS with unknown genetic aetiology. Consequently, pathogenic variants in RIT1 and RASA2 were identified in a small fraction of the cases. ${ }^{4} 5$ These studies underscored the increasing challenges to identify rare, pathogenic variants in disorders comprising high locus heterogeneity, in which the majority of genes have already been identified. In this scenario, to be able to make sense of the large numbers of rare variants typically produced by WES, two reasonable approaches may be applied: one is to study large cohorts and seek candidate genes already known to be involved in the RAS/MAPK pathway, increasing the possibility that more than one individual could harbour rare variants in a common gene; the other is to examine familial cases and search for predicted pathogenic de novo and/or segregating variants without a priori hypotheses regarding the function of the genes.

Herein, these two approaches were applied in a NS Brazilian cohort in order to identify novel genes associated with NS. Subsequently, two additional familial cases from international centres were included.

\section{METHODS}

\section{Brazilian cohort}

Our genetic outpatient clinic follows a large cohort of $>200$ individuals diagnosed with RASopathies, mainly NS, some of which have been previously reported by our group. ${ }^{67}$ They have been screened for mutations in most of the known genes associated with RASopathies by Sanger sequencing or denaturing high performance liquid chromatography, respectively, based on the frequency of the genes in NS and their clinical findings: PTPN11 (ex. 2-15), SOS1 (ex. 1-23), RAF1 (ex 7,14,17), KRAS (ex. 2-6), SHOC2 (ex. 2), CBL (ex. 8-9) and $B R A F$ (ex. 6,11-16). Fifty-eight probands with the clinical diagnosis of NS who fulfilled the diagnostic criteria established by van der Burgt $e t a l^{8}$ and who
To cite: Yamamoto $\mathrm{GL}$, Aguena $\mathrm{M}$, Gos $\mathrm{M}$, et al. J Med Genet 2015;52: 413-421. 
tested negative were selected for WES. Familial cases were prioritised. Written informed consent was obtained prior to collection of samples. Six probands carried mutations in $R I T 1^{9}$ and two in NRAS (data not shown). Among the 50 remaining probands, there were four familial cases: a three-generation family with three affected individuals (Br-F3), a mother and five affected children from three different marriages (Br-F4), a deceased mother and two affected siblings (Br-F7) and a daughter-mother pair (Br-F1).

\section{American family}

The daughter-mother pair (US-F1) was evaluated for the presence of symptoms suggestive of NS. Molecular testing for all known genes associated with RASopathies using a commercially available next generation panel was negative. Consequently, WES was done in both individuals following written informed consent.

\section{Polish family}

A familial case with NS that had no identifiable mutations in the coding exons of PTPN11, SOS1 and RAF1 analysed by Sanger sequencing was selected for WES. They were recruited by an experienced clinical geneticist in outpatient clinic located in Poland and were referred for molecular analysis to the Department of Medical Genetics, Institute of Mother and Child, Warsaw. The study was approved by the local Ethics Committee. The clinical data and DNA samples were obtained with written informed consent for molecular analysis and storage.

\section{Sequencing and filtering of variants}

WES of genomic DNA obtained from the peripheral blood of the 58 affected Brazilian individuals and their affected (8) and unaffected (2) available relatives was performed using Illumina's TrueSeq kits for library preparation and exome capture and the Illumina HiSeq sequencer for paired-end reads of approximately $100 \times 100 \mathrm{bp}$. An average on-target coverage of $60 \times$ was achieved. Alignment of the sequences was performed with the Burrows-Wheeler Aligner. ${ }^{10}$ The Picard and Genome Analysis Tool Kit $(\mathrm{GATK})^{11}$ were used for data processing and variant calling. Variant annotation was performed with ANNOVAR. ${ }^{12}$ Filtering was restricted to retain only heterozygous, nonsynonymous, exonic and/or splicing variants with a reference population frequency of $<0.1 \%$. We used the 1000 Genomes Project National Institutes of Health and the 6500 Exome Sequencing Project Washington University, respectively, as references. In addition, we filtered for an allele frequency of $<0.5 \%$ among 609 elderly Brazilian controls from our centre (unpublished data). Variants shared by familial cases and variants in genes of the RAS/MAPK pathway were selected for further investigation. Predicted pathogenic variants were Sanger sequenced in available relatives when segregated with the clinical phenotype or to confirm de novo status (figure 1). Paternity and maternity in individuals with de novo mutations ( $\mathrm{Br}-2.1$, $\mathrm{Br}-4.2, \mathrm{Br}-5.1$ and $\mathrm{Br}-6.1)$ were confirmed with polymorphic markers. All variants that were considered pathogenic were confirmed through Sanger sequencing.

\section{In silico prediction effects of variants}

In silico analysis of variants was performed with open access software, such as SIFT, PolyPhen2, LRT, Mutation Taster and GERP + + algorithms. Variants were considered to be pathogenic by in silico analysis when three or more of these algorithms classified them as damaging.

\section{Statistical methods}

Rare variants burden test: two-tailed Fisher's exact test with significance level of $\mathrm{p}<0.05$ was applied to compare frequencies between total number of variants in the 50 proband Brazilian cohort and a WES control database of 107 Brazilian individuals affected by other monogenic disorders.

\section{RESULTS}

We performed WES in 50 NS probands without pathogenic variants in genes previously associated with NS. We were able to identify rare, predicted pathogenic variants in two novel genes through the analysis of genes in the RAS/MAPK pathway and the analysis of variants segregating in large families.

\section{SOS2: RAS/MAPK-related gene}

Through the analysis of genes belonging to the RAS/MAPK pathway according to the Kyoto Encyclopedia of Genes and Genomes (KEGG) database, we were able to identify SOS2 (MIM 601247; RefSeq accession number NM_006939.2) missense variants in four probands $(\mathrm{Br}-1.1, \mathrm{Br}-\overline{2} .1, \mathrm{Br}-7.1$ and $\mathrm{Br}-8.1)$ using WES data. Two of them were familial cases $(\mathrm{Br}-1.1$ and $\mathrm{Br}-7.1)$. SOS2 is homologous to SOS1, the second gene most frequently associated with NS. All these variants were confirmed by Sanger sequencing, but in family $\mathrm{Br}-8.1$. In silico analysis of the remaining three variants by SIFT, PolyPhen2, LRT, Mutation Taster and GERP ++ algorithms predicted pathogenicity in residues that are highly conserved across multiple species (table 1).

Studies of segregation or de novo status supported pathogenicity in one familial case (Br-F1) and in one isolated case (Br-2.1). In family Br-F7, there were no available relatives to confirm segregation and therefore it was excluded from further analysis. In total, predicted pathogenic variants in SOS2 were identified in two probands in the Brazilian cohort, reflecting a population frequency of $4 \%(2 / 50)$. When comparing the frequency of all identified SOS2 variants $(4 / 50)$ with the one of controls (3/107), there was no statistically significant difference $(p=0.2102)$. The two heterozygous missense variants, p.M267 K and p.T376S, found in SOS2 in our cohort are both located in the DH domain of the SOS2 protein and p.M267K affects the residue homologous to Met269 in SOS1, a mutation hotspot in NS. The variant p.T376S segregates with the phenotype in Br-F1, whereas p.M267K is de novo in Br-2.1. For comparison, two of the missense heterozygous variants, p.D952N and p.T449A, identified in three controls (all without NS phenotype) are predicted to be either tolerated or benign by in silico analysis. The third variant, p. $\mathrm{R} 334 \mathrm{H}$, is predicted to be probably damaging, with a low frequency in the 6500 exome database. Therefore, even though the burden test was not statistically different from the control population, we consider the variants p.M267K and p.T376S to be pathogenic mutations. Remarkably, the same variant of Br-F1 (p.T376S) was later identified segregating in a family from USA (US-F1; figure 1 and table 1).

\section{LZTR1: a gene not previously associated with the RAS/MAPK pathway}

The study of two large families allowed us to identify a candidate gene for NS not formally associated with the RAS/MAPK pathway. In each proband, WES analysis produced approximately 34000 raw variants in comparison with hg19 reference. After filtering with the aforementioned parameters, each proband still harboured approximately 280 rare, heterozygous 
$\mathrm{Br}-\mathrm{F} 1$

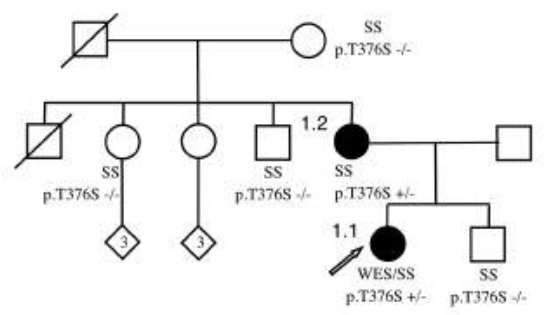

$\mathrm{Br}-\mathrm{F} 2$

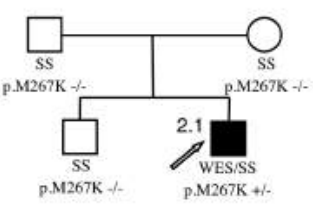

US-F1

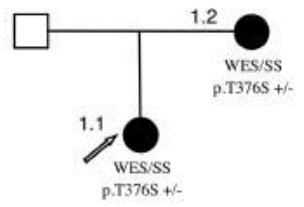

$\operatorname{sos} 2$

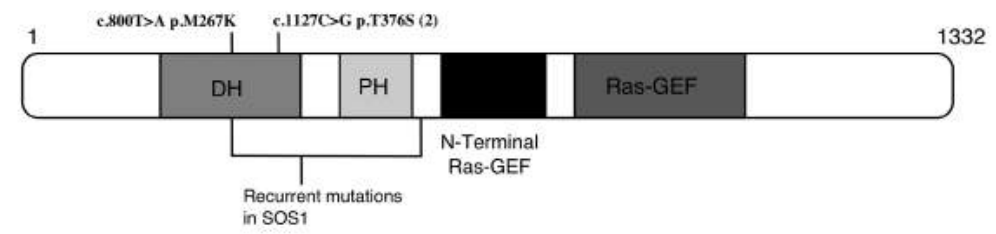

\section{LZTRI Families}

Br-F3

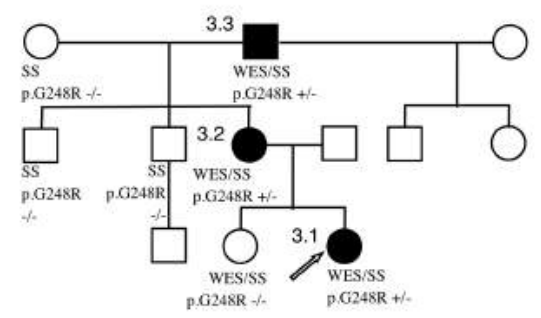

Br-F5

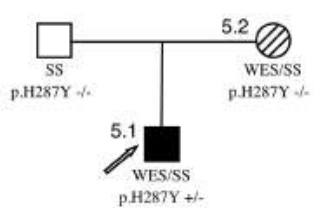

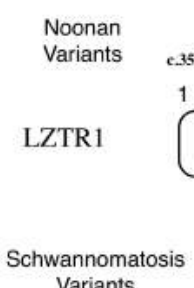

Variants
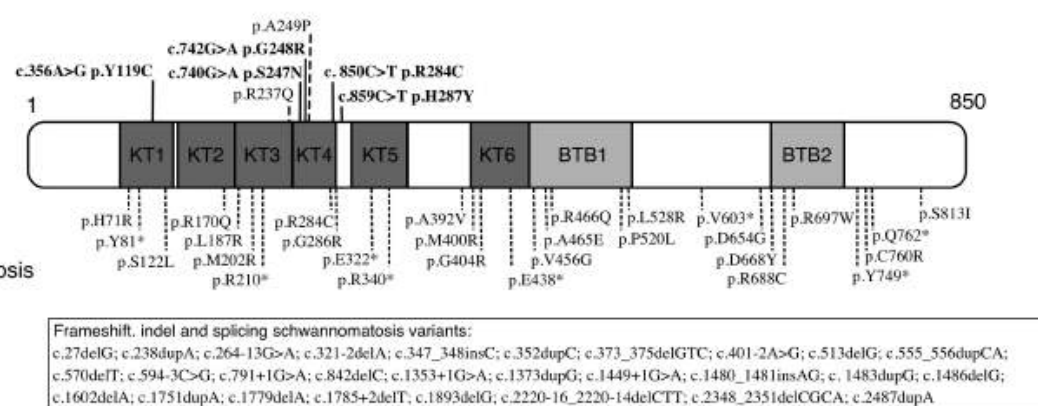

Figure 1 Pedigrees, variants and protein representation of LZTR1 and SOS2. Family pedigrees demonstrating segregation and/or de novo status of the LZTR1 and SOS2 variants. Br-5.2 has neurofibromatosis type 1 (NM_000267:c.2325G>T). Schematic representation of the proteins and their domains showing the mutated residues in the Noonan syndrome and schwannomatosis individuals. In bold: current study, non-bold: previous publications. +/-, heterozygous variant; $-I-$, homozygous reference; $\mathrm{DH}$, Dbl homology; GEF, guanine nucleotide exchanger factor; $\mathrm{PH}$, pleckstrin homology; SS, Sanger sequencing, WES, whole-exome sequencing.

missense variants. Including WES data from affected and unaffected relatives of these probands allowed decreasing the number of possibly pathogenic variants. Thus, in family Br-F3, the analysis of the proband, one unaffected and two affected relatives, identified 24 rare variants that segregated with the NS phenotype, while in family $\mathrm{Br}-\mathrm{F} 4$, with the proband, one unaffected and five affected relatives, only one rare variant was found (see online supplementary table S1). The only gene identified in Br-F4, LZTR1 (MIM 600574; RefSeq accession number NM_006767.3), was also present in the list of rare variants of
$\mathrm{Br}-\mathrm{F} 4$

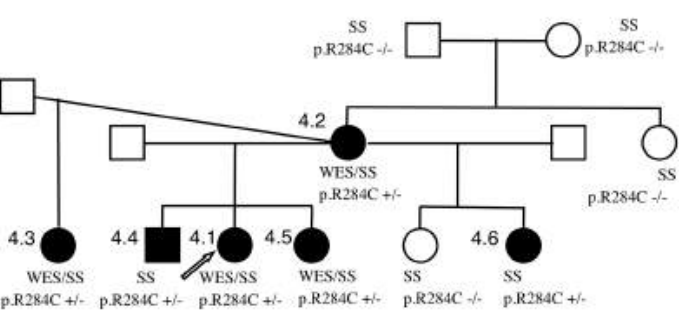

Br-F6

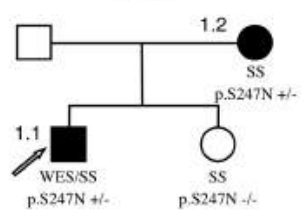

$\mathrm{Br}-\mathrm{F} 3$. Analysis of the remaining Brazilian cohort revealed rare variants in LZTR1 in four additional probands $\mathrm{Br}-5.1, \mathrm{Br}-6.1$, $\mathrm{Br}-7.1$ and $\mathrm{Br}-9.1)$. The variant in $\mathrm{Br}-9.1$ was considered nonpathogenic, because it was present in unaffected relatives, assuming full penetrance. In Br-F7, the LZTR1 variant had a weak in silico pathogenicity prediction and its segregation analysis was not possible because further relatives were not available. The four remaining missense variants (p.G248R, p. R284C, p.H287Y and p.Y119C) segregated according to the phenotype (Br-F3 and Br-F4) in the familial cases and/or were 


\section{Genotype-phenotype correlations}

confirmed to be de novo events (Br-4.2, Br-5.1 and Br-6.1) and in silico analysis predicted pathogenicity. To underscore the association of LZTR1 variants with NS, we performed a rare variant burden test by comparing their frequency in the Brazilian cohort (6/50) versus a control database of WES in 107 Brazilian individuals affected by other monogenic disorders $(1 / 107)$ and observed a highly significant enrichment $(p=0.0044 ; 2$-tailed Fisher's exact test). An additional fifth predicted pathogenic variant (p.S247N) segregating with the phenotype and with damaging in silico prediction was identified in a familial case from Poland (Po-F1; figure 1 and table 1). The five LZTR1 variants (p.G248R, p.R284C, p.H287Y, p.Y119C and p.S247N) are therefore predicted to cause NS.

The clinical findings of the individuals harbouring SOS2 and LZTR1 variants are described in tables 2 and 3, respectively. Their facial photographs are shown in figure 2.

\section{DISCUSSION}

A large cohort, with additional families from collaborative centres, and large pedigrees provided the basis to identify rare predicted pathogenic variants in two novel NS genes, SOS2 and LZTR1, expanding the currently known molecular spectrum of NS specifically and RASopathies in general.

\section{SOS2}

The two known human SOS homologues, SOS1 and SOS2, share $70 \%$ homology between them. To date, only mutations in SOS1 were found to be associated with human disorders, including NS and hereditary gingival fibromatosis type $1 .^{13}$

SOS1, a large multidomain protein, is a RAS-specific guanine nucleotide exchanger factor (GEF) that facilitates the conversion of RAS from the inactive GDP-bound to the active GTP-bound form. ${ }^{13}$ Pathogenic mutations in SOS1 are the second most common molecular cause of NS. The mainly missense mutations and small in-dels are non-randomly distributed across domains of the protein and were classified by Lepri et al ${ }^{14}$ in three distinct classes, based on the predicted role of affected residues and functional consequences derived from the nature of the amino acid change. The first class of mutations (class 1A), located in residues that participate in the interaction of the Dbl homology (DH) and Ras Exchange Motif (REM) domains, is predicted to promote conformational rearrangements of these regions that reduce the enzyme self-inhibition by impairing proper masking of the distal RAS binding site or by acting on the allosteric control of catalytic activity. Specifically, the residue Met269, responsible for $10 \%$ of total NS cases harbouring SOS1 mutations, interacts directly with residues of the REM domain implicated in RAS binding. The missense heterozygous variants found in SOS2 in our cohort (p.M267K and p.T376S) are located in the DH domain. The residue 267 in SOS2 is homologous to residue 269 in SOS1, providing further evidence to its pathogenic nature. Consequently, we hypothesise that mutations in SOS2 cause NS through a mechanism similar to that of SOS1, that is, gain-of-function mutations leading to enhanced signalling and upregulation of the RAS/MAPK pathway.

There is no strong genotype-phenotype correlation in NS. Nevertheless, individuals harbouring a SOS1 mutation usually present with typical NS craniofacial features and cardiac abnormalities, with pulmonary stenosis and septal defects being the most recurrent findings. However, there is a lower prevalence of short stature and cognitive deficits compared with PTPN11-positive individuals. Ectodermal involvement, including curly hair, sparse eyebrows, hyperkeratosis pilaris and

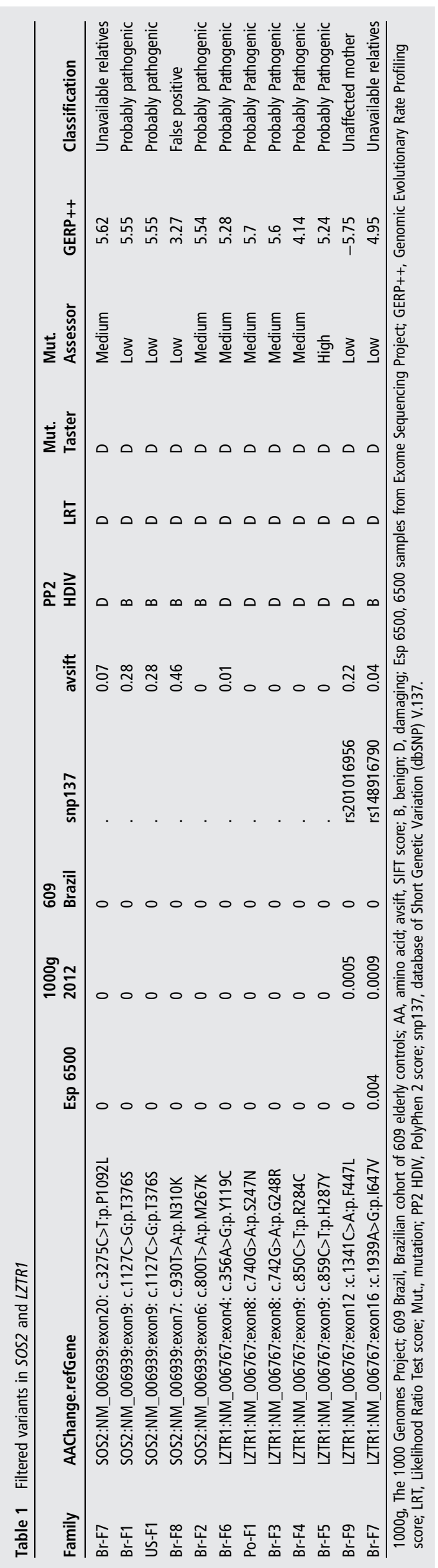


Table 2 Clinical findings in individuals with SOS2 variants

\begin{tabular}{|c|c|c|c|c|c|}
\hline \multirow[b]{2}{*}{ Clinical findings } & \multicolumn{2}{|l|}{ Brazil F1 } & \multirow{2}{*}{$\begin{array}{l}\text { Brazil F2 } \\
\text { Br-2.1 } \\
\text { Proband }\end{array}$} & \multicolumn{2}{|l|}{ USA F1 } \\
\hline & $\begin{array}{l}\text { Br-1.1 } \\
\text { Proband }\end{array}$ & $\begin{array}{l}\text { Br-1.2 } \\
\text { Mother }\end{array}$ & & $\begin{array}{l}\text { US-1.1 } \\
\text { Proband }\end{array}$ & $\begin{array}{l}\text { US-1.2 } \\
\text { Mother }\end{array}$ \\
\hline Sex & Female & Female & Male & Female & Female \\
\hline Age & 13 years 4 months & 51 years & 9 years & 2 years 2 months & 34 years \\
\hline \multicolumn{6}{|l|}{ Perinatal data } \\
\hline Gestational age & Term & & Term & Term & Term \\
\hline BW, g & 3745 & & 3585 & 3459 & \\
\hline Length, $\mathrm{cm}$ & 46 & & 50 & 50.8 & \\
\hline Typical facial features & + & + & + & + & + \\
\hline Current height & $135 \mathrm{~cm}$ (11 years 8 months) & $145 \mathrm{~cm}$ & $110.5 \mathrm{~cm}$ & $83.8 \mathrm{~cm}$ & \\
\hline Height SDS for WHO-standard & -1.8 & -2.8 & -3.9 & -0.3 & \\
\hline Height SDS for NS-standard & 0.8 & -0.5 & -1.4 & 2.7 & \\
\hline Short/webbed neck & + & + & + & + & + \\
\hline Pectus deformity & - & - & - & - & - \\
\hline Cardiac abnormality & AoCo & - & ASD/VSD & PVS & - \\
\hline \multicolumn{6}{|l|}{ GU abnormality } \\
\hline Cryptorchidism & NA & NA & + & NA & NA \\
\hline Renal abnormality & - & & - & $+{ }^{*}$ & \\
\hline Abnormal hemostasis & + & & + & & \\
\hline Prolonged APTT & + & & + & & \\
\hline Factor XI deficiency & - & & - & & \\
\hline Ophthalmological abnormality & + & & & - & \\
\hline Funduscopy & - & & & - & \\
\hline Prominent corneal nerves & + & & & - & \\
\hline Ectodermal findings & + & + & + & + & - \\
\hline Curly hair & + & + & + & + & - \\
\hline Sparse eyebrows & + & + & + & + & - \\
\hline Hyperkeratosis pilaris & + & + & + & - & - \\
\hline Ulerythema ophriogenes & + & + & + & - & - \\
\hline Tumours & - & - & - & - & - \\
\hline Developmental delay & - & - & + & + & - \\
\hline Learning disability & + & - & + & - & - \\
\hline Other findings & & & & Slow eruption of primary dentition & Chronic leg pain \\
\hline Mutation (NM_006939.2) & c.1127C>G; p.T376S & & c.800T>A; p.M267K & c.1127C>G; p.T376s & \\
\hline
\end{tabular}

${ }^{*}$ Mild/moderate left pelviectasis and proximal hydroureter.

AoCo, aorta coarctation; APTT, activated partial thromboplastin time; ASD, atrial septal defect; BW, birth weight; GU, genitourinary; NA, not applicable; NS, Noonan syndrome;

PVS, pulmonary valve stenosis; SDS, SD score; VSD, ventricular septal defect.

ulerythema ophryogenes, is a hallmark of SOS1 patients among NS. ${ }^{14} 15$ Similarly, our SOS2 cases showed an almost identical clinical phenotype with skin abnormalities, especially ulerythema ophryogenes, which was particularly evident in individual Br-2.1 (figure 2), typical NS facial features, and cardiac defects. In contrast, short stature and learning difficulties were frequent in our cohort. No tumours were observed (table 2). As the number of individuals in our cohort is relatively small, the phenotype in individuals harbouring SOS2 mutations will need to be refined through reports of additional SOS2-positive individuals. From this initial study however, ectodermal involvement seems to be a prominent clinical feature of SOS2 mutations.

\section{LZTR1}

LZTR1, leucine-zipper-like transcription regulator 1, encodes a protein member of the BTB-kelch superfamily. Its function is poorly known. It was initially described as a putative transcriptional regulator, ${ }^{16}$ and later it has been proposed that LZTR1 lacks a BACK domain and colocalises exclusively to the cytoplasmic surface of the Golgi network and not to actin, unlike most other BTB-kelch proteins. ${ }^{17}$
Our study indicates that rare variants in LZTR1 are responsible for NS. The missense heterozygous variants found in LZTR1 in our cohort (p.G248R, p.R284C, p.H287Y, p.Y119C and p.S247N) are localised in the kelch (KT) domains, especially KT4, and are predicted to be deleterious by in silico analysis. The only variant in LZTR1 identified in the 107 controls (p.P635L) is not within or near the KT domains. Another piece of evidence giving further support to the role of LZTR1 in NS phenotype comes from the study of Chen et al..$^{5}$ These authors performed WES in 27 NS individuals and two of them harboured rare LZTR1 variants (p.R237Q and p.A249P) in the kelch protein domains (figure 1). However, these variants were not considered responsible for the NS phenotype, since they considered LZTR1 as a gene already associated with a specific disorder, in their case, microdeletion $22 \mathrm{q} 11$. We believe that it is likely that these two variants in LZTR1 are responsible for the NS phenotype in both individuals from that study, resulting in a population frequency of $7.4 \%$ frequency $(2 / 27)$, similar to the $8 \%$ observed in the Brazilian cohort (4/50).

The association of LZTR1 with human diseases began with the $22 \mathrm{q} 11$ microdeletion syndrome, as this gene is localised within the $3 \mathrm{Mb}$ region that is most commonly deleted in the syndrome, but not in the $1.5 \mathrm{Mb}$ deletion that is present in 
Downloaded from http://jmg.bmj.com/ on July 16, 2015 - Published by group.bmj.com

\section{Genotype-phenotype correlations}

Table 3 Clinical findings in individuals with LZTR1 variants

\begin{tabular}{|c|c|c|c|c|c|c|c|c|c|}
\hline \multirow[b]{2}{*}{ Clinical findings } & \multicolumn{3}{|l|}{ Brazil F3 } & \multicolumn{6}{|l|}{ Brazil F4 } \\
\hline & $\begin{array}{l}\text { Br-3.1 } \\
\text { Proband }\end{array}$ & $\begin{array}{l}\text { Br-3.2 } \\
\text { Mother }\end{array}$ & $\begin{array}{l}\text { Br-3.3 } \\
\text { Grandfather }\end{array}$ & $\begin{array}{l}\text { Br-4.1 } \\
\text { Proband }\end{array}$ & $\begin{array}{l}\mathrm{Br}-4.2 \\
\text { Mother }\end{array}$ & $\begin{array}{l}\text { Br-4.3 } \\
\text { Half-sister }\end{array}$ & $\begin{array}{l}\text { Br-4.4 } \\
\text { Brother }\end{array}$ & $\begin{array}{l}\text { Br-4.5 } \\
\text { Sister }\end{array}$ & $\begin{array}{l}\text { Br-4.6 } \\
\text { Half-sister }\end{array}$ \\
\hline Sex & Female & Female & Male & Female & Female & Female & Male & Female & Female \\
\hline Age & 11 years 5 months & 45 years & 69 years & 14 years & 38 years & 16 years & 15 years & 12 years & $\begin{array}{l}3 \text { years } \\
6 \text { months }\end{array}$ \\
\hline \multicolumn{10}{|l|}{ Perinatal data } \\
\hline Gestational age & Term & & & Term & & & Term & Term & Term \\
\hline BW, g & 2270 & & & 2750 & & & 2850 & 2850 & 2790 \\
\hline Length, $\mathrm{cm}$ & 45 & & & & & & & 46 & 46 \\
\hline Typical facial features & + & + & + & + & + & + & + & + & + \\
\hline Current height & $131.5 \mathrm{~cm}$ & $147 \mathrm{~cm}$ & $156 \mathrm{~cm}$ & $146 \mathrm{~cm}$ & $151 \mathrm{~cm}$ & $158 \mathrm{~cm}$ & $153 \mathrm{~cm}$ & $\begin{array}{l}135 \mathrm{~cm} \\
\text { (11 years) }\end{array}$ & $79 \mathrm{~cm}$ (3 years) \\
\hline $\begin{array}{l}\text { Height SDS for } \\
\text { WHO-standard }\end{array}$ & -2.1 & -2.5 & -2.9 & -1.8 & -1.9 & -0.7 & -1.8 & -1.2 & -3.8 \\
\hline Height SDS for NS-standard & 0.4 & -0.1 & 0.2 & 1.7 & 0.5 & 2.6 & 1.6 & 1.3 & -1.0 \\
\hline Short/webbed neck & + & + & + & - & - & - & - & + & - \\
\hline Pectus deformity & + & + & + & + & - & - & - & - & - \\
\hline Cardiac abnormality & PVS/ASD & MVP & MVP & PVS & - & ND & - & - & - \\
\hline \multicolumn{10}{|l|}{ GU abnormality } \\
\hline Cryptorchidism & NA & NA & - & NA & & & - & NA & NA \\
\hline Renal abnormality & - & - & & - & & & - & & \\
\hline Abnormal hemostasis & - & - & + & + & - & & - & & ND \\
\hline Prolonged ATTP & & & & + & & & & & \\
\hline Factor XI deficiency & & & + & - & & & & & \\
\hline Ophthalmological abnormality & + & & & & & & & & \\
\hline Funduscopy & - & & & & & & & & \\
\hline Prominent corneal nerves & + & & & & & & & & \\
\hline Ectodermal findings & - & - & - & - & - & - & + & + & - \\
\hline Curly hair & - & - & - & - & - & - & + & + & - \\
\hline Sparse eyebrows & - & - & - & - & - & - & + & - & - \\
\hline Hyperkeratosis pilaris & - & - & - & - & - & - & + & - & - \\
\hline Ulerythema ophriogenes & - & - & - & - & - & - & - & - & - \\
\hline Tumours & - & - & - & - & - & - & - & - & - \\
\hline Developmental delay & - & - & - & - & - & - & - & - & - \\
\hline Learning disability & - & - & - & - & - & - & - & - & NA \\
\hline Other findings & $\begin{array}{l}\text { Lacrimal duct } \\
\text { obstruction }\end{array}$ & & & & Nevi & & Nevi & Hemangioma & \\
\hline Mutation (NM_006767.3) & c.742G>A; p.G248R & & & c. $850 \mathrm{C}>\mathrm{T}$; & p.R284C & & & & \\
\hline
\end{tabular}

\begin{tabular}{|c|c|c|c|c|}
\hline Clinical findings & $\begin{array}{l}\text { Brazil F5 } \\
\text { Br-5.1 } \\
\text { Proband }\end{array}$ & $\begin{array}{l}\text { Brazil F6 } \\
\text { Br-5.1 } \\
\text { Proband }\end{array}$ & $\begin{array}{l}\text { Poland F1 } \\
\text { Po-1.1 } \\
\text { Proband }\end{array}$ & $\begin{array}{l}\text { Po-1.2 } \\
\text { Mother }\end{array}$ \\
\hline Sex & Male & Female & Male & Female \\
\hline Age & 16 years 1 month & 30 years & 18 years & 53 years \\
\hline \multicolumn{5}{|l|}{ Perinatal data } \\
\hline Gestational age & 35 weeks & Term & Term & \\
\hline BW, g & 2130 & 3930 & 4000 & \\
\hline Length, $\mathrm{cm}$ & 47 & 52 & 53 & \\
\hline Typical facial features & + & + & + & + \\
\hline Current height, $\mathrm{cm}$ & 172.6 & 164 & 183 & 153 \\
\hline Height SDS for WHO-standard & 0.3 & 0.1 & 1.0 & -1.6 \\
\hline Height SDS for NS-standard & 3.9 & 3.2 & 3.9 & 0.9 \\
\hline Short/webbed neck & - & - & + & + \\
\hline Pectus deformity & - & - & + & - \\
\hline Cardiac abnormality & PVS/ASD & LVH & MVI & AoCo \\
\hline \multicolumn{5}{|l|}{ GU abnormality } \\
\hline Cryptorchidism & + & NA & - & \\
\hline Renal abnormality & - & - & - & - \\
\hline Abnormal hemostasis & + & - & - & - \\
\hline
\end{tabular}


Table 3 Continued

\begin{tabular}{|c|c|c|c|c|}
\hline Clinical findings & $\begin{array}{l}\text { Brazil F5 } \\
\text { Br-5.1 } \\
\text { Proband }\end{array}$ & $\begin{array}{l}\text { Brazil F6 } \\
\text { Br-5.1 } \\
\text { Proband }\end{array}$ & $\begin{array}{l}\text { Poland F1 } \\
\text { Po-1.1 } \\
\text { Proband }\end{array}$ & $\begin{array}{l}\text { Po-1.2 } \\
\text { Mother }\end{array}$ \\
\hline Prolonged APTT & + & & & \\
\hline Factor XI deficiency & - & & & \\
\hline Ophthalmological abnormality & + & - & - & Hyperopia \\
\hline Funduscopy & & - & - & - \\
\hline Prominent corneal nerves & + & & & \\
\hline Ectodermal findings & - & - & + & - \\
\hline Curly hair & - & - & + & - \\
\hline Sparse eyebrows & - & - & - & - \\
\hline Hyperkeratosis pilaris & - & - & - & - \\
\hline Ulerythema ophriogenes & - & - & - & - \\
\hline Tumours & - & - & - & $+{ }^{*}$ \\
\hline Developmental delay & + & - & + & - \\
\hline Learning disability & + & - & + & - \\
\hline Other findings & & Lymphedema, varicose veins & & \\
\hline Mutation (NM_006767.3) & c.859C>T; p.H287+ & c. $356 \mathrm{~A}>\mathrm{G} ; \mathrm{p} .+119 \mathrm{C}$ & c. $740 C>A ; p . S 247 N$ & \\
\hline
\end{tabular}

approximately $8 \%$ of the cases. The phenotype of these two most frequent deletions is usually indistinguishable. Thus, haploinsufficiency of LZTR1 does not seem critical to the $22 \mathrm{q} 11$ phenotype. $^{18}$

Somatic mutations with loss of heterozygosity in LZTR1 have been associated with glioblastoma multiforme, a malignant central nervous system tumour. ${ }^{19}$ It has been demonstrated that LZTR1 is an adaptor for CUL3 ubiquitin ligase complexes in a similar manner described for other BTB-KELCH proteins, including KBTBD7 that marks NF1 for degradation and consequently hyperactivates RAS/extracellular signal-regulated kinases (ERK) signalling. ${ }^{20}$ Moreover, several studies demonstrated that germline loss-of-function variants in LZTR1 predispose to an inherited disorder of multiple schwannomas in a familial cancer model. $^{21-24}$ LZTR1-related schwannomatosis tumourigenesis requires a germline mutation in LZTR1, a somatic neurofibromatosis type 2 (NF2) variant in cis, and loss of the other 22q allele (or at least a segment containing wild-type LZTR1 and NF2). ${ }^{22}$ Previously, the same pattern of tumour development has been found in schwannomatosis individuals harbouring germline mutations in SMARCB1. This disorder exhibits a clinical overlap with NF2, but in the latter, bilateral schwannoma of the vestibular nerve is pathognomonic. ${ }^{22}$ NF1 can also present with neurofibromas, a different type of Schwann cell tumours, ${ }^{25}$ and both disorders (NF1 and NF2) are caused by loss-of-function mutations in tumour suppressor genes, NF1 and NF2, respectively. Interestingly, KRAS, another gene of the RAS/MAPK pathway besides NF1, has also been implicated as responsible for a case of a NS individual presenting with schwannomatosis. ${ }^{26}$ Thus, it is possible that the dysregulation of this pathway contributes to the development of schwannomas.

The mechanism by which mutations in LZTR1 confer a NS phenotype is still obscure. Alike tumourigenesis, all genes responsible for RASopathies described thus far cause dysregulation of the RAS/MAPK pathway by increasing ERK signalling, either by gain-of-function mutations in RAS genes and RAS-GEFs, such as PTPN11 and SOS1, or by loss-of-function mutations in GTPase activating proteins, such as NF1. ${ }^{2}$ Similarly, it is fair to assume that missense heterozygous variants in LZTR1 may also lead to an enhanced signal flow through RAS/MAPK pathway. We can rule out haploinsufficiency as the mechanism of NS phenotype since it is not observed in $22 \mathrm{q} 11$ microdeletion syndrome and in the familial cases of schwannomatosis that harbour germline loss-of-function mutations. ${ }^{18}$ The gene variants in LZTR1 reported in schwannomatosis patients include frameshift (19/62) and nonsense (9/62), together with splicing (9/62) and missense (24/62) mutations scattered throughout the gene. ${ }^{21-24}$ There is no overlap with the variants found in our NS individuals, with the exception of p.R284C. As NS shows highly variable expressivity, it would be interesting to confirm whether the woman with schwannomatosis harbouring p.R284C reported by Paganini et $a l^{22}$ does not show NS features.

It has been demonstrated that the development of schwannomas requires loss of both functional LZTR1 alleles, which implies that it has a tumour suppressor function. In that sense if somatic mutations leading to complete loss of protein function are required for tumourigenesis, we could hypothesise that to develop a NS phenotype, germline loss of $>50 \%$ of protein function, in a dominant negative manner, would be required. The fact that the NS individual Po-1.2 from our study developed schwannomas in the right arm gives further support to the hypothesis that his germline variant in LZTR1 is more likely to be a loss-of-function mutation that would lead to the development of tumours when further somatic hits, possibly in NF2 for instance, are added. Unfortunately, material from the schwannoma from Po-1.2 individual was not available, preventing molecular testing. Another fact that corroborates the hypothesis that NS LZTR1 mutations have a negative effect on LZTR1 tumour suppressor function is that two of the variants identified in our cohort were also described in malignant tumour samples: p.G248R (glioma, large intestine carcinoma and melanoma) and p.R284C (endometrium carcinoma) in the catalogue of somatic mutations in cancer (COSMIC database, http://www.sanger.ac.uk/cosmic).

Nevertheless, functional studies are required to unravel the precise role of LZTR1 and whether this gene could be coupled with NF1 and NF2 as a tumour suppressor gene acting in the RAS/MAPK pathway, predisposing to both schwannomatosis and NS. 


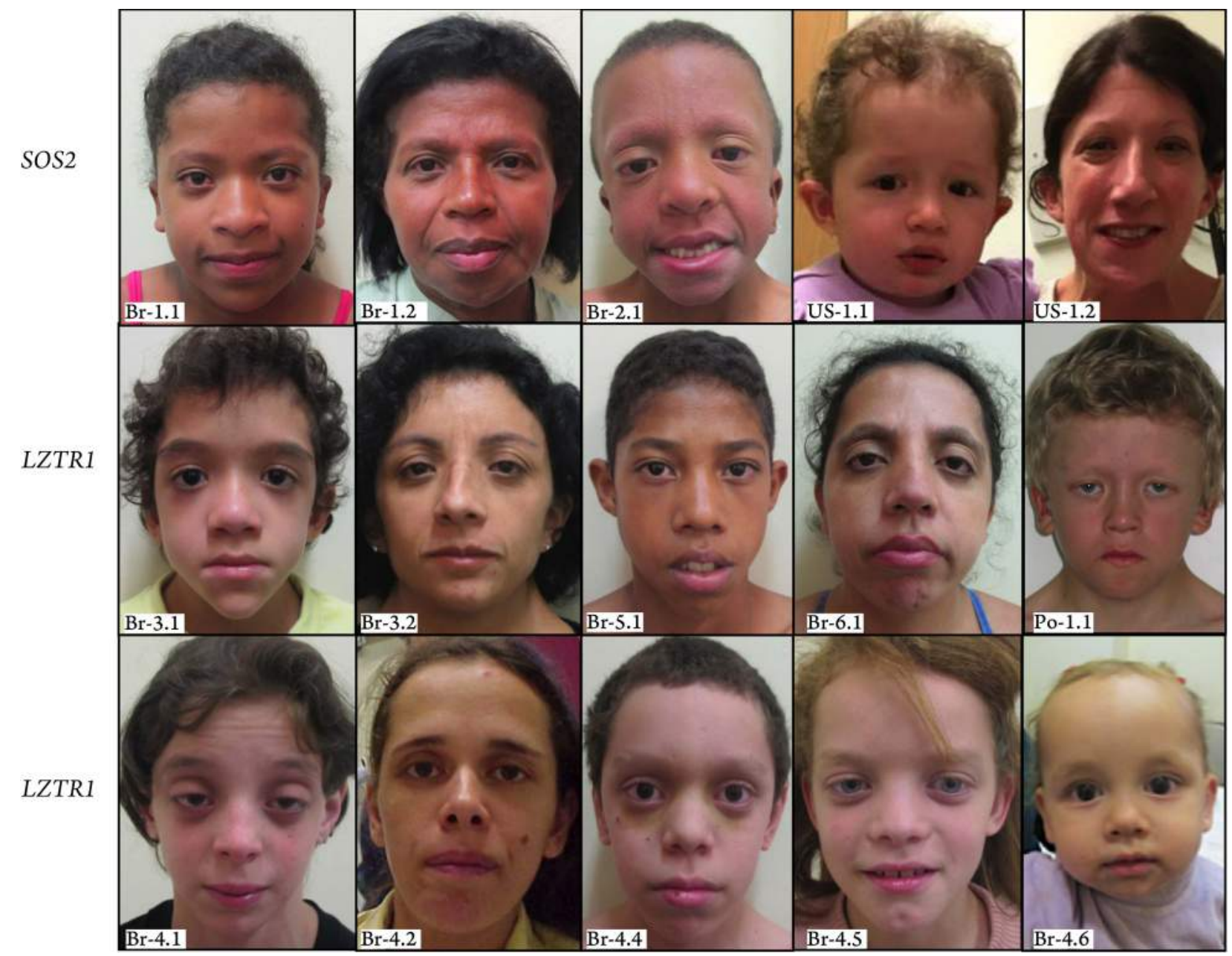

Figure 2 Photographs of individuals from different families with Noonan syndrome. Note typical facial features with downslanting palpebral fissures (US-1.1, $\mathrm{Br}-6.1)$, hypertelorism (Br-1.1, $\mathrm{Br}-3.1, \mathrm{Br}-4.5)$ and ptosis (Br-4.1) and short/webbed neck (Br-2.1, Po-1.1). In SOS2 patients there is marked ectodermal involvement (most pronounced in $\mathrm{Br}-2.1$ ).

The clinical findings in our probands harbouring LZTR1 mutations comprise typical facial features (figure 2) and cardiac abnormalities (mainly pulmonary stenosis) in all of them, with low frequency of short stature, ectodermal involvement and cognitive disabilities. It is possible that LZTR1 germline mutations causing NS also pose a higher risk for schwannomas development in this population, since one of our NS individual (Po-1.2) developed multiple schwannomas in the right arm (table 3). It remains to be elucidated whether this predisposition could also include malignant tumours, since somatic LZTR1 mutations have been associated both with solid and hematological tumours (COSMIC database).

Further reports are necessary to delineate the complete phenotype in this group of individuals. The first impression is that the clinical phenotype is similar to PTPN11 positive individuals, ${ }^{9}$ with the exception of short stature, which was not frequent in our cohort.

In summary, we performed WES in a cohort of NS individuals from different populations, including large familial cases, leading to the identification of two novel genes associated with NS. One of them, LZTR1, is not known to belong to the RAS/MAPK pathway. Mutations in SOS2 and LZTR1 were found in approximately $3 \%$ of all NS individuals. Still, $15 \%-20 \%$ of the molecular basis of NS remains unexplained. Copy number variations encompassing the locus of one of the known genes associated with NS have been rarely reported ${ }^{27}$ and could account for a very small amount of the NS unknown aetiology. Alternatively, it remains to be investigated whether digenic inheritance could also play a role in NS aetiology, in which variants in two or more genes of the RAS/MAPK pathway would be required to overcome a threshold of increased ERK signalling, and consequently manifestation of the NS phenotype. In the latter case, variants that are present in control populations, and which are currently not individually considered as causative, may contribute to the disease when jointly present in a single patient.

\section{Author affiliations}

${ }^{1}$ Unidade de Genética, Instituto da Criança, Hospital das Clínicas da Faculdade de Medicina da Universidade de São Paulo, São Paulo, São Paulo, Brazil

${ }^{2}$ Centro de Pesquisa sobre o Genoma Humano e Células-Tronco, Instituto de Biociências da Universidade de São Paulo, São Paulo, São Paulo, Brazil

${ }^{3}$ Department of Medical Genetics, Institute of Mother and Child, Warsaw, Poland ${ }^{4}$ Division of Genetics and Genomics, Department of Medicine, Boston Children's Hospital, Boston, Massachusetts, USA

${ }^{5}$ Department of Child Neurology, Medical University of Silesia, Katowice, Poland ${ }^{6}$ Department of Human Genetics, McGill University, Montreal, Quebec, Canada ${ }^{7}$ Nemours Children's Hospital Orlando, Orlando, Florida, USA

${ }^{8}$ Departamento de Endocrinologia, Hospital das Clínicas da Faculdade de Medicina da Universidade de São Paulo, São Paulo, São Paulo, Brazil

${ }^{9}$ Instituto de Cardiologia, Hospital das Clínicas da Faculdade de Medicina da Universidade de São Paulo, São Paulo, São Paulo, Brazil

Acknowledgements The authors would like to thank the families for their cooperation. 
Contributors GLY, MA, MG, MB, SF, MSN, MZ, OB, JM, MRP-B and DRB performed the sequencing studies and bioinformatics analysis. $M G, C H, J P, A A, I C$, $A C M, O B, A A L J, A C P, C A K$ and $D R B$ contributed clinical samples and information. GLY, MG, OB, JM, MRP-B and DRB wrote and edited the manuscript.

Funding The Brazilian group was financially supported by FAPESP 2011/17299-3, CEPID/FAPESP 98/14254-2 and CNPq 302605/2013-4. The Polish group was financially supported by the National Science Centre grants: UMO-2013/09/B/NZ2/ 03164 and UMO-2011/01/D/NZ5/01347.

Competing interests None.

Patient consent Obtained.

Ethics approval Ethics Committee of Hospital das Clínicas da Faculdade de Medicina da Universidade de São Paulo/Institute of Mother and Child Warsaw Ethics Committee.

Provenance and peer review Not commissioned; externally peer reviewed.

\section{REFERENCES}

1 Romano AA, Allanson JE, Dahlgren J, Gelb BD, Hall B, Pierpont ME, Roberts AE, Robinson W, Takemoto CM, Noonan JA. Noonan syndrome: clinical features, diagnosis, and management guidelines. Pediatrics 2010;12:746-59.

2 Tartaglia M, Zampino G, Gelb BD. Noonan syndrome: clinical aspects and molecular pathogenesis. Mol Syndromol 2010;1:2-26.

3 Tidyman WE, Rauen KA. The RASopathies: developmental syndromes of Ras/MAPK pathway dysregulation. Curr Opin Genet Dev 2009;19:230-6.

4 Aoki Y, Niihori T, Banjo T, Okamoto N, Mizuno S, Kurosawa K, Ogata T, Takada F, Yano M, Ando T, Hoshika T, Barnett C, Ohashi H, Kawame H, Hasegawa T, Okutani T, Nagashima T, Hasegawa S, Funayama R, Nagashima T, Nakayama K, Inoue S, Watanabe Y, Ogura T, Matsubara Y. Gain-of-function mutations in RIT1 cause Noonan syndrome, a RAS/MAPK pathway syndrome. Am J Hum Genet 2013;93:173-80.

5 Chen PC, Yin J, Yu HW, Yuan T, Fernandez M, Yung CK, Trinh QM, Peltekova VD, Reid JG, Tworog-Dube E, Morgan MB, Muzny DM, Stein L, McPherson JD, Roberts AE, Gibbs RA, Neel BG, Kucherlapati R. Next-generation sequencing identifies rare variants associated with Noonan syndrome. Proc Natl Acad Sci USA 2014:111:11473-8

6 Bertola DR, Pereira AC, Albano LM, De Oliveira PS, Kim CA, Krieger JE. PTPN11 gene analysis in 74 Brazilian patients with Noonan syndrome or Noonan-like phenotype. Genet Test 2006;10:186-91.

7 Brasil AS, Pereira AC, Wanderley LT, Kim CA, Malaquias AC, Jorge AA, Krieger JE, Bertola DR. PTPN11 and KRAS gene analysis in patients with Noonan and Noonan-like syndromes. Genet Test Mol Biomarkers 2010;14:425-32.

8 van der Burgt I, Berends E, Lommen E, van Beersum S, Hamel B, Mariman E. Clinical and molecular studies in a large Dutch family with Noonan syndrome. Am J Med Genet 1994;53:187-91.

9 Bertola DR, Yamamoto GL, Almeida TF, Buscarilli M, Jorge AA, Malaquias AC, Kim CA, Takahashi VN, Passos-Bueno MR, Pereira AC. Further evidence of the importance of RIT1 in Noonan syndrome. Am J Med Genet A 2014;164A:2952-7.

10 Li H, Durbin R. Fast and accurate short read alignment with Burrows-Wheeler transform. Bioinformatics 2009;25:1754-60.

11 McKenna A, Hanna M, Banks E, Sivachenko A, Cibulskis K, Kernytsky A, Garimella K, Altshuler D, Gabriel S, Daly M, DePristo MA. The Genome Analysis Toolkit: a MapReduce framework for analyzing next-generation DNA sequencing data. Genome Research 2010;20:1297-303.

12 Wang K, Li M, Hakonarson H. ANNOVAR: functional annotation of genetic variants from high-throughput sequencing data. Nucleic Acids Research 2010;38:e164.

13 Pierre S, Bats AS, Coumoul X. Understanding SOS (Son of Sevenless). Biochem Pharmacol 2011:82:1049-56.
14 Lepri F, De Luca A, Stella L, Rossi C, Baldassarre G, Pantaleoni F, Cordeddu V, Williams BJ, Dentici ML, Caputo V, Venanzi S, Bonaguro M, Kavamura I, Faienza MF, Pilotta A, Stanzial F, Faravelli F, Gabrielli O, Marino B, Neri G, Silengo MC, Ferrero GB, Torrrente I, Selicorni A, Mazzanti L, Digilio MC, Zampino G, Dallapiccola B, Gelb BD, Tartaglia M. SOS1 mutations in Noonan syndrome: molecular spectrum, structural insights on pathogenic effects, and genotype-phenotype correlations. Hum Mutat 2011;32:760-72.

15 Zenker M, Horn D, Wieczorek D, Allanson J, Pauli S, van der Burgt I, Doerr HG, Gaspar H, Hofbeck M, Gillessen-Kaesbach G, Koch A, Meinecke P, Mundlos S, Nowka A, Rauch A, Reif S, von Schnakenburg C, Seidel H, Wehner LE, Zweier C, Bauhuber S, Matejas V, Kratz CP, Thomas C, Kutsche K. SOS1 is the second most common Noonan gene but plays no major role in cardio-facio-cutaneous syndrome. J Med Genet 2007:44:651-6.

16 Kurahashi H, Akagi K, Inazawa J, Ohta T, Niikawa N, Kayatani F, Sano T, Okada S, Nishisho I. Isolation and characterization of a novel gene deleted in DiGeorge syndrome. Hum Mol Genet 1995;4:541-9.

17 Nacak TG, Leptien K, Fellner D, Augustin HG, Kroll J. The BTB-kelch protein LZTR-1 is a novel Golgi protein that is degraded upon induction of apoptosis. J Biol Chem 2006:281:5065-71.

18 Kobrynski L, Sullivan KE. Velocardiofacial syndrome, DiGeorge syndrome: the chromosome 22q11.2 deletion syndromes. Lancet 2007;370:1443-52.

19 Frattini V, Trifonov V, Chan JM, Castano A, Lia M, Abate F, Keir ST, Ji AX, Zoppoli P, Niola F, Danussi C, Dolgalev I, Porrati P, Pellegatta S, Heguy A, Gupta G, Pisapia DJ, Canoll P, Bruce JN, McLendon RE, Yan H, Aldape K, Finocchiaro G, Mikkelsen $T$, Privé $G G$, Bigner DD, Lasorella $A$, Rabadan $R$, lavarone $A$. The integrated landscape of driver genomic alterations in glioblastoma. Nat Genet 2013:45:1141-9.

20 Hollstei PE, Cichowski K. Identifying the Ubiquitin Ligase complex that regulates the NF1 tumor suppressor and Ras. Cancer Discov 2013;3:880-93.

21 Piotrowski A, Xie J, Liu YF, Poplawski AB, Gomes AR, Madanecki P, Fu C, Crowley MR, Crossman DK, Armstrong L, Babovic-Vuksanovic D, Bergner A, Blakeley JO, Blumenthal AL, Daniels MS, Feit H, Gardner K, Hurst S, Kobelka C, Lee C, Nagy R, Rauen KA, Slopis JM, Suwannarat P, Westman JA, Zanko A, Korf BR, Messiaen LM. Germline loss-of-function mutations in LZTR1 predispose to an inherited disorder of multiple schwannomas. Nat Genet 2014;46:182-7.

22 Paganini I, Chang VY, Capone GL, Vitte J, Benelli M, Barbetti L, Sestini R, Trevisson E, Hulsebos TJ, Giovannini M, Nelson SF, Papi L. Expanding the mutational spectrum of LZTR1 in schwannomatosis. Eur J Hum Genet 2014. [Epub ahead of print]

23 Hutter S, Piro RM, Reuss DE, Hovestadt V, Sahm F, Farschtschi S, Kehrer-Sawatzki H, Wolf S, Lichter P, von Deimling A, Schuhmann MU, Pfister SM, Jones DT, Mautner VF. Whole exome sequencing reveals that the majority of schwannomatosis cases remain unexplained after excluding SMARCB1 and LZTR1 germline variants. Acta Neuropathol 2014;128:449-52.

24 Smith MJ, Isidor B, Beetz C, Williams SG, Bhaskar SS, Richer W, O'Sullivan J, Anderson B, Daly SB, Urquhart JE, Fryer A, Rustad CF, Mills SJ, Samii A, du Plessis D, Halliday D, Barbarot S, Bourdeaut F, Newman WG, Evans DG. Mutations in LZTR1 add to the complex heterogeneity of schwannomatosis. Neurology 2015:84:141-7.

25 Carroll SL. Molecular mechanisms promoting the pathogenesis of Schwann cell neoplasms. Acta Neuropathol 2012;123:321-48.

26 Bertola DR, Pereira AC, Brasil AC, Suzuki L, Leite C, Falzoni R, Tannuri U, Poplawsk $A B$, Janowski KM, Kim CA, Messiaen LM. Multiple, diffuse schwannomas in a RASopathy phenotype patient with germline KRAS mutation: a causal relationship? Clin Genet 2012;81:595-7.

27 Chen JL, Zhu X, Zhao TL, Wang J, Yang YF, Tan ZP. Rare copy number variations containing genes involved in RASopathies: deletion of $\mathrm{SHOC2}$ and duplication of PTPN11. Mol Cytogenet 2014;7:28 


\section{Rare variants in SOS2 and LZTR1 are associated with Noonan syndrome}

Guilherme Lopes Yamamoto, Meire Aguena, Monika Gos, Christina Hung, Jacek Pilch, Somayyeh Fahiminiya, Anna Abramowicz, Ingrid Cristian, Michelle Buscarilli, Michel Satya Naslavsky, Alexsandra C Malaquias, Mayana Zatz, Olaf Bodamer, Jacek Majewski, Alexander A L Jorge, Alexandre C Pereira, Chong Ae Kim, Maria Rita Passos-Bueno and Débora Romeo Bertola

J Med Genet 2015 52: 413-421 originally published online March 20, 2015

doi: 10.1136/jmedgenet-2015-103018

Updated information and services can be found at:

http://jmg.bmj.com/content/52/6/413

\section{These include:}

Supplementary Material

References

Email alerting service
Supplementary material can be found at:

http://jmg.bmj.com/content/suppl/2015/03/20/jmedgenet-2015-103018 .DC1.html

This article cites 26 articles, 8 of which you can access for free at: http://jmg.bmj.com/content/52/6/413\#BIBL

Receive free email alerts when new articles cite this article. Sign up in the box at the top right corner of the online article.

$\begin{array}{cc}\text { Topic } & \text { Articles on similar topics can be found in the following collections } \\ \text { Collections } & \text { Editor's choice (99) } \\ \text { Connective tissue disease (90) } \\ \text { Genetic screening / counselling (836) }\end{array}$

\section{Notes}

To request permissions go to:

http://group.bmj.com/group/rights-licensing/permissions

To order reprints go to:

http://journals.bmj.com/cgi/reprintform

To subscribe to BMJ go to:

http://group.bmj.com/subscribe/ 


\title{
Schinzel-Giedion Syndrome in Two Brazilian Patients: Report of a Novel Mutation in SETBP1 and Literature Review of the Clinical Features
}

\author{
Ellaine Carvalho, ${ }^{1 *}$ Rachel Honjo, ${ }^{1}$ Monize Magalhães, ${ }^{2}$ Guilherme Yamamoto, ${ }^{1,2}$ Katia Rocha, ${ }^{2}$ \\ Michel Naslavsky, ${ }^{2}$ Mayana Zatz, ${ }^{2}$ Maria Rita Passos-Bueno, ${ }^{2}$ Chong Kim, ${ }^{1}$ and Debora Bertola ${ }^{1,2}$ \\ ${ }^{1}$ Genetics Unit, Instituto da Criança, Hospital das Clínicas, Faculdade de Medicina da Universidade de São Paulo, Sao Paulo, Brazil \\ ${ }^{2}$ Centro de Estudos do Genoma Humano, Departamento de Biologia, Instituto de Biociências, Universidade de São Paulo, Sao Paulo, \\ Brazil
}

Manuscript Received: 12 January 2014; Manuscript Accepted: 29 August 2014

Schinzel-Giedion syndrome is a rare autosomal dominant disorder comprising postnatal growth failure, profound developmental delay, seizures, facial dysmorphisms, genitourinary, skeletal, neurological, and cardiac defects. It was recently revealed that Schinzel-Giedion syndrome is caused by de novo mutations in SETBP1, but there are few reports of this syndrome with molecular confirmation. We describe two unrelated Brazilian patients with Schinzel-Giedion syndrome, one of them carrying a novel mutation. We also present a review of clinical manifestations of the syndrome, comparing our cases to patients reported in literature emphasizing the importance of the facial gestalt associated with neurological involvement for diagnostic suspicion of this syndrome. $\odot 2015$ Wiley Periodicals, Inc.

Key words: Schinzel-Giedion syndrome; clinical features; facial gestalt; SETBP1

\section{INTRODUCTION}

Schinzel-Giedion syndrome (SGS) was first described in 1978 in two siblings who presented facial dysmorphisms, renal, and cardiac defects [Schinzel and Giedion, 1978]. This syndrome is recognized by typical craniofacial features (wide fontanels, coarse facies with high protruding forehead, orbital hypertelorism, infraorbital grooves, midface retraction, short upturned nose, and low-set ears) and multiple congenital malformations (genitourinary, skeletal, neurological, and cardiac defects), associated with growth failure, seizures, profound developmental delay, and a propensity to develop neuroectodermal tumors. Recurrent infections and refractory seizures are the major difficulties in the clinical management of these patients. Most affected individuals die before the age of two from respiratory failure or infections [Schinzel and Giedion, 1978; Al-Gazali et al., 1990; Hoischen et al., 2010]. To date, more than 70 cases have been reported in the literature [Schinzel and Giedion, 1978; Donnai and Harris, 1979; Kelley et al., 1982; Al-Gazali et al., 1990; Pul et al., 1990; Maclennan et al., 1991; Herman et al., 1993; Robin et al., 1993;
How to Cite this Article:

Carvalho E, Honjo R, Magalhães M,

Yamamoto G, Rocha K, Naslavsky M, Zatz

M, Passos-Bueno MR, Kim C, Bertola D.

2015. Schinzel-Giedion Syndrome in two

Brazilian patients: Report of a novel

mutation in SETBP1 and literature review of the clinical features.

Am J Med Genet Part A 167A:1039-1046.

Verloes et al., 1993; Alavi et al., 1994; Labrune et al., 1994; Rodriguez et al., 1994; Santos et al., 1994; Antich et al., 1995; Okamoto et al., 1995; Culic et al., 1996; Elliott et al., 1996; Ozkinay et al., 1996; McPherson et al., 1998; Alembik et al., 1999; Rittinger et al., 1999; Shah et al., 1999; Kondoh et al., 2001; Touge et al., 2001; Cooke et al., 2002; Minn et al., 2002; Grosso et al., 2003; Manouvrier-Hanu, 2003; Sandri et al., 2003; Albano et al., 2004; Matsumoto et al., 2005; Beschorner et al., 2007; Al-Mudaffer et al., 2008; Lehman et al., 2008; Sharma and Gonzales, 2009; Hoischen et al., 2010; Suphapeetiporn et al., 2011; Lestner et al., 2012; Watanabe et al., 2012; Ko et al., 2013; Lach and Arredondo, 2013].

Prior to the determination of SGS pathogenesis, the diagnosis of the disease was based on clinical features only. Lehman et al. [2008] have proposed clinical diagnostic criteria that yielded

Conflict of interest: none

${ }^{*}$ Correspondence to:

Ellaine Dóris Fernandes Carvalho, MD, Genetics Unit, Instituto da Criança, Hospital das Clínicas, FMUSP, Avenida Doutor Enéas de Carvalho Aguiar, $647-7^{\circ}$ andar, Cerqueira César, São Paulo, Brasil.

E-mail: ellainecarvalho@hotmail.com

Article first published online in Wiley Online Library

(wileyonlinelibrary.com): 7 February 2015

DOI 10.1002/ajmg.a.36789 
$100 \%$ sensitivity for the previously reported cases, based on the presence of development delay and facial phenotype (prominent forehead, midface retraction, short and upturned nose) plus either hydronephrosis or two of the typical skeletal abnormalities (sclerotic skull base, wide occipital synchondrosis, increased cortical density or thickness, and broad ribs) [Lehman et al., 2008].

It was recently revealed that SGS is caused by de novo heterozygous mutations in SETBP1, although the first description suggested an autosomal recessive mode of inheritance [Schinzel and Giedion, 1978; Donnai and Harris, 1979; Pul et al., 1990; Alavi et al., 1994 Antich at al., 1995]. This gene, located on chromosome 18q21.1, is ubiquitously expressed and its function is not yet fully elucidated. It encodes an oncogenebinding protein and binds to SET domains that are involved in methylation of lysine residues on histone tails [Hoischen et al., 2010]. All mutations described to date are located exclusively in the exon 4 of SETBP1, outside of the SET interacting domain and they do not affect the DNA binding domains of the SET-binding protein (Fig. 1) [Hoischen et al., 2010; Suphapeetiporn et al., 2011; Lestner et al., 2012; Ko et al., 2013]. Although the precise mechanism of how these mutations cause the phenotype is currently unknown, Hoischen et al. [2010] suggested that these mutations could exert a gain of function or a dominantnegative effect, since the patients presenting a partial chromosome 18q deletions, including SETBP1, do not present an SGS phenotype.

The reported recurrence of SGS in siblings [Schinzel and Giedion, 1978; Antich et al., 1995] could be attributed to gonadal mosaicism [Hoischen et al., 2010]. Since the description of the mutations responsible for SGS in 2010, only 17 patients had been tested for mutations in SETBP1 and confirmation of the diagnosis was possible in 16 of them [Hoischen et al., 2010; Suphapeetiporn et al., 2011; Lestner et al., 2012; Ko et al., 2013].

In this study, we report on two unrelated Brazilian patients with SGS confirmed by molecular analysis, one of them with a mutation not previously described. We also present a review of clinical manifestations of SGS and compare our patients with those reported in literature.

\section{CLINICAL REPORTS}

\section{Patient 1}

Patient 1 is an 8 -month-old male infant who is the first child of a nonconsanguineous and healthy couple. There was no family history of congenital abnormalities. Two prenatal ultrasound exams showed bilateral hydronephrosis. Except for the fetal abnormality, the pregnancy was uneventful. The patient was born at term by elective cesarean because of breech presentation. His BW was $2920 \mathrm{~g}$ (25th-50th centile) and BL $43 \mathrm{~cm}$ (<3rd centile); OFC was not available. Apgar scores were 7 and 9 at 1 and $5 \mathrm{~min}$, respectively. At birth, craniofacial and genital anomalies were noted. At 1 month of age, the physical examination disclosed: failure to thrive, microcephaly with large anterior fontanels, protruding forehead with midface retraction, orbital hypertelorism, upslanting palpebral fissures, infraorbital grooves, small upturned nose, retrognathia, anteriorly folded earlobes with normal ear implantation, dorsal hypertrichosis, protruding abdomen, bilateral clinodactyly of the fifth fingers, transitional palmar creases, talipes equinovarus, small testes, and perineal hypospadias. The patient developed respiratory distress and poor feeding during the first days of life. He presented seizures since the first month and severe developmental delay was identified in the follow-up at 8 months of age. This was the last time that the patient was evaluated at our service and no further information was obtained. Figure 2 shows the patient at ages 1 month and 8 months, respectively.

An abdominal ultrasound confirmed bilateral hydronephrosis and radiologic studies showed wormian bones, occipital synchondrosis, sclerotic skull base (Fig. 2), bell-shaped chest with broad ribs, hypoplasia of iliac bones, widening of the pubic symphysis, and widening of distal femoral metaphyses. Brain CT scan revealed bilateral ventriculomegaly. Echocardiogram and G-banded karyotype were normal.

\section{Patient 2}

Patient 2 is a 3-year-old female infant, the first and only child of nonconsanguineous parents with no family history of congenital abnormalities. The mother has been previously diagnosed with hypothyroidism and used levothyroxine during pregnancy. Prenatal

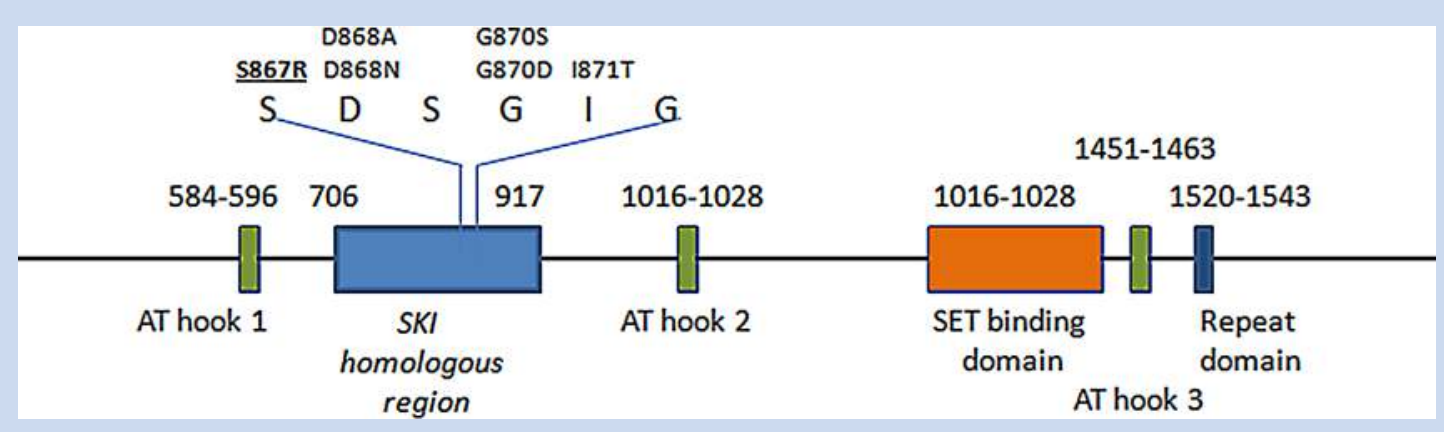

FIG. 1. Known and predicted protein domains of SETBP1 and the mutations clustered in SKI homologous region observed in 18 individuals with Schinzel-Giedion syndrome. It is represented in bold and underlined the novel mutation found in our Patient 2. Modified from: Hoischen et al. Nat Genet. 42(6):483-5http://wileyonlinelibrary.com/journal/ajmga]. 


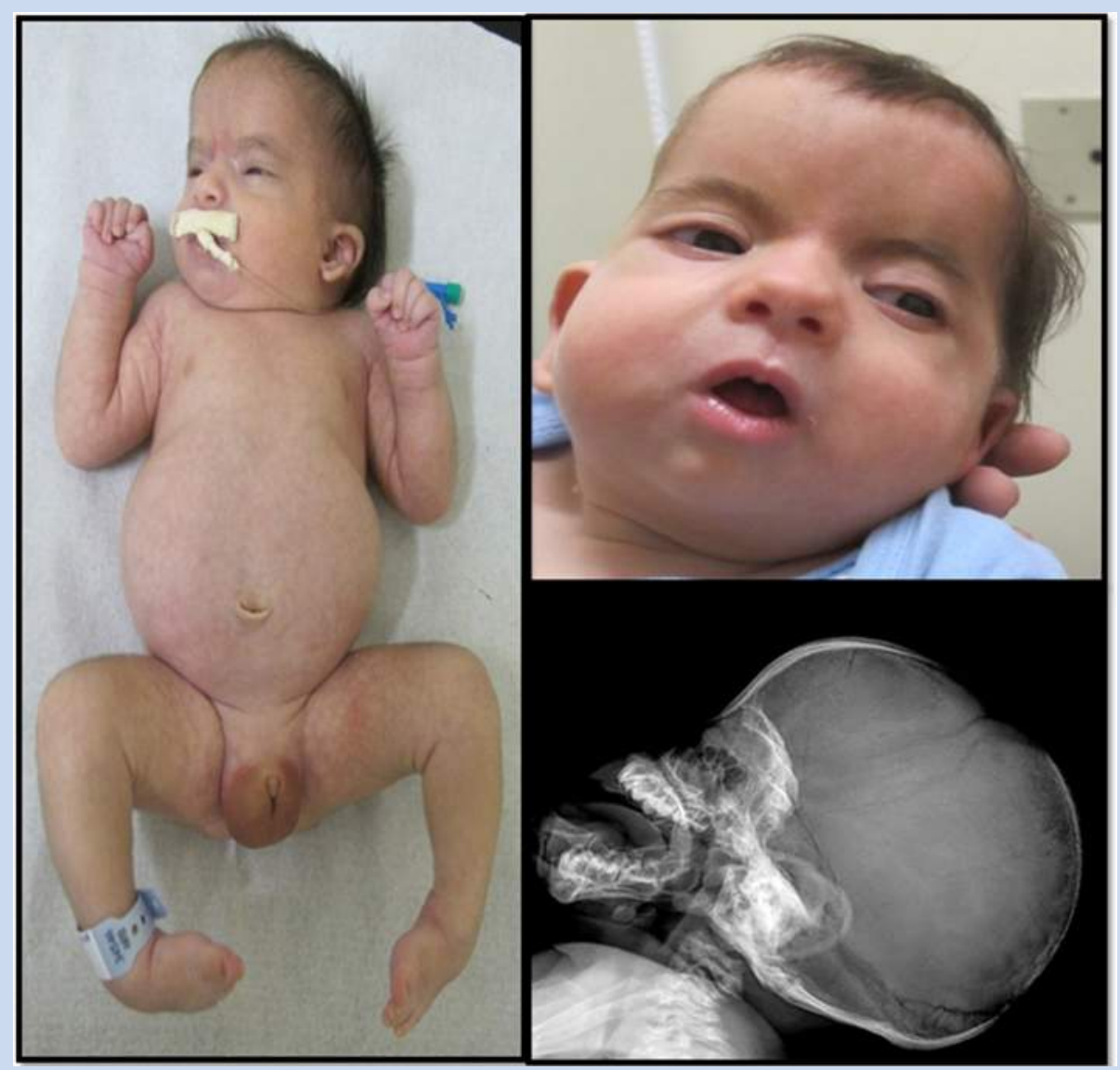

FIG. 2. Patient 1: typical facial features (at 1 and 8 months of age in the left and right, respectively), short neck, protruding abdomen, ambiguous genitalia and talipes. Lateral skull radiograph showing: large anterior fontanels, wormian bones, occipital synchondrosis, and sclerotic and steep base of the skull.

ultrasounds were normal. She was born at term, by cesarean, with a BW of $3185 \mathrm{~g}$ (25th-50th centile), BL of $49 \mathrm{~cm}$ (50-75th centile), and OFC of $34 \mathrm{~cm}$ (50th-75th centile). Apgar scores were 9 and 10 at 1 and $5 \mathrm{~min}$, respectively. At birth, the patient had transient hypothyroidism, poor feeding, and congenital dislocation of the left hip was confirmed by ultrasound. She evolved with severe neuropsychomotor delay and seizures beginning at five months of age, which were initially successfully controlled with anticonvulsant medication. Physical examination at 23 months of age disclosed normal growth parameters, midface retraction, upslanting palpebral fissures, synophrys, thick eyebrows, high nasal bridge, bulbous nose with anteverted nares, retrognathia, simplified and prominent ears, hirsutism, elongated fingers with proximally implanted thumbs, hypoplastic toenails, and clitoral hypertrophy. In the follow-up at 3 years old, her milestones continued severely delayed, despite of physiotherapy and the seizures were refractory to the medications. Additionally, reduced visual acuity with optic nerve pallor, alacrimia, and delayed eruption of the deciduous teeth were also disclosed. Urinary tract ultrasound, echocardiogram, and brain evoked response audiometry were normal. Xrays showed diffuse osteopenia, gracile long bones, left femur with valgus deformity, and vertical acetabulum. Brain MRI revealed reduction of the white matter volume and delayed myelination for age. G-banded karyotype and array-CGH were normal.

The two patients presented here shared the facial gestalt of SGS, the first one with the complementary typical features described in the syndrome and the second one, lacking the frequent genital and skeletal abnormalities. Consequently, molecular analysis of SETBP1 was performed in both individuals.

\section{MATERIALS AND METHODS}

The patients here presented were enrolled in this study, after parental informed consent was obtained. Genomic DNA from peripheral blood was subjected to molecular analysis using specific primers (5'-AGCCGTGCCTTCCAACTTTCAG-3'; 5'CGGTGGGAGATTCTGAACACTTGG-3') for SETBP1 exon 4) analysis (RefSeq NM_015559.2). PCR amplification was made using Taq DNA polymerase (GE Healthcare) and comprising 35 cycles of $45 \mathrm{sec}$ at $94^{\circ} \mathrm{C}, 57 \mathrm{sec}$ at $58^{\circ} \mathrm{C}$, and $60 \mathrm{sec}$ at $72^{\circ} \mathrm{C}$ followed by an extension of $6 \mathrm{~min}$. Sequencing was performed using BigDye Terminator v3.1 Cycle Sequencing kit (Applied Biosystems) on ABI 3730 DNA Analyzer (Applied Biosystems) Sequencer. 
We also performed a detailed review of all patients with SGS reported in literature from January, 1978 to September, 2013 using PubMed database with the keywords "Schinzel-Giedion syndrome". Only articles in English were included. We evaluated a total of 41 articles [Schinzel and Giedion, 1978; Donnai and Harris, 1979; Kelley et al., 1982; Al-Gazali et al., 1990; Pul et al., 1990; Maclennan et al., 1991; Herman et al., 1993; Robin et al., 1993; Verloes et al., 1993; Alavi et al., 1994; Labrune et al., 1994; Rodriguez et al., 1994; Santos et al., 1994; Antich et al., 1995; Okamoto et al., 1995; Culic et al., 1996; Elliott et al., 1996; Ozkinay et al., 1996; McPherson et al., 1998; Alembik et al., 1999; Rittinger et al., 1999; Shah et al., 1999; Kondoh et al., 2001; Touge et al., 2001; Cooke et al., 2002; Minn et al., 2002; Grosso et al., 2003; ManouvrierHanu, 2003; Sandri et al., 2003; Albano et al., 2004; Matsumoto et al., 2005; Beschorner et al., 2007; Al-Mudaffer et al., 2008; Lehman et al., 2008; Sharma and Gonzales, 2009; Hoischen et al., 2010; Suphapeetiporn et al., 2011; Lestner et al., 2012; Watanabe et al., 2012; Ko et al., 2013; Lach and Arredondo, 2013]. The features were considered positive only if they were specifically reported by the authors or seen in photographs.

\section{RESULTS}

In the first patient, DNA sequence analysis of SETBP1 detected the previously described heterozygous mutation: c.2602G $>A$ (NM_015559.2: p.Asp868Asn) (Fig. 3A). In the second patient, a novel heterozygous mutation c.2601C $>$ A (p.Ser867Arg) (Fig. 3B) was found and assumed as pathogenic based on the facts that the mutation was de novo, in silico analysis by PolyPhen2, Sift, and Mutation Taster predicted it as probably damaging, the residue is conserved among different species, and this mutation was not present in 609 controls from the Brazilian population that were exome sequenced.

The clinical findings (including those observed in our patients) are shown in Tables I and II according to its prevalence: present in $\geq 50 \%$ and $30-50 \%$, respectively.

\section{DISCUSSION}

Prior to the identification of the genetic background responsible for a specific genetic disorder, clinical criteria are the sole and important tools to define its diagnosis and are largely applied by clinical geneticists. Once mutations in a gene are unmasked, the importance of these criteria remains as a first step to define which patient should undergo molecular investigation. We described here two patients with SGS, the first one has fulfilled the diagnostic criteria proposed by Lehman et al. [2008]: developmental delay, typical face, skeletal malformations, and hydronephrosis. On the other hand, Patient 2 presented the classic facial phenotype, developmental delay, but neither hydronephrosis nor typical skeletal abnormalities, not fulfilling the diagnostic criteria. In this sense, the facial gestalt was the driving force that led us to perform the molecular analysis in this case. Therefore, caution should be taken not to rely on very restrictive criteria, once the less typical

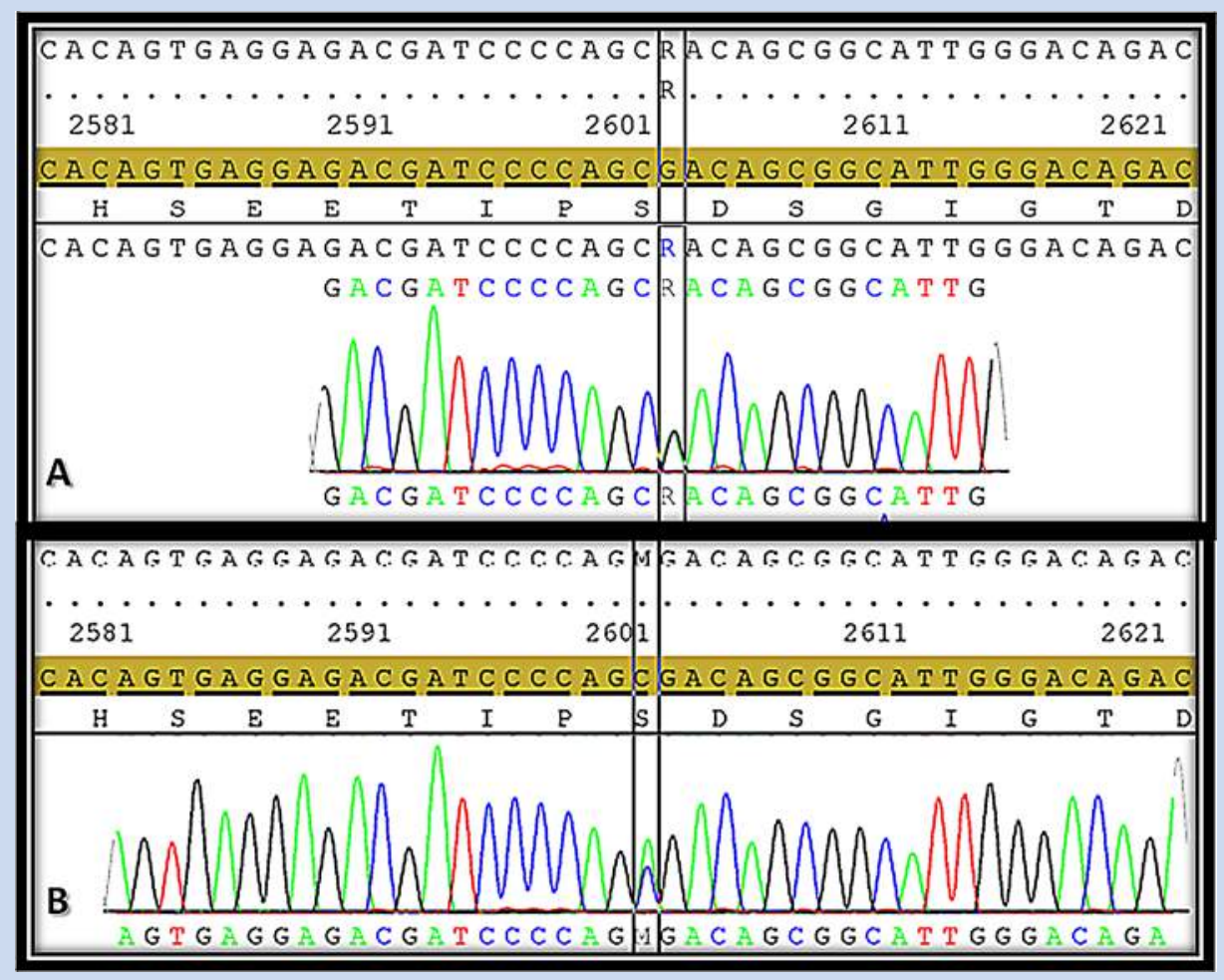

FIG. 3. Chromatograms demonstrating nucleotides changes in mutations analysis of Patients 1 [c.2602G $>A$ ) (A) and 2 (c.2601C $>A$ ) (B). 
TABLE I. Clinical Manifestations That Are Present in $\geq 50 \%$ of Patients

\begin{tabular}{|c|c|c|c|c|c|c|}
\hline & & & \multicolumn{3}{|c|}{ Number of patients in Literature $(n=70)$} & \multirow[b]{2}{*}{$\begin{array}{l}\text { Total of patients } \\
\qquad[\mathrm{n}=72]\end{array}$} \\
\hline & Patient 1 & Patient 2 & $\begin{array}{c}\text { No SETBP1 } \\
\text { analysis } \\
{[\mathrm{n}=53]} \\
\text { No./No. Known }\end{array}$ & $\begin{array}{c}\text { SETBP1 } \\
\text { mutation } \\
{[\mathrm{n}=16]} \\
\text { No./No. Known }\end{array}$ & $\begin{array}{c}\text { No SETBP1 } \\
\text { mutation } \\
{[\mathrm{n}=1]} \\
\text { No./No. Known }\end{array}$ & \\
\hline Craniofacial & + & + & $53 / 53$ & $16 / 16$ & $1 / 1$ & $72 / 72(100 \%)$ \\
\hline Wide fontanelles & + & + & $41 / 41$ & $12 / 14$ & $1 / 1$ & $56 / 72(78 \%)$ \\
\hline High/protruding forehead & + & + & $44 / 44$ & $15 / 16$ & $1 / 1$ & $61 / 72(85 \%)$ \\
\hline Orbital hypertelorism & + & + & $37 / 37$ & $12 / 13$ & $1 / 1$ & $52 / 72(72 \%)$ \\
\hline Midface hypoplasia & + & + & $41 / 41$ & $15 / 15$ & $1 / 1$ & $59 / 72[82 \%]$ \\
\hline Upturned nose & + & + & $39 / 41$ & $16 / 16$ & $1 / 1$ & $58 / 72[81 \%]$ \\
\hline Saddle nose with short bridge & + & + & $42 / 44$ & $13 / 13$ & $1 / 1$ & $58 / 72(81 \%)$ \\
\hline Low-set ears & - & - & $41 / 43$ & $14 / 14$ & $0 / 1$ & $55 / 72(76 \%)$ \\
\hline Neurological & + & + & $49 / 49$ & $16 / 16$ & $1 / 1$ & $68 / 72(94 \%)$ \\
\hline Neuroradiological findings & + & + & $29 / 31$ & $16 / 16$ & $1 / 1$ & $64 / 72(89 \%)$ \\
\hline Seizures and/or abnormal EEG & + & + & $39 / 40$ & $15 / 16$ & $1 / 1$ & $57 / 72(79 \%)$ \\
\hline $\begin{array}{l}\text { Development delay/severe } \\
\text { mental retardation/hypotonia }\end{array}$ & + & + & $42 / 42$ & $14 / 14$ & $1 / 1$ & $59 / 72(82 \%)$ \\
\hline Characteristic skeletal findings & + & - & $46 / 46$ & $14 / 14$ & $1 / 1$ & $62 / 72(86 \%)$ \\
\hline Broad ribs & + & - & $35 / 41$ & $11 / 11$ & $1 / 1$ & $61 / 72(85 \%)$ \\
\hline Wide occipital 'synchondrosis' & + & - & $25 / 33$ & $11 / 11$ & $1 / 1$ & $38 / 72(53 \%)$ \\
\hline Sclerotic base of skull & + & - & $25 / 37$ & $11 / 11$ & $1 / 1$ & $37 / 72(51 \%)$ \\
\hline Urological findings & + & - & $51 / 51$ & $16 / 16$ & $1 / 1$ & $69 / 72(96 \%)$ \\
\hline Congenital hydronephrosis & + & - & $40 / 44$ & $16 / 16$ & $1 / 1$ & $58 / 72(81 \%)$ \\
\hline Vesicoureteric reflux & + & - & $29 / 30$ & $13 / 13$ & $1 / 1$ & $44 / 72(61 \%)$ \\
\hline Genital findings & + & + & $38 / 38$ & $8 / 8$ & NA & $48 / 72(67 \%)$ \\
\hline
\end{tabular}

cases may be undiagnosed. Interestingly, two monozygous twins with a clinical picture resembling SGS, especially in their facial features, but showing relatively good neuropsychomotor development and long survival were described by Joss and Dean [2002]. The authors proposed that SGS diagnosis was unlikely, but hypothesized that the mild phenotype could be explained by a mutation in the gene responsible for SGS, unknown at that time, resulting in less severe disruption of the protein product or by a mutation in another gene belonging to the same pathway [Joss and Dean, 2002].

SGS is a very rare autosomal dominant disorder, which precise incidence is unknown. Detailed literature review associated with the data from our two patients showed that the sex ratio (male/female) is 1.6:1. Prenatal abnormalities were seen in some patients: polyhydramnios (13/18), urogenital findings (bilateral hydronephrosis, pyeloectasia, and multicystic dysplastic kidney) (26/32) and increased nuchal translucency $(2 / 32)$. The majority of them were born at term with an appropriate BL (19/20) and BW (42/43) for gestational age.

Neurological compromise (68/68) is observed since birth, characterized by neonatal asphyxia (8/10), feeding problems $(21 / 21)$, and recurrent apneic spells (18/18). Severe developmental delay is the rule for these patients. Seizures are very common and in most of patients are intractable. There is a wide spectrum of abnormalities observed in the central nervous system in these individuals, ranging from structural abnormalities [Maclennan et al., 1991; Robin et al., 1993; Rodriguez et al., 1994; Watanabe et al., 2012] to altered gyration pattern/migration defects [Beschorner et al., 2007 ; Lestner et al., 2012; Lach and Arredondo, 2013] (Tables I and II). Nonetheless, a neurodegenerative process caused by deficient white matter myelination has been described in some patients more recently [Watanabe et al., 2012; Ko et al., 2013]. Patient 2 here described also showed an abnormal pattern of myelination. Thus, white matter abnormalities emerge as an important CNS finding. It is possible that its presence and, especially its progressive course are under reported, hampered by the severity of the disorder, since these individuals rarely survive beyond the age of two [Al-Mudaffer et al., 2008].

The other two hallmarks of SGS, congenital hydronephrosis, and specific skeletal abnormalities (Tables I and II) are important clues for the diagnosis, but, as shown in Patient 2 here presented, its absence do not rule out its diagnosis.

Along with the severe neurological involvement, neuroepithelial tumors have been reported in eight SGS patients - hepatoblastoma (1), sacrococcygeal teratoma (3), lumbosacral teratoma (1), 
TABLE II. Clinical Manifestations That Are Present in 30-50\% of Patients

Number and of patients in Literature $[n=70]$

\begin{tabular}{ccc}
\hline No SETBP1 & SETBP1 & No SETBP1 \\
analysis & mutation & mutation \\
{$[n=53]$} & {$[n=16]$} & {$[n=1]$}
\end{tabular}

Patient 1 Patient 2 No./No. Known No./No. Known No./No. Known

Total of patients [n=72]

\begin{tabular}{|c|c|c|c|c|c|c|}
\hline \multicolumn{7}{|l|}{ Craniofacial } \\
\hline Coarse face & + & + & $30 / 31$ & $2 / 3$ & NA & $34 / 72(47 \%)$ \\
\hline Wide cranial sutures & - & - & $31 / 31$ & NA & NA & $31 / 72(43 \%)$ \\
\hline Infraorbotal grooves & + & + & $26 / 26$ & $4 / 4$ & NA & $32 / 72(44 \%)$ \\
\hline Short neck /abundant skin & + & - & $24 / 25$ & NA & NA & $25 / 72(35 \%)$ \\
\hline Hypertrichosis & + & + & $31 / 35$ & $1 / 1$ & NA & $34 / 72(47 \%)$ \\
\hline Congenital heart defect & - & - & $19 / 38$ & $7 / 13$ & $0 / 1$ & $26 / 72(36 \%)$ \\
\hline \multicolumn{7}{|l|}{ Neurological } \\
\hline Ventriculomegaly & + & - & $21 / 28$ & $4 / 4$ & NA & $26 / 72(36 \%)$ \\
\hline \multicolumn{7}{|l|}{ Characteristic skeletal findings } \\
\hline Growth retardation & + & - & $26 / 29$ & $2 / 2$ & NA & $29 / 72(40 \%)$ \\
\hline Steep base of skull & - & - & $22 / 32$ & NA & NA & $22 / 72(31 \%)$ \\
\hline Broad metaphyses of long bones & + & - & $20 / 23$ & $1 / 1$ & NA & $22 / 72(31 \%)$ \\
\hline $\begin{array}{l}\text { Hypoplasia of distal } \\
\text { phalanges in hands and/or feet }\end{array}$ & - & - & $23 / 27$ & $3 / 4$ & NA & $26 / 72(36 \%)$ \\
\hline \multicolumn{7}{|l|}{ Genital findings (42M:27F) } \\
\hline Hypospadias & + & NAP & $15 / 15$ & $3 / 4$ & NA & $19 / 42(45 \%)$ \\
\hline Small penis & + & NAP & $12 / 13$ & $2 / 2$ & NA & $15 / 42(36 \%)$ \\
\hline Hypoplasia of the labia majora & NAP & - & $6 / 11$ & $4 / 6$ & NAP & $10 / 27(37 \%)$ \\
\hline
\end{tabular}

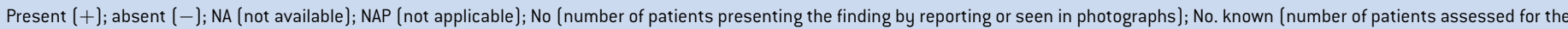
specific finding).

lumbosacral primitive neuroectodermal tumor (1), Wilms tumor (1), and extradural ependymomas (1). Most tumors described so far in SGS were congenital (4/8), but there were also tumors discovered after the first year of life (3/8). One reported patient with a Wilms tumor, detected at the age of 8 years, died of systemic metastatic disease one year after tumor detection [Robin et al., 1993; Rodriguez et al., 1994; Antich et al., 1995; McPherson et al., 1998; Sandri et al., 2003; Matsumoto et al., 2005; Beschorner et al., 2007; Watanabe et al., 2012]. Sacrococcygeal teratoma is the most frequent congenital germ cell tumor, with an incidence of $1 / 35,000$ to $1 / 40,000$ live births [Shue et al., 2013] and is the most frequently found tumor in SGS. The frequency of all tumors in SGS is estimated at $11 \%$, a higher percentage than ones found in other disorders, notably overgrowth syndromes such as BeckwithWiedemann and Simpson-Golabi-Behmel, for which screening protocols are well established [Koufos et al., 1989; Li et al., 2001]. Although in most cases, patients with SGS have a very severe disease with a low life expectancy, we suggest that families should be notified of the increased incidence of embryonic tumors and a periodic tumor screening protocol for tumor surveillance (with periodic renal ultrasound and measurement of serum alphafetoprotein) could be counterbalanced with the severity of patient's clinical framework. Since we do not know the extent of the phenotype very well, it is possible that milder cases could benefit from this approach.
Among the rarer clinical findings, alacrimia is present in our Patient 2 and it was described previously in four out of five individuals evaluated for this feature [Alembik et al., 1999; Minn et al., 2002; Manouvrier-Hanu, 2003]. Congenital alacrimia could be identified as an isolated finding (OMIM 231550) or be part of a small number of monogenic disorders, such as triple A syndrome - achalasiaaddisonianism-alacrimia syndrome (OMIM\#231550), anhidrotic ectodermal dysplasia (305100), and dysautonomia (223900). As a very restricted sign, this ophthalmologic finding raises the possibility of SGS, especially when associated with developmental delay.

The gene responsible for SGS (SETBP1) was recently identified and yielded a high positive rate (18/19) between individuals that fulfill the diagnostic criteria proposed by Lehman et al. [2008]. The only patient who was negative for SETBP1 gene mutations had also shown a typical phenotype, comprising epilepsy, typical facial features, hydronephrosis, and skeletal findings. As the cohort of tested patients is still small, it remains to be determined if SGS is genetically heterogeneous. The five different mutations found so far are clustered in exon 4 , in the SKI homologous region, between the DNA bindings domains. Their prevalence, including our cases, is the following: p.Ile871Tre (6/18-33\%), p.Asp868Asn (5/18-28\%), p.Gli870Ser (4/18-22\%), p.Asp868Ala (1/18-5\%), p.Gli870Asp (1/18-5\%), and p.Ser867Arg (1/18-5\%) (Fig. 1) [Hoischen et al., 2010; Suphapeetiporn et al., 2011; Lestner et al., 2012; Ko et al., 2013]. 
Since the molecular background of this syndrome is now recognized, it is possible that atypical patients or patients with a milder presentation could have mutations in the same gene, broadening the phenotypic spectrum within SETBP1 gene. In this scenario, the diagnostic criteria of SGS would need to be revised in the future. In the meantime, as we described a patient not fulfilling the clinical criteria and showing mutation in SETBP1, we suggest that the facial gestalt associated with neurological involvement would be sufficient to indicate molecular analysis of this particular gene.

\section{REFERENCES}

Al-Gazali LI, Farndon P, Burn J, Flannery DB, Davison C, Mueller RF. 1990. The Schinzel-Giedion syndrome. J Med Genet 27:42-47.

Al-Mudaffer M, Oley C, Price S, Hayes I, Stewart A, Hall CM, Reardon W. 2008. Clinical and radiological findings in Schinzel-Giedion syndrome. Eur J Pediatr 167:1399-1407.

Alavi S, Kher A, Bharucha BA. 1994. Schinzel-Giedion syndrome. Indian Pediatr 31:1111-1114.

Albano LM, Sakae PP, Mataloun MM, Leone CR, Bertola DR, Kim CA. 2004. Hydronephrosis in Schinzel-Giedion syndrome: An important clue for the diagnosis. Rev Hosp Clin Fac Med Sao Paulo 59: 89-92.

Alembik Y, Christmann D, de Saint Martin, Eliot A, Dollfus M, Pauly H, Stoll F. 1999. Schinzel-Giedion syndrome with severe deafness and neurodegenerative process. Ann Genet 42:225-230.

Antich J, Manzanares R, Camarasa F, Krauel X, Vila J, Cusi V. 1995. Schinzel-Giedion syndrome: Report of two sibs. Am J Med Genet 59:96-99.

Beschorner R, Wehrmann M, Ernemann U, Bonin M, Horber V, OehlJaschkowitz B, Meyermann R, Dufke A. 2007. Extradural ependymal tumor with myxopapillary and ependymoblastic differentiation in a case of Schinzel-Giedion syndrome. Acta Neuropathol 113:339-346.

Cooke ME, Davidson LE, Livesey SL. 2002. Schinzel-Giedion syndrome: Interesting facial and orodental features, and dental management. Int J Paediatr Dent 12:66-72.

Culic V, Resic B, Oorthuys JW, Overweg-Plandsoen WC, Hennekam RC. 1996. A Croatian case of the Schinzel-Giedion syndrome. Genet Couns $7: 21-25$.

Donnai D, Harris R. 1979. A further case of a new syndrome including midface retraction, hypertrichosis, and skeletal anomalies. J Med Genet $16: 483-486$.

Elliott AM, Meagher-Villemure K, Oudjhane K, der Kaloustian VM. 1996. Schinzel-Giedion syndrome: Further delineation of the phenotype. Clin Dysmorphol 5:135-142.

Grosso S, Pagano C, Cioni M, Di Bartolo RM, Morgese G, Balestri P. 2003. Schinzel-Giedion syndrome: A further cause of West syndrome. Brain Dev 25:294-298.

Herman TE, Sweetser DA, McAlister WH, Dowton SB. 1993. SchinzelGiedion syndrome and congenital megacalyces. Pediatr Radiol 23:111-112.

Hoischen A, van Bon BW, Gilissen C, Arts P, van Lier B, Steehouwer M, de Vries P, de Reuver R, Wieskamp N, Mortier G, Devriendt K, Amorim MZ, Revencu N, Kidd A, Barbosa M, Turner A, Smith J, Oley C, Henderson A, Hayes IM, Thompson EM, Brunner HG, de Vries BB, Veltman JA. 2010. De novo mutations of SETBP1 cause Schinzel-Giedion syndrome. Nat Genet 42:483-485.
Joss S, Dean JC. 2002. A Schinzel-Giedion-like syndrome-a milder version or a separate condition. Clin Dysmorphol 11:271-275.

Kelley RI, Zackai EH, Charney EB. 1982. Congenital hydronephrosis, skeletal dysplasia, and severe developmental retardation: The Schinzel-Giedion syndrome. J Pediatr 100:943-946.

Ko JM, Lim BC, Kim KJ, Hwang YS, Ryu HW, Lee JH, Kim JS, Chae JH. 2013. Distinct neurological features in a patient with Schinzel-Giedion syndrome caused by a recurrent SETBP1 mutation. Childs Nerv Syst 29:525-529.

Kondoh T, Kamimura N, Tsuru A, Matsumoto T, Matsuzaka T, Moriuchi H. 2001. A case of Schinzel-Giedion syndrome complicated with progressive severe gingival hyperplasia and progressive brain atrophy. Pediatr Int 43:181-184.

Koufos A, Grundy P, Morgan K, Aleck KA, Hadro T, Lampkin BC, Kalbakji A, Cavenee WK. 1989. Familial Wiedemann-Beckwith syndrome and a second Wilms tumor locus both map to 11p15.5. Am J Hum Genet 44:711-719.

Labrune P, Lyonnet S, Zupan V, Imbert MC, Goutieres F, Hubert P, Le Merrer M. 1994. Three new cases of the Schinzel-Giedion syndrome and review of the literature. Am J Med Genet 50:90-93.

Lach B, Arredondo J. 2013. Cobblestone lissencephaly in Schinzel-Giedion syndrome. J Child Neurol 28:259-263.

Lehman AM, McFadden D, Pugash D, Sangha K, Gibson WT, Patel MS. 2008. Schinzel-Giedion syndrome: Report of splenopancreatic fusion and proposed diagnostic criteria. Am J Med Genet A 146A:1299-1306.

Lestner JM, Chong WK, Offiiah A, Kefas J, Vandersteen AM. 2012. Unusual neuroradiological features in Schinzel-Giedion syndrome: A novel case. Clin Dysmorphol 21:152-154.

Li M, Shuman C, Fei YL, Cutiongco E, Bender HA, Stevens C, WilkinsHaug L, Day-Salvatore D, Yong SL, Geraghty MT, Squire J, Weksberg R. 2001. GPC3 mutation analysis in a spectrum of patients with overgrowth expands the phenotype of Simpson-Golabi-Behmel syndrome. Am J Med Genet 102:161-168.

Maclennan AC, Doyle D, Simpson RM. 1991. Neurosonography and pathology in the Schinzel-Giedion syndrome. J Med Genet 28: 547-549.

Manouvrier-Hanu S. 2003. Schinzel-Giedion syndrome and alacrima: A case first described in 1996. Am J Med Genet A 120A:292-293.

Matsumoto F, Tohda A, Shimada K, Okamoto N. 2005. Malignant retroperitoneal tumor arising in a multicystic dysplastic kidney of a girl with Schinzel-Giedion syndrome. Int J Urol 12:1061-1062.

McPherson E, Clemens M, Hoffner L, Surti U. 1998. Sacral tumors in Schinzel-Giedion syndrome. Am J Med Genet 79:62-63.

Minn D, Christmann D, De Saint-Martin A, Alembik Y, Eliot M, Mack G, Fischbach M, Flament J, Veillon F, Dollfus H. 2002. Further clinical and sensorial delineation of Schinzel-Giedion syndrome: Report of two cases. Am J Med Genet 109:211-217.

Okamoto N, Takeuchi M, Kitajima H, Hosokawa S. 1995. A patient with Schinzel-Giedion syndrome and a review of 20 patients. Jpn J Hum Genet 40:189-193.

Ozkinay FF, Akisu M, Kultursay N, Oral R, Tansug N, Sapmaz G. 1996. A genesis of the corpus callosum in Schinzel-Giedion syndrome associated with 47. XXY karyotype. Clin Genet 50:145-148.

Pul M, Yilmaz N, Komsuoglu B. 1990. The Schinzel-Giedion syndrome. A case report and review of the literature. Clin Pediatr (Phila) 29:235239.

Rittinger O, Weiss-Wichert P, Hasenohrl G. 1999. Bilateral hydronephrosis due to megacalicosis as a prenatal sonographic finding in a female with Schinzel-Giedion syndrome. Clin Dysmorphol 8:291-293. 
Robin NH, Grace K, DeSouza TG, McDonald-McGinn D, Zackai EH. 1993. New finding of Schinzel-Giedion syndrome: A case with a malignant sacrococcygeal teratoma. Am J Med Genet 47:852-856.

Rodriguez JI, Jimenez-Heffernan JA, Leal J. 1994. Schinzel-Giedion syndrome: Autopsy report and additional clinical manifestations. Am J Med Genet 53:374-377.

Sandri A, Manazza AD, Bertin D, Silengo M, Basso ME, Forni M, Madon E. 2003. Schinzel-Giedion syndrome with sacrococcygeal teratoma. J Pediatr Hematol Oncol 25:558-561.

Santos H, Cordeiro I, Medeira A, Mendonca E, Antunes NL, Rosa FC. 1994. Schinzel-Giedion syndrome. A patient with hypothyroidism and diabetes insipidus. Genet Couns 5:187-189.

Schinzel A, Giedion A. 1978. A syndrome of severe midface retraction, multiple skull anomalies, clubfeet, and cardiac and renal malformations in sibs. Am J Med Genet 1:361-375.

Shah AM, Smith MF, Griffiths PD, Quarrell OW. 1999. Schinzel-Giedion syndrome: evidence for a neurodegenerative process. Am J Med Genet 82:344-347.
Sharma AK, Gonzales JA. 2009. Scoliosis in a case of Schinzel-Giedion syndrome. Hss J 5:120-122.

Shue E, Bolouri M, Jelin EB, Vu L, Bratton B, Cedars E, Yoke L, Byrne F, Hirose S, Feldstein V, Miniati D, Lee H. 2013. Tumor metrics and morphology predict poor prognosis in prenatally diagnosed sacrococcygeal teratoma: A 25-year experience at a single institution. J Pediatr Surg 48:1225-1231.

Suphapeetiporn K, Srichomthong C, Shotelersuk V. 2011. SETBP1 mutations in two Thai patients with Schinzel-Giedion syndrome. Clin Genet 79:391-393.

Touge H, Fujinaga T, Okuda M, Aoshi H. 2001. Schinzel-Giedion syndrome. Int J Urol 8:237-241.

Verloes A, Moes D, Palumbo L, Elmer C, Francois A, Bricteux G. 1993. Schinzel-Giedion syndrome. Eur J Pediatr 152:421-423.

Watanabe S, Murayama A, Haginoya K, Tanaka S, Togashi N, Abukawa D, Sato A, Imaizumi M, Yoshikawa H, Takayama R, Wakusawa K, Kobayashi S, Sato I, Onuma A. 2012. Schinzel-Giedion syndrome: A further cause of early myoclonic encephalopathy and vacuolating myelinopathy. Brain Dev 34:151-155. 


\title{
Rare Variants in the Epithelial Cadherin Gene Underlying the Genetic Etiology of Nonsyndromic Cleft Lip with or without Cleft Palate
}

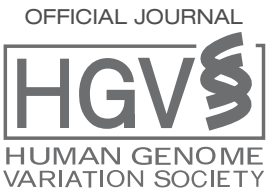

VARIATION SOCIETY www.hgvs.org

\author{
Luciano Abreu Brito, ${ }^{1}$ Guilherme Lopes Yamamoto, ${ }^{1}$ Soraia Melo, ${ }^{2,3}$ Carolina Malcher, ${ }^{1}$ Simone Gomes Ferreira, ${ }^{1}$ \\ Joana Figueiredo, ${ }^{2,3}$ Lucas Alvizi, ${ }^{1}$ Gerson Shigeru Kobayashi, ${ }^{1}$ Michel Satya Naslavsky, ${ }^{1}$ Nivaldo Alonso, ${ }^{4}$ \\ Temis Maria Felix, ${ }^{5}$ Mayana Zatz, ${ }^{1}$ Raquel Seruca, ${ }^{2,3,6}$ and Maria Rita Passos-Bueno ${ }^{1 *}$ \\ ${ }^{1}$ Centro de Pesquisa sobre o Genoma Humano e Células-Tronco, Departamento de Genética e Biologia Evolutiva, Instituto de Biociências, \\ Universidade de São Paulo, São Paulo, Brasil; ${ }^{2}$ IPATIMUP, Institute of Molecular Pathology and Immunology, University of Porto, Porto, Portugal; \\ ${ }^{3}$ Instituto de Investigação e Inovação em Saúde, Universidade do Porto, Porto, Portugal; ${ }^{4}$ Hospital das Clínicas, Faculdade de Medicina, \\ Universidade de São Paulo, São Paulo, Brasil; ${ }^{5}$ Laboratório de Medicina Genômica, Centro de Pesquisa Experimental, Hospital de Clínicas de \\ Porto Alegre, Porto Alegre, Brasil; ${ }^{6}$ Faculty of Medicine, University of Porto, Porto, Portugal
}

Communicated by lain McIntosh

Received 2 February 2015; accepted revised manuscript 17 June 2015.

Published online in Wiley Online Library (www.wiley.com/humanmutation). DOI: 10.1002/humu.22827

\begin{abstract}
Nonsyndromic orofacial cleft (NSOFC) is a complex disease of still unclear genetic etiology. To investigate the contribution of rare epithelial cadherin (CDH1) gene variants to NSOFC, we target sequenced 221 probands. Candidate variants were evaluated via in vitro, in silico, or segregation analyses. Three probably pathogenic variants (c.760G $>A$ [p.Asp254Asn], c. $1023 \mathrm{~T}>\mathrm{G}$ [p.Tyr341*], and c.2351G>A [p.Arg784 His]) segregated according to autosomal dominant inheritance in four nonsyndromic cleft lip with or without cleft palate $(\mathrm{NSCL} / \mathrm{P})$ families (Lod score: 5.8 at $\theta=$ $0 ; 47 \%$ penetrance). A fourth possibly pathogenic variant (c.387+5G>A) was also found, but further functional analyses are needed (overall prevalence of CDH1 candidate variants: $2 \% ; 15.4 \%$ among familial cases). $\mathrm{CDH} 1$ mutational burden was higher among probands from familial cases when compared to that of controls $(P=0.002)$. We concluded that $\mathrm{CDH} 1$ contributes to NSCL/P with mainly rare, moderately penetrant variants, and $\mathrm{CDH} 1$ haploinsufficiency is the likely etiological mechanism. Hum Mutat 0:1, 2015. (ㄷ 2015 Wiley Periodicals, Inc.
\end{abstract}

KEY WORDS: CDH1; oral clefts; gastric cancer; two-hit model; rare variant

N onsyndromic cleft lip with or without cleft palate (NSCL/P) and nonsyndromic cleft palate only (NSCPO) are two complex disorders within the nonsyndromic orofacial cleft (NSOFC)

Additional Supporting Information may be found in the online version of this article. * Correspondence to: Maria Rita dos Santos e Passos-Bueno, Rua do Matão 277, sala 200, Cidade Universitária, São Paulo, SP, 05508-090, Brasil. Tel.: 5511 3091-7740, E-mail: passos@ib.usp.br

Contract grant sponsor(s): Fundação de Amparo à Pesquisa do Estado de São Paulo (FAPESP; CEPID Project 2013/08028-1); Conselho Nacional de Desenvolvimento Científico e Tecnológico (CNPq; 401952/2010-0); Fundos FEDER através do Programa Operacional Factores de Competitividade (COMPETE); Portuguese Foundation for Science and Technology (FCT; PTDC/SAU-ONC/110294/2009, PTDC/BIM-ONC/0171/2012, PEst-0E/EEI/LA0009/2013, and JF post-doctoral grant SFRH/BPD/87705/2012). spectrum [Gorlin et al., 2001]. While the genetic etiology of NSCPO is largely unclear, genetic loci have been systematically implicated in NSCL/P, such as common low-risk 8q24, 10q25, and IRF6 variants [Rahimov et al., 2008; Birnbaum et al., 2009; Mangold et al., 2010, Brito et al., 2012aa, 2012b]. However, given the high heritability attributed to NSCL/P [Hu et al., 1982; Calzolari et al., 1988; Brito et al., 2011], searching for alternative genetic variants or mechanisms is necessary to bridge the missing heritability gap of these malformations.

Rare germline variants in the gene encoding the adhesion molecule epithelial cadherin, CDH1 (MIM\# 192090), have long been associated with diffuse gastric cancer and lobular breast cancer [van Roy and Berx, 2008]. Most recently, CDH1 mutations have been reported in OFC patients in association with gastric cancer [Frebourg et al., 2006; Kluijt, et al. 2012; Benusiglio et al., 2013] or not [Vogelaar et al., 2013; Bureau et al., 2014]. These findings raise the questions as to what the proportion of NSOFC cases underlain by $C D H 1$ variants and their attributed penetrance is, and which types of mutations or mechanisms lead to OFC, cancer, or both phenotypes.

Here, we performed a variant screening for $\mathrm{CDH} 1$ (NM_004360.3) coding region in 221 NSOFC probands (affected by NSCL/P [ $n=189$ ] or NSCPO [ $n=32$ ], either from nonfamilial [ $n=138]$ or familial cases $[n=83]$; Supp. Table S1). Sequencing was performed by using next-generation sequencing (NGS, exome or targeted gene sequencing) and Sanger sequencing (SS), and applied for 65 and 156 probands, respectively. Additional NGS or SS was performed for extra members of familial cases, when available. When exome sequencing was performed in affected members of the same family, we filtered out variants with minor allele frequency greater than $1 \%$ in public databases $(1000$ Genomes Project, and NHLBI ESP exomes) and in our in-house database of 609 Brazilian control exomes (Supp. Methods). Among the 221 probands, we identified a total of 47 variants, of which 12 were absent in our controls (two missense, one nonsense, and nine noncoding or synonymous variants; Supp. Table S2). Variants were submitted to the LOVD database (at http://www.lovd.nl/CDH1).

The novel missense variant c.760G>A (p.Asp254Asn, exon 6) was the most likely causative variant among the main candidates detected by exome analysis (mean coverage of $60 \times$; average of 25,140 variants called for each individual; Supp. Table S3) in families F3788 
and F617 (four affected individuals sequenced in each family; Supp. Fig. S1a and b). Both families segregate NSCL/P, and haplotype analysis of the exome data did not support a close relationship between these families (data not shown). SS of additional two affected and eight unaffected members from these two families supported segregation in accordance with an autosomal dominant model with incomplete penetrance estimated at $53 \%$. Assuming this penetrance, a Lod score of 4.8 was obtained at recombination fraction $(\theta) 0$, under an allele frequency of 0.0001 . The other novel missense variant, c.2351G $>$ A (p.Arg784His, exon 15), was found in the proband of family F1387 through SS. Segregation with NSCL/P was evidenced by its presence in three affected relatives (Supp. Fig. S1c), and penetrance was estimated at $62 \%$. Further, the loss-of-function variant c. $1023 \mathrm{~T}>\mathrm{G}$ (exon 8), predicted to create a stop codon at position 341 of CDH1 (p.Tyr341*), was found in the proband of family F7618 (Supp. Fig. S1d) through SS. Segregation with NSCL/P was suggested by its presence in an affected first cousin once removed. Although this represents the first association between this variant and NSCL/P, an association with hereditary diffuse gastric cancer (HDGC) has been previously observed [Guilford et al., 2010]. Penetrance was estimated at $31 \%$ in this family. Considering the four pedigrees, an overall $47 \%$ penetrance of NSCL/P was estimated, with a maximum Lod score of 5.86 at $\theta=0$ (individual Lod scores: F3788: 2.3; F617: 2.5; F1387: 0.9; F7618: 0.2).

Among the remaining nine noncoding or synonymous novel variants, only two variants were significantly scored by in silico tools for pathogenicity prediction (Supp. Table S4). Variant c.387+5G>A, which possibly decreases exon 3 splice donor site recognition, was found in a NSCL/P proband from a nonfamilial case (parental DNA unavailable for testing whether it is a de novo variant). We considered this variant as possibly pathogenic, although further functional studies are necessary. Variant c.2514C $>\mathrm{T}$ (exon 16), present in two unrelated probands (one isolated and one familial case), was discarded as pathogenic as it did not segregate with NSCL/P in the familial case.

E-cadherin consists of three major domains: a short cytoplasmic, a single transmembrane, and a large extracellular domain, with five repetitive subdomains [Paredes et al., 2012]. The p.Asp254Asn substitution is located at a calcium-binding site comprised by the amino acid sequence Asp-Gln-Asn-Asp, at position 254-257 of CDH1 [Tepass et al., 2000]. This site, in turn, is located in the outmost extracellular subdomain, which plays a major role in the molecular adhesive properties between cadherin trans-dimers [Shapiro et al., 1995]. Calcium binding in the extracellular subdomains is necessary for the cis-dimerization of E-cadherin, and for conferring rigidity to the extracellular domain [Nagar et al., 1996; Pertz et al., 1999]. Importantly, an amino acid substitution in a nearby calcium-binding site has been reported to completely suppress the cellular adhesive properties of E-cadherin in vitro [Ozawa et al., 1990]. The p.Arg784His substitution is located in the cytoplasmic domain, which is important for the assembly of catenins and for promoting cellular signaling [Nelson and Nusse, 2004]. Analyses with in silico tools indicated that these two missense variants are located in highly conserved regions of E-cadherin and probably impair protein function (Supp. Table S4). To determine their pathogenic potential in vitro, we transiently transfected Chinese Hamster Ovary (ATCC number: CCL61) cells, which are negative for E-cadherin expression, with vectors encoding the wild-type (WT) E-cadherin and variants p.Asp254Asn and p.Arg784His (Supp. Methods). As revealed by Western blot and immunocytochemistry analysis, Asp254Asn cells showed decreased total E-cadherin protein expression $(P=0.00053$; Fig. 1A), as well as reduced amount of E-cadherin located in the plasma membrane (Fig. 1B), when compared with cells expressing the WT protein. Furthermore, mutant cells were unable to form cellular aggregates and exhibited a scattered phenotype, contrary to the WT cells, thus clearly indicating impaired adhesive function (Fig. 1C). Even though no structural impact was predicted in the mutated CDH1 protein (performed with FoldX, http://foldx.crg.es/: $\Delta \Delta \mathrm{G}=$ $-0.81 \mathrm{kcal} / \mathrm{mol}$ ), our in vitro assays suggest that p.Asp254Asn may lead to premature degradation, as shown for other cancerrelated $C D H 1$ pathogenic variants [Simoes-Correia et al., 2008, 2012; Figueiredo et al., 2013]. The functional effect of this variant could also be related to disturbances in calcium ion binding, given its location. Arg784His cells, in turn, showed no observable difference from WT cells in total E-cadherin amount, its location in the plasma membrane, and its adhesive behavior (Fig. $1 \mathrm{~A}-\mathrm{C})$. However, this result should not be sufficient to rule out the pathogenicity of this variant, since this in vitro assay may not be able to detect other types of functional effects, such as changes in interactions with other proteins, altering subsequent signaling pathways.

Families F3788 (p.Asp254Asn) and F1387 (p.Arg784His), the only two we were able to reascertain for cancer family history, include mutation carriers aged up to 70 years without cancer. This observation suggests that, under certain circumstances, $C D H 1$ variants might cause NSCL/P alone. The invasive potential of Asp254Asn and Arg784His cells, investigated by an in vitro Matrigel matrix invasion assay, was similar to that of WT cells (Fig. 1D). Thus, it is possible that some E-cadherin mutations increase the risk of NSCL/P alone, while others increase risk of gastric cancer (mutations associated with higher invasiveness). However, it is of note that the current landscape of $\mathrm{CDH} 1$ mutations associated with gastric cancer and $\mathrm{CL} / \mathrm{P}$ does not suggest any preferential distribution of mutations along the E-cadherin molecule (Fig. 2).

The overall prevalence of rare, possibly pathogenic $C D H 1$ variants here reported was $2 \%$ ( 5 out of 221 NSOFC probands). To date, the $\mathrm{CDH} 1$ mutational repertoire in the literature associated with OFC includes 10 different mutations. Six of these mutations have been reported in families also segregating gastric cancer (four affecting mRNA splicing, one nonsense, and one frameshift deletion) [Frebourg et al., 2006; Kluijt et al., 2012; Benusiglio et al., 2013] and four were found in individuals with uncertain history of gastric cancer (one nonsense [Bureau et al., 2014] and three missense in a European cohort [Vogelaar et al., 2013]). Revisiting the list of variants described in the European cohort, we observed that the missense variant c. $88 \mathrm{C}>\mathrm{A}$, which was reported in two patients from that study, was also found in two of our Brazilian controls; after removing this variant, the prevalence of possibly pathogenic $\mathrm{CDH} 1$ mutations in the European cohort becomes 2\%, instead of the previously reported $5 \%$ and now similar to our estimate. Furthermore, considering that two of the possibly pathogenic mutations here reported (p.Asp254Asn and p.Tyr341*) and most of the 10 above-mentioned mutations are predicted to cause $\mathrm{CDH} 1$ loss-of-function, haploinsufficiency in critical stages of embryonic development seems to be the most likely mechanism by which rare variants in $C D H 1$ lead to OFC.

To investigate whether the group of 221 NSOFC probands presents a higher burden of $\mathrm{CDH} 1$ rare variants compared to that of 609 Brazilian controls, we performed a gene-based sequence kernel association test (SKAT) [Wu et al., 2011]. A complementary two-tailed Fisher's exact test was performed to compare the proportion of individuals carrying at least one rare $C D H 1$ variant between probands and controls. Only variants with minor allele frequency $<1 \%$ and with nonneutral prediction in at least one in silico tool were selected for these tests. To avoid methodological bias in the tests, we only included variants from regions that were 

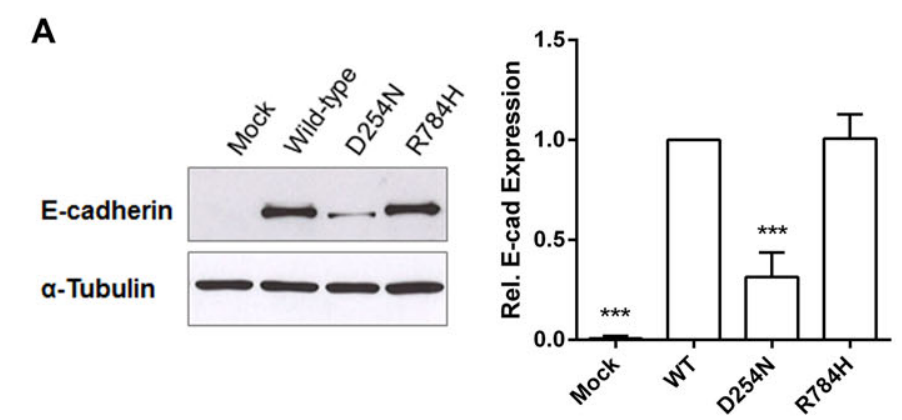

B
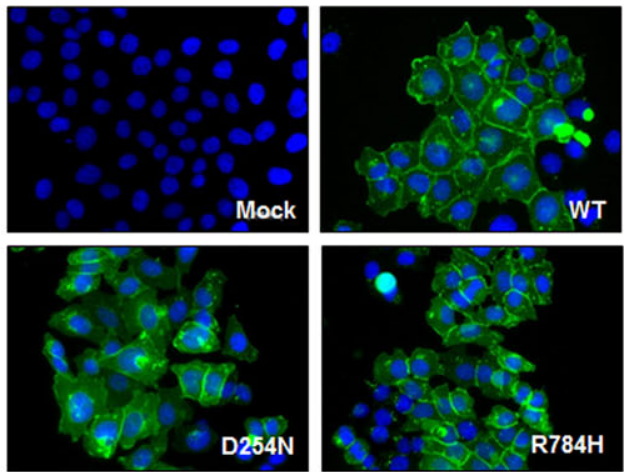
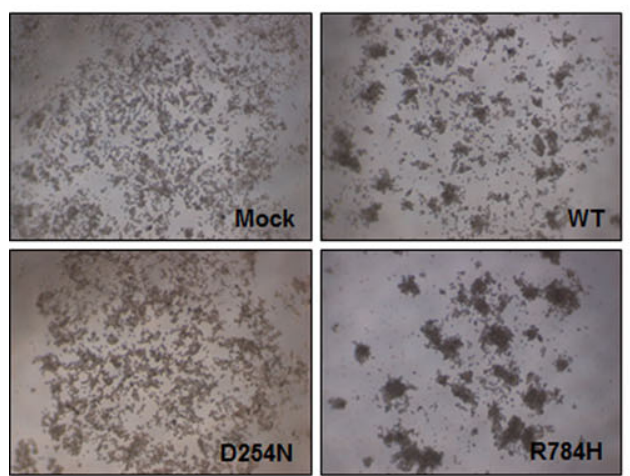

D

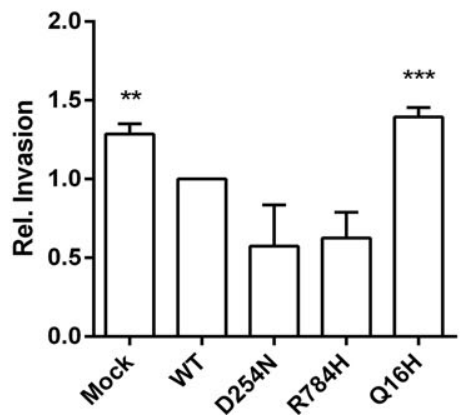

Figure 1. In vitro functional characterization of $\mathrm{CDH1}$ missense variants p.Asp254Asn (D254N) and p.Arg784His (R784H). A: Protein expression levels of Chinese Hamster Ovary cells transfected with the WT E-cadherin, the variants D254N and R784H, and the empty vector (Mock). $\alpha$-Tubulin was used as a loading control. Band intensity was quantified and normalized against WT E-cadherin-expressing cells. The graph shows the average \pm SE of E-cadherin protein level in five independent experiments. B: Immunocytochemistry showing E-cadherin subcellular localization (green staining). Nuclei counterstained with DAPI (blue). Scale bar represents $100 \mu \mathrm{m}$. C: Cell-cell adhesive properties assessed by slow aggregation assays. D: Invasive ability of cells expressing WT or the D254N and R784H variants. The graph shows the number of invasive cells \pm SE of five independent experiments. Cells expressing a known invasive mutation associated with gastric cancer (016H), used as a positive control, showed higher invasive potential than the studied mutations.

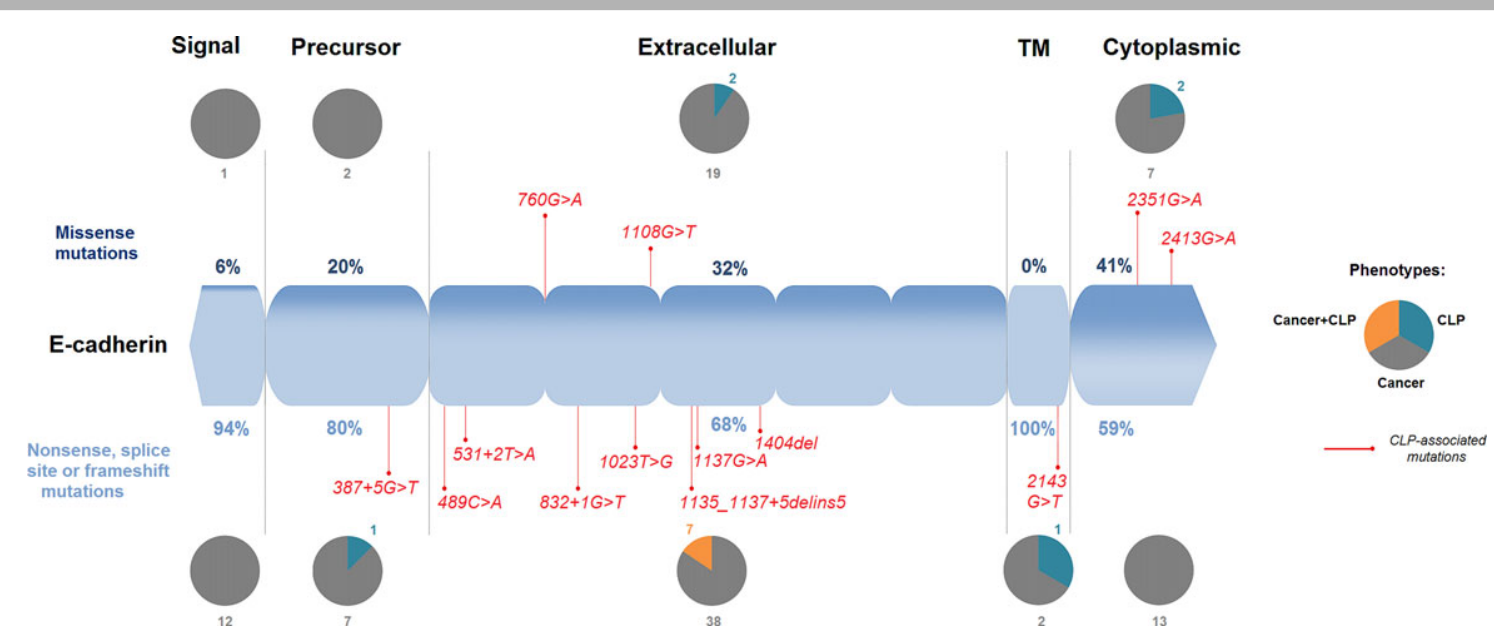

Figure 2. Scheme of $\mathrm{CDH} 1$ protein showing the distribution of $\mathrm{CDH} 1$ germline mutations (missense $\times$ nonsense/splice site/frameshift) associated with gastric cancer [Corso et al., 2012], cleft lip/palate, and both phenotypes. Circles depict the proportion of mutations associated with each phenotype along the protein domains (signal, precursor, extracellular, transmembrane [TM], and cytoplasmic).

covered by both SS and NGS (with minimum coverage of $25 \times$; Supp. Table S5). No significant differences in variant enrichment were detected by SKAT when comparing the 221 NSOFC probands with our 609 control exomes $(P=0.25)$. Similarly, no significant difference was detected in the number of individuals carrying these variants (two-tailed Fisher's exact test $P=0.85$; patients: $9 / 221$ [4\%]; controls: $28 / 609[5 \%])$. Most of the probably pathogenic variants here reported (p.Asp254Asn, p.Tyr341*, and p.Arg784His) were found in familial cases with at least two affected members aside from the probands ( 4 out of 26 families matching the same condition, or $15.4 \%)$. Considering only probands from families with at least two additional affected individuals, significant differences were detected by SKAT $(P=0.002)$ and by two-tailed Fisher's exact test $(P=$ 0.002; patients: $6 / 26$ [23\%]; controls: $28 / 609$ [5\%]). These findings 
suggest that the most noteworthy $\mathrm{CDH} 1$ etiological contribution to NSOFC arises from the fraction of NSCL/P cases involving moderate penetrance, which is best represented by familial cases. Since the previously suggested association between common variants and NSCL/P [Letra et al., 2009; Hozyasz et al., 2014] has not been supported by a large meta-analysis with GWAS data [Ludwig et al., 2012], rare variants seem to be the major contribution of $C D H 1$ to NSCL/P etiology.

Given the lack of correlation between type/location of $\mathrm{CDH} 1$ rare pathogenic variants and NSCL/P or HDGC (Fig. 2), we speculate that a common underlying molecular mechanism could explain both phenotypes. Penetrance of $\mathrm{CDH} 1$ germline mutations implicated in HDGC depends on a second hit, which frequently occurs via promoter hypermethylation of the nonmutated allele, possibly triggered by environmental factors [Oliveira et al., 2009; Zeng et al., 2015]. In this regard, a lifetime exposure to such factors would be in agreement with the higher penetrance in HDGC (80\%) [Pharoah et al., 2001], as compared to NSCL/P (47\%). Germline, pathogenic variants in $\mathrm{CDH} 1$ could determine the resultant phenotype (NSCL/P or gastric cancer) under the influence of the following factors: time (early development or later in life), tissue (craniofacial or gastric structures), and exposure to environmental factors. In addition, given the prevalence of $C D H 1$ pathogenic variants found in this study, we believe that the NSCL/P-associated $\mathrm{CDH} 1$ mutations are currently underrepresented, and future research should focus on their identification.

In summary, our results indicate a consistent role of rare, loss-offunction, moderately penetrant $\mathrm{CDH} 1$ variants in NSCL/P etiology. To better comprehend the mechanisms linking $\mathrm{CDH} 1$ to NSCL/P, as well as the risk of gastric cancer among NSCL/P individuals with mutations in $\mathrm{CDH} 1$, further studies are needed. Finally, $\mathrm{CDH} 1$ testing in NSCL/P familial cases should be discussed for genetic counseling purposes.

\section{Acknowledgments}

We thank the Operation Smile Brazil team and Dr. Daniela Bueno (Hospital Menino Jesus) for the productive collaboration, and Suzana Ezquina, Vitor Aguiar, Vanessa Simões, Dr. Paulo A. Otto, and Dr. Rui M. Ferreira for helpful discussions.

\section{Disclosure statement}

The authors declare no conflict of interest.

\section{References}

Benusiglio PR, Caron O, Consolino E, Duvillard P, Coulet F, Blayau M, Malka D. 2013. Cleft lip, cleft palate, hereditary diffuse gastric cancer and germline mutations in CDH1. Int J Cancer 132:2470.

Birnbaum S, Ludwig KU, Reutter H, Herms S, Steffens M, Rubini M, Baluardo C, Ferrian M, Almeida de Assis N, Alblas MA, Barth S, Freudenberg J, et al. 2009. Key susceptibility locus for nonsyndromic cleft lip with or without cleft palate on chromosome 8q24. Nat Genet 41:473-477.

Brito LA, Bassi CF, Masotti C, Malcher C, Rocha KM, Schlesinger D, Bueno DF, Cruz LA, Barbara LK, Bertola DR, Meyer D, Franco D, et al. 2012a. IRF6 is a risk factor for nonsyndromic cleft lip in the Brazilian population. Am J Med Genet A $158: 2170-2175$.

Brito LA, Cruz LA, Rocha KM, Barbara LK, Silva CB, Bueno DF, Aguena M, Bertola DR, Franco D, Costa AM, Alonso N, Otto PA, et al. 2011. Genetic contribution for non-syndromic cleft lip with or without cleft palate (NS CL/P) in different regions of Brazil and implications for association studies. Am J Med Genet A 155A:1581-1587.

Brito LA, Paranaiba LM, Bassi CF, Masotti C, Malcher C, Schlesinger D, Rocha KM, Cruz LA, Bárbara LK, Alonso N, Franco D, Bagordakis E, et al. 2012b. Region 8q24 is a susceptibility locus for nonsyndromic oral clefting in Brazil. Birth Defects Res A Clin Mol Teratol 94:464-468.

Bureau A, Parker MM, Ruczinski I, Taub MA, Marazita ML, Murray JC, Mangold E, Noethen MM, Ludwig KU, Hetmanski JB, Bailey-Wilson JE, Cropp CD, et al. 2014. Whole exome sequencing of distant relatives in multiplex families implicates rare variants in candidate genes for oral clefts. Genetics 197: 1039-1044.

Calzolari E, Milan M, Cavazzuti GB, Cocchi G, Gandini E, Magnani C, Moretti M, Garani GP, Salvioli GP, Volpato S. 1988. Epidemiological and genetic study of 200 cases of oral cleft in the Emilia Romagna region of northern Italy. Teratology 38:559-564.

Corso G, Marrelli D, Pascale V, Vindigni C, Roviello F. 2012. Frequency of CDH1 germline mutations in gastric carcinoma coming from high- and low-risk areas: metanalysis and systematic review of the literature. BMC Cancer 12:8.

Figueiredo J, Soderberg O, Simoes-Correia J, Grannas K, Suriano G, Seruca R. 2013. The importance of E-cadherin binding partners to evaluate the pathogenicity of E-cadherin missense mutations associated to HDGC. Eur J Hum Genet 21:301309.

Fitzgerald RC, Hardwick R, Huntsman D, Carneiro F, Guilford P, Blair V, Chung DC, Norton J, Ragunath K, VanKrieken JH, Dwerryhouse S, Caldas C. 2010. Hereditary diffuse gastric cancer: updated consensus guidelines for clinical management and directions for future research. J Med Genet 47:436-444.

Frebourg T, Oliveira C, Hochain P, Karam R, Manouvrier S, Graziadio C, Vekemans M, Hartmann A, Baert-Desurmont S, Alexandre C, Lejeune Dumoulin S, Marroni C, et al. 2006. Cleft lip/palate and CDH1/E-cadherin mutations in families with hereditary diffuse gastric cancer. J Med Genet 43:138-142.

Gorlin RJ, Cohen MMJ, Hennekam RCM. 2001. Syndromes of the head and neck. New York: Oxford University Press. p 1344.

Guilford P, Humar B, Blair V. 2010. Hereditary diffuse gastric cancer: translation of $\mathrm{CDH} 1$ germline mutations into clinical practice. Gastric Cancer 13: $1-10$.

Hozyasz KK, Mostowska A, Wojcicki P, Lasota A, Offert B, Balcerek A, DuninWilczynska I, Jagodzinski PP. 2014. Nucleotide variants of the cancer predisposing gene $\mathrm{CDH} 1$ and the risk of non-syndromic cleft lip with or without cleft palate. Fam Cancer 13:415-421.

Hu DN, Li JH, Chen HY, Chang HS, Wu BX, Lu ZK, Wang DZ, Liu XG. 1982. Genetics of cleft lip and cleft palate in China. Am J Hum Genet 34:999-1002.

Kluijt I, Siemerink EJ, Ausems MG, van Os TA, de Jong D, Simoes-Correia J, van Krieken JH, Ligtenberg MJ, Figueiredo J, van Riel E, Sijmons RH, Plukker JT, et al. 2012. CDH1-related hereditary diffuse gastric cancer syndrome: clinical variations and implications for counseling. Int J Cancer 131:367-376.

Letra A, Menezes R, Granjeiro JM, Vieira AR. 2009. AXIN2 and CDH1 polymorphisms, tooth agenesis, and oral clefts. Birth Defects Res A Clin Mol Teratol 85: 169-173.

Ludwig KU, Mangold E, Herms S, Nowak S, Reutter H, Paul A, Becker J, Herberz R, AlChawa T, Nasser E, Böhmer AC, Mattheisen M, et al. 2012. Genome-wide meta-analyses of nonsyndromic cleft lip with or without cleft palate identify six new risk loci. Nat Genet 44:968-971.

Mangold E, Ludwig KU, Birnbaum S, Baluardo C, Ferrian M, Herms S, Reutter H, de Assis NA, Chawa TA, Mattheisen M, Steffens M, Barth S, et al. 2010. Genome-wide association study identifies two susceptibility loci for nonsyndromic cleft lip with or without cleft palate. Nat Genet 42:24-26.

Nagar B, Overduin M, Ikura M, Rini JM. 1996. Structural basis of calcium-induced E-cadherin rigidification and dimerization. Nature 380:360-364.

Nelson WJ, Nusse R. 2004. Convergence of Wnt, beta-catenin, and cadherin pathways. Science 303:1483-1487.

Oliveira C, Sousa S, Pinheiro H, Karam R, Bordeira-Carriço R, Senz J, Kaurah P, Carvalho J, Pereira R, Gusmão L, Wen X, Cipriano MA et al. 2009. Quantification of epigenetic and genetic 2nd hits in CDH1 during hereditary diffuse gastric cancer syndrome progreesion. Gastroenterology 136:2137-2148.

Ozawa M, Engel J, Kemler R. 1990. Single amino acid substitutions in one $\mathrm{Ca}_{2}^{+}$binding site of uvomorulin abolish the adhesive function. Cell 63:1033-1038.

Paredes J, Figueiredo J, Albergaria A, Oliveira P, Carvalho J, Ribeiro AS, Caldeira J, Costa AM, Simoes-Correia J, Oliveira MJ, Pinheiro H, Pinho SS, et al. 2012. Epithelial E- and P-cadherins: role and clinical significance in cancer. Biochim Biophys Acta 1826:297-311.

Pertz O, Bozic D, Koch AW, Fauser C, Brancaccio A, Engel J. 1999. A new crystal structure, $\mathrm{Ca}_{2}{ }^{+}$dependence and mutational analysis reveal molecular details of E-cadherin homoassociation. EMBO J 18:1738-1747.

Pharoah PD, Guilford P, Caldas C. 2001. Incidence of gastric cancer in CDH1 (E-cadherin) mutation carriers from hereditary diffuse gastric cancer families. Gastroenterology 121:1348-1353.

Rahimov F, Marazita ML, Visel A, Cooper ME, Hitchler MJ, Rubini M, Domann FE, Govil M, Christensen K, Bille C, Melbye M, Jugessur A, et al. 2008. Disruption of an AP-2alpha binding site in an IRF6 enhancer is associated with cleft lip. Nat Genet 40:1341-1347. 
Shapiro L, Fannon AM, Kwong PD, Thompson A, Lehmann MS, Grubel G, Legrand JF, Als-Nielsen J, Colman DR, Hendrickson WA. 1995. Structural basis of cell-cell adhesion by cadherins. Nature 374:327-337.

Simoes-Correia J, Figueiredo J, Lopes R, Stricher F, Oliveira C, Serrano L, Seruca R. 2012. E-cadherin destabilization accounts for the pathogenicity of missense mutations in hereditary diffuse gastric cancer. PLoS One 7:e33783.

Simoes-Correia J, Figueiredo J, Oliveira C, van Hengel J, Seruca R, van Roy F, Suriano G. 2008. Endoplasmic reticulum quality control: a new mechanism of E-cadherin regulation and its implication in cancer. Hum Mol Genet 17:3566-3576.

Tepass U, Truong K, Godt D, Ikura M, Peifer M. 2000. Cadherins in embryonic and neural morphogenesis. Nat Rev Mol Cell Biol 1:91-100.

van Roy F, Berx G. 2008. The cell-cell adhesion molecule E-cadherin. Cell Mol Life Sci $65: 3756-3788$
Vogelaar IP, Figueiredo J, van Rooij IA, Simoes-Correia J, van der Post RS, Melo S, Seruca R, Carels CE, Ligtenberg MJ, Hoogerbrugge N. 2013. Identification of germline mutations in the cancer predisposing gene $\mathrm{CDH} 1$ in patients with orofacial clefts. Hum Mol Genet 22:919-926.

Wu MC, Lee S, Cai T, Li Y, Boehnke M, Lin X. 2011. Rare-variant association testing for sequencing data with the sequence kernel association test. Am J Hum Genet 89:82-93.

Yamaoka Y, Kato M, Asaka M. 2008. Geographic differences in gastric cancer incidence can be explained by differences between Helicobacter pylori strains. Intern Med 47:1077-1083.

Zeng W, Zhu J, Shan L, Han Z, Aerxiding P, Quhai A, Zeng F, Wang Z, Li H. 2015. The clinicopathological significance of $\mathrm{CDH} 1$ in gastric cancer: a meta-analysis and systematic review. Drug Des Devel Ther 13:2149-2157. 
Capítulo III

\title{
Envelhecimento e neurogenética
}

\author{
1. Introdução
}

\subsection{A urgência de pesquisas em Envelhecimento}

O segmento populacional que mais cresce em número no mundo é o de idosos e esta taxa é maior nos países em desenvolvimento. Até 2050, projeta-se que a proporção, nas pirâmides etárias, de idosos com mais de 60 anos irá de pouco menos de $20 \%$ para mais de $30 \%$ em países desenvolvidos e o salto será ainda maior em regiões em desenvolvimento (United Nations. Department of Economic and Social Affairs. Population Division.). Esta dinâmica sociodemográfica é percebida de forma ainda mais contundente pela queda progressiva dos níveis de fecundidade e, em particular nas últimas décadas, pelas reduções de mortalidade nas populações idosas, taxa agora deslocada para décadas etárias seguintes (Janssen et al., 2004). Países em desenvolvimento, em particular da América Latina e Caribe, atravessaram nos últimos anos uma mudança radical na distribuição etária e apresentam um comportamento sociodemográfico de transição, com muitos desafios em termos de saúde e inequalidades sociais. Comparativamente, os países desenvolvidos presenciaram o processo de envelhecimento após um relativo período de estabilidade e, mesmo assim, se deparam com desafios de mudança de estrutura social, econômica (no que se refere a idade produtiva e sistemas de previdência). Em países em desenvolvimento, estas disparidades são ainda mais graves. Torna-se, portanto, imprescindível compreender as condições e situações em que vivem os idosos de forma regiãoespecífica (Palloni et al., 2002).

A necessidade de compreender os idosos em âmbito local motivou a implantação, no Brasil, de iniciativas de grande porte, a exemplo da Coorte do Estudo SABE, apresentado no capítulo II como a principal amostra investigada neste trabalho (Lebrão e Laurenti, 2005) e a coorte de 
Bambuí, citada e comentada também no capítulo anterior (Lima-Costa et al., 2015). Neste contexto, o número de variáveis coletado pelo Estudo SABE vem permitindo a elaboração de dezenas de estudos que incluem a análise de diversos aspectos da população idosa de São Paulo como depressão e declínio cognitivo, condições gerais de saúde, saúde bucal, avaliação nutricional, atividades de vida diária, suporte familiar, uso de medicamentos e de serviços de saúde, renda e condição de emprego (Lebrão e Laurenti, 2005). A coleta de amostras biológicas para análises clínicas e extração de DNA, além da inclusão de outros protocolos, como a ressonância magnética do cérebro, se apresentam como uma extensão importante para modelar a interação entre as variáveis ambientais com variáveis biológicas e, potencialmente, contribuem para investigações acerca da biologia do envelhecimento, um tema que é recorrente no meio científico há décadas.

\subsection{Conceitos biológicos}

Do ponto de vista biológico, o processo de envelhecimento é complexo sob diversos ângulos diferentes. Em uma escala celular e molecular, algumas teorias correntes se dividem em duas principais linhas: a hipótese estocástica e a hipótese programada. A primeira se baseia na influência multifatorial sobre o processo do envelhecimento, que neste caso não seria um trato per se, mas uma consequência do acúmulo de eventos em diversos níveis. Pode-se exemplificar com os modelos de senescência, necrose e apoptose, decorrentes de uma série de alterações moleculares estruturais e funcionais decorrentes de mutações no genoma nuclear e mitocondrial, mudança na estequiometria de moléculas pequenas e radicais livres, alteração do colágeno, da membrana, erros aleatórios na síntese de macro e micro-moléculas, mudanças nos eixos endócrinos e imunológicos, entre outros. Todos os eventos são passíveis de interação em menor ou maior grau com o ambiente, direta ou indiretamente (Finch, 2007). O número extenso de variáveis e a dependência temporal de grande parte dos eventos listados acima torna os modelos de envelhecimento complexos e razoavelmente alinhados com a vastidão de evidências específicas encontradas para diversos sistemas biológicos, inclusive com os modelos que permitem a presença de variantes com grande influência em longevidade (Herndon et al., 2002). Haveria, portanto, uma pressão seletiva para os sistemas integrados dos organismos garantirem 
uma sobrevivência mínima pós-reprodutiva, seguida de um conjunto de eventos que globalmente não interferem na adaptabilidade.

A segunda linha de hipóteses se baseia nas teorias de envelhecimento programado, onde eixos centrais moduladores do processo de senescência são alvos de seleção natural e outras forças evolutivas que resultem em desfechos de mais ou menos longevidade. Estes eixos seriam responsáveis pelas cascatas secundárias de mudanças ocorridas com o passar do tempo e o componente estocástico seria resumível a eventos conectados direta ou indiretamente com os eixos (Skulachev et al., 2015). Segundo uma das propostas, o processo de envelhecimento seria mediado por (e decorrente de) um balanço entre as vias de nutrição e inflamação. Sugere-se que o excesso de ingestão de determinadas substâncias como açúcares, vitaminas e gorduras num sentido e a inflamação decorrente de infecções e doenças crônicas em outro sentido podem disparar vias de sinalização que modificam as taxas de crescimento celular e reparo de órgãos e sistemas, que modelariam o balanço entre manutenção e deterioração resultando em diferentes expecativas de vida (Finch, 2007). Este modelo é suportado, em diversos animais (inclusive seres humanos), por diversas evidências de associação entre medidas de sobrevivência e longevidade e variantes genéticas de componentes de vias de sinalização celular, metabolismo lipoprotéico, inibidores de ciclo celular, supressores tumorais, entre outros (Chung et al., 2010).

A despeito da relativa divergência entre as linhas teóricas que se referem ao processo do envelhecimento, a integração de evidências das duas hipóteses não parece improvável, ainda que complexa (Goldsmith, 2015). É relevante comentar que, uma vez colocada a longevidade como um fenótipo, há evidências de segregação familial de extensa longevidade (décadas além da expectativa de vida média) e há longevidade esporádica. A herdabilidade do fenótipo foi estimada em 20-25\% mas este valor é amplamente variável, em particular porque os estudos com gêmeos foram realizados e replicados em países com homogeneidade ambiental e socioeconômica, como mostrada na figura 6-A, retirada de Herskind e colaboradores (1996) e adaptada por Christensen (2006). Curiosamente, foi demonstrado que as chances de sobrevivência até os 80-94 anos para irmãos de centenários era de cerca de quatro vezes maior que de irmãos de indivíduos que morreram aos 74 anos, conforme a figura 6-B (Herskind et al., 1996; Perls et al., 1998; Christensen et al., 2006). Estes estudos estabelecem um limite superior para influência genética, uma vez que a segregação de tal fenótipo pode decorrer do compartilhamento genético e ambiental entre os familiares. 
As evidências para mecanismos comuns de envelhecimento são fortalecidas pela ocorrência de síndromes genéticas raras, essencialmente monogênicas, cujas manifestações simulam o envelhecimento precoce de sistemas, órgãos e tecidos, denominadas síndromes progeróides segmentais como Werner e Hutchinson-Gilford. Os genes afetados nestas desordem são de manutenção da estabilidade de DNA, por reparo de erros da maquinaria de replicação e suporte cromossômico, respectivamente WRN para síndrome de Werner e LMNA para HutchinsonGilford (Kipling et al., 2004). Outras síndromes como Cockaine também apresentam mutações em genes de reparo de DNA como ERCC6 e CKN1, conferindo maior suscetibilidade a condições de fotossensibilidade, além da degeneração de vários sistemas, manifestação típica de síndromes progeróides (Bertola et al., 2006).
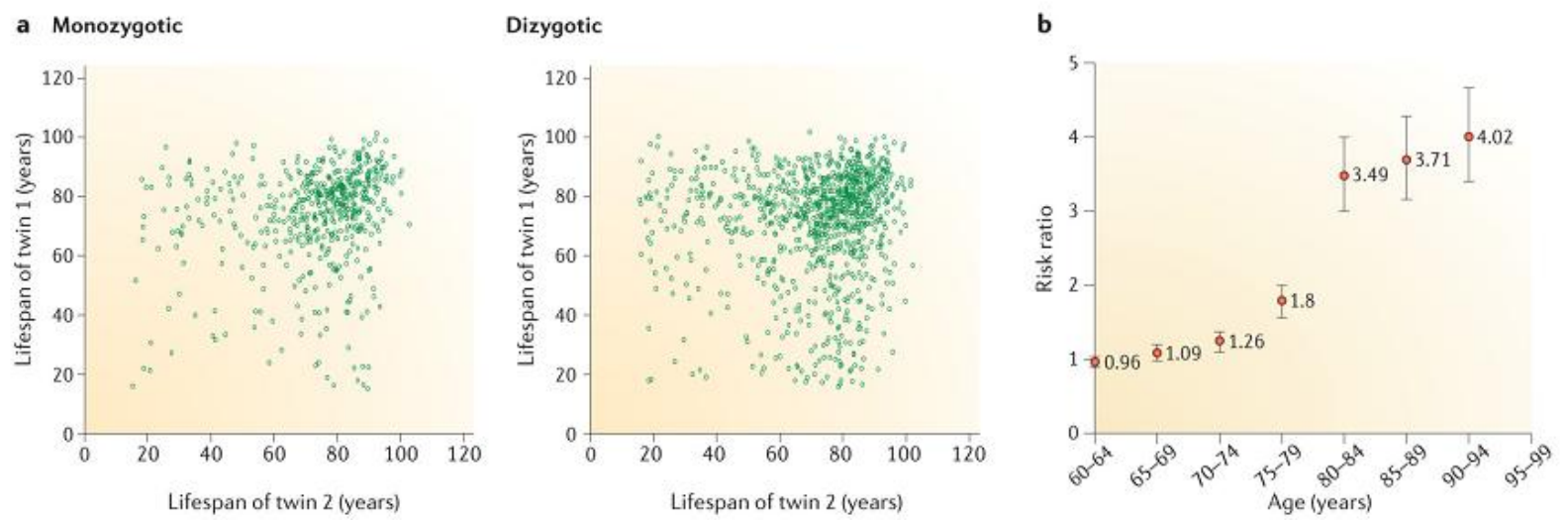

Figura 6. Evidências da contribuição genética para a longevidade. O estudo de Herskind e colaboradores (1996) com milhares de pares de gêmeos monozigóticos e dizigóticos dinamarqueses estimou a herdabilidade de $25 \%$, proporção de variação na sobrevivência devido a variação genética (A). A concordância é maior, em particular, nas décadas de vida após os 80 anos. Irmãos de centenários tem risco de viver mais cerca de quatro vezes maior que irmãos de pessoas que faleceram aos 73 anos de idade, conforme estudo realizado por Perls e colaboradores (1998). Figura retirada de revisão publicada por Christensen e colaboradores (2006).

As evidências de que genes possam influenciar a expectativa de vida apontam que mais do que variantes de longevidade, a ausência de um grande conjunto de variantes de risco parece ser o modelo mais aceitável para grande parte da população longeva. Foram identificadas variantes associadas a sobrevivência em: genes associados ao sistema cardiovascular como os transportadores de lipoproteínas $A P O E$ e $A P O C 3$, o transportador de triglicerídeos $M T T P$, a enzima de conversão de angiotensina I $A C E$; genes ligados ao metabolismo de glicose e sinalização celular como $I G F 1$ e $P I 3 K C B$; genes do sistema imunológico e resposta inflamatória 
como IL6 e TNFa; de respiração celular e metabolismo de radicais livres como CAT, SOD1 e SOD2. A interação entre as diversas variantes genéticas e o ambiente parece contribuir com grande parte da variabilidade da longevidade populacional (não-familial) (Christensen et al., 2006).

É um fato que as grandes mudanças socioeconômicas e tecnológicas, incluindo avanços da medicina e farmacologia, durante o século XX foram fatores decisivos no incremento da expectativa de vida em praticamente $100 \%$, uma vez que, normalmente, a variabilidade genômica se modifica de forma significativa em uma escala temporal mais lenta. Compreender a interação entre os fatores ambientais e genéticos para o envelhecimento é um desafio relevante, uma vez que a composição etária da sociedade já vem sendo afetada por essas rápidas mudanças. O envelhecimento cerebral está frequentemente ligado a declínio cognitivo e afeta de modo significativo a sociedade, através do acometimento de uma proporção grande dos indivíduos, gerando um declínio na qualidade de vida além de ônus nos investimentos em saúde pública e redução na produtividade.

\subsection{Envelhecimento cerebral}

As mudanças cerebrais ocorridas durante o processo de envelhecimento incluem a redução volumétrica, em particular do córtex frontal - responsável por controle de habilidades complexas comportamentais, atencionais e decisórias, e a deterioração da rede vascular. Estas principais mudanças, não ocorrem uniformemente no cérebro, são subjacentes a eventos de declínio cognitivo e aumento na propensão a episódios de derrames isquêmicos ou hemorrágicos. A etiologia destes eventos é heterogênea e diversas manifestações clínicas se iniciam a partir deles, a depender do local, da extensão e da associação com outros fatores (Peters, 2006).

Após os 40 anos, o volume e/ou massa do cérebro diminuem a uma taxa aproximada de 5\% por década, seguida de um aumento nesta taxa após os 70 anos. Apesar de reportarem que esta redução é devida a morte de células neuronais, evidências apontam que a diminuição do volume dos neurônios é parcialmente responsável e estes eventos variam muito de acordo com a região do cérebro, o sexo dos indivíduos e a interação com co-variáveis ambientais (Murphy et al., 1996; Peters, 2006; Mortera e Herculano-Houzel, 2012). 
A alteração mais comum associada ao envelhecimento cerebral é o declínio cognitivo, em particular as funções de memória, mas não limitadas a elas. Outras mudanças neurofisiológicas e comportamentais comumente vem associadas ao declínio cognitivo com diferentes efeitos de acordo com a interação entre as áreas cerebrais. Estas doenças são coletivamente denominadas demências.

\subsection{Demências}

Demência é um termo clínico que agrupa conjuntos de sintomas neuropsicológicos incluindo perda progressiva ou aguda de memória, dificuldades de raciocínio, resolução de problemas ou linguagem. O diagnóstico é primordialmente clínico com base na investigação de habilidades específicas que foram modificadas com o início da manifestação associada a investigação por métodos de imagem. No entanto, a confirmação (ou apropriação mais precisa de um diagnóstico) é dada por métodos histopatológicos. Estima-se que cerca de 25 milhões de pessoas no mundo vivam com demência, que entre 4 e 6 milhões de novos casos sejam diagnosticados por ano e a proporção de afetados em países em desenvolvimento é a maior (números obtido com dados de meta-análise de diversos estudos epidemiológicos sistemáticos) (Ferri et al., 2005).

Os tipos de demência mais comuns são demência frontotemporal, demência com corpos de Lewy, demência vascular e doença de Alzheimer (Hou et al., 2006). A demência frontotemporal (FTLD - Frontotemporal lobal dementia) é uma doença heterogênea neurodegenerativa que agrupa demências menos prevalentes (10-15 por 100 mil indivíduos) que as outras três formas de demência citadas acima, porém mais relevantes em jovens (são inclusive classificadas como présenis e, neste caso, estão abaixo, em prevalência, apenas das formas precoces de Alzheimer). Em decorrência da localização neuroanatômica mais afetada, FTLD se caracteriza clinicamente por comprometimentos comportamentais e de linguagem e são subclassificadas através do grau e especificidade de tais manifestações: desordens predominantemente comportamentais e de personalidade, demências semânticas e afasia primária progressiva. A sobreposição clínca de FTLD com doença de Alzheimer e outras demências dificulta o diagnóstico diferencial, resolvido em boa parte dos casos por exame neuropatológico. Associada a FTLD encontram-se agregados de proteína tau hiperfosforilada, inclusões contendo agregados de TDP-43 e ubiquitina (negativos para tau e $\alpha$-sinucleína), inclusões de neurofilamentos intermediários e outros (Lambert e 
Amouyel, 2010). Casos familiais de FTLD identificaram, inicialmente, mutações no gene que codifica a proteína tau $(M A P T)$, localizado no cromossomo 17. Posteriormente, uma série de mutações foram associadas na mesma região cromossômica no gene da progranulina $(G R N)$, que codifica uma proteína homônima implicada em reparo tecidual, desenvolvimento, inflamação e tumorigênese (Le Ber et al., 2008). Nos últimos anos, uma repetição de hexonucleotídeos em C9ORF72 foi associada consecutivamente com formas esporádicas de Esclerose Lateral Amiotrófica (ELA) e, em particular com formas de sobreposição clínica entre ELA e FTLD (Dejesus-Hernandez et al., 2011).

A demência com corpos de Lewy (DLB - dementia with Lewy bodies) é a terceira forma mais prevalente de demência neurodegenerativa com quase 30\% dos casos. Clinicamente, os pacientes de DLB apresentam características de cognição declinante com aspectos de dificuldade atencional, alucinações recorrentes e parkinsonismo (sinais de tremor, bradicinesia e rigidez) (Bogaerts et al., 2007). Sob uma perspectiva neuropatológica, o cérebro de pacientes acometidos por DLB apresenta uma distribuição e densidade variáveis de corpos de Lewy, agregados protéicos ricos em $\alpha$-sinucleína e associados com outros componentes como proteínas de neurofilamento e ubiquitina. A formação dos corpos de Lewy depende de diversos modificadores como PLK2 e calpaína e a distribuição destes agregados em outras regiões do cérebro como a substância negra no mesencéfalo, produtora de dopamina, pode contribuir com o desenvolvimento de doença de Parkinson e demência de Parkinson, além da sobreposição com doença de Alzheimer (Kim et al., 2014; Sekigawa et al., 2015). Identificou-se, em pacientes esporádicos, mutações associadas a DLB no gene que codifica a $\alpha$-sinucleína ( $S N C A)$ e em genes modificadores, além de diversos loci ligados a formas familiais de DLB (Bogaerts et al., 2007).

Demência vascular é responsável pela maior proporção de casos de demência, perdendo apenas para doença de Alzheimer. A estimativa pode estar subdimensionada devido à sobreposição clínica com diversas formas de demência, considerando que a fisiopatologia delas não é decorrente de contribuições independentes de eventos vasculares. Ainda, os eventos vasculares são comuns em idosos assintomáticos, dificultando ainda mais a distinção clínica (Gamaldo et al., 2006). Os fatores de risco para demência vascular incluem infartos cerebrais decorrentes de isquemias e derrames hemorrágicos (nominalmente acidentes vasculares cerebrais - AVCs) e podem acometer porções corticais e subcorticais. A depender da localização, calibre do vaso e extensão, diferentes desfechos podem ser observados (Leys et al., 2005; Price et al., 
2005). Clinicamente, há uma série de métodos avaliativos que incluem a observação do início da manifestação após episódios de AVCs e deterioração abrupta ou gradual da cognição, suportados por neuroimagens (Bowler, 2005). Como a demência vascular é um grupo tão heterogêneo, os fatores que contribuem para a doença também são diversos. Arterioloesclerose é o fator de risco mais comum e com causas genéticas e ambientais, associadas a distúrbios cardiovasculares frequentes como hipercolesterolemia e dislipidemias. O acúmulo de sítios afetados por arteriolosclerose pode contribuir para isquemia cerebral crônica e eventos agudos de infarto afetando global e localmente o fluxo sanguíneo no cérebro. Outros fatores como aneurismas, suscetibilidade a modificações estruturais nas paredes dos vasos e traumas também contribuem para o acúmulo de eventos vasculares e aumentam a probabilidade de desenvolvimento de demência vascular (Bowler, 2005). Em muitos casos, acometimentos vasculares estão associados à doença de Alzheimer e usa-se o termo "demências mistas" para classificar este grupo sobreposto.

A doença de Alzheimer (DA) é a forma mais prevalente de demência neurodegenerativa. O diagnóstico pode ter classificação definida (dependente da confirmação histopatológica), provável (com manifestação clínica típica, mas sem histologia) ou possível (clínica atípica, mas sem alternativa diagnóstica aparente), sendo que a primeira classificação é, até o momento, inviável do ponto de vista clínico. Estima-se que a sensibilidade e especificidade do diagnóstico provável de doença de Alzheimer seja de 65\% e 75\%, respectivamente (Cummings, 2004). A detecção de biomarcadores plasmáticos e em fluido cerebrospinal é uma estratégia para aprimorar o sucesso diagnóstico (Humpel, 2011). Os sinais clínicos clássicos de doença de Alzheimer são a perda de memória, deterioração da linguagem e deficiências visuo-espaciais. Na progressão da doença, anormalidades motoras e sensoriais, distúrbios de marcha e convulsões podem surgir. As características mais observáveis são as mudanças comportamentais com perda progressiva da capacidade de exercer funções complexas do cotidiano como escrever e fazer cálculos até as atividades básicas como se alimentar. Distúrbios de personalidade podem se desenvolver no início, como mudança de humor e apatia, e na progressão da doença a agitação e episódios psicóticos podem surgir (Cummings, 2004; Sleegers et al., 2010).

A patogênese de DA envolve processos cumulativos, cuja ordem de importância e de aparecimento são pouco claras: a produção e acúmulo de agregados extracelulares do peptídeo $\beta$ amilóide $(\mathrm{A} \beta)$, conhecidos como placas $\mathrm{A} \beta$, e a produção e acúmulo de agregados neurofibrilares 
intracelulares da forma hiperfosforilada da proteína tau, conhecidos como emaranhados neurofibrilares. Ambos os processos parecem estar envolvidos com a morte neuronal e disfunção sináptica decorrentes de neuroinflamação, oxidação e peroxidação lipídica, excitotoxicidade glutamatérgica. Caso estes processos ocorram nos cortices hipocampais e entorrinais, além do giro denteado, afetando a potenciação de longa duração, observa-se correlação com as mudanças neurológicas típicas do início de $\mathrm{AD}$ como perda da memória recente, cuja função é regulada por tais regiões cerebrais (Cummings, 2004; Sleegers et al., 2010).

A integração de diversas vias celulares e o papel de cada proteína nos processos subjacentes à fisiopatologia de AD resultam na sua classificação como doença complexa. Formas monogênicas de herança mendeliana são responsáveis por aproximadamente 5\% dos casos de Alzheimer, em sua maioria de acometimento precoce. Mutações na proteína precursora do peptídeo $\mathrm{A} \beta(A P P)$ e nas enzimas responsáveis por sua clivagem $\beta$ - e $\gamma$-secretases (montadas a partir dos produtos protéicos de PSEN1 e PSEN2, respectivamente) segregam em famílias e provocam a manifestação precoce de Alzheimer (início dos sintomas antes dos 50 anos) em padrão autossômico dominante (Sleegers et al., 2010). A maior parte dos casos de AD são esporádicos e com início dos sintomas após os 65-70 anos. Sugere-se, no entanto, que os processos físiopatológicos se acumulem muitos anos antes do início dos sintomas clínicos, e que estes eventos ocorram em maior ou menor grau em indivíduos que não manifestam sintomas, ou mesmo se estabilizem em pré-sintomas. Neste caso, há uma forma clínica de declínio cognitivo episódico e outros acometimentos comportamentais conhecido como comprometimento cognitivo leve (mild cognitive impairment-MCI) (Cummings, 2004; Jack et al., 2010). A figura 7 ilustra um modelo proposto para a disposição dos marcadores na progressão de DA (Jack et al., 2010). 


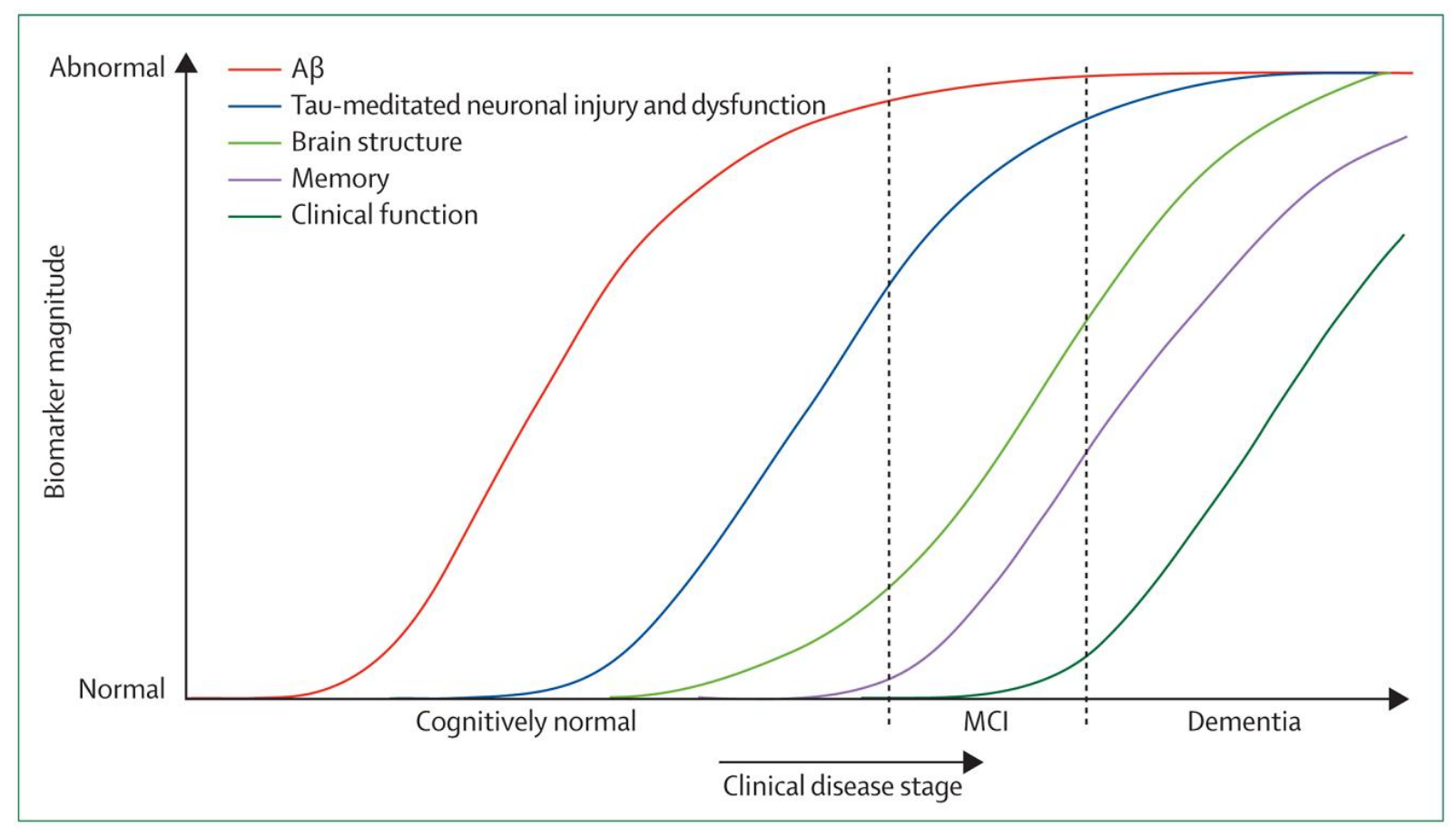

Figura 7. Modelo hipotético de dinâmica de biomarcadores e progressão para doença de Alzheimer (DA). Em função da magnitude dos marcadores (variando de níveis normais para anormais), o modelo propõe a progressão aferida por estado cognitivo, de normal, comprometimento cognitivo leve (MCI) e demência. Os marcadores A $\beta$, danos neuronais mediados por protéina tau hiperfosforilada e atrofia hipocampal são endofenótipos subjacentes aos marcadores clínicos que passam a aparecer com o declínio da memória de curto prazo e, posteriormente, com o comprometimento da função clínica geral. Figura retirada de Jack e cols. (2010).

O estabelecimento e progressão de $\mathrm{AD}$, particularmente as formas esporádicas tardias, parece ser resultante de uma combinação de variantes em diversos genes, como APOE, SORL1, CR1, $A C E, B I N 1, M A R K 4, P I C A L M$ e $C L U$ inclusive variantes de baixo efeito funcional nos genes responsáveis pelas formas precoces (APP, PSEN1 e PSEN2), como ilustrado no modelo da figura 8-A. As funções dos genes variam: indução de apoptose e formação de vesículas sinápticas (BIN1), diferenciação neuronal (MARK4) (Seshadri et al., 2010), transporte de lipídeos e neuroinflamação $(C L U)$, receptor do sistema complemento (CRl) (Lambert et al., 2009), sinalização de tráfico intracelular (Harold et al., 2009) e interação e direcionamento com a proteína precursora de $\mathrm{A} \beta$ (SORL1) (Rogaeva et al., 2007). A maior parte destes genes foi identificada através de estudos populacionais de GWAS, os quais recorrentemente confirmaram a associação do gene $A P O E$ que codifica a Apolipoproteína E (ApoE).

apoE é sintetizada por células hepáticas, neurônios, astrócitos e macrófagos e sua descrição inicial foi associada ao transporte de lipídeos e doenças cardiovasculares, sendo esta proteína um 
dos componentes que facilita a disponibilização plasmática de lipoproteínas ricas em triglicerídeos e colesterol, como remanescentes de quilomícrons, lipoproteínas de densidade muito baixas (very low density lipoproteins - VLDL), intermediárias e algumas classes de alta densidade (high density lipoproteins - HDL).

ApoE tem três isoformas comuns na população, apoE2, apoE3 e apoE4, de acordo com a combinação de resíduos de aminoácidos em duas posições da proteína: apoE3, a forma mais frequente é composta por um resíduo de cisteína na posição 112 e um de arginina na posição 158; apoE4, a segunda forma mais frequente, carrega duas argininas; e apoE2, duas cisteínas. As estruturas de cada isorforma caracterizam-se por diferentes afinidades por transporte de lipoproteínas e interação com receptores. apoE2 é deficiente na ligação ao receptor de LDL e homozigotos para esta variante estão em risco para o desenvolvimento de hiperlipoproteinemia tipo III. A conformação diferente de apoE4 permite a ligação com as maiores formas de VLDL ricos em triglicerídeos e está associada ao aumento nos níveis de triglicerídeos, risco de aterosclerose e está sobrerrepresentado em hiperlipidêmicos e pacientes com doenças cardiovasculares (Mahley et al., 2009).

A associação entre os alelos, $(A P O E \varepsilon 2, \varepsilon 3$ e $\varepsilon 4)$ codificantes para as três isoformas de apoE e DA foi identificada nos anos 1990 e replicada em todos os estudos populacionais por GWAS. É considerado o maior risco genético para $\mathrm{AD}$ em sua versão de início tardio, de herança multifatorial. O alelo $\varepsilon 4$ confere aumento de risco para DA e estima-se que seus valores de oddsratio (razão de chances) seja em torno de 3 para portadores de uma cópia de $\varepsilon 4$ e maior que 14 para homozigotos, em relação aos homizogotos para $\varepsilon 3$ (Genin et al., 2011). O mesmo estudo inferiu um odds-ratio de 0,56 para os portadores do alelo $\varepsilon 2$ (exceto pelos $\varepsilon 2 \varepsilon 4$ ), o que converge com a maior parte das conclusões de estudos em neurologia para a função protetora de $\varepsilon 2$ (Suri et al., 2013). Em virtude de sua associação com fenótipos cardiovasculares, o risco potencial para homozigotos de $\varepsilon 2$ ainda é foco de discussão (como discutido no manuscrito em anexo 10 deste capítulo). Há um aumento na expressão de apoE por astrócitos, microglia ativada e neurônios durante estresse e há evidências que a função de apoE na fisiopatologia de DA esteja envolvida com a produção de $\mathrm{A} \beta$, com a desestabilização da membranas lisossomais (e subsequente indução apoptótica), aumento da fosforilação de tau e neurotoxicidade (Mahley et al., 2006). A figura 8-B esquematiza um resumo dos prováveis mecanismos de envolvimento de apoE4 e DA. 
Estudos que envolvam um número grande de idosos, em particular aqueles que utilizam amostras representativas da população são importantes para o entendimento do estado de saúde cerebral desta faixa etária e oferecem uma oportunidade de investigar a variação normal dos fenótipos associados ao envelhecimento. Estudos longitudinais permitem o acompanhamento e progressão de determinadas manifestações como o declínio cognitivo, especialmente em países em desenvolvimento que contam com diversas diferenças socioeconômicas em relação aos tradicionais estudos de referência.

Neste sentido, pesquisar uma amostra populacional brasileira para conhecer a dinâmica de miscigenação a partir da análise genômica, além de uma referência para doenças raras e de início precoce, controles para doenças de baixa frequência populacional, permite investigar a variação genética e fenotípica em envelhecimento cerebral. 


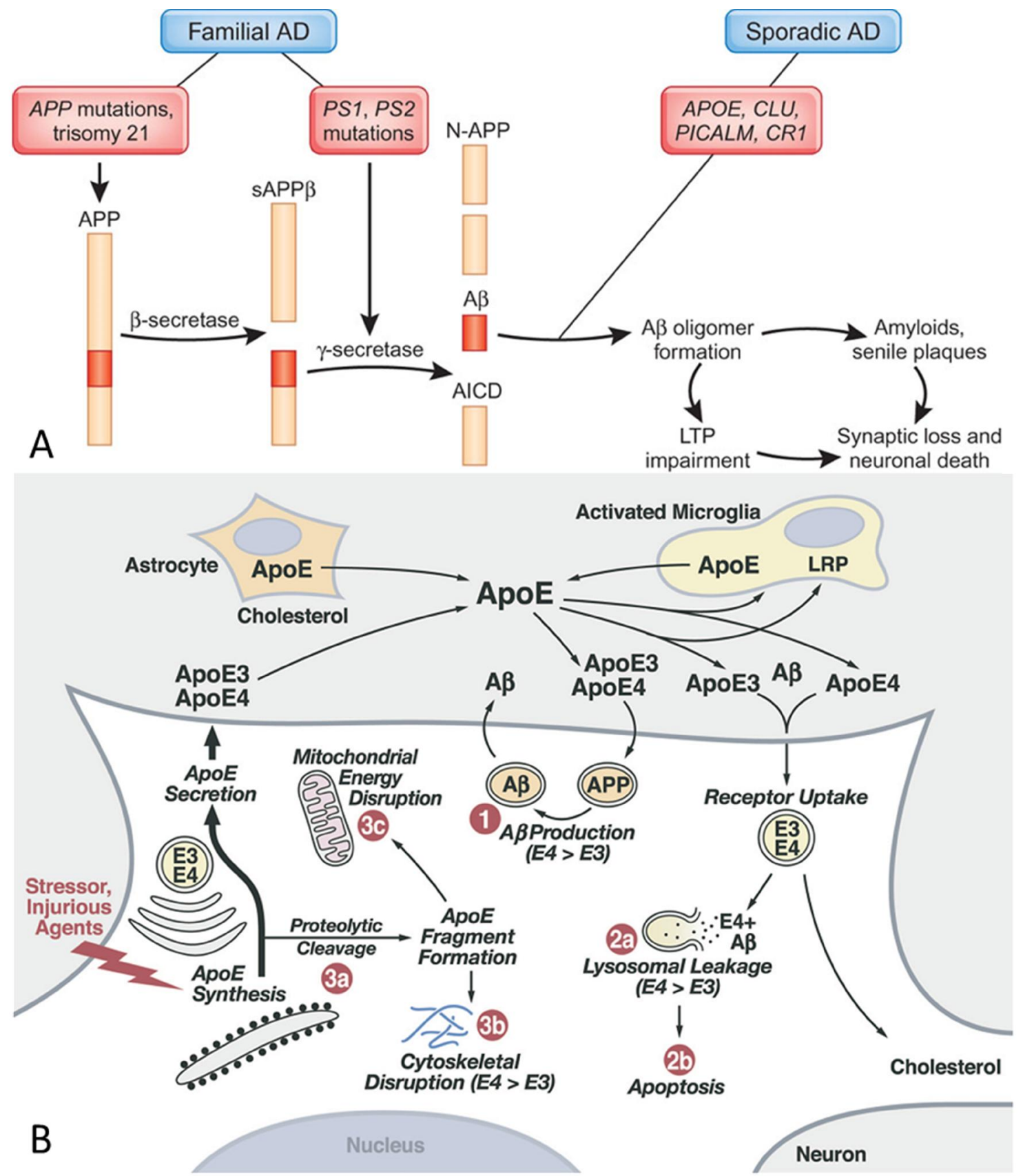

Figura 8. Genes associados à doença de Alzheimer (DA). Modelo de interação fisiopatológica entre os componentes associados a DA de padrão familial e esporádico (A). Figura retirada de van Es \& van den Berg (2009). Modelo de interação comparativa entre as isoformas de apoE (apoE3 e apoE4) e processos celulares envolvidos na fisiopatologia de DA (B), tais como produção de A $\beta$ (1), vazamento lisossomal (2a) seguido de apoptose (2b), proteólise de apoE (3a) com desestabilização do citoesqueleto (3b) e interação mitocondrial (3c). Figura retirada de Mahley e cols. (2006). 


\section{Objetivos}

Investigar marcadores associados a envelhecimento cerebral em amostras de idosos da cidade de São Paulo.

\section{Amostras e métodos}

\subsection{Amostra $80+$}

A ideia inicial de formar um banco de controles para doenças genéticas raras foi formulada pela Profa. Mayana através da coleta de DNA e informações de octagenários cognitivamente saudáveis. Este projeto convergiu com a colaboração do Estudo SABE, descrita no capítulo II, constituindo portanto uma amostra dupla de idosos da cidade de São Paulo: idosos com mais de 60 anos, em coortes representativas da população (Amostra SABE) e idosos com mais de 80 anos, cognitivamente saudáveis, selecionados através de divulgação na ampla mídia (Amostra 80+). Os participantes da Amostra 80+ foram recrutados pelo CEGH-CEL após cadastro por formulário online (www.tinyurl.com/80mais), o qual contém uma explicação sobre os projetos e perguntas sobre escolaridade, hábitos de vida e dominância manual.

Logo que o projeto se iniciou, uma colaboração com o Instituto do Cérebro do Instituto Israelita de Ensino e Pesquisa Albert Einstein (IIEPAE), através do Prof. Edson Amaro Junior, foi estabelecida objetivando realizar ressonância magnética (RM) do cérebro dos indivíduos da amostra composta (SABE e 80+). As metas desta colaboração incluem: construir uma base normativa de neuroimagem por RM para a faixa etaria dos indivíduos com mais de 60 anos; coletar uma série de dados sobre a manutenção e declínio do estado cognitivo e das funções clínicas dos idosos, de modo a construir modelos de progressão do envelhecimento normal e com co-morbidades. Os participantes desta etapa foram todos os indivíduos da amostra combinada $\mathrm{SABE}$ e $80+$ e os únicos critérios de exclusão foram os mesmos para exames de RM, descritos no item 5.4 a seguir. Todos os indivíduos da Amostra 80+ e aqueles participantes da Amostra SABE que vieram ao IIEPAE assinaram Termo de Consentimento Livre e Esclarecido aprovado pelo Comitê de Ética em Pesquisa do IIEPAE (1263-10), no Anexo 12. 


\subsection{Amostra Banco de Cérebros}

Neste período constituiu-se também uma colaboração com o Banco de Encéfalos Humanos, do Grupo de Estudos em Envelhecimento Cerebral da Faculdade de Medicina da USP, referido a partir deste ponto como Banco de Cérebros (BC). O BC foi estabelecido em 2003 com o objetivo de investigar envelhecimento cerebral através de um número grande de autópsias de indivíduos idosos - doadores que entram no Serviço de Verificação de Óbitos da Capital (SVOC) vinculado à Faculdade de Medicina da USP, e prover material de alta qualidade para uma rede de pesquisa multidisciplinar de investigações sobre processos de envelhecimento cerebral e doenças neurodegenerativas a ele associadas (Grinberg et al., 2007).

A amostra já conta com mais 3000 participantes e inclui cérebros de falecidos com mais de 50 anos a partir de consentimento de parente próximo, com termo devidamente aprovado pelo Comitê de Ética em Pesquisa local. Uma série de questionários com validação demonstrada são realizados com os familiares, com o intuito de se estabelecer uma medição do estado cognitivo e outros aspectos neurocomportamentais a respeito do participante. Em seguida, após autópsia, o cérebro (e outros órgãos) é retirado para análises diversas do $\mathrm{BC}$, em particular estudos histopatológicos para averiguação de marcadores ligados a demências e fenótipos vasculares (entre eles, quantidade e distribuição de $\mathrm{A} \beta, \alpha$-sinucleína, proteína tau e ubiquitina) (Grinberg et al., 2007).

\subsection{Processamento do DNA}

Os participantes da Amostra 80+ tem o sangue periférico coletado em tubos em procedimento semelhante ao descrito para a Amostra SABE no capítulo II, item 3.3. As amostras de DNA do $\mathrm{BC}$ foram extraídas de forma semelhante, mas obtidas de sangue da cavidade cardíaca no início das autópsias.

O gene $A P O E$ foi genotipado para os três polimorfismos comuns previamente associados a DA e doenças cardiovasculares. A genotipagem foi realizada através de amplificação aleloespecífica por PCR em tempo-real (Roche LightCyclr 480) por protocolo semelhante ao descrito por Calero e colaboradores (2009). Em duplicatas, cada alelo é interrogado após amplificação de todos os alelos com três pares de oligonucleotídeos variando apenas pelos polimorfismos em 
questão. Os fragmentos de DNA amplificados contendo o alelo interrogado são amplificados de maneira mais eficiente e se aproximam da fase $\log$ de amplificação ao menos 5 ciclos antes das reações de PCR nos fragmentos sem os alelos, possibilitando o contraste das curvas e a inferência direta do genótipo (Calero et al., 2009).

\subsection{Ressonância magnética do cérebro}

Todos os exames são realizados em equipamento de 3 Tesla Magnéton Trio: A Tim System (Siemens Medical, Alemanha), localizado no setor de RM do HIAE (Hospital Israelita Albert Einstein) com a versão de software Syngo B15, utilizando-se de bobina de crânio dedicada de 32 elementos.

O protocolo consiste na aquisição das sequintes sequências:

Duas sequências de localização, a primeira em três planos e a segunda sagital, a fim de orientar a aquisição de imagens através da normalização por macroestruturas neuroanatômicas.

Duas sequências de aquisição volumétrica, objetivando a montagem de um mapa estrutural T1 (tempo de relaxamento do spin), com alta resolução das estruturas anatômicas. Este protocolo possibilita avaliar a variação de espessuras, áreas e volumes de regiões do cérebro associadas a funções assimetricamente ativadas. A análise foi realizada utilizando o pacote FreeSurfer (vFS5.1.0 release, http://surfer.nmr.mgh.harvard.edu/) que tem o princípio de derivar modelos de superfície cortical de cada imagem $\mathrm{T} 1$, em processos automatizados descritos por Fischl e colaboradores (1999) e Dale e colaboradores (1999).

Uma sequência de difusão (DTI) com o objetivo de analisar a conectividade entre diferentes regiões corticais e subcorticais através de inferência, pelo cálculo da anisotropia fracionada (FA), do percurso da água nas fibras axonais subcorticais (substância branca).

Uma sequência de RM funcional será adquirida: o estado de repouso (resting state), para avaliar a conectividade do modo padrão de funcionamento cerebral (Li et al., 2009).

\subsection{Questionários}

Os questionários aplicados incluem a avaliação do humor Visual Analog Mood Scale (VAMS) realizado antes e depois dos protocolos de RM conforme padrão internacional estabelecido 
(Anexo 13), perguntas gerais sobre saúde (Anexo 14), questionário de dominância motora Edinburgh Handedness Inventory (Anexo 15) e questionário de depressão de Beck (Anexo 16).

\subsection{Testes cognitivos e funcionais}

Os testes cognitivos utilizados durante esta etapa foram o Mini Mental State Examination (MMSE) e o 3MS, uma expansão do MMSE. O teste consiste em uma série de perguntas agrupadas em 6 dimensões: orientação, retenção, atenção e cálculo, evocação, linguagem e habilidade construtiva (Anexo 17). Através de uma escala de até 100 pontos, o teste permite indicar com razoável especificidade os indivíduos com declínio cognitivo (3MS $\leq 75$, equivalente a MMSE $\leq 26$ ) (Folstein et al., 1975; Teng e Chui, 1987).

Os testes funcionais sobre habilidade e força manual foram coordenados pela Dra. Telma Busch, no IIEPAE, que conduziu um projeto de pós-doutorado na área de gerontologia funcional, fragilidade e correlação entre fenótipos clínicos e dados de ressonância do cérebro. A habilidade manual é medida através de um tabuleiro de pinos (Pin Pegboard), onde é aferido o número de pinos colocados com cada mão durante o prazo de 30 segundos (três aferições por mão). A força manual é medida com um dinamômetro digital (três aferições por mão). Outra medição funcional realizada foi a velocidade de marcha, através de um teste denominado Time Up and Go (TUG), que consiste na medição do tempo de caminhada em passo habitual numa distância de três metros.

4. Resultados e discussão

Dos 1476 participantes da amostra combinada SABE e 80+, 618 foram até o IIEPAE e 567 realizaram ao menos um protocolo de RM. As distribuições dos indivíduos da amostra $80+$ por idade e sexo estão ilustradas nas tabelas 4 e 5, respectivamente, incluindo a subproporção dos indivíduos que fizeram $\mathrm{RM}$ até o momento. As distribuições dos indivíduos da amostra SABE que realizaram RM por idade e sexo estão representadas nas tabelas 6 e 7, respectivamente.

Os testes cognitivos 3MS e MMSE mostraram alta correlação (ver figura 9), e a maior dispersão de mesmos valores de MMSE em uma faixa de valores de 3MS sugere que a versão expandida do teste seja mais sensível, em concordância com outros estudos (Grace et al., 1995). 
Os resultados do 3MS (0 a 100) em função da idade, de acordo com a amostra, indicam um declínio cognitivo esperado, inclusive na amostra 80+ (figura 10, tabelas 8 e 9).

Tabela 4. Distribuição dos indivíduos da amostra $80+$ por idade

\begin{tabular}{ccccc}
\hline & \multicolumn{2}{c}{$\mathbf{8 0 +}$ Amostra Total } & \multicolumn{2}{c}{$\mathbf{8 0 +}$ RM } \\
\hline Classes de idade (anos)* & $\mathbf{N}$ & Frequência (\%) & N & Frequência (\%) \\
\hline $70-80$ & 9 & 6,77 & 8 & 9,09 \\
$80-90$ & 104 & 78,20 & 68 & 77,27 \\
$90-100$ & 17 & 12,78 & 12 & 13,64 \\
$100+$ & 3 & 2,26 & 0 & 0,00 \\
\hline Total & 133 & 100,00 & 88 & 100,00 \\
\hline *Limite superior de classe não incluso & &
\end{tabular}

Tabela 5. Distribuição dos indivíduos da amostra $80+$ por sexo

\begin{tabular}{|c|c|c|c|c|c|c|}
\hline \multirow[b]{2}{*}{ Sexo } & \multicolumn{3}{|c|}{ 80+ Amostra Total } & \multicolumn{3}{|c|}{ 80+ RM } \\
\hline & $\mathbf{N}$ & $\begin{array}{l}\text { Frequência } \\
\qquad(\%)\end{array}$ & $\begin{array}{c}\text { Idade } \\
\text { (média } \pm \text { d.p.) }\end{array}$ & $\mathbf{N}$ & $\begin{array}{c}\text { Frequência } \\
(\%)\end{array}$ & $\begin{array}{c}\text { Idade } \\
\text { (média } \pm \text { d.p.) }\end{array}$ \\
\hline Masculino & 62 & 46,62 & $84,34 \pm 4,24$ & 40 & 45,45 & $84,21 \pm 4,35$ \\
\hline Feminino & 71 & 53,38 & $85,48 \pm 5,71$ & 48 & 54,55 & $84,97 \pm 4,52$ \\
\hline Total & 133 & 100,00 & $73,16 \pm 5,09$ & 88 & 100,00 & $84,63 \pm 4,44$ \\
\hline
\end{tabular}

Tabela 6. Distribuição dos indivíduos da amostra SABE por idade e RM

\begin{tabular}{ccc}
\hline & \multicolumn{3}{c}{ SABE RM } \\
\hline Classes de idade (anos)* & N & Frequência (\%) \\
\hline $60-70$ & 236 & 49,27 \\
$70-80$ & 151 & 31,52 \\
$80-90$ & 80 & 16,71 \\
$90+$ & 12 & 2,50 \\
\hline Total & 479 & 100,00 \\
\hline *Limite superior de classe não incluso
\end{tabular}

Tabela 7. Distribuição dos indivíduos da amostra SABE por sexo e RM

\begin{tabular}{cccc}
\hline & \multicolumn{3}{c}{$\mathbf{8 0 + \mathbf { R M }}$} \\
\hline Sexo & $\mathbf{N}$ & $\begin{array}{c}\text { Frequência } \\
\mathbf{( \% )}\end{array}$ & $\begin{array}{c}\text { Idade } \\
\text { (média } \pm \text { d.p.) }\end{array}$ \\
\hline Masculino & 165 & 34,45 & $72,03 \pm 7,62$ \\
Feminino & 314 & 65,55 & $71,60 \pm 6,31$ \\
\hline Total & 479 & 100,00 & $71,75 \pm 8,51$ \\
\hline
\end{tabular}


Tabela 8. Proporção dos indivíduos da amostra SABE com declínio cognitivo por idade

\begin{tabular}{|c|c|c|c|c|c|c|c|}
\hline & \multicolumn{3}{|c|}{$3 \mathrm{MS}>78$} & \multicolumn{3}{|c|}{$3 \mathrm{MS} \leq 77$} & \multirow[b]{2}{*}{ OR } \\
\hline $\begin{array}{l}\text { Classes de idade } \\
\quad \text { (anos)* }\end{array}$ & $\mathbf{N}$ & $\begin{array}{l}\text { Proporção no } \\
\text { grupo (\%) }\end{array}$ & $\begin{array}{l}\text { Proporção } \\
\text { total }\end{array}$ & $\mathbf{N}$ & $\begin{array}{l}\text { Proporção no } \\
\text { grupo (\%) }\end{array}$ & $\begin{array}{l}\text { Proporção } \\
\text { total }\end{array}$ & \\
\hline $60-70$ & 195 & 56,20 & 37,14 & 63 & 35,39 & 12,00 & 0,32 \\
\hline $70-80$ & 111 & 31,99 & 21,14 & 52 & 29,21 & 9,90 & 0,47 \\
\hline $80-90$ & 38 & 10,95 & 7,24 & 53 & 29,78 & 10,10 & 1,39 \\
\hline $90+$ & 3 & 0,86 & 0,57 & 10 & 5,62 & 1,90 & 3,33 \\
\hline Total no grupo & 347 & 100 & 66,10 & 178 & 100 & 33,90 & \\
\hline
\end{tabular}

Tabela 9. Proporção dos indivíduos da amostra 80+ com declínio cognitivo por idade

\begin{tabular}{|c|c|c|c|c|c|c|c|}
\hline & & $3 \mathrm{MS}>78$ & & & $3 \mathrm{MS} \leq 77$ & & \\
\hline $\begin{array}{l}\text { Classes de idade } \\
\text { (anos)* }\end{array}$ & $\mathbf{N}$ & $\begin{array}{l}\text { Proporção no } \\
\text { grupo (\%) }\end{array}$ & $\begin{array}{l}\text { Proporção } \\
\text { total }\end{array}$ & $\mathbf{N}$ & $\begin{array}{l}\text { Proporção no } \\
\text { grupo (\%) }\end{array}$ & $\begin{array}{c}\text { Proporção } \\
\text { total }\end{array}$ & OR \\
\hline $60-70$ & 9 & 8,26 & 7,26 & 0 & 0,00 & 0,00 & 0,00 \\
\hline $70-80$ & 90 & 82,57 & 72,58 & 8 & 53,33 & 6,45 & 0,09 \\
\hline $80-90$ & 9 & 8,26 & 7,26 & 5 & 33,33 & 4,03 & 0,56 \\
\hline $90+$ & 1 & 0,92 & 0,81 & 2 & 13,34 & 1,61 & 2,00 \\
\hline Total no grupo & 109 & 100,00 & 87,90 & 15 & 100,00 & 12,10 & \\
\hline
\end{tabular}

A dinâmica das proporções entre indivíduos com e sem declínio é bastante distinta entre as amostras SABE e 80+, provavelmente devido a natureza da amostragem e resultante de variação socioeconômica entre as amostras. Isto é particularmente importante para a amostra SABE, a qual inclui uma proporção de cerca de $30 \%$ de analfabetos e analfabetos funcionais, ao contrário de uma proporção maior de indivíduos de alta escolaridade na amostra $80+$. O teste de estado cognitivo 3MS e especialmente as referências de pontos de corte não estão ajustadas para esse tipo de distribuição. Os valores de odds ratio (OR) calculados a partir das proporções totais (declínio em relação a não declínio) aumentam com as décadas de vida, algo esperado (tabelas 8 e 9). A inflexão dos valores se dá na década dos 80 anos de vida para a amostra SABE (OR=1,39, tabela 8), momento em que há mais chances de se ter algum sinal de declínio cognitivo nesta análise de separação por classes. Apesar dos números dentro de cada classe dos indivíduos da amostra $80+$ serem reduzidos, é possivel notar a tendência a melhores prognoses de estado cognitivo neste grupo em relação à amostra SABE, ainda que na década de vida após os 90 as chances sejam desfavoráveis também para o grupo selecionado de octogenários (tabela 9). É 
fundamental salientar que os valores de corte para 3MS (78) não foram validados para populações com uma proporção de analfabetos, como é o caso da amostra SABE e, adicionalmente, não foram realizadas normalizações pelo nível de escolaridade. É provável, portanto, que parte dos dados estejam subestimando o estado cognitivo, em particular entre os mais jovens com baixa escolaridade.

A análise da espessura cortical global dos cérebros foi realizada para 392 indivíduos (341 da amostra SABE e 51 da amostra 80+) utilizando critérios de exclusão por um ou mais parâmetros: qualidade das neuroimagens, falta de dados de cognição e escolaridade, transtornos psiquiátrico, cognitivos ou sintomas depressivos moderados e graves. Esta etapa de análise foi realizada pela Dra. Joana Ballardin. Um resumo dos resultados está representado na figura 11.

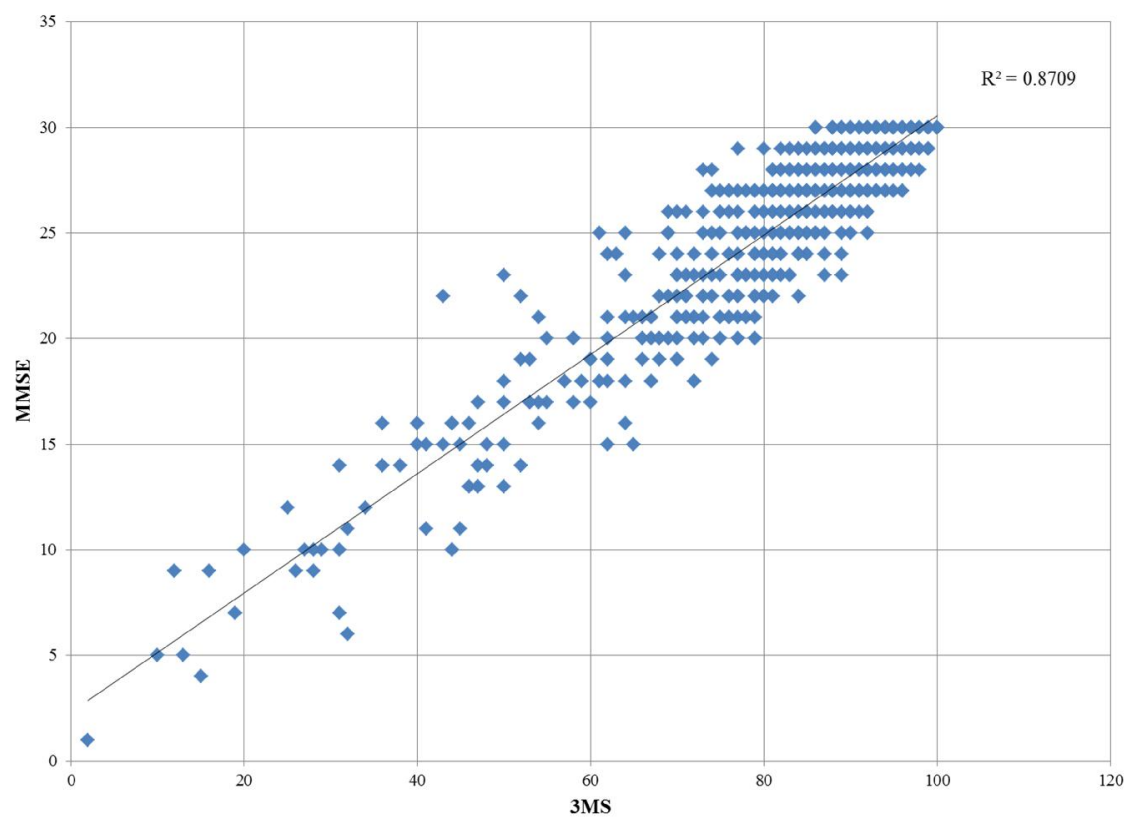

Figura 9. Correlação entre resultados dos testes cognitivos 3 MS (varia de 0 a 100) e MMSE (varia de 0 a 30 ). Valor de $\mathrm{R}^{2}$ da regressão linear indicado na figura. 


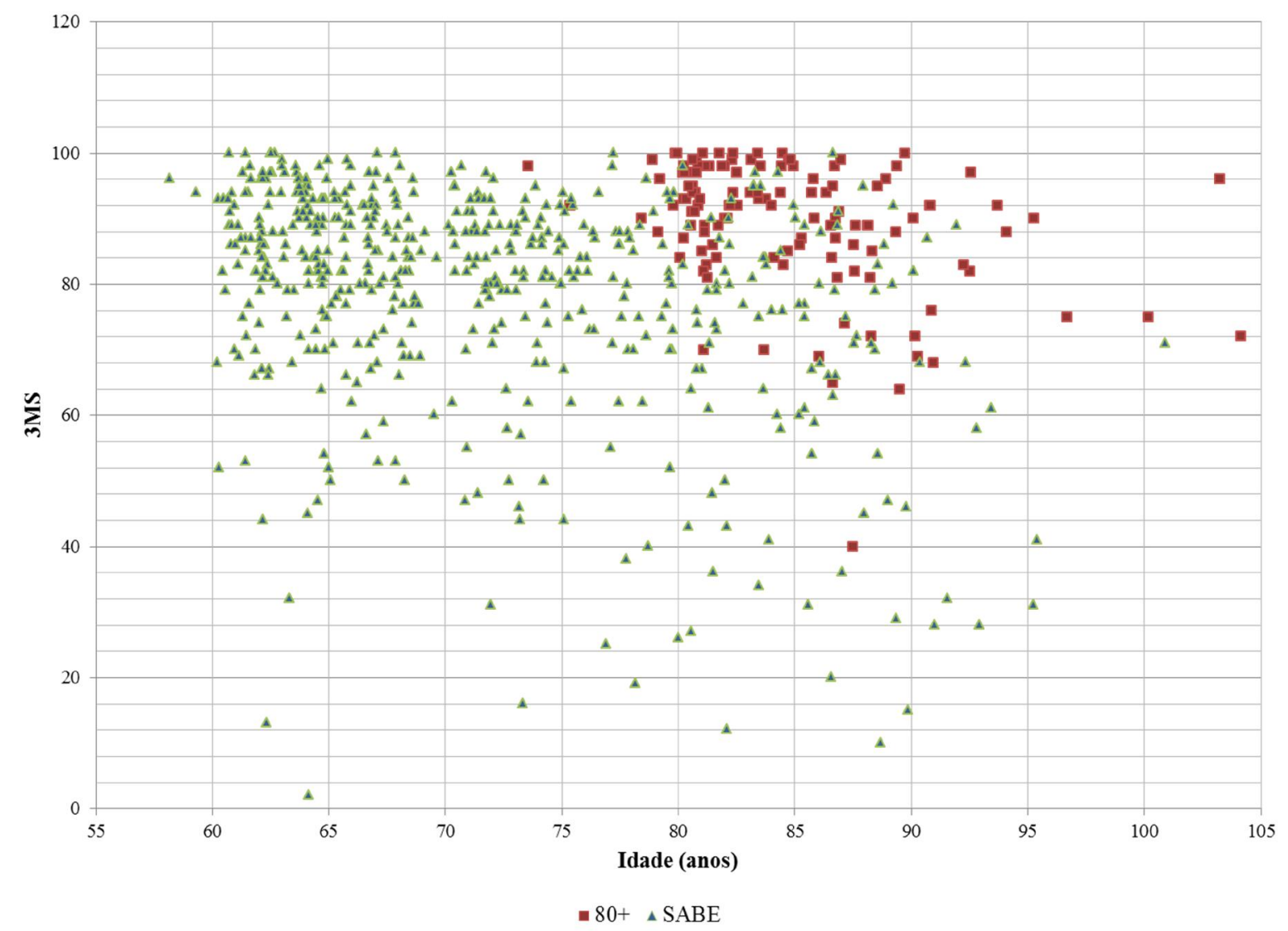

Figura 10. Resultados da avaliação do estado cognitivo por 3MS em função da idade, para as amostras $80+$ e SABE.
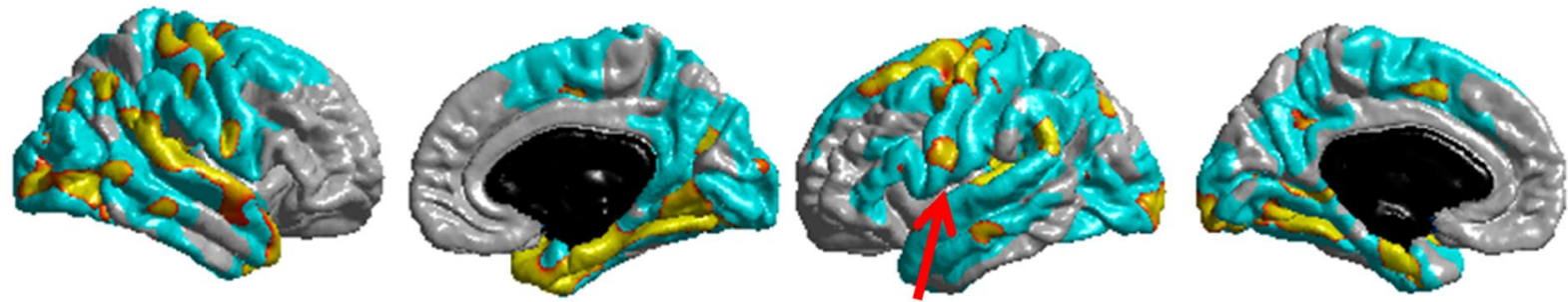

Figura 11. Redução da espessura cortical com a idade. Análise realizada em Freesurfer. A escala de cores representa reduções significativas: em azul numa análise por clusters de vértices (agrupamentos de vértices - as unidades bidimensionais da análise de superfície); em amarelo, as regiões mais significativas por vértices. Hemisfério direito (faces direita/superior e esquerda, respectivamente) e hemisfério esquerdo (faces esquerda/superior e direita, respectivamente).

Os resultados resumidos na figura 11, apontam para uma redução global da espessura cortical média com a idade (regiões em cores). No hemisfério esquerdo, observa-se redução mais significativa no giro pré-central (onde se localiza o córtex motor primário) e a região pars 
opercularis do giro frontal inferior (apontado pela seta vermelha, onde se localiza a área de Broca, responsável pela fala). Estas regiões são descritas por apresentarem redução mais acentuada com a idade (Lemaitre et al., 2012). No hemisfério esquerdo, na região do córtex medial temporal observa-se redução mais acentuada, em conformidade com o que foi descrito previamente (Storsve et al., 2014). Uma análise aprofundada sobre estes resultados, incluindo o parâmetro escolaridade como co-variável, está em elaboração para publicação em breve.

Os dados sobre genótipos de $A P O E$ foram utilizados inicialmente com a amostra do $\mathrm{BC}$ como co-variável em estudo colaborativo que investigou a influência da ancestralidade africana associada a mudanças neuropatológicas comuns às demências. Este estudo foi um dos únicos até a presente data a sugerir que a ancestralidade africana está associada com a menor presença de agregados de $\mathrm{A} \beta$ após ajuste para idade, sexo, presença do alelo $\varepsilon 4$ de $A P O E$, nível socioeconômico e escolaridade (Schlesinger et al., 2013), como descrito no artigo em anexo (Anexo 9).

Ao genotipar cerca de 1100 indivíduos da amostra SABE, observou-se a ocorrência de desvio do equilíbrio Hardy-Weinberg (Hardy-Weinberg equilibrium - HWE). Assume-se que uma população está em aderência estatística ao HWE quando a proporção de genótipos é esperada a partir da frequência alélica, considerando a independência entre os alelos e ausência de migração ou mortalidades seletivas, além de consanguinidade e subestruturas populacionais (Foulkes, 2009). O mesmo desvio não foi encontrado na amostra $\mathrm{BC}$ de mesmo número de indivíduos. Uma discussão sobre o potencial risco em portadores do genótipo $A P O E \varepsilon 2$ \&2, a relação com as frequências deste e dos outros genótipos de $A P O E$ e das origens do desvio estão descritos em um manuscrito no Anexo 10.

Os resultados obtidos sobre velocidade de marcha nos idosos da amostra SABE estão descritos na publicação anexada (Anexo 11). O estudo indicou que a diminuição da velocidade de marcha está associada com idade, escolaridade, dificuldade de desempenhar funções cotidianas, presença de doença cardio vascular e sedentarismo. Estes marcadores servem para modelar aspectos complexos com a fragilidade em idosos e tais modelos podem ser enriquecidos com os dados de variabilidade genética e endofenótipos cerebrais. 


\section{Considerações finais e perspectivas}

A rede de colaborações com grandes estudos populacionais vem demonstrando ser uma estratégia importante para compreensão sobre o envelhecimento da população brasileira e os mecanismos e fatores específicos para a progressão de doenças comuns do envelhecimento. É relevante ressaltar que trata-se de pesquisa inovadora no Brasil pois grande parte dos estudos com números consideráveis de participantes submetidos a ressonância magnética e genômica são conduzidos em países desenvolvidos. As diferenças socioeconômicas, ambientais e, no caso do Brasil, a rica diversidade genética compõem um cenário favorável para a realização de estudos sobre marcadores de doenças e fatores de proteção a doenças do envelhecimento.

As perspectivas imediatas são de continuar coletando neuroimagens dos participantes das amostras SABE e 80+ no intuito de acompanhar mudanças cerebrais ao longo do tempo. Com os dados obtidos na RM, pretende-se criar modelos de interação entre os marcadores para observar o efeito conjunto. Estudos de associação com variantes genéticas podem ser conduzidos pois, apesar do número limitado de amostras para a realização de investigação em fenótipos complexos, há a perspectiva de sequenciar os genomas completos dos indivíduos, o que permite a aplicação de outras estratégias de estudos de variabilidade. Pretende-se intensificar a colaboração entre os grupos, em particular com o Banco de Cérebros, objetivando compreender o efeito de variantes raras em endofenótipos cerebrais e ampliar os estudos do efeito da miscigenação populacional na progressão dos fenótipos associados ao envelhecimento cerebral. 


\section{Referências bibliográficas}

BERTOLA, D. R. et al. Cockayne syndrome type A: novel mutations in eight typical patients. J Hum Genet, v. 51, n. 8, p. 701-5, 2006.

BOGAERTS, V. et al. A novel locus for dementia with Lewy bodies: a clinically and genetically heterogeneous disorder. Brain, v. 130, n. 9, p. 2277-2291, 2007.

BOWLER, J. V. Vascular cognitive impairment. Journal of Neurology, Neurosurgery \& Psychiatry, v. 76, n. suppl_5,p. v35-v44, 2005.

CALERO, O. et al. Apolipoprotein E genotyping method by real time PCR, a fast and cost-effective alternative to the TaqMan and FRET assays. J Neurosci Methods, v. 183, n. 2, p. 238-40, 2009.

CHRISTENSEN, K.; JOHNSON, T. E.; VAUPEL, J. W. The quest for genetic determinants of human longevity: challenges and insights. Nat Rev Genet, v. 7, n. 6, p. 436-48, 2006.

CHUNG, W. H. et al. The role of genetic variants in human longevity. Ageing Res Rev, v. 9 Suppl 1, p. S67-78, 2010 .

CUMMINGS, J. L. Alzheimer's disease. N Engl J Med, v. 351, n. 1, p. 56-67, 2004.

DEJESUS-HERNANDEZ, M. et al. Expanded GGGGCC hexanucleotide repeat in noncoding region of C9ORF72 causes chromosome 9p-linked FTD and ALS. Neuron, v. 72, n. 2, p. 245-56, 2011.

FERRI, C. P. et al. Global prevalence of dementia: a Delphi consensus study. Lancet, v. 366, n. 9503, p. 2112-$2117,2005$.

FINCH, C. The biology of human longevity : inflammation, nutrition, and aging in the evolution of life spans. 1st. Burlington, MA: Academic Press, 2007. xiii, 626 p. ISBN 9780123736574

FOLSTEIN, M. F.; FOLSTEIN, S. E.; MCHUGH, P. R. "Mini-mental state". A practical method for grading the cognitive state of patients for the clinician. J Psychiatr Res, v. 12, n. 3, p. 189--198, 1975.

FOULKES, A. S. Applied statistical genetics with R : for population-based association studies. New York: Springer Verlag, 2009. xxiii, 252 p. ISBN 9780387895536.

GAMALDO, A. et al. Effect of a clinical stroke on the risk of dementia in a prospective cohort. Neurology, v. 67, n. 8, p. 1363-1369, 2006.

GENIN, E. et al. APOE and Alzheimer disease: a major gene with semi-dominant inheritance. Mol Psychiatry, v. 16, n. 9, p. 903-7, 2011.

GOLDSMITH, T. C. Solving the Programmed/Non-Programmed Aging Conundrum. Curr Aging Sci, v. 8, n. 1, p. 34-40, 2015

GRACE, J. et al. Folstein vs modified Mini-Mental State Examination in geriatric stroke. Stability, validity, and screening utility. Arch Neurol, v. 52, n. 5, p. 477-84, 1995.

GRINBERG, L. T. et al. Brain bank of the Brazilian aging brain study group - a milestone reached and more than 1,600 collected brains. Cell Tissue Bank, v. 8, n. 2, p. 151-62, 2007.

HAROLD, D. et al. Genome-wide association study identifies variants at CLU and PICALM associated with Alzheimer's disease. Nat Genet, v. 41, n. 10, p. 1088-93, 2009.

HERNDON, L. A. et al. Stochastic and genetic factors influence tissue-specific decline in ageing C. elegans. Nature, v. 419, n. 6909, p. 808-14, 2002. 
HERSKIND, A. M. et al. The heritability of human longevity: a population-based study of 2872 Danish twin pairs born 1870-1900. Hum Genet, v. 97, n. 3, p. 319-23, 1996.

HOU, C. E. et al. Frequency of Dementia Etiologies in Four Ethnic Groups. Dementia and Geriatric Cognitive Disorders, v. 22, n. 1, p. 42-47, 2006.

HUMPEL, C. Identifying and validating biomarkers for Alzheimer's disease. Trends Biotechnol, v. 29, n. 1, p. 2632, 2011.

JACK, C. R., JR. et al. Hypothetical model of dynamic biomarkers of the Alzheimer's pathological cascade. Lancet Neurol, v. 9, n. 1, p. 119-28, 2010.

JANSSEN, F. et al. Trends in old-age mortality in seven European countries, 1950-1999. J Clin Epidemiol, v. 57 , n. 2, p. 203-16, 2004.

KIM, W. S.; KAGEDAL, K.; HALLIDAY, G. M. Alpha-synuclein biology in Lewy body diseases. Alzheimers Res Ther, v. 6, n. 5, p. 73, 2014.

KIPLING, D. et al. What can progeroid syndromes tell us about human aging? Science, v. 305, n. 5689, p. 1426-31, 2004.

LAMBERT, J.-C.; AMOUYEL, P. Deciphering genetic susceptibility to frontotemporal lobar dementia. Nature Genetics, v. 42, n. 3, p. 189-190, 2010.

LAMBERT, J. C. et al. Genome-wide association study identifies variants at CLU and CR1 associated with Alzheimer's disease. Nat Genet, v. 41, n. 10, p. 1094-9, 2009.

LE BER, I. et al. Phenotype variability in progranulin mutation carriers: a clinical, neuropsychological, imaging and genetic study. Brain, v. 131, n. 3, p. 732-746, 2008

LEBRÃO, M. L.; LAURENTI, R. Saúde, bem-estar e envelhecimento: o estudo SABE no Município de São Paulo. Revista Brasileira de Epidemiologia, v. 8, p. 127-141, 2005.

LEMAITRE, H. et al. Normal age-related brain morphometric changes: nonuniformity across cortical thickness, surface area and gray matter volume? Neurobiol Aging, v. 33, n. 3, p. 617 e1-9, 2012.

LEYS, D. et al. Poststroke dementia. The Lancet Neurology, v. 4, n. 11, p. 752-759, 2005.

LI, Z. et al. Asymmetric connectivity reduction and its relationship to "HAROLD" in aging brain. Brain Res, v. 1295 , p. 149-58, 2009.

LIMA-COSTA, M. F. et al. Genomic ancestry and ethnoracial self-classification based on 5,871 communitydwelling Brazilians (The Epigen Initiative). Sci Rep, v. 5, p. 9812, 2015.

MAHLEY, R. W.; WEISGRABER, K. H.; HUANG, Y. Apolipoprotein E4: a causative factor and therapeutic target in neuropathology, including Alzheimer's disease. Proc Natl Acad Sci U S A, v. 103, n. 15, p. 5644-51, 2006.

. Apolipoprotein E: structure determines function, from atherosclerosis to Alzheimer's disease to AIDS. J Lipid Res, v. 50 Suppl, p. S183-8, 2009.

MORTERA, P.; HERCULANO-HOUZEL, S. Age-related neuronal loss in the rat brain starts at the end of adolescence. Front Neuroanat, v. 6, p. 45, 2012.

MURPHY, D. G. et al. Sex differences in human brain morphometry and metabolism: an in vivo quantitative magnetic resonance imaging and positron emission tomography study on the effect of aging. Arch Gen Psychiatry, v. 53, n. 7, p. 585-94, 1996. 
PALLONI, A.; PINTO-AGUIRRE, G.; PELAEZ, M. Demographic and health conditions of ageing in Latin America and the Caribbean. Int J Epidemiol, v. 31, n. 4, p. 762-71, 2002.

PERLS, T. T. et al. Siblings of centenarians live longer. Lancet, v. 351, n. 9115, p. 1560, 1998.

PETERS, R. Ageing and the brain. Postgrad Med J, v. 82, n. 964, p. 84-8, 2006.

PRICE, C. C. et al. Subcortical vascular dementia: integrating neuropsychological and neuroradiologic data. Neurology, v. 65, n. 3, p. 376-82, 2005.

ROGAEVA, E. et al. The neuronal sortilin-related receptor SORL1 is genetically associated with Alzheimer disease. Nature Genetics, v. 39, n. 2, p. 168-177, 2007.

SCHLESINGER, D. et al. African ancestry protects against Alzheimer's disease-related neuropathology. Mol Psychiatry, v. 18, n. 1, p. 79-85, 2013.

SEKIGAWA, A. et al. Role of alpha- and beta-Synucleins in the Axonal Pathology of Parkinson's Disease and Related Synucleinopathies. Biomolecules, v. 5, n. 2, p. 1000-11, 2015.

SESHADRI, S. et al. Genome-wide analysis of genetic loci associated with Alzheimer disease. JAMA, v. 303, n. 18 , p. $1832-40,2010$.

SKULACHEV, M. V.; SEVERIN, F. F.; SKULACHEV, V. P. Aging as an Evolvability-Increasing Program Which can be Switched Off by Organism to Mobilize Additional Resources for Survival. Curr Aging Sci, v. 8, n. 1, p. $95-$ 109, 2015.

SLEEGERS, K. et al. The pursuit of susceptibility genes for Alzheimer's disease: progress and prospects. Trends in Genetics, v. 26, n. 2, p. 84-93, 2010.

STORSVE, A. B. et al. Differential longitudinal changes in cortical thickness, surface area and volume across the adult life span: regions of accelerating and decelerating change. J Neurosci, v. 34, n. 25, p. 8488-98, 2014.

SURI, S. et al. The forgotten APOE allele: a review of the evidence and suggested mechanisms for the protective effect of APOE varepsilon2. Neurosci Biobehav Rev, v. 37, n. 10 Pt 2, p. 2878-86, 2013.

TENG, E. L.; CHUI, H. C. The Modified Mini-Mental State (3MS) examination. J Clin Psychiatry, v. 48, n. 8, p. 314-8, 1987.

UNITED NATIONS. DEPARTMENT OF ECONOMIC AND SOCIAL AFFAIRS. POPULATION DIVISION. World population prospects : the 2006 revision. New York: United Nations, 2007. ISBN 9789211514292 (v. 1). 


\title{
African ancestry protects against Alzheimer's disease-related neuropathology
}

\author{
D Schlesinger ${ }^{1,2,11}$, LT Grinberg ${ }^{3,4,5,11}$, JG Alba ${ }^{3}$, MS Naslavsky ${ }^{1}$, L Licinio ${ }^{1}$, JM Farfel ${ }^{3,6}$, CK Suemoto SM, $^{3,6}$ \\ RE de Lucena Ferretti ${ }^{3,6,7}$, REP Leite ${ }^{3}$, MP de Andrade $^{3}$, ACF dos Santos ${ }^{8}, \mathrm{H}_{\text {Brentani }}^{8}$, \\ CA Pasqualucci ${ }^{3,9}, \mathrm{R}$ Nitrini ${ }^{3,10}$, W Jacob-Filho ${ }^{3,6}, \mathrm{M} \mathrm{Zatz}^{1}$ and the Brazilian Aging Brain Study Group ${ }^{3}$ \\ ${ }^{1}$ Human Genome Research Center, University of São Paulo, São Paulo, Brazil; ${ }^{2}$ Instituto do Cérebro, \\ Instituto Israelita de Ensino e Pesquisa Albert Einstein, São Paulo, Brazil; ${ }^{3}$ Brazilian Aging Brain Study Group — LIM22, \\ University of Sao Paulo Medical School, São Paulo, Brazil; ${ }^{4}$ Experimental Pathophysiology Discipline, University of \\ Sao Paulo Medical School, São Paulo, Brazil; ${ }^{5}$ Department of Neurology, Memory and Aging Center, UCSF, CA, USA; \\ ${ }^{6}$ Department of Geriatrics, University of Sao Paulo Medical School, São Paulo, Brazil; ${ }^{7}$ Universidade do Grande ABC, \\ Santo André, Brazil; ${ }^{8}$ Hospital A. C. Camargo, São Paulo, Brazil; ${ }^{9}$ Department of Pathology, University of Sao Paulo Medical \\ School, São Paulo, Brazil and ${ }^{10}$ Department of Neurology, University of Sao Paulo Medical School, São Paulo, Brazil
}

\begin{abstract}
Previous studies in dementia epidemiology have reported higher Alzheimer's disease rates in African-Americans when compared with White Americans. To determine whether genetically determined African ancestry is associated with neuropathological changes commonly associated with dementia, we analyzed a population-based brain bank in the highly admixed city of São Paulo, Brazil. African ancestry was estimated through the use of previously described ancestry-informative markers. Risk of presence of neuritic plaques, neurofibrillary tangles, small vessel disease, brain infarcts and Lewy bodies in subjects with significant African ancestry versus those without was determined. Results were adjusted for multiple environmental risk factors, demographic variables and apolipoprotein E genotype. African ancestry was inversely correlated with neuritic plaques $(P=0.03)$. Subjects with significant African ancestry $(n=112,55.4 \%)$ showed lower prevalence of neuritic plaques in the univariate analysis (odds ratio (OR) $0.72,95 \%$ confidence interval $(\mathrm{Cl}) 0.55-0.95, P=0.01$ ) and when adjusted for age, sex, APOE genotype and environmental risk factors (OR $0.43,95 \% \mathrm{Cl} 0.21-$ $0.89, P=0.02$ ). There were no significant differences for the presence of other neuropathological alterations. We show for the first time, using genetically determined ancestry, that African ancestry may be highly protective of Alzheimer's disease neuropathology, functioning through either genetic variants or unknown environmental factors. Epidemiological studies correlating African-American race/ethnicity with increased Alzheimer's disease rates should not be interpreted as surrogates of genetic ancestry or considered to represent African-derived populations from the developing nations such as Brazil.

Molecular Psychiatry (2013) 18, 79-85; doi:10.1038/mp.2011.136; published online 8 November 2011
\end{abstract}

Keywords: Alzheimer's disease; ancestry; dementia; ethnicity; neuropathology; race

\section{Introduction}

Self-declared race and skin color are often used as surrogates for genetic ancestry, despite being poor biological classifiers, especially in countries with admixed populations where significant overlaps between groups exist. ${ }^{1}$ Furthermore, racial categorization is modifiable by environmental factors such as

Correspondence: Professor D Schlesinger, Instituto do Cérebro, IIEP Albert Einstein, São Paulo 05652-900, Brazil or Professor M Zatz, Human Genome Research Center, University of São Paulo, Rua do Matão 277, sala 211, São Paulo 05508-900, Brazil.

E-mails: dschles@einstein.br or mayazatz@usp.br

${ }^{11}$ These authors contributed equally to this work.

Received 18 March 2011; revised 8 September 2011; accepted 12 September 2011; published online 8 November 2011 sunlight exposure, socioeconomic level, physical appearance and cultural aspects. ${ }^{2-4}$ The marked epidemiological differences in health status between racial groups in countries such as Brazil and the United States are likely a combination of genetic and environmental factors, particularly socioeconomic levels. ${ }^{5,6}$

Dementia is a complex phenotype caused by frequently overlapping neuropathological processes such as neuritic plaques and neurofibrillary tangles (Alzheimer's disease), small vessel disease and/or brain infarcts (vascular dementia) and synuclein deposits (Lewy body disease and Parkinson's disease), as well as other rarer alterations. ${ }^{7}$ The clinical diagnosis of dementia is further influenced by the educational level, language and cultural 
aspects. Several studies have shown that African Americans are more frequently diagnosed with dementia (in general) and Alzheimer's disease than Caucasians. ${ }^{8-12}$ These differences may be caused by genetic variants or the environment. ${ }^{13-16}$ Few studies have focused on neuropathological post-mortem diagnosis and none on ancestry-informative marker (AIM) determined genetic ancestry. ${ }^{17-19}$

The quantitative assessment of ancestry using AIMs has been previously demonstrated to be useful in breast cancer epidemiology and lung-function prediction. ${ }^{20,21}$ The population of Brazil is highly admixed, with major historic contributions from European immigrants, African slaves and native Amerindians. ${ }^{22-24}$ The genetic structure of the population of Brazil is approximately $80 \%$ European, $15 \%$ African and 5\% Amerindian, with significant variation between regions. ${ }^{25,26}$

\section{Materials and methods}

\section{Study population}

Brain samples from the Brazilian Aging Brain Study Group of the University of São Paulo Medical School, collected from 2004-2009, were studied. ${ }^{27}$ Exclusion criteria included age at death of less than 50 years, causes of death or tissue condition that impeded neuropathological analysis, informants without knowledge of the functional status of subjects (minimum 1 visit/week) and violent/criminal deaths. Tissue donations were obtained in the municipal São Paulo Autopsy Service, in Brazil. The population base includes all inhabitants of the city of São Paulo, $\sim 11$ million people $(5.6 \%$ of the population of Brazil), and study samples do not significantly deviate from census data for age, sex, race, years of schooling or socioeconomic levels ${ }^{28}$ (data not shown). All tissue donations were made by next-of-kin after providing informed consent, and the study was approved by the institutional review boards of all participating institutions. Knowledgeable informants were interviewed by nurses trained specifically for the questionnaires, including cognitive evaluation (Informant Questionnaire on Cognitive Decline in the Elderly (IQCODE) and Clinical Dementia Rating (CDR)) and demographics. ${ }^{29,30}$

\section{Neuropathological assessment}

All neuropathological diagnoses were carried out by two trained specialists (LTG and MPA). Brains were inspected macroscopically, and lesions of Alzheimer's disease (neuritic plaques and neurofibrillary tangles), Lewy bodies and small vessel disease (microinfarcts, lacunes and small vessel disease) were scored according to the accepted criteria. ${ }^{31-33}$ Immunohistochemistry was done with antibodies against $\beta$-amyloid (4G8, 1/5000, Signet Laboratories, Dedhan, MA, USA), phospho-tau (PHF-1, 1/1000, gift from Peter Davies, New York City, NY, USA) and $\alpha$-synuclein (EQV-1, 1/ 10000 , gift from Kenji Ueda, Tokyo, Japan). If TDP43pathy was suspected, immunostaining for TDP-43
(1/500, ProteinTech Group, Chicago, IL, USA) was performed. All sections were submitted to antigenic retrieval. The reactions were detected using the Vectastain Elite ABC Kit method (Vector Laboratories, Burlingame, CA, USA). Neuritic plaques were classified as absent, mild, moderate or frequent. Neurofibrillary tangles were classified according to the Braak score of 0-VI (ref. 32).

\section{Ancestry estimation and genotyping}

Samples were genotyped for 90 single-nucleotide polymorphisms previously described from an AIM panel reported to efficiently separate Western European, African, Amerindian and East Asian populations. $^{34}$ The AIMs were genotyped using Sequenom MassArray from the Genotyping Facility of the Broad Institute of MIT and Harvard. Samples with more than $90 \%$ call rate were included in the analysis. Singlenucleotide polymorphisms with $>5 \%$ no-call rate were excluded from the analysis. APOE genotype (single-nucleotide polymorphisms rs429358 and rs7412) was determined by RealTime PCR, in duplicates, as previously described. ${ }^{35}$

We estimated ancestry by modeling four ancestral populations $(k=4)$ with admixture in Structure version 2.3.3 (100000 burn-ins, 200000 iterations, LOCPRIOR $=0$ ), alongside samples from the Human Genome Diversity Panel and the HapMap (Phase I) project, both publicly available. ${ }^{36-38}$

\section{Statistical analysis}

Neuropathological variables (neuritic plaques, small vessel disease, infarcts, Lewy bodies) were dichotomized between presence and absence, and neurofibrillary tangles were divided between Braak score $0-$ III and IV-VI. Ancestry was analyzed as a quantitative variable and also dichotomized at 'significant' African ancestry $(>2 \%)$ to separate the two major ancestry groups present-those with European-only ancestry from admixed individuals (mainly European and African). This cutoff was defined based on the level of African ancestry present in $90 \%$ of Caucasian samples from the Human Genome Diversity and HapMap Projects. Subjects of Asian origin $(n=6)$ were excluded from analysis. No subjects were identified as Amerindian by next-of-kin.

Kruskal-Wallis test was used in the initial analysis and confirmed using Spearman's rank correlation (two-sided). Logistic regression was used to model the effect of African ancestry on the presence of neuropathology. Each pathology was considered a separate outcome. Analysis was carried out with adjustment for age at death, sex, years of schooling, socioeconomic level, APOE genotype and family reported cardiovascular risk factors (hypertension, diabetes, hypercholesterolemia, heart failure, arrhythmia, smoking, alcohol consumption and sedentary lifestyle). A subgroup analysis using ancestry restricted to self-declared whites (75\% of the samples) was also done (Supplementary Figure 2). Significant findings were considered when $P<0.05$. 


\section{Results}

Ancestry and race

The study consisted of 202 brain samples with complete genotyping, neuropathology and close relatives' interviews. There were 112 individuals (55.4\%) with significant African ancestry (Table 1, Supplementary Figure 2). Non-white race and genetically determined African ancestry were highly correlated $(P<0.01)$. Some self-declared whites were over $70 \%$ African, while a few non-whites had more than 99\% European ancestry (Figure 1). Table 1 shows demographic characteristics for subjects with significant $(>2 \%)$ African ancestry and those without. African ancestry was associated with lower educational $(P<0.05)$ and socioeconomic levels $(P<0.01)$. There were no differences in cognitive status between groups, as measured by IQCODE or CDR scale.

Ancestry and neuropathology

African ancestry was inversely correlated with neuritic plaques $(P=0.03$, two-sided Spearman's correlation), but not with other neuropathological changes $(P>0.20$ for neurofibrilary tangles, infarcts, small vessel disease and Lewy bodies). The odds ratio (OR) of each neuropathological change for African versus non-African ancestry is shown in Figure 2 and Table 2. The same analysis was done in self-declared Whites (75\% of the sample), with similar results (Supplementary Figure 2).

The prevalence of Alzheimer's disease neuritic plaques was significantly lower in subjects with African ancestry $(0.72$, 95\% confidence interval (CI) 0.55-0.95, $P=0.01$ ) (Figure 2). African ancestry also correlated with less pathology in the subgroup analysis restricted to self-declared whites $(0.63,95 \%$ CI 0.42-0.95, $P=0.02$ ) (Supplementary Figure 1). The prevalence of Alzheimer's related neurofibrilary tangles was higher in subjects with African compared with non-African ancestry, but this was not statistically significant. The prevalence of small vessel disease, brain infarcts and Lewy bodies was higher in subjects with African compared with non-African ancestry, but none were statistically significant. Selfdeclared race showed no statistically significant differences for any of the neuropathological end points (Supplementary Figure 1).

Adjustment for possible confounding factors did not alter the findings (Figure 3). Neuritic plaques were less prevalent in subjects with African ancestry when adjusted for age and sex (OR 0.47, 95\% CI 0.25$0.89, P=0.02$ ), when adjusting for age, sex and APOE4 status (OR 0.35, 95\% CI 0.17-0.70, $P<0.01$ ), and when adjusting for all factors including socioeconomic level, educational level and cardiovascular risk factors (OR 0.43, 95\% CI 0.21-0.89, $P=0.02$; Table 3, Figure 3).

\section{Discussion}

The Brazilian population is highly admixed, with $>90 \%$ of its ancestry derived from African slaves and European immigrants, which makes it ideal for ancestry-related studies. Moreover, Brazilian law

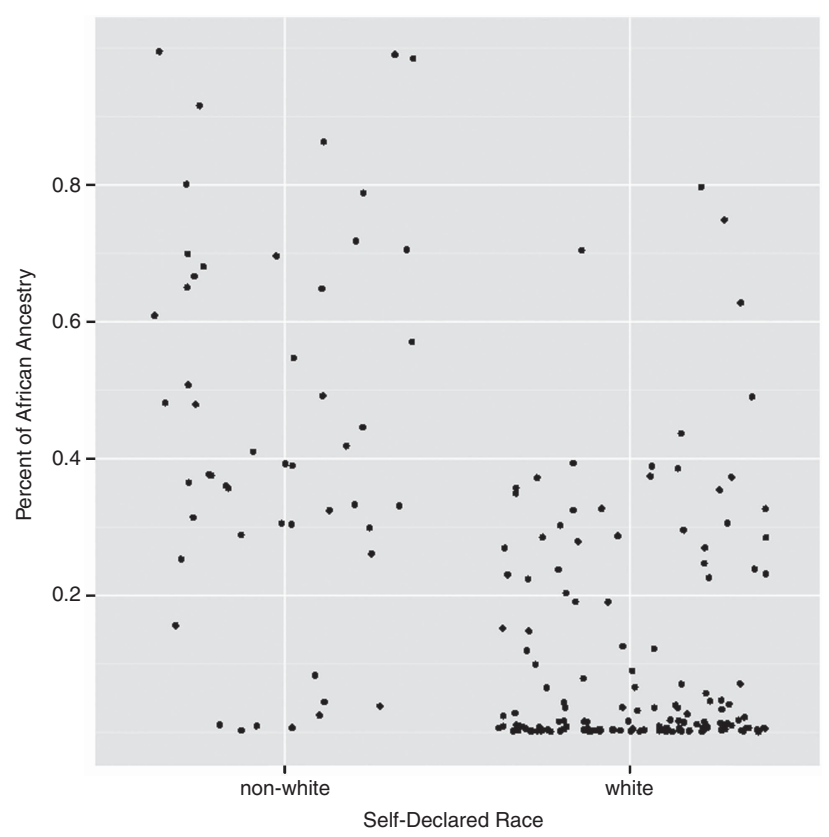

Figure 1 Individual African ancestry estimates according to self-declared race in Brazil.

Table 1 Study characteristics

\begin{tabular}{|c|c|c|c|}
\hline & African ancestry & Non-African ancestry & P-value \\
\hline Number & 112 & 90 & \\
\hline Age at death (mean \pm s.d.) & $74.5 \pm 11.9$ & $76.9 \pm 11.4$ & 0.18 \\
\hline Gender ( $\%$ female) & $57.3 \%$ & $60.0 \%$ & 0.68 \\
\hline Socioeconomic level (mean ABIPEME score \pm s.d.) & $15.5 \pm 9.4$ & $20.3 \pm 9.0$ & $<0.001$ \\
\hline Educational status (mean years of schooling \pm s.d.) & $3.7 \pm 3.7$ & $4.8 \pm 3.8$ & 0.03 \\
\hline Race (\% self-declared White) & $58.0 \%$ & $95.5 \%$ & $<0.001$ \\
\hline Cognitive status $(\%$ CDR $=0$ ) & $67.2 \%$ & $66.2 \%$ & 0.85 \\
\hline Cognitive status (mean IQCODE \pm s.d.) & $3.44 \pm 0.72$ & $3.40 \pm 0.68$ & 0.81 \\
\hline APOE4 status (\% positive) & $26.8 \%$ & $20.0 \%$ & 0.26 \\
\hline
\end{tabular}




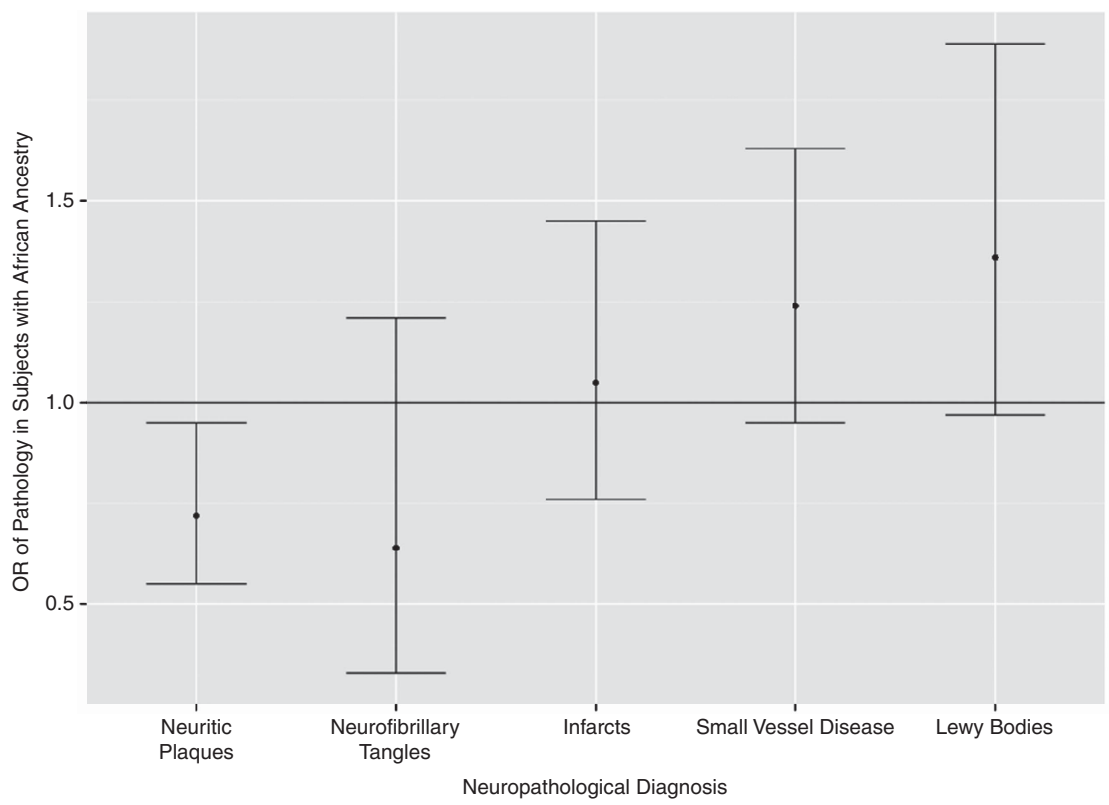

Figure 2 Odds ratio of neuropathological alterations.

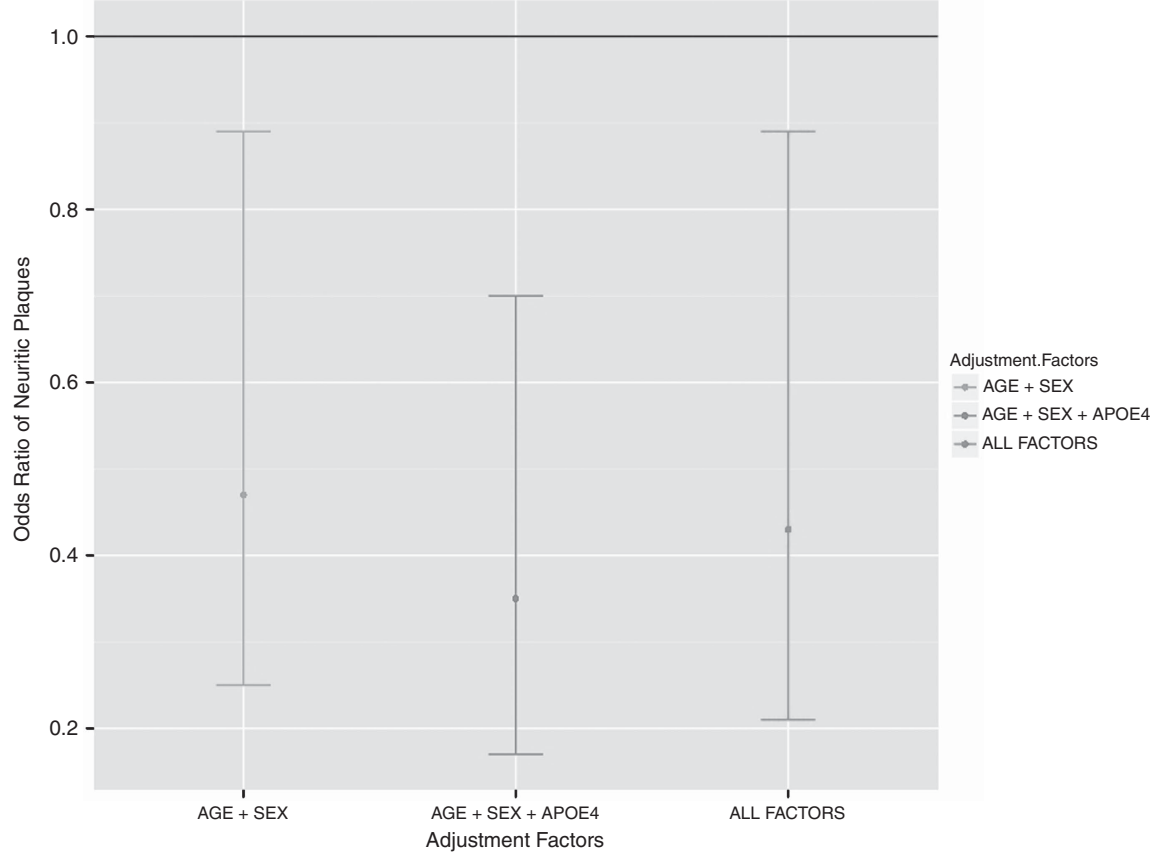

Figure 3 Odds ratio of presence of neuritic plaques, comparing African with non-African ancestry, adjusted for age and sex; age, sex and APOE4 status; and all factors.

mandates that autopsies be performed in all persons without a death certificate, which provides a large recruitment base for populational studies in neuropathology, without bias toward demented persons. The University of São Paulo alone performs more than 14000 autopsies per year, encompassing the full range of demographic variation of the city. The centering of all samples in a single institution also greatly reduced inter-rater variation in both interviews and pathology.

Contrary to previous studies, our results show that African ancestry is highly protective of Alzheimer's disease neuropathology (neuritic plaques), with an adjusted OR of 0.43. This suggests that unknown genetic variants or environmental factors associated with African ancestry reduce the accumulation of 
Table 2 Odds ratio (OR) of pathology, African versus nonAfrican

\begin{tabular}{lcccc}
\hline & OR & Lower & Upper & P-value \\
\hline Neuritic plaques & 0.72 & 0.55 & 0.95 & 0.01 \\
Neurofibrillary tangles & 0.64 & 0.33 & 1.21 & 0.16 \\
Arteriolosclerosis & 1.24 & 0.95 & 1.63 & 0.18 \\
Infarcts & 1.05 & 0.76 & 1.45 & 0.78 \\
Lewy bodies & 1.36 & 0.97 & 1.89 & 0.14 \\
\hline
\end{tabular}

Table 3 Odds ratio (OR) of subjects with African ancestry after adjustment for major factors

\begin{tabular}{lllll}
\hline & \multicolumn{4}{c}{ Neuritic plaques } \\
\cline { 2 - 5 } & OR & Lower & Upper P-value \\
\hline Adjusted for age + sex & 0.47 & 0.25 & 0.89 & 0.02 \\
Adjusted for age + sex + APOE4 & 0.35 & 0.17 & 0.70 & 0.003 \\
Adjusted for & 0.43 & 0.21 & 0.89 & 0.02 \\
Age + sex + APOE4+ & & & & \\
socioeconomic, education & & & & \\
levels and cardiovascular & & & & \\
risk factors & & &
\end{tabular}

$\beta$-amyloid or increase its clearance. The results are robust and are not altered when studying only those who self-defined themselves as whites, when adjusting for APOE4 status only or when adjusting for age and sex only.

Previous studies with the United States population reported a significantly higher prevalence of dementia in African Americans when compared with Caucasians. ${ }^{8-12}$ These differences could be due to cultural differences in the performance on cognitive screening tests, such as the Mini Mental Status Examination, genetic differences between races, environmental differences or likely a combination of factors. ${ }^{13-16} \mathrm{In}$ a study comparing dementia in Nigerians and African Americans, the former had significantly lower disease rates. Our data suggest that these results might be explained not only by environmental differences, but also by the European admixture present in African Americans. ${ }^{39}$ Further studies are needed to confirm this.

Cardiovascular disease risk and stroke also vary between races, but statistical significance often disappears when adjustments for socioeconomic levels are applied. ${ }^{14,40,41}$ Lower educational and socioeconomic levels in those with higher African ancestry may create important differences in disease susceptibility, which is independent of genetics, but confounds the analysis.

To our knowledge, few studies have compared autopsy-diagnosed cases in different races and none used AIMs. ${ }^{17-19}$ The growing clinical use of AIMs was recently shown by Kumar et $a l^{21}$ as a tool for improved lung-function prediction in African

Americans, although this should only be considered an intermediary step toward the use of specific disease-related variants in personalized medicine. ${ }^{42,43}$ Furthermore, dementia is a complex clinical phenotype that may be caused by widely diverse pathologies, and post-mortem diagnosis remains the gold-standard. The specific neuropathology of Alzheimer's disease, Lewy body dementia and vascular dementia may have different underlying biological and genetic causes, and should therefore be studied separately.

A few notes of caution regarding this study should be pointed out. First, although we adjusted for multiple environmental and social factors as well as APOE genotype, other untested environmental factors may be confounding our ancestry results. Second, African populations are highly variable (more so than Europeans), and therefore we cannot state from our data that this effect is applicable to all African populations. ${ }^{13}$ It is unknown if there are population subgroups within Africa with different risk profiles for neuropathological alterations. Actually, our results reinforce the need for more Alzheimer's disease studies in the developing world, for trends identified in the United States may not be universal. Third, we have adjusted our analysis using known cardiovascular risk factors, to focus on unknown genetic factors, but many authors have suggested that ethnic/racial differences in dementia prevalence may in fact be derived from differences in these factors (for example, hypertension, diabetes). A future expansion of this data set is required to answer these questions with confidence, especially regarding vascular dementia.

In conclusion, our study shows, for the first time, that Alzheimer's neuropathological findings depend on the ancestral genetic background. It clearly demonstrates that the presence of neuritic plaques are reduced in persons with African ancestry in a population-based sample, independently of known confounding factors. This should serve as a basis for future genetic studies of Alzheimer's disease, as well as alert against overinterpreting epidemiological studies using race and clinically diagnosed dementia.

\section{Conflict of interest}

The authors declare no conflict of interest.

\section{Acknowledgments}

This work was supported by grants from CEPIDFAPESP (Centro de Pesquisa, Inovação e DifusãoFundação de Amparo a Pesquisa do Estado de São Paulo), INCT (Instituto Nacional de Ciência e Tecnologia), FAPESP (Fundação de Amparo a Pesquisa do Estado de São Paulo), the Alzheimer's Association (NIRG-09-131502 to LTG), CNPq, CAPES, and by the generous donation from Renata and Robert Ruhman. We thank the respondents for all the help and especially for agreeing to participate in the donation 
program. We also thank Professor Carmen Saldiva André for assistance in statistical analysis.

Author contributions: Study concept and design: Schlesinger, Grinberg. Acquisition of data: Schlesinger, Grinberg, Farfel, Suemoto, Ferretti and Andrade. Analysis and interpretation of data: Schlesinger, Grinberg and Zatz. Drafting of the manuscript: Schlesinger, Grinberg and Zatz. Critical revision of the manuscript for important intellectual content: Schlesinger, Grinberg, Jacob-Filho, Nitrini and Zatz. Statistical analysis: Schlesinger. Obtained funding: Grinberg, Jacob-Filho and Zatz. Administrative, technical or material support: Alba, Naslavsky, Licinio, Leite, Santos, Brentani and Pasqualucci. Study supervision: Jacob-Filho, Nitrini and Zatz.

\section{References}

1 Parra FC, Amado RC, Lambertucci JR, Rocha J, Antunes CM, Pena SD. Color and genomic ancestry in Brazilians. Proc Natl Acad Sci USA 2003; 100: 177-182.

2 Davis FJ. Who is Black?: One Nation's Definition, 10th anniversary ed. Pennsylvania State University Press: University Park, PA, 2001.

3 Mörner M. Race Mixture in the History of Latin America. Little: University Park, PA, 1967.

4 Shriver MD, Parra EJ, Dios S, Bonilla C, Norton H, Jovel C et al. Skin pigmentation, biogeographical ancestry and admixture mapping. Hum Genet 2003; 112: 387-399.

5 Anderson NB, Bulatao RA, Cohen B, National Research Council (U.S.). Panel on Race Ethnicity and Health in Later Life. Critical Perspectives on Racial and Ethnic Differences in Health in Late Life. National Academies Press: Washington, DC, 2004.

6 Cooper RS, Kaufman JS, Ward R. Race and genomics. N Engl J Med 2003; 348: 1166-1170.

7 Matthews FE, Brayne C, Lowe J, McKeith I, Wharton SB, Ince P. Epidemiological pathology of dementia: attributable-risks at death in the Medical Research Council Cognitive Function and Ageing Study. PLoS Med 2009; 6: e1000180.

8 Demirovic J, Prineas R, Loewenstein D, Bean J, Duara R, Sevush S et al. Prevalence of dementia in three ethnic groups: the South Florida program on aging and health. Ann Epidemiol 2003; 13: 472-478.

9 Froehlich TE, Bogardus ST, Inouye SK. Dementia and race: are there differences between African Americans and Caucasians? J Am Geriatr Soc 2001; 49: 477-484.

10 Hou CE, Yaffe K, Pérez-Stable EJ, Miller BL. Frequency of dementia etiologies in four ethnic groups. Dement Geriatr Cogn Disord 2006; 22: 42-47.

11 Schoenberg BS, Anderson DW, Haerer AF. Severe dementia Prevalence and clinical features in a biracial US population. Arch Neurol 1985; 42: 740-743.

12 Heyman A, Fillenbaum G, Prosnitz B, Raiford K, Burchett B, Clark C. Estimated prevalence of dementia among elderly black and white community residents. Arch Neurol 1991; 48: 594-598.

13 Tishkoff SA, Reed FA, Friedlaender FR, Ehret C, Ranciaro A, Froment A et al. The genetic structure and history of Africans and African Americans. Science 2009; 324: 1035-1044.

14 Bravata DM, Wells CK, Gulanski B, Kernan WN, Brass LM, Long J et al. Racial disparities in stroke risk factors: the impact of socioeconomic status. Stroke 2005; 36: 1507-1511.

15 Cook BL, Manning WG. Measuring racial/ethnic disparities across the distribution of health care expenditures. Health Serv Res 2009; 44: 1603-1621.

16 Kaufman JS, Cooper RS, McGee DL. Socioeconomic status and health in blacks and whites: the problem of residual confounding and the resiliency of race. Epidemiology 1997; 8: 621-628.
17 Pytel P. Vascular and Alzheimer-type pathology in an autopsy study of African-Americans. Neurology 2006; 66: 433-435.

18 Riudavets MA, Rubio A, Cox C, Rudow G, Fowler D, Troncoso JC. The prevalence of Alzheimer neuropathologic lesions is similar in blacks and whites. J Neuropathol Exp Neurol 2006; 65: $1143-1148$.

19 Wilkins CH, Grant EA, Schmitt SE, McKeel DW, Morris JC. The neuropathology of Alzheimer disease in African American and white individuals. Arch Neurol 2006; 63: 87-90.

20 Fejerman L, John EM, Huntsman S, Beckman K, Choudhry S, Perez-Stable E et al. Genetic ancestry and risk of breast cancer among U.S. Latinas. Cancer Res 2008; 68: 9723-9728.

21 Kumar R, Seibold MA, Aldrich MC, Williams LK, Reiner AP, Colangelo L et al. Genetic ancestry in lung-function predictions. N Engl J Med 2010; 363: 321-330.

22 Cunha MCd, Salzano FM. História dos índios no Brasil. São Paulo, SP: Fundação de Amparo à Pesquisa do Estado de São Paulo: Companhia das Letras: Secretaria Municipal de Cultura, Prefeitura do Município de São Paulo. Companhia das Letras: São Paulo, 1992.

23 Hall GM. Slavery and African Ethnicities in the Americas: Restoring the Links. University of North Carolina Press: Chapel Hill, 2005.

24 Basto FLdB. Síntese da História da Imigração no Brasil. 2 edn. sn: Rio de Janeiro, Brasil, 1998.

25 Lins TC, Vieira RG, Abreu BS, Grattapaglia D, Pereira RW. Genetic composition of Brazilian population samples based on a set of twenty-eight ancestry informative SNPs. Am J Hum Biol 2009; 22: 187-192.

26 Pena SD, Bastos-Rodrigues L, Pimenta JR, Bydlowski SP. DNA tests probe the genomic ancestry of Brazilians. Braz J Med Biol Res 2009; 42: 870-876.

27 Grinberg LT, Ferretti RE, Farfel JM, Leite R, Pasqualucci CA, Rosemberg S, et al. Brazilian Aging Brain Study Group. Brain bank of the Brazilian aging brain study group-a milestone reached and more than 1,600 collected brains. Cell Tissue Bank 2007; 8: 151-162.

28 Ferretti R, Damin A, Brucki S, Morillo L, Perroco T, Campora F et al. Post-Mortem diagnosis of dementia by informant interview. Dement Neuropsychol 2010; 4: 138-144.

29 Jorm AF, Jacomb PA. The Informant Questionnaire on Cognitive Decline in the Elderly (IQCODE): socio-demographic correlates, reliability, validity and some norms. Psychol Med 1989; 19: 1015-1022.

30 Morris JC. The Clinical Dementia Rating (CDR): current version and scoring rules. Neurology 1993; 43: 2412-2414.

31 Mirra SS. The CERAD neuropathology protocol and consensus recommendations for the postmortem diagnosis of Alzheimer's disease: a commentary. Neurobiol Aging 1997; 18: S91-SS4.

32 Braak H, Braak E. Neuropathological stageing of Alzheimer-related changes. Acta Neuropathol 1991; 82: 239-259.

33 McKeith IG, Galasko D, Kosaka K, Perry EK, Dickson DW, Hansen LA et al. Consensus guidelines for the clinical and pathologic diagnosis of dementia with Lewy bodies (DLB): report of the consortium on DLB international workshop. Neurology 1996; 47: 1113-1124.

34 Nassir R, Kosoy R, Tian C, White PA, Butler LM, Silva G et al. An ancestry informative marker set for determining continental origin: validation and extension using human genome diversity panels. BMC Genet 2009; 10: 39.

35 Calero O, Hortiguela R, Bullido MJ, Calero M. Apolipoprotein E genotyping method by real time PCR, a fast and cost-effective alternative to the TaqMan and FRET assays. J Neurosci Methods 2009; 183: 238-240.

$36 \mathrm{Li}$ JZ, Absher DM, Tang H, Southwick AM, Casto AM, Ramachandran $\mathrm{S}$ et al. Worldwide human relationships inferred from genome-wide patterns of variation. Science 2008; 319: 1100-1104.

37 HapMap. A haplotype map of the human genome. Nature 2005; 437: 1299-12320.

38 Pritchard JK, Stephens M, Donnelly P. Inference of population structure using multilocus genotype data. Genetics 2000; 155: 945-959.

39 Ogunniyi A, Baiyewu O, Gureje O, Hall KS, Unverzagt F, Siu SH et al. Epidemiology of dementia in Nigeria: results 
from the Indianapolis-Ibadan study. Eur I Neurol 2000; 7: 485-490.

40 Chiu M, Austin PC, Manuel DG, Tu JV. Comparison of cardiovascular risk profiles among ethnic groups using population health surveys between 1996 and 2007. Can Med Assoc J 2010; 182: E301-EE10.

41 Schwamm LH, Reeves MJ, Pan W, Smith EE, Frankel MR, Olson D et al. Race/ethnicity, quality of care, and outcomes in ischemic stroke. Circulation 2010; 121: 1492-1501.

42 Race, Ethnicity, and Genetics Working Group. The use of racial, ethnic, and ancestral categories in human genetics research. Am J Hum Genet 2005; 77: 519-532.
43 Kidd J, Friedlaender F, Speed W, Pakstis A, De La Vega F, Kidd K. Analyses of a set of 128 ancestry informative single-nucleotide polymorphisms in a global set of 119 population samples. Invest Genet 2011; 2: 1

This work is licensed under the Creative Commons Attribution-NonCommercialNo Derivative Works 3.0 Unported License. To view a copy of this license, visit http://creativecommons.org/licenses/by-nc-nd/3.0/

Supplementary Information accompanies the paper on the Molecular Psychiatry website (http://www.nature.com/mp) 


\section{Is $A P O E \varepsilon 2$ always a protective allele?}

M.S. Naslavsky ${ }^{1}$, G. Bandeira ${ }^{1}$, P. A. Otto $^{1}$, M. L. Lebrão ${ }^{2}$, Y. A. O. Duarte ${ }^{2}$, C.A.

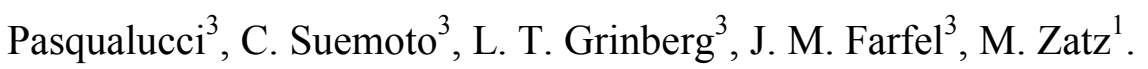

1. Human Genome and Stem cell Research Center, Biosciences Institute, University of São Paulo (USP);

2. Public Health School, USP;

3. Medical School, USP.

Apolipoprotein E (apoE) plays an important role in lipid and cholesterol metabolism and is known to be associated to cardiovascular disease, cognitive decline and Alzheimer's disease neuropathology. The relatively rare allele apoE2 and the frequent allele apoE4 have been considered respectively factors of protection and risk in relation to these conditions. Indeed, a recently reported meta-analysis of genome wide association studies including 53949 individuals from 31 cohorts confirmed that ApoE variants are associated to general cognitive function ${ }^{1}$. We have genotyped two large elderly groups from São Paulo, Brazil: a population-based cohort composed of a census drawn sample, aged 60 and older, and a community-based sample derived from an autopsy service. Surprisingly, we observed that the frequency of the rare homozygous $\varepsilon 2 / \varepsilon 2$ genotype differs significantly between the two samples. Although the frequency of the allele $\varepsilon 2$ did not differ from expected in both cohorts, the genotype $\varepsilon 2 / \varepsilon 2$ was underrepresented in the elderly population and was significantly more frequent in the subjects from the autopsy service suggesting that it may confer an increased risk for carriers.

ApoE is encoded by chromosome $19 \mathrm{q} 13.2 A P O E$ gene. Its three frequent isoforms, apoE2, E3 and E4, are encoded by $A P O E \varepsilon 2, \varepsilon 3$ and $\varepsilon 4$ alleles, which lead to specific sets of amino acid residues in positions 112 and 158. The most common isoform apoE3 contains a residue of cysteine at position 112 and a residue of arginine at 158; in apoE2, the least frequent isoform, the arginine is replaced by cysteine; and apoE4 has a residue of arginine at both sites. $^{2}$

Here we report the results of ApoE allele frequency in two population-derived samples from the city of São Paulo, Brazil. One is derived from the SABE (an acronym in Portuguese for "Health, Well-being and Aging") ${ }^{3}$ population-based cohort, initiated 15 years 
ago and formed by a large dataset of a census-derived sample of 1091 elderly participants aged 60 and older, containing pertinent demographic and socioeconomic information, as well as health status, with all participants included by a multistage stratified sampling. The second sample is derived from the community-based Brazilian Aging Brain Study Group (BABSG), a transversal post-mortem study ${ }^{4}$. It contains biological samples from 1081 individuals deceased at age 50 or older, sourced from the public Central City Autopsy Service - which provides a compulsory postmortem verification for individuals who died of natural causes and performs more than 13000 autopsies per year - whose families consented to participate in neurodegenerative research. Both studies were approved by local ethics committees. Genomic DNA was extracted from peripheral blood or brain tissue and $A P O E$ genotyping was performed by allele-specific PCR, as described by Calero et al (2009) ${ }^{5}$ and confirmed by sequencing. Results are shown in table 1.

Table 1. APOE allele and genotype frequency count values observed in the two elderly samples.

\begin{tabular}{|c|c|c|c|c|c|c|c|c|}
\hline \multirow[b]{3}{*}{ Alleles } & \multicolumn{4}{|c|}{ Observed values } & & & & \\
\hline & \multicolumn{2}{|c|}{ SABE } & \multicolumn{2}{|c|}{ Brain Bank } & & & & \\
\hline & Counts & $\%$ & Counts & $\%$ & & & & \\
\hline E2 & 146 & 6.69 & 133 & 6.15 & & & & \\
\hline E3 & 1762 & 80.75 & 1691 & 78.21 & \multicolumn{4}{|c|}{ HWE expected values } \\
\hline E4 & 274 & 12.56 & 338 & 15.63 & \multicolumn{2}{|l|}{ SABE } & \multicolumn{2}{|c|}{ Brain Bank } \\
\hline Total & 2182 & 100 & 2162 & 100 & Counts $(*)$ & $\%$ & Counts $(*)$ & $\%$ \\
\hline \multicolumn{9}{|l|}{ Genotypes } \\
\hline E2/E2 & 1 & 0.09 & 9 & 0.83 & $4.88(4.94)$ & 0.45 & $4.09(4.13)$ & 0.38 \\
\hline $\mathrm{E} 2 / \mathrm{E} 3$ & 119 & 10.91 & 93 & 8.60 & $117.90(119.59)$ & 10.81 & $104.03(105.95)$ & 9.62 \\
\hline $\mathrm{E} 2 / \mathrm{E} 4$ & 25 & 2.29 & 22 & 2.04 & $18.33(17.45)$ & 1.68 & $20.79(19.90)$ & 1.92 \\
\hline E3/E3 & 723 & 66.27 & 673 & 62.26 & $711.42(712.08)$ & 65.21 & $661.30(662.11)$ & 61.18 \\
\hline $\mathrm{E} 3 / \mathrm{E} 4$ & 197 & 18.06 & 252 & 23.31 & $221.26(220.86)$ & 20.28 & $264.37(263.71)$ & 24.46 \\
\hline $\mathrm{E} 4 / \mathrm{E} 4$ & 26 & 2.38 & 32 & 2.96 & $17.20(16.08)$ & 1.58 & $26.42(25.20)$ & 2.44 \\
\hline Total & 1091 & 100 & 1081 & 100 & 1091 & 100 & 1081 & 100 \\
\hline
\end{tabular}

(*) Values in parentheses were obtained from 10,000 bootstrap simulations under panmixia hypothesis in order to validate the chi-squared analyses presented above.

Adherence to Hardy-Weinberg Equilibrium (HWE) was tested through chi-squared tests validated by bootstrap simulations. The SABE sample showed a strong deviation from HWE $(\mathrm{P}$ exact value $=0.005)$, while the BABSG sample exhibited just a marginal deviation $(\mathrm{P}$ exact value $=0.035)$. The genotypes from both samples were compared in a $3 \times 2$ contingency table and a significant chi-squared value was obtained (c.s. $=18.883 ; 5$ d.f.; $\mathrm{P}=$ 
0.002). The analysis of adjusted residuals (Haberman test) showed that the significance of the test was due to an excess of $\varepsilon 2 / \varepsilon 2$ and $\varepsilon 3 / \varepsilon 4$ individuals from the BABSG sample. Comparing $\varepsilon 2 / \varepsilon 2$ frequencies between both groups(1/1091 vs. 9/1081) by Bross test provided a marginal but significant difference $(\mathrm{p}<0.05)$. When allelic frequencies were compared between both groups (also in a contingency table through another chi-squared test) statistical significance (c.s. $=8.667 ; 2$ d.f.; $\mathrm{P}=0.013$ ) was attained although without any evidence on differences as to the frequency of $\varepsilon 2$ allele (Haberman's residual analysis showed that allele $\varepsilon 4$ frequency was increased and allele $\varepsilon 3$ frequency decreased in the Brain sample).

Despite differences between sampling methods, the observed differences here reported may suggest that the distribution of $A P O E$ genotypes, particularly due to the rare $\varepsilon 2$ homozygous, is not uniform when two elderly samples from a single geographic region are contrasted by a proxy of a survival measure. Both samples derive from individuals with several comorbidities and, as a worldwide standard, the main cause of natural death in the BABSG sample is due to cardiovascular manifestations so that vascular endophenotypes are highly prevalent among its subjects ${ }^{6}$.

$A P O E$ variants have been associated with several conditions that affect multiple systems, particularly late onset Alzheimer's disease (AD) ${ }^{7}$ and several cardiovascular diseases (CVD), such as type III hyperlipoproteinemia (HLP) ${ }^{8}$. These associations may be due to structural and functional differences among apoE isoforms and their interactions with other biological or environmental factors. Stability, folding and ability to bind, transport and mediate VLDL and chylomicrons remnants are apoE properties influenced by the type of isoform that circulates and interacts with liver receptors related to lipid and cholesterol metabolism. ${ }^{8,9}$

In the central nervous system, extracellular amyloid- $\beta$ plaques and intracellular neurofibrillary tangles (aggregates of tau protein in a hyper-phosphorylated state) are the neuropathological hallmarks of AD. Both processes are modified by interaction with different apoE isoforms, probably through aggregate clearance, although there are inconsistencies in which direction and specific processes apoE2 participates. Classical AD's morphological changes, such as hippocampus cortical thickness and white matter integrity, as well as behavioral abilities such as maintenance of cognitive skills, are also associated with different apoE variants, often with increased risk associated to apoE4 carriers versus protection to apoE2 carriers. It has been suggested that these associations take place secondarily to the 
processes of lipid transport, injury repair, glial activation, and neural inflammation, as well as a consequence of oxidative processes and vascularization events. ${ }^{10}$

Large genome-wide association studies ${ }^{5,1}$, validated by functional studies linking apoE4 to the underlying endophenotypes have created a vast body of evidence indicating that this isoform increases the overall risk to cognitive decline, late-onset $\mathrm{AD}$ and other neurologic conditions ${ }^{10}$. apoE4 also plays a role in cardiovascular diseases by changing the stoichiometry of lipoproteins that accelerate or enhance atherosclerosis. apoE4 preferentially binds to trygliceride-rich VLDL, while apoE2 and apoE3 interacts with phospholipid-rich $\mathrm{HDL}^{9}$.

On the other hand, $A P O E \quad \varepsilon 2 / \varepsilon 2$ is a known risk factor for type III hyperlipoproteinemia, especially when combined to other age-related factors that interfere drastically in the production of lipoproteins or impair their clearance such as obesity, diabetes mellitus, hypothyroidism, menopause-linked reduction of estrogen levels, and age-related LDL receptor activity ${ }^{8,9}$.

However, apoE2 protective effects in neurologic conditions have not always been supported by conclusive studies. Suri et al (2013) have comprehensively addressed this issue pinpointing most of the recent reports on the protective effect of this allele, described by them as "the forgotten $A P O E$ allele" 10.

The present findings, based on two population-derived samples from a single geographic area, one is population-based and the second is community-based, suggest that $A P O E \& 2$ homozygous carriers may be at differential risk compared to $\varepsilon 2$ heterozygous carriers and other $A P O E$ genotypes.

Although $A P O E \& 2$ in a single dose seems to be a protective factor against several conditions, this effect is yet to be confirmed in homozygous $\varepsilon 2 / \varepsilon 2$. Indeed, the large majority of reported studies on this subject combine $A P O E \& 2$ heterozygous (often excluding $A P O E$ $\varepsilon 2 / \varepsilon 4$ individuals) and rare homozygous subjects, probably due to the extremely low frequency of the $\varepsilon 2 / \varepsilon 2$ genotype, which might lead to misinterpretation. Additionally, genetic ancestry may influence in such risk values and this factor (not taken into account in the present report) might be particularly relevant in highly admixtured groups like the Brazilian population. 
1. Davies G, Armstrong N, Bis JC, Bressler J, Chouraki V, Giddaluru S et al. Genetic contributions to variation in general cognitive function: a meta-analysis of genome-wide association studies in the CHARGE consortium (N=53 949). Molecular psychiatry 2015.

2. Eichner JE, Dunn ST, Perveen G, Thompson DM, Stewart KE, Stroehla BC. Apolipoprotein E polymorphism and cardiovascular disease: a HuGE review. American journal of epidemiology 2002; 155(6): 487-495.

3. Lebrão MLc, Duarte YAdO, Pan American Health Organization. Representação do Brasil. O Projeto SABE no município de São Paulo : uma abordagem inicial. 1a edn. Organização Pan-Americana de Saúde, OPAS/OMS: Brasília, DF, Brasil, 2003, 255 p.pp.

4. Grinberg LT, Ferretti RE, Farfel JM, Leite R, Pasqualucci CA, Rosemberg S et al. Brain bank of the Brazilian aging brain study group - a milestone reached and more than 1,600 collected brains. Cell and tissue banking 2007; 8(2): 151-162.

5. Calero O, Hortiguela R, Bullido MJ, Calero M. Apolipoprotein E genotyping method by real time PCR, a fast and cost-effective alternative to the TaqMan and FRET assays. Journal of neuroscience methods 2009; 183(2): 238-240.

6. Grinberg LT, Nitrini R, Suemoto CK, Lucena Ferretti-Rebustini RE, Leite RE, Farfel JM et al. Prevalence of dementia subtypes in a developing country: a clinicopathological study. Clinics 2013; 68(8): 1140-1145.

7. Shadyab AH, LaCroix AZ. Genetic factors associated with longevity: A review of recent findings. Ageing research reviews 2015; 19C: 1-7.

8. de Beer F, Stalenhoef AF, Hoogerbrugge N, Kastelein JJ, Gevers Leuven JA, van Duijn CM et al. Expression of type III hyperlipoproteinemia in apolipoprotein E2 (Arg158 --> Cys) homozygotes is associated with hyperinsulinemia. Arteriosclerosis, thrombosis, and vascular biology 2002; 22(2): 294299.

9. Mahley RW, Weisgraber KH, Huang Y. Apolipoprotein E: structure determines function, from atherosclerosis to Alzheimer's disease to AIDS. Journal of lipid research 2009; 50 Suppl: S183-188.

10. Suri S, Heise V, Trachtenberg AJ, Mackay CE. The forgotten APOE allele: a review of the evidence and suggested mechanisms for the protective effect of APOE varepsilon2. Neuroscience and biobehavioral reviews 2013; 37(10 Pt 2): 2878-2886. 


\title{
Factors associated with lower gait speed among the elderly living in a developing country: a cross-sectional population-based study
}

Telma de Almeida Busch ${ }^{1 * \dagger}$, Yeda Aparecida Duarte ${ }^{2 \dagger}$, Daniella Pires Nunes ${ }^{2}$, Maria Lucia Lebrão ${ }^{3}$, Michel Satya Naslavsky ${ }^{4}$, Anelise dos Santos Rodrigues ${ }^{1}$ and Edson Amaro $\mathrm{Jr}^{1,5}$

\begin{abstract}
Background: Among community-dwelling older adults, mean values for gait speed vary substantially depending not only on the population studied, but also on the methodology used. Despite the large number of studies published in developed countries, there are few population-based studies in developing countries with socioeconomic inequality and different health conditions, and this is the first study with a representative sample of population. To explore this, the association of lower gait speed with sociodemographic, anthropometric factors, mental status and physical health was incorporated participants' weight (main weight) in the analysis of population of community-dwelling older adults living in a developing country.
\end{abstract}

Methods: This was a cross-sectional population based on a sample of 1112 older adults aged 60 years and over from Health, Wellbeing and Aging Study cohort 2010. Usual gait speed (s) to walk 3 meters was stratified by sex and height into quartiles. Multiple regression analysis was performed to investigate the independent effect of each factor associated with a slower usual gait speed.

Results: The average walking speed of the elderly was $0.81 \mathrm{~m} / \mathrm{s}-0.78 \mathrm{~m} / \mathrm{s}$ among women and $0.86 \mathrm{~m} / \mathrm{s}$ among men. In the final model, the factors associated with lower gait speed were age $(O R=3.56)$, literacy $(O R=3.20)$, difficulty in one or more IADL $(O R=2.74)$, presence of cardiovascular disease $(O R=2.15)$ and sedentarism. When we consider the $50 \%$ slower, we can add the variables handgrip strength, and the presence of COPD.

Conclusions: Gait speed is a clinical marker and an important measure of functional capacity among the elderly. Our findings suggest that lower walking speed is associated with age, education, but especially with modifiable factors such as impairment of IADL, physical inactivity and cardiovascular disease. These results reinforce how important it is for the elderly to remain active and healthy.

Keywords: Gait, Aged, Older adults, Walking speed

\section{Background}

Population aging is no longer a privilege of developed countries. Brazil has over 15 million elderly people (65 years or over) according to official census (IBGE), which corresponds to around $7.6 \%$ of the total population [1].

The great challenge of aging is to maintain one's functional capacity, an individual's ability to independently carry out activities deemed essential. There are several

\footnotetext{
* Correspondence: telma.busch@gmail.com

${ }^{\dagger}$ Equal contributors

'Hospital Israelita Albert Einstein, Av. Albert Einstein, 670, São Paulo, SP, Brazil Full list of author information is available at the end of the article
}

insidious and silent changes that occur with aging, making the distinction between senescence and senility very difficult [2]. The decline in physical performance is inevitable, and gait speed is considered a global indicator of functional mobility [3]. Reduced speed occurs with age $[4,5]$ even among the healthy elderly [6], and it has a significant impact on one's health and quality of life [6,7].

The change in gait speed is associated with physiological factors [7], behavioural factors [2], and the presence of diseases [8]. It may also increase the risk of falling [9] and result in disability, hospitalization [10-14], and death [15]. Reduced speed is associated with the risk 
of poor health-related outcomes. It is a component of phenotypic fragility [16], and also a clinical measure of functional assessment $[10,17]$.

In spite of the fact that many studies have provided insights into the association between gait speed and all the factors mentioned above, only healthy elderly subjects were included $[18,19]$, or potential confounders were not considered $[19,20]$. These associations were not consistent across studies and few investigations have been conducted with larger community-based, and this is the first one with a random weighted sample of population carried out a two-step sampling procedure with probability proportional to size using census tracts with replacement.

The objective of our study was to identify the factors associated with a lower gait speed in a representative sample of community-dwelling older adults in a developing country with many socioeconomic inequalities.

\section{Methods}

\section{Study design}

This study is part of the SABE (Saúde, Bem Estar $e$ Envelhecimento / Health, Well-Being and Aging) Study. The SABE Study started in 2000 as a multicentre project coordinated by the Pan-American Health Organization, and it has been conducted in seven countries in Latin America and Caribbean. In Brazil, the study has been conducted in the city of São Paulo, selected through the multiple-stage sampling of census regions and it has become a longitudinal study. Survey that included 2.143 elderly individuals aged 60 or older in the city of São Paulo. A new wave has been performed in 2006 in the São Paulo initiative, and in this city the study became longitudinal. 1115 elderly subjects were reinterviewed (cohort A06) and a new cohort (B06) was added, the elderly aged 60-64 $(\mathrm{n}=298)$, totalling 1413 individuals. In 2010, a third wave was performed, 989 elderly subjects (cohorts $\mathrm{A}, \mathrm{n}=748$ and $\mathrm{B}, \mathrm{n}=242$ ) were reinterviewed and a new cohort $(C)$ of the elderly aged $60-64(n=355)$ was added. For this study, the sample was formed by wave 2010, cohorts A, B and C, totalling 1.345 elderly subjects (60 years and over). A detailed description of the methodology used can be found in [21].

For this study, individuals who were unable to perform the specific functional test (bedridden elderly) were excluded $(\mathrm{n}=159)$, as well as subjects with neurological and/ or orthopaedic diseases, or those who used assistive devices in walking, or those with motor impairment resulted from stroke or with any pathological factors that might interfere with the gait $\operatorname{speed}(\mathrm{n}=74)$. The final sample comprised 1112 individuals. Figure 1 (Flowchart). This study received approval from the Human Research Ethics Committee of (IIEPAE) the Institute of Education and Research Albert Einstein (Brazil), protocol number 1360-11. Written informed consent was obtained from the subjects at the time of the interview.

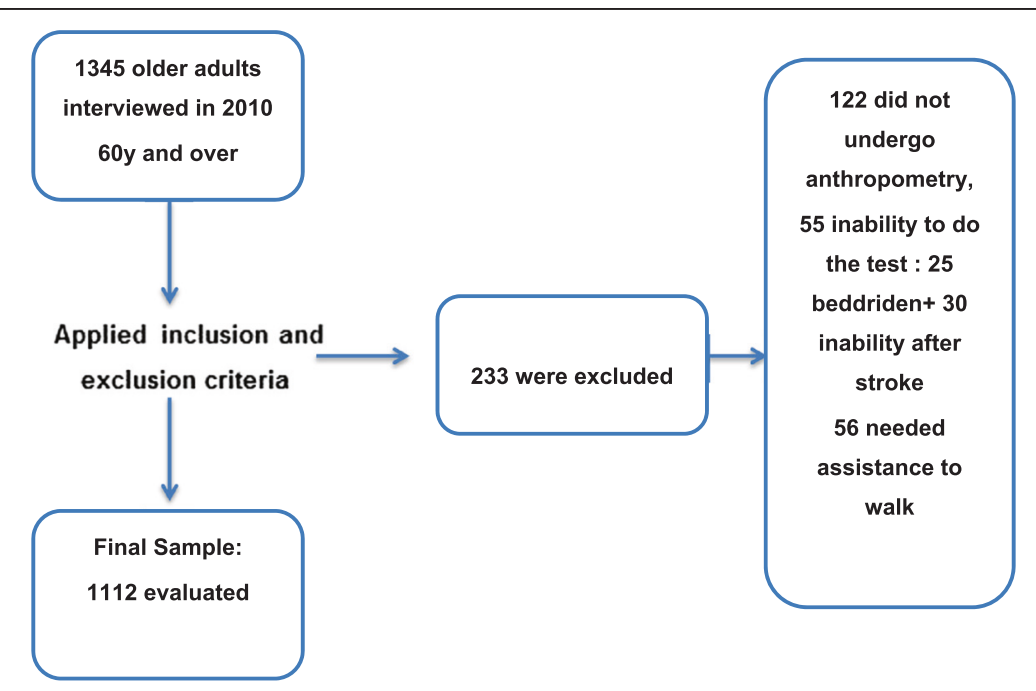

Flowchart of Study Sample

Figure 1 Flowchart of Study Sample. 


\section{Measures and instruments}

All data were collected at the participants' homes by trained research assistants, and they included an intervieweradministered structured questionnaire with items on socioeconomic variables, general health and living conditions, as well as a set of anthropometric measures. The dependent variable in the present study was gait speed. The subject was instructed to walk three meters on a straight line marked on the ground at their usual speed, and thus the obtained time (in seconds) would be counted by using a hand-held stopwatch [22]. Two measurements were made and used for this study. The lowest walking speed $(\mathrm{m} / \mathrm{s})$ was considered. Walking speed was calculated by dividing the distance by the time it takes to cover a distance.

The following were the independent variables: 1 ) sociodemographic variables (age, sex, ethnicity, education, conjugal situation). Two reasons justify why cut-off points of education were set at 1-3years, 4-7 and 8 and more. One of them is that $21.0 \%$ of the elderly have never attended school, and $46.4 \%$ were younger than 4 years of schooling [21]. In addition, other studies have also used the same cut-off points [23,24]; 2) anthropometric variables: weight, height, body mass index (BMI). The classification of nutritional status followed the recommendations of the Pan American Health Organization: [25] 3) general health factors (number of self-reported chronic diseases (hypertension, diabetes mellitus, cardiovascular disease, cerebrovascular disease, chronic obstructive pulmonary disease (COPD), arthritis, osteoporosis), self-perceived general health (good/very good, regular or poor/very poor), and physical activity were evaluated by selfreported physical activity using the International Physical Activity Questionnaire (IPAQ) short form 8. This questionnaire determines the level of physical activity and it has been validated in a sample of the Brazilian population [26]. The practice of physical activity was assessed by the number of minutes spent per week to carry out the activities. This included walking or anything activity. The older adults who devoted 150 minutes weekly to perform moderate physical activities, or 75 minutes to vigorous physical activity, or an equivalent combination of both, were considered active [27]. It means; 4) The cognitive assessment was performed using modified Mini
Mental State Examination - MMSE, validated by Icaza and Albala [28]. This instrument consists of 13 questions that are independent of the school, and its cut-off scores less than or equal to twelve; 5) The depressive symptoms as assessed by the Geriatric Depression Scale(GDS) [29] validated for the Brazilian population; it was considered as a point cut scores greater than or equal to six [30]; 6) Participants who were self-rated as being unable to perform instrumental activities of daily living, or at least one ADL, without any help were defined as dependent. Activities of Daily Living (ADL): crossing fourth walking, eating, bathing, going to the bathroom, transferring from bed to chair and getting dressed. Instrumental Activities of Daily Living (IADL): using transportation, using the phone, going shopping, taking medication, taking care of one's own money; 7) Assessment of motor function by Balance and Gait (Time Up and Go). The TUGT was assessed in the standard manner: patients were asked to rise from a $45 \mathrm{~cm}$-high chair, walk forward $3 \mathrm{~m}$ at their usual walking pace, turn $180^{\circ}$, walk back to the chair and sit down. It was emphasized to participants that they undertake the test at their 'usual walking pace' [31]; 8) The handgrip strength was measured using a dynamometer. The test was performed in the dominant upper limb, in two attempts, which used the highest value obtained.

\section{Statistical analysis}

The Shapiro Will test was performed to investigate whether the continuous variable gait was normally distributed. The dependent variable was not considered normally distributed, so it was stratified into quartiles according to sex and height (Table 1). This choice of stratification was based on literature because gait speed can be expected to be reduced in individuals of greater age and of lesser height, so height was considered a confusion variable that could influence the results [32]. The first quartile consisted of individuals with lower gait speed, and the fourth quartile includes faster gait speed values. For the descriptive analysis, mean and standard error values were calculated for the continuous variables, and proportions were calculated for the categorical variables. Differences between groups were estimated using the Wald test of mean equality and the Chi-Square

Table 1 Gait speed stratified into quartiles according to sex and height

\begin{tabular}{|c|c|c|c|c|c|}
\hline & \multirow[b]{2}{*}{ Quartile } & \multicolumn{2}{|l|}{ Men } & \multicolumn{2}{|l|}{ Women } \\
\hline & & height $\leq 1,66 \mathrm{~m}$ & height $>1,66 \mathrm{~m}$ & height $\leq 1,52 \mathrm{~m}$ & height $>1,52 \mathrm{~m}$ \\
\hline \multirow{4}{*}{ Gait speed $(\mathrm{m} / \mathrm{s})$} & $1^{\circ}$ quartile & $\leq 0,68$ & $\leq 0,78$ & $\leq 0,63$ & $\leq 0,68$ \\
\hline & $2^{\circ}$ quartile & $0,69-0,81$ & $0,79-0,90$ & $0,63-0,78$ & $0,69-0,81$ \\
\hline & $3^{\circ}$ quartile & $0,82-0,97$ & $0,91-1,04$ & $0,79-0,91$ & $0,82-0,95$ \\
\hline & $4^{\circ}$ quartile & $\geq 0,98$ & $\geq 1,05$ & $\geq 0,92$ & $\geq 0,96$ \\
\hline
\end{tabular}


Rao-Scott correction, which considers sample weights for estimates with population weights [33]. We adapted the significance level for the tests a $\mathrm{p}$ value $<0.05$.

To investigate the factors associated with lower gait speed, a multinomial logistic regression was chosen. To multiple analyses, variables with p-value $<0.20$ were selected in the univariate analysis. In the final model, a significance level of $5 \%$ was considered. The software used was Stata ${ }^{\bullet}$ version. The survey commands of the statistical software Stata 10 was used to analyze the data considering the complex sample design. Thus, the participants' weight (main weight) was incorporated in the analysis.

\section{Results}

Most elderly subjects were women (60.3\%), white ethnicity (self-declared) (58.4\%), had between four and seven years of study (38.1\%), lived with someone else (56.7\%), self-reported regular health (51\%), were inactive (59.6\%), had two or more chronic diseases (54.4\%) and 48.3\% were overweight. Prevalence values found were $7.5 \%$ for cognitive impairment and $17.6 \%$ for depressive symptoms. Regarding disability, 33\% were dependent in at least one IADL and $24.7 \%$ in at least one ADL.

The average walking speed of the subjects was $0.81 \mathrm{~m} / \mathrm{s}-$ $0.78 \mathrm{~m} / \mathrm{s}$ among women, and $0.86 \mathrm{~m} / \mathrm{s}$ among men. It was observed that gait speed decreased with older ages $(\mathrm{p}=0.000)$. Among people aged 75 years or older, $46.9 \%$ and $38.7 \%$ illiterate were in the first quartile of gait speed, $(\mathrm{p}<0.001)$ (Table 2). Race/ethnicity had no effect on walking speed $(p=0.939)$. Many factors revealed significant association with lower gait speed as being illiterate (38.7\%), living alone (30.0\%), bad or very bad self-reported health (43\%), and cognitive impairment (60.4\%) (Table 3). Lower handgrip strength of the dominant hand, higher TUG, having some kind of inability, at least one ADL or IADL, and having 2 or more chronic diseases such as AVC or DCV composed the first quartile (Table 3).

In the final model, the factors associated with lower gait speed were being older $(\mathrm{OR}=3.56)$, being illiterate $(\mathrm{OR}=3.20)$, having difficulty in one or more IADL $(\mathrm{OR}=$ $2.74)$, presence of cardiovascular disease $(\mathrm{OR}=2.15)$ and being active as a protection factor (Table 4). When we consider the $50 \%$ slower, we can add the variables handgrip, and presence of COPD.

\section{Discussion}

Knowing the factors associated with lower gait speed in quartiles allows us to propose actions that target each modifiable risk criterion in ageing, and reference values from healthy individuals are important for comparison to other samples and populations with different characteristics and limitations. This is the first study in a developing country with special focus on the social determinants of
Table 2 Distribution (\%) of older adults according to gait speed quartiles

\begin{tabular}{|c|c|c|c|c|c|c|}
\hline \multirow[t]{2}{*}{ Variables } & \multirow[b]{2}{*}{ Total } & \multicolumn{4}{|c|}{ Gait speed (\%) } & \multirow[t]{2}{*}{ Value $p$} \\
\hline & & $1^{\circ} \mathrm{Q}$ & $2^{\circ} \mathrm{Q}$ & $3^{\circ} \mathrm{Q}$ & $4^{\circ} \mathrm{Q}$ & \\
\hline Age & & & & & & 0.000 \\
\hline $60-74$ years & 74.9 & 17.6 & 30.8 & 27.5 & 24.0 & \\
\hline 75 years and more & 25.1 & 46.9 & 27.3 & 16.1 & 9.7 & \\
\hline Sex & & & & & & 0.987 \\
\hline Male & 39.7 & 25.3 & 29.3 & 24.7 & 20.7 & \\
\hline Female & 60.3 & 24.8 & 30.3 & 24.7 & 20.2 & \\
\hline Ethnicity & & & & & & 0.939 \\
\hline No White & 41.6 & 25.7 & 29.9 & 24.7 & 19.7 & \\
\hline White & 58.4 & 24.6 & 29.7 & 24.8 & 21.0 & \\
\hline Education & & & & & & 0.000 \\
\hline Illiterate & 11.8 & 38.7 & 35.8 & 16.4 & 9.1 & \\
\hline 1 to 3 years & 22.4 & 31.4 & 34.3 & 18.0 & 16.3 & \\
\hline 4 to 7 years & 38.1 & 25.6 & 29.5 & 27.3 & 17.6 & \\
\hline 8 years and more & 27.7 & 13.0 & 24.5 & 29.9 & 32.6 & \\
\hline Conjugal situation & & & & & & 0.001 \\
\hline with someone & 43.3 & 21.4 & 30.0 & 24.5 & 24.1 & \\
\hline Alone & 56.7 & 30.0 & 29.2 & 25.1 & 15.7 & \\
\hline BMI & & & & & & 0.701 \\
\hline Underweight & 12.5 & 27.7 & 32.1 & 24.5 & 15.2 & \\
\hline Eutrophic & 39.2 & 23.9 & 28.3 & 26.0 & 21.8 & \\
\hline Overweight & 48.3 & 25.2 & 30.7 & 23.4 & 20.6 & \\
\hline Enough income & & & & & & 0.044 \\
\hline No & 42.9 & 18.5 & 22.5 & 34.8 & 24.0 & \\
\hline Yes & 57.1 & 21.8 & 26.6 & 26.3 & 25.3 & \\
\hline
\end{tabular}

São Paulo-SP, Brazil. SABE Study, 2010. ( $\mathrm{n}=1112)$.

Abbreviations: BMI: Body Mass Index. Income level is presented as monthly income measured in multiples of the minimum wage.

health showing that poor socioeconomic conditions, together with modifiable factors, play an important role in gait speed. Being older, illiterate, having difficulty in one or more instrumental activities of daily living, the presence of cardiovascular disease and being sedentary are independent factors associated with lower walking speed among the elderly.

Our results were similar to those found worldwide [4,32]; and nationally $[30,31]$ they indicate that gait speed decreased with older age. Our older adults, however, were significantly slower than foreign populations $[34,35]$ and their gait speed was slower than the overall fast gait speed of participants who were 70 and older with mobility limitations living in community [36]. Bohannon (2011) found that for healthy women and men aged $70-79$, the usual gait speed was $1.13 \mathrm{~m} / \mathrm{s}$ and $1.26 \mathrm{~m} / \mathrm{s}$, respectively, and for those aged $80-89$, the values were 0.94 and $0.97 \mathrm{~m} / \mathrm{s}$ respectively [36], both higher values 
Table 3 Health status and lifestyle according to gait speed of elderly in São Paulo-SP, Br

\begin{tabular}{|c|c|c|c|c|c|c|}
\hline \multirow[t]{2}{*}{ Variables } & \multirow[t]{2}{*}{ Total } & \multicolumn{4}{|c|}{ Gait speed (\%) } & \multirow[t]{2}{*}{ Value $p$} \\
\hline & & $1^{\circ} \mathrm{Q}$ & $2^{\circ} \mathrm{Q}$ & $3^{\circ} \mathrm{Q}$ & $4^{\circ} \mathrm{Q}$ & \\
\hline Handgrip - (SE)* & $25.8(0.4)$ & $22.9(0.7)$ & $25.0(0.6)$ & $27.0(0.7)$ & $28.6(0.9$ & 0.000 \\
\hline TUG/mean (SE) ${ }^{* *}$ & $12.9(0.2)$ & $17.6(0.4)$ & $12.6(0.1)$ & $11.1(0.2)$ & $9.7(0.1)$ & 0.000 \\
\hline Self-rated health & & & & & & 0.000 \\
\hline Very good & 51.0 & 16.1 & 30.3 & 28.0 & 25.6 & \\
\hline Regular & 42.5 & 28.4 & 30.0 & 25.1 & 16.5 & \\
\hline Bad/very bad & 6.5 & 43.0 & 25.6 & 13.2 & 18.1 & \\
\hline $\begin{array}{l}\text { Cognitive } \\
\text { mpairment }\end{array}$ & & & & & & 0.000 \\
\hline Yes & 7.5 & 60.4 & 29.0 & 3.8 & 6.7 & \\
\hline No & 92.5 & 22.1 & 30.0 & 26.3 & 21.5 & \\
\hline Depression & & & & & & 0.006 \\
\hline Yes & 17.6 & 28.2 & 36.4 & 21.1 & 14.3 & \\
\hline No & 82.4 & 21.9 & 28.8 & 26.7 & 22.6 & \\
\hline Physical activity & & & & & & 0.070 \\
\hline Sedentary & 59.6 & 28.1 & 29.8 & 23.6 & 18.5 & \\
\hline Active & 40.4 & 20.4 & 30.1 & 26.2 & 23.3 & \\
\hline IADL disability & & & & & & 0.000 \\
\hline No & 67.0 & 16.7 & 27.9 & 29.8 & 25.5 & \\
\hline Yes & 33.0 & 41.3 & 33.9 & 14.5 & 10.4 & \\
\hline BADL disability & & & & & & 0.000 \\
\hline No & 75.3 & 19.6 & 29.5 & 27.9 & 23.0 & \\
\hline Yes & 24.7 & 41.5 & 31.2 & 14.7 & 12.6 & \\
\hline Chronic disease & & & & & & 0.004 \\
\hline None & 16.8 & 17.6 & 29.7 & 24.8 & 27.9 & \\
\hline 1 & 28.8 & 20.3 & 28.7 & 26.7 & 24.2 & \\
\hline 2 or more & 54.4 & 29.8 & 30.6 & 23.5 & 16.1 & \\
\hline Hipertension & 66.4 & 28.6 & 29.6 & 23.2 & 18.6 & 0.003 \\
\hline Diabetes & 25.3 & 27.0 & 30.7 & 23.2 & 19.1 & 0.727 \\
\hline COPD & 9.3 & 24.3 & 44.5 & 22.8 & 8.4 & 0.001 \\
\hline DCV & 22.8 & 32.6 & 31.8 & 24.5 & 11.1 & 0.000 \\
\hline AVC & 3.5 & 58.3 & 23.8 & 10.1 & 7.8 & 0.000 \\
\hline Artrithis & 32.3 & 28.9 & 32.5 & 23.4 & 15.2 & 0.012 \\
\hline
\end{tabular}

SABE Study, 2010.

Abbreviations: COPD:Chronic Obstructive Pulmonary Disease, DCV:Cardiovascular Disease, AVC: Cerebrovascular Accident. SE: Standard Error *TesteWald: the means are statistically different from each other in walking speed quartiles $(p<0.05)$ except between the means of the 1 st and 2 nd quartiles $(p=0.186){ }^{* *}$ TesteWald: the means are statistically different from each other in walking speed quartiles $(p$ $<0.001)$.

compared to our result. The gait speed of older adults in our study were similar to the elderly aged 80-89 living in community in Dublin(Ireland), 30 percent of whom needed more assistance to walk and longer TUG, 14.2 s (versus 5.6) compared to the Brazilian sample showed in this study [37].

Older adults aged 75 or over observed in our study were 3.56 (OR) more likely to be slower compared to
Table 4 Factors associated with gait speed according to quartiles of older adults

\begin{tabular}{|c|c|c|c|c|c|c|}
\hline & $1^{\circ} \mathrm{Q}$ & $p$ & $2^{\circ} \mathrm{Q}$ & $p$ & $3^{\circ} \mathrm{Q}$ & $p$ \\
\hline \multicolumn{7}{|l|}{ Age } \\
\hline 60 to $74 y$ & 1.00 & & 1.00 & & 1.00 & \\
\hline $75 y$ and more & 3.56 & 0.000 & 1.45 & 0.230 & 1.21 & 0.098 \\
\hline \multicolumn{7}{|l|}{ Education } \\
\hline illiterate & 3.20 & 0.017 & 2.97 & 0.024 & 1.74 & 0.216 \\
\hline 1 to $3 y$ & 2.78 & 0.003 & 2.17 & 0.011 & 1.10 & 0.779 \\
\hline 4 to $7 y$ & 2.93 & 0.000 & 2.10 & 0.005 & 1.59 & 0.067 \\
\hline 8 y or more & 1.00 & & 1.00 & & 1.00 & \\
\hline Handgrip & 0.98 & 0.154 & 0.97 & 0.023 & 0.98 & 0.362 \\
\hline \multicolumn{7}{|l|}{ IADL } \\
\hline No & 1.00 & & 1.00 & & 1.00 & \\
\hline Yes & 2.74 & 0.000 & 1.90 & 0.009 & 1.08 & 0.762 \\
\hline \multicolumn{7}{|l|}{ DCV } \\
\hline No & 1.00 & & 1.00 & & 1.00 & \\
\hline Yes & 2.15 & 0.006 & 1.82 & 0.037 & 2.05 & 0.017 \\
\hline \multicolumn{7}{|l|}{ COPD } \\
\hline No & 1.00 & & 1.00 & & 1.00 & \\
\hline Yes & 1.45 & 0.368 & 2,85 & 0.368 & 2.03 & 0.089 \\
\hline \multicolumn{7}{|l|}{ Active } \\
\hline No & 1.00 & & 1.00 & & 1.00 & \\
\hline Yes & 0.56 & 0.027 & 0.66 & 0.062 & 0.80 & 0.358 \\
\hline
\end{tabular}

SABE Study, 2010.

Abbreviations: IADL: Instrumental Activities of Daily Living; ADL: Activities of Daily Living.

The model was adjusted for mini mental state examination, ADL, conjugal situation.

younger subjects, and causal factors have been widely cited in the literature such as the loss of alpha motor neurons after the seventh decade [34], the loss of type II fibres [35] and muscle mass, with more rapid decline after age 65 [36,37] and the interposition of fat in muscle decreases muscle contraction [10].

Interestingly, comparing our results with those obtained from another sample of Brazilian elderly subjects - FIBRA network study (Frailty among Brazilian Older Adults), our average gait speed value was slower than the average of $(1.11 \mathrm{~m} / \mathrm{s})$ that study. The FIBRA study included subjects from different Brazilian cities with different Human Development Indexes, at an increased average age of $71.4[34,35,37,38]$. Besides that, the percentage of illiterate older adults was smaller and the methodology was different from our research. Unlike the FIBRA study, which used a convenience sample, ours used a weigthing sample in which a weight is attributed to each individual, which indeed makes it a representative sample of the city of Sao Paulo. Other studies included volunteer subjects [33,32] or only women [34]. 
Maybe these differences can explain why independent associations between gait speed and educational level or income were observed only in our study. Another relevant point: our data indicate a population of elderly patients living in São Paulo with chronic diseases that affect mobility and result in low physical activity [38]. According to international literature, our older adults are deemed as frail and [39] at high risk of poor outcome [10] and poor survival [8].

Despite gait assessment being a quick, safe, inexpensive and highly reliable measure, methodology can vary widely making it difficult to compare studies. Similar methods can differ in walking length, and different populations weaken the comparisons.

Although in Studenski's research (2011) the vast majority of the sample comprised white men and women, similar characteristics observed in our study, the mean gait speed in older adults was $0.92 \mathrm{~m} / \mathrm{s}$ [8], a higher value compared to our study despite $45 \%$ of all participants being older than 85. Watson [6], analyzing data from well-functioning sub-cohort (USA), found mean gait speed of $1.20 \mathrm{~m} / \mathrm{s}$ and the mean gait speed of the first quartile slower than $1.05 \mathrm{~m} / \mathrm{s}$; a higher value comparing to our results although mean age of sample was higher (75.2 years) Although the subjects in Watson's studies were older, and $68.2 \%$ of them were sedentary, they were faster. A factor that may have influenced his study more favourably is that his sample comprised greater numbers of men and black individuals; moreover, those subjects had more education than the ones in our sample. However, similarly to our results, the participants in the lower quartile of gait speed were more likely to be older, sedentary, have less education and have more chronic health conditions.

Our results revealed that gait speed increases with the highest level of education (OR 3.20), similar to that found in Brunner's study (2009) [40]. Years of schooling are used as a proxy for social status and, thus, health condition. Most of the elderly individuals in Brazil live in poor conditions, particularly in São Paulo, a city with great economic and social contrasts (almost $40 \%$ of the elderly subjects were illiterate). Although education alone does not ensure the end of social discrimination, it is part of the formation of a more egalitarian society and a critical factor in reducing socioeconomic disparities. Despite the positive correlation between education and income, education is considered a major factor in overcoming income inequality. Educational level is a protective factor and prevents poor outcomes in health. Individuals with more education are more likely to obtain financial resources, seek medical advice and detect diseases earlier; therefore, they have better self-reported health, get better health treatment and better understand the importance of prevention, such as doing physical activity and, thereby, decrease their chance of comorbidity. It is a fact that prevalence of chronic disease may also be influenced by an individual's access to health services, by their socioeconomic condition, and self-reported health status [41]. Self-reported health is recognized internationally as an indicator of health status, and may justify a positive association with gait speed in bivariate analyses.

Although a positive correlation between handgrip and gait speed was observed, the handgrip association did not remain significant to the first quartile of gait speed in the final model, probably due to the fact that the subjects were already very committed in walking speed.

Regarding the TUG, our study found a mean of $12.9 \mathrm{~s}$, a higher value than the results found in an meta-analysis (9.4 s) [39]. Although we did not explore the mechanisms underlying the changes observed in this study, the negative correlation found between TUG and gait speed shows the importance of evaluation of gait and balance. Gait is dependent on postural control and the integration of various systems, such as proprioceptive, visual and vestibular, their sensory input, integration in the Central Nervous System (CNS) and, depending on effective motor response $[39,40]$ and gait assessment, it is a form of prevention against disability and motor decline [16].

Another population-based study revealed that each increment of one standard deviation in the usual gait speed was associated with a reduced likelihood of disability from 26 to $44 \%$ [41]. Similarly, our current findings revealed $33.7 \%$ of subjects disabled in one or more instrumental activities with $2.74(\mathrm{OR})$ to be on the first quartile of gait speed.

The results presented here show in bivariate analysis that the presence of cognitive impairment was significantly associated with gait speed. The same results were found in other studies, reinforcing the notion that cognition influences gait speed $[6,42,43]$. The significant association between gait and cognition maybe can be explained by the influence of cognitive aspects and mood on the maintenance of functional capacity, and by the need of physical and intellectual integrity to remain autonomous and independent. Although it is discussed whether cognitive decline is a predisposing or precipitating factor in the decline of gait speed [44], our data seems to indicate that the decline in physical function is secondary to cognition. Perhaps most of the older adults in São Paulo cannot afford cognitive rehabilitation services.

Regarding depression, the present results show that depression levels have a positive correlation to gait speed, which agrees with what Mossey and colleagues presented (2000) [45]. Adopting a healthier lifestyle is an important part of treating depression, e.g. doing physical activities on a regular basis. Previously published systematic reviews and meta-analysis concluded that exercise reduces depressive symptoms among patients with a 
chronic disease [46,47]. Research has also shown that depressed patients are less fit and have diminished physical work capacity [48], which in turn may contribute to other physical health problems. Depression in Brazil is underdiagnosed, probably because its diagnosis is often hampered by the presence of comorbidities, the difficulty of the healthcare teams to recognize it and the lack of mental health care in the primary health care system. Studies show that between $50-60 \%$ of the cases of depression are not detected or adequately treated [49]. Furthermore, depending on the intensity of the depressive symptoms, it becomes impossible to motivate the subject to do physical activity.

In the final model, those who considered being active showed to be significantly associated with higher walking speed. One of the important ways to prevent the insidious loss of bone and muscle strength is to stay active. When an individual loses muscle strength, walking becomes less frequent and slower, as one becomes physically unconditioned. Consequently, the individual becomes more sensitive to fatigue and, thereby, increases inactivity. Once this vicious cycle is triggered, it ends up compromising initially instrumental activities and, subsequently, the basic ones if nothing is done to halt the cycle. Physical inactivity is an important risk to cardiovascular disease. It was shown, however, that it is preventable, up to $80 \%$, by eliminating shared risk factors such as physical inactivity [50]. Our data revealed an important association between cardiovascular diseases with the lowest quartile of gait speed in the final model. This reinforces the fact that the usual speed of gait is related to aerobic capacity showing association with functional reserve [51]. Walking imposes demands on the nervous, cardiovascular, pulmonary, musculoskeletal and hematologic systems, as they require more oxygen to contract the muscles. These systems work synergistically - if one of them does not work well, it can impair gait speed [8].

Other studies showed that regular exercise significantly improved physical fitness (aerobic capacity), walking capacity and cardiovascular dimensions [52].

Considering the relevance of this problem, Matsudo and colleagues interviewed 2001 individuals aged 14-77 in 29 cities within the state of Sao Paulo and showed that the levels of physical activity did not differ among age ranges. There were similarities between the genders, but people from metropolitan regions and the poorer ones were less active [53]. Probably the modern world with electronic novelties encourages a sedentary life style.

Another study conducted in Santos (a beach city in Brazil) recruited healthy elders of both genders as volunteers, who also led a sedentary life style. Their gait speed was $1.34 \mathrm{~m} / \mathrm{s}$ among men, and $1.27 \mathrm{~m} / \mathrm{s}$ among women. The values of gait speed found were significantly lower than those foreign benchmarks $(p<0.05)[32,54]$ but higher than our findings in São Paulo, probably because of different habits and socioeconomic backgrounds. It is important to mention that although our data has been adjusted for height, the average height of the Brazilian elderly population is shorter compared to populations of a similar age range from developed countries.

Regarding cerebrovascular disease and the lack of association with lower walking speed in the final model, it could be explained by the exclusion of all individuals with motor sequels, which could have influenced gait measures. COPD is a systemic disease that affects beyond the respiratory, cardiovascular and muscular systems. Among the muscle changes are loss of muscle mass, loss of efficiency to carry out protein synthesis, decrease in type I fibres $[55,56]$. There are several factors that can cause these changes in the muscular system such as chronic hypoxemia, prolonged usage of high doses of corticosteroids, nutritional changes, the response to systemic inflammation and even physical deconditioning [56]. The inability to exercise and the ventilatory limitations increase deconditioning, which ends up compromising their functionality [55]. These factors may explain the significant association between lower gait and COPD found in the bivariate analyses. However, this association was not found in the multivariate analyses. Although $54.4 \%$ of the elderly subjects reported two or more chronic diseases, $50.9 \%$ related their health as very good, which reinforces that health is no longer measured by the presence or absence of diseases, but by the degree of preservation of one's functional capacity and independence. Such result was also evidenced by the high prevalence of elderly people without disability in basic and instrumental activities. What is at stake in old age is autonomy, the ability of the elderly to remain socially integrated and, for all purposes, health [57]. In our study, $46 \%$ of the elderly aged 75 years or over were in the first quartile, which could be related to the prevalence of more chronic diseases and worse handgrip strength; they had lower educational levels and were inactive, similar to other studies $[6,9]$.

\section{Study limitations}

Despite the advantages of quickness and costs of the cross-sectional study, it presents limitations since it does not allow one to identify causality, whether the factors identified as associated to lower gait speed came before or after it, since expositions and outcomes are collected at the same moment. This may also explain the lack of significance between race and lower gait speed found in this study. In addition, the presence of chronic diseases, health condition, disability and physical activity were assessed by means of self -reporting, which may result in over or under-estimation of prevalence. However, participants report only those conditions diagnosed by a physician. 
As to physical activity, IPAQ was validated in a sample of the Brazilian population. Older adults who used assistive devices to walk, or those with severe neurological conditions, were excluded, which might limit the external validity of the study. Our current results show that poor socioeconomic conditions present in developing countries influence lower walking speed such as education, and they may be particularly related to some modifiable factors such as impairment of IADL, physical inactivity and cardiovascular disease.

\section{Conclusion}

The current results revealed an elderly population with a lower average speed compared to older adults from developed countries. A population-based cross sectional study reflected the exact condition of the elderly. It suggested that biological and socioeconomic factors such as one's education level and lifestyle might interfere in one's health condition, as it may also explain the different patterns of gait speed.

The identification of the factors related to lower walking speed is essential to elaborate preventive actions to be carried out before senior citizens reach worse gait speed, which can be a proxy for other conditions that lead to an undesirable health outcome. These results alert for the prevention of CVD avoiding lower gait speed and impaired functional capacity, thus reinforcing the importance for the elderly to remain active and age healthy.

\section{Competing interests}

The authors declare that they have no competing interests.

\section{Authors' contributions}

TAB and YAD worked on the conception and design, data analysis and interpretation and drafting of this article, performed a critical review of the manuscript and approved the final version to be published. DPN worked on data analysis and interpretation, performed a critical review of the manuscript and approved the final version to be published. MSN and ASR performed a critical review of the manuscript and approved the final version to be published. MLL and EAJ worked on the interpretation of the data, performed a critical review of the manuscript and approved the final version to be published.

\section{Authors' information}

MLL and YAD are chief investigators in a health, wellbeing and aging (SABE) research study, a multicentre project coordinated by the Pan-American Health Organization and conducted in seven countries in Latin America and the Caribbean which studies the determinants of health and health-related conditions in older adults living in cities with different development indexes.

\section{Acknowledgements}

We would like to thank all the elderly people that participated in this research, and $M L L$ for her competent and affectionate coordination of the SABE Project, which together with YAD has made this study a reality.

\section{Author details}

${ }^{1}$ Hospital Israelita Albert Einstein, Av. Albert Einstein, 670, São Paulo, SP, Brazil. ${ }^{2}$ Department of Nursing, School of Nursing, University of São Paulo, São Paulo, SP, Brazil. ${ }^{3}$ Department of Epidemiology, School of Public Health, University of São Paulo, São Paulo, SP, Brazil. ${ }^{4}$ Human Genome Research Center, University of São Paulo, São Paulo, SP, Brazil. ${ }^{5}$ Department of Radiology, University of São Paulo, São Paulo, SP, Brazil.
Received: 28 September 2014 Revised: 2 October 2014

Accepted: 12 March 2015

Published online: 01 April 2015

\section{References}

1. IBGE Instituto Brasileiro de Geografia e Estatística: Projeções e estimativas da população do Brasil e das Unidades de Federação (2014). Accessed 31 march 2015. http://www.ibge.gov.br/apps/populacao/projecao/-.

2. Thal DR, Del Tredici K, Braak H. Neurodegeneration in normal brain aging and disease. Sci Aging Knowledge Environ. 2004;2004(23):e26

3. Ferrucci $L$, Bandinelli S, Benvenuti E, Di lorio A, Macchi $C$, Harris TB, et al. Subsystems contributing to the decline in ability to walk: bridging the gap between epidemiology and geriatric practice in the InCHIANTI study. J Am Geriatr Soc. 2000;48(12):1618-25.

4. Tolea MI, Costa PT, Terracciano A, Griswold M, Simonsick EM, Najiar SS, et al. Sex-specific correlates of walking speed in a wide age-ranged population. J Gerontol B Psychol Sci Soc Sci. 2010;65B(2):174-84.

5. Ko SU, Hausdorff JM, Ferrucci L. Age-associated differences in the gait pattern changes of older adults during fast-speed and fatigue conditions: results from the Baltimore longitudinal study of ageing. Age Ageing. 2010;39(6):688-94

6. Watson NL, Rosano C, Boudreau RM, Simonsick EM, Ferrucci L, Sutton-Tyrrell K, et al. Executive function, memory, and gait speed decline in well-functioning older adults. J Gerontol A Biol Sci Med Sci. 2010;65(10):1093-100.

7. Teixeira-Leite $\mathrm{H}$, Manhaes AC. Association between functional alterations of senescence and senility and disorders of gait and balance. Clinics (Sao Paulo). 2012:67(7):719-29.

8. Studenski S, Perera S, Patel K, Rosano C, Faulkner K, Inzitari M, et al. Gait speed and survival in older adults. JAMA. 2011:305(1):50-8.

9. Quach L, Galica AM, Jones RN, Procter-Gray E, Manor B, Hannan MT, et al. The nonlinear relationship between gait speed and falls: the Maintenance of Balance, Independent Living, Intellect, and Zest in the Elderly of Boston Study. J Am Geriatr Soc. 2011;59(6):1069-73.

10. Abellan van Kan G, Rolland Y, Andrieu S, Bauer J, Beauchet O, Bonnefoy M, et al. Gait speed at usual pace as a predictor of adverse outcomes in community-dwelling older people an International Academy on Nutrition and Aging (IANA) Task Force. J Nutr Health Aging. 2009;13(10):881-9.

11. Montero-Odasso M, Schapira M, Soriano ER, Varela M, Kaplan R, Camera LA, et al. Gait velocity as a single predictor of adverse events in healthy seniors aged 75 years and older. J Gerontol A Biol Sci Med Sci. 2005;60(10):1304-9.

12. Cesari M, Kritchevsky SB, Penninx BW, Nicklas BJ, Simonsick EM, Newman AB, et al. Prognostic value of usual gait speed in well-functioning older people-results from the Health, Aging and Body Composition Study. J Am Geriatr Soc. 2005:53(10):1675-80.

13. Studenski S, Perera S, Wallace D, Chandler JM, Duncan PW, Rooney E, et al. Physical performance measures in the clinical setting. J Am Geriatr Soc. 2003;51(3):314-22.

14. Guralnik JM, Ferrucci L, Pieper CF, Leveille SG, Markides KS, Ostir GV, et at. Lower extremity function and subsequent disability: consistency across studies, predictive models, and value of gait speed alone compared with the short physical performance battery. J Gerontol A Biol Sci Med Sci. 2000;55(4):M221-31.

15. Hardy SE, Perera S, Roumani YF, Chandler JM, Studenski SA. Improvement in usual gait speed predicts better survival in older adults. J Am Geriatr Soc. 2007;55(11):1727-34

16. Fried LP, Tangen CM, Walston J, Newman AB, Hirsch C, Gottdiener J, et al. Frailty in older adults: evidence for a phenotype. J Gerontol A Biol Sci Med Sci. 2001;56(3):M146-56.

17. Graham JE, Ostir GV, Fisher SR, Ottenbacher KJ. Assessing walking speed in clinical research: a systematic review. J Eval Clin Pract. 2008;14(4):552-62.

18. Camicioli R, Howieson D, Oken B, Sexton G, Kaye J. Motor slowing precedes cognitive impairment in the oldest old. Neurology. 1998;50(5):1496-8.

19. Marquis S, Moore MM, Howieson DB, Sexton G, Payami H, Kaye JA, et al. Independent predictors of cognitive decline in healthy elderly persons. Arch Neurol. 2002:59(4):601-6.

20. Waite LM, Grayson DA, Piguet O, Creasey H, Bennett HP, Broe GA. Gait slowing as a predictor of incident dementia: 6-year longitudinal data from the Sydney Older Persons Study. J Neurol Sci. 2005;229-230:89-93.

21. Lebrão MLDY, organizador. O Projeto SABE no município de São Paulo: uma abordagem inicial. Brasília: Organização Pan-Americana da Saúde; 2003. 
22. Guralnik JM, Simonsick EM, Ferrucci L, Glynn RJ, Berkman LF, Blazer DG, et al. A short physical performance battery assessing lower extremity function: association with self-reported disability and prediction of mortality and nursing home admission. J Gerontol. 1994;49(2):M85-94.

23. Herrera Jr E, Caramelli P, Silveira AS, Nitrini R. Epidemiologic survey of dementia in a community-dwelling Brazilian population. Alzheimer Dis Assoc Disord. 2002;16(2):103-8.

24. Barreto SM, Passos VM, Lima-Costa MF. Obesity and underweight among Brazilian elderly: the Bambui Health and Aging Study. Cad Saude Publica. 2003;19(2):605-12.

25. Guía clínica para atención primaria a las personas adultas mayores / Clinical guidelines for attention primary to the older adults. In: Organización Panamericana de la Salud. División Promoción y Protección de la Salud. Programa de Salud de la Familia y Población. Unidad de Envejecimiento y Salud. Washington, DC; Organizacion Panamericana de la Salud; ene. 2003. 405 p. (OPS. Promoción de la Salud y Envejecimiento Activo. Serie Materiales de Capacitación, 1) http://www.sld.cu/galerias/pdf/sitios/ gericuba/introduccion.pdf. Accessed 31 march 2015.

26. Matsudo S, Araújo T, Matsudo V, Andrade D, Andrade E, Oliveira LC, et al. Questionário Internacional de Atividade Física (IPAQ): Estudo de validade e reprodutibilidade no Brasil. Rev Bras Ativ Fis Saúde. 2001;6(2):14.

27. McGough EL, Kelly VE, Logsdon RG, McCurry SM, Cochrane BB, Engel JM, et al. Associations between physical performance and executive function in older adults with mild cognitive impairment: gait speed and the timed "up \& go" test. Phys Ther. 2011;91(8):1198-207.

28. Icaza MC, Albala C. PROJETO SABE. Minimental State Examination (MMSE) del Studio de dementia en Chile: análisis estatístico. OPAS. 1999;19:1-18.

29. Yesavage JA, Brink TL, Rose TL, Lum O, Huang V, Adey M, et al. Development and validation of a geriatric depression screening scale: a preliminary report. J Psychiatr Res. 1982;17(1):37-49.

30. Almeida OP, Almeida SA. Reliability of the Brazilian version of the ++abbreviated form of Geriatric Depression Scale (GDS) short form. Arq Neuropsiquiatr. 1999;57(2B):421-6.

31. Podsiadlo D, Richardson S. The timed "Up \& Go": a test of basic functional mobility for frail elderly persons. J Am Geriatr Soc. 1991;39(2):142-8.

32. Bohannon RW. Comfortable and maximum walking speed of adults aged 20-79 years: reference values and determinants. Age Ageing. 1997;26(1):15-9.

33. Rao J, Scott AJ. On chi-squared tests for multiway contingency tables with cell proportions estimated from survey data. Ann Stat. 1984;12(1):15.

34. Abreu SSECC. Gait speed, balance and age: a correlational study among elderly women with and without participation in a therapeutic exercise program. Rev Bras Fisioter. 2008;12(4):7.

35. Novaes RD MA, Dourado VZ. Usual gait speed assessment in middle-aged and elderly Brazilian subjects.2011,15 (2):117-22. Rev Bras Fisioter. 2011;15(2):6.

36. Bohannon RW, Williams Andrews A. Normal walking speed: a descriptive meta-analysis. Physiotherapy. 2011;97(3):182-9.

37. Romero-Ortuno R, Cogan L, Cunningham CU, Kenny RA. Do older pedestrians have enough time to cross roads in Dublin? A critique of the Traffic Management Guidelines based on clinical research findings. Age Ageing. 2010;39(1):80-6.

38. Ruggero CR, Bilton $T L$, Teixeira LF, Ramos Jde $L$, Alouche $S R$, Dias RC, et al. Gait speed correlates in a multiracial population of community-dwelling older adults living in Brazil: a cross-sectional population-based study. BMC Public Health. 2013;13:182.

39. Bohannon RW. Grip strength predicts outcome. Age Ageing. 2006;35(3):320. author reply 320 .

40. Horak FB, Henry SM, Shumway-Cook A. Postural perturbations: new insights for treatment of balance disorders. Phys Ther. 1997;77(5):517-33.

41. Kuo HK, Leveille SG, Yen CJ, Chai HM, Chang CH, Yeh YC, et al. Exploring how peak leg power and usual gait speed are linked to late-life disability: data from the National Health and Nutrition Examination Survey (NHANES), 1999-2002. Am J Phys Med Rehabil. 2006;85(8):650-8.

42. Liu-Ambrose T, Davis JC, Nagamatsu LS, Hsu CL, Katarynych LA, Khan KM. Changes in executive functions and self-efficacy are independently associated with improved usual gait speed in older women. BMC Geriatr. 2010;10:25.

43. Holtzer R, Verghese J, Xue X, Lipton RB. Cognitive processes related to gait velocity: results from the Einstein Aging Study. Neuropsychology. 2006;20(2):215-23.

44. Fitzpatrick AL, Buchanan CK, Nahin RL, Dekosky ST, Atkinson HH, Carlson MC, et al. Associations of gait speed and other measures of physical function with cognition in a healthy cohort of elderly persons. J Gerontol A Biol Sci Med Sci. 2007;62(11):1244-51.

45. Mossey JM, Gallagher RM, Tirumalasetti F. The effects of pain and depression on physical functioning in elderly residents of a continuing care retirement community. Pain Med. 2000;1(4):340-50.

46. Herring MP, Puetz TW, O'Connor PJ, Dishman RK. Effect of exercise training on depressive symptoms among patients with a chronic illness: a systematic review and meta-analysis of randomized controlled trials. Arch Intern Med. 2012;172(2):101-11.

47. Schwandt M, Harris JE, Thomas S, Keightley M, Snaiderman A, Colantonio A. Feasibility and effect of aerobic exercise for lowering depressive symptoms among individuals with traumatic brain injury: a pilot study. J Head Trauma Rehabil. 2012;27(2):99-103.

48. Craft LL, Perna FM. The Benefits of Exercise for the Clinically Depressed. Prim Care Companion J Clin Psychiatry. 2004;6(3):104-11.

49. Andrade LH, Wang $Y$, Andreoni S, Silveira CM, Alexandrino-Silva C, Siu ER, et al. Mental Disorders in Megacities: Findings from the São Paulo Megacity Mental Health Survey, Brazil. PLoS ONE. 2012;7(2):e31879. doi:10.1371/ journal.pone.0031879.

50. 2008-2013 Action Plan for the Global Strategy for the Prevention and Control of Noncommunicable Diseases.

51. Fiser WM, Hays NP, Rogers SC, Kajkenova O, Williams AE, Evans CM, et al. Energetics of walking in elderly people: factors related to gait speed. J Gerontol A Biol Sci Med Sci. 2010;65(12):1332-7.

52. American College of Sports M, Chodzko-Zajko WJ, Proctor DN, Fiatarone Singh MA, Minson CT, Nigg CR, et al. American College of Sports Medicine position stand. Exercise and physical activity for older adults. Med Sci Sports Exerc. 2009;41(7):1510-30.

53. Matsudo SM, Matsudo VR, Araujo T, Andrade D, Andrade E, Oliveira L. Nível de atividade física da população do Estado de São Paulo: análise de acordo com o gênero, idade, nível socioeconômico, distribuição geográfica e de conhecimento. Rev Bras Ciên e Mov. 2002;10(4):41-50.

54. Oberg T, Karsznia A, Oberg K. Basic gait parameters: reference data for normal subjects, 10-79 years of age. J Rehabil Res Dev. 1993;30(2):210-23.

55. Maltais F, LeBlanc P, Jobin J, Casaburi R. Peripheral muscle dysfunction in chronic obstructive pulmonary disease. Clin Chest Med. 2000;21(4):665-77.

56. Agusti A, Sauleda J, Morla M, Miralles C, Busquets X. Skeletal muscle dysfunction in COPD. Cell mechanisms. A.G.N. Arch Bronconeumol. 2001;37(4):197-205.

57. Ramos LR. Fatores determinantes do envelhecimento saudável em idosos residentes em centro urbano: Projeto Epidoso, São Paulo. Cad Saude Publica. 2003;19:793-7.

\section{Submit your next manuscript to BioMed Central and take full advantage of:}

- Convenient online submission

- Thorough peer review

- No space constraints or color figure charges

- Immediate publication on acceptance

- Inclusion in PubMed, CAS, Scopus and Google Scholar

- Research which is freely available for redistribution 


\section{Termo de Consentimento Livre e Esclarecido - v. 1 01/01/2011 : \\ Estudo de Correlação de Ressonância com Variantes Genéticas em Octagenários Saudáveis}

Esta pesquisa visa criar e testar um banco de imagens funcionais do cérebro de homens e mulheres saudáveis, com mais de 80 anos, enquanto realizam atividades de linguagem e movimentação das mãos. Esses resultados serão integrados com a análise do genoma dessas pessoas.

O principal benefício desta pesquisa é conhecer e estabelecer critérios de ativação cerebral normal em pessoas que preservam a capacidade cognitiva. Ainda, no caso específico de linguagem, é importante ampliar os estudos das áreas cerebrais envolvidas em português falado no Brasil.

Os resultados dessas pesquisas serão muito importantes para ampliar nossos conhecimentos sobre a interface entre a imagem cerebral e nossos genes. Além disso, permitirá obter um padrão de normalidade do funcionamento cerebral para que pacientes com alterações cerebrais possam ser comparados e assim determinar qual a natureza dessas eventuais alterações.

Você responderá a alguns questionários, e no dia do exame ficará no interior de um aparelho de ressonância magnética por 20 minutos, que é semelhante a um pequeno túnel. Durante todo o procedimento você será observado (a) pela equipe. Poderá se comunicar através de um microfone e ouvir o médico através de um fone de ouvido (que também serve para reduzir o ruído produzido pelo aparelho). Algumas pessoas não se sentem à vontade quando entram no aparelho de ressonância magnética, já que é um lugar fechado. Caso você decida, poderá ser retirado do aparelho a qualquer momento.

Será também colhida uma pequena quantidade de sangue $(10 \mathrm{ml})$ de uma veia do seu braço. Deste sangue, será extraído o material genético (DNA), que será utilizado para pesquisas que correlacionem seu genoma com características identificadas na ressonância magnética e/ou nos questionários.

A qualquer momento desta pesquisa você poderá contatar o pesquisador nos números abaixo, para esclarecimentos sobre o curso da pesquisa.

A qualquer momento você poderá se recusar a participar ou retirar seu consentimento, sem penalização alguma. Caso um dia você venha a utilizar os serviços deste hospital, a retirada do consentimento não implicará em qualquer mudança no seu tratamento.

As informações que possam identificá-lo (a) serão retiradas, e codificadas de maneira a assegurar a garantia do sigilo e privacidade quanto aos dados confidenciais envolvidos nesta pesquisa.

Estão previstos ressarcimentos (item IV da Res. 196/96) de despesas de transporte e alimentação.

Apesar do exame não ter fins diagnósticos (ele não é completo para isto), o exame pode eventualmente mostrar alterações inesperadas em uma pessoa sadia. Se isto ocorrer, diga se:

- o (a) Sr.(a) gostaria de ser informado: sim ( ) ou não ( ).

Caso opte por ser informado, o (a) Sr. (a) receberá as orientações necessárias conforme o achado.

Em caso de dúvida relacionada a esta pesquisa, o (a) Sr. (a) poderá entrar em contato com Dr. Edson Amaro Jr, tel. 3747-2487, ou Dr. David Schlesinger, tel. 3747-1366.

Lí e estou de acordo com os termos acima,

São Paulo, de de

Voluntário: Assinatura:

Pesquisador: Assinatura:

Testemunha 1: Assinatura:

Testemunha 2: Assinatura: 
Base Normativa de fMRI - HIAE - V A M S - pré

Nome:

Horário: .... horas .... min. Data: ..../..../....

INSTRUÇÕES: Avalie como você se sente agora em relação aos itens abaixo e marque cada linha com um traço vertical no ponto que melhor descreve seus sentimentos. O centro de cada linha indica como você habitualmente se encontra e as extremidades indicam o máximo de cada condição.

ALERTA

SONOLENTO

CALMO

AGITADO

FORTE

FRACO

CONFUSO

COM IDÉIAS

CLARAS

ÁGIL

DESAJEITADO

APÁTICO

DINÂMICO

SATISFEITO

INSATISFEITO

PREOCUPAD

TRANQUILO

$\mathrm{O}$

PERSPICAZ

RACIOCÍNIO

DIFÍCIL

RELAXADO

TENSO

DISTRAÍDO

ATENTO

CAPAZ

INCAPAZ

TRISTE

ALEGRE

AMISTOSO

HOSTIL

INTERESSAD

DESINTERESSA

$\mathrm{O}$

DO

RETRAÍDO

SOCIÁVEL 


\section{O(A) SR(A). PODERIA, POR FAVOR, RESPONDER ÀS SEGUINTES PERGUNTAS A RESPEITO DE SUA SAÚDE:}

Tem dores de cabeça freqüentes?.

Tem falta de apetite?

Dorme mal?

Assusta-se com facilidade?

Tem tremores na mão?

Sente-se nervoso(a), tenso(a) ou preocupado(a)?

Tem má digestão?

Tem dificuldade de pensar com clareza?

Tem se sentido triste ultimamente?

Tem chorado mais do que de costume?

Encontra dificuldades para realizar com satisfação as suas atividades diárias?...

Tem dificuldades para tomar decisões?

Tem dificuldades no serviço (seu trabalho é penoso, lhe causa sofrimento)?........

É incapaz de desempenhar um papel útil em sua vida?

Tem perdido o interesse pelas coisas?

Você se sente uma pessoa inútil, sem préstimo?

Tem tido a idéia de acabar coma vida?.

Sente-se cansado(a) o tempo todo?

Tem sensações desagradáveis no estômago?

Você se cansa com facilidade?.
SIM $\square \quad \mathrm{NÃO} \square$

$\mathrm{SIM} \square \quad \mathrm{N} \tilde{\mathrm{A}} \mathrm{O}$

$\mathrm{SIM} \square \quad \mathrm{NÃO} \square$

SIM $\square \quad \mathrm{NÃO} \square$

$\mathrm{SIM} \square \quad \mathrm{NÃO} \square$

$\mathrm{SIM} \square \quad \mathrm{NÃO} \square$

SIM $\square \quad$ NÃO $\square$

SIM $\square \quad$ NÃO $\square$

SIM $\square \quad$ NÃO $\square$

SIM $\square \quad \mathrm{NÃO} \square$

SIM $\square \quad$ NÃO $\square$

SIM $\square \quad$ NÃO $\square$

SIM $\square \quad N \tilde{N O} \square$

SIM $\square \quad$ NÃO $\square$

SIM $\square \quad$ NÃO $\square$

SIM $\square \quad N \tilde{N} \mathrm{O} \square$

SIM $\square \quad$ NÃO $\square$

SIM $\square \quad$ NÃO $\square$

SIM $\square \quad$ NÃO $\square$

SIM $\square \quad \mathrm{NÃO} \square$ 


\section{Questionário: Dominância Motora \\ Edinburgh Handedness Inventory (EHI) \\ Oldfield (1971)}

Por favor, indique as suas preferências de uso das mãos nas atividades a seguir, assinalando com um + a coluna apropriada. Onde a preferência for tão forte que você nem tentaria utilizar a outra mão sem ser forçado, assinale com ++ . Caso a mão for realmente indiferente para a atividade, marque com um + em cada coluna.

Algumas atividades costumam requisitar as duas mãos. Nesses casos, a parte da tarefa ou o objeto que se utiliza a mão preferencial está indicado entre parênteses.

Por favor, tente responder todas as questões, apenas deixe em branco aquelas atividades que você não teve a experiência de realizar.

\begin{tabular}{c|l|c|c}
\hline \multicolumn{2}{l|}{} & Mão Esquerda & Mão Direita \\
\hline 1 & Escrever & & \\
\hline 2 & Desenhar & & \\
\hline 3 & Arremessar (uma bola) & & \\
\hline 4 & Manipular uma tesoura & & \\
\hline 5 & Segurar uma escova de dentes & & \\
\hline 6 & Manipular uma faca (sem o garfo) & & \\
\hline 7 & Manipular uma colher & & \\
\hline 8 & Segurar uma vassoura (mão superior) & & \\
\hline 9 & Riscar um fósforo & & \\
\hline 10 & Abrir a tampa de uma caixa & & \\
\hline
\end{tabular}




\section{Inventário para Depressão de Beck}

Neste questionário existem grupos de afirmativas. Por favor leia cada uma delas e selecione a afirmativa que melhor descreva como você se sentiu NA SEMANA QUE PASSOU, INCLUINDO O DIA DE HOJE. Desenhe um círculo ao lado da afirmativa que tiver selecionado.

Se várias afirmativas no grupo parecem aplicar-se igualmente bem, circule cada uma delas. Certifique-se de ter lido todas as afirmativas antes de fazer sua escolha.

\section{1) $\quad 0 \quad$ Não me sinto triste.}

1 Sinto-me triste.

2 Sinto-me triste o tempo todo e não consigo sair disso.

3 Estou tão triste e infeliz que não posso agüentar.

2) $0 \quad$ Não estou particularmente desencorajado quanto ao futuro.

1 Sinto-me desencorajado quanto ao futuro.

2 Sinto que não tenho nada por que esperar.

3 Sinto que o futuro é sem esperança e que as coisas não podem melhorar.

3) $\quad 0 \quad$ Não me sinto fracassado.

1 Sinto que falhei mais do que o indivíduo médio.

2 Quando olho para trás em minha vida, tudo que vejo é uma porção de fracassos.

3 Sinto que sou um fracasso completo como pessoa.

4) 0 Obtenho tanta satisfação com as coisas como costumava fazer.

1 Não gosto das coisas da maneira como costumava gostar.

2 Não consigo mais sentir satisfação real com coisa alguma.

3 Estou insatisfeito ou entediado o tempo todo.

5) $\quad 0 \quad$ Não me sinto particularmente culpado.

1 Sinto-me culpado boa parte do tempo.

2 Sinto-me muito culpado a maior parte do tempo.

3 Sinto-me culpado o tempo todo.

6) $0 \quad$ Não sinto que esteja sendo punido.

1 Sinto que posso ser punido.

2 Sinto que estou sendo punido.

7) 0 Não me sinto desapontado comigo mesmo.

1 Sinto-me desapontado comigo mesmo.

2 Sinto-me aborrecido comigo mesmo.

3 Eu me odeio.

8) $\quad 0 \quad$ Não sinto que seja pior que qualquer outra pessoa.

1 Critico minhas fraquezas ou erros.

2 Responsabilizo-me o tempo todo por minhas falhas.

3 Culpo-me por todas as coisas ruins que acontecem.

9) 0 Não tenho nenhum pensamento a respeito de matar.

1 Tenho pensamentos sobre me matar mas não os levaria adiante.

2 Gostaria de matar.

3 Eu me mataria se tivesse uma oportunidade. 
10) 0 Não costumo chorar mais que o habitual.

1 Choro mais agora do que costumava fazer.

2 Atualmente choro o tempo todo.

3 Eu costumava conseguir chorar, mas agora não consigo, mesmo que queira.

11) $0 \quad$ Não me irrito mais agora que em qualquer outra época.

1 Fico molestado ou irritado mais facilmente do que costumava.

2 Atualmente sinto-me irritado todo tempo.

3 Absolutamente não me irrito com as coisas que costumavam irritar-me.

12) $0 \quad$ Não perdi o interesse nas outras pessoas.

1 Interesso-me menos do que costumava pelas outras pessoas.

2 Perdi a maior parte do meu interesse nas outras pessoas.

3 Perdi todo o meu interesse nas outras pessoas.

13) $0 \quad$ Tomo decisões mais ou menos tão bem como em qualquer outra época.

1 Adio minhas decisões mais do que costumava.

2 Tenho maior dificuldade em tomar decisões mais do que antes.

3 Não consigo mais tomar decisões.

14) 0 Não sinto que minha aparência seja pior do que costumava ser.

1 Preocupo-me por estar parecendo velho ou sem atrativos.

2 Sinto mudanças permanentes em minha aparência que me fazem parecer sem atrativos.

3 Considero-me feio.

15) $\quad 0 \quad$ Posso trabalhar mais ou menos tão bem quanto antes.

1 Preciso de um esforço extra para começar qualquer coisa.

2 Tenho que me forçar muito até fazer qualquer coisa.

3 Não consigo fazer nenhum trabalho.

16) $0 \quad$ Durmo tão bem quanto de hábito.

1 Não durmo tão bem quanto costumava.

2 Acordo 1 ou 2 horas mais cedo do que de hábito e tenho dificuldade de voltar a dormir.

3 Acordo várias horas mais cedo do que costumava e tenho dificuldade de voltar a dormir.

17) $0 \quad$ Não fico mais cansado que o hábito.

1 Fico cansado com mais facilidade do que costumava.

2 Sinto-me cansado ao fazer quase qualquer coisa.

3 Estou cansado demais para fazer qualquer coisa.

18) $0 \quad$ Meu apetite não está pior do que de hábito.

1 Meu apetite não é tão bom como costumava ser.

2 Meu apetite está muito pior agora.

3 Não tenho mais nenhum apetite.

19) $0 \quad$ Não perdi muito peso se é que perdi algum ultimamente.

$1 \quad$ Perdi mais de $2,5 \mathrm{~kg}$.

2 Perdi mais de $5,0 \mathrm{~kg}$

3 Perdi mais de 7,5 kg

Estou deliberadamente tentando perder peso, comendo menos:( ) Sim ( ) Não. 
\begin{tabular}{lll}
\hline 20) & 0 & Não me preocupo mais de hábito com minha saúde. \\
1 & Preocupo-me com problemas físicos, como dores e
\end{tabular}

ventre.

2 Estou muito preocupado com problemas físicos e é difícil pensar em muito mais que isso.

3 Estou tão preocupado com meus problemas físicos que não consigo pensar em outra coisa.

21) 0 Não tenho observado qualquer mudança recente em meu interesse sexual.

1 Estou menos interessado por sexo do que costumava.

2 Estou bem menos interessado em sexo atualmente.

3 Perdi completamente o interesse por sexo.

TOTAL: 


\begin{tabular}{|c|c|c|c|c|c|}
\hline $3 \mathrm{MS}$ & $3 \mathrm{MS}$ & Max & MMSE & Max & Observações \\
\hline Data de Nascimento (DIA, MÊS, ANO) & & 3 & & & \\
\hline Local de Nas cimento (CIDADE, ESTADO) & & 2 & & & \\
\hline Registro ("CAMISA", “MARROM”, “HONESTIDADE") & & 3 & & 3 & \\
\hline Executivo (“5 até 1") & & 2 & & & $1 \mathrm{pt}=1$ ou 2 erros \\
\hline Executivo ("MUNDO" ao contrário) & & 5 & & 5 & \\
\hline Memória (“CAMISA”, “MARROM”, “HONESTIDADE") & & 9 & & 3 & 2 pts = cada dica ("uma cor"), 1 pt = cada opção ("azul, marrom, preto") \\
\hline Orientação Tem poral ("ANO") & & 8 & & 1 & 4 pts $=$ errou por 1 ano, 2 pts = errou por até 5 anos \\
\hline Orientação Tem poral ("ESTAÇÃO") & & 1 & & 1 & \\
\hline Orientação Tem poral ("MÊS") & & 2 & & 1 & $1 \mathrm{pt}=$ errou por $1 \mathrm{mês}$ \\
\hline \begin{tabular}{|l|l|} 
Orientação Tem poral ("DIA DO MESs") \\
\end{tabular} & & 3 & & 1 & $2 \mathrm{pts}=$ errou por até 2 dias, $1 \mathrm{pt}=$ errou por até 5 dias \\
\hline Orientação Tem poral ("DIA DA SEMANA") & & 1 & & 1 & \\
\hline Orientação Espacial (“ESTADO”, “CIDADE”, “BAIRRO”, “HOSPITAL”) & & 5 & & 5 & 2 pts para "CIDADE" \\
\hline Nomeação (“TESTA", “QUEXO”, “'OMBRO”, "COTOVEO”, “PUNHO”) & & 5 & & & \\
\hline Fluência (“ANIMAIS DE 4 PATAS") em 30 segundos & & 10 & & & 1 pt para cada \\
\hline Similaridades ("BRAÇO-PERNA") & & 2 & & & $1 \mathrm{pt}=$ resposta $\mathrm{m}$ ais ou menos \\
\hline Similaridades (“RIR-CHORAR") & & 2 & & & $1 \mathrm{pt}=$ resposta $\mathrm{m}$ ais ou menos \\
\hline Similaridades (“COMER-DORMIR") & & 2 & & & $1 \mathrm{pt}=$ resposta $\mathrm{m}$ ais ou menos \\
\hline Repetição ("EU QUERO IR PARA CASA") & & 2 & & & $1 \mathrm{pt}=$ até $2 \mathrm{erros}$ \\
\hline Repetição ("NEM AQUI, NEM ALI, NEM LÁ") & & 3 & & 1 & $1 \mathrm{pt}$ cada parte \\
\hline Leitura ("FECHE OS OLHOS") & & 3 & & 1 & $2 \mathrm{pts}=$ necessita estimulo, $1 \mathrm{pt}=$ somente leitura \\
\hline Escrita ("EU QUERO IR PARA CASA") & & 5 & & 1 & \\
\hline \begin{tabular}{|l|l} 
Desenho dos Pentágonos \\
\end{tabular} & & 10 & & 1 & cada pentágono: $4 \mathrm{pts}=$ lados parecidos $3 \mathrm{pts}=$ lados assimétricos $(>2: 1) 2 \mathrm{pts}=$ outra figura fechada $1 \mathrm{pt}=2+$ linhas \\
\hline Comando Verbal ("PEGUE O PAPE COM A MÃO ESQUERDA, DOBRE UMA VEZ, E COLOQUE NA MESA") & & 3 & & 3 & \\
\hline \begin{tabular}{|l|l|} 
Memória ("CAMISA", "MARROM", "HONESTIDADE") & \\
\end{tabular} & & 9 & & & 2 pts = cada dica ("uma cor"), 1 pt = cada opção ("azul, marrom, preto") \\
\hline
\end{tabular}

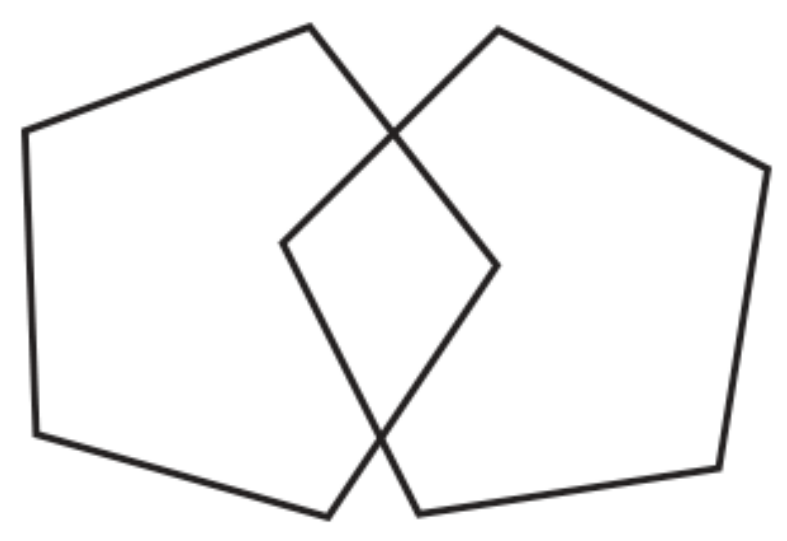




\title{
Capítulo IV
}

\section{Lateralidade cerebral}

\author{
1. Introdução
}

1.1. Dominância motora e de linguagem

O comportamento cognitivo humano é controlado pelo sistema nervoso, cuja atividade está centralizada no cérebro, o qual apresenta uma subdivisão macroanatômica de dois hemisférios, o direito e o esquerdo. O córtex é a camada mais externa do cérebro, dividida entre quatro regiões bem definidas (lobos frontal, temporal, parietal e occipital) que abrigam os principais centros responsáveis pelo raciocínio, linguagem, sensações visão, controle motor voluntário e outras funções ativadas por sítios localizados de maneira bilateral entre os hemisférios. Diversas funções atribuídas a regiões corticais são ativadas assimetricamente, ou seja, um dos hemisférios assume a função com ativação mais proeminente em relação à mesma região contralateral. A dominância manual, ou dominância motora, que é a preferência e habilidade no uso de um dos membros em detrimento do outro, é um exemplo de característica que é controlada assimetricamente pelo córtex (Knecht et al., 2000; Sun e Walsh, 2006).

É comum identificar dominância motora em animais, nos quais a razão se aproxima de um: numa população, é possível contar aproximadamente o mesmo número de indivíduos com preferência de uso dos membros direito e esquerdo (Sagasti, 2007). Entretanto há divergências entre os estudos. Pesquisas com chimpanzés indicaram uma proporção de $65 \%$ de indivíduos com preferência motora do lado direito, enquanto outros trabalhos não conseguiram replicar esta observação. Outro estudo com bonobos não apontou nenhum dos lados como preferencial, dentro da escala populacional. Em todos os casos, há críticas sobre os métodos de estudos, especialmente quando aplicados sobre animais em cativeiro mas enfatiza-se a dificuldade de 
estudos na natureza (Hugdahl e Westerhausen, 2010). Para humanos, a proporção verificada é variável de acordo com a população, mas sempre gira em torno de $90 \%$ de destros.

O processamento da linguagem é outra função claramente lateralizada no cérebro. Esta característica já é conhecida há mais de 150 anos, a partir do clássico estudo do anatomista francês Paul Broca, publicado em 1861. Desde então acumularam-se evidências de assimetria funcional entre os hemisférios corticais. Broca identificou a lesão unilateral de uma região do córtex esquerdo no cérebro de um paciente que se comunicava utilizando vocabulário de apenas uma palavra, distúrbio denominado na época como afemia (Keller et al., 2009). A região delimitada pela lesão, no lobo frontal e às margens do sulco lateral, passou a ser conhecida como área de Broca, responsável pela expressão linguística, independente da compreensão. Contemporâneo a Broca, o neurologista alemão Carl Wernicke associou outra região, também no hemisfério esquerdo, comum a lesionados afetados por um tipo de afasia específica do processo de compreensão da linguagem. A região do lobo temporal, situada na outra margem do sulco lateral, passou a se chamar área de Wernicke (Sun e Walsh, 2006).

A assimetria das áreas de linguagem foi extensivamente investigada após o trabalho de Broca. A área de Broca foi caracterizada como responsável particularmente (mas não exclusivamente) pela expressão e articulação motora da fala (Keller et al., 2009), apresentando conexões diretas com a área de Wernicke, responsável pela compreensão da linguagem (Hickok, 2009). Essas características foram atribuídas inicialmente quanto à localização no hemisfério esquerdo, enquanto o hemisfério direito abrigaria áreas com outras funções associadas à linguagem como atenção espacial, reconhecimento de formas (escrita) e prosódia. No entanto, para uma parte da população, demonstrou-se que estes centros relacionados à linguagem estariam posicionados em diferentes hemisférios, indicando variabilidade populacional e alguma correlação entre as dominâncias manual e linguística (Corballis, 2003). Há evidências de ligação entre a dominância motora e linguística. Estudos de lesionados com consequências linguísticas apontaram que cerca de $96 \%$ dos destros tinham a região lesionada no hemisfério esquerdo, enquanto os $4 \%$ restantes no hemisfério direito. Em canhotos, a proporção de lesionados no hemisfério esquerdo caia para $66 \%$, sendo os $34 \%$ distribuidos igualmente entre lesões bilaterais e de hemisfério direito. A hipótese de completa ligação, isto é, uma dominância hemisférica com consequências para a linguagem e preferência manual pode ser descartada, uma vez que a função de linguagem não é espelhada em canhotos. No entanto, algum grau de correlação é observado apontando para a 
hipótese que, ao menos em alguns indivíduos, um conjunto de fatores pode estar influenciando ambas assimetrias (Rasmussen e Milner, 1975; Annett, 2002).

Pela fácil observação e relativa praticidade na medição e análise, a dominância manual ou motora é a função assimetricamente ativada no cérebro mais frequentemente investigada. A medida de dominância manual é geralmente obtida a partir de questionários, os quais objetivam quantificar o grau de dominância. Uma grande área cortical é dedicada a representação motora das mãos e, raramente, o grau de habilidade é idêntico ou mesmo próximo entre as duas mãos, ou seja, quase sempre há uma direção de preferência. Ainda que a proporção seja variável, por questões culturais e em particular pela definição dos termos, o percentual de destros nas população humanas é consideravelmente constante, próximo a $90 \%$. No entanto, tradicionalmente se dicotomizam os indivíduos em destros e canhotos (e ambidestros ou de dominância mista) ou em destros e não-destros. Sendo assim, os critérios adotados para classificar são razoavelmente arbitrários e podem explicar as inconsistências na literatura (Beaton et al., 2000).

Sabe-se que "100\% canhotos" ou indivíduos que realizam todas as atividades manuais com a mão esquerda são mais raros do que os "100\% destros", num sentido que os cortes de distribuição entre destros e não-destros representam uma divisão entre dois grupos com variâncias bem distintas. Os não-destros são um grupo bem mais heterogêneo que os destros, e os completamente canhotos representam menos de 5\% da população (Beaton et al., 2000). A ambidestria, em seu sentido estrito, é a ausência de preferência manual para qualquer (ou boa parte das) atividades e é um fenótipo raro (estima-se $0,3 \%$ ). A preferência de uso de uma das mãos para um conjunto de atividade e a outra para outro conjunto é bem mais frequente e pode ser denominada dominância mista. Dominância manual pode ser vista como uma variável contínua com indivíduos apresentando preferência por uso de uma das mão em praticamente todas as atividades. Apesar de ser muito correlato com habilidade manual e razoavelmente correlato com força manual, a preferência parece se apresentar como um terceiro eixo fenotípico mais acoplado com o componente direcional do que mecanístico (habilidade) ou físico (força) (Annett, 2002).

\subsection{Bases neurológicas da lateralidade cerebral}

Quanto às origens neurais da assimetria funcional e estrutural no cérebro, diversos estudos buscam evidências para construção de modelos. Nas últimas duas décadas, diversos estudos 
contribuiram para o surgimento e aperfeiçoamento da teoria que centraliza o hipocampo como região crucial na origem e manutenção de certos padrões de lateralidade cerebral (Tang, 2003).

O hipocampo é uma estrutura encefálica presente em mamíferos, localizada abaixo do lobo temporal medial, bilateralmente disposta nos dois hemisférios e cuja função está intimamente relacionada com a formação da memória e a aprendizagem (Mu e Gage, 2011). A organização dos circuitos neurais no hipocampo, caracterizada como unidirecional, recebe entradas de sistemas sensoriais e remete os estímulos a regiões de processamento mais complexo como o neocórtex (Li et al., 2009).

Os conceitos básicos da teoria hipocampal da lateralidade cerebral são resumidos à função de aprendizagem e formação inicial da memória, através das modificações sinápticas dependentes de experiência (Tang, 2003). Os primeiros experimentos que influenciaram a formulação desta hipótese descreveram que a lateralidade cerebral era resultante não apenas da estimulação sensorial ou lesões assimétricas, mas também de estímulos não enviesados como o estresse prénatal e a manipulação de recém-nascidos. O estudo, realizado em ratos, apontou que lesões corticais nos hemisférios direito e esquerdo causaram efeitos distintos apenas em animais que foram manipulados em um período crítico após o nascimento. Esta manipulação consistia em separar o indivíduo da ninhada e progenitora e transferi-lo a uma nova gaiola durante um período imediato após o nascimento. Este procedimento, sem viés para qualquer um dos lados, modificou os padrões de lateralidade cerebral (verificados por efeitos de lesão) (Denenberg et al., 1978). Com metodologia semelhante, outras características lateralizadas como a "dominância de pata" foram afetadas, o que fortalece a hipótese que a assimetria pode, em ratos, depender da experiência adquirida (Tang, 2003).

Os resultados demonstrados por experimentos de assimetria dependente de experiência levantam o questionamento de como o cérebro transforma estímulos complexos e não necessariamente assimétricos em modificações no padrão de lateralidade cerebral, as quais influenciam diretamente o comportamento. Segundo o modelo de redes neurais, o cérebro pode ser considerado uma rede de neurônios que recebe estímulos de diversos órgãos sensoriais e remete para circuitos específicos que conduzem respostas funcionais. Neste modelo, a intensidade de conexão, numa forma mínima de sinapses, entre neurônios é modificada de duas maneiras: não supervisionada, quando a intensidade da conexão aumenta com a ativação simultânea de dois neurônios; supervisionada, quando a intensidade é modulada pelo erro, ou seja, um sistema 
paralelo pode oferecer uma referência e dar um feedback (Tang, 2003). Partindo destes conceitos básicos, o desenvolvimento da lateralidade cerebral pode ser visto como resultante da dominância de ativações neuronais e favorecimento de certas conexões dentro de um sistema inicialmente bilateral e simétrico. Com o reforço positivo ao longo do desenvolvimento, a lateralização preferencial passaria a ser o conjunto de caminhos com menos "custo" energético para as ativações funcionais.

Ao considerar o hipocampo como a região chave para o surgimento e desenvolvimento do padrão assimétrico no cérebro através das modificações neuronais em processos de aprendizagem, é possível discutir o papel de hormônios e neurotransmissores. Uma vez que estes componentes neuroquímicos são fundamentais para modificar a excitabilidade neuronal e plasticidade sináptica, é razoável considerar a sua participação na modelagem da conectividade cerebral (Tang, 2003).

A teoria hipocampal da lateralidade cerebral utiliza-se de algumas propriedades dos componentes neuroquímicos que os colocam como candidatos da assimetria cerebral centralizada no hipocampo.

A primeira propriedade é o papel destes componentes como amplificadores ou inibidores da ativação neuronal em estruturas corticais importantes como o hipocampo e neocórtex. As modificações sinápticas dependentes de atividade são reguladas por estes componentes, que influenciam a reorganização mais duradoura das redes corticais. É esperado, portanto, que estes eventos tenham um papel fundamental na lateralização das funções cerebrais (Tang, 2003).

O segundo ponto é a escala de atuação destes componentes neuroquímicos. Uma vez que eles fazem parte de um sistema evolutivamente conservado em primatas, e considerando um sentido amplo de similaridades, também em mamíferos e aves, por parcimônia é relevante considerá-los como fonte da lateralização funcional do cérebro. Ainda que em proporções distintas, este trato é compartilhado entre mamíferos e aves (Tang, 2003).

Favorecendo a teoria, vários estudos indicaram evidências que os componentes neuroquímicos estão assimetricamente distribuídos, tanto em concentração, quanto no perfil de seus receptores (Tang, 2003). Foi demonstrado, por exemplo, que a distribuição assimétrica de receptores de serotonina 1A está associada espacialmente a regiões corticais ligadas ao processamento auditivo e à linguagem, ainda que não tenha sido encontrada distribuição assimétrica no hipocampo (Fink et al., 2009). 
Por fim, os componentes neuroquímicos tem a propriedade de difundir para diversas regiões do hemisfério cerebral independente do seu local de origem. Feixes de neurônios colinérgicos partindo do septo mesial e do núcleo basal inervam o hipocampo e o neocortex, respectivamente. O hipocampo também recebe entradas noradrenérgicas originadas no loco cerúleo (região chave na fisiologia do sono), entradas serotonérgicas dos núcleos da rafe (principal foco de distribuição de serotonina) e entradas dopaminérgicas de áreas do tegmento ventral (área importante para o sistema de recompensa) (Tang, 2003).

O fato dos padrões de ativação assimétrica serem difusos, mas interligados por vias específicas, pode ser a chave da modelagem da origem e manutenção da lateralidade cerebral. Barnéoud e Vanderloos sugeriram em 1993 que a correlação entre a preferência de patas em roedores (análogo à dominância manual em humanos) e a preferência das vibrissas poderia ser explicada por circuitos paralelos que levam a informação sensorial ao córtex de forma assimétrica ou, alternativamente, por um par de genes ligados que controlariam ambos os fenótipos (Barneoud e Van Der Loos, 1993).

\subsection{Consequências da lateralização e do desvio em humanos}

A especialização dos hemisférios cerebrais para processar informações de forma assimétrica é uma característica encontrada em boa parte dos vertebrados e, recentemente, descreveu-se também em invertebrados (Rogers, 2010). Sabe-se, entretanto, que em uma escala populacional, grande parte dos animais não apresenta desvios de assimetria, isto é, próximo a metade dos indivíduos apresentam, para cada função, dominância para um hemisfério e a outra metade para o outro hemisfério. Diversos estudos de comportamento sugerem que há vantagens individuais em ter um cérebro assimétrico, em particular para o processamento de várias tarefas simultaneamente de forma a paralelizar as ativações (Halpern et al., 2005).

Curiosamente, a variabilidade e a manutenção das proporções de indivíduos com diferentes dominâncias motoras não são características tão difundidas quanto especialização hemisférica entre animais não-humanos. Estudos com impressões negativas em paredes de cavernas, ferramentas e diferenças anatômicas nos ossos sugere que a proporção de canhotos não tenha mudado nos últimos milhares de anos, com uma minoria de $8-20 \%$ mantida até as sociedades contemporâneas (Faurie e Raymond, 2004). Pouco se sabe sobre o surgimento deste desvio, mas 
algumas postulações foram construídas sobre as vantagens da manutenção desta diferença de frequências. Raymond e colaboradores (1996) propuseram um mecanismo de seleção negativa dependente de frequência, para interações de luta. Como canhotos são menos frequentes, passa a ser maior a probabilidade de confrontarem um oponente destro em uma luta física. Desta maneira, canhotos estariam mais habituados a confrontar oponentes destros do que vice-versa, usufruindo assim de uma vantagem estratégica enquanto se mantiverem em baixa frequência (Raymond et al., 1996). Este modelo é apoiado por observações em esportes de interação direta como o beisebol e o críquete, onde a frequência de canhotos é muito maior do que na população geral ou em outros esportes e pode chegar a 50\% (Abrams e Panaggio, 2012). O questionamento sobre os motivos para a frequência dos canhotos não aumentar na população levou a construção de modelos de simulação. Um dos mais recentes sugere que a frequência é mantida por um balanço entre as atividades sociais competitivas (como esportes de interação e confrontos por luta) e cooperativas (como o compartilhamento de ferramentas). A frequência de canhotos, portanto, seria resultante de um equilíbrio (Abrams e Panaggio, 2012).

Desde 1980, sabe-se que o cérebro de indivíduos afetados por algumas doenças neuropsiquiátricas, de manifestação durante o desenvolvimento, tem padrões de assimetria distintos da variação normal. Dentre elas estão dislexia, distúrbios de aprendizagem, autismo e esquizofrenia (Bartley et al., 1993). As diferenças de assimetria vão desde anormalidades por função até a reversão total dos padrões nos lobos frontal, temporal, parietal e occipital em pacientes com estes distúrbios. Um modelo sugerido por Crow (2000) propõe que o mesmo mecanismo que permitiu a especialização funcional assimétrica para a linguagem, por interferir diferencialmente nas habilidades verbais (em função do grau e direção da dominância), poderia aumentar a predisposição para falhas de integração inter-hemisférica. Sendo assim, o "custo" de cérebros lateralizados (mais eficientes para paralelização e aperfeiçoamento da linguagem) seriam os riscos de, em episódios de alterações genéticas e/ou estímulos ambientais que interfiram na padronização da assimetria, estabelecer condições de déficits graves de linguagem e comunicação, com psicose e alucinações auditivas. Estas características estariam subjacentes a condições complexas como esquizofrenia e autismo (Crow, 2000).

Em esquizofrênicos, a redução da assimetria do componente fonológico da linguagem parece ser o fator mais fortemente associado aos sintomas (Angrilli et al., 2009). Em estudo combinando ressonância magnética estrutural e funcional, demonstrou que o grau de redução da assimetria foi 
correlacionado com a severidade dos sintomas em esquizofrênicos e sugere que a medição da assimetria seja um marcador para esquizofrenia (Oertel et al., 2010). Uma das consequências de tais disrupções nos padrões de assimetria é a variação na dominância motora, o que explicaria a relativa maior frequência de canhotos e dominância mista entre os afetados por tais doenças (Crow et al., 1996).

A redução da assimetria funcional no córtex cerebral parece ser comum durante o envelhecimento. Esta tendência é amplamente discutida no modelo HAROLD (Hemispheric Asymmetry Reduction in OLDer adults) (Cabeza, 2002). A base de evidências deste modelo é sustentada pela diminuição da assimetria em atividades relacionadas a aspectos cognitivopragmáticos da linguagem no córtex pré-frontal. O mecanismo de compensação é proposto como uma das consequências da redução da capacidade funcional e realocação para outra região, comumente o equivalente contralateral. O processo de plasticidade funcionaria de forma semelhante ao de adultos que sofreram acidentes vasculares cerebrais em regiões associadas à linguagem (Thulborn et al., 1999; Cabeza, 2002).

\subsection{Genética da lateralidade cerebral}

Teorias sobre a influência genética da lateralidade cerebral são formuladas há mais de um século, particularmente aquelas que se baseiam na dominância manual como fenótipo mais evidente de lateralidade cerebral. As primeiras teorias datam de 1911, quando Jordan sugeriu que a dominância manual esquerda seria resultante de um padrão de herança mendeliano autossômico recessivo clássico. Poucos anos depois, esta hipótese foi descartada com a observação de famílias onde ambos os pais canhotos tem uma proporção elevada de filhos destros. Trankell (1955) concluiu que apesar destas divergências, estimou-se uma herança recessiva com penetrância incompleta (entre 0,4 e 0,45 ). Teorias atuais consideram um modelo monogênico ou oligogênico acrescido de expressividade variável: uma distribuição composta de média zero (para um genótipo homozigoto) e de média desviada (para os outros genótipos). Desta forma, a curva de distribuição populacional seria uma composição de duas curvas normais, uma com média zero (acaso) e uma com média desviada (Annett, 1972; Mcmanus, 1985). Uma explicação mais aprofundada sobre este modelo está apresentada adiante. 
Aparentemente há mais homens que mulheres canhotas, mas em poucos estudos essa diferença atingiu significância estatística. Outras publicações mostraram maior frequência de canhotos entre filhos e filhas de mães canhotas do que de pais canhotos (Annett, 2009). Este padrão sugere que o modelo de herança talvez seja multifatorial com diferentes limiares de acordo com o sexo.

Há extensa evidência que a lateralidade cerebral e comportamental se desenvolvem ainda no útero. Estudos com ultrassom indicaram mais movimentação do braço direito que o esquerdo em quase $90 \%$ fetos e uma correlação quase perfeita entre a escolha do dedão colocado na boca em período intra-uterino com a mão dominante da infância (Francks, 2015). Os resultados de uma meta-análise de 35 estudos com gêmeos foram confirmados em uma investigação de grande porte utilizando mais de 25 mil famílias: aproximadamente $25 \%$ da variância de preferência manual (auto-reportada ou reportada pelos pais) é devido a efeitos genéticos aditivos enquanto o restante devido a efeitos ambientais ou randômicos (Medland et al., 2009).

A observação da influência genética de situs inversus pode trazer implicações para os estudos de lateralidade cerebral. Esta condição rara consiste no posicionamento inverso de orgãos internos, particularmente os viscerais. Foi observado que uma linhagem mutante de camundongos com alta frequência de situs inversus era portadora de uma deleção no gene kif3B, codificante de uma cinesina. Esta foi posteriormente identificada como parte do sistema ciliar que direciona o fluxo de substâncias com pulsações preferenciais para um sentido, gerando um vetor resultante para um dos lados do embrião provocando um gradiente da proteína de sinalização SHH. Os camundongos mutados apresentavam aleatoriedade no movimento dos cílios e, como consequência, 50\% deles apresentavam fenótipo de situs inversus (Layton, 1976; Nonaka et al., 1998). Em humanos, esta condição também é associada a perda da motilidade ciliar, uma doença rara chamada Síndrome de Kartagener ou Discinesia Ciliar Primária.

Entretanto, a possibilidade de ser o mesmo gene ligado a este fenótipo ou de existir uma sobreposição entre a manifestação de situs inversus e lateralidade cerebral foi descartada em estudos que demonstraram que não há alteração dos padrões populacionais de assimetria cerebral em portadores da condição (Kennedy et al., 1999; Tanaka et al., 1999). Em outras palavras, o número de canhotos, de pessoas com a linguagem e audição processadas pelo hemisfério direito parece ser semelhante entre os portadores de situs inversus e a população geral. 
A modelagem de teorias genéticas sobre a origem da lateralidade cerebral é, portanto, difícil dadas as evidências de herança variável e definições pouco consistentes. Annett (1972) formulou a teoria atualmente mais discutida.

Denominada de Right Shift (RS) ou "desvio à direita", a teoria proposta baseia-se em dados empíricos e teóricos levantados por Annett. Foi sugerido que a distribuição da população seria normal (com variância influenciada pelo acaso), somada a um desvio à direita, influenciado geneticamente pela presença de um alelo rs+ do gene hipotético $R S$. A teoria sugere a dominância do hemisfério esquerdo sobre o direito e todas as características lateralizadas, a exemplo de dominância motora e de linguagem, seriam derivadas. Segundo o modelo, os portadores do genótipo rs-- (ausência do alelo $\mathrm{rs}^{+}$) apresentam a distribuição assimétrica ao acaso, ou seja, metade dos indivíduos com este genótipo apresentam o hemisfério esquerdo como dominante para a linguagem e a outra metade apresentam o outro hemisfério. A presença do alelo interfere nesta distribuição ao acaso, desviando-a para o hemisfério esquerdo. Adicionalmente, a correlação entre dominância motora e dominância de linguagem só seria observada em portadores do alelo, os indivíduos rs-- teriam portanto independência entre as dominâncias, igualmente distribuidas ao acaso (Annett, 2009).

De acordo com essa hipótese, os portadores do alelo rs+, em uma ou duas cópias, terão uma distribuição normal, mas de média maior que zero, ou seja, desviada para direita do eixo, aumentando a frequência das características lateralizadas para o hemisfério esquerdo. Observando a dominância motora, por exemplo, partindo da prerrogativa que $10 \%$ de toda população (qualquer genótipo) seja de canhotos, então $34 \%$ dos rs-- e menos de $5 \%$ dos rs++ serão canhotos (Annett, 1998). A figura 12 traz a demonstração do modelo. Em 12-A, as distribuições podem seguir uma contribuição dominante do alelo $\mathrm{rs}^{+}$para a assimetria da linguagem e uma contribuição aditiva para a dominância manual. Em 12-B, os desempenhos de habilidade manual projetados para todos os indivíduos (curva pontilhada) e para os genótipos, atribuindo o corte de $10 \%$ de canhotos $(\mathrm{X})$ ou $30 \%$ de não destros $(\mathrm{Y})$. Por fim, 12-C resume com a apresentação de frequências hipotéticas baseadas na proporção populacional de 9,27\% de indivíduos dominantes para linguagem no hemisfério direito baseado em estudos de lesão e sequelas linguísticas. No quadro 12-C há também um resumo de como o modelo pode explicar as vantagens dos hemisférios, riscos de distúrbios cognitivos decorrentes de problemas nos padrões normais de assimetria cerebral e percentuais de canhotos por genótipo (Annett, 1998). 


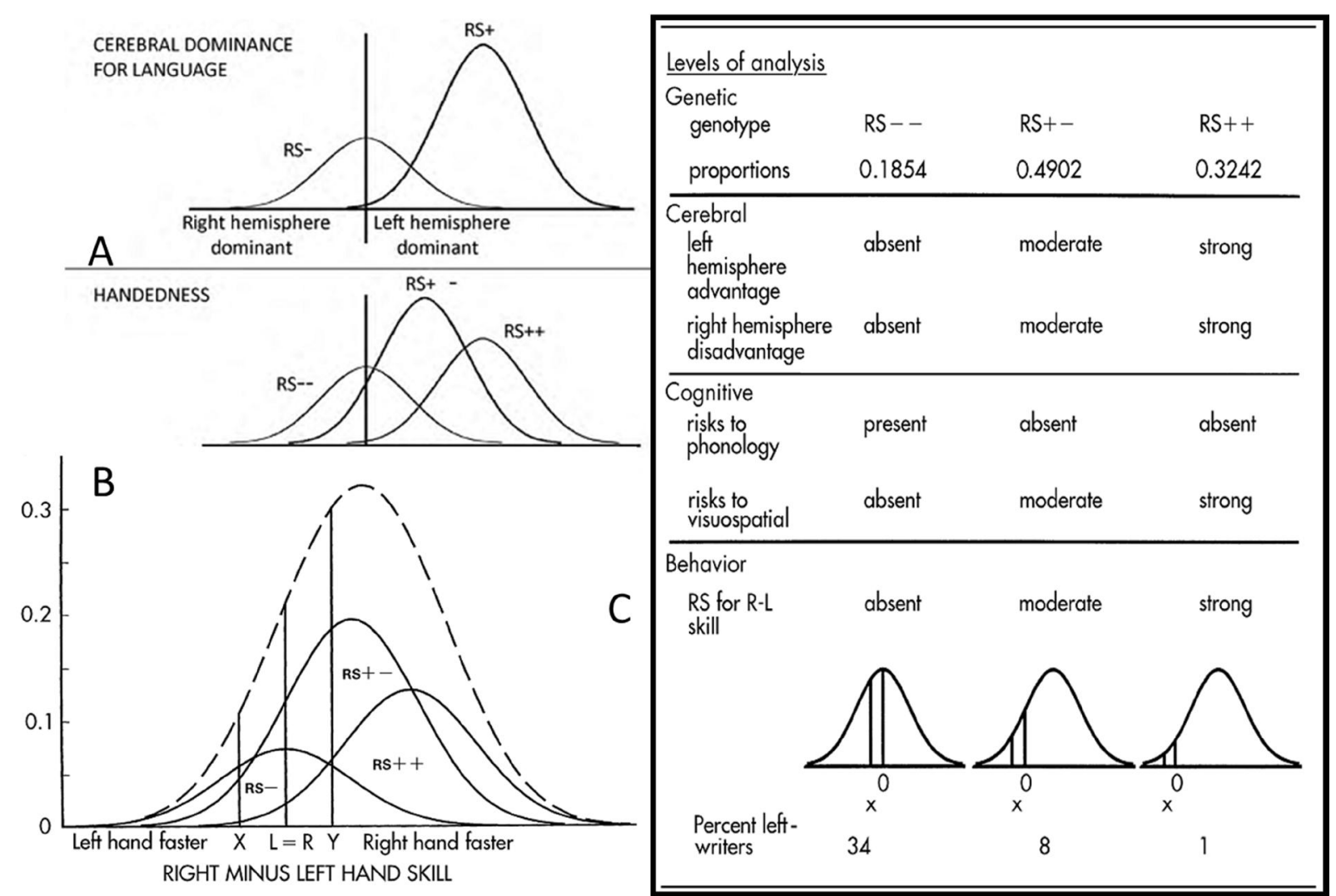

Figura 12. Modelo teórico para genética da lateralidade Right Shift de Marian Annett (1972). Distribuições dos fenótipos de dominância linguística e manual com os genótipos hipotéticos (A). Distribuições dos fenótipos quantitativos de habilidade manual para os genótipos com cortes em $10 \%$ de canhotos $(\mathrm{X})$ ou $30 \%$ de não destros (Y) (B). Resumo dos desfechos hipotéticos de acordo com o genótipo, inclusive com as frequências genotípicas baseadas em dados de proporção de hemisférios direitos dominantes para linguagem (C). Retirado de Annett, 1998. O heterozigoto atingiria uma proporção próxima a frequência máxima $(49,02 \%)$, convergente com a teoria de polimorfismo balanceador e vantagem do heterozigoto.

Usando um princípio semelhante, mas específico para dominância manual (e não para lateralidade cerebral, como Annett), McManus (2002) sugeriu que um gene só atue sobre a característica com um alelo D para destros e C para distribuição ao acaso. Sendo assim, todos os indivíduos DD seriam destros, $75 \%$ dos indivíduos CD seriam destros e 50\% dos indivíduos CC seriam destros (Mcmanus, 1985).

Uma hipótese levantada é a de expressão diferencial de genes entre os hemisférios como um marcador da lateralização (Hawrylycz et al., 2012). O gene LMO4 codifica uma proteína com função de fator de transcrição envolvido com neurogênese e projeção axonal em camundongos. A expressão do RNA mensageiro de LMO4 foi demonstrada como a mais assimétrica em córtex fetos humanos das semanas $12-18$ e a partir da $19^{\text {a }}$ a assimetria de expressão é reduzida (Sun et 
al., 2005). Não foi possível identificar se a expressão assimétrica de LMO4 induz a lateralização ou é consequência de outros fatores do desenvolvimento.

Estudos identificaram genes associados a algum comportamento ou fenótipo lateralizado, em sua maioria em conjunto com outras condições. FOXP2 é um regulador transcricional do desenvolvimento que controla o crescimento e diferenciação de uma classe neuronal que enerva estruturas associadas a produção da fala. Nos anos 1990, a identificação de mutações neste gene em famílias afetadas por dispraxia, uma desordem neuromotora que impede a produção linguística, revolucionou este campo do conhecimento, uma vez que polimorfismos neste gene foram extensivamente descritos como fatores de suscetibilidade a esquizofrenia, doenças do espectro autista e dislexia (Kang e Drayna, 2011; Li et al., 2013). Considerando FOXP2 como um forte candidato a participar da lateralização, ao menos da linguagem, Ocklenburg e colaboradores (2013) investigaram a sua associação com audição dicótica (dominância auditiva) e campo visual (dominância visual) em pouco mais de 400 sujeitos. Dois SNPs foram significativamente associados, apontando para uma possível participação do gene na variação de assimetria cerebral (Ocklenburg et al., 2013b). O mesmo grupo identificou um polimorfismo do gene que codifica o receptor de colecistoquinina A $(C C K A R)$ próximo ao sítio consenso de splicing associado a dominância auditiva. $\mathrm{O}$ gene foi estudado como alvo candidato por estar ligado a esquizofrenia e este polimorfismo em particular já havia sido associado a risco para a doença (Ocklenburg et al., 2013a). Um outro estudo realizado anteriormente pelo mesmo grupo também identificou associação entre um polimorfismo do gene GRIN2B que codifica a subunidade $2 \mathrm{~B}$ do receptor de N-metil D-aspartato (NMDA) e dominância auditiva (Ocklenburg et al., 2011). Mesmo com sugestões dos autores em todos os estudos, as associações entre lateralidade cerebral com variantes de FOXP2, CCKAR e GRIN2B ainda não foram validadas em amostras independentes ou através de experimentos funcionais.

A expansão de repetições $\mathrm{CAG}$ no gene receptor de andrógenos foi associada com a probabilidade de mulheres serem canhotas, mas uma relação inversa foi observada em homens. Os autores discutem que esse paradoxo é explicável pela interação com testosterona e que esse mecanismo poderia esclarecer a diferença de frequência de canhotos entre homens e mulheres, ainda que de pequena magnitude (Medland et al., 2005). Indivíduos com dislexia submetidos ao teste de habilidade manual com pinos (pin pegboard) foram os sujeitos de um GWAS quantitativo e uma variante do gene (PCSK6) que codifica uma protease que processa e ativa a 
proteína Nodal, envolvida em diferenciação celular e na organização do eixo de simetria visceral direita-esquerda. O resultado foi replicado pelo mesmo grupo em outras duas coortes independentes de afetados por dislexia, mas o mesmo SNP não foi associado, porém uma variante do tipo repetições em tandem próxima ao gene foi associada ao grau de dominância manual. Os achados reacendem as hipóteses de não-dissociação, ao menos mecanística, entre os padrões de assimetria visceral e cerebral (Scerri et al., 2011; Brandler et al., 2013).

Também utilizando um grupo de indivíduos afetados por dislexia, neste caso com pares de irmãos, Francks e colaboradores (2002) mapearam por linkage a região 2p12-q11 ligada à habilidade manual medida por pin pegboard (Francks et al., 2002). Apesar de não terem encontrado uma relação detectável entre a dislexia e a habilidade manual nesta amostra, demonstraram que o sinal de linkage foi replicado em 105 pares de irmãos canhotos e que a herança dos irmãos afetados era exclusivamente paterna (não conseguiram observar isso na amostra de irmãos canhotos por não terem os genótipos dos pais. Com a mesma região ligada associada repetidamente a esquizofrenia, o grupo propôs que a região seria alvo de imprinting e responsável por assimetrias manuais e distúrbios neuropsiquiátricos (Francks et al., 2003).

O mesmo grupo prosseguiu investigando a região e genotipou 87 SNPs cobrindo quatro genes da região em irmãos afetados por dislexia e seus pais e identificaram que o gene LRRTM1 é alvo de imprinting e sua expressão é ativa apenas no homólogo de origem paterna, observado através de análise de haplótipos (específicos do pai ou da mãe) e em células híbridas A9. Entretanto, o grupo não conseguiu replicar em amostras de australianos e chineses, nem verificaram a experessão monoalélica em cérebros humanos post-mortem de doadores normais, apesar de encontrarem a expressão do gene, simétrica entre os hemisférios, nos cérebros por hibridização in situ. Os autores comentam que não há como concluir o papel deste gene na fisiopatologia de esquizofrenia (associado anteriormente) ou dislexia, nem explicar a variabilidade entre os fenótipos de assimetrias manuais (Francks et al., 2007). A não replicabilidade dos achados de Francks e colaboradores (2007) gerou críticas devido a erros na análise de haplótipos em desequilíbrio de ligação, bem como generalizações de assertivas e não demonstração de expressão mono-alélica em amostras humanas (Crow et al., 2009). 


\subsection{Fascículo arqueado: dissecção virtual}

O estudo de certas funções cerebrais assimetricamente ativadas apresenta dificuldades metodológicas em diversos níveis. Por exemplo, a dominância manual é uma das poucas funções lateralizadas facilmente acessadas através de questionários e, portanto, sujeita à variabilidade de métodos e a fatores intrínsecos à característica: pressão social e analfabetismo interferem no resultado caso a pergunta seja sobre a mão com a qual se escreve. São obstáculos que dificultam a fatoração qualitativa e quantitativa de suas bases biológicas gerando potenciais elementos de confusão. As técnicas de neuroimagem permitem avaliar a estrutura e a função de forma mais direta e adequada para funções como a linguagem, que até poucas décadas dependiam de estudos de lesão ou protocolos invasivos como o teste de Wada (que anestesia um hemisfério para confirmar dominância linguística e servir de parâmetro pré-operatório). Os fenótipos que estão num nível intermediário entre o comportamento/clínica e os processos teciduais/celulares e moleculares são conhecidos como endofenótipos. Dentre os endofenótipos ligados a lateralidade cerebral pode-se incluir assimetria de espessuras e volumes corticais e subcorticais, variações anatômicas, quantificação de substâncias por imageamento molecular, ativação funcional mensurável por ressonância magnética ou eletroencefalografia.

A ressonância magnética em equipamento com campo magnético 3 Tesla permite a aquisição de protocolos estruturais com unidade volumétrica na escala de $1 \mathrm{~mm}^{3}$. Além disso, é possível obter neuroimagens das quais a inferência de conectividade permite traçar um mapeamento de regiões ligadas fisicamente (Diffusion Tensor Imaging - DTI) ou temporalmente (Resting State Functional MRI - rsfMRI).

DTI é uma técnica de ressonância magnética que permite a reconstrução de parâmetros direcionais da difusibilidade da água nos tecidos. Por uma análise de anisotropia fracionada, a qual calcula a diferença direcional das direções percorridas pela água, é possível inferir estruturas que restringem o movimento, tais como longas fibras nervosas. Com esse método, portanto, é possível reconstruir tratos e fascículos de substância branca formados por longas fibras axonais. Este método tem sido usado para medir quantitativamente o tamanho, espessura e densidade de fibras dentro de tratos de funções mapeadas e importantes para processos de formação de memória, linguagem e controle motor (Catani e Thiebaut De Schotten, 2008). 
A possibilidade de realizar a dissecção virtual dos tratos de substância branca se tornou uma das técnicas mais aplicadas nos últimos anos. O grande desafio permanece no grau de automatização da extração das regiões de interesse (ROIs) do cérebro: os algoritmos de obtenção de ROIs geralmente diminuem a capacidade de aferição da variabilidade inter-individual dos tratos, ou mesmo a variabilidade encontrada em processos patológicos. A extração manual, por outro lado, pode trazer erros relacionados ao operador e variância não relacionada ao trato propriamente.

Um grupo da King's College London, liderado pelo Prof. Marco Catani, elaborou métodos semi-manuais para a obtenção de tratos individualizados e geraram um atlas (Catani e Thiebaut De Schotten, 2008), como pode ser visto em exemplo na figura 13-A. Em seguida, foi realizada a quantificação de parâmetros em cada um dos tratos e derivação de índices associados à assimetria de cada trato, exemplificados na figura 13-B (Thiebaut de Schotten. et al., 2011).

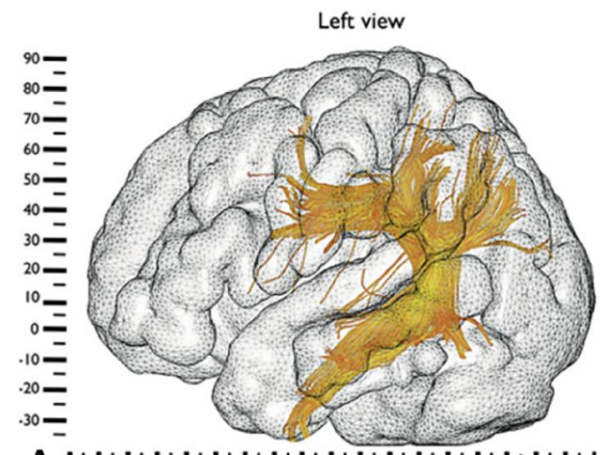

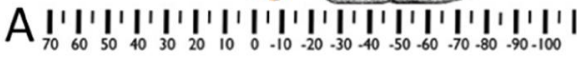

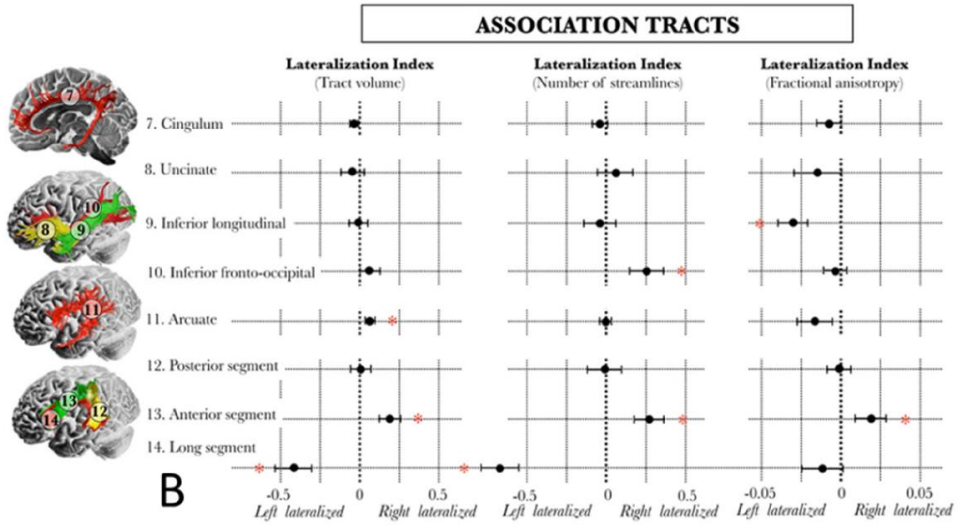

B

Figura 13. Dissecção de tratos subcorticais. Fascículo arqueado esquerdo dissecado virtualmente a partir de dados de DTI (A), retirado de Catani e colaboradores (2008). Índices de lateralidade de cada trato de substância branca obtidos a partir de parâmetros do DTI (volume, número de fibras e anisotropia fracionada) (B), retirado de Thiebaut de Schotten e colaboradores (2011).

O fascículo arqueado é um trato de substância branca que conecta o lobo frontal ao lobo temporal, nas áreas de Broca e Wernicke respectivamente. Este conjunto de fibras é importante para a produção da linguagem falada; a região de Wernicke ativa o processo de compreensão linguística, semântica e a área de Broca é responsável pelo programa motor da fala, a expressão linguística propriamente. Lesões no fascículo arqueado estão correlacionadas com um tipo específico de distúrbio de linguagem denominado afasia de condução, em que o indivíduo afetado 
compreende palavras, fala corretamente mas é incapaz de repetir frases. Apesar de o fascículo arqueado estar presente bilateralmente na região subcortical, o seu volume (e por consequência número de fibras) é comumente assimétrico, sendo o do hemisfério esquerdo maior. Essa assimetria está fortemente correlacionada à dominância linguística (Hong et al., 2009).

Uma terceira região cortical foi apontada por Norman Geschwind como crucial para comunicação e linguagem. Localizada no lobo parietal, próxima ao final do sulco lateral, a região conhecida como lóbulo parietal inferior ou território de Geschwind participa do reconhecimento de estímulos faciais e interpretação de informações sensoriais. A descoberta de uma via alternativa, passando por esta área e ligando indiretamente as regiões de Broca e Wernicke, tornou o fascículo arqueado fracionável em segmento longo (que liga diretamente as regiões de Broca e Wernicke), segmento anterior (que liga Broca a Geschwind) e segmento posterior (que liga Geschwind a Wernicke) (Catani e Thiebaut De Schotten, 2012).

O trato cortico-espinal é um grande aglomerado de fibras de substância branca que descende do córtex motor para a medula espinhal e é essencial para o controle motor voluntário dos braços, tronco e pernas. Há uma correlação elevada entre a espessura das fibras descendentes do hemisfério esquerdo, que cruzam e participam do controle lateral direito do corpo, com a dominância manual preferencial direita (Catani e Thiebaut De Schotten, 2008).

O papel destas estruturas em comportamentos lateralizados, tais como a linguagem e a dominância manual, pode representar uma oportunidade para estudo dos componentes genéticos subjacentes 


\section{Objetivo}

Identificar componentes genéticos associados a lateralidade cerebral utilizando endofenótipos quantitativos.

\section{Amostra e métodos}

\subsection{Amostra SABE e $80+$}

A amostra utilizada neste estudo foi o conjunto de indivíduos do grupo composto pelas Amostra SABE e Amostra 80+, descritas nos capítulo II e III, que participaram da etapa de ressonância magnética descrita no capítulo III.

\subsection{Diffusion Tensor Imaging (DTI): dissecção de tratos e fascículos}

Entre o final do mês de agosto e início de outubro de 2013, realizei um estágio no Neuroanatomy and Tractography Laboratory (NatBrainLab) do King's College London, em parceria com o Prof. Dr. Marco Catani e Dr. Michel Thiebaut de Schotten. O objetivo desta colaboração foi a análise dos tratos de substância branca do cérebro. A medida de tratos e fascículos (agrupamentos axonais subjacentes ao córtex (substância branca), conectando regiões do córtex) é possível através do método de ressonância magnética conhecido por Diffusion Tensor Imaging (DTI) e de ampla relevância uma vez que mensura a forma, volume, tamanho e integridade de conexões cerebrais e potencialmente revela a assimetria funcional de circuitos associados à linguagem (fascículo arqueado) e à dominância manual (trato corticospinal).

O método consistiu na aquisição das imagens por DTI em equipamento de ressonância magnética Siemens Magneton Trio, 32 canais. Conversão dos dados utilizando o software Diffusion Toolkit v. 0.6.2.1 e a dissecção dos tratos e fascículos utilizando o software TrackVis v. 0.5.2.1. A etapa automatizada (com algoritmo proprietário do grupo do Prof. Catani e Dr. Michel Thiebaut) correspondeu a delimitação dos tratos.

O grupo desenvolveu um método automatizado de dissecção virtual de sete tratos por hemisfério: fascículo arqueado (segmento longo - LS, segmento anterior - AS, segmento 
posterior - PS), fascículo fronto-occipital inferior (IFOF), fascículo longitudinal inferior (ILF), trato frontal aslant (FAT) e fascículo uncinado (Unc). O primeiro, já comentado acima, é uma trato de associação que conecta três regiões associadas à linguagem (territórios de Broca, Wernicke e Geschwind). O IFOF conecta os lobos frontal, temporal e occipital. Apesar de serem pouco conhecidas, as funções deste fascículo incluem a integração do processamento semântico e atencional durante a comunicação (Kvickstrom et al., 2011). O ILF conecta a região anterior do lobo temporal ao lobo occipital e evidências sugerem que esteja correlacionado ao circuito do processamento semântico acoplado ao sistema visual, e seria uma via alternativa ao IFOF (Mandonnet et al., 2007). O FAT é um trato recentemente descrito que conecta o território de Broca a regiões frontais mediais, dentre elas a área pré-motora suplementar (planejamento) e está associada a fluência verbal (Catani et al., 2013). O fascículo uncinado liga o lobo temporal ao giro frontal inferior e regiões do lobo frontal, com conexões na amígdala e hipocampo. Sua função está relacionada à memória auditiva (verbal), integrando parte do circuito linguístico.

Uma subamostra sorteada de dez cérebros (cada com dois hemisférios e 14 tratos, sendo sete por hemisfério) foi separada para dissecção manual utilizando o TrackVis objetivando a validação do método automatizado (correlação por Pearson). As correlações foram calculadas em relação a seis variáveis obtidas pelo TrackVis: número de fibras (contadas dentro de um trato dissecado), comprimento de fibras (média em milímetros daquelas delimitadas pelo trato), difusibilidade média (MD, mobilidade média das moléculas de água por fibra), difusibilidade perpendicular (medida da direção transversa à fibra, indicando possível lesão axonal ou na mielina), imagem ponderada de difusão (DWI, é uma medida de deslocamento global da água) e anisotropia fracionada (FA, medida do deslocamento unidirecional da água, uma variável que foi demonstrada como referência indireta da integridade das fibras e sensível a mudanças estruturais) (Alexander et al., 2007; Thiebaut de Schotten et al., 2011). FA será a variável referencial do método automatizado, devido a sua replicabilidade. As outras variáveis foram obtidas para a validação manual individual do método automatizado.

Como dito acima, anisotropia fracionada (FA) é uma inferência da preservação microestrutural (uma vez referida como "integridade") da fibra, indo de 0 a 1 , valor correspondente ao máximo de fluxo de moléculas de água numa direção em relação às outras duas direções possíveis. A medida inicialmente obtida foi a de anisotropia fracionada média, por 
trato. A distribuição da quantificação de FA em cada trato deve ser normal, com algumas curvas tendendo as médias para a direita ou esquerda, com os índices calculados pela fórmula abaixo:

$$
\text { L.I. }=(\text { FAdireito }- \text { FAesquerdo }) /(\text { FAdireito }+ \text { FAesquerdo })
$$

onde L.I. é o índice de lateralidade, FAdireito é o valor de anisotropia fracionada do trato no hemisfério direito e FAesquerdo o seu equivalente no hemisfério esquerdo. L.I. varia entre -1 (totalmente lateralizado para a esquerda) a +1 (totalmente a direita), passando por 0 quando os valores são iguais (simétricos). Escolheu-se inicialmente os tratos associados à linguagem (FAT, LS, AS e PS), uma vez que a lateralização deste fenótipo é amplamente discutido na literatura.

\subsection{SNP-set Kernel Association Test (SKAT)}

Apesar dos estudos de associação por varredura genômica (GWAS) terem identificado centenas de loci envolvidos em diversas doenças e tratos humanos, as variantes comuns (selecionadas para os GWAS) explicam apenas uma proporção pequena da herdabilidade dos tratos, em particular daqueles de natureza complexa. Com o sequenciamento de nova geração de genomas ou exomas completos, a inclusão de variantes raras tem permitido explicar parte desta herdabilidade perdida. Diversos métodos vem sendo desenvolvidos para integrar dados sobre variantes raras e comuns em estudos de associação ou de ligação, objetivando expandir o poder estatístico de investigação do papel de genes e seu efeito em fenótipos. Testes que colapsem ou resumem a diversidade de variantes raras de uma região genômica para uma medida vem sendo utilizados para buscar associações com fenótipos complexos. Estes testes são conhecidos como testes de carga genética (burden tests) e apresentam limitações no sentido de assumir que todas as variantes influenciam os fenótipos numa mesma direção e com a mesma magnitude. O método SKAT (Sequence/SNP-set Kernel Association test ou "teste de associação por padrões em sequências e conjuntos de SNPs) propõe uma abordagem de regressão com combinação entre variantes comuns e raras, para fenótipos dicotômicos ou contínuos e com ajuste para covariáveis, dentre elas matrizes de pesos sobre a relevância biológica das variáveis e ajustes para estratificação populacional (Wu et al., 2011). 
Para testar a associação entre variantes genéticas e os fenótipos de assimetria de tratos de substância branca envolvidos com linguagem, os métodos propostos pelo pacote SKAT foram escolhidos. A estratégia consiste em subdividir os indivíduos de três formas distintas a partir dos índices de lateralidade (LI) derivados dos valores de anisotropia fracionada (FA) por trato/fascículo. A primeira divisão de grupos, denominada "Extremos" (divisão A) consistiu em agrupar os 30 indivíduos com índices extremos em cada direção. Desta forma, um grupo passa a ter 30 indivíduos com valores de LI no sentido do hemisfério esquerdo e outro grupo, 30 indivíduos com LI no sentido do hemisfério direito. O método de SKAT foi aplicado para a função "Skat_Null_Model" com ajuste para amostras pequenas e regressão binária (fenótipos dicotômicos) (Wu et al., 2011). Também dicotômica, a segunda divisão de grupos, denominada "Radial" (divisão B) agrupou 15 indivíduos de cada extremo (formando um grupo de 30 indivíduos) versus um grupo de 30 indivíduos do centro da distribuição. O intuito é comparar lateralizados com não-lateralizados, uma vez que como não se sabe a priori a direção do efeito de cada variante, é possível hipotetizar que os valores combinados de efeito possam otimizar o modelo de associação entre os genes envolvidos em lateralização dos tratos de substância branca, em comparação com menos variantes e menos expressão fenotípica. Em outras palavras, o acúmulo de variantes nos potenciais genes associados seria, nesta hipótese, subjacente ao fenótipo "lateralizados". A terceira forma de associação seria quantitativa, em que cada valor de LI individual seria atribuído no modelo de associação com a diversidade por gene. As três formas estão representadas nas figuras 14-A, 14-B e 14-C, respectivamente.

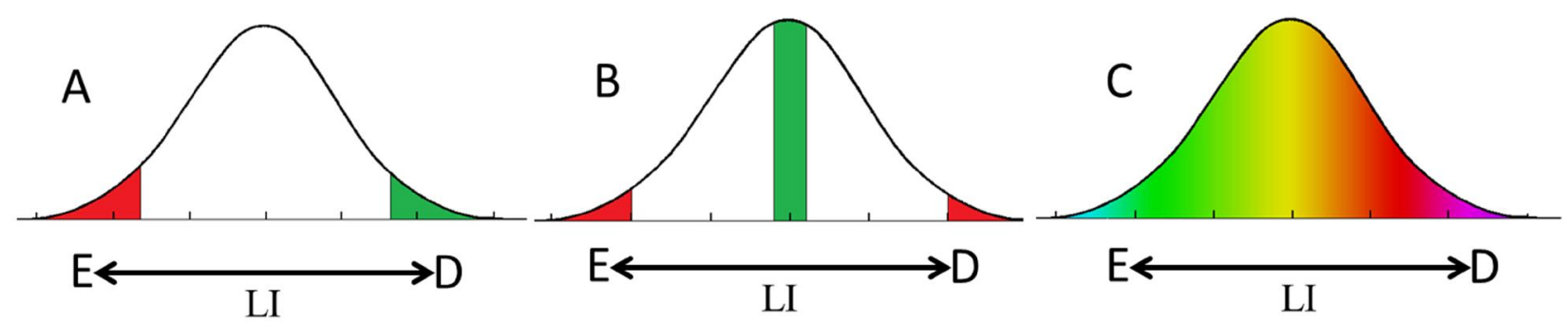

Figura 14. Representação das divisões de grupos por fenótipos de assimetria dos tratos de substância branca (índices de lateralidade - LI, de anisotropia fracionada - FA). "Extremos" representa os grupos de 30 indivíduos cada em cada extremidade da distribuição (vermelha e verde, representando as máximas assimetrias de cada trato/fascículo) (A). "Radial" representa os grupos de 30 indivíduos cada representado as extremidades conjuntamente (15 por extremidade, vermelho, mais lateralizados) e o centro da distribuição (verde, menos lateralizados) (B). Por fim, a distribuição quantitativa dos fenótipos de assimetria (C). 
Sendo o SKAT uma análise de enriquecimento de variantes em determinados fenótipos, três estratégias poderiam ser adotadas: 1) $S N P$-set por gene, onde para cada gene se identificam variantes raras e comuns e testa-se a distribuição nos grupos (fenótipos dicotômicos) ou no conjunto amostral (fenótipo quantitativo); 2) Gene-set por via biológica, ontogenia ou grupos personalizados, onde para cada conjunto de genes com definições do usuário poderia ser associado nos grupos ou no conjunto; e, 3) genome-wide, qualquer das duas abordagens acima, mas de maneira a cobrir todo o genoma, isto é os conjuntos de SNP-sets para todos os genes ou os genes para todas as vias ou ontogenias, seguido de um ranqueamento por p-valores significativos para obtenção de uma lista de candidatos. É possível utilizar matrizes de pesos para cada variante, caso conhecida a função (ou provável função) nos algoritmos do SKAT. No entanto, para uma primeira rodada de análises foi escolhida a não atribuição de pesos.

Para o presente estudo, foram escolhidas as estratégias 1) e 2) com divisões de grupos em A) e B), uma vez que o número de amostras com sobreposição de exomas sequenciados e RM-DTI com análise dos tratos é de 230 indivíduos, considerado baixo para uma abordagem genome-wide com fenótipos quantitativos. Os genes candidatos foram aqueles previamente descritos com envolvimento em assimetria cerebral e/ou linguagem: LRRTM1, AR, CCKAR, PCSK6, LMO4, FOXP2 e GRIN2B. Testou-se o gene-set desta lista "GeneSet-ASY", representando o conjunto de variantes de todos os genes e os SNP-sets para cada gene foram obtidos a partir dos dados dos exomas (filtrados para variantes de base única, sem indels). O software utilizado para rodar os pacotes e funções de SKAT foi o R x64 v3.1.2.. Os protocolos de bioinformática e de SKAT foram realizados com auxílio da Dra. Suzana Ezquina e MSc. Carolina Malcher, do CEGH-CEL.

Utilizou-se as medidas de LI-FA de quatro dos sete tratos dissecados por hemisfério, todos envolvidos com linguagem: FAT, LS, AS e PS. Como comentado nos itens acima, FAT conecta a área de Broca à área motora pré-suplementar e cíngulo anterior e sua degeneração está associada a afasia progressiva primária. LS, AS e PS são componentes do fascículo arqueado, segmentos longo, anterior e posterior, respectivamente. Eles conectam a região de compreensão da fala (Wernicke) à área de produção da fala (Broca) diretamente (LS) ou indiretamente (PS-AS) via território de Geschwind. 


\subsection{Outras medidas de lateralização}

Os voluntários responderam um questionário de dominância manual, padronizado e frequentemente utilizado em estudos de lateralidade (Corballis, 2003). Conhecido como Edinburgh Handedness Inventory (EHI), este questionário busca identificar a mão preferencialmente utilizada em atividades diárias, e torna possível a obtenção de um índice de lateralidade que varia de -100 (totalmente canhoto) a 100 (totalmente destro), em cálculo de índice semelhante ao de FA, mas multiplicado por 100 (Oldfield, 1971). Outros questionários de dominância manual foram desenvolvidos, porém após a elaboração do EHI muitos questionários foram descontinuados. Os questionários desenvolvidos após o EHI ainda não foram amplamente replicados e, desta forma, este estudo optou por aplicar apenas o EHI.

Comentado no capítulo III, houve coleta de dados clínicos sobre habilidade manual e força manual durante a visita ao HIAE. Estes dados foram coletados sob coordenação da Dra. Telma Busch, que conduziu um projeto de pós-doutorado na área de fragilidade em idosos e gerontologia funcional. Estes dados poderão ser integrados na análise de correlação entre preferência manual (dominância) e habilidade e força. A habilidade foi medida através de um tabuleiro de pinos (pin pegboard), onde é aferido o número de pinos colocados com cada mão durante o prazo de 30 segundos (três aferições por mão), amplamente utilizado como fenótipo de lateralidade da habilidade manual (Francks et al., 2002). A força manual foi medida com um dinamômetro digital (três aferições por mão). 


\section{Resultados e discussão}

\subsection{Redução da assimetria cortical}

A análise da redução da assimetria da espessura cortical com o envelhecimento é parte de um estudo maior conduzido pela Dra. Joana Balardin. Os resultados preliminares sugerem que a redução mais significativa foram nas regiões orbitofrontal, lateral dorsal e frontal inferior em particular nas áreas de Broca e adjacências, além dos limites do sulco temporal superior (próximo às regiões de Wernicke e Geschwind) (seta vermelha, figura 15). Estas são áreas intimamente envolvidas em linguagem e são naturalmente mais lateralizada em grande parte da população. Este resultado é convergente com a teoria de redução geral da assimetria em idosos e a observação de que quanto mais assimétrica a região, maior a probabilidade de redução da lateralização (Cabeza, 2002).

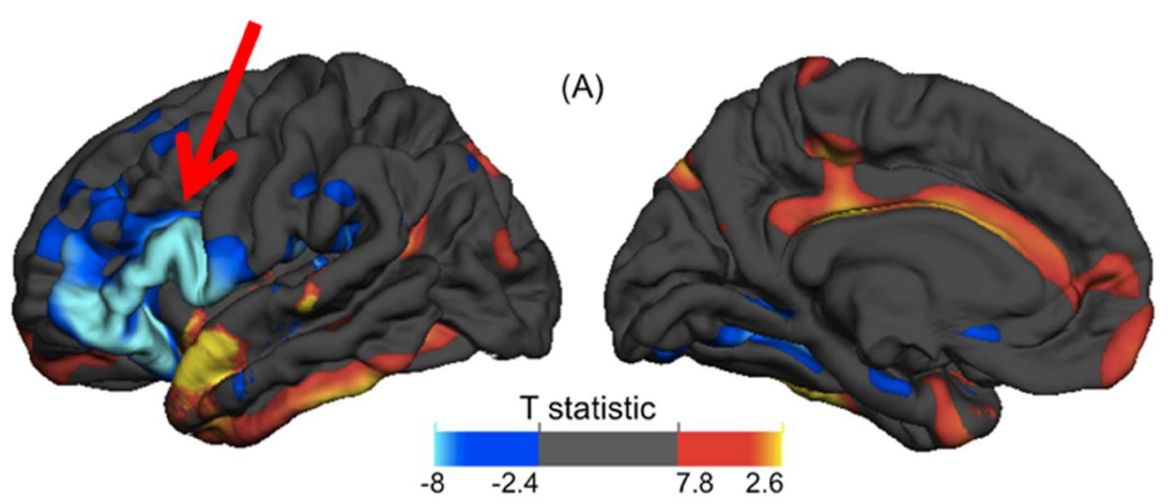

Figura 15. Redução da assimetria de espessura cortical com o envelhecimento. Em azul claro-escura, maiores reduções no hemisfério esquerdo. Em vermelho-amarelo, maiores reduções no hemisfério direito. Análise parcial, trabalho em elaboração por Dra. Joana Balardin e Dr. Edson Amaro.

\subsection{Distribuição de medidas de lateralização funcional}

Os índices de lateralidade medidos pelo questionário EHI apresentaram distribuição desviada para os valores positivos, conforme esperado (figura 16). A tabela 10 indica o número de indivíduos com cada índice de lateralidade, sua proporção e o acumulado. A referência de nãodestros representando cerca de $10 \%$ foi aproximada. O motivo pelo valor ter sido inferior $(8,27 \%)$ 
pode ser devido a maior pressão social em realizar atividades com a mão direita para esta faixa etária.

Tabela 10. Números de indivíduos $(\mathrm{N})$ por índices de lateralidade (LI) do questionário EHI e

\begin{tabular}{cccc}
\multicolumn{4}{c}{ frequências. } \\
\hline LI & $\mathbf{N}$ & $\mathbf{\%}$ & \% Acumulado \\
\hline-100 & 9 & 1,58 & 1,58 \\
-90 & 1 & 0,18 & 1,76 \\
-80 & 2 & 0,35 & 2,11 \\
-70 & 2 & 0,35 & 2,46 \\
-60 & 3 & 0,53 & 2,99 \\
-50 & 3 & 0,53 & 3,52 \\
-40 & 5 & 0,88 & 4,40 \\
-30 & 2 & 0,35 & 4,75 \\
-20 & 2 & 0,35 & 5,11 \\
-10 & 1 & 0,18 & 5,28 \\
0 & 1 & 0,18 & 5,46 \\
10 & 2 & 0,35 & 5,81 \\
20 & 1 & 0,18 & 5,99 \\
30 & 3 & 0,53 & 6,51 \\
40 & 10 & 1,76 & 8,27 \\
50 & 11 & 1,94 & 10,21 \\
60 & 14 & 2,46 & 12,68 \\
70 & 25 & 4,40 & 17,08 \\
80 & 111 & 19,54 & 36,62 \\
90 & 82 & 14,44 & 51,06 \\
100 & 278 & 48,94 & 100,00 \\
\hline Total & 568 & 100,00 & \\
\hline & & &
\end{tabular}

As medidas de força manual (medidas por dinamômetro em $\mathrm{kg}$ ) e habilidade manual (medida por pin pegboard, contagem de pinos colocados com cada mão em 30 segundos) foram dispostas em histogramas separados por sexo (figura 17). Observa-se distribuição normal com diferenças nítidas entre homens e mulheres e mais força e habilidade na mão direita para a maioria dos indivíduos. 


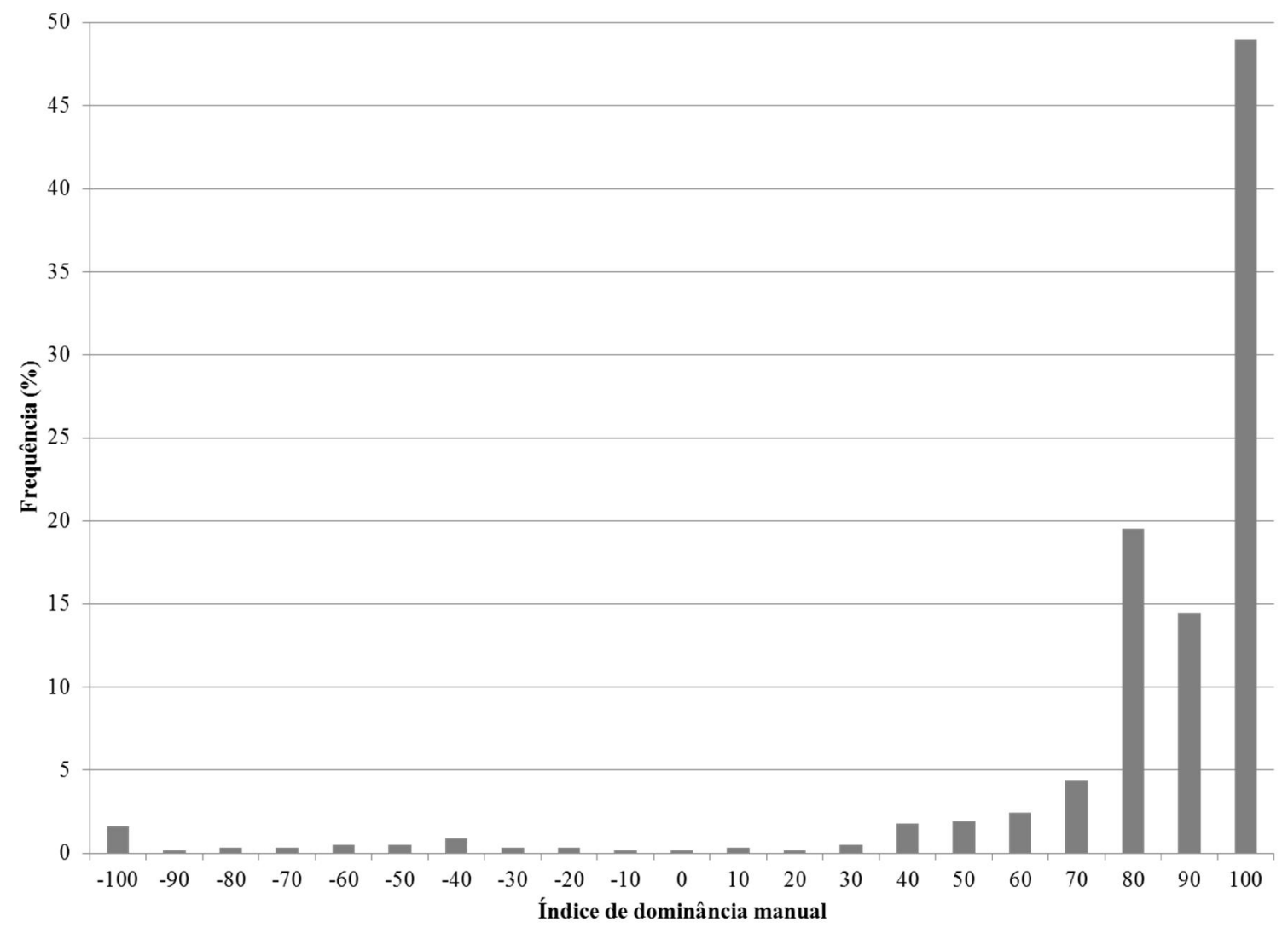

Figura 16. Histograma de índices de dominância manual, obtidos com questionário Edinburgh Handedness Inventory $(\mathrm{n}=568)$. 

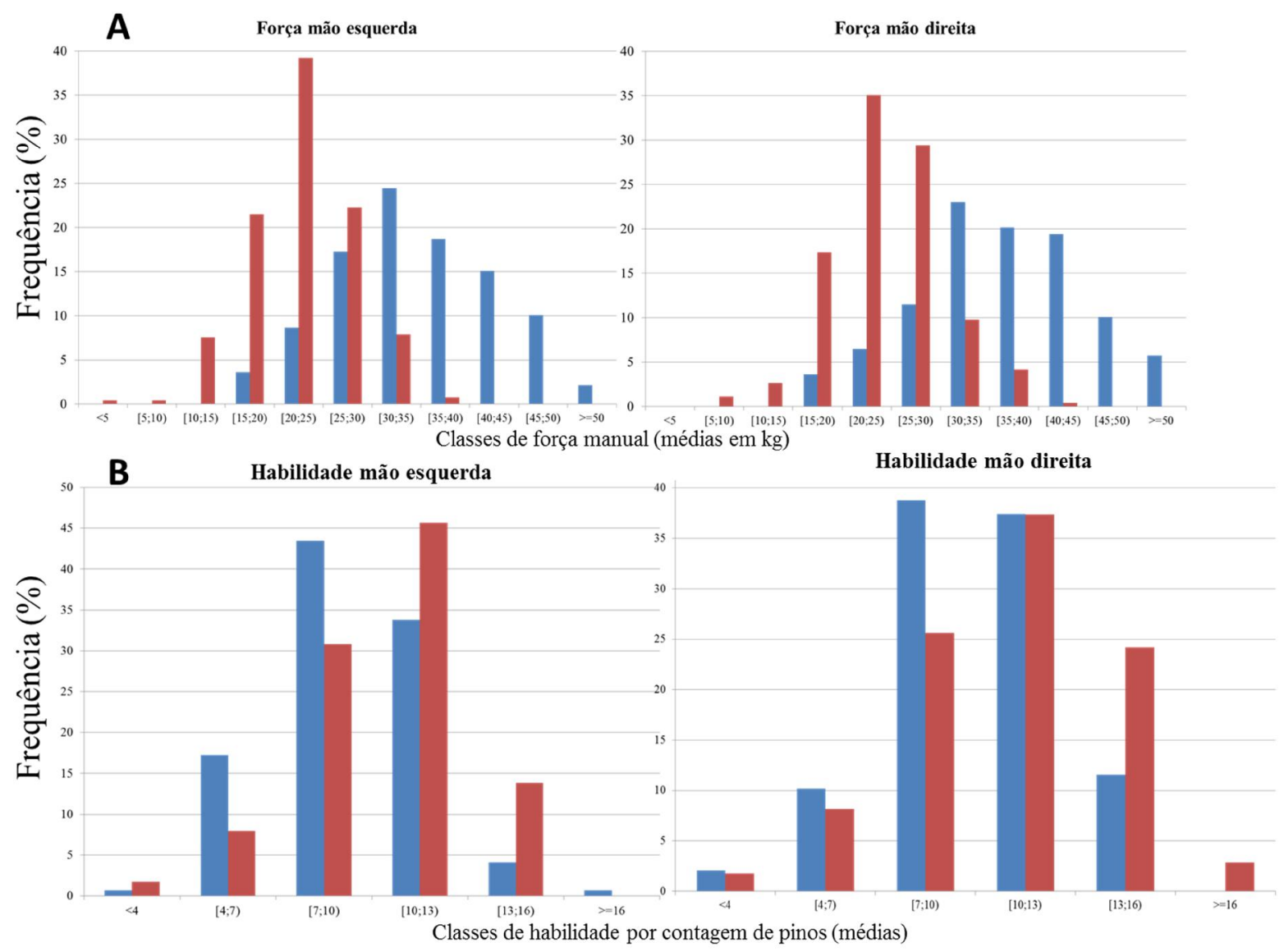

Figura 17. Distribuição de força e habilidade nas mãos esquerda e direita em homens (barras azuis) e mulheres (barras vermelhas). Histograma contendo o desempenho no teste de força manual, em classes de força por $\mathrm{kg}$, para a mão esquerda $(n=404)$ e direita $(n=404)$, entre homens $(n=139)$ e mulheres $(n=265)(A)$. Histograma contendo o desempenho no teste de habilidade manual, em classes com número de pinos colocados em 30 segundos, para a mão esquerda $(n=434)$ e direita $(n=428)$, entre homens $(n=145$ - esquerda/147- direita) e mulheres $(n=289$ direita/281- esquerda).

\subsection{Dissecção automatizada}

A dissecção virtual dos sete tratos de substância branca por hemisfério pelo TrackVis apresenta-se visualmente em imagens tridimensionais. Um exemplo de um dos indivíduos da amostra estudada está ilustrado na figura 18. 

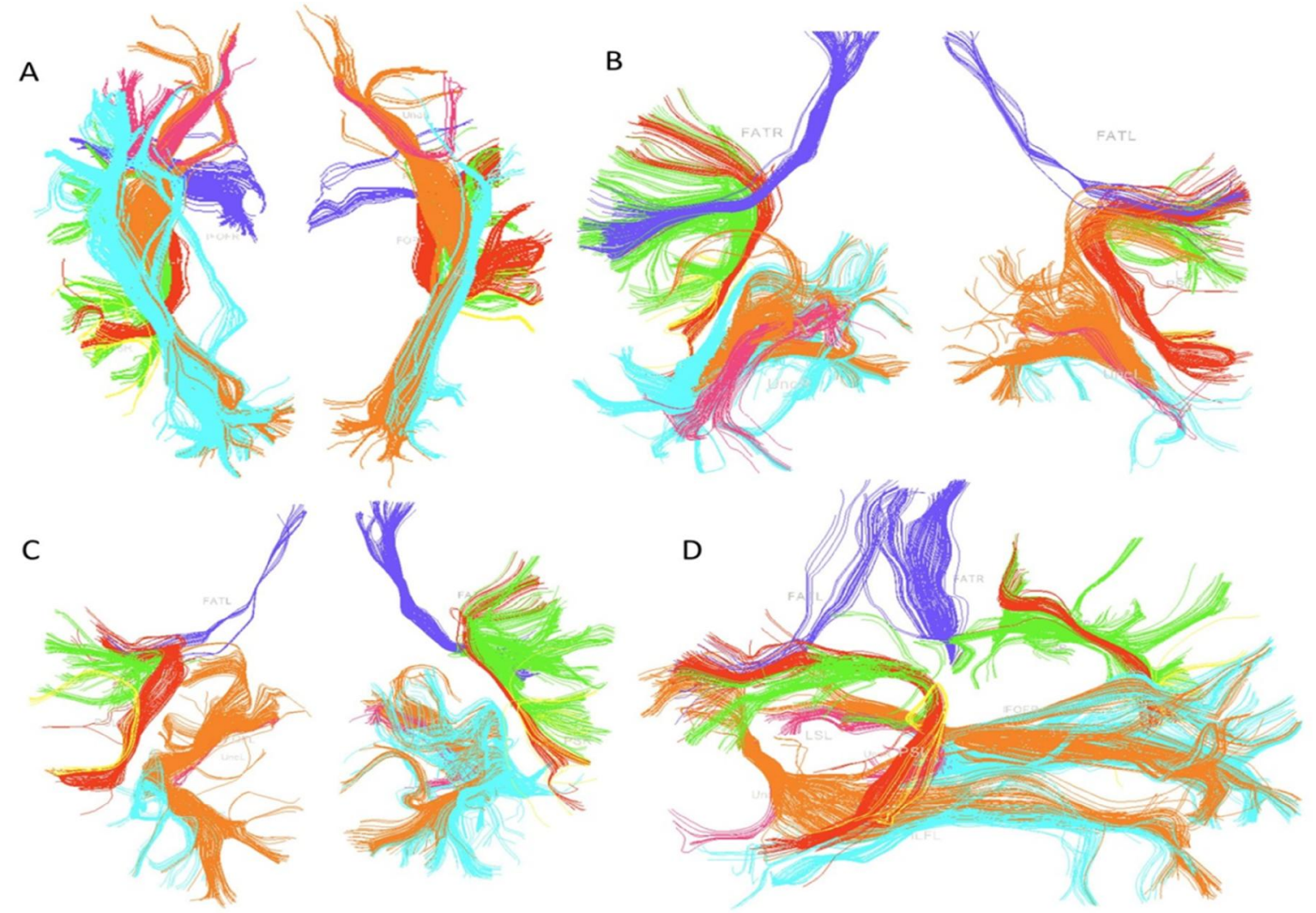

Figura 18. Tratografia para os sete tratos selecionados por hemisfério de um indivíduo. Vista inferior (A), vista ventral (B), vista dorsal (C), vista lateral esquerda (D). Cada cor representa um trato (bilateralmente disposto): vermelho (segmento longo do fascículo arqueado - LS), verde (segmento anterior do fascículo arqueado - AS), amarelo (segmento posterior do fascículo arqueado), roxo (trato frontal aslant - FAT), laranja (fascículo frontooccipital inferior - IFOF), azul claro (fascículo longitudinal inferior - ILF) e rosa (fascículo uncinado - Unc). Visualização em software TrackVis 0.5.2.

A distribuição dos valores de FA por trato em cada hemisfério e os índices de lateralidade (LI) estão ilustrados nas figuras 19 a 25. Os histogramas estão na seguinte ordem: distribuição do trato no hemisfério esquerdo, distribuição dos índices de lateralidade e distribuição do trato no hemisfério direito para LS (figura 19), AS (figura 20), PS (figura 21), FAT (figura 22), IFOF (figura 23), ILF (figura 24) e Unc (figura 25). Cada distribuição tem 8 classes de mesmo tamanho e estão em escalas específicas para cada trato. Apenas os valores de LI são apresentados de maneira "normalizada", uma vez que trata-se da razão entre a diferença e a soma dos valores de FA para cada trato, de cada indivíduo.

Nota-se que as distribuições são normais e que há tendências a desvios para a direita ou esquerda da média, em particular, para alguns tratos como o FAT e o AS (parte do fascículo arqueado) tal desvio na anisotropia fracionada é acentuado e se reflete na distribuição dos índices de assimetria. 

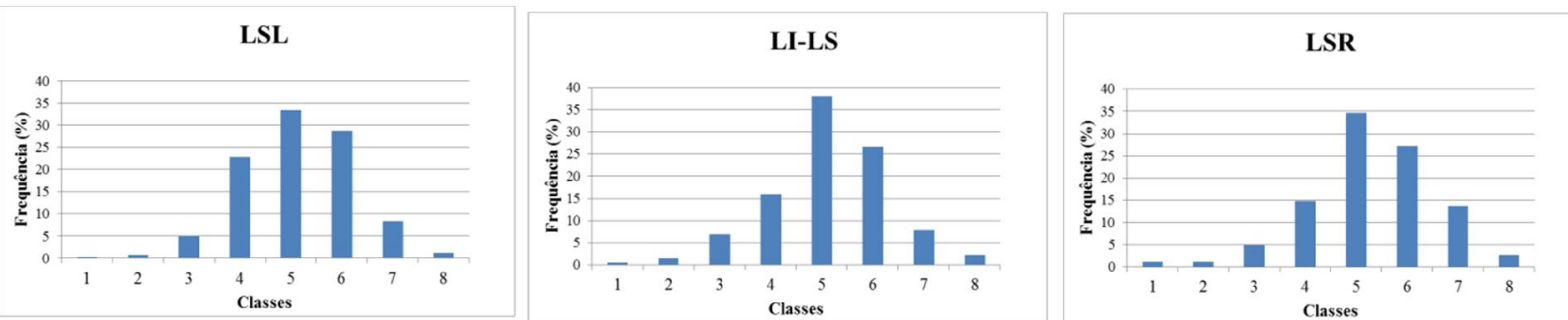

Figura 19. Histogramas de anisotropia fracionada (FA) média do segmento longo do fascículo arqueado (LS): esquerdo (LSL), direito (LSR) e histograma dos índices de lateralidade (LI). Eixo vertical corresponde ao percentual de indivíduos em cada classe. Classes de tamanho uniforme. LSL: $\mathrm{n}=461$; mediana de FA =0,457; mínimo-máximo $=0,335$ a 0,546; tamanho da classe $=0,026$. LSR: $\mathrm{n}=372$; mediana de $\mathrm{FA}=0,444$; mínimo-máximo $=0,324$ a 0,523; tamanho da classe $=0,024$. LI-LS: $\mathrm{n}=344$; mediana de $\mathrm{FA}=-0,011$; mínimo-máximo $=-0,136$ a 0,079 ; tamanho da classe $=0,027$.
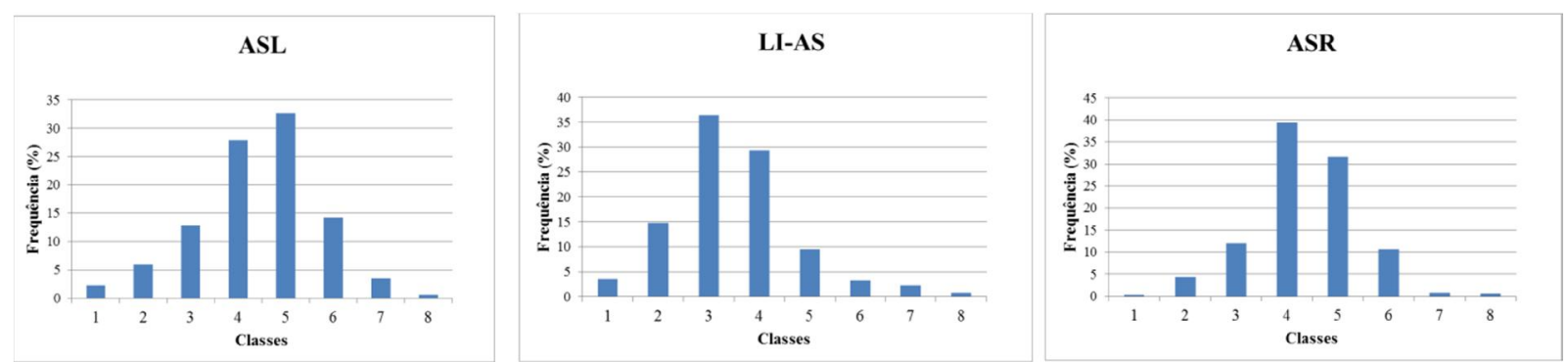

Figura 20. Histogramas de anisotropia fracionada (FA) média do segmento anterior do fascículo arqueado (AS): esquerdo (ASL), direito (ASR) e histograma dos índices de lateralidade (LI). Eixo vertical corresponde ao percentual de indivíduos em cada classe. Classes de tamanho uniforme. ASL: $\mathrm{n}=484$; mediana de FA =0,398; mínimo-máximo $=0,294$ a 0,502; tamanho da classe $=0,026$. ASR: $\mathrm{n}=517$; mediana de $\mathrm{FA}=0,404$; mínimo-máximo $=0,307$ a 0,510; tamanho da classe $=0,025$. LI-AS: $\mathrm{n}=481$; mediana de $\mathrm{FA}=0,009$; mínimo-máximo $=-0,083$ a 0,176 ; tamanho da classe $=0,032$.
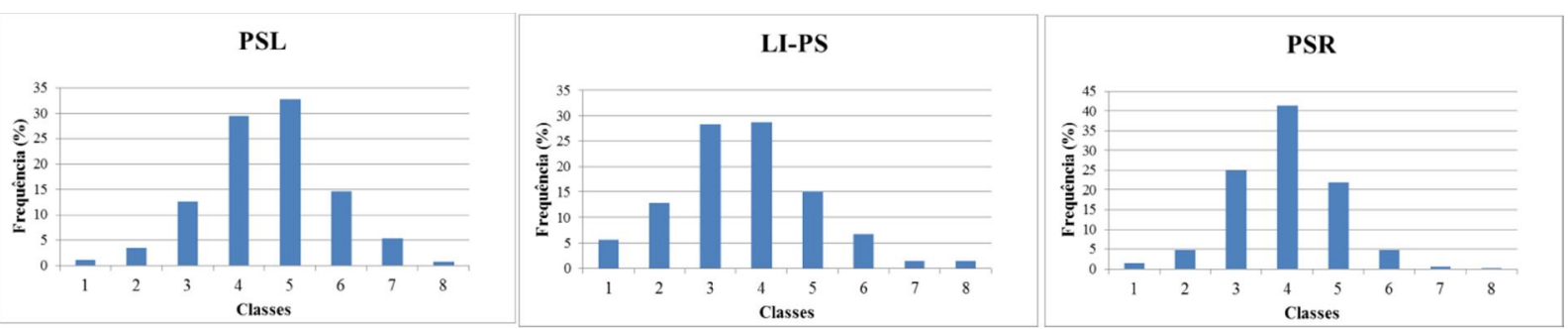

Figura 21. Histogramas de anisotropia fracionada (FA) média do segmento posterior do fascículo arqueado (PS): esquerdo (PSL), direito (PSR) e histograma dos índices de lateralidade (LI). Eixo vertical corresponde ao percentual de indivíduos em cada classe. Classes de tamanho uniforme. PSL: $\mathrm{n}=431$; mediana de FA =0,416; mínimo-máximo $=0,312$ a 0,514; tamanho da classe $=0,025$. PSR: $\mathrm{n}=505 ;$ mediana de $\mathrm{FA}=0,382 ;$ mínimo-máximo $=0,303$ a 0,487 ; tamanho da classe $=0,022$. LI-PS: $\mathrm{n}=431$; mediana de $\mathrm{FA}=-0,042 ;$ mínimo-máximo $=-0,118$ a 0,$077 ;$ tamanho da classe $=0,024$. 

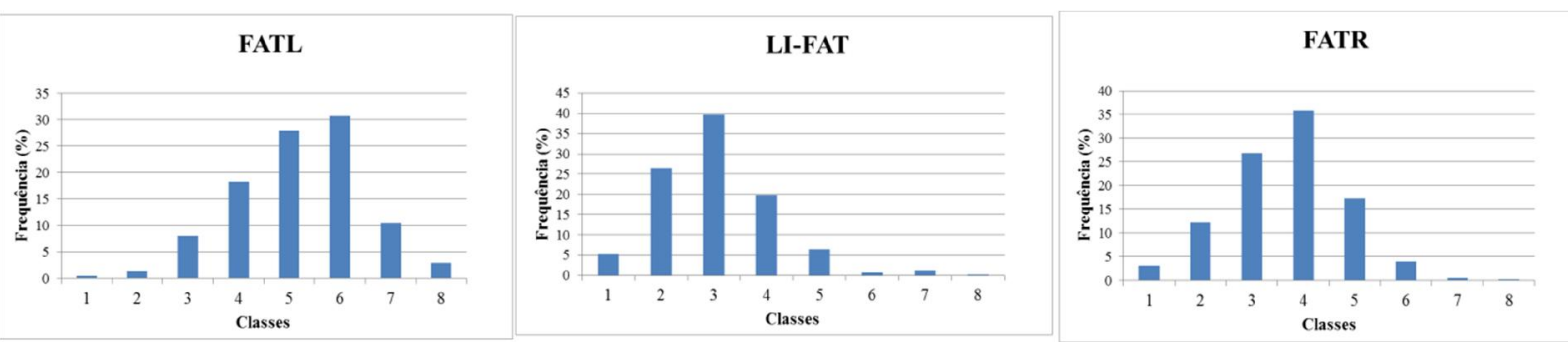

Figura 22. Histogramas de anisotropia fracionada (FA) média do trato aslant frontal (FAT): esquerdo (FATL), direito (FATR) e histograma dos índices de lateralidade (LI). Eixo vertical corresponde ao percentual de indivíduos em cada classe. Classes de tamanho uniforme. FATL: $n=449$; mediana de $\mathrm{FA}=0,412$; mínimo-máximo $=0,320$ a 0,476; tamanho da classe $=0,019$. FATR: $\mathrm{n}=424$; mediana de $\mathrm{FA}=0,412$; mínimo-máximo $=0,341$ a 0,519 ; tamanho da classe $=0,022$. LI-FAT: $n=403$; mediana de $\mathrm{FA}=-0,002$; mínimo-máximo $=-0,055$ a 0,118 ; tamanho da classe $=0,021$.
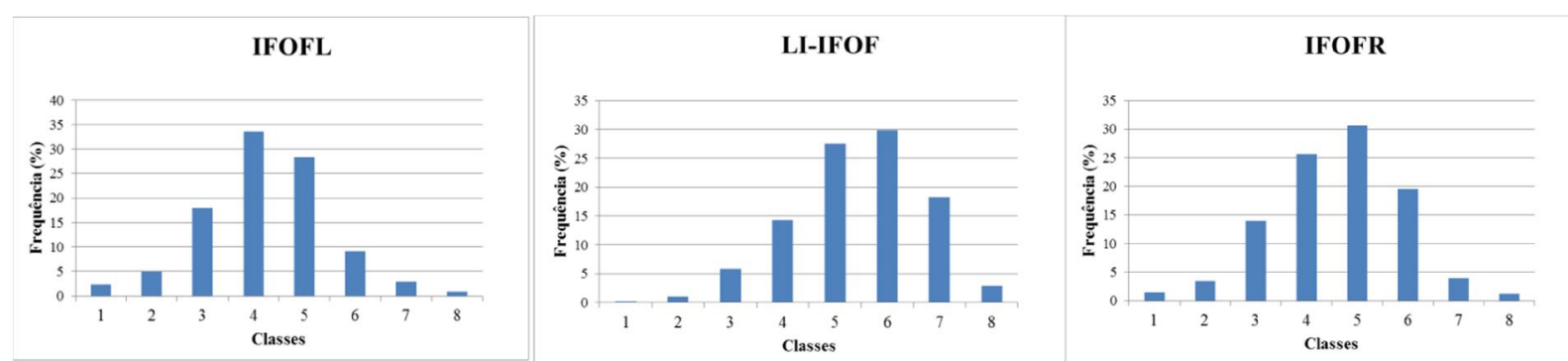

Figura 23. Histogramas de anisotropia fracionada (FA) média do fascículo fronto-occipital inferior (IFOF): esquerdo (IFOFL), direito (IFOFR) e histograma dos índices de lateralidade (LI). Eixo vertical corresponde ao percentual de indivíduos em cada classe. Classes de tamanho uniforme. IFOFL: $\mathrm{n}=480$; mediana de $\mathrm{FA}=0,459$; mínimo-máximo $=0,379$ a 0,459 ; tamanho da classe $=0,021$. IFOFR: $\mathrm{n}=486$; mediana de $\mathrm{FA}=0,451$; mínimo-máximo $=0,373$ a 0,524; tamanho da classe $=0,018$. LI-IFOF: $\mathrm{n}=476$; mediana de $\mathrm{FA}=-0,008$; mínimo-máximo $=-0,080$ a 0,034 ; tamanho da classe $=0,014$.
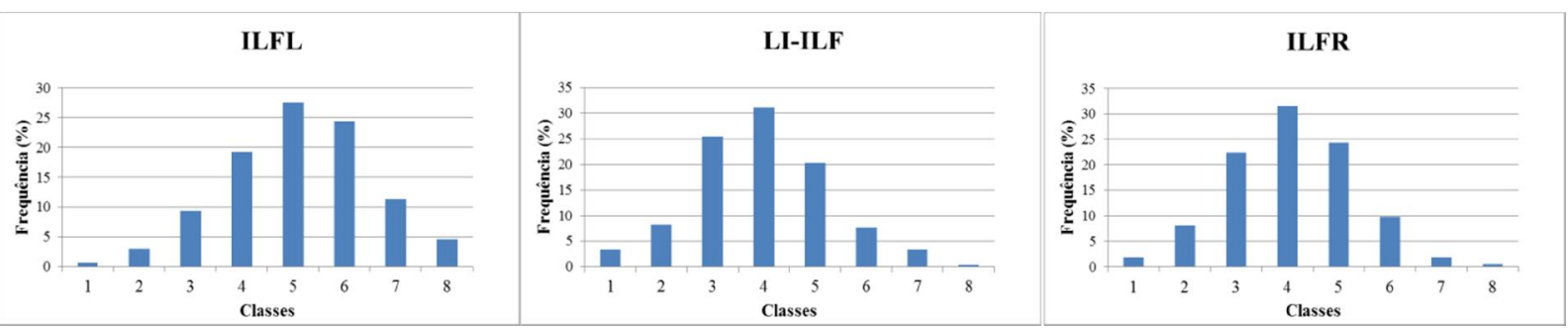

Figura 24. Histogramas de anisotropia fracionada (FA) média do fascículo longitudinal inferior (ILF): esquerdo (ILFL), direito (ILFR) e histograma dos índices de lateralidade (LI). Eixo vertical corresponde ao percentual de indivíduos em cada classe. Classes de tamanho uniforme. ILFL: $n=483$; mediana de FA = 0,449; mínimo-máximo = 0,354 a 0,518; tamanho da classe $=0,020$. ILFR: $\mathrm{n}=495$; mediana de $\mathrm{FA}=0,432$; mínimo-máximo $=0,368$ a 0,511 ; tamanho da classe = 0,018. LI-ILF: $\mathrm{n}=482$; mediana de $\mathrm{FA}=-0,020$; mínimo-máximo = -0,084 a 0,064; tamanho da classe $=0,018$. 

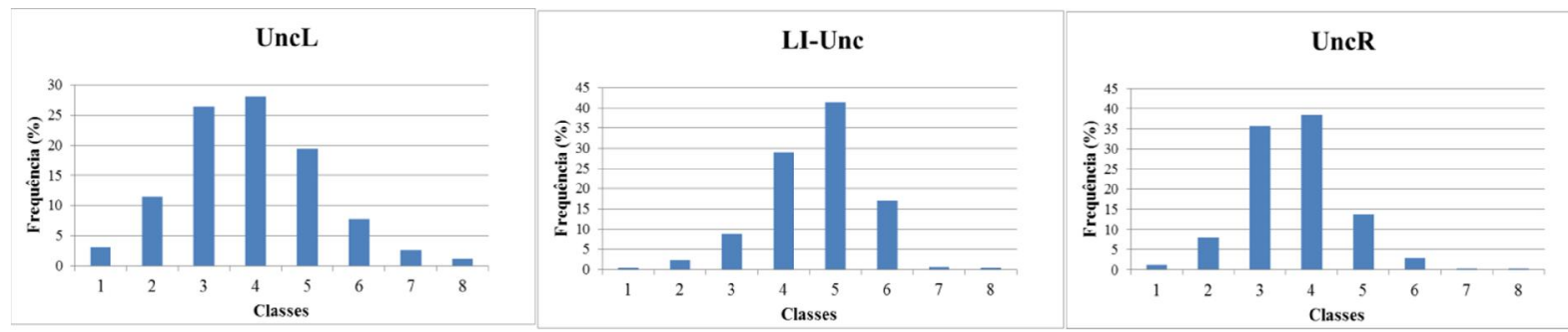

Figura 25. Histogramas de anisotropia fracionada (FA) média do fascículo uncinado (Unc): esquerdo (UncL), direito (UncR) e histograma dos índices de lateralidade (LI). Eixo vertical corresponde ao percentual de indivíduos em cada classe. Classes de tamanho uniforme. UncL: $\mathrm{n}=489$; mediana de $\mathrm{FA}=0,405$; mínimo-máximo $=0,338$ a 0,497 ; tamanho da classe $=0,019$. UncR: $\mathrm{n}=520$; mediana de $\mathrm{FA}=0,383$; mínimo-máximo $=0,310$ a 0,495 ; tamanho da classe $=0,023$. LI-Unc: $\mathrm{n}=489$; mediana de $\mathrm{FA}=-0,027$; mínimo-máximo $=-0,163$ a 0,097; tamanho da classe $=$ 0,032 .

\subsection{Dissecção manual: validação}

O método de dissecção automatizado desenvolvido pelo grupo do Prof. Marco Catani e Prof. Michel Thiebaut de Schotten se mostra útil por desempenhar a extração de dados sobre tratos e fascículos de substância branca de um número grande de cérebros simultaneamente. A validação do método torna-se importante para evitar falsos positivos e dissecções espúrias. Para isso, realizou-se a dissecção manual individual de dez cérebros para os mesmos sete tratos/fascículos de substância branca e estimou-se a correlação para os seis parâmetros medidos pelo software TrackVis. Os resultados estão plotados em gráficos na figura 26 e as correlações descritas na legenda.

Apesar dos coeficientes de correlação não terem sido altos, a análise gráfica revelou que um conjunto grande dos pontos apresenta um grau razoável de correlação. Os pontos plotados próximos a $(0,0)$ ou sobre os eixos X ou Y no gráfico de "Comprimento Fibras" (figura 26) indicam estruturas que não foram identificadas por ambos os métodos, pelo método automatizado ou pelo método manual, respectivamente. Ao averiguar as correlações por indivíduo para todos os tratos, por parâmetro (tabela 11), observamos que a variação inter-individual é decisiva para o sucesso da extração automatizada e que, em média, as correlações atingiram significância estatística para os 14 tratos (com $\alpha<0,05$ ou $\alpha<0,01,12$ d.f.), como ilustrado na tabela 12 . 


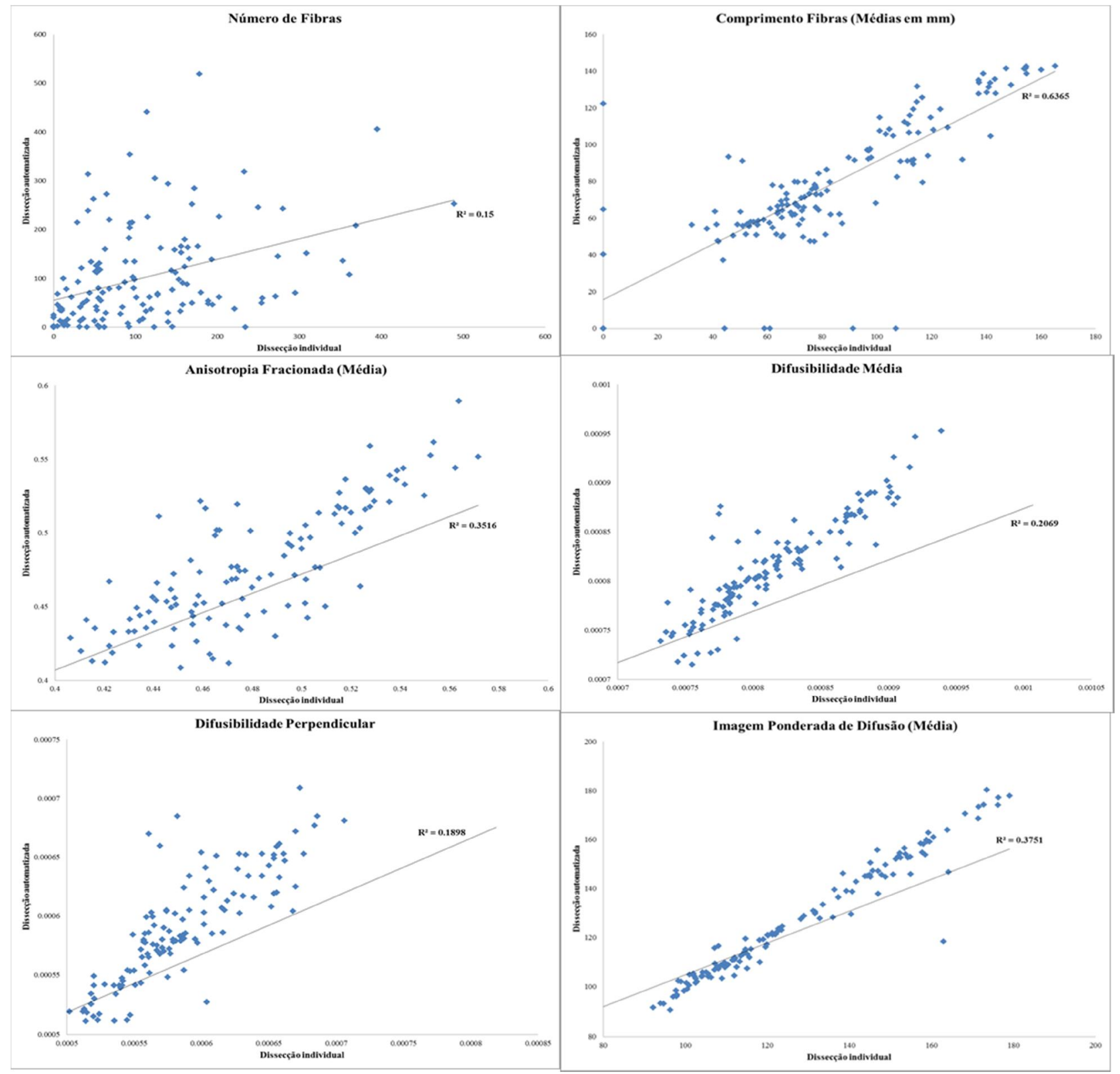

Figura 26. Correlações obtidas a partir de comparação dos tratos extraídos de dez indivíduos utilizando o método automatizado (eixo y) e individual (eixo x), para seis parâmetros quantitativos. Coeficientes de correlação Pearson $\mathrm{R}^{2}$ : 0,15 (número de fibras), 0,6365 (comprimento médio de fibras em milímetros), 0,3516 (anisotropia fracionada), 0,2069 (difusibilidade média), 0,1898 (difusibilidade perpendicular) e 0,3751 (imagem ponderada de difusão, valores médios). 
Tabela 11. Coefícientes de correlação (Pearson) por indivíduo para 14 tratos por cérebro.

\begin{tabular}{ccccccc}
\hline Sujeito & $\begin{array}{c}\text { Número } \\
\text { de fibras }\end{array}$ & $\begin{array}{c}\text { Anisotropia } \\
\text { fracionada }\end{array}$ & $\begin{array}{c}\text { Difusibilidade } \\
\text { média }\end{array}$ & $\begin{array}{c}\text { Difusibilidade } \\
\text { perpendicular }\end{array}$ & $\begin{array}{c}\text { Imagem ponderada } \\
\text { de difusão }\end{array}$ & Comp. \\
\hline $\mathbf{1}$ & 0,4672 & 0,7576 & 0,6471 & 0,6703 & 0,9117 & 0,9530 \\
$\mathbf{2}$ & 0,3913 & 0,5769 & $-0,3551$ & 0,5238 & $-0,0137$ & 0,7652 \\
$\mathbf{3}$ & 0,5886 & 0,5642 & 0,7861 & 0,0233 & 0,5894 & 0,8156 \\
$\mathbf{4}$ & 0,1804 & 0,1568 & 0,0455 & $-0,0310$ & $-0,0767$ & 0,4028 \\
$\mathbf{5}$ & 0,4933 & 0,8800 & 0,5853 & 0,6117 & 0,7684 & 0,9350 \\
$\mathbf{6}$ & 0,3730 & 0,0370 & 0,5179 & 0,6333 & $-0,0347$ & 0,7707 \\
$\mathbf{7}$ & 0,2463 & 0,9794 & 0,9984 & 0,9913 & 0,9904 & 0,9481 \\
$\mathbf{8}$ & 0,7277 & 0,7217 & 0,7170 & 0,5013 & 0,5639 & 0,8908 \\
$\mathbf{9}$ & 0,1073 & 0,0164 & 0,0307 & 0,1972 & 0,5607 & 0,6812 \\
$\mathbf{1 0}$ & 0,4571 & 0,6189 & 0,2900 & $-0,0135$ & 0,4067 & 0,9268 \\
\hline
\end{tabular}

Escala crescente (em módulo) de vermelho a verde de acordo com o coeficiente de correlação $\mathrm{R}^{2}$ de Pearson.

Tabela 12. Significância estatística para os coeficientes de correlação (Pearson) por indivíduo para 14 tratos por cérebro.

\begin{tabular}{|c|c|c|c|c|c|c|}
\hline Sujeito & $\begin{array}{l}\text { Número } \\
\text { de fibras }\end{array}$ & $\begin{array}{c}\text { Anisotropia } \\
\text { fracionada }\end{array}$ & $\begin{array}{c}\text { Difusibilidade } \\
\text { média }\end{array}$ & $\begin{array}{l}\text { Difusibilidade } \\
\text { perpendicular }\end{array}$ & $\begin{array}{c}\text { Imagem ponderada } \\
\text { de difusão }\end{array}$ & Comp. \\
\hline 1 & 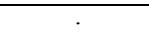 & $\mathrm{x}$ & 0 & $\mathrm{x}$ & $\mathrm{x}$ & $\mathrm{x}$ \\
\hline 2 & . & 0 & . & . & . & $\mathrm{x}$ \\
\hline 3 & o & o & $\mathrm{x}$ & . & o & $\mathrm{x}$ \\
\hline 4 & · & . & . & . & . & . \\
\hline 5 & . & $\mathrm{x}$ & o & o & $\mathrm{x}$ & $\mathrm{x}$ \\
\hline 6 & . & . & . & $\mathrm{o}$ & . & $\mathrm{x}$ \\
\hline 7 & . & $\mathrm{x}$ & $\mathrm{x}$ & $\mathrm{x}$ & $\mathrm{x}$ & $\mathrm{x}$ \\
\hline 8 & $\mathrm{x}$ & $\mathrm{x}$ & $\mathrm{x}$ & . & o & $\mathrm{x}$ \\
\hline 9 & . & . & . & . & o & $\mathrm{x}$ \\
\hline 10 & . & o & . & . & . & $\mathrm{x}$ \\
\hline
\end{tabular}

Código: $\mathrm{x}=$ Significância a $\mathrm{p}<0,01 ; 12$ d.f.. $\mathrm{o}=$ Significância a $\mathrm{p}<0,05 ; 12$ d.f $(14$ tratos $)$

4.5.Associação entre genes candidatos e índices de lateralidade

A associação entre a diversidade de genes com envolvimento previamento descrito em lateralidade cerebral, conforme comentado no penúltimo item da introdução, foi testada utilizando o teste de enriquecimento SKAT e a divisão de grupos exposta na metodologia. Os resultados (p-valores) estão ilustrados na tabela 13. Os valores não estão ajustados para múltiplos testes. 
Tabela 13. Enriquecimento* de variantes (SKAT) em genes envolvidos com lateralidade cerebral em grupos descritos por índices de lateralidade de tratos de substância branca

\begin{tabular}{|c|c|c|c|c|c|c|c|c|c|}
\hline Trato & Grupos & GeneSet-Asy & LRRTM1 & FOXP2 & $A R$ & GRIN2B & CCKAR & LMO4 & PCSKG \\
\hline FAT & Extremos & 0,5023 & 0,8260 & 0,0848 & 0,2197 & 0,7279 & 0,3791 & 0,9002 & 0,3625 \\
\hline AS & Extremos & 0,4761 & 0,9724 & 0,1256 & 0,0462 & 0,3175 & 0,1897 & 0,2051 & 0,9439 \\
\hline PS & Extremos & 0,4190 & 0,8325 & 0,3607 & 0,3185 & 0,6931 & 0,7528 & 0,3763 & 0,2193 \\
\hline LS & Extremos & 0,2775 & 0,7893 & 0,0362 & 0,4747 & 0,5048 & 0,2103 & 0,4519 & 0,3135 \\
\hline FAT & Radial & $\mathbf{0 , 0 2 0 9}$ & 0,2204 & 0,0023 & 0,8030 & 0,3811 & 0,5302 & 0,0513 & 0,1450 \\
\hline AS & Radial & 0,6866 & 0,3278 & 0,9360 & 0,5752 & 0,7357 & 0,2436 & 0,5802 & 0,3463 \\
\hline PS & Radial & 0,6539 & 0,5605 & 0,0016 & 0,9188 & 0,7865 & 0,3439 & 0,3650 & 0,7161 \\
\hline LS & Radial & 0,6560 & 0,5258 & 0,4744 & 0,1692 & 0,7693 & 0,7250 & 0,1304 & 0,7084 \\
\hline
\end{tabular}

Ao reunir as variantes dos sete genes previamente descritos como envolvidos com lateralidade cerebral em um gene-set chamado GeneSet-Asy, a única divisão de grupos que apresentou enriquecimento significativo foi com a "Radial" com o trato FAT. A interpretação direta indica que a separação entre grupos mais lateralizados e menos lateralizados pode ser explicada pela distribuição de diversidade de variantes deste conjunto. Para verificar qual ou quais genes poderiam eventualmente estar influenciando essa associação, investigou-se um a um.

Observando a tabela 13, o gene $A R$ mostrou-se estatisticamente significativo para o trato AS com a divisão de grupos "Extremos" $(\mathrm{p}=0,0462)$. Isso significaria que a divisão entre mais lateralizados para a direita e mais lateralizados para a esquerda pode ser explicada, ao menos parcialmente, com a distribuição de variantes no gene $A R$.

O resultado mais significativo (tabela 13), no entanto, foi observado com o gene FOXP2. Os menores p-valores foram encontrados para este gene, com três sinais de associação: o primeiro sinal ( $p=0,0362)$ com a divisão "Extremos" no segmento longo (LS) do fascículo arqueado indica que mais lateralizados para a esquerda e mais lateralizados para a direita apresentam diversidades distintas de variantes genéticas em $F O X P 2$; os outros resultados são ainda mais significativos com a divisão "Radial", onde os mais lateralizados para FAT ( $\mathrm{p}=0,0023)$ e para o segmento posterior (PS) do fascículo arqueado $(\mathrm{p}=0,0016)$ tem uma diversidade de variantes distintas em FOXP2 que os mais simétricos.

Localizado no cromossomo 7q31, o gene FOXP2 (forkhead box P2) codifica um fator de transcrição (Foxp2) expresso principalmente no cérebro. Mutações em FOXP2 foram extensivamente implicadas com distúrbios no neurodesenvolvimento da linguagem, orodispraxias e outros distúrbios que acomentem a produção e processamento da fala. Demonstrou-se que a proteína Foxp2 está envolvida em processamento e integração sensorial em áreas corticais e 
subcorticais, além de estar envolvida com a aquisição e desempenho de habilidades motoras (French e Fisher, 2014). A sequencia proteica de Foxp2 é considerada altamente conservada e duas diferenças em aminoácidos são exclusivas de humanos, sugerindo inclusive o seu papel crucial na evolução dos Homo sapiens (Konopka et al., 2009). Filhotes de camundongos e pássaros com mutações ou com expressão reduzida do ortologo de Foxp2 apresentam vocalização alterada (French e Fisher, 2014).

Por sua participação na circuitaria de linguagem, FOXP2 foi previamente considerado um candidato envolvido com a lateralização de algumas estruturas cerebrais. Pinel e colaboradores (2012) testaram 37 SNPs em FOXP2 contra padrões de ativação do cérebro por RM funcional com paradigmas de linguagem. Dois SNPs foram associados restritos a ativação do lado esquerdo no giro frontal inferior e no giro pré-central. $\mathrm{O}$ giro frontal inferior envolve a área de Broca, responsável pela produção da fala e o córtex associado no giro pré-central está envolvido com a representação motora dos lábios e laringe (Pinel et al., 2012). O trato frontal aslant (FAT) conecta a área de Broca com a região motora pré-suplementar, a qual está envolvida com o planejamento dos programas motores e pode ser um dos fatores importantes no processo de fluência da fala. A disrupção deste trato está envolvida com afasia progressiva primaria (Catani et al., 2013).

O próximo passo imediato, para esclarecer a natureza da associação é anotar as variantes, de modo a compreender as possíveis funções. O fato de o método SKAT, como aplicado aqui, não incluir informações funcionais sobre as variantes, acarreta na não direcionalidade da associação. Se isto corresponder com o efeito de variantes raras e comuns neste gene estarem influenciando o padrão de assimetria, a despeito da direção, tal método se mostrará mais poderoso com a divisão de grupos "Radial". Se, entretanto, o acúmulo de variantes (interferindo na diversidade) for responsável por modificar a assimetria para um hemisfério ou outro, a estratégia de grupos "Extremos" se mostraria mais robusta. Independentemente dos cenários, a análise deverá ser continuada com o estudo das variantes responsáveis pelo sinal estatístico encotnrado, seguido de testes funcionais para estabelecer evidências ou refutar hipóteses acerca desta proposta de correlação genótipo-fenótipo. 


\section{Considerações finais e perspectivas}

A lateralidade cerebral é um fenótipo complexo e envolve diversas funções, dentre elas a linguagem e a dominância motora. Apesar de conhecida a variabilidade fenotípica para estes tratos e a participação de componentes genéticos, pouco se sabe dos mecanismos de desenvolvimento e manutenção da assimetria. A perda da assimetria é observável durante o envelhecimento e em distúrbios neuropsiquiátricos como esquizofrenia e dislexia.

A busca por genes envolvidos em lateralidade cerebral trouxe resultados pontuais para genes candidatos e resultados controversos em investigações genômicas. Uma das dificuldades é realizar a fenotipagem, uma vez que (com exceção da dominância motora) características lateralizadas como a linguagem são de difícil acesso clínico. A medição de endofenótipos mostrou-se uma estratégia razoável para aplicar no esforço de identificar componentes genéticos subjacentes aos fenótipos.

Este estudo buscou a associação entre índices de assimetria derivados de um parâmetro específico de tratos e fascículos de substância branca utilizando um protocolo de ressonância magnética. Os tratos escolhidos estão envolvidos com linguagem. A estratégia de associação genética escolhida envolveu um método de resumo de variabilidade comum e rara em uma medida de diversidade, a qual pode ser usada para testar o enriquecimento de variantes em um determinado grupo de indivíduos, neste caso separados por assimetria de tratos de substância branca. Inicialmente buscou-se por uma estratégia de genes candidatos, escolhidos por terem sido descritos previamente como envolvidos com assimetria cerebral.

Um achado preliminar de associação entre diversidade de variantes em FOXP2 e assimetria de dois tratos envolvidos com linguagem, FAT e segmento posterior (PS) do fascículo arqueado pode contribuir para o entendimento da formação da assimetria e variabilidade na lateralização da linguagem.

As perspectivas imediatas para a continuidade deste estudo incluem:

- Identificar quais variantes em $F O X P 2$ contribuiram para o sinal de associação com os índices de lateralidade medidos; 
- Realizar o estudo de associação genome-wide quantitativo (sem divisão de grupos) utilizando o método SKAT para enriquecimento em: todos os genes do genoma (diversidade por gene), conjuntos de genes por vias e conjuntos de genes da via de FOXP2;

- Elaborar modelos de assimetria integrando dados de outros fenótipos lateralizados, incluindo a inferência dos padrões de ativação cortical com os dados de rsfMRI;

- Aumentar a amostra de indivíduos com ressonância magnética e sequenciamento de exomas ou genomas completos; 


\section{Referências bibliográficas}

ABRAMS, D. M.; PANAGGIO, M. J. A model balancing cooperation and competition can explain our right-handed world and the dominance of left-handed athletes. J R Soc Interface, v. 9, n. 75, p. 2718-22, 2012.

ALEXANDER, A. L. et al. Diffusion tensor imaging of the brain. Neurotherapeutics, v. 4, n. 3, p. 316-29, 2007.

ANGRILLI, A. et al. Schizophrenia as failure of left hemispheric dominance for the phonological component of language. PLoS One, v. 4, n. 2, p. e4507, 2009.

ANNETT, M. The distribution of manual asymmetry. Br J Psychol, v. 63, n. 3, p. 343-58, 1972.

Handedness and cerebral dominance: the right shift theory. J Neuropsychiatry Clin Neurosci, v. 10, n. 4, p. 459-69, 1998.

ANNETT, M. Handedness and brain asymmetry : the right shift theory. Hove: Psychology, 2002. ISBN $1841691046:{ }^{149.95 .}$

ANNETT, M. The genetic basis of lateralization. In: SOMMER, I. E. C. e KAHN, R. S. (Ed.). Language lateralization and psychosis. Cambridge, UK ; New York: Cambridge University Press, 2009. cap. 5, p.pp. 73-86. ISBN 9780521882842 (hbk.).

BARNEOUD, P.; VAN DER LOOS, H. Direction of handedness linked to hereditary asymmetry of a sensory system. Proc Natl Acad Sci U S A, v. 90, n. 8, p. 3246-50, 1993.

BARTLEY, A. J. et al. Sylvian fissure asymmetries in monozygotic twins: a test of laterality in schizophrenia. Biol Psychiatry, v. 34, n. 12, p. 853-63, 1993.

BEATON, A.; HUGDAHL, K.; RAY, P. Lateral asymmetries and interhemispheric transfer in aging: A review and some new data. In: MANDAL, M. K.;BULMAN-FLEMING, M. B., et al (Ed.). Side bias : a neuropsychological perspective. Dordrecht ; Boston: Kluwer Academic Publishers, 2000. p.xix, 350 p. ISBN 0792366603 (hardcover alk. paper).

BRANDLER, W. M. et al. Common variants in left/right asymmetry genes and pathways are associated with relative hand skill. PLoS Genet, v. 9, n. 9, p. e1003751, 2013.

CABEZA, R. Hemispheric asymmetry reduction in older adults: the HAROLD model. Psychol Aging, v. 17, n. 1, p. 85-100, 2002.

CATANI, M. et al. A novel frontal pathway underlies verbal fluency in primary progressive aphasia. Brain, v. 136, n. Pt 8, p. 2619-28, 2013.

CATANI, M.; THIEBAUT DE SCHOTTEN, M. A diffusion tensor imaging tractography atlas for virtual in vivo dissections. Cortex, v. 44 (8), n. 0010-9452 (Print), p. 1105-32, 2008.

CATANI, M.; THIEBAUT DE SCHOTTEN, M. Atlas of human brain connections. Oxford ; New York: Oxford University Press, 2012. xii, 519 p. ISBN 9780199541164 (alk. paper)

0199541167 (alk. paper).

CORBALLIS, M. C. From mouth to hand: gesture, speech, and the evolution of right-handedness. Behav Brain Sci, v. 26, n. 2, p. 199-208; discussion 208-60, 2003.

CROW, T. J. Schizophrenia as the price that homo sapiens pays for language: a resolution of the central paradox in the origin of the species. Brain Res Brain Res Rev, v. 31, n. 2-3, p. 118-29, 2000. 
CROW, T. J. et al. Where and what is the right shift factor or cerebral dominance gene? A critique of Francks et al. (2007). Laterality, v. 14, n. 1, p. 3-10, 2009.

CROW, T. J.; DONE, D. J.; SACKER, A. Cerebral lateralization is delayed in children who later develop schizophrenia. Schizophr Res, v. 22, n. 3, p. 181-5, 1996.

DENENBERG, V. H. et al. Infantile stimulation induces brain lateralization in rats. Science, v. 201, n. 4361, p. 1150-2, 1978.

FAURIE, C.; RAYMOND, M. Handedness frequency over more than ten thousand years. Proc Biol Sci, v. 271 Suppl 3, p. S43-5, 2004.

FINK, M. et al. Lateralization of the serotonin-1A receptor distribution in language areas revealed by PET. Neuroimage, v. 45, n. 2, p. 598-605, 2009.

FRANCKS, C. Exploring human brain lateralization with molecular genetics and genomics. Ann N Y Acad Sci, 2015.

FRANCKS, C. et al. Parent-of-origin effects on handedness and schizophrenia susceptibility on chromosome 2p12q11. Hum Mol Genet, v. 12, n. 24, p. 3225-30, 2003.

FRANCKS, C. et al. A genomewide linkage screen for relative hand skill in sibling pairs. Am J Hum Genet, v. 70, n. 3, p. 800-5, 2002.

FRANCKS, C. et al. LRRTM1 on chromosome 2p12 is a maternally suppressed gene that is associated paternally with handedness and schizophrenia. Mol Psychiatry, v. 12, n. 12, p. 1129-39, 1057, 2007.

FRENCH, C. A.; FISHER, S. E. What can mice tell us about Foxp2 function? Curr Opin Neurobiol, v. 28, p. 72-9, 2014.

HALPERN, M. E. et al. Lateralization of the vertebrate brain: taking the side of model systems. J Neurosci, v. 25, n. 45 , p. 10351-7, 2005.

HAWRYLYCZ, M. J. et al. An anatomically comprehensive atlas of the adult human brain transcriptome. Nature, v. 489, n. 7416, p. 391-9, 2012.

HICKOK, G. The functional neuroanatomy of language. Phys Life Rev, v. 6, n. 3, p. 121-43, 2009.

HONG, J. H. et al. The anatomical location of the arcuate fasciculus in the human brain: A diffusion tensor tractography study. Brain Research Bulletin, v. 80, n. 1-2, p. 52-55, 2009.

HUGDAHL, K.; WESTERHAUSEN, R. The two halves of the brain : information processing in the cerebral hemispheres. Cambridge, Mass.: MIT Press, 2010. vii, 694 p., 12 p. of plates ISBN 9780262014137 (hardcover alk. paper)

0262014130 (hardcover alk. paper).

KANG, C.; DRAYNA, D. Genetics of speech and language disorders. Annu Rev Genomics Hum Genet, v. 12, p. 145-64, 2011.

KELLER, S. S. et al. Broca's area: nomenclature, anatomy, typology and asymmetry. Brain Lang, v. 109, n. 1, p. 29-48, 2009.

KENNEDY, D. N. et al. Structural and functional brain asymmetries in human situs inversus totalis. Neurology, v. 53 , n. 6, p. 1260-5, 1999. 
KNECHT, S. et al. Handedness and hemispheric language dominance in healthy humans. Brain, v. $123 \mathrm{Pt} 12$, p. 2512-8, 2000.

KONOPKA, G. et al. Human-specific transcriptional regulation of CNS development genes by FOXP2. Nature, v. 462, n. 7270, p. 213-7, 2009.

KVICKSTROM, P. et al. Selective frontal neurodegeneration of the inferior fronto-occipital fasciculus in progressive supranuclear palsy (PSP) demonstrated by diffusion tensor tractography. BMC Neurol, v. 11, p. 13, 2011.

LAYTON, W. M., JR. Random determination of a developmental process: reversal of normal visceral asymmetry in the mouse. J Hered, v. 67, n. 6, p. 336-8, 1976.

LI, T. et al. FoxP2 is significantly associated with schizophrenia and major depression in the Chinese Han Population. World Journal of Biological Psychiatry, v. 14, n. 2, p. 146-150, 2013.

LI, Y.; MU, Y.; GAGE, F. H. Development of neural circuits in the adult hippocampus. Curr Top Dev Biol, v. 87, p. 149-74, 2009.

M., T. D. S. et al. Atlasing location, asymmetry and inter-subject variability of white matter tracts in the human brain with MR diffusion tractography. Neuroimage, v. 54 (1), n. 1095-9572 (Electronic), p. 49-59, 2011.

MANDONNET, E. et al. Does the left inferior longitudinal fasciculus play a role in language? A brain stimulation study. Brain, v. 130, n. Pt 3, p. 623-9, 2007.

MCMANUS, I. C. Handedness, language dominance and aphasia: a genetic model. Psychol Med Monogr Suppl, v. 8, p. $1-40,1985$.

MEDLAND, S. E. et al. Opposite effects of androgen receptor CAG repeat length on increased risk of lefthandedness in males and females. Behav Genet, v. 35, n. 6, p. 735-44, 2005.

MEDLAND, S. E. et al. Genetic influences on handedness: data from 25,732 Australian and Dutch twin families. Neuropsychologia, v. 47, n. 2, p. 330-7, 2009.

MU, Y.; GAGE, F. H. Adult hippocampal neurogenesis and its role in Alzheimer's disease. Mol Neurodegener, v. 6, p. $85,2011$.

NONAKA, S. et al. Randomization of left-right asymmetry due to loss of nodal cilia generating leftward flow of extraembryonic fluid in mice lacking KIF3B motor protein. Cell, v. 95, n. 6, p. 829-37, 1998.

OCKLENBURG, S. et al. Cholecystokinin A receptor (CCKAR) gene variation is associated with language lateralization. PLoS One, v. 8, n. 1, p. e53643, 2013a.

. FOXP2 variation modulates functional hemispheric asymmetries for speech perception. Brain Lang, v. 126, n. 3, p. 279-84, 2013 b.

OCKLENBURG, S. et al. Variation in the NMDA receptor 2B subunit gene GRIN2B is associated with differential language lateralization. Behav Brain Res, v. 225, n. 1, p. 284-9, 2011.

OERTEL, V. et al. Reduced laterality as a trait marker of schizophrenia--evidence from structural and functional neuroimaging. J Neurosci, v. 30, n. 6, p. 2289-99, 2010.

OLDFIELD, R. C. The assessment and analysis of handedness: the Edinburgh inventory. Neuropsychologia, v. 9, n. 1, p. 97-113, 1971. 
PINEL, P. et al. Genetic variants of FOXP2 and KIAA0319/TTRAP/THEM2 locus are associated with altered brain activation in distinct language-related regions. J Neurosci, v. 32, n. 3, p. 817-25, 2012.

RASMUSSEN, T.; MILNER, B. Clinical and surgical studies of the cerebral speech areas in man. In: ZULCH, K. J.;CREUTZFELDT, O., et al (Ed.). Cerebral Localization. New York: Springer-Verlag, 1975.

RAYMOND, M. et al. Frequency-dependent maintenance of left handedness in humans. Proc Biol Sci, v. 263, n. 1377, p. 1627-33, 1996.

ROGERS, L. J. Relevance of brain and behavioural lateralization to animal welfare. Applied Animal Behaviour Science, v. 127, n. 1-2, p. 1-11, 2010.

SAGASTI, A. Three ways to make two sides: genetic models of asymmetric nervous system development. Neuron, v. 55, n. 3, p. 345-51, 2007.

SCERRI, T. S. et al. PCSK6 is associated with handedness in individuals with dyslexia. Hum Mol Genet, v. 20, n. 3, p. 608-14, 2011.

SUN, T. et al. Early asymmetry of gene transcription in embryonic human left and right cerebral cortex. Science, v. 308, n. 5729, p. 1794-8, 2005.

SUN, T.; WALSH, C. A. Molecular approaches to brain asymmetry and handedness. Nat Rev Neurosci, v. 7, n. 8, p. 655-62, 2006.

TANAKA, S. et al. Dichotic listening in patients with situs inversus: brain asymmetry and situs asymmetry. Neuropsychologia, v. 37, n. 7, p. 869-74, 1999.

TANG, A. C. A hippocampal theory of cerebral lateralization. In: HUGDAHL, K. e DAVIDSON, R. J. (Ed.). The asymmetrical brain. Cambridge, Mass.: MIT Press, 2003. cap. 2, p.37-68. ISBN 0262083094 (alk. paper).

THULBORN, K. R.; CARPENTER, P. A.; JUST, M. A. Plasticity of language-related brain function during recovery from stroke. Stroke, v. 30, n. 4, p. 749-54, 1999.

WU, M. C. et al. Rare-variant association testing for sequencing data with the sequence kernel association test. Am J Hum Genet, v. 89, n. 1, p. 82-93, 2011. 